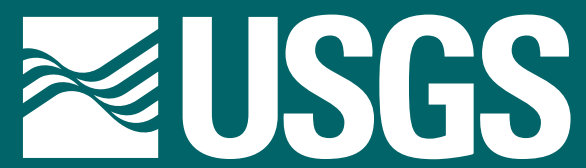

\title{
Geologic Studies in Alaska by the U.S. Geological Survey, 1998
}

U.S. Geological Survey Professional Paper 1615

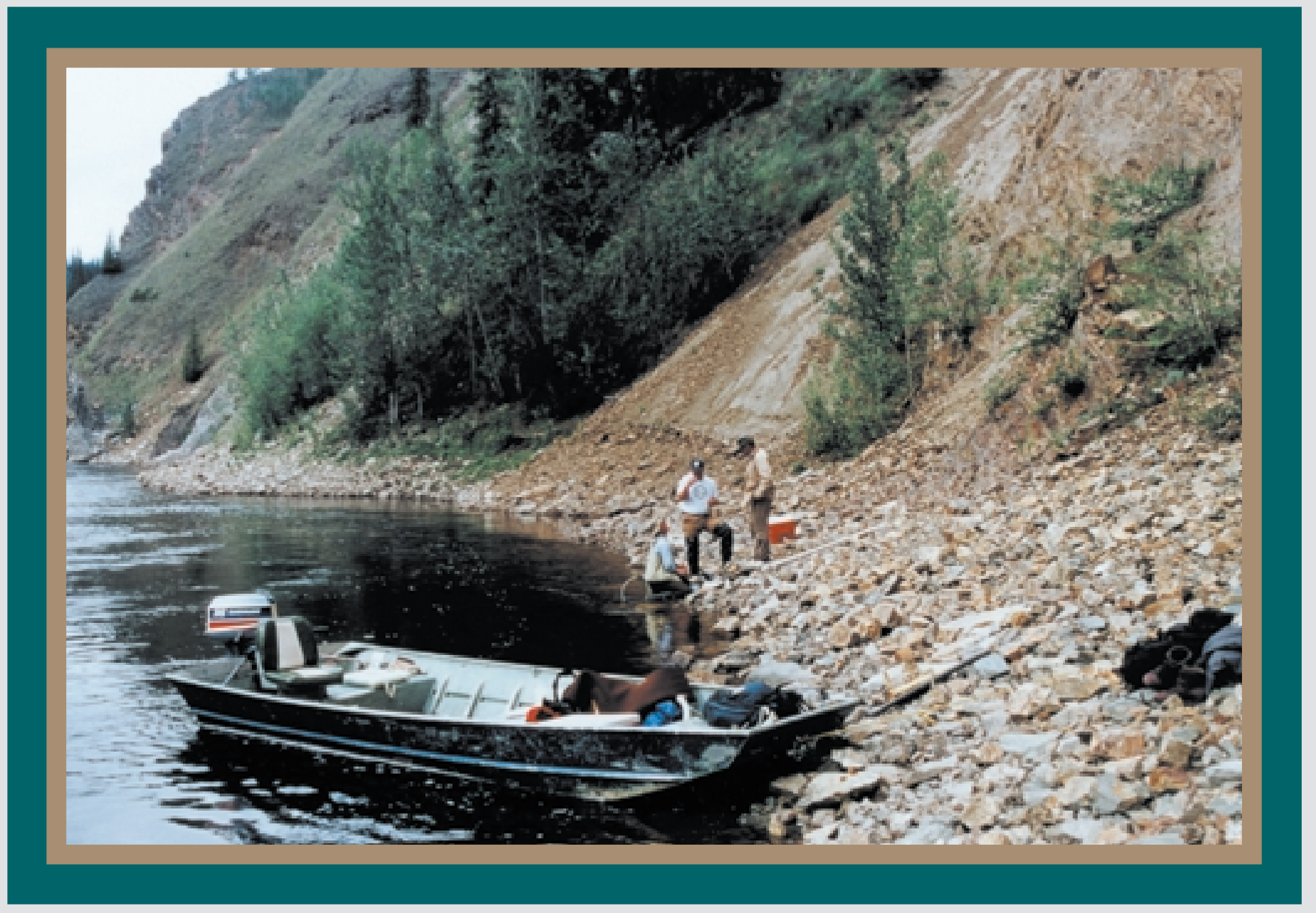


Cover. Photograph of the Fortymile River in east-central Alaska cutting through sulfidebearing siliciclastic metasedimentary rocks of the Taylor Mountain assemblage (see article by Day and others, this volume). These rocks are fine grained, light gray, and weather to a characteristic rusty brown as a result of oxidation of contained sulfide minerals. The degree to which river- and stream-water chemistry is affected by this and other rock-unit outcrops is being investigated. This work is important to understanding the relative contribution of natural trace-metal sources versus mining-related sources. 


\section{Geologic Studies in Alaska by the U.S. Geological Survey, 1998}

Edited by Karen D. Kelley and Larry P. Gough

U.S. Geological Survey Professional Paper 1615

U.S. Department of the Interior

U.S. Geological Survey 


\section{U.S. Department of the Interior}

Bruce Babbitt, Secretary

\section{U.S. Geological Survey \\ Charles G. Groat, Director}

First printing July 2000

For sale by U.S. Geological Survey, Information Services

Box 25286, Federal Center

Denver, CO 80225

This publication is also available online at:

http://greenwood.cr.usgs.gov/pub/ppapers/p1615/

Any use of trade, product, or firm names in this publication

is for descriptive purposes only and

does not imply endorsement by the U.S. Government 


\section{Contents}

Introduction

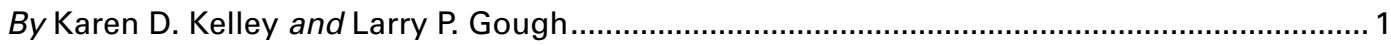

\section{GEOLOGIC FRAMEWORK}

New geochronological evidence for the timing of early Tertiary ridge subduction in southern Alaska

By Dwight C. Bradley, Randall Parrish, William Clendenen, Daniel Lux, Paul W. Layer, Matthew Heizler, and D. Thomas Donley.

Mount Mageik: A compound stratovolcano in Katmai National Park

By Wes Hildreth, Judy Fierstein, Marvin A. Lanphere, and David F. Siems 23

Paleozoic strata of the Dyckman Mountain area, northeastern Medfra quadrangle, Alaska

By Julie A. Dumoulin, Dwight C. Bradley, and Anita G. Harris 43

Reconnaissance bedrock geology of the southeastern part of the Kenai quadrangle, Alaska

By Dwight C. Bradley and Frederic H. Wilson 59

Geologic setting of the Fortymile River area-Polyphase deformational history within part of the eastern Yukon-Tanana uplands of Alaska

By Warren C. Day, Bruce M. Gamble, Mitchell W. Henning, and Bruce D. Smith .65

Stratigraphic variation in petrographic composition of Nanushuk Group sandstones at Slope Mountain, North Slope, Alaska

By Mark J. Johnsson and Nikolas K. Sokol. 83

\section{ENVIRONMENT AND CLIMATE}

Regional baseline geochemistry and environmental effects of gold placer mining operations on the Fortymile River, eastern Alaska

By Richard B. Wanty, Bronwen Wang, Jim Vohden, Paul H. Briggs, and Allen L. Meier

Bedrock assemblages of the Bering Strait region: Implications for offshore metal sources in the marine environment

By Travis L. Hudson and R.W. Saltus. 
An evaluation of methods for identifying and interpreting buried soils

in late Quaternary loess in Alaska

By Daniel R. Muhs, Thomas A. Ager, Josh M. Been, Joseph G. Rosenbaum, and

Richard L. Reynolds

Postglacial vegetation history of the Kachemak Bay area, Cook Inlet, south-central Alaska

By Thomas A. Ager

The chemical characteristics of ground water near Fairbanks, Alaska

By G. Lang Farmer, Richard J. Goldfarb, Michael R. Lilly, Bob Bolton, Allen L. Meier, and Richard F. Sanzolone

\section{RESOURCES}

Isotopic ages from intrusive rocks near the Stuyahok gold placer deposits, south-central Holy Cross quadrangle, Alaska

By Marti L. Miller, Robert D. Tucker, Paul W. Layer, and Thomas K. Bundtzen

Sulfur-, oxygen-, and carbon-isotope studies of $\mathrm{Ag}-\mathrm{Pb}-\mathrm{Zn}$ vein-breccia occurrences, sulfide-bearing concretions, and barite deposits in the north-central Brooks Range, with comparisons to shale-hosted stratiform massive sulfide deposits

By Karen D. Kelley, David L. Leach, and Craig A. Johnson 189

Geology and geochemistry of $\mathrm{Zn}-\mathrm{Pb}-\mathrm{Ag}$ vein-breccias at Whoopee Creek, Alaska

By Jeanine M. Schmidt 203

\section{BIBLIOGRAPHIES}

U.S. Geological Survey reports on Alaska released in 1998

Compiled by John P. Galloway and Susan Toussaint .221

Reports on Alaska in non-USGS publications released in 1998 that include USGS authors

Compiled by John P. Galloway and Susan Toussaint .223

IV 


\section{Contributors to this Professional Paper}

\section{Anchorage}

Bradley, Dwight C.

Dumoulin, Julie A.

Gamble, Bruce M.

Gough, Larry P.

Miller, Marti L.

Schmidt, Jeanine M.

Wilson, Frederic H.

U.S. Geological Survey

4200 University Drive

Anchorage, AK 99508

Wang, Bronwen

U.S. Geological Survey

4230 University Drive

Anchorage, AK 99508

Henning, Mitchell W.

Alaska Department of Natural Resources

Anchorage, AK 99503-5948

\section{Denver}

Ager, Thomas A., Mail Stop 980

Been, Josh M., Mail Stop 980

Briggs, Paul H., Mail Stop 973

Day, Warren C., Mail Stop 973

Goldfarb, Richard J., Mail Stop 964

Johnson, Craig A., Mail Stop 963

Kelley, Karen D., Mail Stop 964

Leach, David L., Mail Stop 973

Meier, Allen L., Mail Stop 973

Muhs, Daniel R., Mail Stop 980

Reynolds, Richard L., Mail Stop 980

Rosenbaum, Joseph G., Mail Stop 980

Saltus, R.W., Mail Stop 964

Sanzolone, Richard F., Mail Stop 973

Siems, David F., Mail Stop 973

Smith, Bruce D., Mail Stop 973

Wanty, Richard B., Mail Stop 973

U.S. Geological Survey

P.O. Box 25046, Mail Stop

Denver Federal Center

Denver, CO 80225

\section{Fairbanks}

Bolton, Bob

Layer, Paul W.

Lilly, Michael R.

University of Alaska, Fairbanks

Fairbanks, AK 99775
Vohden, Jim

Alaska Department of Natural Resources 3700 Airport Way

Fairbanks, AK 99709

Bundtzen, Thomas K.

Pacific Rim Geological Consulting

P.O. Box 81906

Fairbanks, AK 99708

\section{Menlo Park}

Fierstein, Judy, Mail Stop 910

Galloway, John P., Mail Stop 904

Hildreth, Wes, Mail Stop 910

Lanphere, Marvin A., Mail Stop 937

Toussaint, Susan, Mail Stop 955

U.S. Geological Survey

345 Middlefield Road, Mail Stop

Menlo Park, CA 94025

\section{Reston}

Harris, Anita G., Mail Stop 926A

U.S. Geological Survey

National Center, Mail Stop

12201 Sunrise Valley Drive

Reston, VA 20192

\section{Others}

Johnsson, Mark J.

California Coastal Commission

45 Fremont St., Suite 2000

San Francisco, CA 94105-2219

Sokol, Nikolas K.

857 Penn St.

Bryn Mawr, PA 19010

Parrish, Randall

British Geological Survey

Keyworth, Notts, U.K.

Clendenen, William

Brown University

Providence, RI

currently at

Exxon Production Research

Houston, TX

Lux, Daniel

University of Maine

Orono, ME 


\section{Others (continued)}

\section{Heizler, Matthew}

New Mexico Institute of Mining and Technology Socorro, NM

Donley, D. Thomas

Department of Geology

Boston University

Boston, MA 02215

and

U.S. Geological Survey

Anchorage, AK 99508
Hudson, Travis L.

Applied Geology

1432 Fox Hollow Road

Sequim, WA 98382

Farmer, G. Lang

Department of Geological Sciences and CIRIES

Campus Box 399, University of Colorado

Boulder, CO 80309-0216

\section{Tucker, Robert D.}

Department of Earth and Planetary Sciences

Washington University

St. Louis, MO 63130-4899 


\title{
Geologic Studies in Alaska by the U.S. Geological Survey, 1998
}

\author{
Edited by Karen D. Kelley and Larry P. Gough
}

\section{Introduction}

\author{
By Karen D. Kelley and Larry P. Gough
}

The 14 papers that follow continue the series ${ }^{1}$ of U.S. Geological Survey (USGS) reports on investigations in the geologic sciences in Alaska. The series presents new and sometimes preliminary findings that are of interest to earth scientists in academia, government, and industry; to land and resource managers; and to the general public. Reports presented in Geologic Studies in Alaska cover a broad spectrum of topics from all parts of the State (fig. 1), which serves to emphasize the diversity of USGS efforts to meet the Nation's needs for earth-science information in Alaska.

The papers in this volume are organized under the topics Geologic Framework, Environment and Climate, and Resources. Such an organization is intended to reflect the scope and objectives of USGS programs currently active in Alaska. Geologic framework studies provide background information that is the scientific basis for present and future studies of the environment, mineral and energy resources, paleoclimate, and hazards in Alaska. One paper presents ages of numerous igneous intrusive rocks in southern Alaska (Bradley and others). The authors demonstrate a systematic, along-strike diachronous age trend of near-trench magmatism in this region during the early Tertiary. Hildreth and others provide a map, rock descriptions, and chemical compositions of a geologically young volcanic center in Katmai National Park. Another paper describes the results of sedimentologic and paleontologic comparisons of lower Paleozoic, deep-water-facies rock units in central Alaska (Dumoulin and others). The authors show which of these scattered occurrences are likely to correlate with one another, suggest likely source regions, and provide a structural restoration of occurrences that have been fragmented by large fault motions. The paper by Bradley and Wilson provides the reconnaissance geology of the southeast part of the Kenai quadrangle. Another paper discusses the character, origin, and deformation of the major bedrock units within the Fourmile River area in east-central Alaska (Day and others). Further understanding the bedrock geology of this area is important for the assessment of potential environmental effects of placer-gold mining operations. The last Geologic Framework paper presents stratigraphic variations in composition within sandstones of the Nanushuk Group in the North Slope (Johnsson and Sokol). Studying the variations in the compositions of fluvial/deltaic sandstones of the Nanushuk Group is important in assessing climate change in northern Alaska during the Cretaceous.

Environmental studies are the emphasis of five papers. One study focuses on the environmental effects of gold-placer mining operations on the Fortymile River area of eastern Alaska (Wanty and others). The authors conclude that there is relatively little effect on metal content or turbidity of waters downstream from suction-dredge operations in this region. A second study presents an interesting synthesis and discussion of onshore geology, regional gravity and magnetic data, information about mineral deposits, and natural

1 From 1975 through 1988, the Geologic Studies in Alaska series was published as USGS Circulars, which were initially titled "The United States Geological Survey in Alaska: Accomplishments during 19xx." From 1989 to 1994, the series was published as the more formal USGS Bulletins. As a result of reorganization of USGS publications, beginning in 1995 the series has been published as USGS Professional Papers. 


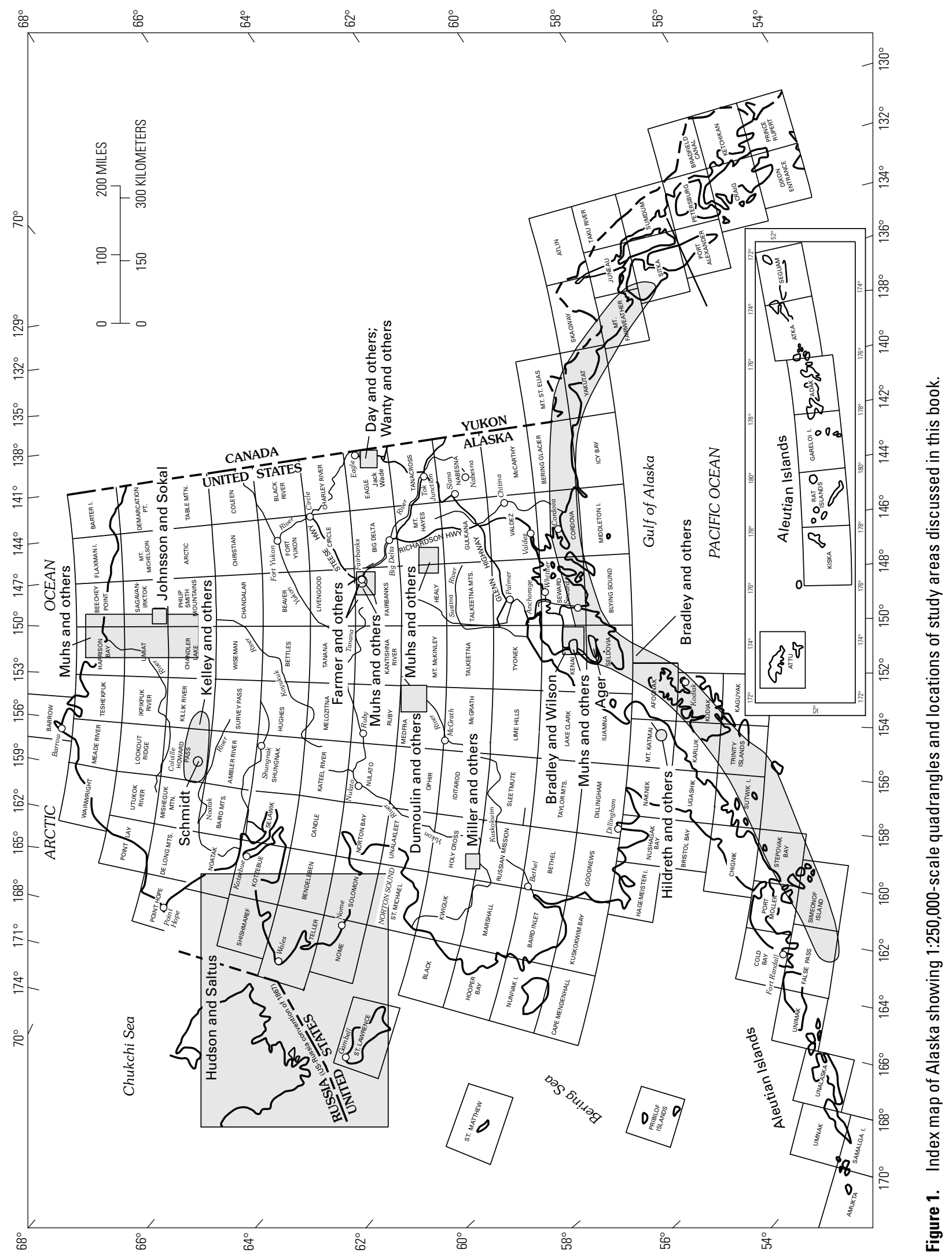


processes that disperse metals in the Bering Strait region (Hudson and Saltus). The source and dispersion of metals in this region is significant because elevated metal concentrations have been noted in tissues of some Pacific walrus in the Bering Sea. Two papers deal with climatic conditions during the Quaternary. Muhs and others present morphological and chemical criteria for identifying buried soils that developed in loess under a variety of different vegetation types. Loess sequences contain detailed records of Quaternary environmental conditions. The second paper presents the results of pollen analyses of two late Quaternary deposits in the southern Cook Inlet region (Ager). These results present the first dated postglacial vegetation histories for southern Cook Inlet in south-central Alaska and present useful examples of postglacial vegetation development under the partial influence of maritime climates. The fifth environmental paper presents major- and trace-element abundances, and $\mathrm{Sr}$ and $\mathrm{Pb}$ isotopic compositions of ground waters near Fairbanks (Farmer and others). The geochemical and isotopic compositions can be used to characterize these waters and assess the factors controlling variations in dissolved arsenic concentrations.

Resource papers include one that presents recently obtained ages of gold-mineralized dikes from the Stuyahok area in the Holy Cross quadrangle (Miller and others). The results suggest that the Stuyahok dikes are part of the Late Cretaceous and early Tertiay belt of gold-bearing deposits such as Donlin Creek and the Marshall-Kako Creek area in the Kuskokwim mineral belt. The last two resource papers focus on $\mathrm{Ag}-\mathrm{Pb}-\mathrm{Zn}$ (with or without $\mathrm{Ba}$ ) occurrences and deposits in the Brooks Range of Alaska. Kelley and others present stable-isotope data that supports a genetic relationship between vein-breccia occurrences in clastic rocks and overlying shale-hosted massive sulfide deposits, such as the Red Dog deposit in northwestern Alaska. Soil and stream-sediment geochemical analyses and detailed descriptions of the vein-breccia occurrence at Whoopee Creek make up the subject matter of the last Resource paper (Schmidt).

Two bibliographies at the end of the volume present reports about Alaskan earth sciences in USGS publications during 1998, and reports about Alaska by USGS authors in non-USGS publications during the same period. 


\title{
New Geochronological Evidence for the Timing of Early Tertiary Ridge Subduction in Southern Alaska
}

\author{
By Dwight C. Bradley, Randall Parrish, William Clendenen, Daniel Lux, Paul W. Layer, \\ Matthew Heizler, and D. Thomas Donley
}

\section{Abstract}

We present new $\mathrm{U} / \mathrm{Pb}$ (monazite, zircon) and ${ }^{40} \mathrm{Ar} /{ }^{39} \mathrm{Ar}$ (biotite, amphibole) ages for 10 Tertiary plutons and dikes that intrude the Chugach-Prince William accretionary complex of southern Alaska. The Sanak pluton of Sanak Island yielded ages of $61.1 \pm 0.5 \mathrm{Ma}$ (zircon) and $62.7 \pm 0.35$ (biotite). The Shumagin pluton of Big Koniuji Island yielded a $\mathrm{U} / \mathrm{Pb}$ zircon age of 61.1 \pm 0.3 Ma. Two biotite ages from the Kodiak batholith of Kodiak Island are nearly identical at $58.3 \pm 0.2$ and $57.3 \pm 2.5$ Ma. Amphibole from a dike at Malina Bay, Afognak Island, is 59.3 $\pm 2.2 \mathrm{Ma}$; amphibole from a dike in Seldovia Bay, Kenai Peninsula, is 57.0 $\pm 0.2 \mathrm{Ma}$. The Nuka pluton, Kenai Peninsula, yielded ages of $56.0 \pm 0.5 \mathrm{Ma}$ (monazite) and $54.2 \pm 0.1$ (biotite). Biotite plateau ages are reported for the Aialik (52.2 $\pm 0.9 \mathrm{Ma})$, Tustumena (53.2 $\pm 1.1 \mathrm{Ma})$, Chernof (54.2 $\pm 1.1 \mathrm{Ma})$, and Hive Island (53.4 $\pm 0.4 \mathrm{Ma}$ ) plutons of the Kenai Peninsula. Together, these new results confirm, but refine, the previously documented along-strike diachronous age trend of near-trench magmatism during the early Tertiary. We suggest that this event began at 61 Ma at Sanak Island, 2-4 m.y. later than previously supposed. An intermediate dike near Tutka Bay, Kenai Peninsula, yielded a hornblende age of $115 \pm 2 \mathrm{Ma}$. This represents a near-trench magmatic event that had heretofore gone unrecognized on the Kenai Peninsula; correlative Early Cretaceous near-trench plutons are known from the western Chugach Mountains near Palmer.

\section{Introduction}

Early Tertiary near-trench plutons of the Sanak-Baranof belt in southern Alaska (fig. 1) have been widely interpreted as the product of ridge subduction (Hill and others, 1981; Helwig and Emmet, 1981; Moore and others, 1983; Bradley and others, 1993; Sisson and Pavlis, 1993; Haeussler and others, 1995). Bradley and others (1993) showed that magmatism was a timetransgressive event, beginning at 66-63 Ma at the western end of the belt (an age that we revise herein), and ending around $50 \mathrm{Ma}$ at the eastern end. On this basis, Bradley and others (1993) inferred that a trench-ridge-trench triple junction, which marked the site of ridge subduction, migrated 2,200 km in 13-16 m.y. In the past few years, several new ${ }^{40} \mathrm{Ar} /{ }^{39} \mathrm{Ar}$ and $\mathrm{U} / \mathrm{Pb}$ ages from near-trench intrusions in south-central Alaska have been published (Taylor and others, 1994; Haeussler and others, 1995; Poole, 1996) that confirm, but refine, this age progression. Here we report and document $3 \mathrm{U} / \mathrm{Pb}$ and $10^{40} \mathrm{Ar} /{ }^{39} \mathrm{Ar}$ ages from the western half of the Sanak-Baranof belt. Eight of these ages are entirely new. One was previously published in a dissertation (Clendenen, 1991). The rest were cited by Bradley and others (1993) in their compilation, but the analytical data and supporting diagrams have never been published.

The present paper reports results from three somewhat interrelated research efforts involving five different geochronology labs. As a graduate student at Brown University in the late 1980's, William Clendenen began geochronological and thermochronological studies of several near-trench plutons along the Gulf of Alaska margin. Samples for dating were provided by Timothy Byrne, Malcolm Hill, Peter Vrolijk, and Dwight Bradley. Clendenen obtained six of the ${ }^{40} \mathrm{Ar} /{ }^{39} \mathrm{Ar}$ dates reported herein, in cooperation with Matthew Heizler at the State University of New York at Albany. As part of this effort, Randall Parrish, then at the Geological Survey of Canada, obtained $\mathrm{U} / \mathrm{Pb}$ ages on zircon and monazite separates from two of Clendenen's samples. A third U/Pb age was obtained recently by Parrish, now at the British Geological Survey, in connection with the present paper. From 1988 to 1993, Bradley and coworkers mapped the Seldovia quadrangle (fig. 2) under the Alaska Mineral Resource Assessment Program of the U.S. Geological Survey (Bradley and others, 1999). Two intrusiverock samples from the Seldovia quadrangle were among those dated by Clendenen; one sample was dated and published by Hauessler and others (1995); and four other samples, ages of which are reported herein, were dated by Dan Lux at the University of Maine. Tom Donley, meanwhile, was studying emplacement mechanisms of near-trench plutons in southcentral Alaska as part of a graduate research project under Timothy Kusky at Boston University. Part of this work involved new ${ }^{40} \mathrm{Ar} /{ }^{39} \mathrm{Ar}$ geochronology, which is reported herein, by Paul 

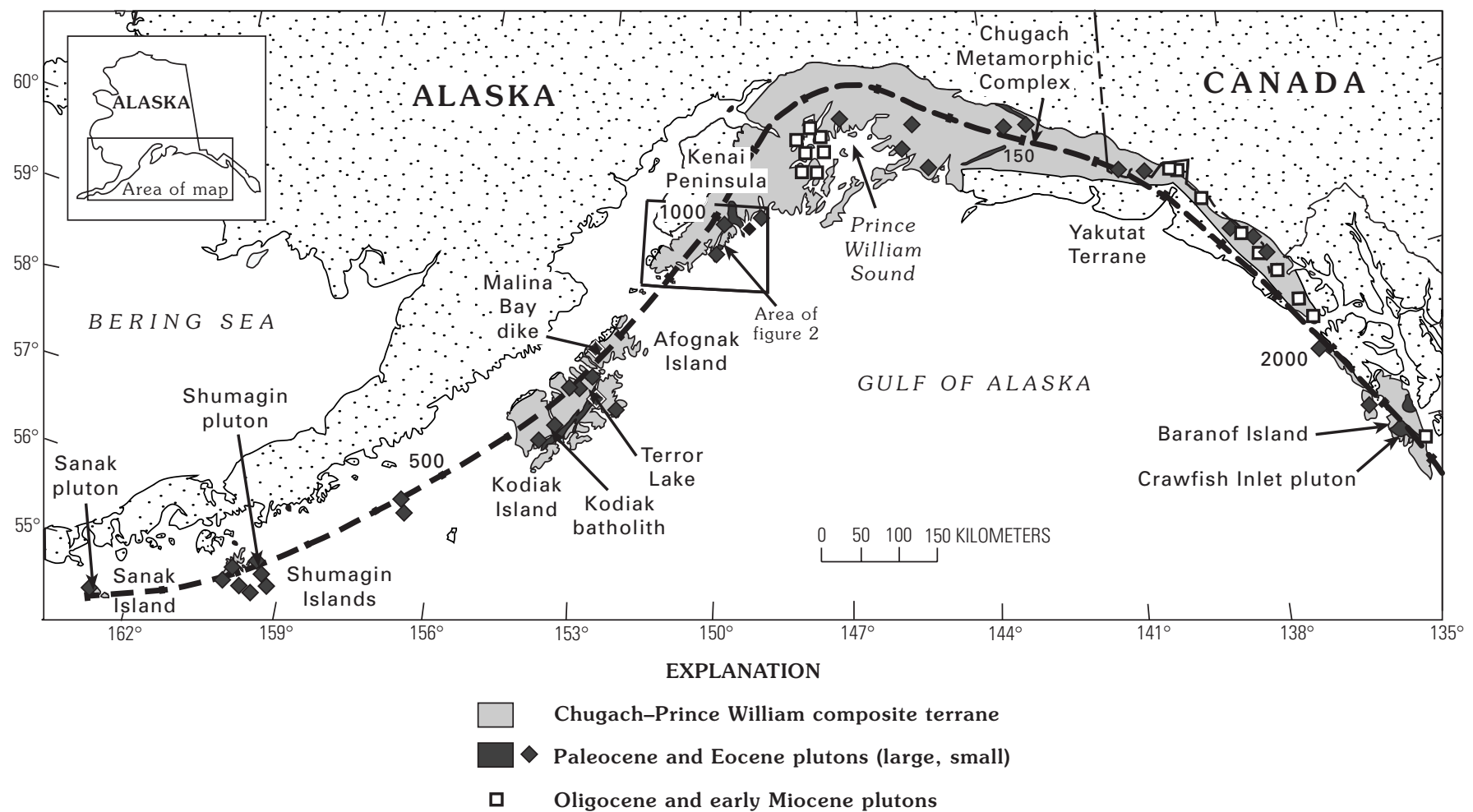

Figure 1. Generalized geologic map of southern Alaska showing plutons of Sanak-Baranof plutonic belt, Chugach-Prince William composite terrane, and localities mentioned in text. Numbers along dashed reference line show distance in kilometers from southern tip of Sanak Island to Baranof Island.

Layer at University of Alaska, Fairbanks. The aim of the present paper is to document the ages of these tectonically significant intrusive rocks-hard-won results from inaccessible places that might not otherwise have been published.

\section{Regional Geology}

Plutons of the Sanak-Baranof belt intrude a complexly deformed Mesozoic and Cenozoic accretionary prism known as the Chugach-Prince William composite terrane (the term "composite" is omitted below for brevity) (fig.1). Plafker and others (1994) provided a thorough review and comprehensive bibliography of the regional geology; in this paper we will discuss only the western half of the belt. The inboard part of the ChugachPrince William terrane is mostly underlain by a melange of relatively competent blocks and fault slices of basalt, chert, and graywacke, surrounded by a phacoidally cleaved argillaceous matrix (Uyak and McHugh Complexes; Connelly, 1978; Bradley and Kusky, 1992). Outboard of the melange is a belt of Upper Cretaceous flysch, assigned to the Shumagin Formation, Kodiak Formation, and Valdez Group (Moore, 1973; Nilsen and Moore, 1979; Nilsen and Zuffa, 1982). Still farther outboard lie belts of flysch assigned to the Ghost Rocks Formation and Orca Group (Moore and others, 1983; Moore and Allwardt, 1980; Helwig and Emmet, 1981). The Ghost Rocks Formation and Orca Group contain mafic volcanic rocks that evidently were erupted in or near a trench and have been cited as one line of evidence for ridge subduction (Moore and others, 1983; Bradley and others, 1993; Lytwyn and others, 1997). Penetrative deformation in the accretionary prism (thrust imbrication, folding, melange formation) and regional metamorphism (typically prehnite-pumpelleyite to greenschist facies) occurred during and shortly after subduction-accretion during the Cretaceous and early Tertiary (Kusky and others, 1997). Near-trench plutons of the Sanak-Baranof belt were emplaced into the accretionary prism after most of this deformation. Another tract of accreted deep-sea turbidites (Eocene Sitkalidak Formation and the outboard part of the Orca Group; Moore and Allwardt, 1980; Helwig and Emmet, 1981) lies outboard of the Sanak-Baranof belt; these younger turbidites are not cut by the plutons and, hence, are probably younger.

Paleocene to Eocene plutons of the Sanak-Baranof belt are mainly granodiorite, granite, and tonalite (Hudson, 1983). Some of the plutons are elongate parallel to structural grain of the accretionary prism; others are transverse. Some are enormous - the Kodiak batholith, for example, is more than $100 \mathrm{~km}$ long and as wide as $10 \mathrm{~km}$. In the eastern Chugach Mountains, magmatism was accompanied by high-grade regional metamorphism and anatectic melting of flysch (Hudson and Plafker, 1982; Sisson and others, 1989; Barker and others, 1992; Pavlis and Sisson, 1995). Paleocene to Eocene intermediate to silicic dikes are plentiful in some regions, such as the Kenai Peninsula. Oligocene to early Miocene plutons intruded the Chugach-Prince William terrane in southeastern Alaska and Prince William Sound; post-Eocene plutons have not been recognized from the Kenai Peninsula to Sanak Island. 


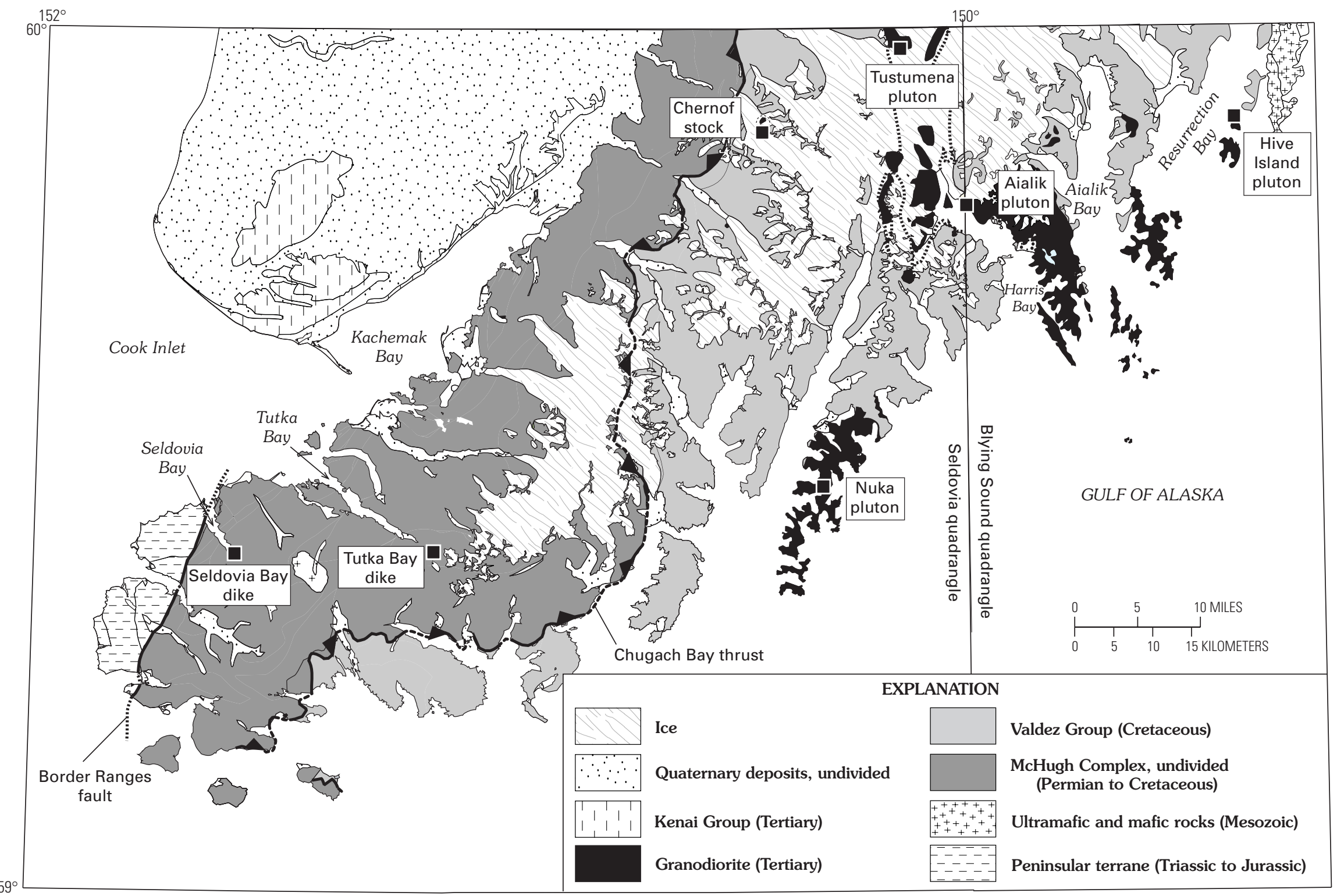

Figure 2. Geologic map of parts of the Seldovia and Blying Sound quadrangles showing locations of newly dated intrusive rocks (black squares). Geology from Bradley and others (1999) and Tysdal and Case (1979). 


\section{Analytical Methods}

\section{$\mathrm{U}-\mathrm{Pb}$ analyses}

$\mathrm{U}-\mathrm{Pb}$ analyses were done at the Geological Survey of Canada, Ottawa, and the British Geological Survey, Keyworth. Analytical methods follow procedures outlined by Parrish and others (1987) and utilize zircon abrasion (Krogh, 1982), teflon microcapsule dissolution (Parrish, 1987), a mixed ${ }^{205} \mathrm{~Pb}^{-233} \mathrm{U}-$ ${ }^{235} \mathrm{U}$ tracer (Parrish and Krogh, 1987), multicollector mass spectrometry, and numerical error propagation (Roddick, 1987). Analyses at the Geological Survey of Canada were done on a MAT 261 mass spectrometer; those at the British Geological Survey were done on a VG 354 mass spectrometer using a Daly ion counter in peak switching mode for both $\mathrm{U}$ and $\mathrm{Pb}$. Analytical blanks for $\mathrm{U}$ and $\mathrm{Pb}$ are 3 and 10 picograms, respectively. Regression of the two analyses of sample S-70 used a York (1969) regression. Correction for common lead followed the model of Stacey and Kramers (1975) using ca. 60-Ma Pb. U-Pb results are presented in figure 3 and table 1. Errors on concordia diagrams are shown at the $2 \sigma$ level.

\section{${ }^{40} \mathrm{Ar} /{ }^{39} \mathrm{Ar}$ analyses}

${ }^{40} \mathrm{Ar} /{ }^{39} \mathrm{Ar}$ analyses were performed at three geochronology laboratories: University of Maine at Orono, State University of New York at Albany, and University of Alaska at Fairbanks. Analytical methods are described below for each lab, and data are presented separately in tables 2, 3, and 4. At all three laboratories, the decay constants recommended by Steiger and Jäger (1977) were used to calculate ages. Methods of data acquisition and analysis differ in detail between the laboratories, and no attempt was made to report the results according a uniform scheme. The argon laboratories at University of Maine and University of Alaska quote results as plateau ages, and, although the two labs use slightly different definitions as to what constitutes a "plateau," this makes no practical difference with any of the data in question. Similarly, argon results from the State University of New York are quoted as isochron ages; these would barely change if recalculated as plateau ages. The incremental heating steps used in the age calculations are indicated in figure 4.

\section{${ }^{40} \mathrm{Ar} /{ }^{39} \mathrm{Ar}$ Analytical Methods - State University of New York, Albany}

Samples were wrapped in tin foil and irradiated in the $\mathrm{H}$ 75 position at the University of Michigan Ford Reactor. Neutron flux was monitored with Fe-mica biotite (age=307.3 Ma), and correction factors for interfering reactions were determined with $\mathrm{K}_{2} \mathrm{SO}_{4}$ glass and $\mathrm{CaF}_{2}$. Mass spectrometry and argon extraction line information follows the procedures detailed in Harrison and Fitz Gerald (1986). Analytical results are presented in table 2 .
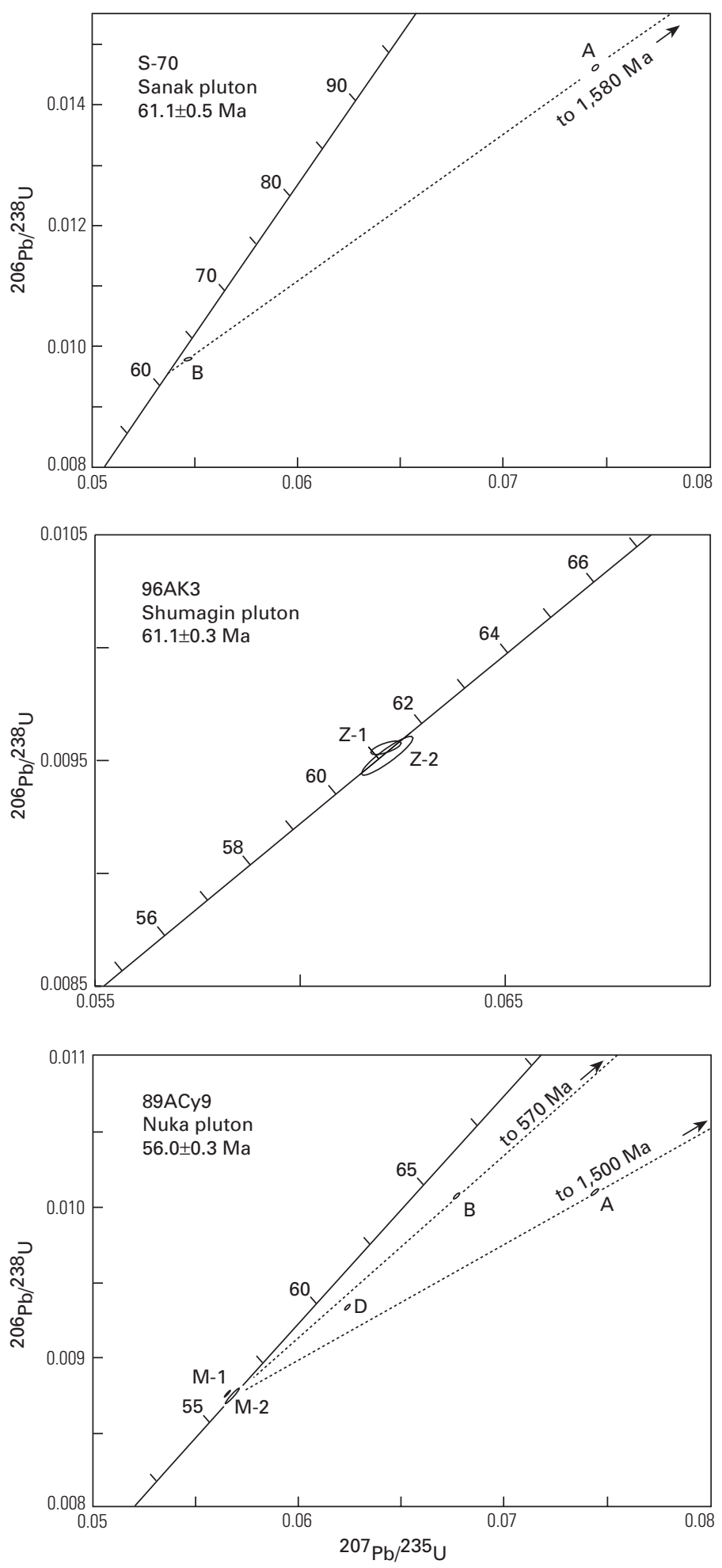

Figure 3. Concordia diagrams for Sanak, Shumagin, and Nuka plutons. Because each fraction consisted of multiple grains, upper intercepts at 1,580 Ma (Sanak pluton) and $570 \mathrm{Ma}$ (Nuka pluton) likely represent averages of inherited ages. See table 1 for explanation of A, B, D, M-1, M-2, Z-1, and Z-2. Errors are shown at $2 \sigma$ level.

\section{${ }^{40} \mathrm{Ar} /{ }^{39} \mathrm{Ar}$ Analytical Methods-University of Maine, Orono}

Samples, flux monitors (SBG-7 inter-lab standard), and $\mathrm{K}$ and $\mathrm{Ca}$ salts were encapsulated in aluminum foil and 
Table 1. Uranium-lead data for intrusive rocks from southern Alaska.

[Mineral fraction: 1, elongate; e, equant; a, air-abraded in laboratory. *, radiogenic $\mathrm{Pb}$, corrected for spike, fractionation, blank, and common $\mathrm{Pb}$; \#, measured ratio, corrected only for spike and fractionation; @, total common $\mathrm{Pb}$ in analysis; **, radiogenic ${ }^{208} \mathrm{~Pb}$, expressed as percent of total radiogenic $\mathrm{Pb} ;{ }^{\wedge}$, uncertainties are 1 sigma (percent); ^^, uncertainties are 2 sigma (Ma). Analyses of samples S-70 and 88ACy9 done at Geological Survey of Canada, Ottawa. Analysis of sample 96AK3 done at British Geological Survey]

\begin{tabular}{|c|c|c|c|c|c|c|c|c|c|c|c|c|c|c|c|}
\hline $\begin{array}{l}\text { Mineral } \\
\text { fraction }\end{array}$ & $\begin{array}{l}\text { Wt. } \\
(\mathrm{mg})\end{array}$ & $\begin{array}{c}\mathrm{U} \\
(\mathrm{ppm})\end{array}$ & $\begin{array}{c}\mathrm{Pb}^{*} \\
(\mathrm{ppm})\end{array}$ & $\begin{array}{l}{ }^{206} \mathrm{~Pb} \# / \\
{ }^{204} \mathrm{~Pb}\end{array}$ & $\begin{array}{c}\mathrm{Pb}_{\mathrm{c}} @ \\
(\mathrm{pg})\end{array}$ & $\begin{array}{c}{ }^{208} \mathrm{~Pb}^{* *} \\
(\%)\end{array}$ & $\begin{array}{c}{ }^{206} \mathrm{~Pb}^{\wedge} / \\
{ }^{238} \mathrm{U}\end{array}$ & $\begin{array}{c} \pm \\
(\%) \\
\end{array}$ & $\begin{array}{c}{ }^{207} \mathrm{~Pb}^{\wedge} / \\
{ }^{235} \mathrm{U}\end{array}$ & $\begin{array}{c} \pm \\
(\%)\end{array}$ & $\begin{array}{l}\text { Corr. } \\
\text { coeff. }\end{array}$ & $\begin{array}{c}{ }^{207} \mathrm{~Pb}^{\wedge} / \\
{ }^{206} \mathrm{~Pb}\end{array}$ & $\begin{array}{c} \pm \\
(\%) \\
\end{array}$ & $\begin{array}{c}207 / 206 \text { age } \\
\text { (Ma) }\end{array}$ & $\begin{array}{l}\text { Error } \\
\text { (Ma) }\end{array}$ \\
\hline \multicolumn{16}{|c|}{ Sample S-70 (Sanak pluton) } \\
\hline A, zircon, a, e & 0.05 & 288 & 4.13 & 479 & 28 & 6.7 & 0.014609 & 0.14 & 0.13165 & 0.18 & 0.65 & 0.06536 & 0.14 & 785.8 & 5.8 \\
\hline B, zircon, a, 1 & 0.03 & 308 & 2.9 & 254 & 28 & 6.4 & 0.009784 & 0.13 & 0.06563 & 0.50 & 0.55 & 0.04865 & 0.44 & 131.0 & 20 \\
\hline \multicolumn{16}{|c|}{ Sample 88ACy9 (Nuka pluton) } \\
\hline A, zircon, a,e & 0.17 & 727 & 6.89 & 6511 & 12 & 3.7 & 0.010087 & 0.10 & 0.07443 & 0.11 & 0.94 & 0.05351 & 0.04 & 350.6 & 1.7 \\
\hline $\mathrm{B}$, zircon, a, e & 0.17 & 841 & 7.86 & 4130 & 22 & 3.0 & 0.010065 & 0.10 & 0.06774 & 0.11 & 0.93 & 0.04881 & 0.04 & 138.9 & 1.9 \\
\hline $\mathrm{D}$, zircon, a, 1 & 0.08 & 861 & 7.47 & 3670 & 11 & 3.1 & 0.009330 & 0.09 & 0.06239 & 0.11 & 0.91 & 0.04850 & 0.04 & 123.7 & 2.0 \\
\hline M-1, monazite & 0.19 & 5489 & 56.8 & 20908 & 28 & 23.7 & 0.008746 & 0.26 & 0.05678 & 0.27 & 0.99 & 0.04708 & 0.03 & 53.5 & 1.4 \\
\hline M-2, monazite & 0.26 & 5150 & 93.5 & 10808 & 70 & 56.3 & 0.008762 & 0.11 & 0.05658 & 0.12 & 0.96 & 0.04683 & 0.03 & 40.8 & 1.5 \\
\hline
\end{tabular}

[*Z, zircon; **, atomic ratio of Th to $\mathrm{U}^{*}{ }^{\wedge}$, measured ratio, corrected for spike and $\mathrm{Pb}$ fractionation $(0.13 \% / \mathrm{amu})$; ^^, total common $\mathrm{Pb}$ in analysis, corrected for fractionation and spike; *^, corrected for blank $\mathrm{Pb}$ and $\mathrm{U}$, and common $\mathrm{Pb}$ (Stacey-Kramers model) $\mathrm{Pb}$ equivalent to interpreted age of mineral]

\begin{tabular}{|c|c|c|c|c|c|c|c|c|c|c|c|c|c|c|c|c|c|c|}
\hline \multicolumn{19}{|c|}{ Sample 96AK3 (Shumagin pluton) } \\
\hline Analysis* & $\begin{array}{l}\text { Weight } \\
\text { (mg) }\end{array}$ & $\begin{array}{c}\mathrm{U} \\
(\mathrm{ppm})\end{array}$ & $\begin{array}{l}\mathrm{Pb}^{* *} \\
(\mathrm{ppm})\end{array}$ & $\begin{array}{l}{ }^{206} \mathrm{~Pb}^{\wedge} / \\
{ }^{204} \mathrm{~Pb}\end{array}$ & $\begin{array}{c}\mathrm{Pb}_{\mathrm{c}}{ }^{\wedge \wedge} \\
(\mathrm{pg})\end{array}$ & $\begin{array}{c}\mathrm{Th}^{* *} / \\
\mathrm{U}\end{array}$ & $\begin{array}{c}{ }^{206} \mathrm{~Pb}^{* \wedge} / \\
{ }^{238} \mathrm{U}\end{array}$ & $\begin{array}{l}1 \mathrm{std} \\
\text { err } \\
(\%)\end{array}$ & $\begin{array}{c}{ }^{207} \mathrm{~Pb}^{* \wedge} / \\
{ }^{235} \mathrm{U}\end{array}$ & $\begin{array}{c}1 \mathrm{std} \\
\text { err } \\
(\%)\end{array}$ & $\begin{array}{c}{ }^{207} \mathrm{~Pb}^{*} \wedge / \\
{ }^{206} \mathrm{~Pb}\end{array}$ & $\begin{array}{l}1 \mathrm{std} \\
\text { err } \\
(\%)\end{array}$ & $\begin{array}{c}{ }^{206} \mathrm{~Pb}^{*} \wedge / \\
{ }^{238} \mathrm{U} \\
\text { (Ma) }\end{array}$ & $\begin{array}{c}2 \mathrm{std} \\
\text { err } \\
(\mathrm{Ma})\end{array}$ & $\begin{array}{c}{ }^{207} \mathrm{~Pb}^{*} \wedge / \\
{ }^{235} \mathrm{U} \\
\text { (Ma) }\end{array}$ & $\begin{array}{l}2 \text { std } \\
\text { err } \\
(\mathrm{Ma})\end{array}$ & $\begin{array}{c}{ }^{207} \mathrm{~Pb}^{*} \wedge / \\
{ }^{206} \mathrm{~Pb} \\
(\mathrm{Ma})\end{array}$ & $\begin{array}{c}2 \text { std } \\
\text { err } \\
(\mathrm{Ma})\end{array}$ \\
\hline $\mathrm{Z}-1$ & 0.162 & 293.9 & 2.659 & 1041 & 28 & 0.17 & 0.009557 & 0.16 & 0.06209 & 0.3 & 0.04712 & 0.22 & 61.3 & 0.2 & 61.2 & 0.4 & 55.4 & 10.5 \\
\hline $\mathrm{Z}-2$ & 0.128 & 270.2 & 2.464 & 1582 & 13 & 0.21 & 0.009521 & 0.45 & 0.06212 & 0.51 & 0.04732 & 0.21 & 61.1 & 0.5 & 61.2 & 0.6 & 65.5 & 9.9 \\
\hline
\end{tabular}


Table 2. ${ }^{40} \mathrm{Ar} /{ }^{39} \mathrm{Ar}$ data for intrusive rocks from southern Alaska.

[Analyses done at State University of New York, Albany]

\begin{tabular}{|c|c|c|c|c|c|c|c|c|c|}
\hline $\begin{array}{l}\text { Temp } \\
\left({ }^{\circ} \mathrm{C}\right)\end{array}$ & ${ }^{40} \mathrm{Ar} /{ }^{39} \mathrm{Ar}$ & ${ }^{37} \mathrm{Ar} /{ }^{39} \mathrm{Ar}$ & ${ }^{36} \mathrm{Ar} /{ }^{39} \mathrm{Ar}$ & $\begin{array}{l}\text { Moles } \\
{ }^{39} \mathrm{Ar}\end{array}$ & $\begin{array}{l}\% \text { total } \\
{ }^{39} \mathrm{Ar}\end{array}$ & $\%{ }^{40} \mathrm{Ar}^{*}$ & ${ }^{40} \mathrm{Ar}^{*} /{ }^{39} \mathrm{Ar}_{\mathrm{K}}$ & $\begin{array}{l}\text { Age } \\
(\mathrm{Ma})\end{array}$ & $\begin{array}{l}1 \text { sigma } \\
\text { error (Ma) }\end{array}$ \\
\hline \multicolumn{10}{|c|}{ Sample 88ADw230, Seldovia Bay dike, amphibole, J = 0.004546} \\
\hline 850 & 79.84 & 2.728 & 257.8 & 0.479 & 3.20 & 4.85 & 3.891 & 31.6 & 11.7 \\
\hline 950 & 12.96 & 7.067 & 19.89 & 0.39 & 5.81 & 57.0 & 7.539 & 60.8 & 6.1 \\
\hline 1,000 & 9.374 & 9.752 & 10.97 & 1.08 & 13.0 & 71.1 & 6.764 & 54.6 & 2.0 \\
\hline 1,020 & 8.206 & 10.61 & 6.616 & 1.27 & 21.5 & 83.3 & 6.943 & 56.1 & 2.1 \\
\hline 1,040 & 7.950 & 10.78 & 6.876 & 1.06 & 28.6 & 81.8 & 6.619 & 53.5 & 3.1 \\
\hline 1,050 & 7.639 & 11.09 & 4.156 & 1.37 & 37.8 & 91.9 & 7.137 & 57.6 & 1.2 \\
\hline 1,060 & 7.631 & 11.23 & 5.192 & 1.23 & 46.0 & 88.0 & 6.830 & 55.2 & 1.9 \\
\hline 1,100 & 7.795 & 11.29 & 4.936 & 3.89 & 72.0 & 89.8 & 7.075 & 57.1 & 0.8 \\
\hline 1,150 & 7.903 & 11.04 & 6.041 & 1.71 & 83.4 & 85.3 & 6.838 & 55.2 & 2.0 \\
\hline \multirow[t]{2}{*}{1,450} & 7.785 & 11.30 & 4.827 & 2.49 & 100 & 90.0 & 7.098 & 57.3 & 1.1 \\
\hline & & & & & & & $\begin{array}{r}\text { Total gas age }= \\
\mathbf{K}_{2} \mathbf{0}=\end{array}$ & $\begin{array}{l}\text { 55.6 Ma } \\
0.40 \text { percent }\end{array}$ & \\
\hline
\end{tabular}

\begin{tabular}{|c|c|c|c|c|c|c|c|c|c|}
\hline \multicolumn{10}{|c|}{ Sample M-19-88, Malina Bay dike, amphibole, J = 0.004531} \\
\hline 750 & 64.71 & 0.8520 & 183.8 & 0.555 & 6.65 & 16.1 & 10.43 & 83.3 & 15.6 \\
\hline 850 & 18.93 & 2.478 & 35.16 & 0.168 & 8.67 & 44.7 & 8.684 & 69.6 & 10.1 \\
\hline 900 & 12.76 & 6.692 & 11.70 & 0.100 & 9.87 & 71.5 & 9.744 & 77.9 & 12.8 \\
\hline 930 & 11.11 & 5.154 & 4.710 & 0.063 & 10.6 & 81.0 & 10.05 & 80.4 & 13.1 \\
\hline 960 & 11.51 & 7.385 & 37.84 & 0.072 & 11.5 & 6.07 & 0.7694 & 6.3 & 26.1 \\
\hline 990 & 11.71 & 12.28 & 16.15 & 0.147 & 13.3 & 62.7 & 7.753 & 62.3 & 17.1 \\
\hline 1,020 & 10.64 & 18.16 & 20.28 & 0.659 & 21.2 & 53.5 & 5.834 & 47.1 & 2.8 \\
\hline 1,040 & 9.475 & 20.30 & 12.58 & 1.67 & 41.2 & 73.5 & 7.104 & 57.2 & 1.0 \\
\hline 1,070 & 8.761 & 20.32 & 9.965 & 2.81 & 75.0 & 80.3 & 7.165 & 57.6 & 0.6 \\
\hline 1,110 & 10.02 & 20.11 & 15.46 & 0.765 & 84.2 & 66.0 & 6.786 & 54.6 & 2.4 \\
\hline 1,140 & 8.781 & 19.64 & 11.05 & 1.03 & 96.5 & 75.8 & 6.814 & 54.9 & 2.5 \\
\hline 1,200 & 7.728 & 10.46 & 24.33 & 0.053 & 97.1 & 12.7 & 1.175 & 9.6 & 48.2 \\
\hline 1,450 & 9.506 & 17.17 & 4.559 & 0.241 & 100 & 93.6 & 9.323 & 74.6 & 7.7 \\
\hline & & & & & & & $\begin{array}{r}\text { Total gas age }= \\
\mathbf{K}_{\mathbf{2}} \mathbf{0}=\end{array}$ & $\begin{array}{l}58.3 \mathrm{Ma} \\
0.23 \text { percent }\end{array}$ & \\
\hline \multicolumn{10}{|c|}{ Sample 88ACy9, Nuka pluton, biotite, J = 0.002943} \\
\hline 600 & 66.65 & 0.0798 & 200.7 & 0.930 & 1.59 & 11.0 & 7.338 & 38.5 & 2.6 \\
\hline 650 & 12.42 & 0.0187 & 7.402 & 7.56 & 14.6 & 82.2 & 10.22 & 53.5 & 0.3 \\
\hline 700 & 10.71 & 0.0072 & 1.266 & 12.2 & 35.5 & 96.4 & 10.33 & 54.0 & 0.2 \\
\hline 800 & 10.66 & 0.0078 & 0.9271 & 9.15 & 51.2 & 97.3 & 10.37 & 54.2 & 0.2 \\
\hline 870 & 10.83 & 0.0082 & 1.201 & 4.78 & 59.4 & 96.5 & 10.46 & 54.7 & 0.3 \\
\hline 950 & 10.89 & 0.0086 & 1.080 & 6.07 & 69.8 & 96.9 & 10.56 & 55.2 & 0.3 \\
\hline 1,050 & 10.65 & 0.0095 & 1.161 & 13.6 & 93.1 & 96.6 & 10.30 & 53.9 & 0.1 \\
\hline 1,150 & 10.55 & 0.0558 & 0.7973 & 3.10 & 98.4 & 97.4 & 10.31 & 53.9 & 0.2 \\
\hline \multirow[t]{2}{*}{1,350} & 10.65 & 0.0306 & 2.856 & 0.952 & 100 & 91.3 & 9.793 & 51.3 & 1.0 \\
\hline & & & & & & & $\begin{array}{r}\text { Total gas age }= \\
\mathbf{K}_{2} \mathbf{0}=\end{array}$ & $\begin{array}{l}53.8 \mathrm{Ma} \\
7.38 \text { percent }\end{array}$ & \\
\hline
\end{tabular}

sealed in silica glass vials. These were irradiated in the L67 position of the Ford Nuclear Reactor at the University of Michigan. Micas and flux monitors weighed approximately 35 $\mathrm{mg}$. Samples were heated in a molybdenum crucible within the ultra-high-vacuum system on line to the mass spectrometer using radio-frequency induction. Temperature estimates have an estimated uncertainty of $\pm 50^{\circ} \mathrm{C}$. Inert gases were purified using standard gettering techniques. The isotopic composition of Ar was measured digitally using a Nuclide 6-60-SGA 1.25 mass spectrometer. All data were corrected for mass discrimination and interfering argon isotopes produced during irradiation (Dalrymple and others, 1981). Error calculations included both the uncertainty in the analytical measurement and the uncertainty in the J-value and are reported at the $2 \sigma$ level. A plateau age represents the mean of ages in consecutive increments that are not different based on $2 \sigma$ analytical uncertainties. Analytical results are presented in table 3 .

\section{${ }^{40} \mathrm{Ar} /{ }^{39} \mathrm{Ar}$ Analytical Methods-University of Alaska, Fairbanks}

Samples were wrapped in aluminum foil and arranged in one of two levels, labeled top and bottom, within aluminum cans of $2.5-\mathrm{cm}$ diameter and $4.5-\mathrm{cm}$ height. Samples of hornblende 
Table 2. ${ }^{40} \mathrm{Ar} /{ }^{39} \mathrm{Ar}$ data for intrusive rocks from southern Alaska-Continued.

\begin{tabular}{|c|c|c|c|c|c|c|c|c|c|}
\hline $\begin{array}{l}\text { Temp } \\
\left({ }^{\circ} \mathrm{C}\right)\end{array}$ & ${ }^{40} \mathrm{Ar} /{ }^{39} \mathrm{Ar}$ & ${ }^{37} \mathrm{Ar} /{ }^{39} \mathrm{Ar}$ & ${ }^{36} \mathrm{Ar} /{ }^{39} \mathrm{Ar}$ & $\begin{array}{l}\text { Moles } \\
{ }^{39} \mathrm{Ar}\end{array}$ & $\begin{array}{l}\% \text { total } \\
{ }^{39} \mathrm{Ar}\end{array}$ & $\%{ }^{40} \mathrm{Ar}^{*}$ & ${ }^{40} \mathrm{Ar}^{*} /{ }^{39} \mathrm{Ar}_{\mathrm{K}}$ & $\begin{array}{l}\text { Age } \\
\text { (Ma) }\end{array}$ & $\begin{array}{l}1 \text { sigma } \\
\text { error (Ma) }\end{array}$ \\
\hline \multicolumn{10}{|c|}{ Sample TLP-95, Kodiak batholith, biotite, J = 0.005599} \\
\hline 600 & 44.11 & 0.2723 & 142.0 & 1.21 & 1.10 & 4.59 & 2.033 & 20.4 & 2.3 \\
\hline 670 & 6.817 & 0.0611 & 6.413 & 7.16 & 7.64 & 70.0 & 4.793 & 47.8 & 0.4 \\
\hline 740 & 6.533 & 0.0180 & 2.090 & 14.1 & 20.5 & 88.3 & 5.783 & 57.5 & 0.2 \\
\hline 800 & 6.424 & 0.0522 & 1.625 & 8.86 & 28.6 & 90.2 & 5.814 & 57.8 & 0.3 \\
\hline 850 & 6.865 & 0.0720 & 2.767 & 5.15 & 33.3 & 85.7 & 5.918 & 58.8 & 0.4 \\
\hline 930 & 6.841 & 0.0437 & 2.021 & 7.63 & 40.3 & 89.0 & 6.113 & 60.7 & 0.1 \\
\hline 1,020 & 6.539 & 0.0264 & 1.247 & 27.5 & 65.5 & 92.2 & 6.039 & 60.0 & 0.1 \\
\hline 1,100 & 6.351 & 0.0220 & 1.163 & 32.0 & 94.6 & 92.4 & 5.875 & 58.4 & 0.1 \\
\hline 1,200 & 6.949 & 0.1372 & 3.116 & 5.41 & 99.6 & 84.5 & 5.903 & 58.7 & 0.6 \\
\hline \multirow[t]{2}{*}{1,350} & 16.20 & 0.3129 & 30.03 & 0.469 & 100 & 43.4 & 7.210 & 71.4 & 5.2 \\
\hline & & & & & & & $\begin{array}{r}\text { Total gas age }= \\
\mathbf{K}_{2} \mathbf{0}=\end{array}$ & $\begin{array}{l}57.8 \mathrm{Ma} \\
7.15 \text { percent }\end{array}$ & \\
\hline \multicolumn{10}{|c|}{ Sample TL-2-87, Kodiak batholith, biotite, J = 0.005580} \\
\hline 600 & 28.46 & 0.1567 & 87.91 & 1.59 & 3.00 & 8.27 & 2.361 & 23.6 & 1.0 \\
\hline 670 & 6.775 & 0.0241 & 3.978 & 6.33 & 14.9 & 80.5 & 5.467 & 54.2 & 0.5 \\
\hline 720 & 6.298 & 0.0087 & 1.104 & 11.7 & 37.0 & 92.6 & 5.839 & 57.8 & 0.2 \\
\hline 790 & 6.282 & 0.0184 & 0.5791 & 10.3 & 56.4 & 95.0 & 5.979 & 59.2 & 0.3 \\
\hline 850 & 6.512 & 0.0432 & 1.193 & 2.68 & 61.4 & 92.1 & 6.029 & 59.7 & 0.6 \\
\hline 920 & 9.745 & 0.0301 & 11.12 & 2.81 & 66.8 & 64.7 & 6.326 & 62.6 & 0.7 \\
\hline 1,020 & 11.53 & 0.0190 & 15.71 & 1.34 & 69.3 & 58.2 & 6.753 & 66.7 & 1.5 \\
\hline 1,060 & 6.516 & 0.0138 & 1.351 & 7.15 & 82.8 & 91.6 & 5.984 & 59.3 & 0.3 \\
\hline 1,130 & 6.261 & 0.0213 & 0.5614 & 7.61 & 97.1 & 95.0 & 5.963 & 59.1 & 0.3 \\
\hline 1,200 & 6.355 & 0.1312 & 1.082 & 0.943 & 98.9 & 91.5 & 5.910 & 58.5 & 2.0 \\
\hline \multirow[t]{3}{*}{1,350} & 6.417 & 0.0894 & 1.682 & 0.590 & 100 & 87.9 & 5.792 & 57.4 & 2.1 \\
\hline & & & & & & & Total gas age $=$ & 57.6 Ma & \\
\hline & & & & & & & $\mathbf{K}_{2} \mathbf{0}=$ & 3.99 percent & \\
\hline \multicolumn{10}{|c|}{ Sample S-70, Sanak pluton, biotite, J = 0.002981} \\
\hline 600 & 21.25 & 0.1554 & 45.82 & 2.37 & 3.82 & 36.2 & 7.713 & 41.0 & 0.9 \\
\hline 650 & 14.87 & 0.0270 & 10.44 & 3.28 & 9.11 & 79.1 & 11.78 & 62.3 & 0.3 \\
\hline 700 & 12.75 & 0.0109 & 2.712 & 7.05 & 20.5 & 93.6 & 11.94 & 63.1 & 0.3 \\
\hline 750 & 12.23 & 0.0274 & 2.282 & 3.86 & 26.7 & 94.2 & 11.54 & 61.0 & 0.4 \\
\hline 800 & 12.10 & 0.0219 & 0.9366 & 7.90 & 39.5 & 97.6 & 11.82 & 62.5 & 0.3 \\
\hline 870 & 12.20 & 0.0329 & 0.9448 & 3.66 & 45.4 & 97.5 & 11.92 & 63.0 & 0.5 \\
\hline 950 & 12.82 & 0.0747 & 1.226 & 4.03 & 51.9 & 97.0 & 12.45 & 65.7 & 0.3 \\
\hline 1,050 & 12.22 & 0.0386 & 0.9487 & 17.4 & 80.0 & 97.6 & 11.93 & 63.1 & 0.1 \\
\hline 1,150 & 11.96 & 0.0791 & 0.9172 & 11.3 & 98.3 & 97.6 & 11.68 & 61.7 & 0.2 \\
\hline \multirow[t]{3}{*}{1,350} & 12.27 & 0.1108 & 3.253 & 1.07 & 100 & 91.6 & 11.30 & 59.8 & 1.4 \\
\hline & & & & & & & Total gas age = & 61.8 Ma & \\
\hline & & & & & & & $\mathbf{K}_{2} \mathbf{O}=$ & 7.76 percent & \\
\hline
\end{tabular}

Hb3gr (with an age of 1,071 Ma) and MMHb-1 (with an age of $513.9 \mathrm{Ma}$ ) were used to monitor the neutron flux. The samples were irradiated for $70 \mathrm{MWh}$ in position $5 \mathrm{c}$ of the uraniumenriched research reactor of McMaster University in Hamilton, Ontario. Upon their return from the reactor, the samples and monitors were loaded into 2-mm-diameter holes in a copper tray that was then loaded in a ultra-high-vacuum extraction line. The monitors were fused, and samples step-heated using a 6-watt argon-ion laser using the technique described in York and others (1981) and Layer and others (1987). Argon purification was achieved using a liquid nitrogen cold trap and a SAES Zr-Al getter at $400^{\circ} \mathrm{C}$. The samples were then analyzed in a VG-3600 mass spectrometer at the Geophysical Institute, University of
Alaska, Fairbanks. The argon isotopes measured were corrected for system blank and mass discrimination, as well as calcium, potassium, and chlorine interference reactions following procedures outlined in McDougall and Harrison (1988). For each sample, a plateau age was determined from three or more consecutive fractions whose ages are within $2 \sigma$ of each other and total more than 50 percent of gas release. Three samples of each mineral were dated, yielding three plateau ages. These were averaged together for a weighted mean plateau age; the weighting is the inverse of the variance (square of the standard deviation). The error associated with the mean age takes into account the individual errors on each sample (weighted error). The detailed analyses are given in table 4 , with all ages quoted to the $\pm 1 \sigma$ level). 
Table 3. ${ }^{40} \mathrm{Ar} /{ }^{39} \mathrm{Ar}$ data for intrusive rocks from southern Alaska.

[Analyses done at University of Maine, Orono. rad, radiogenic]

\begin{tabular}{|c|c|c|c|c|c|c|c|c|c|}
\hline $\begin{array}{l}\text { Temp } \\
\left({ }^{\circ} \mathrm{C}\right)\end{array}$ & ${ }^{40} \mathrm{Ar} /{ }^{39} \mathrm{Ar}$ & ${ }^{37} \mathrm{Ar} /{ }^{39} \mathrm{Ar}$ & ${ }^{36} \mathrm{Ar} /{ }^{39} \mathrm{Ar}$ & $\begin{array}{l}\text { Moles } \\
{ }^{39} \mathrm{Ar}\end{array}$ & $\begin{array}{l}\% \text { total } \\
{ }^{39} \mathrm{Ar}\end{array}$ & $\begin{array}{l}\% \text { rad } \\
{ }^{40} \mathrm{Ar}\end{array}$ & $\mathrm{K} / \mathrm{Ca}$ & $\begin{array}{l}\text { Age } \\
\text { (Ma) }\end{array}$ & $\begin{array}{c}1 \text { sigma } \\
\text { error (Ma) }\end{array}$ \\
\hline \multicolumn{10}{|c|}{ Sample 91ADW55g, Chernof pluton, biotite, $\mathrm{J}=0.006255$, plateau age $=54.2 \pm 1.1 \mathrm{Ma}$} \\
\hline 775 & 5.491 & 0.006 & 0.0022 & 189.0 & 21.3 & 88.1 & 86.6 & 53.8 & 0.6 \\
\hline 860 & 5.502 & 0.011 & 0.0023 & 120.0 & 13.5 & 87.2 & 42.9 & 53.3 & 0.7 \\
\hline 910 & 5.539 & 0.013 & 0.0021 & 82.9 & 9.3 & 88.2 & 36.3 & 54.3 & 0.8 \\
\hline 980 & 5.516 & 0.042 & 0.0023 & 67.1 & 7.5 & 87.6 & 11.7 & 53.7 & 1.3 \\
\hline 1,060 & 5.405 & 0.017 & 0.0017 & 206.1 & 23.2 & 90.2 & 28.9 & 54.2 & 0.9 \\
\hline 1,180 & 5.143 & 0.083 & 0.0009 & 95.7 & 10.8 & 94.6 & 5.9 & 54.1 & 0.8 \\
\hline Fuse & 7.104 & 0.068 & 0.0073 & 128.3 & 14.4 & 69.4 & 7.2 & 54.8 & 0.8 \\
\hline Totals & & & & 889.2 & 100.0 & & & 54.0 & 0.8 \\
\hline \multicolumn{10}{|c|}{ Sample 93ASB66, Tutka dike, hornblende, $\mathrm{J}=0.006268$, plateau age $=115.0 \pm 1.7 \mathrm{Ma}$} \\
\hline 930 & 160.30 & 0.979 & 0.4568 & 2.9 & 0.2 & 15.8 & 0.50 & 266.6 & 41.8 \\
\hline 930 & 153.76 & 4.626 & 0.4594 & 3.7 & 0.3 & 11.9 & 0.11 & 197.1 & 26.6 \\
\hline 1,070 & 27.01 & 5.247 & 0.0544 & 35.8 & 2.6 & 41.9 & 0.09 & 124.2 & 4.6 \\
\hline 1,070 & 12.43 & 4.610 & 0.0078 & 875.8 & 63.8 & 84.4 & 0.11 & 115.2 & 1.4 \\
\hline 1,120 & 12.80 & 4.705 & 0.0093 & 168.9 & 12.3 & 81.2 & 0.10 & 114.2 & 1.6 \\
\hline 1,155 & 13.35 & 4.634 & 0.0109 & 69.1 & 5.0 & 78.5 & 0.11 & 115.1 & 2.1 \\
\hline 1,190 & 15.66 & 4.729 & 0.0186 & 38.0 & 2.8 & 67.2 & 0.10 & 115.6 & 3.8 \\
\hline 1,250 & 22.59 & 5.180 & 0.0377 & 3.5 & 0.3 & 52.4 & 0.09 & 129.6 & 38.3 \\
\hline 1,310 & 13.26 & 5.256 & 0.0115 & 30.4 & 2.2 & 77.3 & 0.09 & 112.8 & 4.4 \\
\hline Fuse & 12.49 & 4.733 & 0.0072 & 144.1 & 10.5 & 85.8 & 0.10 & 117.7 & 1.3 \\
\hline Totals & & & & $1,372.2$ & 100.0 & & & 116.1 & 1.9 \\
\hline \multicolumn{10}{|c|}{ Sample 92AKu71b, Tustumena pluton, biotite, $\mathrm{J}=0.006578$, plateau age $=53.2 \pm 1.1 \mathrm{Ma}$} \\
\hline 675 & 14.718 & 0.306 & 0.0350 & 13.2 & 1.3 & 29.7 & 1.6 & 51.1 & 3.0 \\
\hline 775 & 8.062 & 0.017 & 0.0118 & 42.2 & 4.2 & 56.6 & 28.7 & 53.3 & 1.5 \\
\hline 845 & 6.061 & 0.069 & 0.0050 & 90.0 & 9.0 & 75.6 & 7.1 & 53.6 & 1.4 \\
\hline 940 & 5.430 & 0.006 & 0.0028 & 194.7 & 19.4 & 84.5 & 89.1 & 53.7 & 0.8 \\
\hline 1,030 & 5.291 & 0.032 & 0.0026 & 206.9 & 20.6 & 85.0 & 15.5 & 52.6 & 0.6 \\
\hline 1,130 & 4.947 & 0.026 & 0.0014 & 260.4 & 25.9 & 91.6 & 18.9 & 53.0 & 0.6 \\
\hline Fuse & 4.913 & 0.026 & 0.0015 & 197.2 & 19.6 & 90.9 & 18.7 & 52.3 & 0.7 \\
\hline Totals & & & & $1,004.6$ & 100.0 & & & 52.9 & 0.8 \\
\hline
\end{tabular}

\section{Geochronological Results}

\section{Sanak Pluton}

The Sanak pluton crops out on a remote island at the extreme southwestern end of the Sanak-Baranof plutonic belt. The sample for age determination was originally collected by Casey Moore and was acquired by Clendenen from Malcolm Hill. The same sample previously yielded a K/Ar biotite age of $61.4 \pm 1.8 \mathrm{Ma}$ (Moore, 1974a) and an $\mathrm{Rb} / \mathrm{Sr}$ isochron age of 62.7 $\pm 1.2 \mathrm{Ma}$ (Hill and others, 1981). Hill and others (1981) reported the following mineral assemblage: 26 percent quartz, 44 percent plagioclase, 7 percent potassium feldspar, 21 percent biotite, 1 percent oxides, 2 percent muscovite, and trace amounts of apatite, zircon, and kyanite. Two fractions of euhedral clear magmatic zircons were analyzed (table 1, fig. 3). For reasons outlined below, the results suggest a crystallization age of $61.1 \pm 0.5 \mathrm{Ma}$. Fraction A was composed of relatively equant multifaceted crystals, whereas fraction B was composed of needle-shaped elongate crystals. Fraction A contained some faint older xenocrystic cores, and this was borne out by significant zircon inheritance in the analyses. ${ }^{207} \mathrm{~Pb} /{ }^{206} \mathrm{~Pb}$ ages are 786 and $131 \mathrm{Ma}$ for fractions A and B, respectively. The zircons were strongly abraded and were low in uranium (288$308 \mathrm{ppm}$ ); these two factors together suggest that there would have been minimal secondary $\mathrm{Pb}$ loss from the zircons reflected in the analyses. The regression of the two points (fractions A and B) yields an upper intercept of about 1,580 $\mathrm{Ma}$, suggesting this as the average age of the inherited component. The lower intercept, $61.1 \pm 0.5 \mathrm{Ma}$, is interpreted as the age of magmatic crystallization. Fraction B is not concordant, and 61.1 Ma represents a minimum age due to the possibility of minor $\mathrm{Pb}$ loss. The ${ }^{206} \mathrm{~Pb} /{ }^{238} \mathrm{U}$ age of fraction $\mathrm{B}$ is 62.7 Ma, which, given its strong abrasion and low $\mathrm{U}$ concentration, is an absolute maximum age for the magmatic component. A biotite separate from sample S70, dated by the ${ }^{40} \mathrm{Ar} /$ ${ }^{39} \mathrm{Ar}$ method, yielded a slightly irregular age spectrum (table 2 , fig. 4). The corresponding isochron age is $62.7 \pm 0.38 \mathrm{Ma}$, in agreement with the other results. 
Table 4. ${ }^{40} \mathrm{Ar} /{ }^{39} \mathrm{Ar}$ data for intrusive rocks from southern Alaska.

[Analyses done at University of Alaska, Fairbanks. atmos., atmospheric]

\begin{tabular}{|c|c|c|c|c|c|c|c|c|c|c|c|c|c|c|c|}
\hline $\begin{array}{l}\text { Laser power } \\
\quad(\mathrm{mW})\end{array}$ & $\begin{array}{l}\text { Cumulative } \\
{ }^{39} \mathrm{Ar}\end{array}$ & $\begin{array}{l}{ }^{40} \mathrm{Ar} /{ }^{39} \mathrm{Ar} \\
\text { measured }\end{array}$ & \pm & $\begin{array}{l}{ }^{37} \mathrm{Ar} /{ }^{39} \mathrm{Ar} \\
\text { measured }\end{array}$ & \pm & $\begin{array}{l}{ }^{36} \mathrm{Ar} /{ }^{39} \mathrm{Ar} \\
\text { measured }\end{array}$ & \pm & $\begin{array}{l}\% \text { atmos. } \\
{ }^{40} \mathrm{Ar}\end{array}$ & \pm & $\mathrm{Ca} / \mathrm{K}$ & \pm & $\begin{array}{l}{ }^{40} \mathrm{Ar}^{*} / \\
{ }^{39} \mathrm{Ar}_{\mathrm{K}}\end{array}$ & \pm & $\begin{array}{l}\text { Age } \\
\text { (Ma) }\end{array}$ & $\stackrel{ \pm}{ \pm}(\mathrm{Ma})$ \\
\hline \multicolumn{16}{|c|}{$\begin{array}{l}\text { 95TD002b, Hive Island pluton, biotite \#1 } \\
\text { Weighted average of } \mathrm{J} \text { from standards }=0.006450 \pm 0.000028\end{array}$} \\
\hline 50 & 0.0268 & 8.587 & 0.160 & 0.014 & 0.007 & 0.017 & 0.005 & 59.61 & 16.27 & 0.026 & 0.013 & 3.457 & 1.396 & 39.8 & 15.9 \\
\hline 100 & 0.0548 & 6.175 & 0.065 & 0.017 & 0.013 & 0.005 & 0.003 & 24.42 & 13.79 & 0.031 & 0.024 & 4.645 & 0.849 & 53.3 & 9.6 \\
\hline 150 & 0.0832 & 5.184 & 0.063 & -0.007 & -0.011 & 0.003 & 0.002 & 19.49 & 13.24 & -0.013 & 0.019 & 4.151 & 0.685 & 47.7 & 7.8 \\
\hline 200 & 0.0990 & 5.260 & 0.104 & 0.014 & 0.022 & 0.008 & 0.005 & 44.05 & 28.11 & 0.025 & 0.040 & 2.927 & 1.472 & 33.7 & 16.8 \\
\hline 300 & 0.1288 & 5.909 & 0.078 & 0.012 & 0.010 & 0.006 & 0.003 & 32.63 & 16.88 & 0.021 & 0.019 & 3.962 & 0.995 & 45.5 & 11.3 \\
\hline 500 & 0.2992 & 5.325 & 0.034 & 0.002 & 0.002 & 0.002 & 0.000 & 11.10 & 2.67 & 0.004 & 0.003 & 4.709 & 0.145 & 54.0 & 1.6 \\
\hline 700 & 0.3171 & 6.069 & 0.119 & -0.026 & -0.012 & 0.007 & 0.002 & 32.01 & 9.55 & -0.048 & 0.022 & 4.107 & 0.584 & 47.2 & 6.6 \\
\hline 1,000 & 0.3689 & 5.475 & 0.034 & -0.006 & -0.004 & 0.003 & 0.001 & 16.33 & 4.56 & -0.011 & 0.007 & 4.557 & 0.250 & 52.3 & 2.8 \\
\hline 1,500 & 0.5768 & 5.009 & 0.024 & 0.001 & 0.001 & 0.001 & 0.000 & 6.89 & 1.13 & 0.002 & 0.003 & 4.638 & 0.061 & 53.2 & 0.7 \\
\hline 2,000 & 0.7230 & 5.007 & 0.035 & 0.002 & 0.002 & 0.001 & 0.000 & 4.40 & 1.88 & 0.003 & 0.004 & 4.759 & 0.099 & 54.5 & 1.1 \\
\hline 4,000 & 1.0000 & 4.946 & 0.022 & 0.003 & 0.001 & 0.001 & 0.000 & 6.22 & 1.78 & 0.006 & 0.002 & 4.612 & 0.090 & 52.9 & 1.0 \\
\hline Integrated & & 5.253 & 0.013 & 0.002 & 0.001 & 0.002 & 0.000 & 12.83 & 1.42 & 0.004 & 0.002 & 4.554 & 0.075 & 52.2 & 0.9 \\
\hline \multicolumn{16}{|c|}{$\begin{array}{l}\text { 95TD002b, Hive Island pluton, biotite } \# 2 \\
\text { ted average of } \mathrm{J} \text { from standards }=0.006450 \pm 0.000028\end{array}$} \\
\hline 100 & 0.0321 & 7.125 & 0.118 & -0.007 & -0.021 & 0.009 & 0.004 & 35.61 & 16.02 & -0.012 & 0.038 & 4.569 & 1.141 & 52.4 & 12.9 \\
\hline 300 & 0.3282 & 5.266 & 0.027 & -0.001 & -0.001 & 0.002 & 0.000 & 9.52 & 1.63 & -0.002 & 0.003 & 4.739 & 0.089 & 54.3 & 1.0 \\
\hline 600 & 0.6352 & 4.956 & 0.015 & 0.001 & 0.001 & 0.001 & 0.000 & 6.51 & 1.96 & 0.002 & 0.002 & 4.606 & 0.098 & 52.8 & 1.1 \\
\hline 900 & 0.8927 & 4.896 & 0.038 & -0.001 & -0.001 & 0.001 & 0.001 & 5.14 & 3.38 & -0.001 & 0.002 & 4.618 & 0.168 & 52.9 & 1.9 \\
\hline 1,200 & 0.9543 & 5.058 & 0.064 & 0.014 & 0.018 & 0.000 & -0.002 & -0.07 & 14.63 & 0.026 & 0.033 & 5.033 & 0.738 & 57.6 & 8.3 \\
\hline 1,500 & 0.9716 & 4.966 & 0.101 & 0.045 & 0.045 & 0.002 & 0.009 & 13.50 & 52.61 & 0.083 & 0.082 & 4.271 & 2.599 & 49.0 & 29.4 \\
\hline 2,000 & 0.9833 & 4.903 & 0.174 & -0.015 & -0.071 & 0.011 & 0.007 & 69.00 & 45.24 & -0.028 & 0.130 & 1.511 & 2.206 & 17.5 & 25.4 \\
\hline 5,000 & 0.9977 & 5.153 & 0.151 & -0.014 & -0.065 & 0.007 & 0.007 & 42.69 & 38.54 & -0.025 & 0.119 & 2.936 & 1.977 & 33.9 & 22.6 \\
\hline 9,000 & 1.0000 & 4.242 & 0.796 & 0.123 & 0.300 & -0.003 & -0.052 & -17.76 & 421.28 & 0.225 & 0.550 & 4.962 & 15.482 & 56.8 & 174.6 \\
\hline Integrated & & 5.109 & 0.015 & 0.001 & 0.002 & 0.002 & 0.000 & 9.29 & 2.10 & 0.002 & 0.004 & 4.608 & 0.108 & 52.8 & 1.2 \\
\hline \multicolumn{16}{|c|}{$\begin{array}{c}\text { 95TD002b, Hive Island pluton, biotite } \# 3 \\
\text { Weighted average of } \mathrm{J} \text { from standards }=0.006450 \pm 0.000028\end{array}$} \\
\hline 100 & 0.0409 & 6.991 & 0.091 & -0.011 & -0.006 & 0.010 & 0.001 & 40.79 & 4.29 & -0.020 & 0.012 & 4.122 & 0.305 & 47.3 & 3.5 \\
\hline 300 & 0.1615 & 5.549 & 0.035 & 0.001 & 0.002 & 0.003 & 0.000 & 15.11 & 1.51 & 0.001 & 0.004 & 4.686 & 0.089 & 53.7 & 1.0 \\
\hline 900 & 0.3638 & 5.302 & 0.020 & -0.001 & -0.001 & 0.002 & 0.000 & 12.23 & 1.25 & -0.002 & 0.002 & 4.628 & 0.068 & 53.1 & 0.8 \\
\hline 1,200 & 0.7757 & 5.702 & 0.030 & 0.001 & 0.001 & 0.004 & 0.000 & 18.27 & 0.80 & 0.001 & 0.001 & 4.637 & 0.053 & 53.2 & 0.6 \\
\hline 1,500 & 0.8074 & 5.115 & 0.046 & -0.013 & -0.009 & 0.001 & 0.001 & 5.64 & 6.07 & -0.025 & 0.017 & 4.799 & 0.312 & 55.0 & 3.5 \\
\hline 2,000 & 0.8360 & 5.140 & 0.057 & -0.011 & -0.013 & 0.001 & 0.001 & 5.17 & 6.80 & -0.021 & 0.024 & 4.847 & 0.352 & 55.5 & 4.0 \\
\hline 5,000 & 0.9223 & 4.892 & 0.030 & -0.002 & -0.004 & 0.000 & 0.001 & 2.63 & 3.52 & -0.004 & 0.007 & 4.735 & 0.174 & 54.3 & 2.0 \\
\hline 9,000 & 1.0000 & 4.964 & 0.033 & -0.007 & -0.004 & 0.000 & -0.001 & -0.98 & 3.30 & -0.013 & 0.008 & 4.983 & 0.166 & 57.1 & 1.9 \\
\hline Integrated & & 5.493 & 0.015 & -0.002 & -0.001 & 0.003 & 0.000 & 14.61 & 0.67 & -0.003 & 0.002 & 4.666 & 0.039 & 53.5 & 0.5 \\
\hline
\end{tabular}


Table 4. ${ }^{40} \mathrm{Ar} /{ }^{39} \mathrm{Ar}$ data for intrusive rocks from southern Alaska—Continued.

\begin{tabular}{|c|c|c|c|c|c|c|c|c|c|c|c|c|c|c|c|}
\hline $\begin{array}{l}\text { Laser power } \\
\quad(\mathrm{mW})\end{array}$ & $\begin{array}{l}\text { Cumulative } \\
{ }^{39} \mathrm{Ar}\end{array}$ & $\begin{array}{l}{ }^{40} \mathrm{Ar} /{ }^{39} \mathrm{Ar} \\
\text { measured }\end{array}$ & \pm & $\begin{array}{l}{ }^{37} \mathrm{Ar} /{ }^{39} \mathrm{Ar} \\
\text { measured }\end{array}$ & \pm & $\begin{array}{l}{ }^{36} \mathrm{Ar} /{ }^{39} \mathrm{Ar} \\
\text { measured }\end{array}$ & \pm & $\begin{array}{l}\% \text { atmos. } \\
{ }^{40} \mathrm{Ar}\end{array}$ & \pm & $\mathrm{Ca} / \mathrm{K}$ & \pm & ${ }^{{ }^{40} \mathrm{Ar}^{*} /}$ & \pm & $\begin{array}{l}\text { Age } \\
\text { (Ma) }\end{array}$ & $\stackrel{ \pm}{ \pm}$ \\
\hline \multicolumn{16}{|c|}{$\begin{array}{l}\text { 91 AKU003, Harris Bay pluton, biotite \#1 } \\
\text { ted average of } \mathrm{J} \text { from standards }=0.006450 \pm 0.000028\end{array}$} \\
\hline 50 & 0.0029 & 9.834 & 0.366 & 0.142 & 0.060 & 0.023 & 0.014 & 68.30 & 41.57 & 0.260 & 0.110 & 3.109 & 4.008 & 35.8 & 45.7 \\
\hline 100 & 0.0276 & 6.495 & 0.056 & 0.015 & 0.010 & 0.007 & 0.002 & 31.88 & 7.77 & 0.027 & 0.018 & 4.405 & 0.505 & 50.5 & 5.7 \\
\hline 150 & 0.1035 & 5.738 & 0.035 & 0.007 & 0.002 & 0.005 & 0.000 & 23.66 & 2.41 & 0.013 & 0.004 & 4.358 & 0.141 & 50.0 & 1.6 \\
\hline 200 & 0.1668 & 5.196 & 0.037 & 0.009 & 0.003 & 0.002 & 0.000 & 12.24 & 2.57 & 0.017 & 0.006 & 4.535 & 0.138 & 52.0 & 1.6 \\
\hline 300 & 0.2724 & 4.984 & 0.042 & 0.006 & 0.001 & 0.002 & 0.001 & 10.17 & 4.31 & 0.010 & 0.002 & 4.451 & 0.217 & 51.1 & 2.5 \\
\hline 500 & 0.4342 & 4.865 & 0.023 & 0.002 & 0.001 & 0.001 & 0.000 & 6.60 & 1.54 & 0.003 & 0.002 & 4.517 & 0.078 & 51.8 & 0.9 \\
\hline 700 & 0.5723 & 4.858 & 0.024 & 0.001 & 0.002 & 0.001 & 0.000 & 7.20 & 1.71 & 0.003 & 0.004 & 4.482 & 0.086 & 51.4 & 1.0 \\
\hline 1,000 & 0.6972 & 4.758 & 0.027 & 0.003 & 0.002 & 0.001 & 0.000 & 6.56 & 2.07 & 0.006 & 0.003 & 4.419 & 0.101 & 50.7 & 1.1 \\
\hline 1,500 & 0.8127 & 4.778 & 0.041 & -0.002 & -0.002 & 0.001 & 0.000 & 7.39 & 2.54 & -0.003 & 0.003 & 4.398 & 0.127 & 50.5 & 1.4 \\
\hline 2,000 & 0.8821 & 4.758 & 0.035 & 0.003 & 0.003 & 0.001 & 0.001 & 8.10 & 3.56 & 0.006 & 0.006 & 4.346 & 0.172 & 49.9 & 1.9 \\
\hline 4,000 & 1.0000 & 4.739 & 0.040 & 0.004 & 0.002 & 0.001 & 0.000 & 4.30 & 2.39 & 0.007 & 0.004 & 4.508 & 0.120 & 51.7 & 1.4 \\
\hline Integrated & & 4.973 & 0.011 & 0.004 & 0.001 & 0.002 & 0.000 & 10.02 & 0.88 & 0.007 & 0.001 & 4.449 & 0.045 & 51.0 & 0.6 \\
\hline \multicolumn{16}{|c|}{$\begin{array}{l}\text { 91 AKU003, Harris Bay pluton, biotite \#2 } \\
\text { ted average of } \mathrm{J} \text { from standards }=0.006450 \pm 0.000028\end{array}$} \\
\hline 100 & 0.0352 & 7.746 & 0.117 & 0.063 & 0.006 & 0.011 & 0.001 & 42.70 & 3.63 & 0.116 & 0.011 & 4.422 & 0.292 & 50.7 & 3.3 \\
\hline 200 & 0.1661 & 5.931 & 0.032 & 0.004 & 0.002 & 0.004 & 0.000 & 18.39 & 1.80 & 0.007 & 0.003 & 4.817 & 0.111 & 55.2 & 1.2 \\
\hline 300 & 0.3160 & 5.288 & 0.026 & 0.005 & 0.001 & 0.002 & 0.000 & 10.13 & 1.62 & 0.010 & 0.002 & 4.727 & 0.089 & 54.2 & 1.0 \\
\hline 500 & 0.5423 & 5.030 & 0.017 & 0.003 & 0.001 & 0.001 & 0.000 & 7.62 & 0.73 & 0.006 & 0.002 & 4.620 & 0.040 & 53.0 & 0.5 \\
\hline 700 & 0.7350 & 4.885 & 0.014 & 0.006 & 0.001 & 0.001 & 0.000 & 4.98 & 1.09 & 0.010 & 0.002 & 4.614 & 0.055 & 52.9 & 0.6 \\
\hline 900 & 0.8189 & 4.851 & 0.042 & 0.000 & -0.002 & 0.000 & 0.000 & 2.25 & 2.65 & 0.000 & 0.004 & 4.714 & 0.135 & 54.0 & 1.5 \\
\hline 1,100 & 0.8652 & 4.815 & 0.030 & 0.016 & 0.004 & 0.001 & 0.001 & 6.09 & 3.97 & 0.029 & 0.008 & 4.495 & 0.192 & 51.6 & 2.2 \\
\hline 1,300 & 0.9176 & 4.773 & 0.039 & -0.004 & -0.003 & 0.000 & 0.001 & 2.64 & 4.37 & -0.008 & 0.006 & 4.619 & 0.211 & 53.0 & 2.4 \\
\hline 1,500 & 0.9478 & 4.688 & 0.052 & -0.021 & -0.006 & 0.000 & -0.002 & -3.01 & 10.18 & -0.038 & 0.010 & 4.799 & 0.477 & 55.0 & 5.4 \\
\hline 2,000 & 1.0003 & 4.728 & 0.026 & -0.004 & -0.003 & 0.001 & 0.001 & 3.29 & 5.07 & -0.008 & 0.006 & 4.544 & 0.240 & 52.1 & 2.7 \\
\hline 5,000 & 1.0000 & 32.834 & 6.076 & 1.265 & 0.595 & 0.126 & 0.088 & 113.40 & 1010.63 & 2.323 & 1.094 & -4.400 & 25.127 & -51.9 & 300.9 \\
\hline Integrated & & 5.180 & 0.010 & 0.005 & 0.001 & 0.002 & 0.000 & 9.53 & 0.72 & 0.008 & 0.001 & 4.660 & 0.038 & 53.4 & 0.5 \\
\hline \multicolumn{16}{|c|}{$\begin{array}{c}\text { 91AKU003, Harris Bay pluton, biotite \#3 } \\
\text { Weighted average of } \mathrm{J} \text { from standards }=0.006450 \pm 0.000028\end{array}$} \\
\hline 900 & 0.3417 & 4.707 & 0.031 & 0.013 & 0.002 & 0.001 & 0.001 & 4.97 & 3.52 & 0.024 & 0.003 & 4.446 & 0.168 & 51.0 & 1.9 \\
\hline 1,100 & 0.6030 & 4.840 & 0.037 & 0.007 & 0.004 & 0.002 & 0.001 & 12.60 & 4.58 & 0.013 & 0.007 & 4.205 & 0.223 & 48.2 & 2.5 \\
\hline 1,300 & 0.8198 & 4.853 & 0.037 & 0.007 & 0.007 & 0.002 & 0.001 & 11.41 & 8.52 & 0.013 & 0.013 & 4.274 & 0.413 & 49.0 & 4.6 \\
\hline 1,500 & 0.8659 & 4.874 & 0.087 & -0.003 & -0.023 & 0.008 & 0.004 & 49.05 & 22.63 & -0.006 & 0.042 & 2.469 & 1.098 & 28.2 & 12.3 \\
\hline 2,000 & 0.9664 & 4.728 & 0.060 & 0.000 & -0.009 & 0.005 & 0.002 & 29.99 & 14.77 & 0.000 & 0.017 & 3.290 & 0.695 & 37.7 & 7.9 \\
\hline 5,000 & 1.0000 & 4.632 & 0.124 & 0.064 & 0.030 & 0.007 & 0.006 & 44.99 & 39.11 & 0.117 & 0.056 & 2.532 & 1.801 & 28.8 & 20.4 \\
\hline Integrated & & 4.774 & 0.019 & 0.006 & 0.003 & 0.001 & 0.001 & 5.61 & 4.67 & 0.011 & 0.006 & 4.479 & 0.223 & 46.7 & 1.8 \\
\hline
\end{tabular}



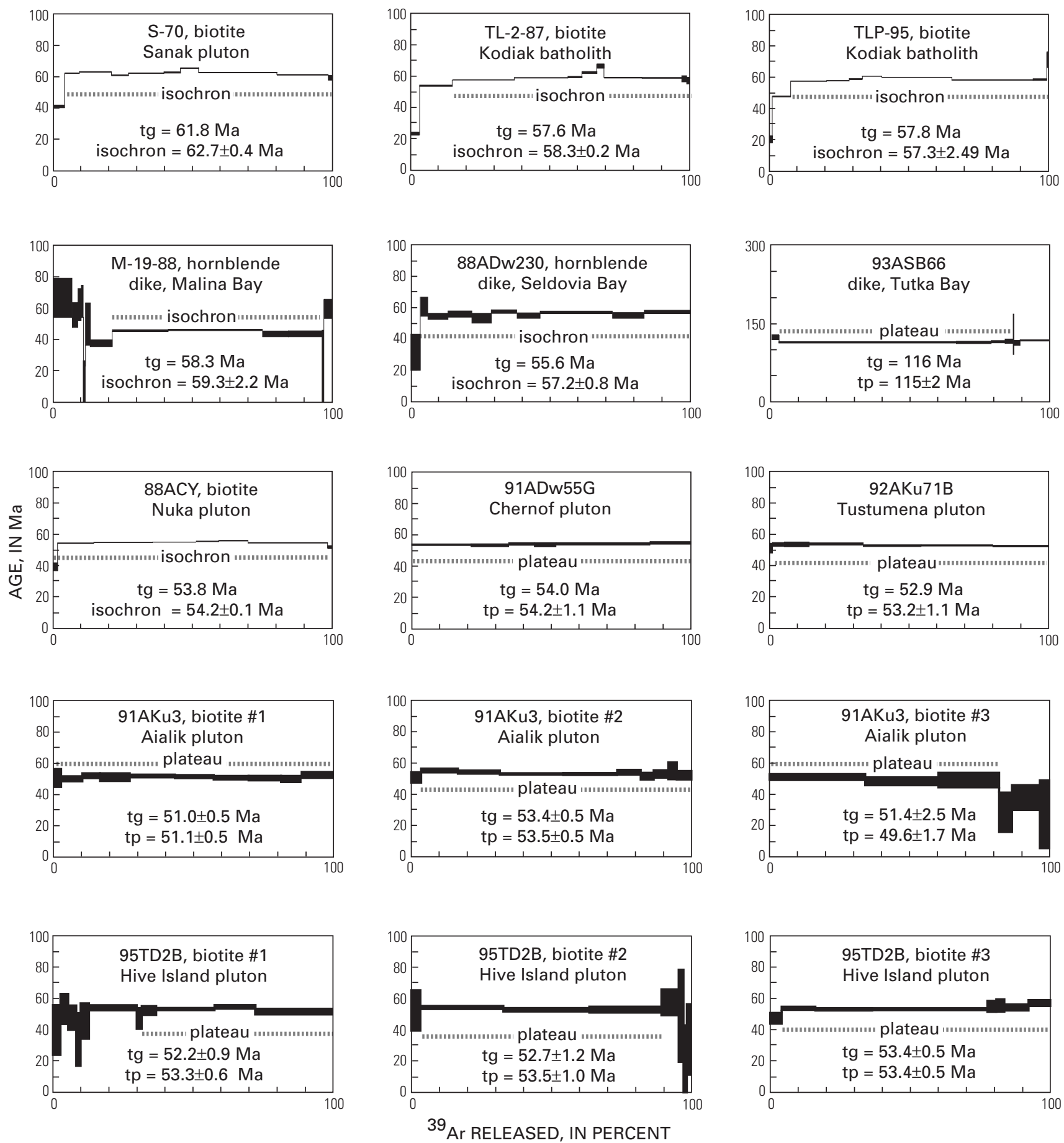

Figure 4. Argon release spectra for plutons dated in this study. Dashed lines indicate steps used to calculate isochron and plateau ages. tg, total gas (integrated) age; tp, plateau age.

\section{Shumagin Pluton}

The outer Shumagin Islands, an archipelago located 175$240 \mathrm{~km}$ along strike from the southwestern end of the SanakBaranof plutonic belt, are underlain by Upper Cretaceous turbidites intruded by early Tertiary granodiorite. It is not known whether the granodiorite exposed on various islands (Moore, 1974b) represents a single, irregularly shaped pluton, or more than one. The sample for age determination was collected on Big Koniuji Island by Maurice Witschard. The dating sample is a medium- to coarse-grained, nonfoliated biotite granodiorite. According to Hill and others (1981), three granodiorite samples from near our dating-sample location average 69 percent $\mathrm{SiO}_{2}$ and 3.1 percent $\mathrm{K}_{2} \mathrm{O}$. Two fractions of euhedral, clear, magmatic zircons were analyzed (table 1, fig. 3). Both fractions were concordant and unequivocally indicate a crystallization age of $61.1 \pm 0.3 \mathrm{Ma}$ (mean of two ${ }^{206} \mathrm{~Pb} /{ }^{238} \mathrm{U}$ ages). As summarized by Bradley and others (1993), eight previously published $\mathrm{K} / \mathrm{Ar}$ (biotite) and $\mathrm{Rb} / \mathrm{Sr}$ (mineral/whole-rock isochron) ages from the Shumagin pluton range from 57.4 \pm 2.9 to 
$60.7 \pm 1.8 \mathrm{Ma}$; one K/Ar muscovite age was significantly older at $65.6 \pm 3.3 \mathrm{Ma}$. Our new $\mathrm{U} / \mathrm{Pb}$ zircon age eclipses these older age determinations.

\section{Kodiak Batholith at Terror Lake}

The Kodiak batholith is one of the largest near-trench plutons in the world, more than $100 \mathrm{~km}$ long and 5-10 km wide. One of two granodiorite samples was obtained by Peter Vrolik from the hydroelectric tunnel at Terror Lake; the other was collected by Clendenen from the peak above the tunnel. Both samples were analyzed by the ${ }^{40} \mathrm{Ar} /{ }^{39} \mathrm{Ar}$ method (fig. 4, table 2 ). Biotite separates from the two samples yielded slightly humped age spectra, giving isochron ages of $58.3 \pm 0.2$ and $57.8 \pm 2.5 \mathrm{Ma}$.

\section{Malina Bay Dike}

A 1-m-thick dike, cutting the Uyak Complex at Malina Bay on Afognak Island, was analyzed by the ${ }^{40} \mathrm{Ar} /{ }^{39} \mathrm{Ar}$ method. The results were reported by Clendenen (1991) and are repeated here. The age spectrum shows anomalously old ages in the early steps but has a plateau represented by 75 percent of total gas released. Data from these four steps give an isochron age of 59.3 $\pm 2.2 \mathrm{Ma}$ (fig. 4, table 2).

\section{Seldovia Bay Dike}

A dike that cuts the McHugh Complex near the head of Seldovia Bay (fig. 2) was analyzed by the ${ }^{40} \mathrm{Ar} /{ }^{39} \mathrm{Ar}$ method. The dike, collected by Will White, is a leucocratic porphyry containing feldspar and hornblende phenocrysts. Aside from the sample location, little else is known about this rock; a hand sample and major-element data apparently once existed but could not be located. A hornblende separate yielded a mainly flat, but somewhat irregular, age spectrum corresponding to an isochron age of $57.0 \pm 0.2 \mathrm{Ma}$ (fig. 4, table 2).

\section{Tutka Bay Dike}

The most surprising age reported herein is from a dike that cuts massive graywacke of the McHugh Complex about $4 \mathrm{~km}$ southeast of the head of Tutka Bay (fig. 2). The dike is a hornblende-phyric basaltic andesite (56.6 weight percent $\mathrm{SiO}_{2}$; D.C. Bradley, unpub. data, 1994). A hornblende separate yielded a ${ }^{40} \mathrm{Ar} /{ }^{39} \mathrm{Ar}$ method plateau age of $115.0 \pm 1.7 \mathrm{Ma}$ (fig. 4, table 3). This unexpected result is the only pre-Tertiary age reported in the present paper; its possible significance is discussed in a later section.

\section{Nuka Pluton}

The Nuka pluton crops out along the southern coast of the Kenai Peninsula in the eastern Seldovia quadrangle (fig. 2). The rock is a medium- to coarse-grained granodiorite containing biotite, muscovite, and rare hornblende. Xenocrysts of kyanite have been observed (Donley and others, 1995). Four wholerock samples from the Nuka pluton vary from 67.3 to 72.4 weight percent $\mathrm{SiO}_{2}$ and 1.9 to 2.2 weight percent $\mathrm{K}_{2} \mathrm{O}$ (D.C. Bradley, unpub. data, 1994). Locally, the plutonic rocks have a weak tectonic foliation; elsewhere they are unfoliated. A sample of granodiorite from the Nuka pluton (88ACy9, collected by Bela Csejtey) yielded equant and elongate crystals of magmatic zircon, some with xenocrystic cores (fig. 3, table 1). All of the zircons contained a significant inherited component, which includes ages as young as $570 \mathrm{Ma}$ and probably older than 1,500 Ma. A precise crystallization age cannot be derived from the zircons because of the significant scatter due to variable age of inheritance and lack of concordant data. Fortunately, igneous monazite is also an accessory mineral in this rock; two analyses yield concordant to slightly reversely discordant ages at 56.0 Ma. The points are slightly above concordia due to the excess ${ }^{206} \mathrm{~Pb}$ typical of igneous monazite (see Scharer, 1984, for a more detailed explanation) resulting from excess ${ }^{230}$ Th upon crystallization. ${ }^{207} \mathrm{~Pb} /{ }^{235} \mathrm{U}$ ages of monazite are unaffected by this problem and have consistent and overlapping ages of 56.0 $\pm 0.3 \mathrm{Ma}$, which we regard as the best estimate of the age of crystallization of monazite as well as zircon. A biotite separate from sample $88 \mathrm{ACy} 9$ was also analyzed by the ${ }^{40} \mathrm{Ar} /{ }^{39} \mathrm{Ar}$ method (table 2). The age spectrum is nearly flat but has a slight hump shape; the corresponding isochron age is $54.2 \pm 0.1 \mathrm{Ma}$ (fig. 4, table 2).

\section{Chernof Stock}

The Chernof stock crops out in nunataks near the confluence of the Chernof Glacier and Harding Icefield (fig. 2). It is a nonfoliated, medium-grained biotite granodiorite. Majorelement whole-rock analysis of the dating sample showed 71.4 weight percent $\mathrm{SiO}_{2}$ and 1.8 weight percent $\mathrm{K}_{2} \mathrm{O}$ (D.C. Bradley, unpub. data, 1994). A biotite separate yielded a plateau age of

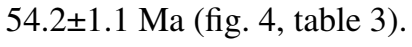

\section{Aialik Pluton}

The Aialik pluton crops out along the southern coast of the Kenai Peninsula southwest of Seward, in the Blying Sound and Seldovia quadrangles (fig. 2). Tysdal and Case (1979) informally called it the "granite of Harding Icefield region" and assigned it an Eocene age. The largest contiguous part of the pluton underlies the peninsula between Harris and Aialik Bays; nearby islands of granodiorite to the southeast and nearby nunataks of granodiorite to the northwest are very likely part of the same pluton. The Tustumena and Hive Island plutons are discussed under separate headings belowthey are similar in age and lithology and might, in fact, be continuous beneath ice and water with the main part of the Aialik pluton. In the Seldovia quadrangle, the Aialik pluton is a medium- to coarse-grained granodiorite containing biotite, muscovite, rare hornblende, and xenocrystic kyanite (Donley and others, 1995). Tysdal and Case (1979) reported subordinate granitic and tonalitic phases in the Blying Sound quadrangle. Two whole-rock samples from the pluton in Seldovia quadrangle vary from 69.3 to 73.4 weight percent $\mathrm{SiO}_{2}$ and 2.9 to 3.9 weight percent $\mathrm{K}_{2} \mathrm{O}$ (D.C. Bradley, 
unpub. data, 1994). The pluton locally displays a tectonic foliation that also affects aplitic dikes (T. Kusky, unpub. field notes, 1991). A biotite separate from the pluton at Harris Bay, collected by Tim Kusky and analyzed at University of Alaska, Fairbanks, yielded three plateau ages: $51.1 \pm 0.5,53.5 \pm 0.5$, and 49.6 $\pm 1.7 \mathrm{Ma}$ (fig. 4, table 4). The weighted mean age for the sample is $52.2 \pm 0.9 \mathrm{Ma}$, which probably reflects the cooling age of the biotite.

\section{Tustumena Pluton}

The Tustumena pluton crops out in remote nunataks in the Seldovia and Kenai quadrangles, around the confluence of the Tustumena Glacier and Harding Icefield (fig. 2). It was not even known to exist until 1992, when the Seldovia D1 and D2 quadrangles were mapped (Bradley and others, 1999). In 1998, Bradley and Wilson (this volume) traced it northward into the Kenai quadrangle. The Harding Icefield obscures its relationship with the Nuka and Aialik plutons, of which it may be a part. Where sampled in reconnaissance, the Tustumena pluton consists of medium-grained, nonfoliated biotite granodiorite. A biotite separate, collected by Tim Kusky, yielded a plateau age of 52.2 \pm 1.1 Ma (table 3, fig. 4), which probably reflects the cooling age of the biotite.

\section{Hive Island Pluton}

Hive and Rugged Islands, near the mouth of Resurrection Bay, are composed of granodiorite (fig. 2). As noted above, it is not known whether or not these plutonic rocks are continuous with the main body of the Aialik pluton. Biotite from granodiorite at Hive Island, collected by Tom Donley, yielded three plateau ages of $53.3 \pm 0.6,53.5 \pm 1.0$, and $53.4 \pm 0.5$ Ma (table 4, fig. 4). The weighted mean age is $53.4 \pm 0.4 \mathrm{Ma}$, which we interpret as the cooling age of the biotite. This result overlaps with the mean age of the Aialik pluton at Harris Bay, permitting correlation.

\section{Discussion}

\section{Early Tertiary Near-Trench Magmatism}

The new isotopic ages allow some refinements to a plot of age versus distance along strike for intrusive rocks of the SanakBaranof belt (fig. 5). Figure 5 and table 5 include the new data from the present study, as well as other pertinent results since the last modifications were made to the age-distance plot published in Bradley and others (1993); these include ages in Hauessler and others (1995) and Poole (1996).

Bradley and others (1993) suggested that magmatism at the Sanak end of the plutonic belt probably began at 66-63 Ma. The value of $63 \mathrm{Ma}$ was based on two conventional K/Ar and two $\mathrm{Rb} / \mathrm{Sr}$ ages $(61.4 \pm 1.8$ to $63.1 \pm 1.2 \mathrm{Ma})$ of unknown reliablity.
We regard the new $61.1 \pm 0.5 \mathrm{Ma}$ zircon age for the Sanak pluton as a more reliable estimate of the age of emplacement than any of these earlier findings. The value of $66 \mathrm{Ma}$ for initiation of Sanak-Baranof magmatism made allowance for the conventional K/Ar muscovite age of $65.6 \pm 3.3 \mathrm{Ma}$ from the Shumagin pluton, the next pluton in the belt. In light of our new 61.1-Ma $\mathrm{U} / \mathrm{Pb}$ age of this pluton, we can suggest with confidence that near-trench magmatism commenced at about $61 \mathrm{Ma}$ at the western end of the Sanak-Baranof belt. The west-to-east age progression suggests the migration of a triple junction about $2,200 \mathrm{~km}$ along strike in about $11 \mathrm{~m}$.y., at an average rate of about $200 \mathrm{~km} / \mathrm{m}$.y. This is somewhat faster than the rate of $140-170 \mathrm{~km} / \mathrm{m}$.y. suggested by Bradley and others (1993).

As discussed by Bradley and others (1993), several factors complicate tectonic interpretations based on figure 5. First, the Chugach-Prince William terrane has been displaced some distance northward as a result of Tertiary motion on coast-parallel dextral faults (Coe and others, 1985; Bol and others, 1992). Bol and others (1992) estimated $13 \pm 9^{\circ}$ of northward motionequivalent to somewhere between $\sim 400$ and $\sim 2,400 \mathrm{~km}$. The position of the triple junction, inferred from near-trench plutons within the Chugach-Prince William terrane, must have been a commensurate distance farther south. Second, paleomagnetic data suggest that the southern Alaska orocline formed sometime during the interval between 65 and $35 \mathrm{Ma}$ (Coe and others, 1985); Alaska's southern margin must have been considerably straighter before than after. The essentially linear trend of ages in figure 5 would be difficult if not impossible to achieve by the migration of a trench-ridge-trench triple junction along the margin in its present, oroclinal configuration. Accordingly, it seems reasonable to conclude that the oroclinal bend could not have been imposed until after the triple junction had migrated past the oroclinal axis in Prince William Sound, around 54 Ma. A third complication relates to the unknown geometry of any transform faults associated with the subducting ridge system: the spacing, length, and sense of motion of such transforms are highly conjectural because the relevant parts of the Kula and Farallon plates have long since been subducted. In the area of figure 1, alternating pluton-rich and pluton-poor sectors of the Chugach terrane might perhaps record the subduction of ridge segments and transform segments, respectively. Poole (1996) invoked a transform offset to explain near-trench intrusive ages that deviate from the broadly linear age trend (fig. 5), east of the present study area. Sisson and Pavlis (1993) and Pavlis and Sisson (1995) explained the lengthy history of near-trench metamorphism and magmatism in the Chugach Metamorphic Complex (fig. 1) in terms of a reorganization of the PacificKula-Farallon system, and a resulting short-term reversal of the migrating trench-ridge-trench triple junction. This corresponds to the "56-Ma plate reorganization" of Engebretson and others (1985). The age of this reorganization, however, is younger than previous accounts (e.g., Sisson and Pavlis, 1993; Pavlis and Sisson, 1995) would suggest. The reorganization occurred during Chron 23R, the age of which is now fixed between 52.35 and $51.75 \mathrm{Ma}$, based on the most recent compilation of Pacific magnetic anomalies (Atwater and Severinghaus, 1989), coupled with the new magnetic polarity time scale of Berggren and others (1995). Finally, the possibility that the subducting ridge was one other than the Kula-Farallon ridge cannot be ruled out. 


\section{Early Cretaceous Near-Trench Magmatism}

The Early Cretaceous dike from Tutka Bay drainage is the only rock dated in the present paper that does not have an early Tertiary age. Judging from the age spectrum for this sample, there seems no reason to doubt an age of about $115 \mathrm{Ma}$. During the Seldovia mapping project, more than 200 basalt, andesite, dacite, and rhyolite dikes were sampled and their attitudes and thicknesses measured. Roughly half of the dikes cut the Maastrichtian Valdez Group and hence cannot be as old as 115 Ma. Those that cut only the McHugh Complex are similar to dikes cutting the Valdez Group, and most are probably Tertiary in age; but a few, at least, may be Early Cretaceous. Most dikes in the Seldovia quadrangle strike roughly east-west and are subvertical (Bradley and others, 1995); the Tutka Bay dike strikes northeast-southwest and dips moderately to the northwest. This dike represents a near-trench magmatic event that has gone unrecognized in the Kenai Peninsula. It may be related to leucotonalite to trondhjemite plutons that were emplaced into the McHugh Complex and its backstop in the western Chugach Mountains near Palmer (Pavlis and others, 1988). The plutons near Palmer are not very well dated: the most reliable determination appears to be ${ }^{40} \mathrm{Ar} /{ }^{39} \mathrm{Ar}$ plateau age of $118 \mathrm{Ma}$

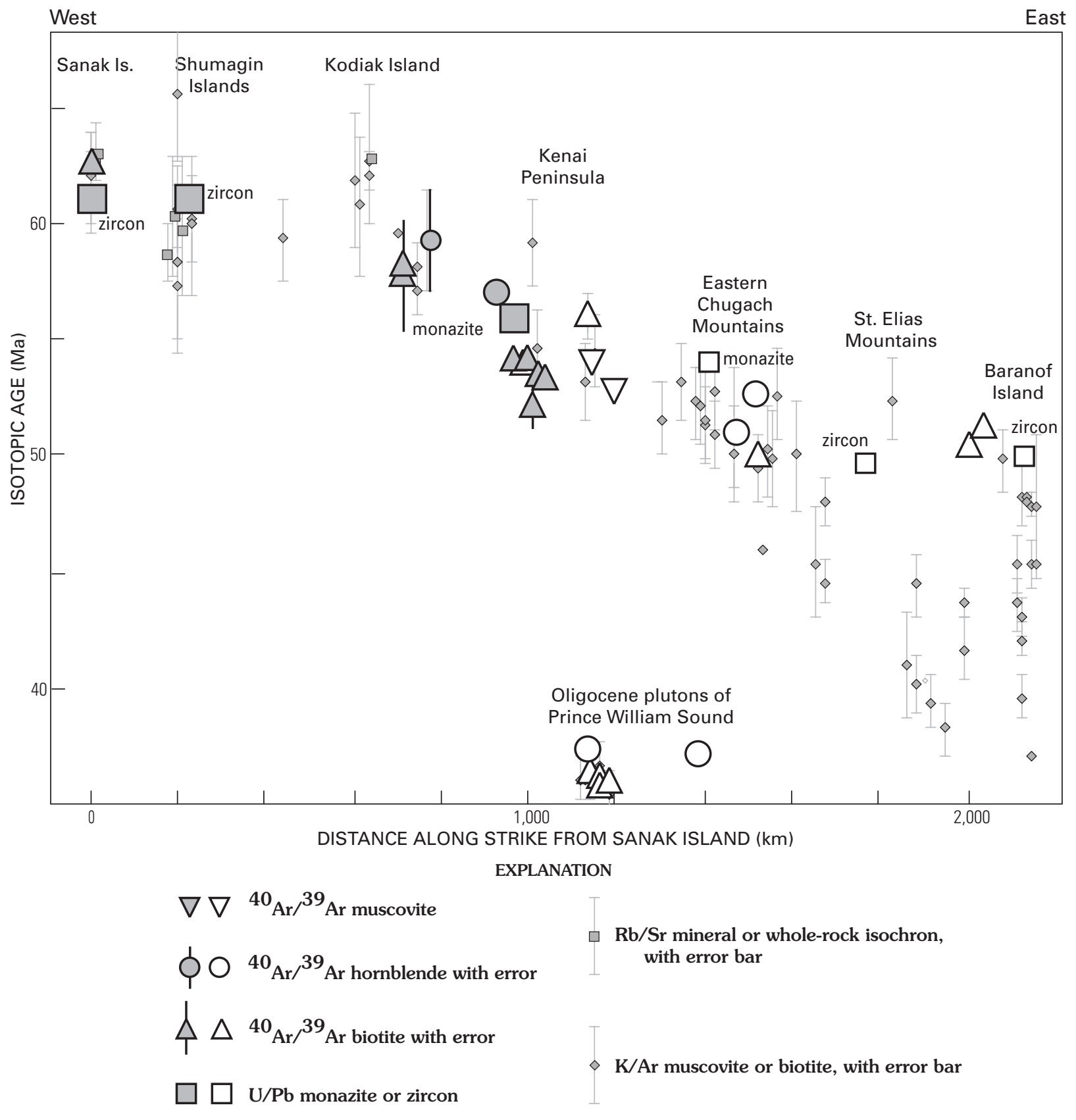

Figure 5. Isotopic age plotted against distance along strike for early Tertiary intrusive rocks of the Sanak-Baranof plutonic belt. See figure 1 for distance from Sanak Island. New and recent data (summarized in table 5) are highlighted by filled symbols; the remaining data are from the compilation by Bradley and others (1993). Most error bars for ${ }^{40} \mathrm{Ar} /{ }^{39} \mathrm{Ar}$ and $\mathrm{U} / \mathrm{Pb}$ data are smaller than the symbols; a few error bars are omitted from crowded areas for clarity. Note the diachronous trend in ages of older to the west and younger to the east, indicating a migrating trench-ridge-trench triple junction (Bradley and others, 1993). 
Table 5. Summary of new isotopic ages of intrusive rocks from the Sanak-Baranof belt, southern Alaska.

[Abbreviations for 1:250,000-scale quadrangles: AF, Afognak; BS, Blying Sound; CV, Cordovia; FP, False Pass; KD, Kodiak; SB, Stepovak Bay; SR, Seward; SV, Seldovia; YA, Yakutat. Distance along strike was measured from the western tip of Sanak Island on Beikman's (1980) geologic map of Alaska]

\begin{tabular}{|c|c|c|c|c|c|c|c|c|c|}
\hline Igneous body & Quad & $\begin{array}{l}\text { Field number } \\
\text { or location }\end{array}$ & $\begin{array}{l}\text { Latitude } \\
\text { (N.) }\end{array}$ & $\begin{array}{l}\text { Longitude } \\
\text { (W.) }\end{array}$ & $\begin{array}{l}\text { Age } \\
(\mathrm{Ma})\end{array}$ & $\begin{array}{l}\text { Error } \\
\text { (m.y.) }\end{array}$ & Method & $\begin{array}{l}\text { Dist. from } \\
\text { Sanak Is. } \\
(\mathrm{km})\end{array}$ & Reference or geochronologist \\
\hline Sanak pluton & FP & S70 & $54^{\circ} 29.2^{\prime}$ & $162^{\circ} 45.8^{\prime}$ & 61.1 & 0.5 & $\mathrm{U} / \mathrm{Pb}$ zircon & 5 & Parrish (this study) \\
\hline Sanak pluton & FP & S70 & $54^{\circ} 29.2^{\prime}$ & $162^{\circ} 45.8^{\prime}$ & 62.7 & 1.2 & 40Ar/39Ar biotite & 5 & Clendenen \& Heizler (this study) \\
\hline Shumagin pluton & SB & 96AK3 & $55^{\circ} 12^{\prime} 04^{\prime \prime}$ & $159^{\circ} 32^{\prime} 02^{\prime \prime}$ & 61.1 & 0.3 & $\mathrm{U} / \mathrm{Pb}$ zircon & 230 & Parrish (this study) \\
\hline Kodiak batholith, Terror Lk. & $\mathrm{KD}$ & TLP-95 & $57^{\circ} 39.44^{\prime}$ & $152^{\circ} 58.25^{\prime}$ & 57.3 & 2.52 & ${ }^{40} \mathrm{Ar} /{ }^{39} \mathrm{Ar}$ biotite & 715 & Clendenen \& Heizler (this study) \\
\hline Kodiak batholith, Terror Lk. & $\mathrm{KD}$ & TL-2-87 & $57^{\circ} 39.29^{\prime}$ & $152^{\circ} 58.33^{\prime}$ & 58.3 & 0.2 & ${ }^{40} \mathrm{Ar} /{ }^{39} \mathrm{Ar}$ biotite & 715 & Clendenen \& Heizler (this study) \\
\hline Dike, Malina Bay & $\mathrm{AF}$ & M-19-88 & $58^{\circ} 12.6^{\prime}$ & $153^{\circ} 00.1^{\prime}$ & 59.3 & 2.2 & 40Ar/39Ar hornblende & 765 & Clendenen \& Heizler (this study) \\
\hline Dike, Seldovia Bay & SV & 88ADw230 & $59^{\circ} 23.6^{\prime}$ & $150^{\circ} 39.9^{\prime}$ & 57.0 & 0.2 & ${ }^{40} \mathrm{Ar} /{ }^{39} \mathrm{Ar}$ hornblende & 920 & Clendenen \& Heizler (this study) \\
\hline Dike, Tutka Bay & SV & 93ASB66 & $59^{\circ} 23^{\prime} 38^{\prime \prime}$ & $151^{\circ} 13^{\prime} 7^{\prime \prime}$ & 115.0 & 1.7 & ${ }^{40} \mathrm{Ar} /{ }^{39} \mathrm{Ar}$ hornblende & 930 & Lux (this study) \\
\hline Nuka pluton & SV & 88АСy9 & $59^{\circ} 28.4^{\prime}$ & $150^{\circ} 20.2^{\prime}$ & 54.2 & 0.1 & ${ }^{40} \mathrm{Ar} /{ }^{39} \mathrm{Ar}$ biotite & 970 & Clendenen \& Heizler (this study) \\
\hline Nuka pluton & SV & 88АCy9 & $59^{\circ} 28.4^{\prime}$ & $150^{\circ} 20.2^{\prime}$ & 56.0 & 0.5 & $\mathrm{U} / \mathrm{Pb}$ monazite & 970 & Parrish (this study) \\
\hline Chernof stock & SV & 91ADw55g & $59^{\circ} 52^{\prime} 58^{\prime \prime}$ & $150^{\circ} 27^{\prime} 23^{\prime \prime}$ & 54.2 & 1.1 & ${ }^{40} \mathrm{Ar} /{ }^{39} \mathrm{Ar}$ biotite & 1,000 & Lux (this study) \\
\hline Tustumena pluton & SV & $92 \mathrm{AKu} 71 \mathrm{~b}$ & $59^{\circ} 58^{\prime} 38^{\prime \prime}$ & $150^{\circ} 9^{\prime} 40^{\prime \prime}$ & 53.2 & 1.1 & ${ }^{40} \mathrm{Ar} /{ }^{39} \mathrm{Ar}$ biotite & 1,020 & Lux (this study) \\
\hline Aialik pluton, Harris Bay & SV & 91AKu3 & $59^{\circ} 47^{\prime} 30^{\prime \prime}$ & $149^{\circ} 59^{\prime} 30^{\prime \prime}$ & 52.2 & 0.9 & ${ }^{40} \mathrm{Ar} /{ }^{39} \mathrm{Ar}$ biotite & 1,010 & Layer (this study) \\
\hline Hive Island (Aialik?) pluton & $\mathrm{BS}$ & 95TD3b & $59^{\circ} 53^{\prime} 30^{\prime \prime}$ & $149^{\circ} 22^{\prime}$ & 53.4 & 0.4 & ${ }^{40} \mathrm{Ar} /{ }^{39}$ Ar biotite & 1,040 & Layer (this study) \\
\hline Thunder Bay granitic sill & SV & 92PH454B & $59^{\circ} 32^{\prime} 34^{\prime \prime}$ & $150^{\circ} 10^{\prime} 50^{\prime \prime}$ & 53.7 & 0.1 & ${ }^{40} \mathrm{Ar} /{ }^{39} \mathrm{Ar}$ biotite & 990 & Haeussler and others (1995) \\
\hline Granite at Granite mine & SR & $92 \mathrm{PH} 216 \mathrm{E}$ & $60^{\circ} 58^{\prime} 19^{\prime \prime}$ & $148^{\circ} 12^{\prime} 40^{\prime \prime}$ & 56 & 1 & ${ }^{40} \mathrm{Ar} /{ }^{39} \mathrm{Ar}$ biotite & 1,170 & Haeussler and others (1995) \\
\hline Crow Pass felsic intrusion & AN & 91AKU137 & $61^{\circ} 02^{\prime} 53^{\prime \prime}$ & $149^{\circ} 06^{\prime} 28^{\prime \prime}$ & 54.1 & 0.1 & ${ }^{40} \mathrm{Ar} /{ }^{39} \mathrm{Ar}$ white mica & 1,150 & Haeussler and others (1995) \\
\hline Granite at Homestake mine & AN & $92 \mathrm{PH} 215 \mathrm{C}$ & $61^{\circ} 04^{\prime} 49^{\prime \prime}$ & $148^{\circ} 16^{\prime} 30^{\prime \prime}$ & 52.8 & 0.1 & ${ }^{40} \mathrm{Ar} /{ }^{39} \mathrm{Ar}$ white mica & 1,190 & Haeussler and others (1995) \\
\hline Sill, Van Cleve Glacier & $\mathrm{CV}$ & 94APo36 & $60^{\circ} 45^{\prime} 49^{\prime \prime}$ & $144^{\circ} 11^{\prime} 23^{\prime \prime}$ & 54 & $\begin{array}{l}\text { not } \\
\text { given }\end{array}$ & $\mathrm{U} / \mathrm{Pb}$ monazite & 1,410 & Poole (1996) \\
\hline Novatak Glacier pluton & YA & 95APo13 & $59^{\circ} 36^{\prime} 02^{\prime \prime}$ & $138^{\circ} 32^{\prime} 32^{\prime \prime}$ & 49 & $\begin{array}{l}\text { not } \\
\text { given }\end{array}$ & $\begin{array}{l}\mathrm{U} / \mathrm{Pb} \text { zircon; lower } \\
\text { intercept age }\end{array}$ & 1,770 & Poole (1996) \\
\hline
\end{tabular}


on hornblende; conventional $\mathrm{K} / \mathrm{Ar}, \mathrm{Rb} / \mathrm{Sr}$, and unpublished $\mathrm{U} / \mathrm{Pb}$ ages range from 135 to $103 \mathrm{Ma}$. Pavlis and others (1988) offered two possible explanations for the Early Cretaceous near-trench magmatic event. Their preferred model involved shallow melting at a young subduction zone; a viable alternative, however, is that the melts formed during a ridge-trench encounter, much like the widespread early Tertiary near-trench intrusives that we attribute to subduction of the Kula-Farallon ridge.

\section{Acknowledgments}

Samples were collected by Casey Moore, Malcolm Hill, Peter Vrolik, Bela Csejtey, Timothy Kusky, Will White, Sherman Bloomer, and Maurice Witschard (arranged by Peter Haeussler). Kusky's field work was supported, in part, by NSF grant 9304647. Clendenen's part in preparing the manuscript was with permission of Exxon Production Research. The argon lab at the State University of New York at Albany was directed by Mark Harrison. Tim Plucinsky did some of the mineral separations at the U.S. Geological Survey, Anchorage. E. Anne Kinsman assisted with the U/Pb work at the Geological Survey of Canada, Ottawa. Manuscript reviews were provided by Jim Riehle and Tim Kusky.

\section{References}

Atwater, Tanya, 1989, Plate tectonic history of the northeast Pacific and western North America, in Winterer, E.L., Hussong, D.M., and Decker, R.W., eds., The Geology of North America: The Eastern Pacific Ocean and Hawaii: Geological Society of America DNAG Series, v. N, p. 21-72.

Atwater, Tanya, and Severinghaus, Jeff, 1989, Tectonic map of the northeast Pacific region, in Winterer, E.L., Hussong, D.M., and Decker, R.W., eds., The Geology of North America: The Eastern Pacific Ocean and Hawaii: Geological Society of America DNAG Series, v. N, plate $3 \mathrm{~B}$.

Barker, F., Farmer, G.L., Ayuso, R.A., Plafker, George, and Lull, J.S., 1992, The $50 \mathrm{Ma}$ granodiorite of the eastern Gulf of Alaska: Melting of the accretionary prism in the forearc: Journal of Geophysical Research, v. 97, p. 6757-6778.

Beikman, H., 1980, Geologic map of Alaska: U.S. Geological Survey, scale $1: 2,500,000$.

Berggren, W.A., Kent, D.V., Swisher, C.C., III, Aubry, Marie-Pierre, 1995, A revised Cenozoic geochronology and chronostratigraphy, in Berggren, W.A. , Kent, D.V., Aubry, Marie-Pierre, Hardenbol, Jan, eds., Geochronology, Time Scales and Global Stratigraphic Correlation: SEPM Special Publication 54, p. 129-212.

Bol, A.J., Coe, R.S., Gromme, C.S., and Hillhouse, J.W., 1992, Paleomagnetism of the Resurrection Peninsula, Alaska: Implications for the tectonics of southern Alaska and the Kula-Farallon ridge: Journal of Geophysical Research, v. 97, p. 17213-17232.

Bradley, D.C., Haeussler, P., and Kusky, T.M., 1993, Timing of early Tertiary ridge subduction in southern Alaska, in Dusel-Bacon, C., and Till, A., eds., Geologic Studies in Alaska by the U.S. Geological Survey, 1992: U.S. Geological Survey Bulletin 2068, p. 163-177.
Bradley, D., Haeussler, P., Nelson, S., Kusky, T., Donley, D.T., and Goldfarb, R., 1995, Geologic effects of Paleogene ridge subduction, Kenai Peninsula [abs.]: Geological Society of America, Abstracts with Programs, v. 27, no. 5, p. 7.

Bradley, D.C., and Kusky, T.M., 1992, Deformation history of the McHugh Complex, Seldovia quadrangle, south-central Alaska, in Bradley, D.C., and Ford, A., eds., Geologic Studies in Alaska by the U.S. Geological Survey, 1990: U.S. Geological Survey Bulletin 1999, p. 17-32.

Bradley, D.C., Kusky, T., Haeussler, P., Karl, S., and Donley, D.T., 1999, Geologic map of the Seldovia quadrangle, Alaska: U.S. Geological Survey Open-File Report 99-18, scale 1:250,000.

Clendenen, W.S., 1991, Thermal history and vertical tectonics of the southern Alaska convergent margin: Providence, R.I., Brown University, Ph.D. dissertation, $177 \mathrm{p}$.

Coe, R.S., Globerman, B.R., Plumley, P.R., and Thrupp, G.A., 1985, Paleomagnetic results from Alaska and their tectonic implications, in Howell, D.G., ed., Tectonostratigraphic Terranes of the CircumPacific Region: Houston, Circum-Pacific Council for Energy and Mineral Resources, p. 85-108.

Connelly, W., 1978, Uyak Complex, Kodiak Islands, Alaska: A Cretaceous subduction complex: Geological Society of America Bulletin, v. 89, p. 755-769.

Dalrymple, G.B., Alexander, E.C., Jr., Lanphere, M.A., and Kraker, G.P., 1981 , Irradiation of samples for ${ }^{40} \mathrm{Ar} /{ }^{39} \mathrm{Ar}$ dating using the Geological Survey TRIGA Reactor: U.S. Geological Survey Professional Paper $1176,55 \mathrm{p}$.

Donley, D.T., Kusky, T., and Bradley, D.C., 1995, Emplacement of Tertiary Nuka, Aialik, and related near-trench plutons, Chugach accretionary wedge, Alaska [abs.]: Geological Society of America, Abstracts with Programs, v. 27, no. 5, p. 15.

Engebretson, D.C., Cox, Allan, and Gordon, R.G., 1985, Relative motions between oceanic and continental plates in the Pacific Basin: Geological Society of America Special Paper 206, 59 p.

Haeussler, P., Bradley, D., Golfarb, R., and Snee, L., 1995, Link between ridge subduction and gold mineralization in southern Alaska: Geology, v. 23, p. 995-998.

Harrison T.M., and Fitz Gerald, J.D., 1986, Exsolution in hornblende and its consequences for ${ }^{40} \mathrm{Ar} /{ }^{39} \mathrm{Ar}$ age spectra and closure temperature: Geochimica Cosmochimica Acta, v. 50, p. 247-253.

Helwig, J., and Emmet, P., 1981, Structure of the early Tertiary Orca Group in Prince William Sound and some implications for the plate tectonic history of southern Alaska: Journal of the Alaska Geological Society, v. 1, p. 12-35.

Hill, M., Morris, J., and Whelan, J., 1981, Hybrid granodiorites intruding the accretionary prism, Kodiak, Shumagin, and Sanak Islands, southwest Alaska: Journal of Geophysical Research, v. 86, p. 10569 10590

Hudson, Travis, 1983, Calc-alkaline plutonism along the Pacific rim of southern Alaska, in Roddick, J.A., ed., Circum-Pacific Plutonic Terranes: Geological Society of America Memoir 159, p. 159-169.

Hudson, Travis, and Plafker, George, 1982, Paleogene metamorphism in an accretionary flysch terrane, eastern Gulf of Alaska: Geological Society of America Bulletin, v. 93, p. 1280-1290.

Krogh, T.E., 1982, Improved accuracy of U-Pb zircon dating by the creation of more concordant systems using air abrasion techniques: Geochimica et Cosmochimica Acta, v. 46, p. 637-649.

Kusky, T.M., Bradley, D.C., Haeussler, P.J, and Karl, S.J., 1997, Controls on accretion of flysch and melange belts at accretionary margins: Evidence from the Chugach Bay thrust and Iceworm melange, Chugach accretionary wedge, Alaska: Tectonics, v. 16, p. 855-878. 
Layer, P.W., Hall, C.M., and York, D., 1987, The derivation of ${ }^{40} \mathrm{Ar} /{ }^{39} \mathrm{Ar}$ age spectra of single grains of hornblende and biotite by laser step heating: Geophysical Research Letters, v. 14, p. 757-760.

Lytwyn, J., Casey, J., Gilbert, S., and Kusky, T., 1997, Arc-like mid-ocean ridge basalt formed seaward of a trench-forearc system just prior to ridge subduction: An example from some accreted ophiolites in southern Alaska: Journal of Geophysical Research, v. 102, p. 1022510243.

McDougall, I. and Harrison, T.M., 1988, Geochronology and thermochronology by the ${ }^{40} \mathrm{Ar} /{ }^{39} \mathrm{Ar}$ method: New York, Oxford University Press, $212 \mathrm{p}$.

Moore, J.C., 1973, Cretaceous continental margin sedimentation, southwestern Alaska: Geological Society of America Bulletin, v. 84, p. 595-614.

Moore, J.C., 1974a, Geologic and structural map of the Sanak Islands, southwestern Alaska: U.S. Geological Survey Miscellaneous Investigations Map 1-817, scale 1:63,360.

Moore, J.C., 1974b, Geologic and structural map of part of the outer Shumagin Islands, southwestern Alaska: U.S. Geological Survey Miscellaneous Investigations Map I-815, scale 1:63,360.

Moore, J.C., and Allwardt, A., 1980, Progressive deformation of a Tertiary trench slope, Kodiak islands, Alaska: Journal of Geophysical Research, v. 85, p. 4741-4756.

Moore, J.C., Byrne, T., Plumley, P.W., Reid, M., Gibbons, H., and Coe, R.S., 1983, Paleogene evolution of the Kodiak Islands, Alaska: Consequences of ridge-trench interaction in a more southerly latitude: Tectonics, v. 2, p. 265-293.

Nilsen, T.H., and Moore, G.W., 1979, Reconnaissance study of Upper Cretaceous to Miocene stratigraphic units and sedimentary facies, Kodiak and adjacent islands, Alaska: U.S. Geological Survey Professional Paper 1093, $34 \mathrm{p}$.

Nilsen, T.H., and Zuffa, G.G., 1982, The Chugach terrane, a Cretaceous trench-fill deposit, southern Alaska: Special Publications of the Geological Society of London, v. 10, p. 213-227.

Parrish, R.R., 1987, An improved micro-capsule for zircon dissolution in U-Pb geochronology: Isotope Geoscience, v. 66, p. 99-102.

Parrish, R.R., and Krogh, T.E., 1987, Synthesis and purification of ${ }^{205} \mathrm{~Pb}$ for U-Pb geochronology: Isotope Geoscience, v. 66, p. 103-110.

Parrish, R.R., Roddick, J.C., Loveridge, W.D., and Sullivan, R.W., 1987, Uranium-lead analytical techniques at the geochronology laboratory, Geological Survey of Canada, in Radiogenic Age and Isotopic Studies: Report 1, Geological Survey of Canada, Paper 87-2, p. 3-7.
Pavlis, T.L., and Sisson, V.B., 1995, Structural history of the Chugach Metamorphic Complex in the Tana River region, eastern Alaska: A record of Eocene ridge subduction: Geological Society of America Bulletin, v. 107, p. 1333-1355.

Plafker, G., Moore, J.C., and Winkler, G.R., 1994, Geology of the southern Alaska margin, in Plafker, G., and Berg, H., eds., The Geology of Alaska: Boulder, Colo., Geological Society of America, Geology of North America, v. G-1, p. 389-449.

Poole, A.R., 1996, Age and geochemical constraints on ridge subduction for igneous rocks of the eastern Chugach Mountains, Alaska: Houston, Rice University, unpub. Master's thesis, 83 p.

Roddick, J.C., 1987, Generalized numerical error analysis with applications to geochronology and thermodynamics. Geochimica et Cosmochimica Acta, v. 51, p. 2129-2135.

Scharer, U. 1984, The effect of initial ${ }^{230}$ Th disequilibrium on young $\mathrm{U}-\mathrm{Pb}$ ages: The Makalu case, Himalaya: Earth and Planetary Science Letters, v. 61, p. 191-204.

Sisson, V.B., Hollister, L.S., and Onstott, T.C., 1989, Petrologic and age constraints on the origin of a low-pressure/high-temperature metamorphic complex, southern Alaska: Journal of Geophysical Research, v. 94, p. 4392-4410.

Sisson, V.B., and Pavlis, T.L., 1993, Geologic consequences of plate reorganization: An example from the Eocene southern Alaska forearc: Geology, v. 21, p. 913-916.

Stacey, J.S., and Kramers, J.D., 1975, Approximation of terrestrial lead isotope evolution by a two-stage model: Earth and Planetary Science Letters, v. 26, p. 207-221.

Steiger, R.H., and Jäger, E., 1977, Subcommission on Geochronology: Convention on decay constants in geo- and cosmochronology: Earth and Planetary Science Letters, v. 36, p. 359-362.

Taylor, C.D., Goldfarb, R.J., Snee, L.W., Ghent, C.A., Karl, S.M., and Haeussler, P.J., 1994, New age data for gold deposits and granites, Chichagof mining district, southeast Alaska: Evidence for a common origin [abs.]: Geological Society of America Abstracts with Programs, v. 26, no. 7, p. A140.

Tysdal, R.G., and Case, J.E., 1979, Geologic map of the Seward and Blying Sound quadrangles, Alaska: U.S. Geological Survey Miscellaneous Investigations Series I-1150, 12 p., 1 sheet, scale 1:250,000.

York, D., 1969, Least squares fitting of a straight line with correlated errors: Earth and Planetary Science Letters, v. 5, p. 320-324.

York, D., Hall, C.M., Yanase, Y., Hanes, J.A., and Kenyon, W.J., 1981, ${ }^{40} \mathrm{Ar} /$ ${ }^{39} \mathrm{Ar}$ dating of terrestrial minerals with a continuous laser: Geophysical Research Letters, v. 8, p. 1136-1138.

Reviewers: Jim Riehle, Tim Kusky. 


\title{
Mount Mageik: A Compound Stratovolcano in Katmai National Park
}

\author{
By Wes Hildreth, Judy Fierstein, Marvin A. Lanphere, and David F. Siems
}

Beautifully sky blue, [his eyes] peered at you from seemingly all angles at once as he cocked his head first on one side, then on the other. He gave spontaneous evidence of being the character dog of the trip. That is why I named him Mageik, after the great volcano that, with Katmai, guards the entrance to the former Valley of Ten Thousand Smokes.

Bernard R. Hubbard

Mush You Malemutes (1932)

\section{Abstract}

Mount Mageik is an ice-clad 2,165-m andesite-dacite stratovolcano in the Katmai volcanic cluster at the head of the Valley of Ten Thousand Smokes. New K-Ar ages indicate that the volcano is as old as $93 \pm 8 \mathrm{ka}$. It has a present-day volume of 20 $\mathrm{km}^{3}$ but an eruptive volume of about $30 \mathrm{~km}^{3}$, implying a longterm average volumetric eruption rate of about $0.33 \mathrm{~km}^{3}$ per 1,000 years. Mount Mageik consists of four overlapping edifices, each with its own central summit vent, lava-flow apron, and independent eruptive history. Three of them have small fragmental summit cones with ice-filled craters, but the fourth and highest is topped by a dacite dome. Lava flows predominate on each edifice; many flows have levees and ice-contact features, and many thicken downslope into piedmont lava lobes 50$200 \mathrm{~m}$ thick. Active lifetimes of two (or three) of the component edifices may have been brief, like that of their morphological and compositional analog just across Katmai Pass, the Southwest (New) Trident edifice of 1953-74. The North Summit edifice of Mageik may have been constructed very late in the Pleistocene and the East Summit edifice (along with nearby Mount Martin) largely or entirely in the Holocene. Substantial Holocene debris avalanches have broken loose from three sites on the south side of Mount Mageik, the youngest during the Novarupta fallout of 6 June 1912. The oldest one was especially mobile, being rich in hydrothermal clay, and is preserved for 16 $\mathrm{km}$ downvalley, probably having run out to the sea. Mageik's fumarolically active crater, which now contains a hot acid lake, was never a magmatic vent but was reamed by phreatic explosions through the edge of the dacite summit dome. There is no credible evidence of historical eruptions of Mount Mageik, but the historically persistent fumarolic plumes of Mageik and Martin have animated many spurious eruption reports. Lavas and ejecta of all four component edifices of Mageik are plagioclaserich, pyroxene-dacites and andesites (57-68 weight percent $\mathrm{SiO}_{2}$ ) that form a calcic, medium-K, typically low-Ti arc suite. The Southwest Summit edifice is larger, longer lived, and compositionally more complex than its companions. Compared to other centers in the Katmai cluster, products of Mount Mageik are readily distinguishable chemically from those of Mount Griggs, Falling Mountain, Mount Cerberus, and all prehistoric components of the Trident group, but some are similar to the products of Mount Martin, Southwest Trident, and Novarupta. The crater lake, vigorous superheated fumaroles, persistent seismicity, steep ice blanket, and numerous Holocene dacites warrant monitoring Mount Mageik as a potential source of explosive eruptions and derivative debris flows.

\section{Introduction}

Mount Mageik is a 2,165-m-high andesite-dacite compound stratovolcano adjacent to Katmai Pass at the head of the Valley of Ten Thousand Smokes (fig. 1). Consisting of a tightly bunched group of four overlapping cones (fig. 2), Mageik rivals Mount Katmai as the broadest $\left(80 \mathrm{~km}^{2}\right)$ and most productive $\left(30 \mathrm{~km}^{3}\right)$ edifice in the Katmai volcanic cluster (Hildreth, 1987). All within $15 \mathrm{~km}$ of Mount Mageik, the Katmai cluster includes Alagogshak, Martin, Katmai, and Griggs volcanoes, four discrete cones of Trident volcano, several peripheral lava domes, and the flank vent called Novarupta that produced the great eruption of 1912 (Griggs, 1922; Fierstein and Hildreth, 1992). 


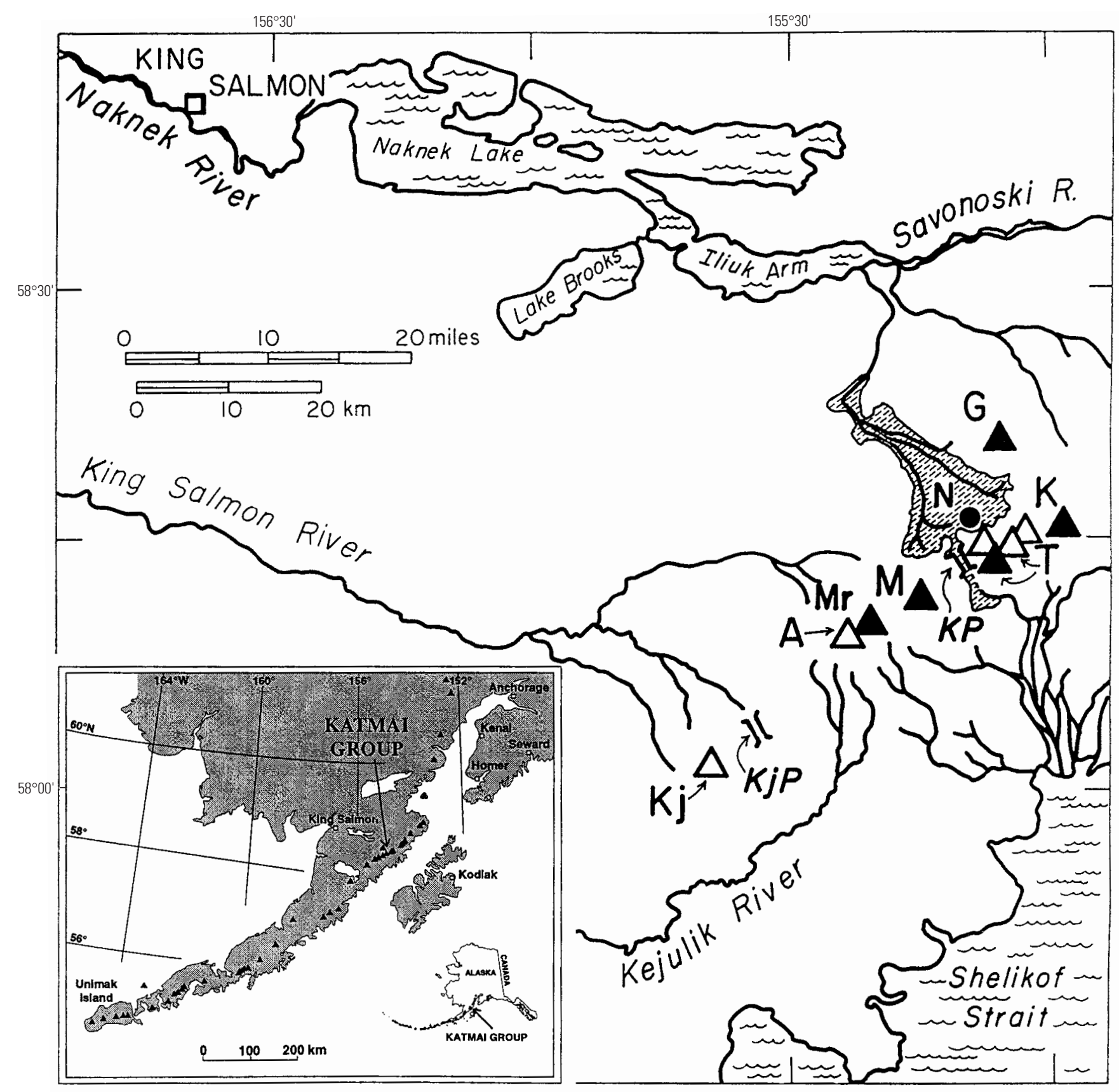

Figure 1. Map showing part of the volcanic chain along the Alaska Peninsula, southeast of the town of King Salmon. Solid triangles indicate cones active during the Holocene; open triangles indic ate Pleistocene cones long extinct. The Katmai volcanic cluster includes Alagogshak (A), Martin (Mr), Mageik (M), Griggs (G), Trident (T; three extinct cones and one recently active cone), and Mount Katmai (K). Farther southwest is Kejulik (Kj) volcano. Solid circle (N) indicates Novarupta, site of the great explosive eruption of 1912, when ignimbrite (shaded valley fill) was emplaced in the Valley of Ten Thousand Smokes (Fierstein and Hildreth, 1992). Low points along the volcanic axis, which here forms the Alaska Peninsula drainage divide, include Katmai Pass (KP) and Kejulik Pass (KjP).

The four crowded cones of Mount Mageik epitomize the remarkable proximity of so many volcanic centers in this district, a clustering quite unusual for the Alaska PeninsulaAleutian Arc.

The Mageik complex is superimposed upon a ruggedly glaciated ridge of subhorizontal siltstone and sandstone of the Jurassic Naknek Formation (Riehle and others, 1993; Detterman and others, 1996) that forms the Alaska Peninsula drainage divide in this area (fig. 1). Because Mageik and many other centers along the axial volcanic chain in the Katmai district straddle the basement divide, their eruptive products can flow either southeastward down the Pacific slope toward Shelikof Strait or northwestward toward Bristol Bay and the Naknek Lake system.

Mageik is a native Alaskan name pronounced muh-GEEK. The Mageik edifice was recognized as a young volcano by J.E. Spurr, who led a U.S. Geological Survey (USGS) party across Katmai Pass in October 1898, and part of the volcano was sketched on the reconnaissance topographic map of his route (Spurr, 1900). Spurr did not, however, mention any name for 


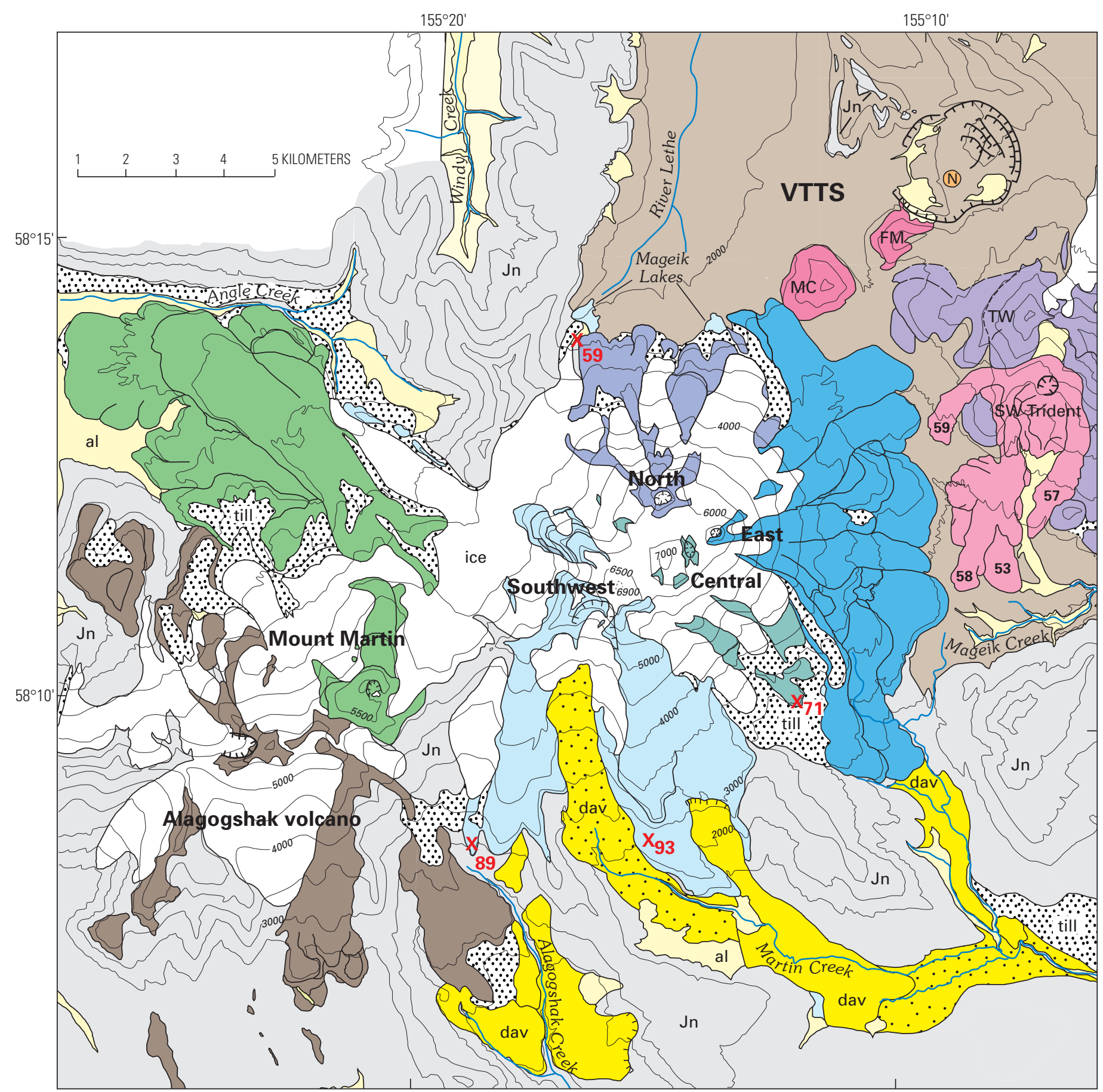

Figure 2. Simplified geologic map of Mount Mageik and its immediate surroundings. Eruptive products of Alagogshak volcano, Mount Martin, and Southwest Trident are indicated in brown, green, and magenta, respectively, and the four discrete centers of Mount Mageik in shades of blue. Year of emplacement of successive lava flows (1953-59) from Southwest Trident are indicated: 53, 57, 58, 59. Also identified at the head of the Valley of Ten Thousand Smokes (VTTS) are the 1912 rhyolite dome, Novarupta (N), and late Pleistocene dacite domes, Falling Mountain (FM) and Mount Cerberus (MC). Purple pattern (TW) shows part of glaciated prehistoric components of the Trident group. Pale tan pattern in VTTS and Mageik Creek is 1912 ignimbrite. Bright yellow pattern (dav) includes debris avalanches and landslides. Pale yellow (al) is alluvium, much of it reworked 1912 ejecta. Glacial ice is white, coarse stipple is till, and gray regional basement (Jn) is Jurassic Naknek Formation (plus scattered surficial deposits and minor Tertiary intrusive rocks, not shown separately). Craters atop volcanic cones, backfilled 1912 vent depression around Novarupta, and scarps of debris-avalanche headwalls are indicated by hachures. Locations of samples dated by K-Ar method (table 2) are indicated by red $X$, accompanied by age (in ka). Topographic base simplified from USGS 1:63,360 quadrangles Mt. Katmai A-4, A-5, B-4, B-5. Elevations in feet; contour interval $500 \mathrm{ft}(1 \mathrm{~m}=3.28 \mathrm{ft})$. 
the volcano, even though he was accompanied by ten local porters. The name first(?) appears on a National Geographic Society map published in 1913 (Martin, 1913), well before the first Griggs expedition to the area (Griggs, 1922).

Although Mount Mageik is not known to have erupted historically, its near-summit fumaroles have been continuously active for at least the last century. The fumarolic crater was first visited in 1923 by C. Yori and C.N. Fenner (Fenner, 1930). Our own fieldwork, which began in 1976, included extensive sampling on foot in 1979 of the northern and eastern flanks and of the fumarolic crater, and it concluded with mapping and sampling by helicopter each summer from 1996 to 1998 as part of a volcano-hazards assessment of the whole Katmai cluster. Owing to its present-day fumarolic and seismic activity, its extensive ice cover, and its numerous dacitic eruptions in the Holocene, we consider Mount Mageik to be a hazardous volcano capable of englacial lava flows, explosive ejection of far-flung tephra, and generation of far-reaching debris flows.

\section{Ice-Mantled Compound Edifice}

Each of Mageik's four ice-mantled summits (figs. 2, 3) is a discrete eruptive center, and each is the source of numerous andesite and dacite lava flows (57-68 percent $\mathrm{SiO}_{2}$; table 1), many of which are 50-200 m thick distally. Three of the four centers are of late Pleistocene age, but the East Summit is largely or entirely a Holocene center. Ice-filled craters atop
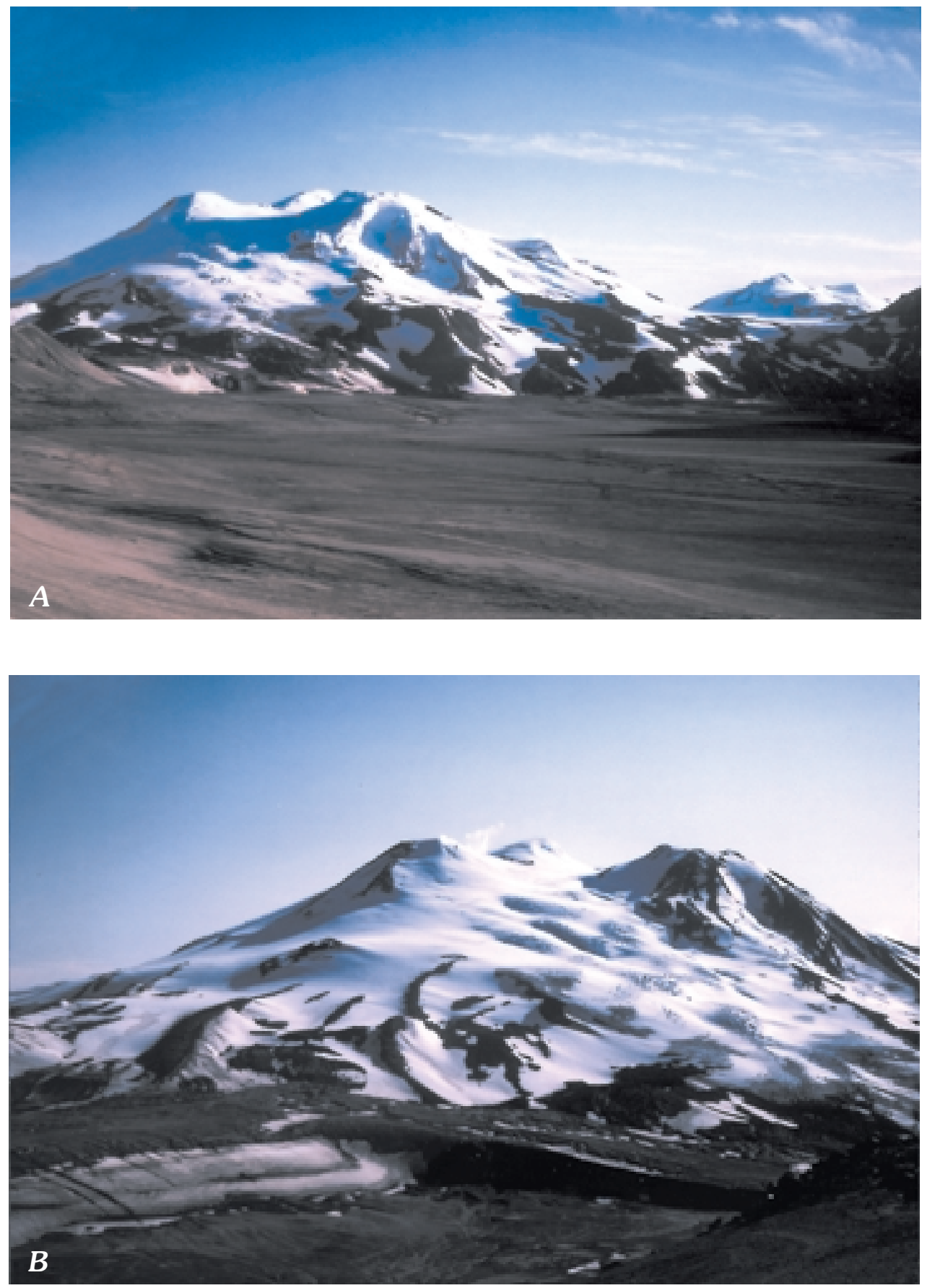

Figure 3. Ice-clad Mount Mageik as viewed southwestward from $A$, the Valley of Ten Thousand Smokes and $B$, the summit of Falling Mountain. East Summit is on left skyline in both panels. North Summit to its right is topped by an ice-filled crater, from which a blocky corrugated dacite lava flow extends $1 \mathrm{~km}$ northeast, toward the camera. Central Summit, highest point on the mountain at just over 7,100 ft $(2,165$ $\mathrm{m})$, rises on background skyline with fumarolically active crater below it to its left. Southwest Summit is hidden. In $A$, Mount Martin rises on the right skyline, $7 \mathrm{~km}$ southwest of Mageik's North Summit. At base of Mageik, North Summit lavas end in glacially eroded buttresses that stand precipitously above the valley-filling 1912 ignimbrite. In $B$, fumarolic plume rises from the phreatic crater, and levees of northeast-flowing bifurcating lava (mapped in fig. 2) emerges from the glacier below the East Summit. 
Table 1. Chemical analyses of eruptive products, Mount Mageik.

[The 10 major oxides (reported in weight percent) are normalized to $\mathrm{H}_{2} 0$-free totals of 99.6 weight percent (allowing 0.4 weight percent for trace oxides and hallogens); determinations by wavelength-dispersive XRF in USGS laboratory at Lakewood, Colorado; D.F. Siems, analyst. Rb, Sr, and Zr (in parts per million) determined by energy-dispersive XRF by D.F. Siems. Precision and accuracy are discussed by Bacon and Druitt (1988). FeO* is total iron calculated as FeO. "Original total" is the volatile-free sum of the 10 oxides, as analyzed, before normalization, with total iron calculated as $\mathrm{Fe}_{2} \mathrm{O}_{3}$. LOI=weight loss on ignition at $\left.900^{\circ} \mathrm{C}\right]$

\begin{tabular}{|c|c|c|c|c|c|c|c|c|c|c|c|c|c|c|c|}
\hline & $\mathrm{SiO}_{2}$ & $\mathrm{TiO}_{2}$ & $\mathrm{Al}_{2} \mathrm{O}_{3}$ & $\mathrm{FeO}^{*}$ & $\mathrm{MnO}$ & $\mathrm{MgO}$ & $\mathrm{CaO}$ & $\mathrm{Na}_{2} \mathrm{O}$ & $\mathrm{K}_{2} \mathrm{O}$ & $\mathrm{P}_{2} \mathrm{O}_{5}$ & LOI & $\begin{array}{c}\text { Original } \\
\text { total }\end{array}$ & $\mathrm{Rb}$ & $\mathrm{Sr}$ & $\mathrm{Zr}$ \\
\hline \multicolumn{16}{|c|}{ Central Summit } \\
\hline $\begin{array}{l}\text { K-193 } \\
\end{array}$ & 60.8 & 0.74 & 16.5 & 6.60 & 0.13 & 3.28 & $6: 52$ & $3.6 \mathrm{I}$ & 1.34 & 0.07 & - & 98.80 & 28 & 308 & $\overline{132}$ \\
\hline K-2118 & 63.1 & 0.66 & 15.9 & 5.87 & 0.11 & 2.81 & 5.69 & 3.50 & 1.77 & 0.14 & 0.30 & 99.04 & 41 & 234 & 144 \\
\hline K-2143 & 64.9 & 0.64 & 15.6 & 5.38 & 0.11 & 2.36 & 4.97 & 3.56 & 1.98 & 0.14 & 0.24 & 99.00 & 42 & 221 & 160 \\
\hline $\mathrm{K}-2144$ & 57.8 & 0.80 & 17.2 & 8.03 & 0.15 & 3.85 & 7.20 & 3.29 & 1.15 & 0.16 & - & 99.46 & 22 & 287 & 113 \\
\hline K-2268 & 60.1 & 0.73 & 16.7 & 6.82 & 0.14 & 3.48 & 6.61 & 3.55 & 1.32 & 0.15 & 0.22 & 98.73 & 23 & 259 & 131 \\
\hline K-2271 & 64.1 & 0.69 & 16.0 & 5.36 & 0.11 & 2.45 & 5.34 & 3.74 & 1.60 & 0.16 & 0.35 & 98.82 & 31 & 250 & 149 \\
\hline K-2427 & 62.9 & 0.66 & 16.2 & 5.97 & 0.12 & 2.76 & 5.84 & 3.41 & 1.68 & 0.15 & 0.01 & 98.98 & 36 & 246 & 143 \\
\hline$\underline{K}-2429$ & 66.0 & 0.62 & 15.1 & 5.09 & 0.10 & 2.24 & 4.68 & 3.44 & 2.14 & 0.14 & 0.09 & 99.04 & 46 & 202 & 173 \\
\hline \multicolumn{16}{|c|}{ East Summit } \\
\hline $\begin{array}{l}\text { K-167 } \\
\end{array}$ & 63.8 & 0.66 & 15.9 & 5.49 & 0.11 & 2.45 & 5.46 & 3.75 & 1.74 & 0.17 & 0.20 & 98.80 & 37 & 250 & 153 \\
\hline K-178 & 63.4 & 0.71 & 15.8 & 6.08 & 0.12 & 2.54 & 5.55 & 3.71 & 1.65 & 0.09 & - & 98.70 & 37 & 262 & 154 \\
\hline K-196 & 62.3 & 0.69 & 16.8 & 5.87 & 0.13 & 2.65 & 5.52 & 3.92 & 1.60 & 0.07 & - & 98.33 & 37 & 262 & 152 \\
\hline K-197A & 63.1 & 0.69 & 15.9 & 5.90 & 0.12 & 2.82 & 5,45 & 3.87 & 1.68 & 0.08 & - & 99.43 & 39 & 246 & 155 \\
\hline K-197-B & 63.9 & 0.67 & 15.9 & 5.59 & 0.12 & 2.52 & 5.33 & 3.73 & 1.73 & 0.16 & 0.16 & 99.20 & 33 & 244 & 156 \\
\hline K-218 & 60.1 & 0.67 & 16.5 & 6.74 & 0.13 & 3.71 & 7.10 & 3.39 & 1.26 & 0.06 & - & 99.29 & 28 & 269 & 125 \\
\hline K-2151 & 61.5 & 0.71 & 16.3 & 6.40 & 0.13 & 3.27 & 6.13 & 3.57 & 1.45 & 0.16 & 0.36 & 99.06 & 27 & 247 & 131 \\
\hline K-2152 & 63.0 & 0.70 & 16.2 & 5.64 & 0.12 & 2.70 & 5.53 & 3.92 & 1.59 & 0,18 & 0.00 & 99.26 & 33 & 288 & 157 \\
\hline K-2160 & 61.6 & 0.71 & 16.3 & 6.40 & 0.13 & 3.17 & 6.16 & 3.58 & 1.45 & 0.16 & 0.26 & 98.83 & 29 & 252 & 131 \\
\hline $\mathrm{K}-2272$ & 62.7 & 0.68 & 16.0 & 6.03 & 0.08 & 3.37 & 5.84 & 3.31 & 1.48 & 0.16 & 2.86 & 95.97 & 27 & 234 & 146 \\
\hline K-2273 & 64.1 & 0.75 & 15.1 & 6.04 & 0.12 & 2.90 & 5.13 & 3.71 & 1.55 & 0.15 & 1.05 & 97.67 & 29 & 257 & 146 \\
\hline K-2493A & 62.0 & 0.69 & 16.2 & 6.11 & 0.12 & 3.05 & 6.13 & 3.49 & 1.59 & 0.22 & 0.63 & 98.26 & 34 & 253 & 155 \\
\hline $\mathrm{K}-2548$ & 60.0 & 0.74 & 17.0 & 6.83 & 0.13 & 3.03 & 6.61 & 3.52 & 1.49 & 0.23 & 0.24 & 99.06 & 34 & 299 & 140 \\
\hline K-2425 & 63.5 & 0.69 & 16.0 & 5.67 & 0.12 & 2.58 & 5.50 & 3.67 & 1.68 & 0.17 & 0.19 & 98.85 & 35 & 240 & 153 \\
\hline K-2426 & 63.5 & 0.68 & 15.8 & 5.96 & 0.12 & 2.76 & 5.46 & 3.52 & 1.70 & 0.15 & 0.34 & 98.64 & 35 & 238 & 155 \\
\hline $\mathrm{K}-2430$ & 62.4 & 0.69 & 16.2 & 6.09 & 0.12 & 2.93 & 5.91 & 3.54 & .57 & 0.16 & 0.03 & 99.42 & 33 & 242 & 142 \\
\hline $\mathrm{K}-2431$ & 60.6 & 0.73 & 16.5 & 6.75 & 0.14 & 3.41 & 6.51 & 3.44 & 1.35 & 0.15 & - & $99: 48$ & 27 & 259 & 131 \\
\hline K-2432 & 62.0 & 0.73 & 16.2 & 6.04 & 0.13 & 3.10 & 5.96 & 3.74 & 1.48 & 0.17 & - & 99.29 & 29 & 291 & 140 \\
\hline K-2434 & 63.0 & 0.71 & 1.5 .9 & 6.00 & 0.12 & 2.84 & 5.62 & 3.56 & 1.63 & 0.16 & - & 99.02 & 35 & 243 & 147 \\
\hline K-2435 & 62.6 & 0.70 & 16.2 . & 6.01 & 0.12 & 2.79 & 5.78 & 3.61 & 1.59 & 0.17 & 0.14 & 98.83 & 34 & 249 & 138 \\
\hline $\mathrm{K}-2436$ & 63.5 & 0.70 & 15.9 & 5.82 & 0.12 & 2.66 & 5.45 & 3.62 & 1.68 & 0.16 & 0.31 & 98.68 & 30 & 238 & 142 \\
\hline K-2438 & 63.9 & 0.68 & 15.8 & 5.68 & 0.12 & 2.60 & 5.38 & 3.61 & 1.74 & 0.15 & 0.13 & 97.97 & 40 & 242 & 154 \\
\hline \multicolumn{16}{|c|}{ North Summit } \\
\hline K-176 & 63.0 & 0.70 & 15.8 & 6.20 & 0.12 & 2.78 & 5.91 & 3.46 & 1.57 & 0.06 & - & 98.75 & 37 & 239 & $\overline{152}$ \\
\hline K-207 & 63.6 & 0.68 & 15.8 & 5.71 & 0.12 & 2.59 & 5.45 & 3.74 & 1.73 & 0.16 & 0.06 & 99.23 & 31 & 242 & 147 \\
\hline K-209 & 60.5 & 0.65 & 16.6 & 6.55 & 0.13 & 3.47 & 7.07 & 3.57 & 1.06 & 0.05 & - & 99.36 & 20 & 269 & 114 \\
\hline K-210 & 63.0 & 0.68 & 16.1 & 6.04 & 0.12 & 2.70 & 5.91 & 3.41 & 1.48 & 0.12 & 0.13 & 99.43 & 30 & 249 & 141 \\
\hline K-211 & 62.8 & 0.68 & 15.8 & 6.25 & 0.12 & 2.56 & 6.10 & 3.75 & 1.48 & 0.06 & - & 98.89 & 35 & 251 & 136 \\
\hline K-212 & 62.3 & 0.65 & 16.7 & 5.85 & 0.11 & 2.53 & 6.45 & 3.54 & 1.42 & 0.12 & 0.50 & 98.53 & 32 & 249 & 144 \\
\hline $\mathrm{K}-213$ & 63.4 & 0.65 & 16.2 & 5.66 & 0.10 & 2.42 & 6.03 & 3.43 & 1.55 & 0.12 & 0.13 & 98.80 & 36 & 238 & 145 \\
\hline $\mathrm{K}-215$ & 61.7 & 0.69 & 16.2 & 6.39 & 0.13 & 3.14 & 6.39 & 3.47 & 1.45 & 0.07 & - & 98.50 & 33 & 257 & 137 \\
\hline K-222 & 60.6 & 0.73 & 16.6 & 6.81 & 0.13 & 3.33 & 6.62 & 3.53 & 1.17 & 0.12 & - & 98.63 & 24 & 272 & 119 \\
\hline $\mathrm{K}-223$ & 60.6 & 0.75 & 16.2 & 6.96 & 0.14 & 3.49 & 6.62 & 3.57 & 1.23 & 0.08 & - & 99.75 & 25 & 271 & 122 \\
\hline $\mathrm{K}-223-\mathrm{A}$ & 60.6 & 0.74 & 16.6 & 6.67 & 0.13 & 3.33 & 6.55 & 3.53 & 1.24 & 0.17 & 0.68 & 98.83 & 21 & 266 & 115 \\
\hline K-2092 & 62.7 & 0.65 & 16.0 & 5.91 & 0.12 & 3.03 & 5.95 & 3.47 & 1.64 & 0.16 & 0.28 & 98.81 & 38 & 264 & 149 \\
\hline $\mathrm{K}-2265$ & 62.8 & 0.67 & 15.9 & 5.96 & 0.12 & 3.00 & 5,86 & 3.47 & 1.67 & 0.15 & 0.27 & 98.80 & 32 & 247 & 142 \\
\hline K-2267 & 60.6 & 0.74 & 16.6 & 6.73 & 0.13 & 3.31 & 6.54 & 3.56 & 1.24 & 0.17 & - & 98.74 & 22 & 268 & 122 \\
\hline K-2269 & 63.5 & 0.68 & 16.8 & 5.65 & 0.09 & 2.54 & 5.27 & 3.31 & 1.66 & 0.14 & 1.91 & 97.22 & 35 & 222 & 152 \\
\hline K-2437 & 61.5 & 0.71 & 16.5 & 6.49 & 0.13 & 2.99 & 6.13 & 3.59 & 1.42 & 0.17 & 0.10 & 99.17 & 27 & 269 & 128 \\
\hline $\mathrm{K}-2475$ & 62.0 & 0.70 & 16.3 & 6.26 & 0.12 & 3.02 & 6.10 & 3.43 & 1.49 & 0.15 & - & 98.73 & 29 & 251 & 132 \\
\hline K-2481 & 64.2 & 0.68 & 15.6 & 5.62 & 0.12 & 2.59 & 5.32 & 3.53 & 1.83 & 0.15 & 0.09 & 98.66 & 44 & 237 & 167 \\
\hline \multicolumn{16}{|c|}{ Southwest Summit } \\
\hline K-2052 & 65.1 & 0.61 & 16.1 & 5.01 & 0.13 & 2.12 & 4.49 & 4.26 & 1.65 & 0.19 . & 0.56 & 98.66 & 27 & 249 & 131 \\
\hline K-2056 & 57.7 & 0.80 & 16.5 & 7.55 & 0.14 & 4.35 & 7.74 & 3.18 & 1.43 & 0.19 & 0.94 & 98.51 & 29 & 284 & 125 \\
\hline K-2091 & 62.0 & 0.70 & 16.2 & 6.40 & 0.12 & 3.03 & 5.67 & 3.41 & 1.84 & 0.17 & 0.28 & 98.87 & 46 & 258 & 162 \\
\hline K-2113 & 63.4 & 0.68 & 16.1 & 5.90 & 0.12 & 2.48 & 5.07 & 3.54 & 2.13 & 0.19 & 0.80 & 98.37 & 46 & 257 & 179 \\
\hline K-2114 & 61,4 & 0.78 & 16.4 & 6.74 & 0.13 & 2.99 & 5.76 & 3.47 & 1.78 & 0.18 & 0.60 & 98.42 & 37 & 271 & 156 \\
\hline K-2116 & 59.2 & 0.73 & 16.3 & 7.05 & 0.13 & 4.03 & 7.19 & 3.20 & 1.57 & 0.19 & 0.16 & 98.91 & 35 & 304 & 139 \\
\hline K-2117 & 58.9 & 0.73 & 16.2 & 7.13 & 0.14 & 4.11 & 7.37 & 3.23 & 1.55 & 0.19 & 0.38 & 99.33 & 35 & 306 & 141 \\
\hline K-2126 & 65.1 & 0.57 & 15.9 & 5.19 & 0.12 & 2.26 & 4.73 & 3.69 & 1.90 & 0.16 & 0.34 & 98.65 & 34 & 245 & 128 \\
\hline K-2127 & 65.1 & 0.57 & 15.8 & 5.26 & 0.12 & 2.33 & 4.70 & 3.72 & 1.91 & 0.16 & 0.58 & 99.07 & 39 & 246 & 132 \\
\hline $\mathrm{K}-2128$ & 63.9 & 0.67 & 16.0 & 5.71 & 0.12 & 2.42 & 4.89 & 3.52 & 2.23 & 0.18 & 0.41 & 98.80 & 55 & 249 & 182 \\
\hline K-2129 & 61.4 & 0.86 & 16.1 & 6.92 & 0.12 & 2.92 & 5.57 & 3.36 & 2.08 & 0.20 & 1.00 & 98.03 & 45 & 247 & 190 \\
\hline K-2130 & 61.9 & 0.75 & 16.3 & 6.47 & 0.13 & 2.85 & 5.68 & 3.52 & 1.88 & 0.18 & 0.10 & 99.04 & 47 & 271 & 162 \\
\hline K-2131 & 63.4 & 0.70 & 16.0 & 5.86 & 0.12 & 2.53 & 5.25 & 3.57 & 2.03 & 0.17 & 0.15 & 98.95 & 49 & 265 & 174 \\
\hline K-2131-A & 56.3 & 0.92 & 17,7 & 8.46 & 0.15 & 4.03 & 7.30 & 3.25 & 1.28 & 0.19 & 0.40 & 98.60 & 25 & 321 & 116 \\
\hline K-2132 & $67: 9$ & 0.51 & 15.8 & 3.98 & 0.08 & 1.53 & 3.74 & 3.82 & 2.17 & 0.15 & 1.18 & 98.33 & 43 & 236 & 143 \\
\hline K-2133 & 65.5 & 0.58 & 15.8 & 4.81 & 0.13 & 2.11 & 4.63 & 4.07 & 1.77 & 0,17 & 1.10 & 98.21 & 35 & 241 & 131 \\
\hline K-2136 & 60.4 & 0.80 & 16.6 & 7.09 & 0.14 & 3.23 & 6.01 & 3.47 & 1.67 & 0.20 & 0.18 & 99.03 & 38 & 293 & 149 \\
\hline K-2171 & 65.5 & 0.63 & 15.4 & 5.21 & 0.10 & 2.20 & 4.79 & 3.59 & 2.11 & 0.14 & 0.74 & 98.32 & 47 & 206 & 165 \\
\hline K-2171-A & 62.6 & 0.66 & 16.1 & 6.13 & 0.12 & 2.86 & 5.92 & 3.46 & 1.64 & 0.16 & 0.25 & 99.01 & 37 & 239 & 138 \\
\hline K-2264 & 62.4 & 0.73 & 16.0 & 6.28 & 0.12 & 2.78 & 5.70 & 3.55 & 1.85 & 0.15 & 0.24 & 98.76 & 46 & 263 & 160 \\
\hline K-2270 & 57.4 & 0.71 & 17.4 & 7.29 & 0.14 & 4.29 & 8.27 & 3.00 & 0.93 & 0.16 & 0.84 & 98.70 & 17 & 287 & 100 \\
\hline
\end{tabular}


the North and East Summits are usually obscured by snow, but an ice-free 350-m-wide phreatic crater that lies between the East and Central Summits contains an acid lake and several jet-like superheated fumaroles. About 30 percent of the present-day surface of Mageik is covered by glacial ice, including about 80 percent of the four-summit region, where rock outcrops are limited to scattered windows through the ice, most of them very steep.

\section{Southwest Summit}

The Southwest Summit vent supplied the products that make up the southwestern half of the volcano (fig. 2). Although it is the stratigraphically oldest and most ice-ravaged of the four components, it remains the most voluminous, providing about half the mass of present-day Mount Mageik. Most products of the Southwest Summit (57-68 percent $\mathrm{SiO}_{2}$ ) are compositionally distinguishable from those of the other three in being generally richer in $\mathrm{K}_{2} \mathrm{O}$ (table 1). Basal lava flows in two areas yield $\mathrm{K}$-Ar ages close to $90 \mathrm{ka}$, which thus apparently dates the initiation of volcanic activity at Mount Mageik (table 2). For convenient discussion, we treat the many lava flows of the Southwest Summit edifice as four spatially distinct groups:

(1) The SSE. planeze is a stack of at least seven andesite and dacite lava flows having an exposed maximum total thickness of at least $350 \mathrm{~m}$. There is no simple compositional progression, as the most silicic lava known to have erupted from Mount Mageik is in the middle of the stack. As dips lessen downslope from $25^{\circ}$ or $30^{\circ}$ proximally to about $10^{\circ}$ distally, most of the flows thicken; the two thickest ( 62 percent and 65 percent $\mathrm{SiO}_{2}$ ) each reach about $150 \mathrm{~m}$ at their eroded distal termini.

(2) A stack of about eight andesite and dacite lava flows (61-64 percent $\mathrm{SiO}_{2}$ ), each 30-100 m thick, makes up the southtrending ridge separating the headwaters of Alagogshak and Martin Creeks. The maximum exposed thickness of the southdipping stack is $275 \mathrm{~m}$ on the cliffs facing Martin Creek.

(3) Remnants of a single andesite flow line the north edge of the glacial trough that runs northwestward toward Angle Creek where its distal extremity is $150 \mathrm{~m}$ thick. One of the least silicic lavas (57.7 percent $\mathrm{SiO}_{2}$ ) sampled at Mount Mageik, the flow was no doubt far more extensive prior to glacial erosion. In common with the southerly stacks of lavas just described, this flow probably extended down-canyon several kilometers beyond its present limit; all three glacially truncated termini today lie about $6 \mathrm{~km}$ from the Southwest Summit vent.

(4) The great northwest buttress, its 600-m cliffs surrounded by ice (figs. 2, 4), exposes a set of andesite-dacite lava flows (62-65.5 percent $\mathrm{SiO}_{2}$ ) that dip gently away from the Southwest Summit; several are as thick as $100 \mathrm{~m}$ and one exceeds $200 \mathrm{~m}$ (fig. 4).

The Southwest Summit itself $(2,105 \mathrm{~m} ; 6,900 \mathrm{ft})$ is an icecovered mound $1 \mathrm{~km}$ wide that rises $180 \mathrm{~m}$ above the saddle to its east. The only exposure is on the sheer south face where coarse ejecta suggest the edge of a fragmental cone (rather than a dome) concealed by the icecap. At the east end of this face, a stubby andesite lava flow that issues from the cone emerges from beneath the icecap and extends steeply down the ESE. spur for some $500 \mathrm{~m}$. At 57.4 percent $\mathrm{SiO}_{2}$, this is the

Table 2. Whole-rock potassium-argon ages and analytical data.

[Analysts: Potassium by D.F. Siems; Argon by F.S. McFarland and J.Y. Saburomaru (Menlo Park, California). Constants: $\left.\lambda=0.581 \times 10^{-10} \mathrm{y}^{-1} ; \lambda_{\mathrm{b}}=4.962 \times 10^{-10} \mathrm{y}^{-1} ;{ }^{40} \mathrm{~K} / \mathrm{K}=1.167 \times 10^{-4} \mathrm{~mol} / \mathrm{mol}\right]$

\begin{tabular}{|c|c|c|c|c|c|c|}
\hline \multirow{2}{*}{$\begin{array}{l}\text { Sample } \\
\text { number }\end{array}$} & \multirow{2}{*}{$\begin{array}{l}\text { Location } \\
\text { (see fig. 2) }\end{array}$} & \multicolumn{2}{|r|}{$\mathrm{Wt} \%$} & \multicolumn{2}{|c|}{ Radiogenic ${ }^{40} \mathrm{Ar}$} & \multirow{2}{*}{$\begin{array}{c}\text { Calculated } \\
\text { age }\end{array}$} \\
\hline & & $\mathrm{SiO}_{2}$ & $\overline{\mathrm{K}_{2} \mathrm{O}}$ & $10^{-13} \mathrm{~mol} / \mathrm{g}$ & $\%$ & \\
\hline K-2130 & $\begin{array}{l}\text { Martin Creek, } \\
\text { West Fork; NE. } \\
\text { wall, 2300-ft rim. } \\
\text { Basal lava flow. }\end{array}$ & 61.9 & $2.009 \pm 0.007$ & 2.681 & 9.5 & $93 \pm 8 \mathrm{ka}$ \\
\hline K-2136 & $\begin{array}{l}\text { Alagogshak Creek, } \\
\text { 2800-ft nose } \\
\text { in headwaters. } \\
\text { Basal lava flow. }\end{array}$ & 60.4 & $1.830 \pm 0.005$ & 2.356 & 10.8 & $89 \pm 8 \mathrm{ka}$ \\
\hline K-2144 & $\begin{array}{l}\text { Upper bowl of North } \\
\text { Fork, Martin Creek; } \\
2600 \text {-ft rim of thick } \\
\text { basal lava flow, } \\
4 \text { km SE. of Mageik's } \\
\text { Central Summit. }\end{array}$ & 57.8 & $1.250 \pm 0.001$ & 1.282 & 5.4 & $71 \pm 11 \mathrm{ka}$ \\
\hline $\mathrm{K}-2267 \mathrm{~A}$ & $\begin{array}{l}\text { NW. base Mount } \\
\text { Mageik, } 300 \mathrm{~m} \mathrm{S.} \\
\text { of W. Mageik Lake. } \\
\text { Basal lava flow. }\end{array}$ & 60.6 & $1.344 \pm 0.001$ & 1.138 & 6.6 & $59 \pm 11 \mathrm{ka}$ \\
\hline
\end{tabular}




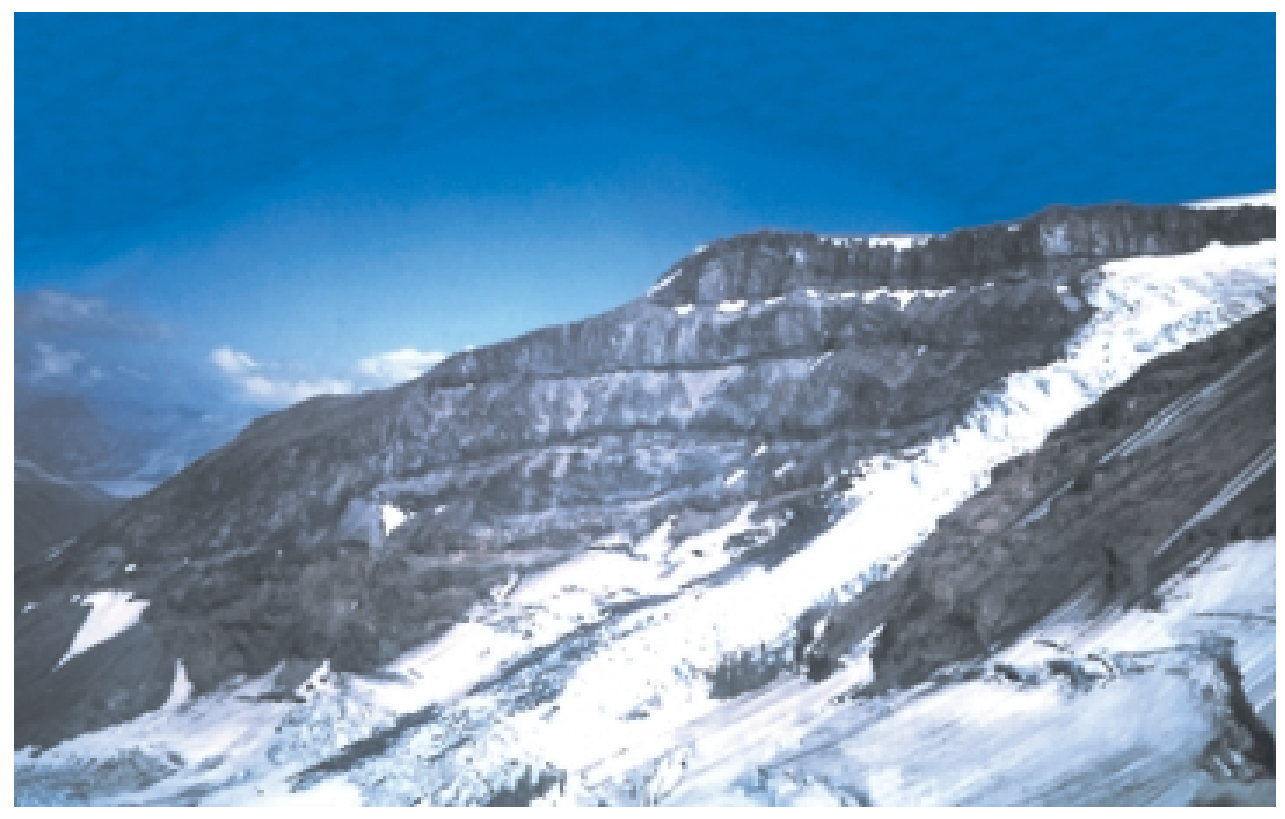

Figure 4. Northwest buttress of Mount Mageik. View toward NNE. with Valley of Ten Thousand Smokes in distant background. Stack of andesite-dacite lava flows from Southwest Summit vent is 600 $\mathrm{m}$ thick. Top flow is $100 \mathrm{~m}$ thick and third flow from top thickens downslope to more than $200 \mathrm{~m}$. Note $10^{\circ}$ dips, vertical noncolumnar jointing, thick massive zones, thinness of darker (glassier) flow-breccia zones intercalated, and relative conformity of upper part of the stack. Thinner flows at base of buttress and in wall at right are likewise from the Southwest Summit vent.

most mafic lava sampled anywhere on Mount Mageik (table 1). The icecap that mantles the Southwest Summit is too thick to reveal whether it fills a small crater atop the cone, but a slight depression in the ice suggests that. A major cirque headwall just southwest of the cone provides the largest exposure of severely hydrothermally altered rock on Mount Mageik. This is the source of a clay-rich debris-avalanche deposit that covers the floor of Martin Creek for more than $16 \mathrm{~km}$ downstream (fig. 2).

\section{Central Summit}

The Central Summit is a 1-km-wide ice-clad knob that rises 180-250 $\mathrm{m}$ above the adjacent saddles that separate it from the other summits. At an elevation of more than $2,165 \mathrm{~m}$ $(7,100 \mathrm{ft})$, it forms the highest point on the volcano. The steep north and west faces of the knob are sheer ice, but the east face was exposed by explosive excavation of the fumarolically active crater at its eastern base. The ice-mantled southern slope is gentler but smooth, providing no hint of a depression that might conceal an ice-filled crater, and low on the slope are two small exposures of blocky dacite lava (64 percent $\mathrm{SiO}_{2}$ ) that could be exogenous lobes of a lava dome. The 100-m-high western wall of the crater appears to be one massive lava, consistent with the Central Summit being a lava dome, although (slightly altered) blocks from that wall yield 61-63 percent $\mathrm{SiO}_{2}$, similar but not identical to the blocky lava on the south slope. Lava flows radiating away from the Central Summit vent are exposed $1-1.5 \mathrm{~km}$ to the northwest as windows of andesite (60 percent $\mathrm{SiO}_{2}$ ) through the ice and as far as $4 \mathrm{~km}$ down the southeast slope (fig. 2) as a set of glaciated benches and cleavers (58-66 percent $\mathrm{SiO}_{2}$ ). Even ignoring the ice cover, products of the Central Summit are estimated to make up only about 15 percent of the surface area of Mount Mageik (fig. 2). Their volumetric proportion is likely to be larger owing to partial concealment by products of the younger North and East Summit vents.
The age relationship between the Central and Southwest Summit edifices, both ubiquitously glaciated, is equivocal as their contacts are everywhere obscured by ice. The Central Summit is nonetheless inferred to be the younger of the pair on the basis of (a) the more advanced hydrothermal alteration of parts of the Southwest Summit edifice, (b) the apparent structural underpinning of Central Summit lavas on the southeast slope by those of the Southwest Summit, (c) the northeastwardyounging trend among the three companion edifices, and (d) the compositional distinctiveness of the higher $\mathrm{K}$ products of the Southwest Summit relative to those of the three (younger) edifices. The basal lava flow of the stack dipping southeast from the Central Summit gave a K-Ar age of $71 \pm 11 \mathrm{ka}$, clearly younger than the approximately 90 -ka basal lavas of the Southwest Summit (table 2).

\section{North Summit}

The North Summit $(2,012 \mathrm{~m} ; 6,600 \mathrm{ft})$ rises only $100 \mathrm{~m}$ above the saddle to its south (fig. 5) but has long steep slopes in all other directions (figs. 2, 3). Although its eruptive products (60.5-64 percent $\mathrm{SiO}_{2}$ ) are glacially modified everywhere, erosion is more severe lower on the edifice. An ice-filled crater 300 $\mathrm{m}$ wide is still well formed, and the surface of a 1-km-long proximal dacitic lava flow high on the northeast slope (fig. 3) remains blocky and scoriaceous. Exposures along the crater rim are intensely altered solfatarically, but products elsewhere are fresh and generally at least partly glassy. As the North Summit vent is high on the northern slope of the older edifice (figs. 2, 3), all of its 10-12 exposed lavas flowed approximately northward. Most of the flows are 25-75 m thick medially where dipping $20^{\circ}-30^{\circ}$, but several thicken substantially downslope where they encountered lesser gradients and in some cases were probably impounded by thick glacial ice. Glacially eroded termini of andesite-dacite lava flows 100-200 m thick at the northern base of Mount Mageik (figs. 2, 3) today support precipitous waterfalls and some of the most spectacular scenery in the district. 


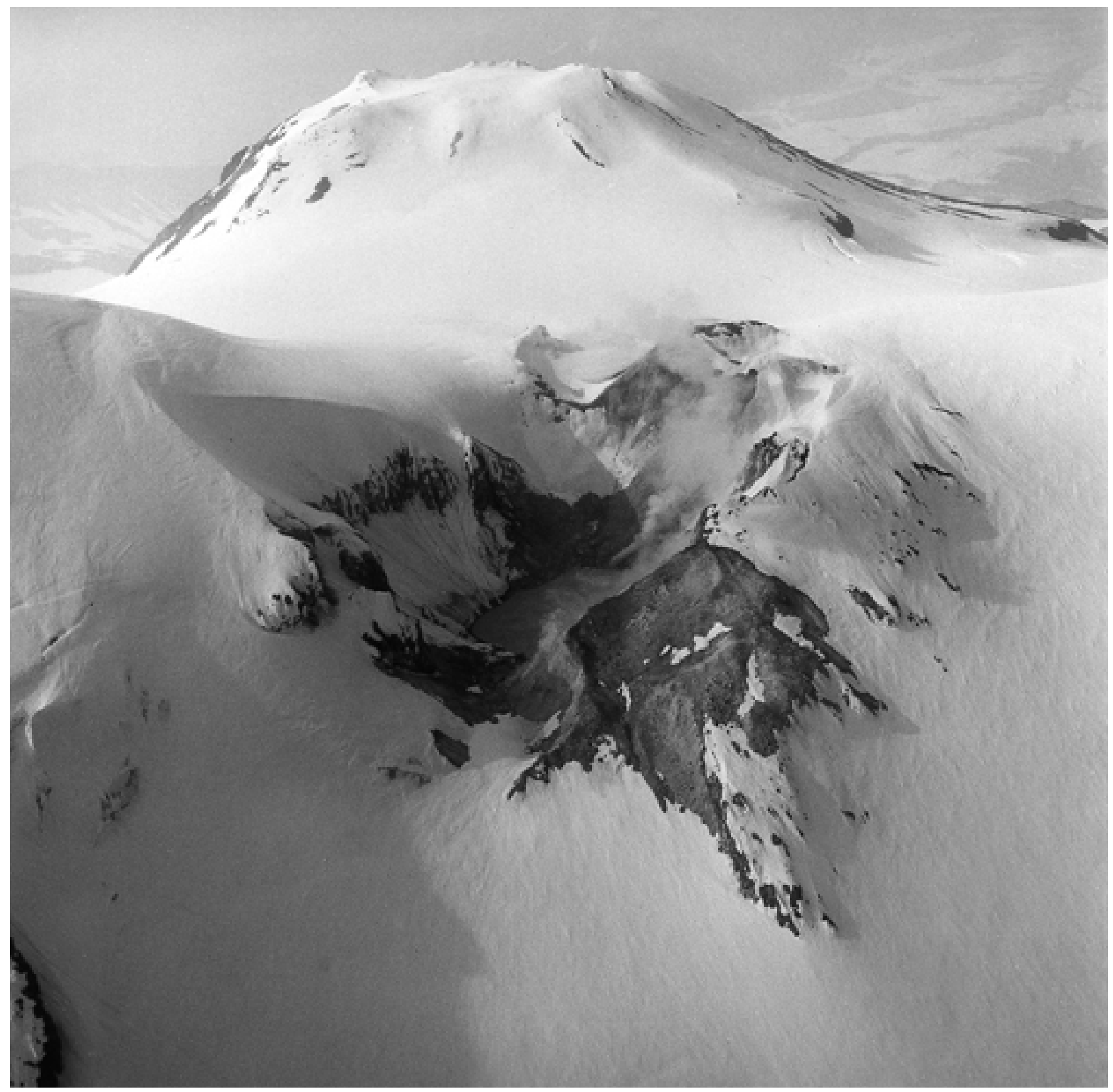

Figure 5. Aerial view northwestward of fumarolically active crater and North Summit of Mount Mageik. Rock walls and talus around crater are dacite of Central Summit, which lies partly out of field of view to left. Veneer of scattered dacite blocks mantles outer slope at lower right. Crater contains fumarole groups visible to south and northeast of its $125-\mathrm{m}$-wide acid lake. North Summit is $1 \mathrm{~km}$ beyond the crater and rises $50 \mathrm{~m}$ higher than the crater rim. Just discernible atop snow-draped North Summit is the flat surface of its own ice-filled crater and part of its (solfatarically altered) northwest rim. National Park Service photograph by W.S. Keller, summer 1969.

Despite the ubiquitous (and ongoing) glacial erosion, the North Summit edifice is thought to be young-late Pleistocene certainly and perhaps also in part early Holocene. Its northwesternmost basal lava flow, a fresh andesite that rests on Jurassic basement about $300 \mathrm{~m}$ south of West Mageik Lake, yields a KAr age of $59 \pm 11 \mathrm{ka}$ (table 2 ).

\section{East Summit}

The East Summit (2,012 m; 6,600 ft), was also built against the preexisting edifice, so (in common with the North Summit) its summit rim rises barely $50 \mathrm{~m}$ above the adjacent saddle and its lava flows were constrained to spread downslope very asymmetrically - in this case into the easterly sector (figs. 2, 3).

About a dozen lava flows (60-64 percent $\mathrm{SiO}_{2}$ ) descend toward Katmai Pass and Mageik Creek, forming a series of leveed tongues, stairstep benches, and sprawling piedmont lava lobes, each 50-150 m thick distally. From the vent at an elevation of more than 2,010 m, two of the flows extend $6 \mathrm{~km}$ to termini as low as 300-350 $\mathrm{m}$ in Martin Creek. One of the youngest flows bifurcates to the northeast (fig. 3), one of its lobes banking against the Mount Cerberus dacite dome and the other halting at 
Katmai Pass against the toe of an andesite lava flow from West Trident volcano (fig. 2). The East Summit vent is marked by an ice-filled crater about $250 \mathrm{~m}$ wide. Its rim is strewn with coarse scoriae and dense glassy blocks of phreatomagmatic ejecta, and exposed there locally are the blocky to rubbly surfaces of thin lava-flow veneers (64 percent $\mathrm{SiO}_{2}$ ) that largely drained away downslope. In contrast to the North Summit rim, no fumarolically altered exposures were seen around the crater rim of the East Summit, although altered fragmental strata do crop out high on the east face.

The East Summit edifice appears to be entirely Holocene in age. Although all of its lava flows are being eroded proximally by active glaciers, none of the lower benches, lobes, and leveed lava tongues are glacially scoured. The many flows (fig. 2) nonetheless exhibit considerable variation in relative retention of primary surface roughness, aeolian silt accumulation, incipient soil development, and gully incision, suggesting that the dozen or so Holocene lavas represent not a single episode but at least three eruptive episodes substantially separated in time. A thick cover of pumiceous 1912 fallout on low-relief parts of these flows makes any such relative age assessments hard to quantify.

\section{Similarity to Southwest (New) Trident Cone of 1953-74}

Each of the four summits is a discrete eruptive center, each the source of numerous lava flows from a simple fixed vent, expressed either as a plug dome or a cratered fragmental cone. We infer that each had a discrete conduit system independent of those of its companions, at least at shallow levels, and that each of the four centers underwent separate independent periods of activity. The morphological, structural, and compositional similarity of all four Mageik centers to an edifice just across Katmai Pass that was built from scratch starting in 1953 is striking and instructive.

Beginning in February 1953, a new andesite-dacite edifice (figs. 2,6) was built at the southwest margin of the Trident volcanic group (Snyder, 1954; Ray, 1967). Although referred to informally as "New Trident," we recommend calling it Southwest Trident, in anticipation of the day it ceases to be Trident's youngest component. During two decades of sporadic explosive activity (largely vulcanian), a new $3-\mathrm{km}^{2}$ fragmental cone was constructed of block-and-ash deposits, scoria, agglutinate, and intercalated lava flows to an elevation of about 1,515 m (GPS measurement by M. Coombs, 1997) on the site of a former fumarole at about $1,174 \mathrm{~m}$ on the glacially eroded southwest flank of Trident I (the central and highest cone of the Trident group). Although relief on its south slope exceeds $700 \mathrm{~m}$, the new cone therefore has a central thickness of only $340 \mathrm{~m}$ and a volume of about $0.3 \mathrm{~km}^{3}$. At successive stages of cone construction, four blocky leveed lava flows effused from its central vent in 1953, 1957, 1958, and during the winter of 1959-60 (fig. 6). Each lava flow is $30-70 \mathrm{~m}$ thick and $2.5-4.5 \mathrm{~km}$ long, and altogether they add about $0.35 \mathrm{~km}^{3}$ to the eruptive volume. The cone's summit is today marked by a shallow crater, $350 \mathrm{~m}$ wide, that was the site of several small interim plugs, which were emplaced after the final lava flow and were repeatedly destroyed by intermittent explosive activity (1960-74). Black ash clouds rose 6-9 km several times between 1953 and 1968 and perhaps to $12 \mathrm{~km}$ once or twice; undated ballistic blocks are strewn as far as $3 \mathrm{~km}$ from the vent. A single layer of coarse ash, typically 5$17 \mathrm{~cm}$ thick, is preserved at a few protected sites as far as $7 \mathrm{~km}$ northeast. Liberal estimates of total fallout yield less than 0.05 $\mathrm{km}^{3}$, giving a total eruptive volume of about $0.7 \mathrm{~km}^{3}$. Most of the fallout and at least half the total volume of lava and proximal ejecta were emplaced within the first four months, before June 1953 (Snyder, 1954). Minor ejections of tephra, some involving plug blowout, took place from 1963 to 1974, but volumetrically significant eruptions were over by 1963. Numerous fumaroles, superheated and sulfurous in the 1960's but near- or sub-boiling today, persist on upper parts of the cone (fig. 6).

The width of the crater, the size of the fragmental cone, and the intercalation within the cone itself of the proximal parts of effusive lava flows with the progressively accumulating pyroclastic debris are similar to the equivalent features on Mageik. The blocky leveed lava flows of 1953-60 are morphologically and texturally similar to the young coulees from the East Summit of Mageik, and many of the steep rubbly flow-fronts are of similar height. Their magmas were similar as well, as the lavas and scoria blocks erupted from 1953 to 1963 are olivine-poor two-pyroxene andesite and dacite (57-65 percent $\mathrm{SiO}_{2}$; Hildreth and Fierstein, 2000), many of which are hard to distinguish (fig. 7) from the comparable products of East Mageik (60-64 percent $\mathrm{SiO}_{2}$ ) If the cone and lavas of 1953-74 had vented on the opposite side of Katmai Pass, they would no doubt have been regarded as a fifth component of Mount Mageik.

The volume of Southwest Trident is an order of magnitude smaller than those of the East and Southwest components of Mageik but not drastically smaller than volumes of the North and Central Mageik centers (fig. 2). Could any of these have been constructed in 20 years? We have found little evidence for severe erosional unconformities within any of the four Mageik edifices (e.g., fig. 4), despite the prevalence of glacial ice. We may never know how long their eruptive lifetimes lasted, but, whether 20 years, 200, or 2,000, it seems likely that each component cone of Mount Mageik grew fairly rapidly.

\section{Fumarolically Active Crater}

Mageik's fuming crater is about $100 \mathrm{~m}$ deep, $450 \mathrm{~m}$ long, and 280-400 $\mathrm{m}$ wide at the rim (fig. 5). It penetrates the margin of the Central Summit dome (fig. 2) and is clearly separated by a gentle 300-m-wide saddle from the East Summit. Elongate north-south, the crater's eastern and western walls are precipitous, but notches at both ends permit access. Its talus-mantled lower walls funnel down to an ovoid lake about $125 \mathrm{~m}$ wide that occupies much of the crater floor. Fumarolic discharge through the lake keeps the water yellow-green, acid ( $\mathrm{pH}=1-2)$, as hot as $72^{\circ} \mathrm{C}$, and in a continual state of roiling agitation. The resulting waves pile up a fringe of yellow sulfurous frothy spindrift along the shoreline. Several fumaroles, some quite vigorous, emerge from the talus south and northeast of the lake as well as beneath it. Some are superheated; the hottest one measured in 1979 was $172^{\circ} \mathrm{C}$. According to recent work by R.B. Symonds (Cascades Volcano Observatory, oral commun., 1998), the Mageik fumaroles are predominantly steam but are rich in $\mathrm{CO}_{2}$ and $\mathrm{H}_{2} \mathrm{~S}$ 

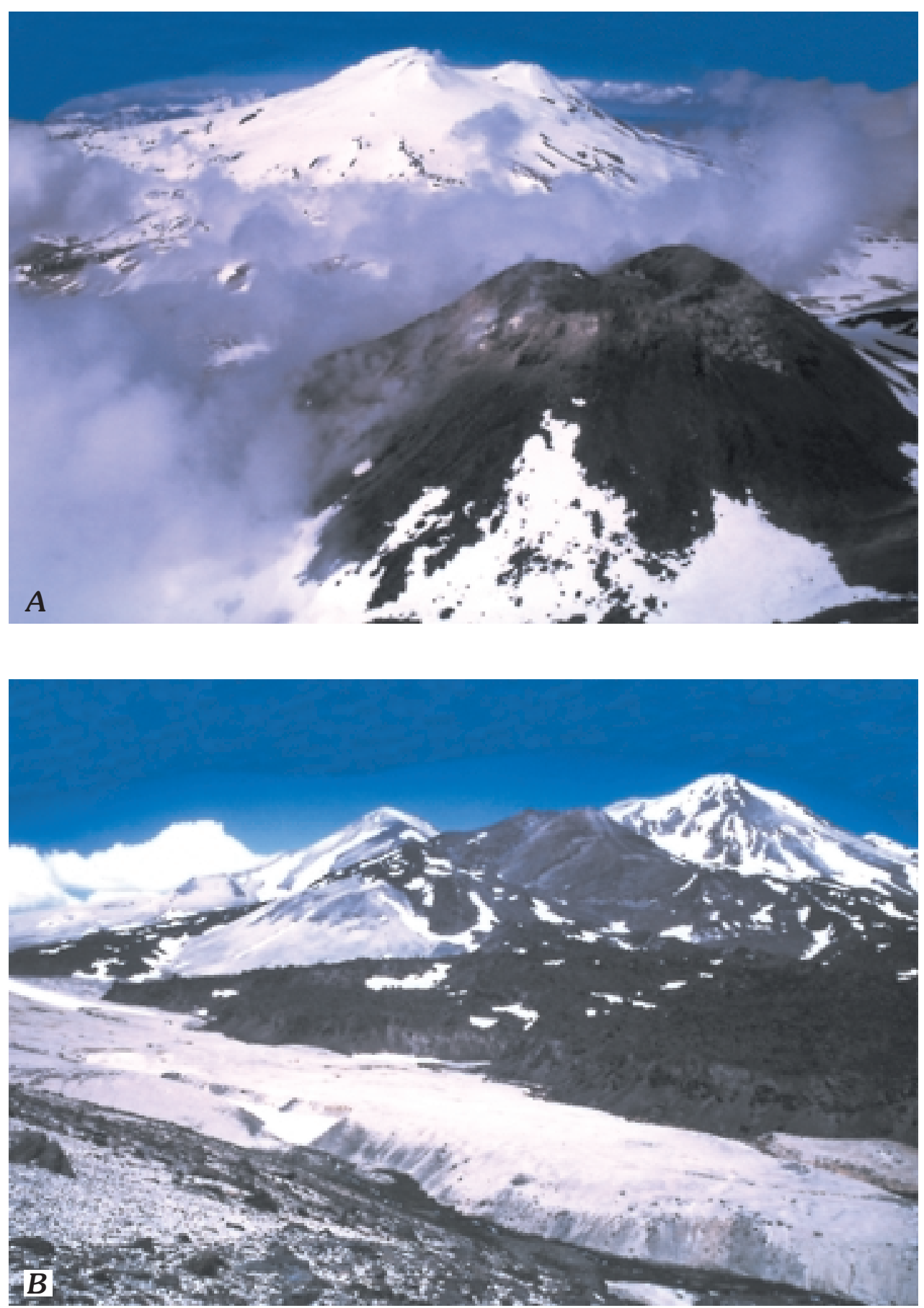

Figure 6. Southwest (New) Trident edifice constructed 1953-74. A, View westward over coarsely fragmental cone, showing 350-m-wide crater and, just outside the rim, pale collar zone marked by solfataric alteration and weak fumaroles. East and North Summit cones of snow-covered Mount Mageik, 8 km farther west, are structurally, morphologically, and compositionally similar, but their craters are now filled by ice. Levees of Holocene lava flows from the East Summit can be seen emerging from the icecap at midslope and descending into clouds drifting through Katmai Pass, which separates Trident from Mageik (fig. 2). Atop Mageik, small puffs of fumarolic vapor on skyline rise from open phreatic crater hidden between East Summit and Central (true) Summit behind it. $B$, View northeastward of Southwest Trident across upper Mageik Creek from big southeastern piedmont lava lobe of Mount Mageik (fig. 2). Dark fragmental cone has $700 \mathrm{~m}$ relief on this (downslope) side. In foreground, blocky andesitedacite lava flows of 1953 and 1958 have flow-fronts 50-70 $\mathrm{m}$ high and rest on thin white ignimbrite of 1912, which in turn overlies gray glacial deposits. At far left near Katmai Pass is dark andesite lava flow of 1959-60, and at far right center (with snowpatches) is leveed lava flow of 1957. On skyline beyond 1953-74 cone are glaciated edifices of the Trident group: West Trident at left, Trident I at right, and a bit of East Trident in distance at extreme right. and have $\mathrm{C}$ - and He-isotope ratios typical of magmatic gases from arc volcanoes. Depending on wind and condensation conditions, their combined plume is commonly visible from afar, but it rarely rises as high as $1 \mathrm{~km}$ above the crater rim and is never as large as the fumarolic plume from nearby Mount Martin. Though the rim is surrounded by glacial ice (fig. 5), the thermal flux keeps the crater largely ice-free. Even fresh snow quickly acquires from the fumaroles a yellow dusting of sulfur sublimate.

When the crater was first visited by Fenner and Yori on 4 August 1923 (Fenner, 1930), its configuration was essentially the same as today (fig. 8), except that instead of the present 125$\mathrm{m}$-wide lake there were two shallow muddy pools $(10 \mathrm{~m}$ and 15-20 m wide) that were made to boil and fountain by the fumarolic discharge through them. Fenner noted the unstable rockfall talus, the angularity of the talus blocks, the sublimates of sulfur on rocks and snow, the strong sulfurous fumes, and the fumarolic roar like "a great waterfall."

Fenner also noted loose blocks of lava and finer debris on the glacier near the crater's southeast rim, attributing them to relatively recent ejection. We have likewise found such blocks scattered as far as the East Summit, about 600 m northeast of the crater and at least $50 \mathrm{~m}$ higher than the saddle between them. Lithologically, the blocks resemble the rock making up the walls of the crater, which was excavated explosively through a dome (or single thick lava flow) of massive pyroxene-plagioclase dacite (63-64 percent $\mathrm{SiO}_{2}$ ). Part of the Central Summit, the crater-wall dacite is heavily jointed, irregularly oxidized, and incipiently acid-altered along fractures. That such alteration is only moderate, rather than advanced and pervasive 

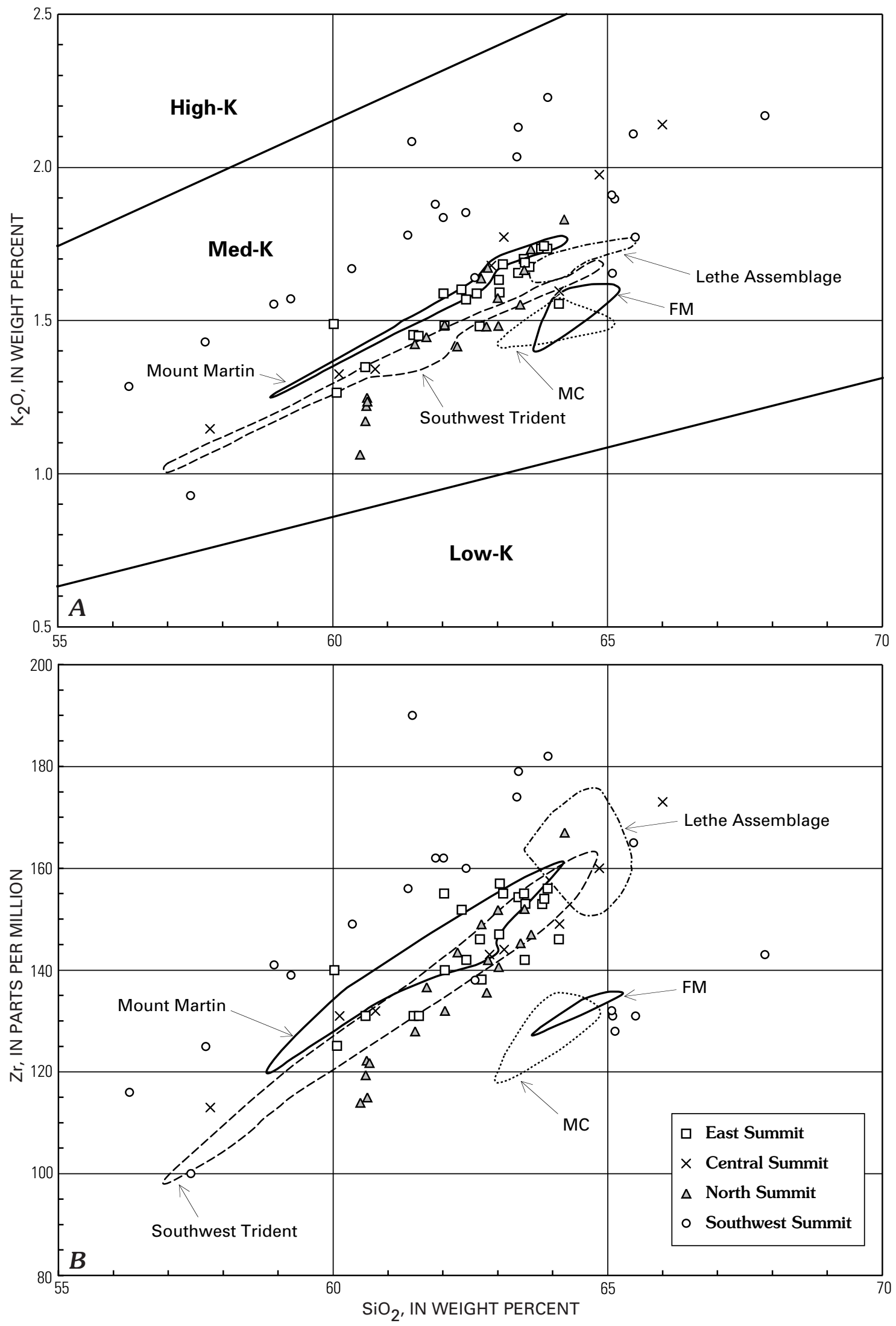

Figure 7. Whole-rock compositional data for the four centers making up Mount Mageik, as identified in inset. The conventional division in arc suites between andesite and dacite at 63 percent $\mathrm{SiO}_{2}$ is, as usual, an arbitrary tick on a continuum. In addition to Mageik data, fields outlining the compositional ranges determined for our suites of samples from nearby Mount Martin ( $n=13$ ) and Southwest (New) Trident $(n=15)$ are shown for comparison, along with fields for 11 pumice blocks from the Lethe Assemblage and 4 samples each from the Falling Mountain (FM) and Mount Cerberus (MC) domes (fig. 2). $A, \mathrm{~K}_{2} \mathrm{O}$ vs. $\mathrm{SiO}_{2} . B, \mathrm{Zr}$ vs. $\mathrm{SiO}_{2}$. Data from Hildreth and others (1999); Hildreth and Fierstein (2000); and table 1 , this report. 


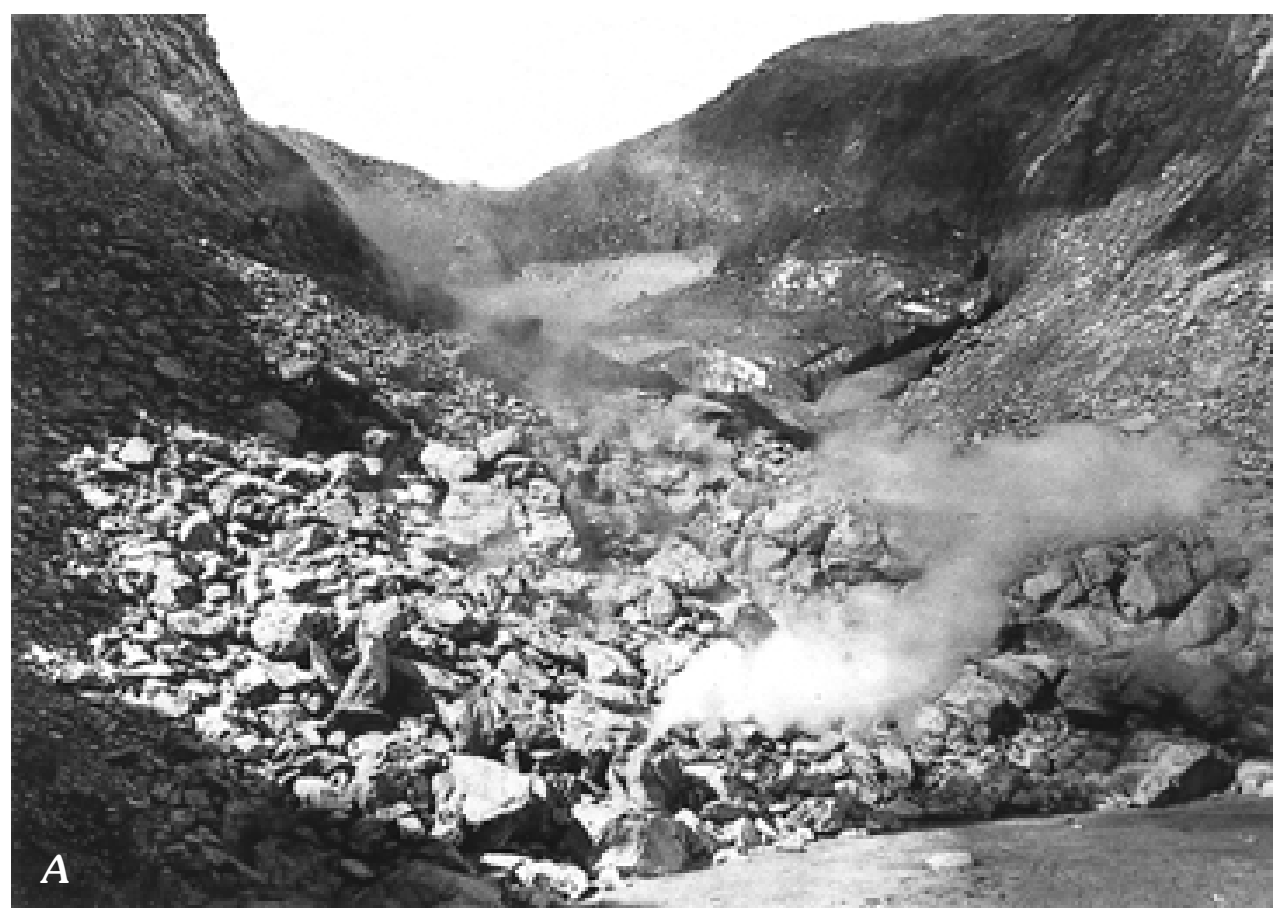

Figure 8. Fumarolically active crater of Mount Mageik in 1923 and 1979. A, View north along crater floor toward north notch, by C. Yori on 4 August 1923. Talus blocks and crater walls are massive dacite of Central Summit. Hidden by talus are two shallow muddy ponds described by Fenner (1930). B, View south from just below north notch, by W. Hildreth 10 July 1979. Much of crater floor is occupied by $125-\mathrm{m}$-wide hot acid lake, which remained much the same when we last saw it on 28 July 1997. Fumarole groups are vigorously active in talus south and northeast of the lake as well as beneath it. Note that pumice, scoriae, agglutinate, and other juvenile ejecta are lacking in both views.

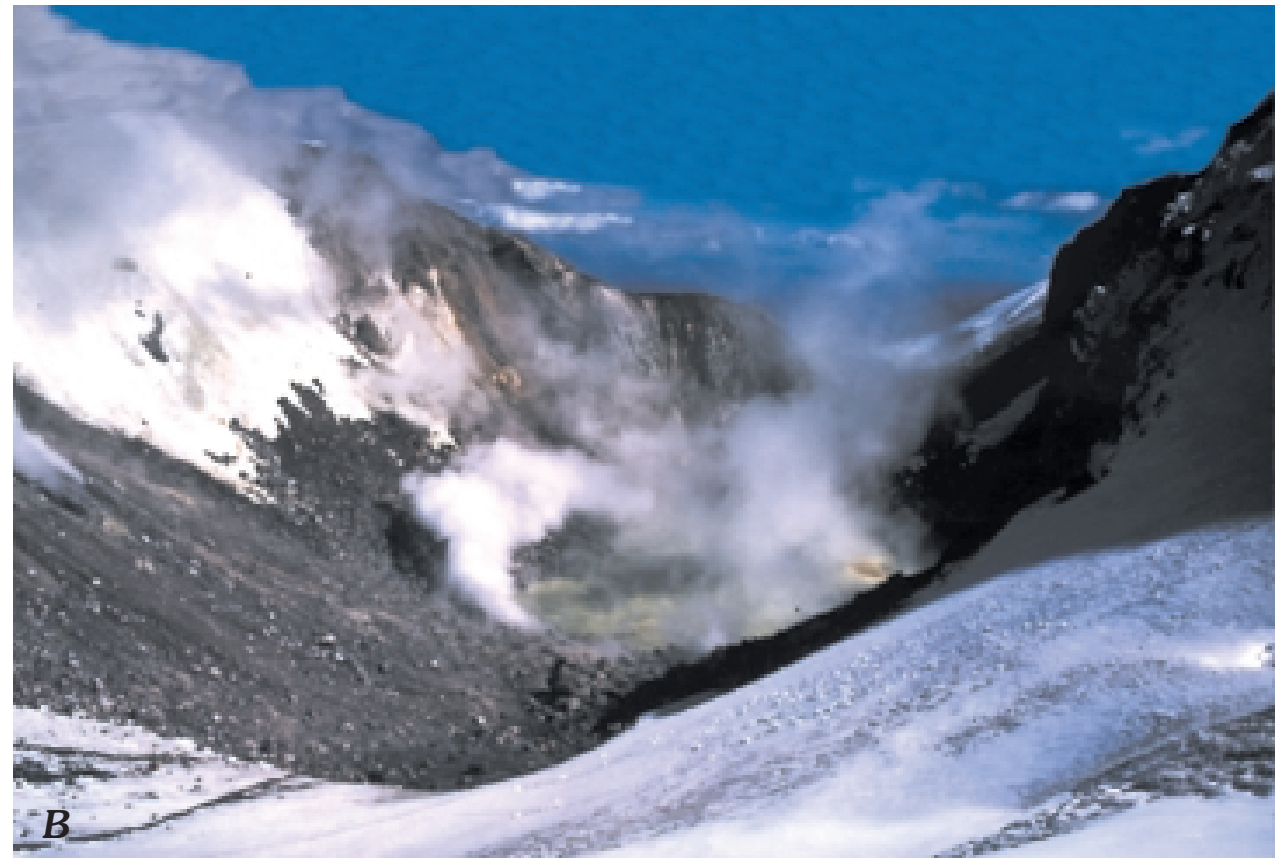

as on the North Summit rim and on cirque headwalls adjacent to the Southwest Summit, suggests that the crater is of fairly recent origin. The lack of any juvenile ejecta indicates that the craterforming event was phreatic, and the absence of a constructional ejecta ring around the crater suggests that vigorous phreatic explosions dispersed about $0.01 \mathrm{~km}^{3}$ of shattered dacite blocks as a thin but extensive sheet across the summit glaciers. The fumarolically active crater is therefore not a magmatic vent in the sense that each of the four summits is.

\section{Holocene Activity}

Unglaciated lava flows indicate that the East Summit of Mount Mageik has erupted several times since the shrinkage of the regionally extensive glaciers (Riehle and Detterman, 1993) that marked the Pleistocene-Holocene transition. All unequivocally unglaciated eruptive products of Mageik have issued from the East Summit vent, which appears to be of Holocene age in its entirety. It appears unlikely that the North Summit, second 
youngest of the four centers, has been active in the Holocene, but the evidence does not necessarily exclude minor lingering activity there in the early Holocene. All lava flows from the North Summit are laterally glaciated (fig. 3), and their distal flow surfaces are everywhere ice-scoured. Nonetheless, preservation of crags and ridges of friable acid-altered ejecta around the crater rim (fig. 5) and of primary surface morphology on a stubby proximal lava flow (fig. 3) raises some doubts about overinterpreting the age significance of glacial erosion on a volcano sustaining active glaciers. The small proximal lobe might be early Holocene.

Unglaciated lavas from the East Summit vent (figs. 2, 3, 6) include at least 10 discrete vent-derived flows and an additional eight flow lobes that may or may not have budded or branched from the others. All are blocky flows of plagioclase-rich twopyroxene andesite or dacite (60-64 percent $\mathrm{SiO}_{2}$ ), most of them leveed and corrugated, with steep flow-fronts and margins that are typically $50-150 \mathrm{~m}$ high. Below the Neoglacial ice limit, the lava flows are unglaciated, but small differences in surface degradation and aeolian silt accumulation suggest at least three independent episodes of Holocene emplacement. There could well have been 10 or more such eruptive episodes but, on the other hand, the 1953-60 activity at nearby Trident demonstrated that four discrete lava flows could be emplaced in 7 years. The two northernmost lava flows from the East Summit center are younger than a locally widespread fall deposit that is bracketed by ${ }^{14} \mathrm{C}$ ages elsewhere to be about 4,000 years old. The southeasternmost lava flow from the East Summit is overlain by this tephra as well as by another regional ash that fell about 5,500 ${ }^{14} \mathrm{C}$ years ago.

A glassy nonwelded lithic pyroclastic-flow deposit, as thick as $2.5 \mathrm{~m}$, is locally exposed atop the $2,400-\mathrm{ft}$ rim of the broad piedmont lava lobe $4 \mathrm{~km}$ east of the East Summit (fig. 2). In a dark-gray matrix of coarse andesitic ash, black juvenile lapilli are massive, poorly vesicular, glassy silicic andesite (62 percent $\mathrm{SiO}_{2}$; table 1, sample K-2493A). This is the only Holocene pyroclastic-flow deposit identified at Mount Mageik, and it evidently erupted from the East Summit vent. The deposit is variously overlain by 1912 fallout directly, by $10-25 \mathrm{~cm}$ of pre-1912 aeolian silt, or locally by $10-50 \mathrm{~cm}$ of clayey, orange-brown, diamict, rich in rounded clasts of fresh and hydrothermally altered andesite that probably avalanched from the brow of the East Summit.

Correlation of postglacial ashfall layers intercalated with peat, incipient soils, and ubiquitous aeolian silt mantling the lowlands around the Katmai cluster is an ongoing project that will be published separately. At least eight tephras age-bracketed between 500 and $8,500{ }^{14} \mathrm{C}$ years B.P. are locally derived from centers in the Katmai cluster. All represent explosive ejecta that are dacitic or andesitic in bulk composition. A few probably issued from Mageik's East Summit, and at least one tephra is compositionally similar to the Holocene dacite lava flows (fig. 2) of Mount Martin.

\section{Spurious Eruption Reports}

Mount Mageik's conspicuous fumarolic plume, like that of adjacent Mount Martin (fig. 3), has animated many spurious eruption reports. Not a single one of the 20th century tephra eruptions of Mageik listed in "Volcanoes of the World" (Simkin and Siebert, 1994) seems plausible. Configuration of the crater has not changed since it was first photographed in 1923 (fig. 8); there are no juvenile ejecta in the crater or around its rim (except a scattering of 1912 pumice lapilli); and the only late Holocene fall deposits on or near the lower flanks of Mageik are the Novarupta pumice falls of 1912 and the black Trident ash of 1953-74.

In particular, Jaggar (1927) repeated a fisherman's story reported in Seattle and Tacoma newspapers-in August 1927 "we noticed a gigantic puff at the top of Mageik" and that soon "it began to rain pumice stone" on their boat in Shelikof Strait "50 miles off the Alaska Peninsula." Although fumarolic "puffs" are common, there is no evidence of a post-1912 Plinian pumice-fall deposit anywhere between Mount Mageik and Shelikof Strait (fig. 1). The report also mentioned fine white ash falling on the decks. Fine white ashfall is still produced occasionally today during spells of dry summer weather when windstorms loft ash from the barren surface of the Valley of Ten Thousand Smokes to altitudes of many kilometers.

The supposed eruption of Mount Mageik listed for 1936 appears to be based wholly on a romantic travel book (Hutchison, 1937) that mentions a brief call by the S.S. Starr at Halibut Bay on the southwest corner of Kodiak Island, $95 \mathrm{~km}$ south of Mageik. Although the writer did not land, the captain "brought back some interesting specimens of pumice stone with which the waters of the harbour were sprinkled as well as the shore. It had been vomited from the crater of the giant Mageik... on the 4th and 5th of July, a week previous to our visit." Commerce, tourism, and patriotism, like literature, commonly assert their artistic license. The floating pumice was, of course, that of 1912, which lines the beaches of Shelikof Strait to this day. On a trip to Katmai Bay in 1934, Hubbard (1935, p. 208) had witnessed the 1912 pumice floating in Shelikof Strait "in irregular lines many miles long," remobilized from the shorelines by storms and tides. Along with the fumarolic plumes, the far-flung Plinian pumice of 1912 will probably continue to inspire imaginative eruption reports well into the 21 st century, as it has during much of the 20th.

\section{Debris Avalanches from Mount Mageik}

Holocene debris avalanches from three different sites on the south slopes of Mount Mageik devastated the forks of Martin Creek (fig. 2). The oldest and largest broke loose from the strongly acid-altered southwest face of the Southwest Summit and flowed down the west fork for at least 16 $\mathrm{km}$. It no doubt further spread out onto the floodplain of Katmai River (fig. 1) but has since been stripped there. Orange-brown, yellow, white, and clay-rich like its headwall source rocks, this unit was far more mobile than the other two. At least $70 \mathrm{~m}$ thick proximally (where partly reworked by Neoglacial ice), the deposit is marked medially by an abundance of subdued hummocks 5-15 $\mathrm{m}$ high, but distally it spread into a low-relief sheet 5-10 m thick. Being 0.8 to 1.4 $\mathrm{km}$ wide along its entire length, the deposit today covers at least $15 \mathrm{~km}^{2}$. If it averages $50 \mathrm{~m}$ thick proximally, $15 \mathrm{~m}$ 
medially, and $5 \mathrm{~m}$ distally, its volume is about $0.35 \mathrm{~km}^{3}$. Although no datable organic material was found, the unglaciated deposit fills a glacial valley and is certainly Holocene, most likely early Holocene judging from the subdued morphology of its hummocky surface.

The smallest of the three debris-avalanche deposits came down the east fork of Martin Creek, covers an area of about $2.7 \mathrm{~km}^{2}$, and is $15-25 \mathrm{~m}$ thick distally at the junction of the forks (fig. 2). Intermediate in age relative to the other two, it consists almost entirely of fresh andesite (massive to scoriaceous and apparently monolithologic), contains abundant angular blocks as large as $5 \mathrm{~m}$, and supports hummocks 5-15 $\mathrm{m}$ high. Hummocky to its terminus, it ends abruptly where it meets the older avalanche deposit (fig. 2). We estimate its volume to be about $0.025 \mathrm{~km}^{3}$, but its source and proximal path are covered by Holocene lava flows from the East Summit (fig. 2). Analysis of a large distal block yields 60.0 percent $\mathrm{SiO}_{2}$ and 1.49 percent $\mathrm{K}_{2} \mathrm{O}$ (table 1; sample $\mathrm{K}-2548$ ), consistent with derivation from East Summit lavas but not unequivocal (fig. 7). Local reddening of the gritty matrix suggests (but does not prove) hot avalanching such as commonly takes place during extrusion of a viscous lava on a steep slope. Based on tephra layers as old as 5,500 ${ }^{14} \mathrm{C}$ years B.P. that are intercalated within $70-110 \mathrm{~cm}$ of aeolian silt that overlies the avalanche deposit, we estimate its emplacement age to be middle Holocene.

The youngest of the three was emplaced in Martin Creek on 6 June 1912 during the eruption at Novarupta, presumably triggered by the seismicity accompanying caldera collapse at Mount Katmai (Hildreth, 1991). The deposit is overlain by most of the 1912 fallout but not by the earliest layers (Fierstein and Hildreth, 1992). Described in detail by Griggs (1920, 1922), who called it "the Mageik Landslide", the 1912 avalanche deposit extends $6 \mathrm{~km}$ southeast of its headwall and overruns the medial part of the more subdued larger deposit (fig. 2). Consisting predominantly of angular blocks of fresh dacite, it broke loose from a steep face glacially carved into a stack of dacite lava flows that make up the southeast planeze of the Southwest Summit edifice, leaving behind a 120-m-high scarp with a rim at the 3,000-ft level. The deposit has millions of angular blocks larger than $1 \mathrm{~m}$ (mostly dacite, plus sparse basement sandstone), contains dacite slabs as long as $20 \mathrm{~m}$, and supports hummocks as high as $20 \mathrm{~m}$. It locally left superelevated trimlines and ponded drainages along its abrupt margins. About $800 \mathrm{~m}$ wide proximally, the deposit spreads out to $1.5 \mathrm{~km}$ medially and covers about $6 \mathrm{~km}^{2}$. Griggs (1920) estimated its area as more than $10 \mathrm{~km}^{2}$, but this included parts of the subjacent older deposit. Although thickness $(5-30 \mathrm{~m})$ is hard to average, the volume is probably in the range $0.05-$ $0.1 \mathrm{~km}^{3}$.

Much smaller avalanches of altered debris from the steep east face of the East Summit have probably been common, but deposits are obscured by ice, snow, and 1912 fallout. The most obvious sources on Mount Mageik (fig. 2) for future avalanches are the altered headwall of the west fork of Martin Creek, the northwest face of the ridge west of that headwall, lava-flow dipslopes of the northwest buttress, and the steep fragmental cones of the East and North Summits.

\section{Geochronology}

K-Ar ages were measured for whole-rock samples of andesitic lava flows that rest on Jurassic basement rocks at the bottom of the Mageik volcanic pile in four different drainages (fig. 2; table 2). Two erupted at the Southwest Summit, one at the Central Summit, and one at the North Summit. Sample selection criteria and analytical methods were described by Hildreth and Lanphere (1994). Seeking high-precision age determinations of late Pleistocene rocks, we employed the multiplecollector mass spectrometer (Stacey and others, 1981) at the U.S. Geological Survey in Menlo Park.

In uppermost Alagogshak Creek at the southwestern limit of Mageik lavas, the basal lava flow of the stack of Southwest Summit lavas that forms the south-trending ridge separating Martin and Alagogshak Creeks yields an age of $89 \pm 8 \mathrm{ka}$. An analytically indistinguishable age of $93 \pm 8 \mathrm{ka}$ was determined for the basal lava flow along the eastern wall of Martin Creek at the bottom of the stack of flows that forms the main planeze dipping SSE. away from the Southwest Summit vent. Farther northeast, in a glaciated bowl at the head of the north fork of Martin Creek, the basal lava flow from the Central Summit yields an age of $71 \pm 11 \mathrm{ka}$, confirming our stratigraphic inference that the Central Summit pile postdates the Southwest Summit. A thick lava flow from the North Summit vent forms a 150$m$ cliff that commands West Mageik Lake and rests on Jurassic strata a few hundred meters south of the lake. Stratigraphically one of the oldest products of the North Summit edifice, this lava yielded an age of $59 \pm 11 \mathrm{ka}$. No attempt was made to date by $\mathrm{K}$ Ar any lavas from the East Summit edifice, which is entirely postglacial.

\section{Eruptive Volumes}

Mount Mageik has suffered glacial erosion throughout its existence, the present climate being globally the mildest during its approximately 90-k.y. lifetime. The rapid glacial erosion promoted by Pleistocene expansions of glacial ice that recurrently blanketed much of the Alaska Peninsula (Riehle and Detterman, 1993) makes it difficult to estimate the volumes actually erupted.

At 2,165 m, the true summit today rises $1,500 \mathrm{~m}$ above the adjacent Valley of Ten Thousand Smokes and 1,300-1,600 m above the southerly base of the volcano. On the west, however, the ridge of Jurassic basement rocks that forms the saddle between Mageik and Martin is as high as 1,555 m, only $610 \mathrm{~m}$ lower than the summit. Nonetheless, northeastward beneath Mount Mageik this basement ridge diminishes sharply in elevation, failing to crop out at 800-m-high Katmai Pass, 1,365 m lower than the summit. Katmai Pass and the adjacent area now beneath the East Mageik edifice were the lowest local crossing of the Alaska Peninsula rangecrest long before construction of the Mageik edifice.

Taking into account the constraints provided by the basement elevations, the modern topography, and the (poorly exposed) overlapping relationships among Mageik's four component edifices, we estimate their present-day volumes as 
follows: Southwest Summit $9-10 \mathrm{~km}^{3}$, Central Summit $4 \mathrm{~km}^{3}$, North Summit $1.5 \mathrm{~km}^{3}$, and East Summit $5 \mathrm{~km}^{3}$, yielding a total of about $20 \mathrm{~km}^{3}$. Attempting to reconstruct (pre-erosion) eruptive volumes of each edifice, we tenuously estimate that more than 40 percent of the Southwest Summit has been removed by erosion, more than 30 percent of the Central Summit, at least 20 percent of the North Summit, and 5-10 percent of the East Summit. Such estimates neglect any intracanyon lavas that might have flowed far from the edifice. Using these rough estimates, then, we calculate original edifice volumes of $15-17,6$, 2 , and $5.5 \mathrm{~km}^{3}$, respectively, yielding a total of about $30 \mathrm{~km}^{3}$ erupted. The late Pleistocene Lethe Assemblage (discussed below) along with a possibly correlative regional ashfall (Reger and others, 1996), if from Mageik, could add an additional 1 $\mathrm{km}^{3}$ or more to the total. No other potentially Mageik-derived tephra layer identified in the region is likely to add more than $0.1 \mathrm{~km}^{3}$. For a 90-k.y. lifetime, an eruptive volume of $30 \mathrm{~km}^{3}$ yields an average eruption rate of $0.33 \mathrm{~km}^{3}$ per 1,000 years. This lies in the range typical of long-term average rates for well-studied arc stratovolcanoes $\left(0.1-1 \mathrm{~km}^{3} / \mathrm{k}\right.$.y.) but far below the rates of peak episodes ( $>5 \mathrm{~km}^{3} / \mathrm{k}$.y.) (Hildreth and Lanphere, 1994). Such large volumetric eruption rates may well have characterized activity at Mount Mageik during construction of each of its component edifices.

\section{Mount Martin}

A few kilometers southwest of Mageik (figs. 1-3), Mount Martin consists of a small fragmental cone and a staircase of 10 overlapping coulees of blocky dacite, each 75-100 m thick, that descends northwestward for $10 \mathrm{~km}$. Although its summit exceeds $1,860 \mathrm{~m}$ in elevation, the $2-\mathrm{km}$-wide cone itself has local relief of only $500 \mathrm{~m}$, owing to its construction upon a high ridge of Jurassic basement rocks. The extremely asymmetrical distribution of lava flows with respect to the summit vent (fig. 2) resembles those of Southwest Trident and the North and East Summits of Mageik. Of the $7-\mathrm{km}^{3}$ present-day volume we estimate for Mount Martin, the cone represents only 5 percent and the $31-\mathrm{km}^{2}$ lava-flow field about 95 percent. Scoriaceous and massive glassy (phreatomagmatically ejected) blocks of the cone are andesitic (58.5-61 percent $\left.\mathrm{SiO}_{2}\right)$, whereas the sequence of coulees is largely dacitic (62.5-64.2 percent $\left.\mathrm{SiO}_{2}\right)$. A widespread fallout deposit is compositionally similar to the coulees. Despite a cone-encircling collar of active glaciers, erosion of the cone and coulees is almost insignificant, indicating that Mount Martin is a Holocene volcano in its entirety. Glaciated lavas adjacent to its west flank are chemically and stratigraphically distinguished as flows from Alagogshak volcano (Hildreth and others, 1999). The cone of Mount Martin is marked by a persistent steam plume derived from as many as 20 fumaroles that are precipitating sulfur in the talus northwest of a shallow lake on the floor of its 300-m-wide crater. Like the plume of Mount Mageik, the larger plume of Mount Martin is the basis of many spurious eruption reports. A USGS overfight in 1998 detected significant concentrations of $\mathrm{CO}_{2}$ and $\mathrm{SO}_{2}$ in the Martin plume (M. Doukas, Cascades Volcano Observatory, oral commun., 1999).

\section{Composition Of Eruptive Products}

Many separate lava flows and a few near-vent scoria bombs were collected on Mount Mageik, and about 69 samples were analysed by X-ray fluorescence spectroscopy. Results are given in table 1 and illustrated in figure 7 . Virtually all samples are plagioclase-rich two-pyroxene andesites and dacites, all of which also carry Fe-Ti oxides. Sparse olivine occurs in some of the most mafic rocks, and rare amphibole is present in one or two of the most silicic. Glass-bearing blebs and clots of plagioclase-pyroxene microdiorite are present in many of the samples, but, in contrast to neighboring Trident volcano, ordinary 1- to $10-\mathrm{cm}$ mafic magmatic inclusions are relatively uncommon in Mageik lavas.

All 69 samples plot in the medium-K field of figure 7, and all fall in the calcalkaline field on a conventional $\mathrm{FeO} * / \mathrm{MgO}$ vs. $\mathrm{SiO}_{2}$ diagram (not shown). Alkali-lime intersections at 63-64 percent $\mathrm{SiO}_{2}$ define calcic suites (Peacock, 1931) for all components of Mount Mageik, as previously also determined for Novarupta (Hildreth, 1983) and for nearby Martin and Alagogshak volcanoes (Hildreth and others, 1999). $\mathrm{SiO}_{2}$ ranges from 57.4 to 67.9 percent, the entire range being represented in products of the Southwest Summit alone (fig. 7). The lone mafic magmatic inclusion analysed gave 56.3 percent $\mathrm{SiO}_{2}$. The range in $\mathrm{SiO}_{2}$ is comparable to those of suites from Trident, Martin, and Alagogshak but much more restricted than those of Novarupta and Mount Katmai (Hildreth, 1987; Hildreth and others, 1999; Hildreth and Fierstein, 2000). Mageik products form a typical low-Ti arc suite, containing only $0.51-0.86$ percent $\mathrm{TiO}_{2}$; the mafic inclusion has 0.92 percent. Contents of $\mathrm{Al}_{2} \mathrm{O}_{3}$ are ordinary for arc suites, ranging from 15.1 to 17.4 percent; the mafic inclusion has 17.7 percent. Relatively primitive material has not erupted here, all samples having less than 4.4 percent $\mathrm{MgO}$. The lone Sr-isotope determination for a Mageik lava, a Holocene dacite from the East Summit, yielded a ${ }^{87} \mathrm{Sr} /$ ${ }^{86} \mathrm{Sr}$ ratio of 0.70366 , at the upper end of the range $(0.70335-$ 0.70366 ) of relatively sparse data for nonrhyolitic products of the Katmai cluster (Hildreth, 1987).

Figure 7 illustrates the limited compositional ranges of the younger centers compared to that of the larger and longer lived Southwest Summit edifice. The North Summit (60.5-64.2 percent $\left.\mathrm{SiO}_{2}\right)$ and East Summit (60.0-64.1 percent $\mathrm{SiO}_{2}$ ) have the shortest arrays, whereas the Central Summit array (57.8-66.0 percent $\mathrm{SiO}_{2}$ ) is similar to those of Mount Martin (58.9-64.2 percent $\mathrm{SiO}_{2}$ ) and Southwest Trident (56.9-64.8 percent $\mathrm{SiO}_{2}$ ). The contrast between the scattered arrays of all four Mageik centers and the narrowly linear trends for Holocene Mount Martin and 1953-74 Southwest Trident suggests more complex magmatic histories, and thus implicitly longer eruptive histories, for the Mageik centers.

Compositionally most complex is the Southwest Summit suite, which extends in $\mathrm{SiO}_{2}$ from 56.3 to 67.9 percent and, for example, among its dacites alone, from 1.65 to 2.23 percent $\mathrm{K}_{2} \mathrm{O}$ and from 128 to $182 \mathrm{ppm} \mathrm{Zr}$ (fig. 7). The least potassic sample $\left(0.93\right.$ percent $\left.\mathrm{K}_{2} \mathrm{O}\right)$ is from the highest exposure on the Southwest Summit, a lava ledge at the southeast edge of the summit-mantling icecap at the 6,700-ft level; it is thus likely to be among the youngest products erupted from the Southwest 
Summit vent. The five low- $\mathrm{Zr}$ dacites that plot apart from other Mageik samples on the $\mathrm{Zr}-\mathrm{SiO}_{2}$ panel of figure 7 are all lavas from the stack of flows at the 2,500- to 3,300-ft level of the southeast planeze, directly downslope from the Southwest Summit (fig. 2); they apparently reflect enhanced effects of zircon fractionation from the magmas or greater retention of zircon in the residues of melts that contributed to the magmas. The stratigraphically oldest lava flows of the Southwest Summit edifice erupted at about $90 \mathrm{ka}$ (table 2), but we have no evidence to estimate the age of its youngest activity. Its wider and more severe hydrothermal alteration, its deeper glacial incision, its larger eruptive volume, and its greater compositional heterogeneity all point to an eruptive lifetime much longer than those of its companion edifices. The magma system beneath the Southwest Summit probably produced quasi-independent batches that evolved and erupted in several episodes over an interval that might well have exceeded 20 k.y.

The Falling Mountain (FM) and Mount Cerberus (MC) fields (fig. 7) for the two big dacite lava domes at Katmai Pass (fig. 2) are representative of the compositionally allied products of pre-Holocene components of Trident volcano, which are generally deficient in $\mathrm{K}_{2} \mathrm{O}$ and $\mathrm{Zr}$ relative to eruptive products of Mount Mageik and the rest of the Katmai cluster (Hildreth and Fierstein, 2000), including Novarupta, Mount Katmai, and Southwest (New) Trident itself. The dacite domes are thus unrelated to the Mageik (and Novarupta) plumbing systems. Although they are similar in age to the Southwest Summit edifice (Hildreth and Fierstein, 2000), the domes are unequivocally older than the nearby North and East Summit edifices of Mount Mageik.

\section{Lethe Assemblage}

Extensive remnants of a late Pleistocene deposit rich in dacite pumice are exposed along the walls of lower Windy Creek and River Lethe (fig. 2) in the Valley of Ten Thousand Smokes, about $15 \mathrm{~km}$ northwest of Mount Mageik. The pumice is compositionally similar (though not identical) to younger Mageik lavas (fig. 7) as well as to a few of the younger eruptive units from Mount Katmai (Hildreth and Fierstein, 2000). First described by Pinney and Beget (1991), the deposit consists of fines-poor sandy debris flows rich in rounded dacite pumice clasts (as large as $40 \mathrm{~cm}$ ) interstratified with massive emplacement units of coarse (phenocryst) sand, evidently transported by hyperconcentrated streamflow. At least 10 pumiceous debrisflow units, 0.1 to $4 \mathrm{~m}$ thick, have gradational contacts with (and a coarse sandy matrix continuous with) the interstratified beds of massive sand, which are as thick as $10 \mathrm{~m}$ ! The sand beds consist predominantly of plagioclase and pyroxene crystals (like those in the pumice); they display ubiquitous water-escape (dish) structures and carry sparse dispersed lithics (mostly picked up during flowage) and abundant dispersed granules and small lapilli of dacite pumice. For the whole assemblage, the greatest thickness observed is $25-30 \mathrm{~m}$ on the walls of the river gorges where there is no basal exposure. Although many of the pumicerich flow units are lenticular, there is no significant unconformity or intercalation of normal fluvial gravel within the assemblage.
All the flow units thus appear to have been deposited rapidly in response to a single eruptive event.

The assemblage is widely overlain by several meters of till, and, wherever its base is exposed, it also rests directly upon till. A few of the debris flows spilled northwestward across a low marshy divide into upper Margot Creek, leaving behind a (now wind-deflated) veneer of dacite pumice clasts atop hilly till deposits bordering the marsh. Most of the assemblage, however, appears to have ponded in a shallow $3-\mathrm{km}^{2}$ paleodepression that may have held a shallow periglacial lake. What else could have trapped and rapidly dumped $30 \mathrm{~m}$ of poorly sorted fast-moving debris? As no equivalent ignimbrite is recognized anywhere in the district, we envisage an eruption scenario wherein a sub-Plinian pumice shower was rapidly remobilized by snowmelt into slurries that poured off the glaciated source edifice and down an ice-filled paleovalley during a nonmaximal glacial stage when valley glaciers were extensive but parts of the surrounding lowlands were ice-free. As documented for the Novarupta dacite fall deposits of 1912 (Fierstein and Hildreth, 1992), much of the primary medial fallout of the phenocrystrich dacite would have been crystal ash, accounting for the volumetric dominance of the sand facies. In addition to segregation during flow, either pulsatory eruption or repeated remobilization of coarse proximal pumice from slopes of the ice-clad volcano would account for the recurrent intercalation of pumiceous debris flows throughout the thick deposit of massive sand.

The present-day valleys leading from Mount Mageik and Mount Katmai to the Lethe Assemblage provide no additional exposures of such deposits, as virtually all likely areas are covered by the 1912 ignimbrite (fig. 2). Likewise, we have searched for but not found remnants of any correlative deposits south of the volcanic axis, so the physical evidence linking the deposit to Mount Mageik is tenuous. The phenocryst assemblage in the pumice (plagioclase, hypersthene, augite, and Fe-Ti oxides), though the same as in the Mageik lavas, is so commonplace that it is not diagnostic. Figure 7, however, illlustrates that the dacite pumice in the Lethe Assemblage is compositionally close to the evolved end of the range identified for the products of Mageik's East and North Summits. Figure 7 shows furthermore that the Lethe pumice is distinguishable from eruptive products of Mount Martin and from the late Pleistocene lava domes, Mount Cerberus and Falling Mountain, at the head of the Valley of Ten Thousand Smokes (fig. 2). The 1953-74 products of Southwest Trident are only slightly less potassic than the Lethe pumice, but all prehistoric products of the Trident volcanic group are similar to the domes in being significantly less potassic and much poorer in $\mathrm{Zr}$ (fig. 7). Agglutinated dacite fall units high on Mount Katmai (Hildreth and Fierstein, 2000) represent the only potential alternative to a Mageik source recognized in the Katmai cluster. The field and compositional evidence now in hand weigh slightly in favor of Mount Katmai rather than Mount Mageik as the source of the Lethe pumice, but the choice remains unresolved.

An ashfall layer widespread in late Pleistocene deposits on the Kenai Peninsula 260-380 km northeast of the Katmai cluster has been correlated with the Lethe Assemblage by Reger and others (1996) on the basis of microprobe determinations of glass compositions. From stratigraphic relationships in the Kenai Lowland, they inferred an age for the tephra slightly younger 
than $16,000{ }^{14} \mathrm{C}$ years B.P. For the Lethe Assemblage itself, we have obtained an older limiting age of $18,980 \pm 90{ }^{14} \mathrm{C}$ years B.P. for a rip-up clast of silty soil enclosed in the massive sand deposit near Windy Creek. Pinney and Beget (1991) published an upper limiting age of $12,640 \pm 100{ }^{14} \mathrm{C}$ years B.P. for "organic silt" nearby, which they inferred from their interpretation of the local glacial deposits to be younger than the Lethe Assemblage. If Reger and others (1996) are correct in their correlation, the far-flung eruption was certainly Plinian, even though no equivalent proximal pumice-fall deposit is known to have survived in the Mageik-Katmai region.

\section{Evidence for Present-Day Magma Storage}

Gravity and seismic data that identify a low-density lowvelocity region centered near Katmai Pass are summarized by Ward and others (1991). A southeasterly gravity traverse that crossed the volcanic axis by way of Katmai Pass showed crossaxial width of the anomalous region to be about $15 \mathrm{~km}$, but the data are insufficient to know how far it extends along the axis. Of the several seismic stations in the Katmai array, only the one in Katmai Pass (central to the gravity anomaly) consistently showed travel-time delays for deep local and regional earthquakes. The delays require great thickness for the low-velocity domain, which may well extend deeper than $20 \mathrm{~km}$ (Ward and others, 1991), thus involving most or all of the crust. Their seismic data also indicated significant attenuation of P- and Swaves, but they found no screening of S-waves (in contrast to seismic reconnaissance studies 25 years earlier; Matumoto, 1970). To explain the data, they invoked present-day crustal magma storage, favoring scattered small magma bodies rather than a large chamber. Recent and ongoing analysis by P-wave tomography has identified a moderately low-velocity anomaly $(4.4 \mathrm{~km} / \mathrm{s})$, shallower than $3 \mathrm{~km}$, beneath the same area in Katmai Pass (Jolly and others, 1998).

The pattern of seismicity recognized by Ward and others (1991) has persisted during the 1990's, as the Alaska Volcano Observatory continues to locate 40-130 earthquakes each month along and near the volcanic axis of the Katmai cluster. Most of the earthquakes located fall into four persistent clusters: (1) beneath the volcanic line from Mount Martin to Southwest Mageik; (2) beneath Katmai Pass and the northwest slope of the Trident group; (3) beneath Mount Katmai, especially its northern slopes; and (4) east of Mount Griggs (figs. 1, 2). Nearly all the earthquakes are smaller than magnitude 2.5 , and only a few events have been in the range 3.0-4.5. Many are shallower than $5 \mathrm{~km}$, and nearly all are shallower than $10 \mathrm{~km}$. The dense shallow seismicity seems inconsistent with present-day uppercrustal storage of voluminous magma and is more likely to reflect flow of gases and fluids, attendant volume changes, and hydraulic microfracturing in hydrothermal systems, along with slip-threshold reduction in geochemically weakened rocks. If magma bodies other than small distributed pods and dikes are now present in the evidently brittle top $10 \mathrm{~km}$ of the crust, they are more likely to underlie the gaps between the seismic clusters. In the area specifically addressed in the present paper, if shallow chambers exist at all, they would thus lie beneath the East Summit of Mageik (fig. 2) or between Trident and Mount Katmai (fig. 1). Beneath the seismic clusters themselves, however, any large magma chambers today are probably deeper than $10 \mathrm{~km}$-i.e., below the brittle zone.

Vigorous fumaroles in the Katmai cluster are good evidence that magma stored somewhere below is actively degassing, though this provides little or no control on depths, distribution, volume, or degree of crystallization of such magma. Superheated fumaroles in the crater of Mount Mageik (fig. 8) and high on Mount Griggs are steam dominated but rich in $\mathrm{CO}_{2}, \mathrm{SO}_{2}$, and $\mathrm{H}_{2} \mathrm{~S}$ and have magmatic He-isotope ratios 7-8 times the atmospheric value (R.B. Symonds, oral commun., 1998). Boiling-temperature fumaroles on the southeast flank of Trident have similarly magmatic signatures and have discharged vigorously since before 1916 when first recorded (photo on p. 99 of Griggs, 1922). Though never yet sampled directly, many fumarolic jets in the crater of Mount Martin are precipitating abundant sulfur, are probably superheated, and combine to discharge the biggest and (olfactorily) $\mathrm{H}_{2} \mathrm{~S}$-richest plume in the Katmai district. A 1998 USGS flight through the Martin plume detected strong concentrations of $\mathrm{SO}_{2}$ and $\mathrm{CO}_{2}$ (M. Doukas, oral commun., 1999). Atop the Southwest Trident cone (fig. 6), numerous fumaroles must have been superheated during the 1953-74 eruptive episode and were still depositing sulfur and remained at or above the boiling point in 1979, but they have since declined both thermally and in $\mathrm{H}_{2} \mathrm{~S}$ output.

The vigorous fumaroles of Martin, Mageik, Trident, and Griggs have apparently been continuously active with little change in style or configuration since they were first photographed in the period 1913-19 (Griggs, 1922), but not one of these volcanoes produced any ejecta in 1912 or has erupted at any time since. In contrast, the fumaroles at all three volcanic vents that did erupt in the 20th century (Southwest Trident, Novarupta, and Mount Katmai) have been in decline. Magma appears to be distributed widely and discretely beneath the Katmai cluster. Depletion or exhaustion of local magma bodies by eruption may have little impact on coexisting independent components of the crustal magma storage system that underlies the volcanic line.

\section{Glacier Retreat}

Although about 30 percent of the surface area of Mount Mageik is covered by ice, the ice volume has historically been shrinking substantially. Three north-flowing glaciers descend the north flank of Mount Mageik (figs. 2, 3). In 1912, two of them still terminated on what is now the floor of the Valley of Ten Thousand Smokes, where the 1912 ignimbrite banked against them (photo on p. 264 of Griggs, 1922). By 1951 (the year of our first set of aerial photographs), recession of their termini by $200 \mathrm{~m}$ and $400 \mathrm{~m}$, respectively, had created the ignimbrite-surrounded depressions occupied by West and East Mageik Lakes (fig. 2). By 1987, the year of our latest aerial photographs, total post-1912 recession of the termini was $900 \mathrm{~m}$ for the western glacier and $700 \mathrm{~m}$ for the eastern. The terminus of the third glacier lying between them, just short of the valley floor in 1912, receded about $500 \mathrm{~m}$ between 1951 and 1987. 
The terminus of the northwest-flowing Angle Creek glacier, fed from the icefield west of Mount Mageik, receded about $350 \mathrm{~m}$ between 1951 and 1987 and about $1.2 \mathrm{~km}$ from its Neoglacial (Little Ice Age?) maximum, which postdated emplacement of the adjacent dacite coulees from Mount Martin (fig. 2) at about $4 \mathrm{ka}$.

On the southeast flank of Mount Mageik, three southeastflowing parallel glaciers (fig. 2) have all retreated substantially. The easternmost, which remarkably had advanced along the central trough of a Holocene lava flow, confined between its high levees, retreated $1.5 \mathrm{~km}$ between 1951 and 1987. During the same interval, the middle one retreated $450 \mathrm{~m}$. By 1987, the western one had retreated about $1 \mathrm{~km}$ since 1951 and (judging by the distribution of till and 1912 fallout) about $1.7 \mathrm{~km}$ from its probable 1912 terminus. Termini of a few lesser glaciers that flow eastward toward Katmai Pass (fig. 2) have retreated 600$800 \mathrm{~m}$ since 1951 and $1.2-1.7 \mathrm{~km}$ from their Neoglacial (Little Ice Age?) maxima. Likewise, the terminus of the small axial glacier in upper Martin Creek, fed from the cirque below Mageik's Southwest Summit, has retreated $1.1 \mathrm{~km}$ since 1951.

Pronounced shrinkage of the glacial cover on steep parts of the Mageik edifice elevates the likelihood of failure of oversteepened glacial deposits, cliffy stacks of rubbly lava flows, and hydrothermally altered parts of the volcano. By lifting the deformable ice envelope sealing such unstable materials, the retreat of glaciers can actually increase the hazards of debris avalanches and derivative downstream debris flows.

The generality and magnitude of 20th century retreat of glaciers on Mount Mageik are noteworthy and probably reflect climatic controls on the ice budget. It is unlikely that the thermal budget of the volcano is a factor, as neither warm springs nor hot spots have been observed on Mageik, other than in the fumarolically active crater, which has undergone no major changes historically. Nor is the 1912 fallout likely to be a factor; it thinned across Mount Mageik from $50 \mathrm{~cm}$ at the northeast to about $5 \mathrm{~cm}$ at the southwest, and nearly all of it was removed from the glaciers within a few years. In contrast, only $4-11 \mathrm{~km}$ northeast of Mount Mageik, in the principal fallout sector downwind from Novarupta, the Knife Creek Glaciers received (and remain covered by) a thick blanket of 1912 fallout (Fierstein and Hildreth, 1992), yet the termini of three of the five Knife Creek Glaciers (Glaciers 1, 3, and 4 of Hildreth, 1987, 1991) actually advanced about $100 \mathrm{~m}$ between 1951 and 1987, edging out over the adjacent 1912 ignimbrite. The buff pumice mantle may actually retard glacial ablation.

\section{Conclusions}

The principal volcano hazards in this wilderness region are to aviation, fish and wildlife resources, and backcountry travellers. Because so much magma was withdrawn so recently from the Novarupta-Katmai storage system in 1912 and from beneath Trident in 1953-60, it may be that Mount Mageik and Mount Martin have become the local centers most likely to erupt next. Mageik's later history of erupting $0.5-5 \mathrm{~km}^{3}$ batches of phenocryst-rich intermediate magma in discrete episodes, similar to that of Southwest Trident in 1953-74, suggests distributed crustal magma storage rather than a large zoned reservoir capable of caldera-forming eruption. The abundance of Holocene dacite nonetheless highlights the likelihood of explosive eruptions of intermediate magnitude. Phreatomagmatic or vulcanian ash clouds or even sub-Plinian to Plinian pumice eruptions are possible and could reach altitudes of 6-15 km (20,000 to 50,000 $\mathrm{ft}$ ). The icecap, crater lakes, and year-round snow cover raise the likelihood of phreatic and phreatomagmatic eruptions and generation of debris flows that could have impacts on Shelikof Strait and the Naknek Lake system.

\section{Acknowledgments}

Michelle Coombs, Anita Grunder, Dave Johnston, and Dave Tucker helped with the fieldwork, Tracey Felger and Jan Cecil with map preparation, Forrest McFarland and James Saburomaru with K-Ar dating, and John Paskievitch with sometimes challenging field logistics. Janis Meldrum of the National Park Service provided prints of figures 5 and $8 A$. For encouraging this work, we are especially grateful to Terry Keith at the helm of the Alaska Volcano Observatory. Helpful review comments by Jake Lowenstern, Bob Symonds, Seth Moran, and Bea Ritchie improved the manuscript. Recalling our introductory epigraph, we note that blue-eyed Mageik made the first ascent of Shishaldin volcano and the first winter ascent of Mount Katmai (in both instances barefoot), providing an example of tenacity, endurance, doggedness, foolhardiness, and footwork motivational to this project.

\section{References Cited}

Bacon, C.R., and Druitt, T.H., 1988, Compositional evolution of the zoned calcalkaline magma chamber of Mount Mazama, Crater Lake, Oregon: Contributions to Mineralogy and Petrology, v. 98, p. 224-256.

Detterman, R.L., Case, J.E., Miller, J.W., Wilson, F.H., and Yount, M.E., 1996, Stratigraphic framework of the Alaska Peninsula: U.S. Geological Survey Bulletin 1969-A, 74 p.

Fenner, C.N., 1930, Mount Katmai and Mount Mageik: Zeitschrift für Vulkanologie, Band 13, p. 1-24.

Fierstein, J., and Hildreth, W., 1992, The Plinian eruptions of 1912 at Novarupta, Katmai National Park, Alaska: Bulletin of Volcanology, v. 54, p. $646-684$.

Griggs, R.F., 1920, The great Mageik landslide: Ohio Journal of Science, v. 20, no. 8, p. 325-354.

Griggs, R.F., 1922, The Valley of Ten Thousand Smokes: Washington, D.C., National Geographic Society, 340 p.

Hildreth, W., 1983, The compositionally zoned eruption of 1912 in the Valley of Ten Thousand Smokes, Katmai National Park, Alaska: Journal of Volcanology and Geothermal Research, v. 18, p. 1-56.

Hildreth, W., 1987, New perspectives on the eruption of 1912 in the Valley of Ten Thousand Smokes, Katmai National Park, Alaska: Bulletin of Volcanology, v. 49, p. 680-693.

Hildreth, W., 1991, The timing of caldera collapse at Mount Katmai in response to magma withdrawal toward Novarupta: Geophysical Research Letters, v. 18, p. 1541-1544. 
Hildreth, W., and Fierstein, J., in press, The Katmai volcanic cluster and the great eruption of 1912: Geological Society of America Bulletin.

Hildreth, W., Fierstein, J., Lanphere, M.A., and Siems, D.F., 1999, Alagogshak volcano: A Pleistocene andesite-dacite stratovolcano in Katmai National Park, in Kelley, K.D., ed., Geologic Studies in Alaska by the U.S. Geological Survey, 1997: U.S. Geological Survey Professional Paper 1614, p. 105-113.

Hildreth, W., and Lanphere, M.A., 1994, Potassium-argon geochronology of a basalt-andesite-dacite arc system: The Mount Adams volcanic field, Cascade Range of southern Washington: Geological Society of America Bulletin, v. 106, p. 1413-1429.

Hubbard, B.R., 1932, Mush you malemutes: New York, The America Press, $179 \mathrm{p}$.

Hubbard, B.R., 1935, Cradle of the storms: New York, Dodd, Mead \& Co., $285 \mathrm{p}$.

Hutchison, I.W., 1937, Stepping stones from Alaska to Asia: London \& Glasgow, Blackie \& Son, $246 \mathrm{p}$.

Jaggar, T.A., 1927, Eruption of Mageik in Alaska: The Volcano Letter, no. 147, Hawaiian Volcano Observatory. [Implausible eruption report.]

Jolly, A.D., Moran, S.C., and McNutt, S.R., 1998, P-wave tomography at Katmai National Park, Alaska Peninsula, Alaska: Eos, Transactions American Geophysical Union, v. 79, no. 46, p. F621.

Martin, G.C., 1913, The recent eruption of Katmai volcano in Alaska: National Geographic Magazine, v. 24, p. 131-181.

Matumoto, T., 1970, Seismic body waves observed in the vicinity of Mount Katmai, Alaska, and evidence for the existence of molten chambers: Geological Society of America Bulletin, v. 82, p. 29052920.

Peacock, M.A., 1931, Classification of igneous rock series: Journal of Geology, v. 39, p. 54-67.

Pinney, D.S., and Beget, J.E., 1991, Late Pleistocene volcanic deposits near the Valley of Ten Thousand Smokes, Katmai National Park,
Alaska, in Reger, R.D., ed., Short Notes on Alaskan Geology 1991: Alaska Division of Geological \& Geophysical Surveys Professional Report 111, p. 45-53.

Ray, D.K., 1967, Geochemistry and petrology of the Mt. Trident andesites, Katmai National Monument, Alaska: University of Alaska, Fairbanks, Ph.D. thesis, $198 \mathrm{p}$.

Reger, R.D., Pinney, D.S., Burke, R.M., and Wiltse, M.A., 1996, Catalog and initial analyses of geologic data related to middle to late Quaternary deposits, Cook Inlet region, Alaska: Alaska Division of Geological \& Geophysical Surveys Report of Investigations 95-6, 188 p.

Riehle, J.R., and Detterman, R.L., 1993, Quaternary geologic map of the Mount Katmai quadrangle and adjacent parts of the Naknek and Afognak quadrangles, Alaska: U.S. Geological Survey Map I-2032, scale 1:250,000.

Riehle, J.R., Detterman, R.L., Yount, M.E., and Miller, J.W., 1993, Geologic map of the Mount Katmai quadrangle and adjacent parts of the Naknek and Afognak quadrangles, Alaska: U.S. Geological Survey Map I-2204, scale 1:250,000.

Simkin, T., and Siebert, L., 1994, Volcanoes of the World: Tucson [Arizona], Geoscience Press, 349 p.

Snyder, G.L., 1954, Eruption of Trident volcano, Katmai National Monument, Alaska: U.S. Geological Survey Circular 318, 7 p.

Spurr, J.E., 1900, A reconnaissance in southwestern Alaska in 1898, p. 31-264 in Twentieth Annual Report of the U.S. Geological Survey to the Secretary of the Interior, 1898-1899; Part VII, Explorations in Alaska in 1898: Washington, Government Printing Office, 1900.

Stacey, J.S., Sherrill, N.D., Dalrymple, G.B., Lanphere, M.A., and Carpenter, N.V., 1981, A five-collector system for the simultaneous measurement of argon isotope ratios in a static mass spectrometer: International Journal of Mass Spectrometry \& Ion Physics, v. 39, p. 167-180.

Ward, P.L., Pitt, A.M., and Endo, E., 1991, Seismic evidence for magma in the vicinity of Mt. Katmai, Alaska: Geophysical Research Letters, v. 18, p. 1537-1540.

Reviewers: J.B. Lowenstern and R.B. Symonds 


\title{
Paleozoic Strata of the Dyckman Mountain Area, Northeastern Medfra Quadrangle, Alaska
}

\author{
By Julie A. Dumoulin, Dwight C. Bradley, and Anita G. Harris
}

\begin{abstract}
Paleozoic rocks in the Dyckman Mountain area (northeastern Medfra quadrangle; Farewell terrane) include both shallowand deep-water lithologies deposited on and adjacent to a carbonate platform. Shallow-water strata, which were recognized by earlier workers but not previously studied in detail, consist of algal-laminated micrite and skeletal-peloidal wackestone, packstone, and lesser grainstone. These rocks are, at least in part, of Early and (or) Middle Devonian age but locally could be as old as Silurian; they accumulated in shallow subtidal to intertidal settings with periodically restricted water circulation. Deepwater facies, reported here for the first time, are thin, locally graded beds of micrite and calcisiltite and subordinate thick to massive beds of lime grainstone and conglomerate. Conodonts indicate an age of Silurian to Middle Devonian; the most tightly dated intervals are early Late Silurian (early to middle Ludlow). These strata formed as hemipelagic deposits, turbidites, and debris flows derived from shallow-water lithologies of the Nixon Fork subterrane. Rocks in the Dyckman Mountain area are part of a broader facies belt that is transitional between the Nixon Fork carbonate platform to the west and deeper water, basinal lithologies (Minchumina "terrane") to the east. Transitional facies patterns are complex because of Paleozoic shifts in the position of the platform margin, Mesozoic shortening, and Late Cretaceous-Tertiary disruption by strike-slip faulting.
\end{abstract}

\section{Introduction}

Lower and middle Paleozoic strata crop out across much of the eastern half of the Medfra quadrangle in central Alaska. A well-exposed section that consists largely of shallow-water facies is flanked on the east by more poorly exposed, roughly coeval deeper water deposits; these two successions, separated by a strand of the Iditarod-Nixon Fork fault, were included in the Nixon Fork and Minchumina terranes, respectively, by Patton and others (1994) and Silberling and others (1994) (fig. 1). Rocks of both these successions, as well as correlative strata to the south and southwest, were called Farewell terrane by Decker and others (1994) and were interpreted to have formed along a single continental margin.
The Nixon Fork terrane in the Medfra quadrangle includes about 5,500 m of Ordovician through Devonian, chiefly platform carbonate rocks. Four formations are recognized (Dutro and Patton, 1982). Shallow-water strata make up the Novi Mountain Formation (Lower Ordovician), most of the Telsitna Formation (Ordovician), and the Whirlwind Creek Formation (Upper Silurian and Devonian); deeper water facies occur in the uppermost part of the Telsitna and throughout the Paradise Fork Formation (Silurian and Lower Devonian) (Dumoulin and others, 1999).

Patton and others (1994) subdivided their Minchumina terrane into two subterranes. The East Fork subterrane is confined to the Medfra quadrangle and comprises the Upper Cambrian through Lower Devonian East Fork Hills Formation (Dutro and Patton, 1982; Dumoulin and others, 1999), which is a sequence of thin-bedded, fine-grained, commonly silty and (or) dolomitic limestone. The Telida subterrane to the northeast encompasses sparse, discontinuous exposures of unnamed Precambrian(?) and Paleozoic argillite, chert, phyllite, sandstone, and limestone. Eastern exposures of the Telida have compositional ties to terranes in the Livengood quadrangle (northeast of area shown in fig. 1) and contain much less carbonate than exposures to the west; petrographic data thus suggest that the Telida subterrane as presently defined is an artificial construct made up of two distinct sequences of disparate provenance (Dumoulin and others, 1999).

We agree with Decker and others (1994) that lower Paleozoic strata throughout their Farewell terrane probably formed along the same continental margin, but we find their terminology for subdivisions of the Farewell awkward and inadequate for the Medfra area. In this paper, we follow the usage of Bundtzen and others (1997) and Blodgett (1998); we refer to chiefly shallow-water, Ordovician through Devonian rocks in the Nixon Fork terrane of Patton and others (1994) as "Nixon Fork subterrane" and use "Dillinger subterrane" for lower Paleozoic deep-water facies in the McGrath and Lime Hills quadrangles to the south and the Mt. McKinley and Healy quadrangles to the southeast (fig. 1). Rocks not easily assigned to either of these subterranes, such as strata in the Minchumina terrane of Patton and others (1994), are referred to by formation name or map-unit name, as appropriate.

In the northeastern part of the Medfra quadrangle, the boundary between the Nixon Fork subterrane and coeval 


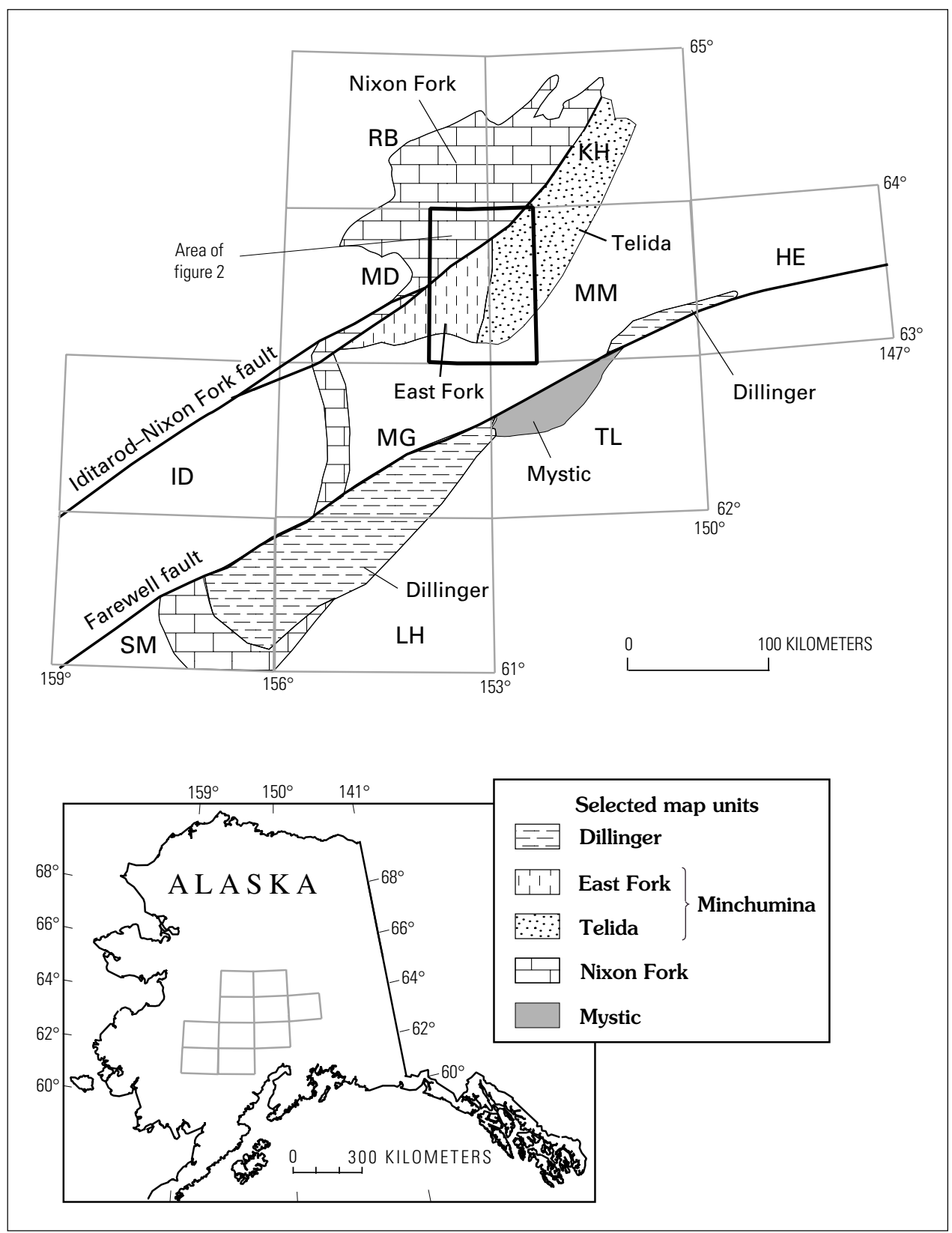

Figure 1. Location of quadrangles and selected tectonostratigraphic terranes and subterranes mentioned in text. Dillinger, Nixon Fork, and Mystic are considered (Bundtzen and others, 1997) subterranes of Farewell terrane (Decker and others, 1994); East Fork and Telida are subterranes of Minchumina terrane (Patton and others, 1994). All or part of Minchumina "terrane" is included in Farewell terrane by some authors; see text for discussion. Dillinger and Nixon Fork south of lat $63^{\circ} \mathrm{N}$. modified from Decker and others (1994) and Silberling and others (1994); East Fork, Nixon Fork north of lat $63^{\circ} \mathrm{N}$., and Telida from Patton and others (1994); Dillinger north of lat $63^{\circ} \mathrm{N}$. and Mystic from Wilson and others (1998). Quadrangles: HE, Healy; ID, Iditarod; KH, Kantishna River; LH, Lime Hills; MD, Medfra; MG, McGrath; MM, Mt. McKinley; RB, Ruby; SM, Sleetmute; TL, Talkeetna.

deep-water facies is complex. Deep-water strata (Ordovician chert and argillite unit, part of the Minchumina terrane of Patton and others, 1994) are exposed between neritic deposits of the Novi Mountain and Telsitna Formations to the west and unnamed shallow-water carbonate rocks in the Dyckman Mountain area (herein called Dyckman Mountain unit) to the east (fig. 2). The Dyckman Mountain strata were originally mapped as Whirlwind Creek Formation (Patton and others, 1980) but were later included in the Minchumina terrane (Patton and others, 1984, 1994) and interpreted as a Middle and Late Devonian carbonate platform built out over older deep-water facies (W.W. Patton, written commun., 1998).

In this paper, we present new lithologic and fossil data demonstrating that carbonate rocks of the Dyckman Mountain unit formed in both deep- and shallow-water settings and are probably of Silurian and Devonian age. These strata provide additional evidence that Paleozoic rocks of the Nixon Fork subterrane, and much if not all of the Minchumina terrane, formed along a single continental margin that was later deformed and dismembered by folding and strike-slip faulting. 


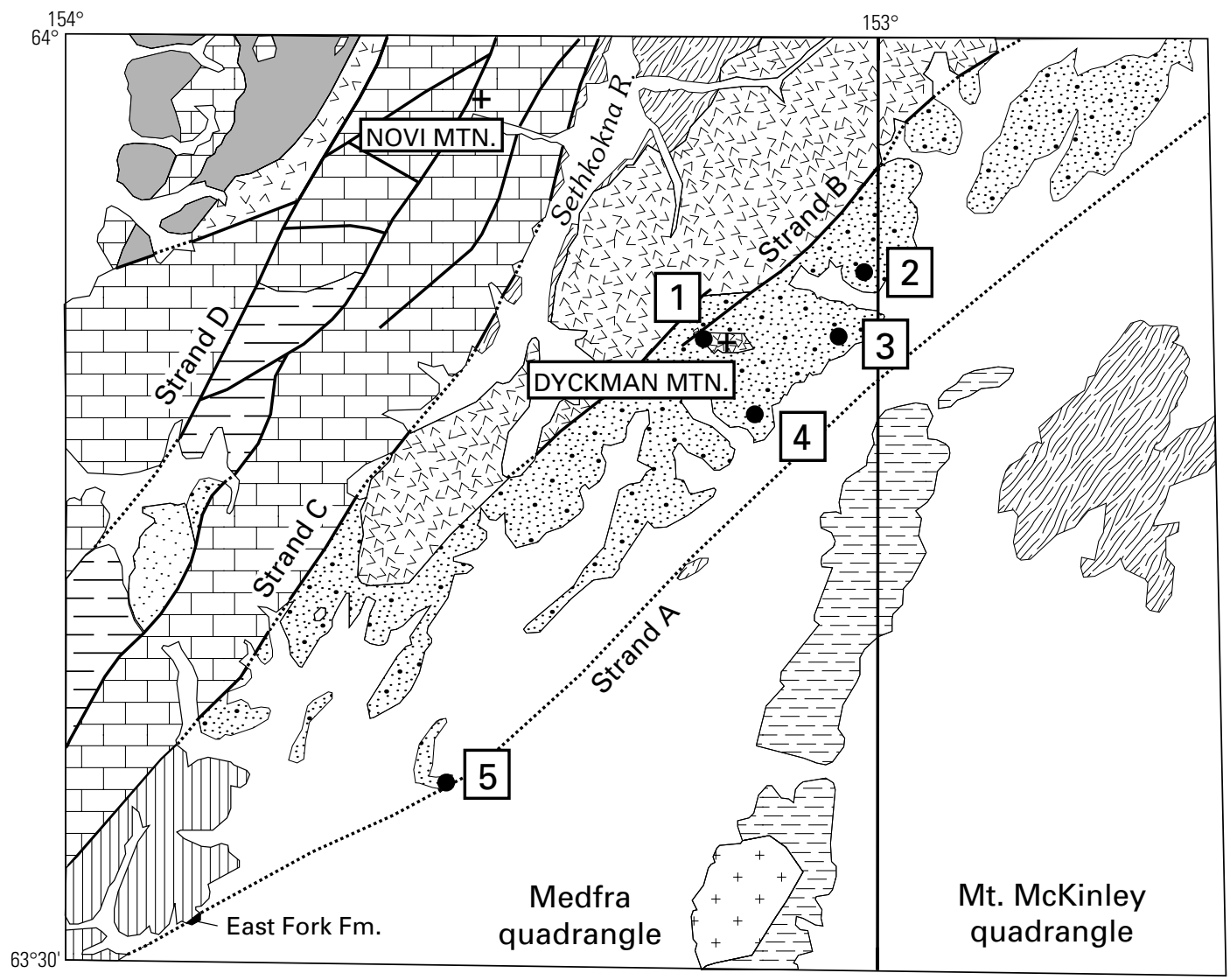

EXPLANATION

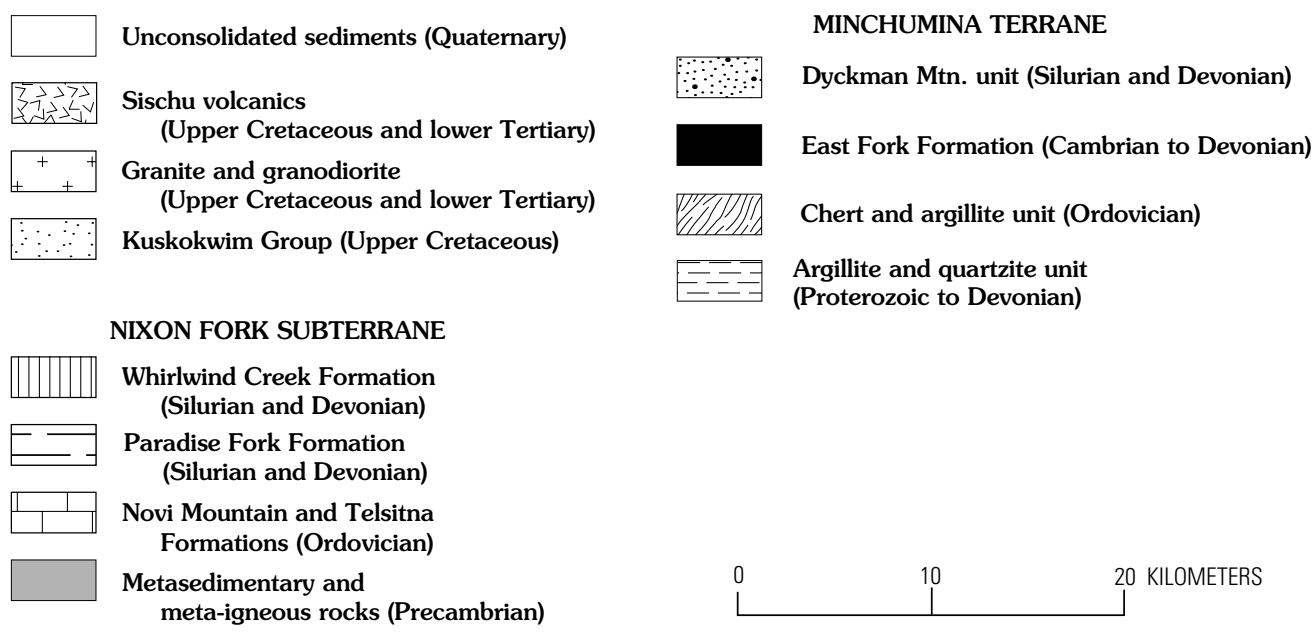

Figure 2. Location of lithologic and fossil collections from study area; geologic mapping modified from Patton and others (1980) and Béla Csejtey, Jr. (unpub. data, 1993, as compiled in Wilson and others, 1998). Grouping of units in the explanation is modified from Patton and others (1994). Strands A, B, C, and D refer to splays of the Iditarod-Nixon Fork fault system mentioned in text. Novi Mountain and Telsitna Formations as shown include outcrops of Whirlwind Creek Formation too small to show at scale of map. Ordovician chert and argillite unit in this area includes abundant fine-grained limestone and dolostone.

\section{Silurian-Devonian Strata in the Dyckman Mountain Area}

Paleozoic carbonate rocks in the Dyckman Mountain area were mapped and briefly mentioned by Eakin (1918), Patton and others (1980), and Dutro and Patton (1982) but have not otherwise been previously described. Lithologic and fossil data from adjacent areas in the eastern Medfra quadrangle are reported by Patton and others (1980), Dutro and Patton (1982), and Dumoulin and others (1999). Much of the Dyckman Mountain area is covered-exposures are confined largely to a few unvegetated ridge-tops. We examined strata at five localities (fig. 2) and summarize the Paleozoic stratigraphy of the area in figure 3 (column 3, "rocks of Dyckman Mtn. area"). 


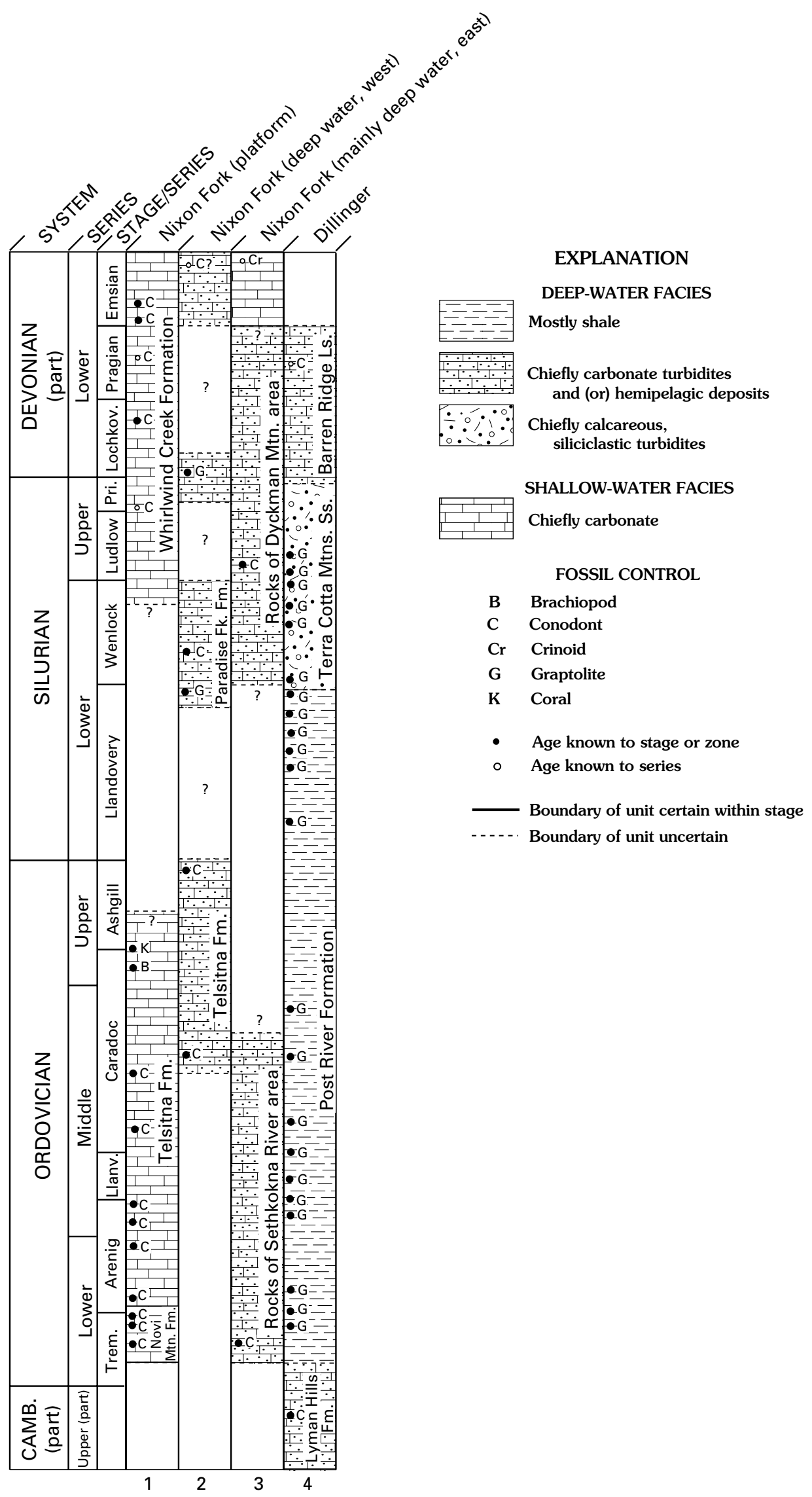

Figure 3. Correlation, lithologies, fossil control, and depositional environments of uppermost Cambrian to Lower Devonian rocks in selected areas of central Alaska. Only fossil groups that most narrowly restrict age of collection or unit are listed. Column 1 is a composite of all shallow-water strata west of strand $C$ of the Iditarod-Nixon Fork fault; column 2 is a similar composite of deep-water strata between strands $C$ and $D$; column 3 shows strata (chiefly deep-water) east of strand $\mathrm{C}$. See figure 2 for location of fault strands. Data sources: columns 1 and 2, Dutro and Patton (1982); Dumoulin and others (1999); A.G. Harris and J.E. Repetski, unpub. data. Column 3, Dumoulin and others (1999); this paper. Column 4, Bundtzen and others (1994); Churkin and Carter (1996). The former Llandeilo Series is now considered a stage of the Llanvirn Series (Fortey and others, 1995).

Microlithofacies were established through field observations and study of 39 thin sections; age and biofacies determinations are based on six conodont collections (table 1) and several megafossil assemblages. Interpretations of depositional environments follow models in Wilson (1975) and Scholle and others (1983). 


\section{Shallow-Water Facies}

\section{Lithologies}

Shallow-water facies occur at localities 1, 3, 5 and possibly 2 (fig. 2); they are best exposed at locality $3,6.5 \mathrm{~km}$ east of Dyckman Mountain, where at least 180 m of light-grayweathering, dark-gray limestone crops out discontinuously
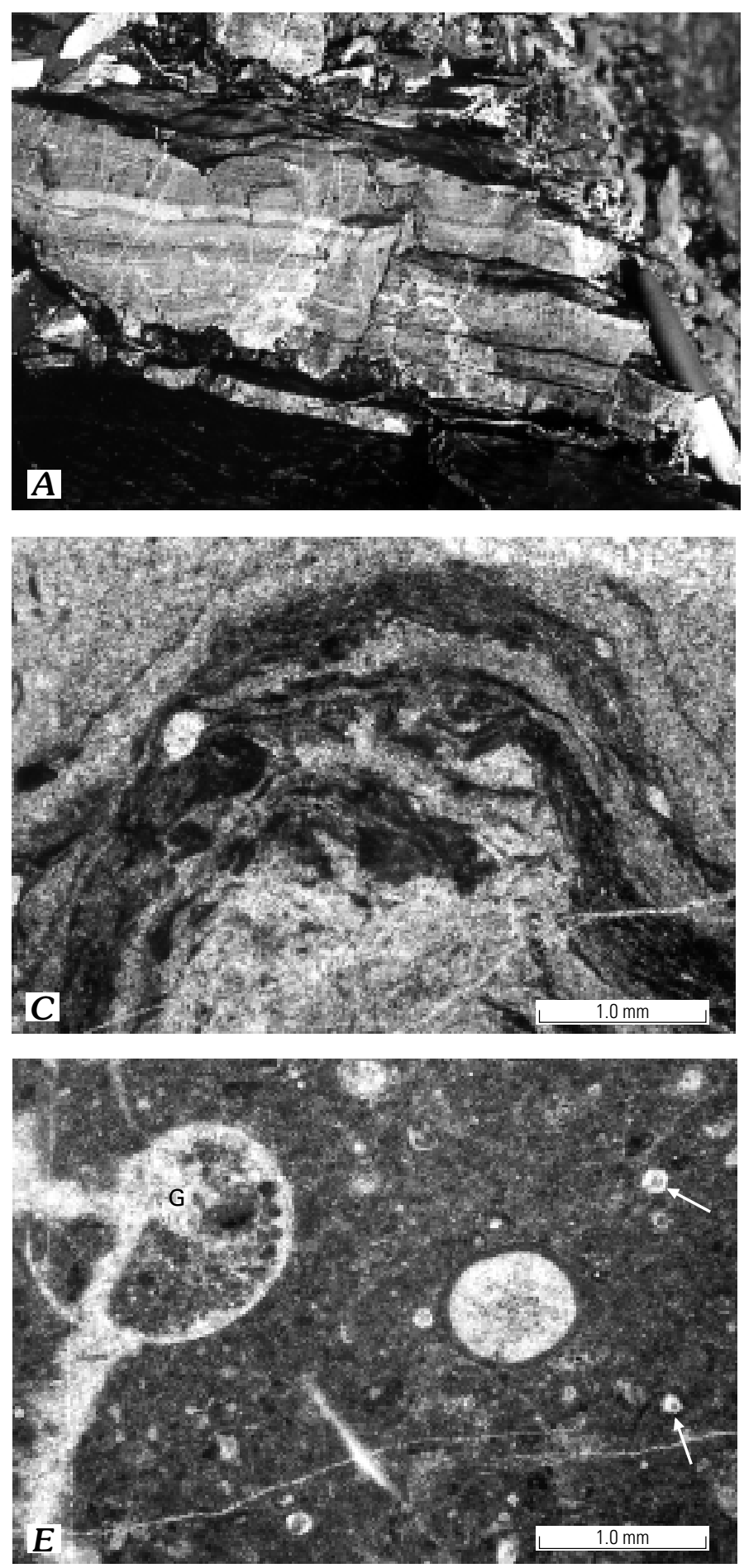

along the western half of a southwest-trending ridge (98AD409; table 1). Most of the lower part of the section is finely laminated micrite (fig. 4A) with rare calcispheres, gastropods, ostracodes, and coralline fragments. Darker laminae, $1.5 \mathrm{~cm}$ to $<200 \mu \mathrm{m}$ thick, are rich in peloids and (or) dolomite rhombs; some laminae are crinkly and form mounds $\leq 1 \mathrm{~cm}$ high as well as millimeter-thick coatings on skeletal grains (figs. $4 C, 4 D$ ). Cycles, $15-25 \mathrm{~cm}$ thick, dominate the upper part of the section and consist of lime micrite and peloidal packstone and grainstone that
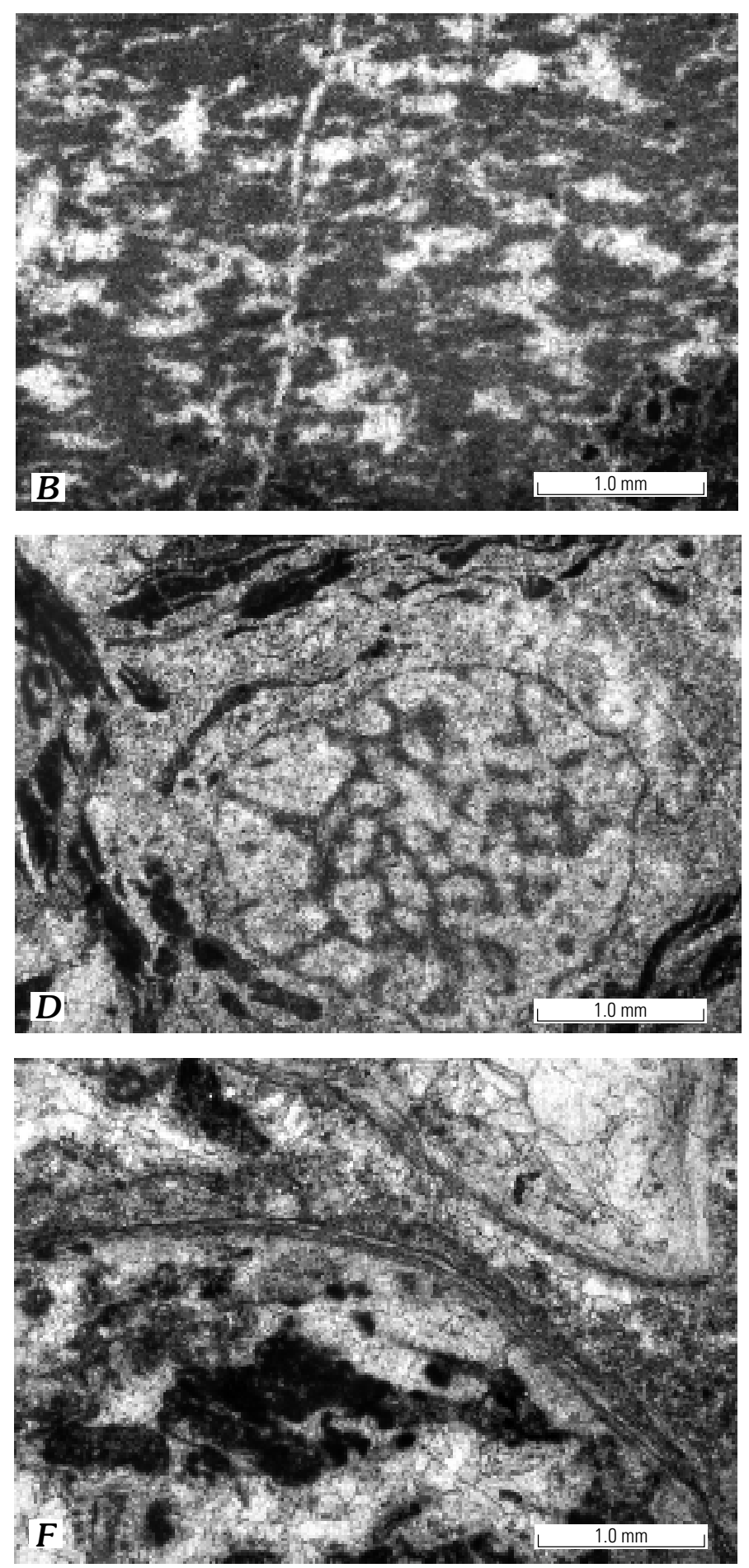

Figure 4. Sedimentary features of shallow-water facies, Dyckman Mountain area (fig. 2, loc. 3). $A-D, 0$ utcrop view $(A)$ and photomicrographs of finely laminated micrite; note light-colored, spar-filled fenestrae in $B$. Crinkly, probable algal laminae form millimeter-scale mounds in $C$ and coat coralline material in $D$. E, Skeletal-peloid wackestone with gastropod $(G)$ and calcispheres (arrows). F, Brachiopod-peloid grainstone. 
$\underset{\infty}{\infty}$ Table 1. Conodont data for localities shown on figure 2.

Letters in field number refer to collector: AD, J.A. Dumoulin. Abbreviations: CAI, color alteration index; indet., indeterminate]

\begin{tabular}{|c|c|c|c|c|}
\hline $\begin{array}{l}\text { Locality no., } \\
\text { (Facies) }\end{array}$ & $\begin{array}{l}\text { Quadrangle } \\
\text { latitude/ } \\
\text { longitude }\end{array}$ & $\begin{array}{l}\text { Conodont fauna and CAI } \\
\text { (Field no.; USGS Colln. no.) }\end{array}$ & Age & Biofacies \\
\hline $\begin{array}{l}1 \text { (Shallow- } \\
\text { water) }\end{array}$ & $\begin{array}{l}\text { Medfra D-1 } \\
63^{\circ} 50^{\prime} 30^{\prime \prime} \\
153^{\circ} 12^{\prime} 40^{\prime \prime}\end{array}$ & $\begin{array}{l}\text { BARREN } \\
(98 A D 405 A)\end{array}$ & & \\
\hline 2 (Deep-water) & $\begin{array}{l}\text { Medfra D-1 } \\
63^{\circ} 52^{\prime} 40^{\prime \prime}\end{array}$ & $\begin{array}{l}2 \text { Panderodus unicostatus (Branson and Mehl) } \\
1 \text { indet. bar or blade fragment }\end{array}$ & $\begin{array}{l}\text { Silurian- } \\
\text { Middle Devonian }\end{array}$ & $\begin{array}{l}\text { Indeterminate (too fev } \\
\text { conodonts). }\end{array}$ \\
\hline
\end{tabular}

$\mathrm{CAI}=3.5$

(98AD423B; 12615-SD)

\section{Medfra D-1 BARREN}

$63^{\circ} 52^{\prime} 45^{\prime \prime} \quad(98 \mathrm{AD} 424 \mathrm{C})$

$153^{\circ} 00^{\prime} 50^{\prime \prime}$

3 (Shallow- $\quad$ Medfra D-1

water)

$\left(63^{\circ} 50^{\prime} 24^{\prime \prime}\right.$

$\left.153^{\circ} 03^{\prime} 08^{\prime \prime}\right)$

7 Panderodus unicostatus (Branson and

Mehl) (fig. 5D)

6 mostly incomplete Pa elements Ozarkodina? n. sp. (figs. 5A-C)

$\mathrm{CAI}=4$

(97AD40B; 12596-SD)

\section{Medfra D-1 BARREN}

$63^{\circ} 50^{\prime} 12^{\prime \prime} \quad$ (98AD409B)

$153^{\circ} 04^{\prime} 00^{\prime \prime}$

Medfra D-1

$63^{\circ} 50^{\prime} 19.5^{\prime \prime}$

$153^{\circ} 03^{\prime} 45^{\prime \prime}$
4 Panderodus unicostatus (Branson and Mehl) fragments

$\mathrm{CAI}=5$

(98AD409Z; 12608-SD)
SilurianMiddle Devonian
Indeterminate (too few conodonts); the panderodids are small and probably represent a postmortem winnow.
Sample near top of 10-m-thick section.

Medium-dark-gray, light-gray-weathering,

fetid, peloidal-skeletal packstone with

crinoids, coral pieces, brachiopods, and

ostracodes; beds $10 \mathrm{~cm}$ thick.

$11 \mathrm{~kg}$ of rock was processed.

Sample of 30-cm-thick bed of pebbly limestone conglomerate, clasts $(0.5-5 \mathrm{~mm}$ in diameter) are gray-, yellow- and red-weathering micrite, calcisiltite, and peloidal grainstone; interbedded with thinner bedded, mediumgray, red-weathering micrite and calcisiltite.

$8.9 \mathrm{~kg}$ of rock was processed.

About $120 \mathrm{~m}$ stratigraphically below 98AD423; sample from 0.5 -m-thick, finely parallel laminated bed several meters above base of 4 - to 5-m-thick outcrop. Sampled bed is dark-gray, medium-dark-gray-weathering dolomitic micrite; beds here mostly $2-10 \mathrm{~cm}$ thick. $11.5 \mathrm{~kg}$ of rock was processed.

Indistinct, 20-cm-thick beds of gray skeletalpeloidal packstone/grainstone with brachiopods, corals, and crinoids.

conodonts). Probably middle to shallow shelf depositional setting.

Corals and brachiopods collected near this location identified as Middle Devonian in Eakin (1918).

$9.9 \mathrm{~kg}$ of rock processed.

Sample from 25-cm bed, $1 \mathrm{~m}$ below top of 20 $\mathrm{m}$ section and about $60 \mathrm{~m}$ stratigraphically lower than 98AD409Z; stratigraphic level probably close to that of 97AD40. Sample is dark-gray, light-gray-weathering, fetid gastropod-peloid wackestone that grades up into coral-peloid wackestone.

$9.9 \mathrm{~kg}$ of rock was processed.

Sample from 30-cm-thick bed of sparse skeletal wackestone with calcispheres, gastropods, and ostracodes.

$9.2 \mathrm{~kg}$ of rock was processed. 
Table 1. Conodont data for localities shown on figure 2-Continued.

Letters in field number refer to collector: AD, J.A. Dumoulin. Abbreviations: CAI, color alteration index; indet., indeterminate]

\begin{tabular}{|c|c|c|c|c|c|}
\hline 4 (Deep-water) & $\begin{array}{l}\text { Medfra D-1 } \\
63^{\circ} 48^{\prime} 00^{\prime \prime} \\
153^{\circ} 09^{\prime} 05^{\prime \prime}\end{array}$ & $\begin{array}{l}1 \text { Panderodus unicostatus (Branson and Mehl) } \\
1 \mathrm{M} \text { Pedavis sp. indet. (figs. 5E, F) } \\
\text { Pelekysgnathus sp. indet. } \\
1 \mathrm{P} \text { and } 4 \text { coniform elements (figs. } 5 \mathrm{H}-\mathrm{K}) \\
\text { UNASSIGNED ELEMENTS: } \\
1 \mathrm{~Pb}, 2 \mathrm{Sb}(2 \text { morphotypes), and } 1 \text { coniform } \\
3 \text { indet. bar, blade, and platform fragments } \\
\text { REDEPOSITED CONODONTS: } \\
1 \text { belodinid of Middle-Late Ordovician morphotype } \\
\text { (fig. } 5 \mathrm{G}) \\
\text { CAI=3.5 } \\
\text { (98AD415C; } 12612 \text {-SD) }\end{array}$ & $\begin{array}{l}\text { early Late Silurian } \\
\text { (early-middle } \\
\text { Ludlow) }\end{array}$ & $\begin{array}{l}\text { Indeterminate (too few conodonts; } \\
\text { faunule includes a redeposited } \\
\text { conodont). }\end{array}$ & $\begin{array}{l}\text { Lithologically similar (and stratigraphically equiva- } \\
\text { lent?) to } 98 \mathrm{AD} 423 \mathrm{~B} \text { (loc. } 2 \text { ). Six-m-thick debris } \\
\text { flow, overlain by } 2 \mathrm{~m} \text { of well-bedded micrite. Sam- } \\
\text { ple from debris flow, } 2.5 \mathrm{~m} \text { above base. Flow is } \\
\text { clast-supported conglomerate, with clasts of dark- } \\
\text { gray micrite and calcisiltite as much as } 12 \mathrm{~cm} \text { in } \\
\text { diameter. Some clasts have fine parallel laminae; } \\
\text { some contain skeletal fragments, peloids, and (or) } \\
\text { coated grains. Sample from } 30 \text {-cm-thick interval } \\
\text { with clasts mostly }<1 \mathrm{~cm} \text {. } \\
\text { Upper age limit of sample constrained by strati- } \\
\text { graphic position. } \\
10.0 \text { kg of rock was processed. }\end{array}$ \\
\hline & & $\begin{array}{l}\text { All conodonts are chiefly small and incomplete con- } \\
\text { iform elements. } \\
1 \text { M icriodontid element (fig. } 5 \mathrm{P}) \\
2 \text { Panderodus unicostatus (Branson and Mehl) } \\
\text { UNASSIGNED ELEMENTS: } \\
2 \text { coniform ( } 2 \text { morphotypes; figs. } 5 \mathrm{~N}, \mathrm{O} \text { ) and } 2 \mathrm{M} \\
\text { elements of Silurian-Middle Devonian morpho- } \\
\text { types } \\
8 \text { indet. mostly coniform fragments } \\
\text { CAI=4-4.5 } \\
\text { (98AD415E; 12613-SD) }\end{array}$ & $\begin{array}{l}\text { early Late Silurian } \\
\text { (early-middle } \\
\text { Ludlow) }\end{array}$ & $\begin{array}{l}\text { Indeterminate (too few generically } \\
\text { identifiable conodonts). The } \\
\text { conodonts are small and broken } \\
\text { which suggests a postmortem } \\
\text { distal winnow into an off-shelf } \\
\text { depositional setting. }\end{array}$ & $\begin{array}{l}\text { Sample from } 30-\mathrm{cm}-\text { thick interval of laminated } \\
\text { micrite and calcisiltite, just above debris flow sam- } \\
\text { pled in } 98 \mathrm{AD} 415 \mathrm{C} \text {; medium dark gray, light gray } \\
\text { weathering, in beds } 1-20 \mathrm{~cm} \text { thick with } 1 \text { - to } 2 \text {-cm- } \\
\text { thick, recessive (shaly?) interlayers. } \\
\text { Upper age limit of sample constrained by strati- } \\
\text { graphic position. } \\
13.9 \mathrm{~kg} \text { of rock was processed. }\end{array}$ \\
\hline & $\begin{array}{l}\text { Medfra D-2 } \\
63^{\circ} 48^{\prime} 10^{\prime \prime} \\
153^{\circ} 09^{\prime} 19^{\prime \prime}\end{array}$ & $\begin{array}{l}\text { All conodonts are robust, relatively large fragments. } \\
3 \text { Pa fragments Kockelella sp. indet. of middle Wen- } \\
\text { lock-middle Ludlow morphotype (fig. } 5 \mathrm{~L} \text { ) } \\
1 \text { Pa fragment Ozarkodina? sp. indet. of Ludlow- } \\
\text { Lochkovian morphotype (fig. 5M); this fragment } \\
\text { resembles } O z \text {. crispa (Walliser) } \\
22 \text { indet. bar, blade, and platform fragments } \\
\text { CAI=5 } \\
\text { (98AD417C; } 12614-\mathrm{SD})\end{array}$ & $\begin{array}{l}\text { early Late Silurian (no } \\
\text { younger than middle } \\
\text { Ludlow; likely } \\
\text { middle Ludlow). } \\
\text { Kleffner }(1995) \text {, on } \\
\text { the basis of graphic } \\
\text { correlation, shows } \\
\text { the lowest } O z . \\
\text { crispa appearing } \\
\text { immediately after } \\
\text { the extinction of the } \\
\text { youngest } \\
\text { kockelellid. The } \\
\text { collection could } \\
\text { represent a level } \\
\text { near the base of the } \\
O z . \text { crispa Subzone } \\
\text { of the } O z . \\
\text { remscheidensis } \\
\text { Zone (middle } \\
\text { Ludfordian). }\end{array}$ & $\begin{array}{l}\text { Indeterminate (too few generically } \\
\text { identifiable conodonts). }\end{array}$ & $\begin{array}{l}\text { About } 90 \mathrm{~m} \text { stratigraphically higher than } 98 \mathrm{AD} 415 \text {; } \\
\text { sample from } 10 \text {-cm-thick bed of lime clast grain- } \\
\text { stone that is interbedded with limestone conglom- } \\
\text { erate; clasts (mostly } 0.5-2 \mathrm{~mm} \text { in diameter) of } \\
\text { micrite, calcisiltite, skeletal wackestone, and } \\
\text { peloidal packstone and grainstone. } \\
\text { Lower age limit of sample restricted to Ludlow by } \\
\text { stratigraphic position. } \\
10.8 \text { kg of rock was processed. }\end{array}$ \\
\hline $\begin{array}{l}5 \text { (Shallow- } \\
\text { water) }\end{array}$ & $\begin{array}{l}\text { Medfra C-2 } \\
\left(63^{\circ} 35^{\prime} 57^{\prime \prime}\right. \\
\left.153^{\circ} 31^{\prime} 09^{\prime \prime}\right)\end{array}$ & $\begin{array}{l}\text { BARREN } \\
\text { (97AD26A) }\end{array}$ & $\begin{array}{l}\text { late Early-early Middle } \\
\text { Devonian (Emsian- } \\
\text { Eifelian) on the } \\
\text { basis of two-hole } \\
\text { crinoid columnals. }\end{array}$ & & $\begin{array}{l}\text { Mapped by Patton and others (1980) as East Fork } \\
\text { Hills Formation but lithologically unlike this unit. } \\
\text { Massive, medium-gray, peloid-skeletal wacke- } \\
\text { stone/packstone containing sparse crinoid ossicles } \\
\text { (some with two holes) and coral fragments. } \\
9.6 \text { kg of rock processed. }\end{array}$ \\
\hline
\end{tabular}


grade upward into gastropod-peloid wackestone (fig. 4E) and then into coralline-peloid wackestone and packstone. Other bioclasts in these beds are calcispheres, calcareous spicules, ostracodes, algae(?), and rare crinoid ossicles and brachiopod fragments.

Massive outcrops of medium- to light-gray-weathering, medium- to dark-gray limestone form the topographically highest part of the ridge at locality 3 (97AD40; table 1), about $0.5 \mathrm{~km}$ northeast of the rocks just described. The stratigraphic level of these beds is probably close to that of the western sequence (98AD409), but cannot be precisely determined due to structural complexity and poor exposure between the two sections. Laminated micrite and peloidal mudstone to packstone, much like rocks described above, contain locally abundant, spar-filled horizontal fenestrae as well as rare ostracodes, calcispheres, and algae (fig. 4B). This lithology forms intervals about $20 \mathrm{~cm}$ thick intercalated with indistinct beds, 20 to $50 \mathrm{~cm}$ thick, of skeletalpeloidal packstone and grainstone; bioclasts are mostly coral and stromatoporoid fragments, brachiopods, and crinoid ossicles (fig. $4 F$ ).

About 5 to $10 \mathrm{~m}$ of section on the west side of Dyckman Mountain (fig. 2, loc. 1) is quite similar to strata described above from the east side of locality 3 (97AD40). Skeletal-peloidal wackestone with gastropods, ostracodes, calcispheres, and crinoid ossicles grades upward into packstone containing brachiopod and favositid coral fragments and rare quartz silt. Peloids are of two types in these strata (and in the sections described above). Some are rounded to slightly ovoid and generally $\leq 100$ $\mu \mathrm{m}$ in diameter; others are more irregular in size and shape and may exceed $200 \mu \mathrm{m}$ in size. The former predominate in muddier layers and likely formed as fecal pellets; the latter occur mostly in skeletal-rich intervals and are probably micritized bioclasts.

Light-gray-weathering, dark-gray limestone along the top of the ridge at locality 2 most likely also formed in a shallowwater setting. Strata here are 3- to 5-cm-thick beds of peloidal grainstone with rare bioclasts.

Shallow-water limestone is also exposed about $30 \mathrm{~km}$ southwest of Dyckman Mountain at Little Hog Butte (fig. 2, loc. 5). These rocks were mapped as East Fork Hills Formation by Patton and others (1980) but are lithologically unlike that unit, which consists chiefly of thin-bedded, gray to grayish-orange, locally silty and dolomitic limestone (Dutro and Patton, 1982; Dumoulin and others, 1999). Strata at locality 5, in contrast, are massive, medium-gray, slightly recrystallized beds of peloidalskeletal wackestone and packstone. Peloids are large (200 $\mu \mathrm{m}-2$ $\mathrm{mm}$ ) and irregular in shape, and are probably micritized skeletal grains. Recognizable bioclasts are mainly two- and lesser fourhole crinoid ossicles and rare coral fragments.

\section{Age}

Conodont and other fossil data suggest an Early and (or) Middle Devonian age for shallow-water strata in the Dyckman Mountain area, although some parts of the section could be as old as Early Silurian (table 1). Three samples taken for conodonts from localities 1, 3, and 5 (fig. 2) were barren; another sample from locality 3 yielded only long- ranging elements of Panderodus unicostatus. A third sample from locality 3 also contained $P$. unicostatus as well as elements of a distinct new species of Ozarkodina? (figs. 5A-5C). Corals and brachiopods from locality 3 were considered in Eakin (1918) to be of Middle Devonian age; the coral Cladopora sp. of Silurian-Devonian age was identified in a sample from this locality by W.A. Oliver, Jr., (oral commun., 1999). Two- and four-hole crinoid columnals in the rocks at locality 5 restrict their age to late Early or early Middle Devonian (Emsian or Eifelian).

\section{Depositional Environment}

Sedimentary features and faunal assemblages indicate that the rocks described above were deposited in a shallow-marine setting with locally restricted circulation. Crinkly (probably algal) laminae, fenestral fabric, and the abundance of peloids all suggest a shallow subtidal to intertidal setting. Fossils tolerant of high and (or) variable salinity, such as gastropods, calcispheres, and ostracodes, predominate in these strata and imply deposition in inner-shelf or platform environments. The scarcity and low diversity of conodonts in our large samples (9$11 \mathrm{~kg}$; table 1) confirm a shallow-water, partly restricted environment. Local coral-rich beds, however, indicate that some parts of the succession formed in more open, middle- to innershelf settings with normal-marine salinity.

\section{Deep-Water Facies}

\section{Lithologies}

Deep-water strata were examined at localities 2 and 4 (fig. 2). More than $210 \mathrm{~m}$ of section is discontinuously exposed at locality 4 , and at least $120 \mathrm{~m}$ of similar rock occurs beneath probable shallow-water facies at locality 2 . In both areas, meter- to decameter-thick intervals of thin-bedded, fine-grained limestone (fig. 6A) are intercalated with subordinate thicker to massive beds of pebbly lime grainstone and limestone conglomerate (figs. 6B-6D).

Fine-grained limestone intervals are dark gray but weather to light or medium gray or locally (particularly at loc. 2) to distinctive pale shades of yellow, orange, and red. Beds are $<1$ to 10 $\mathrm{cm}$ thick and commonly finely laminated; laminae reflect small variations in size (graded couplets; fig. 6A) and (or) organic content and are generally subtler, more closely spaced, and less irregular than those in the shallow-water facies. Some intervals have recessive shaly partings, and Eakin (1918, p. 26) reported subordinate interbeds of dark "slate." Limestone lithologies range from mudstone (grains $\leq 4 \mu \mathrm{m}$ ) to calcisiltite (grains chiefly 8-20 $\mu \mathrm{m}$, rarely to $150 \mu \mathrm{m}$ ); a few mudstone layers are partly dolomitized. Rare small peloids and bioclasts occur locally; possible calcitized radiolarians were noted in one sample.

Coarser grained strata are found sporadically throughout the section at locality 4 and in the middle part of the section at locality 2. Most beds are 10 to $30 \mathrm{~cm}$ thick, but a massive layer at least $6 \mathrm{~m}$ thick occurs about $90 \mathrm{~m}$ below the top of the section at locality 4 (figs. $6 B, 6 C$ ). All beds examined were clast supported; in some samples, clasts are outlined by stylolites and packing has been enhanced by pressure solution. Clasts are 


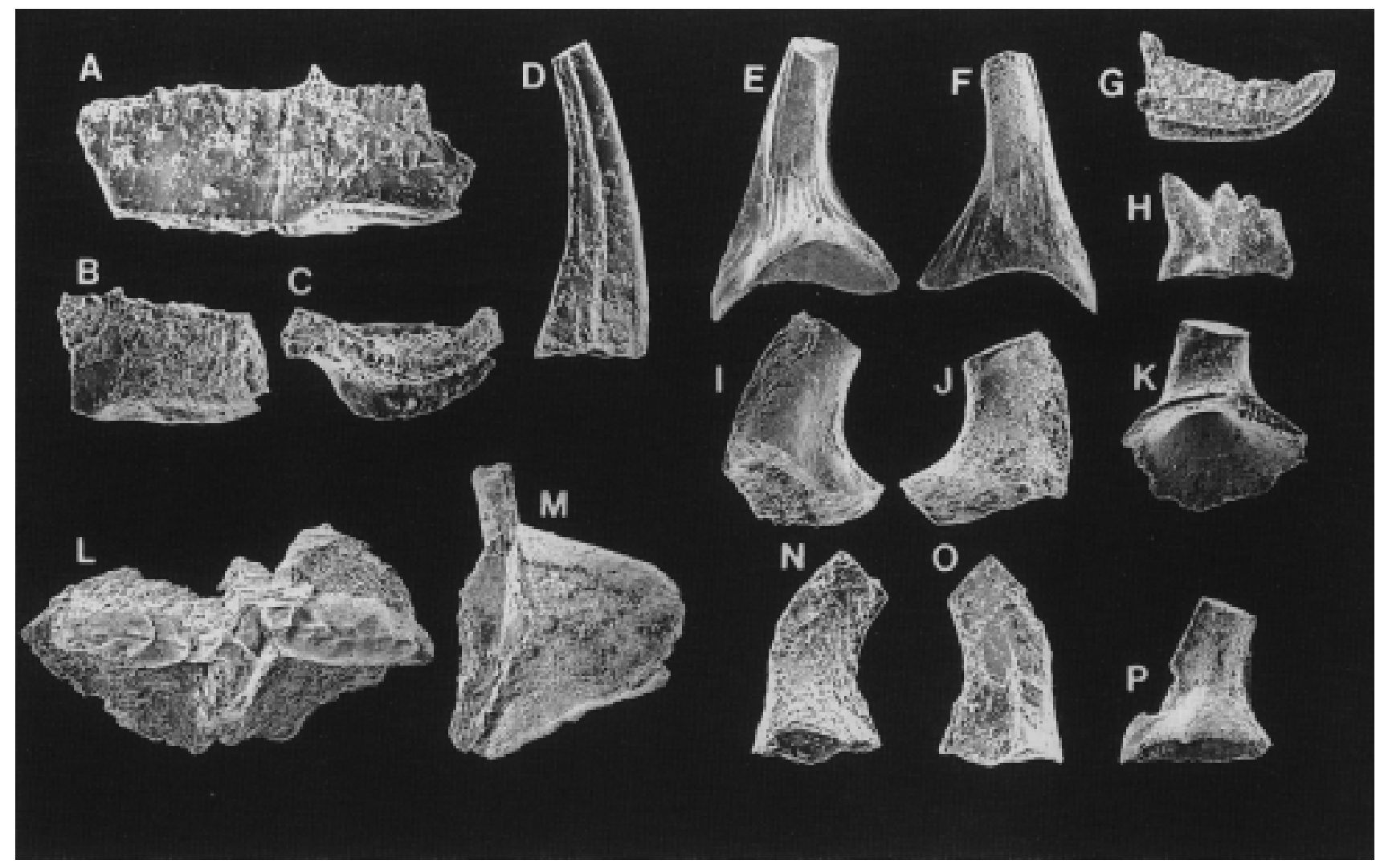

Figure 5. Conodonts from Paleozoic rocks in the Dyckman Mountain area, northeastern Medfra quadrangle, central Alaska (scanning electron micrographs of carbon-coated specimens; illustrated specimens are reposited in the U.S. National Museum, USNM, Washington, D.C.). See table 1 for lithologic description of sample and analysis and age assignment of faunule and figure 2 for geographic and geologic position.

A-D, Silurian-Middle Devonian, USGS colln. 12596-SD (fig. 2, loc. 3).

A-C, Ozarkodina? n. sp., outer lateral and upper views of two Pa elements, x100, USNM 50155-56. Pa elements are characterized by many fine short denticles that are relatively uniform, fused throughout most of their length, and restricted to the upper onefourth of a comparatively high blade. All our specimens are incomplete; the largest (A), has at least 25 denticles and lacks a distinct cusp. The expanded basal cavity lies in the posterior half of the element.

D, Panderodus unicostatus (Branson and Mehl), outer lateral view, x75, USNM 501157.

E-K, early Late Silurian, USGS colln. 12612-SD (fig. 2, loc. 4).

E, F, Pedavis sp. indet., M element, inner and outer lateral views, x50, USNM 501158.

G, Redeposited Middle-Late Ordovician belodinid, lateral view, x60, USNM 501159.

H-K, Pelekysgnathus sp. indet.; P (lateral view), Sc (outer and inner lateral views), and Sa? (posterior view) elements, x60, USNM 501160-62.

L, M, early-middle Ludlow, USGS colln. 12614-SD (fig. 2, loc. 4), x50.

L, Kockelella sp. indet. of middle Wenlock-middle Ludlow morphotype, posterior fragment of Pa element, upper view, USNM 501163.

M, Ozarkodina? sp. indet. of early Late Silurian morphotype, posterior fragment of Pa element, upper view, USNM 501164. This specimen resembles the middle-late Ludlow index Oz. crispa (Walliser).

N-P, early Late Silurian-Early Devonian, USGS colln. 12613-SD (fig. 2, loc. 4).

$\mathrm{N}, \mathrm{O}$, Unassigned coniform Sb? element, inner and outer lateral views, X150, USNM 501165.

$\mathrm{P}$, Icriodontid? M element, inner lateral view, x60, USNM 501166

mostly dark gray in a lighter gray matrix but some clasts weather yellow or red. Maximum clast size is generally about 4 $\mathrm{cm}$ and reaches $12 \mathrm{~cm}$ in some beds; average clast size ranges from $500 \mu \mathrm{m}$ to $1 \mathrm{~cm}$. The largest clasts are generally elongate. Clasts may be finely laminated or graded and are rounded to irregular in form; these shapes suggest that most clasts were only partly lithified when deposited. Clasts are chiefly lime mudstone (micrite), calcisiltite, and peloidal packstone and grainstone (fig. 6D), but fragments of ooid grainstone, skeletal wackestone, and coarse skeletal debris were also observed. Bioclasts include gastropods, brachiopods, and possible algae. Matrix is generally micrite or calcareous silt; calcite cement occurs locally. Both clasts and matrix contain virtually no siliciclastic material. 

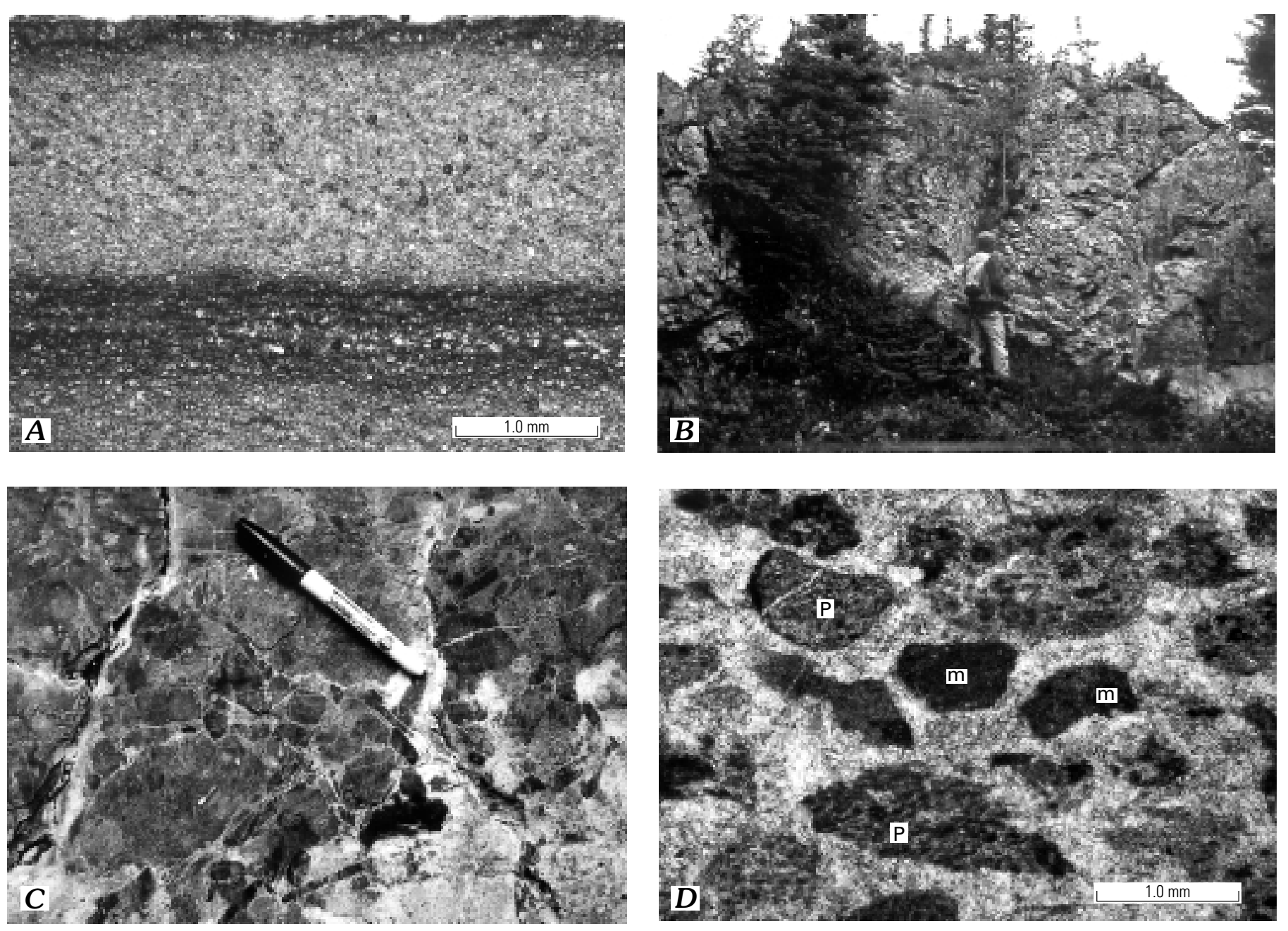

Figure 6. Sedimentary features of deep-water facies, Dyckman Mountain area (fig. 2, loc. 4) in outcrop $(B, C)$ and photomicrographs $(A, D)$. $A$, Graded couplets of calcisiltite (light) and dolomitic lime mudstone (dark). $B-D$, Carbonate clast debris flow; clasts chiefly micrite (m) and peloidal grainstone (P).

Age

Conodont faunas indicate that deep-water facies in the Dyckman Mountain area are Silurian to Middle Devonian, most probably Silurian; they contain redeposited forms as old as Middle or Late Ordovician (table 1; fig. 5G). A single collection from locality 2 (fig. 2) yielded only a few specimens of the same long-ranging panderodid recovered from the shallow-water facies, but three assemblages from locality 4 are more biostratigraphically useful. The most diagnostic collection (98AD417C), from redeposited lime grainstone in the uppermost part of the section, is of Silurian (early-middle Ludlow, possibly middle Ludlow) age. Conodonts in this sample are typical of shallow-water settings and could be either older forms reworked into younger deposits or penecontemporaneous forms hydraulically transported into a deeper water environment. Several lines of evidence, however, imply that the shallow-water source facies and the deeper water depositional facies for these conodonts were essentially coeval. As noted above, most carbonate clasts were relatively unlithified when deposited, indicating that clast transport took place soon after initial sedimentation of the clast material. In addition, the other collections from locality 4 , including one from a fine-grained interval of "background" sediment (discussed below), are compatible with a Ludlow age. Taken together, these data suggest that deepwater strata at locality 4 accumulated largely during early Late Silurian time.

\section{Depositional Environment}

Deep-water strata in the Dyckman Mountain area originated as hemipelagic deposits, fine-grained distal turbidites, and subordinate coarser debris flows derived from a carbonate platform and deposited in a slope and (or) basinal setting. Laminae in fine-grained intervals (micrite and calcisiltite) may have had several origins. Some laminae may be varves formed through cyclic changes in productivity and (or) detrital influx; graded couplets are more likely distal turbidites. Laminated micrite at locality 2 (fig. 2) is deformed by minor disharmonic folds of probable slump origin; such folds suggest deposition in a slope environment.

We interpret coarser intervals of lime grainstone and conglomerate as debris flows made of shallow- and deep-water carbonate clasts. Abundant fragments of micrite and calcisiltite are identical to, and probably derived from, the fine-grained hemipelagic interbeds, but clasts rich in peloids, coated grains 
(including ooids), and bioclasts such as gastropods and algae must have originated in a shallow-water shelf or platform setting. Conodonts and sedimentary textures suggest that shallowwater clasts were derived from beds equivalent in age and facies to the Novi Mountain, Telsitna, and Whirlwind Creek Formations in the Nixon Fork subterrane. Middle and (or) Late Ordovician belodinid conodonts, like that redeposited in sample 98AD415C (table 1; fig. 2, loc. 4), occur in the Telsitna, and Silurian ozarkidinids (98AD417C) are common in parts of the Whirlwind Creek. Ooid grainstone is abundant in the Novi Mountain (Dutro and Patton, 1982) and also reported from the Telsitna (Measures and others, 1992); peloidal packstone and grainstone are found throughout the Nixon Fork subterrane but are particularly abundant in the Telsitna.

\section{Structure}

The Dyckman Mountain area lies between two strands (A and B) of the Iditarod-Nixon Fork fault system (fig. 2), which underwent 88-94 km of dextral displacement during the Late Cretaceous and Tertiary (Miller and Bundtzen, 1988, 1992). Strand A, which has a strong topographic expression, separates the Dyckman rocks of the present study from deep-water strata that Patton and others (1994) assigned to the Minchumina terrane. Strand B is not as strongly expressed topographically. Across it, Dyckman rocks are juxtaposed against the Upper Cretaceous and lower Tertiary Sischu volcanics. For lack of piercing points, there is no direct evidence for the amount of displacement on either strand (Dumoulin and others, 1999). Based on documented offsets elsewhere (Miller and Bundtzen, 1988), both strands are inferred to have undergone a few to a few tens of kilometers of dextral horizontal displacement; strand $\mathrm{B}$, in addition, has a vertical component of displacement, northwest side down.

Paleozoic rocks of the Dyckman Mountain area have been folded, presumably in Mesozoic time, about northeast-trending axes. Folds are open to tight, with subhorizontal axes and steep axial surfaces. The folding is likely related to regional shortening that affects all Paleozoic rocks of the Farewell terrane, regardless of proximity to strike-slip faults. It is unlikely that any significant shortening in the Dyckman Mountain area is related to transpression between strands of the Iditarod fault system because the Sischu volcanics, which depositionally overlie the Dyckman unit, are essentially undeformed (Eakin, 1918). Owing to the poor exposure, difficult access, and the still poorly defined internal stratigraphy, it is not yet possible to trace folds -or stratigraphic horizons - at the scale of 1:63,360 in the Dyckman Mountain area. Were such detailed mapping available, a valley-and-ridge map pattern like that documented for the Dillinger subterrane in the McGrath quadrangle (Bundtzen and others, 1997) might also be expected here.

Although folded and faulted, Paleozoic rocks in the Dyckman Mountain area lack penetrative fabrics. Conodonts in these strata have color alteration indices of 3.5 to 5 , indicating that the host rocks reached temperatures of at least $180^{\circ}-300^{\circ} \mathrm{C}$ (Epstein and others, 1977). Limestone textures in most thin sections show no evidence of recrystallization.

Resistant bodies of limestone breccia occur at localities 2 and 3 (fig. 2). The full extent and attitude of these bodies could not be determined because of limited exposures, but they are at least several meters across in outcrop. At locality 3, randomly oriented blocks of laminated limestone up to a few meters in length float in a matrix of fine-grained calcite. A similar breccia at locality 2 is pervaded by multiple generations of calcite veins, some with crystals $\geq 2 \mathrm{~cm}$ across, and is juxtaposed against bedded carbonate rocks along an east-west-striking dextral fault. Together, these features suggest a tectonic rather than sedimentary origin for the breccia bodies. Structurally controlled breccias that cut carbonate rocks of the Nixon Fork subterrane near Reef Ridge (20 km southwest of the area of figure 2) contain zinc-(lead-cadmium) mineralization (Schmidt, 1997). We took several samples for geochemical analyses from the Dyckman breccias, but none showed any evidence of mineralization.

\section{Correlation}

Available stratigraphic and faunal data suggest that deepwater facies are largely older than, and grade upward into, shallow-water facies in the Dyckman Mountain area (fig. 3). Some shallow-water strata could be slightly older than, and (or) coeval with, deeper water rocks. As noted above, much of the Dyckman area is covered; vegetated slopes are probably underlain chiefly by fine-grained limestone and shale. Siliciclastic strata equivalent to the Ordovician chert and argillite unit, exposed to the north along the Sethkokna River (fig. 2), may also underlie carbonate rocks northeast of Dyckman Mountain (Eakin, 1918).

Faunal and sedimentologic data suggest correlations between Paleozoic strata in the Dyckman area and coeval rocks in both the Nixon Fork and Dillinger subterranes. Shallowwater Dyckman facies are similar in many respects to the Whirlwind Creek Formation, exposed to the southwest in the Nixon Fork subterrane. The Whirlwind Creek (Upper Silurian and Devonian) is characterized by cycles of algal laminite that grade up into pelloidal and then fossiliferous limestone; notable fossils are ostracodes, gastropods, brachiopods, stromatoporoids, and corals (Dutro and Patton, 1982). Unlike Dyckman-area rocks, the Whirlwind Creek includes abundant dolostone; dolomite breccias are locally common and host zinc and lead-zinc mineral occurrences in the Reef Ridge area (Schmidt, 1997).

Shallow-water rocks of the Dyckman Mountain area also resemble the Cheeneetnuk Limestone, which crops out in the central part of the Nixon Fork subterrane (southwestern McGrath quadrangle) (Blodgett and Gilbert, 1983; Decker and others, 1994). The upper part of the Cheeneetnuk is Middle Devonian (early Eifelian); the lower part is undated but may be of Early Devonian age. The unit accumulated in a deepeningupward depositional regime; shallow subtidal to intertidal facies grade up into open-marine deposits. Like shallow-water strata in the Dyckman area, the Cheeneetnuk contains intervals of algal laminite as well as fossiliferous beds rich in corals, brachiopods, and crinoids. The Cheeneetnuk also includes dolomitic horizons, however, and the fauna in its upper third is considerably more diverse than that observed in Dyckman-area rocks.

Deep-water strata near Dyckman Mountain are lithologically most similar to parts of the Dillinger subterrane exposed to the southeast and south (fig. 1). In the Mt. McKinley and Healy quadrangles, map unit DOs (Ordovician to 
Devonian metasedimentary sequence of Csejtey and others, 1992) consists, in part, of thin-bedded to massive calcareous turbidites and debris flows interbedded with micritic intervals (these rocks make up subunit $\mathrm{C}$ of Dumoulin, Bradley, and Harris, 1998). Carbonate conglomerate in subunit $\mathrm{C}$, like that in the Dyckman Mountain area, forms beds at least $5 \mathrm{~m}$ thick and contains clasts, chiefly of micrite (lime mudstone), that are as much as $12 \mathrm{~cm}$ long; siliciclastic material is rare or absent in most sections. Conodonts from this subunit are late Early Silurian (Wenlock). Similar calcareous turbidites and limestone conglomerate also occur in the Dillinger subterrane in the southeastern McGrath and northwestern Lime Hills quadrangles (Bundtzen and others, 1988, 1994); these strata (Barren Ridge Limestone of Churkin and Carter, 1996) are Late Silurian (Ludlow) to Early Devonian in age.

Finer grained deep-water strata in the Dyckman Mountain area also resemble the Paradise Fork Formation in the Nixon Fork subterrane. The Paradise Fork consists of fissile to laminated micrite and calcisiltite interbedded with shale and subordinate grainstone rich in micritic clasts; it is mostly of middle Early Silurian (late Llandovery to early Wenlock) age but is locally as young as Early Devonian (Dumoulin and others, 1999). Silurian kockelellid conodonts similar to those in Dyckman sample 98AD417C (table 1; loc 4, fig. 2; fig. 5L) also occur in the Paradise Fork.

\section{Discussion}

Our new data from the Dyckman Mountain area shed light on the relation between shallow-water facies of the Nixon Fork subterrane and coeval deep-water strata ("Minchumina terrane") and on the nature of the shelf-to-basin transition near the northern end of the Nixon Fork carbonate platform.

In the northeastern part of the Medfra quadrangle, the boundary between the Nixon Fork and Minchumina "terranes" proved difficult to define (figs. 1, 2). It was originally drawn along strand A of the Iditarod-Nixon Fork fault (Patton and others, 1980) but was later shifted west to follow strand C (Patton and others, 1984, 1994). Shallow-water "Nixon Fork" facies are not recognized east of strand A and deep-water "Minchumina" rocks do not occur west of strand D, but between these strands, a complex alternation of deep- and shallow-water strata exists (fig. 2). Deep-water facies (Paradise Fork Formation) interfinger with shallow-water deposits between strands $\mathrm{C}$ and D; deep-water facies of the Dyckman Mountain area underlie (and might also interfinger with) shallow-water strata between strands $\mathrm{A}$ and $\mathrm{B}$.

Facies patterns throughout the Farewell terrane have been disrupted by Late Cretaceous and Tertiary strike-slip faulting. Restoration of a total of $90 \mathrm{~km}$ of dextral map-separation along strands A, B, C, and D of the Iditarod-Nixon Fork fault and 150 $\mathrm{km}$ of dextral map-separation along the Farewell fault produces a horseshoe-shaped basin ringed by shallow-water facies on three sides (fig. 9 of Dumoulin and others, 1999). In this reconstruction, which distinguished only "primarily shallow water" and "primarily deep water" successions, a fault slice of deepwater strata (between strands B and C) remains isolated from the broader tract of basinal rocks to the east.
A more realistic reconstruction recognizes an intermediate facies belt transitional between deep- and shallow-water strata (fig. 7) Such transitional facies include interfingering platform and off-platform deposits as well as off-platform strata that are clearly linked to the adjacent platform margin. Using this approach, all of the Nixon Fork subterrane exposed east of strand D could be considered "transitional." Intercalated shallow- and deep-water strata are best documented between fault strands C and D. Here, deeper water facies of Middle and Late Ordovician age interfinger with roughly coeval shallow-water strata in the upper part of the Telsitna Formation, and Silurian and Early Devonian deep-water deposits of the Paradise Fork adjoin age-equivalent neritic sequences of the Whirlwind Creek Formation (Dumoulin and others, 1999). Intercalated platform and off-platform strata characterize much of the Farewell terrane basin margin to the south, as documented in sections at Lone Mountain and White Mountain in the McGrath quadrangle (Decker and others, 1994; T. Bundtzen, written commun., 1997).

Even where intercalation of platform and off-platform facies is not evident, deep-water strata in the northeastern Medfra quadrangle can be tied to contemporaneous neritic deposits. Faunal assemblages and redeposited clast lithologies suggest that deep-water strata east of Iditarod fault strand A were derived from shallow-water facies of the Nixon Fork subterrane. Conodonts from calcareous turbidites in the Ordovician chert and argillite unit (between strands B and C) match those from the lower part of the Novi Mountain Formation species for species (Dumoulin and others, 1999). And, as noted above, clast textures and specific conodonts found in Silurian debris flows of the Dyckman Mountain area indicate derivation from Ordovician and Silurian Nixon Fork subterrane rocks.

Patton and others (1994, p. 247) suggested that "the absence of a transitional facies between the fault-bounded blocks" of the Nixon Fork and Minchumina terranes argues against their interpretation as parts of a single coherent terrane. We propose that a "transitional facies" as defined above marks the northern edge of the Nixon Fork carbonate platform and documents shifts in the position, and perhaps the nature, of the platform margin through time. This margin appears to have backstepped from east to west (present-day coordinates) between Early Ordovician and Early Silurian time, and then prograded east again later in the Silurian. Changes from chiefly fine grained off-platform deposits (such as those in the Paradise Fork Formation) to coarser grained strata, like those in the Dyckman Mountain area, may reflect both local and more widespread factors ranging from steepness of the platform margin to eustatic shifts.

We agree with Patton and others (1994), however, that transitions from shallow- to deep-water strata along certain parts of the northern Nixon Fork margin are relatively abrupt and are best explained by faulting. For example, less than $10 \mathrm{~km}$ separates Ordovician shallow-water facies at Novi Mountain from coeval deep-water rocks along the Sethkokna River. In addition, compositional differences between western and eastern exposures of the Minchumina terrane suggest that it consists of two or more roughly coeval sequences of disparate origin (Dumoulin and others, 1999). Only the eastern parts of this terrane (the East Fork subterrane and western exposures of the Telida 


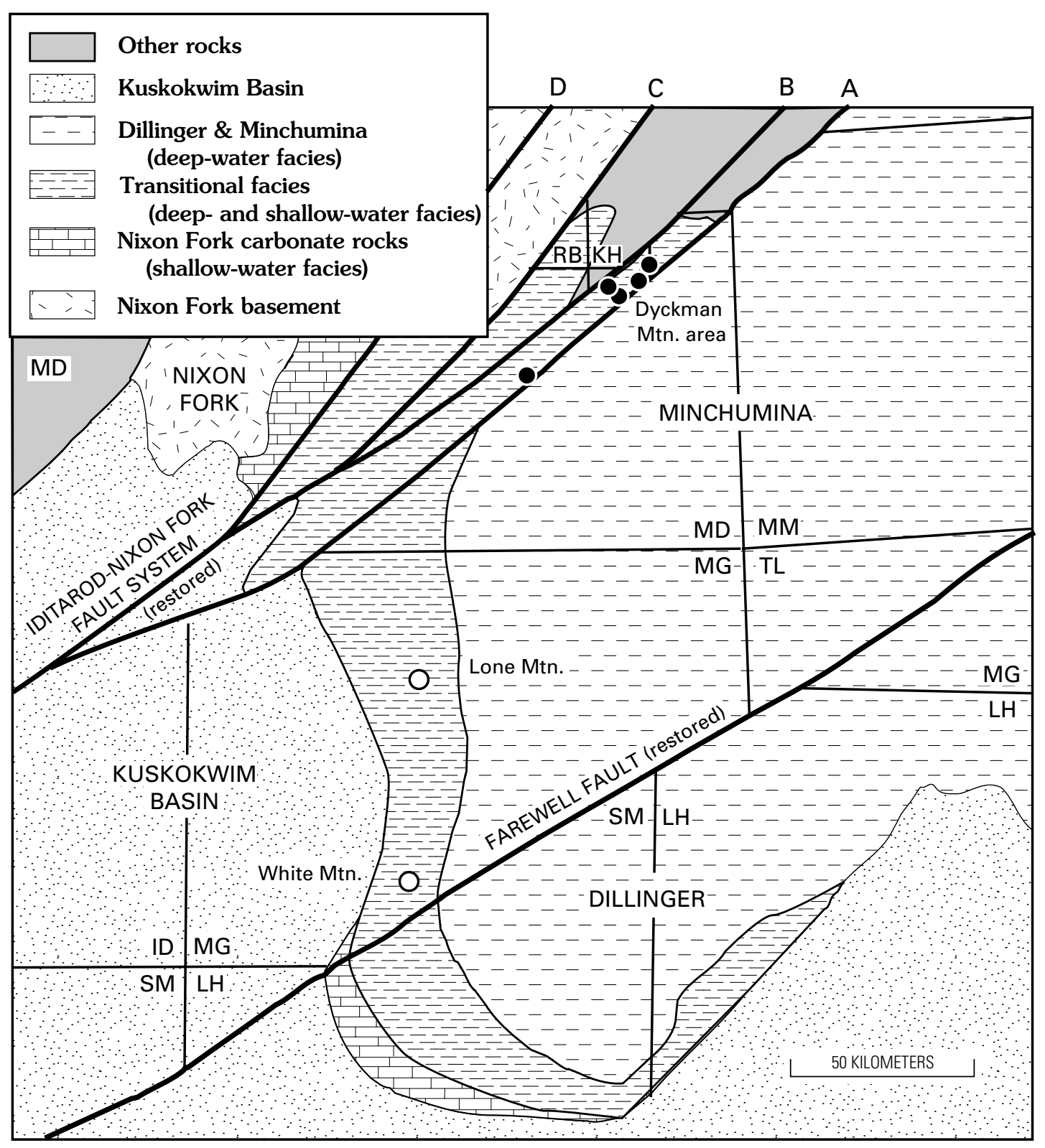

Figure 7. Palinspastic map of study area. Letters $A, B, C$, and D refer to strands of the Iditarod-Nixon Fork fault system mentioned in text. Restoration of 90 and $150 \mathrm{~km}$ of dextral strike-slip on the Iditarod and Farewell faults, respectively, aligns the deep-water Dillinger and Minchumina terranes in a position east of the Nixon Fork carbonate platform. Black dots are locations plotted in figure 2. Fine lines are quadrangle boundaries; quadrangle abbreviations as in figure 1.

subterrane) are rich in carbonate and can be confidently interpreted as derived from the Nixon Fork carbonate platform. Eastern exposures of the Telida consist chiefly of siliceous hemipelagic deposits and quartzofeldspathic turbidites and may correlate with parts of the Wickersham and Livengood terranes to the northeast (Livengood quadrangle).

The ultimate origin of Paleozoic rocks in central Alaska remains contentious. Some authors have suggested that the Farewell terrane is a displaced fragment of the North American (Laurentian) continental margin (Decker and others, 1994), whereas others have interpreted it as a sequence rifted away from the Siberian craton (Blodgett, 1998). Biogeographic affinities of Paleozoic faunas can help to constrain the paleogeographic position of rocks in central Alaska, but the faunas from the Dyckman Mountain area are not particularly useful for such analyses. Megafossils in the shallow-water strata have not been studied in sufficient detail to allow their biogeographic characterization. Worldwide, deep-water conodont faunas are relatively cosmopolitan, as are most normal-marine shallow-water conodont faunas of Silurian and Devonian age.

The sparse conodont collections from the Dyckman Mountain area conform to these trends and provide only general information on the paleogeographic affinities of the faunules. These poorly productive, low-diversity collections contain chiefly broken, specifically and biostratigraphically nondiagnostic conodonts. Specimens that are specifically identifiable are long-ranging cosmopolites (for example, Panderodus unicostatus) or new species (figs. 5A-5C). Ordovician conodont 
faunas from the Medfra quadrangle, in contrast, contain a notable component of provincial forms; these forms include elements typical of both Siberian and Laurentian biotic provinces (Dumoulin, Bradley, Harris, and Repetski, 1998). This distinctive combination of Siberian and Laurentian faunal affinities also characterizes lower Paleozoic strata in northern Alaska (Dumoulin and Harris, 1994).

Conodont collections from the Dyckman Mountain area do constrain the general paleobiogeographic setting of this part of the Farewell terrane. The occurrence of Late Silurian and Devonian icriodontids and pedavids as well as a redeposited Ordovician belodinid indicates that, during the Middle Ordovician to Middle Devonian, the Dyckman Mountain area most likely lay in a tropical to subtropical paleogeographic setting.

\section{Conclusions}

Paleozoic rocks in the Dyckman Mountain area, previously mapped as the Whirlwind Creek Formation (Patton and others, 1980) and thought to be exclusively shallow-water facies, also include deep-water lithologies. Shallow-water strata are Devonian and perhaps in part Silurian and formed in shallow subtidal to intertidal, locally restricted settings; deep-water rocks are Silurian and perhaps in part Devonian and represent hemipelagic deposits, turbidites, and debris flows. Conodonts and clast lithologies indicate that the deep-water strata were derived from beds equivalent in age and facies to the Novi Mountain, Telsitna, and Whirlwind Creek Formations in the Nixon Fork subterrane to the west.

Rocks in the Dyckman Mountain area are part of a broader facies belt, disrupted by folding and strike-slip faulting, that is transitional between the Nixon Fork carbonate platform to the west and exclusively deeper water deposits (western part of the Minchumina terrane) to the east. In this belt, shallow- and deep-water lithologies interfinger, and faunal and petrologic evidence ties deep-water strata to specific units of the platform sequence. Complex facies patterns in these transitional strata reflect not only later structural disturbance but progradation and backstepping of the platform margin through time. The transitional facies belt provides evidence that, as to the south in the McGrath quadrangle, lower Paleozoic shallow- and deep-water strata in the northeastern Medfra quadrangle formed along the same continental margin and should be considered part of the Farewell terrane.

\section{References Cited}

Blodgett, R.B., 1998, Emsian (late Early Devonian) fossils indicate a Siberian origin for the Farewell terrane, in Clough, J.G., and Larson, Frank, eds., Short Notes on Alaska Geology 1997: Alaska Division of Geological \& Geophysical Surveys Professional Report 118, p. 53-61.

Blodgett, R.B., and Gilbert, W.G., 1983, The Cheeneetnuk Limestone, a new Early(?) to Middle Devonian Formation in the McGrath A-4 and A-5 quadrangles, west-central Alaska: Alaska Division of Geological \& Geophysical Surveys Professional Report 85, 6 p.

Bundtzen, T.K., Harris, E.E., and Gilbert, W.G., 1997, Geology of the eastern half of the McGrath quadrangle, Alaska: Alaska Division of
Geological \& Geophysical Surveys Report of Investigations 97-14a, 34 p., 1 pl., scale 1:125,000.

Bundtzen, T.K., Kline, J.T., Smith, T.E., and Albanese, M.D., 1988, Geology of the McGrath A-2 quadrangle, Alaska: Alaska Division of Geological \& Geophysical Surveys Professional Report 91, 20 p., 1 pl., scale $1: 63,360$.

Bundtzen, T.K., Laird, G.M., Blodgett, R.B., Clautice, K.H., and Harris, E.E., 1994, Geology of the Gagaryah River area, Lime Hills C-5 and C-6 quadrangles, southwest Alaska: Alaska Division of Geological \& Geophysical Surveys Public Data File 94-40, 17 p., 1 pl., scale $1: 63,360$.

Churkin, Michael, Jr., and Carter, Claire, 1996, Stratigraphy, structure, and graptolites of an Ordovician and Silurian sequence in the Terra Cotta Mountains, Alaska Range, Alaska: U.S. Geological Survey Professional Paper 1555, $84 \mathrm{p}$.

Csejtey, Béla, Jr., Mullen, M.W., Cox, D.P., and Stricker, G.D., 1992, Geology and geochronology of the Healy quadrangle, south-central Alaska: U.S. Geological Survey Miscellaneous Investigations Series Map I-1961, 63 p., 2 pls., scales 1:250,000 and 1:360,000.

Decker, John, Bergman, S.C., Blodgett, R.B., Box, S.E., Bundtzen, T.K., Clough, J.G., Coonrad, W.L., Gilbert, W.G., Miller, M.L., Murphy, J.M., Robinson, M.S., and Wallace, W.K., 1994, Geology of southwestern Alaska, in Plafker, George, and Berg, H.C., eds., The Geology of Alaska: Boulder, Colo., Geological Society of America, The Geology of North America, v. G-1, p. 285-310.

Dumoulin, J.A., Bradley, D.C., and Harris, A.G., 1998, Sedimentology, conodonts, structure, and regional correlation of Silurian and Devonian metasedimentary rocks in Denali National Park, in Gray, J.E., and Riehle, J.R., eds., Geologic Studies in Alaska by the U.S. Geological Survey, 1996: U.S. Geological Survey Professional Paper 1595, p. 71-98.

Dumoulin, J.A., Bradley, D.C., Harris, A.G., and Repetski, J.E., 1999, Lower Paleozoic deep-water facies of the Medfra area, central Alaska, in Kelley, K.D., ed., Geologic Studies in Alaska by the U.S. Geological Survey, 1997: U.S. Geological Survey Professional Paper 1614, p. 73-103.

Dumoulin, J.A., Bradley, D.C., Harris, A.G., and Repetski, J.E., 1998, Sedimentology, conodont biogeography, and subsidence history of the Nixon Fork terrane, Medfra quadrangle, Alaska [abs.]: Celle, Germany, Abstracts, International Conference on Arctic Margins III, p. 49.

Dumoulin, J.A., and Harris, A.G., 1994, Depositional framework and regional correlation of pre-Carboniferous metacarbonate rocks of the Snowden Mountain area, central Brooks Range, northern Alaska: U.S. Geological Survey Professional Paper 1545, 74 p.

Dutro, J.T., Jr., and Patton, W.W., Jr., 1982, New Paleozoic formations in the northern Kuskokwim Mountains, west-central Alaska, in Stratigraphic notes, 1980-1982: U.S. Geological Survey Bulletin 1529-H, p. H13-H22.

Eakin, H.M., 1918, The Cosna-Nowitna region: U.S. Geological Survey Bulletin 667, $54 \mathrm{p}$.

Epstein, A.G., Epstein, J.B., and Harris, L.D., 1977, Conodont color alteration-An index to organic metamorphism: U.S. Geological Survey Professional Paper 995, $27 \mathrm{p}$.

Fortey, R.A., Harper, D.A.T., Ingham, J.K., Owen, A.W., and Rushton, A.W.A., 1995, A revision of Ordovician series and stages from the historical type area: Geological Magazine, v. 132, no. 1, p. 15-30.

Kleffner, M.A., 1995, A conodont- and graptolite-based Silurian chronostratigraphy, in Mann, K.O., Lane, H.R., and Scholle, P.A., eds., Graphic Correlation: SEPM Special Publication No. 53, p. 159-176. 
Measures, E.A., Rohr, D.M., and Blodgett, R.B., 1992, Depositional environments and some aspects of the fauna of Middle Ordovician rocks of the Telsitna Formation, northern Kuskokwim Mountains, Alaska, in Bradley, D.C., and Dusel-Bacon, Cynthia, eds., Geologic Studies in Alaska by the U.S. Geological Survey, 1991: U.S. Geological Survey Bulletin 2041, p. 186-201.

Miller, M.L., and Bundtzen, T.K., 1988, Right-lateral offset solution for the Iditarod-Nixon Fork fault, western Alaska: U.S. Geological Survey Circular 1016, p. 99-103.

Miller, M.L., and Bundtzen, T.K., 1992, Geologic history of the postaccretionary rocks, Iditarod quadrangle, west-central Alaska [abs.]: Geological Society of America Abstracts with Programs, Cordilleran Section Meeting, v. 24, no. 5, p. 71.

Patton, W.W., Jr., Box, S.E., Moll-Stalcup, E.J., and Miller, T.P., 1994, Geology of west-central Alaska, in Plafker, George, and Berg, H.C., eds., The Geology of Alaska: Boulder, Colo., Geological Society of America, The Geology of North America, v. G-1, p. 241-269.

Patton, W.W., Jr., Moll, E.J., Dutro, J.T., Jr., Silberman, M.L., and Chapman, R.M., 1980, Preliminary geologic map of the Medfra quadrangle, Alaska: U.S. Geological Survey Open-File Report 80-811A, scale 1:250,000.

Patton, W.W., Jr., Moll, E.J., and King, H.D., 1984, The Alaskan Mineral Resources Assessment Program: Guide to information contained in the folio of geologic and mineral-resource maps of the Medfra quadrangle, Alaska: U.S. Geological Survey Circular $928,11 \mathrm{p}$.

Schmidt, J.M., 1997, Strata-bound carbonate-hosted $\mathrm{Zn}-\mathrm{Pb}$ and $\mathrm{Cu}$ deposits of Alaska, in Goldfarb, R.J., and Miller, L.D., eds., Mineral Deposits of Alaska: Economic Geology Monograph 9, p. 90-119.

Scholle, P.A., Bebout, D.G., and Moore, C.H., 1983, Carbonate depositional environments: American Association of Petroleum Geologists Memoir 33, $708 \mathrm{p}$.

Silberling, N.J., Jones, D.L., Monger, J.W.H., Coney, P.J., Berg, H.C., and Plafker, George, 1994, Lithotectonic terrane map of Alaska and adjacent parts of Canada, in Plafker, George, and Berg, H.C., eds., The Geology of Alaska: Boulder, Colo., Geological Society of America, The Geology of North America, v. G-1, plate 3, 1 sheet, scale 1:2,500,000.

Wilson, J.L., 1975, Carbonate facies in geologic history: New York, Springer-Verlag, $471 \mathrm{p}$.

Wilson, F.H., Dover, J.H., Bradley, D.C., Weber, F.R., Bundtzen, T.K., and Haeussler, P.J., 1998, Geologic map of central (Interior) Alaska: U.S. Geological Survey Open-File Report 98-133, 3 sheets, scale 1:500,000, $63 \mathrm{p}$.

Reviewers: T.K. Bundtzen and W.W. Patton, Jr. 


\title{
Reconnaissance Bedrock Geology of the Southeastern Part of the Kenai Quadrangle, Alaska
}

\author{
By Dwight C. Bradley and Frederic H. Wilson
}

\begin{abstract}
We present a new reconnaissance geologic map of the southeastern part of the Kenai quadrangle that improves on previously published maps. Melange of the McHugh Complex is now known to form a continuous strike belt that can be traced from the Seldovia to the Valdez quadrangle; a problematic 75$\mathrm{km}$-long gap in the McHugh Complex in the Kenai and Seldovia quadrangles does not exist. An Eocene near-trench pluton underlies a range of nunataks in Harding Icefield.
\end{abstract}

\section{Introduction}

The bedrock geology of the southeastern part of the Kenai 1:250,000-scale quadrangle (fig. 1) has never been mapped systematically. The map of the Cook Inlet region by Magoon and others (1976) shows geology in this corner of the Kenai quadrangle, but their compilation was derived from two inadequate sources: Karlstrom (1964) and Martin and others (1915). The map of Quaternary deposits in the Kenai lowland by Karlstrom (1964) also shows the distribution of bedrock in northwestern foothills of the Kenai Mountains; however, his investigations of the bedrock were incidental and, in light of knowledge gained since the 1960's, his unit assignments need revision. For the area of high mountains and icefields to the southeast, Magoon and others (1976) cited Martin and others (1915) as the primary source; this area, however, was left mostly blank on the Martin map. It is hardly surprising, therefore, that the compilation map of Magoon and others (1976) should show a problematic map pattern in the Seldovia and Kenai quadrangles: a $75-\mathrm{km}$ gap in the outcrop belt of a regionally extensive melange unit - the McHugh Complex.

Specific problems with the geologic map of the Kenai quadrangle became apparent during recent mapping in the Seldovia quadrangle to the south (Bradley and others, 1999; Kusky, Bradley, Haeussler, and Karl, 1997). In the northern Seldovia quadrangle and southeastern Kenai quadrangle, Magoon and others (1976) showed the Upper Cretaceous Valdez Group as the only bedrock unit. New mapping in the Seldovia quadrangle revealed the presence of a large granodiorite batholith, a wide belt of melange assigned to the Permian to Cretaceous McHugh Complex, and a correspondingly smaller area underlain by the Valdez Group. The granodiorite and melange were traced to the northern edge of the Seldovia quadrangle. It was clear from that point that comparable revisions would also be needed in the adjacent Kenai quadrangle.

In the present study, we traced the boundary between Valdez Group and McHugh Complex about $75 \mathrm{~km}$ across the southeastern corner of the Kenai quadrangle and better delimited the northern extent of the granodiorite (fig. 2). The mapping was done in one day with a helicopter in September 1998. The U.S. Geological Survey has no immediate plans to systematically map the bedrock geology of the Kenai quadrangle, and thus we report our reconnaissance observations here.

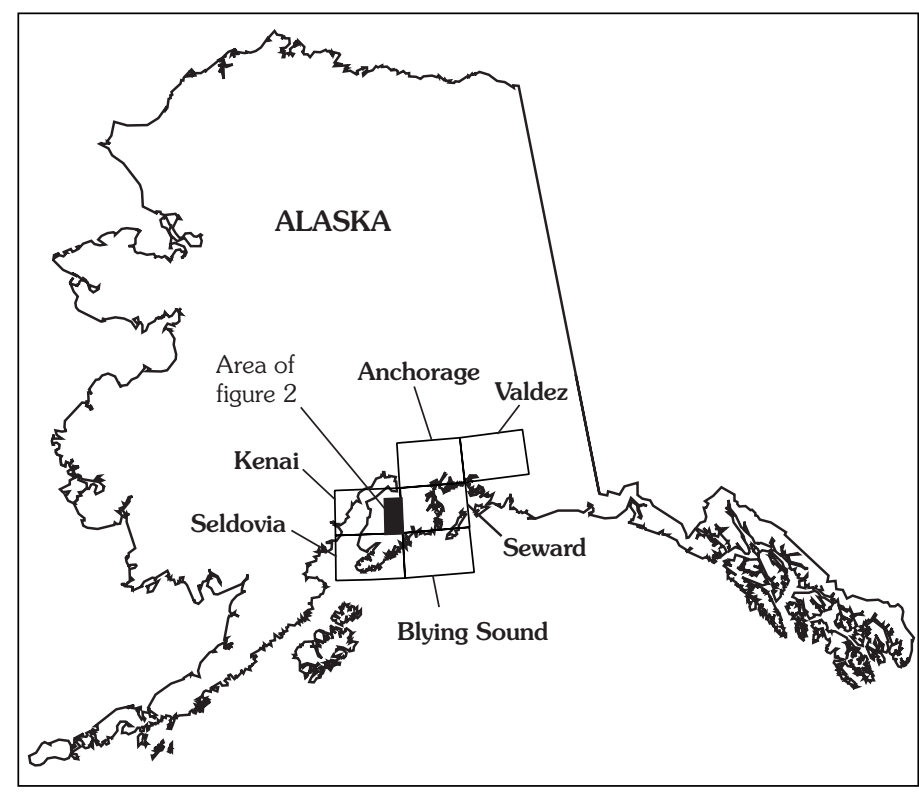

Figure 1. Map of Alaska showing area of figure 2 and 1:250,000-scale quadrangles referred to in text. 


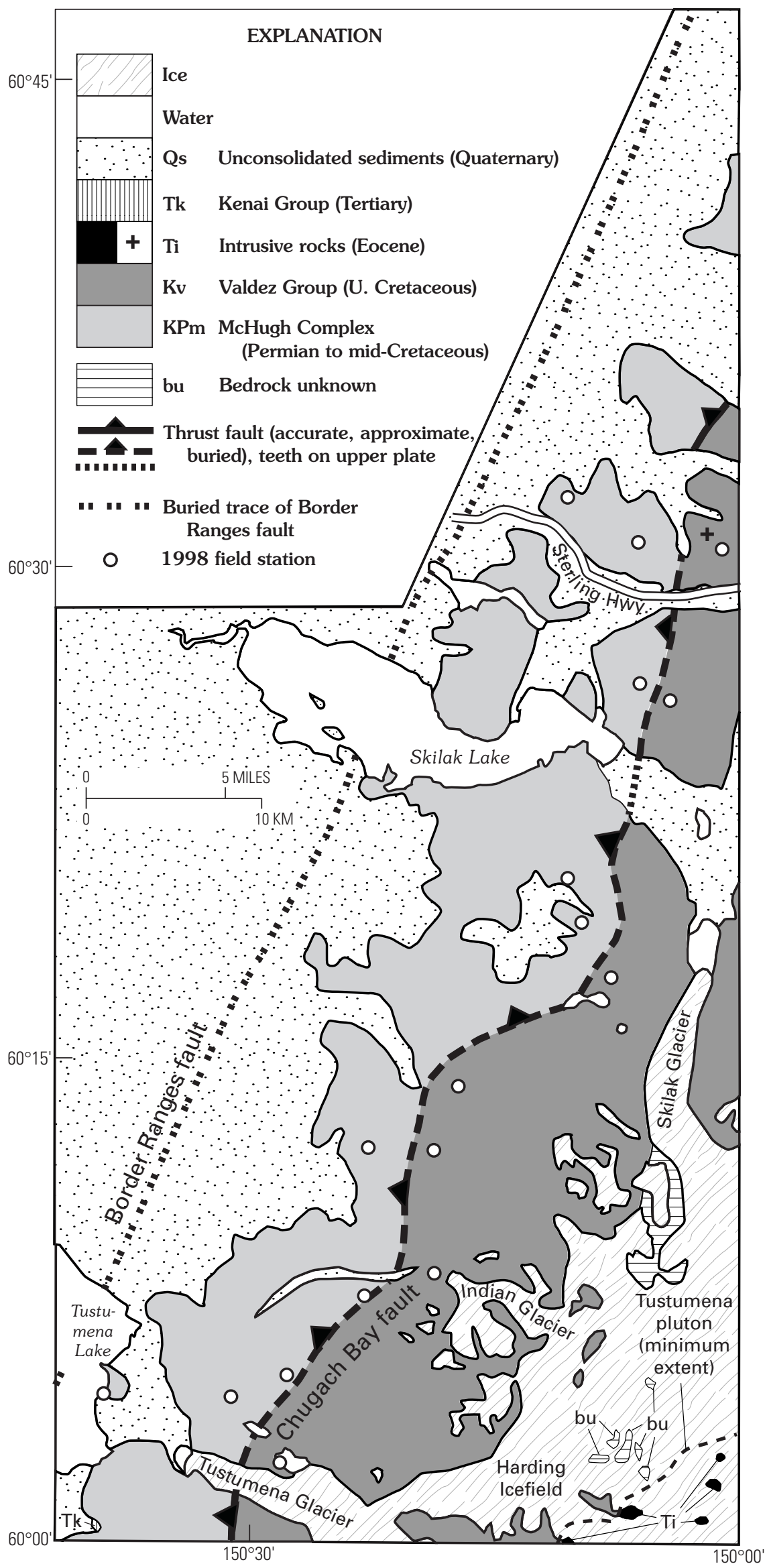

Figure 2. Bedrock geologic map on southeastern Kenai quadrangle, Alaska. Bedrock geology is based on this study; distribution of Quaternary sediments is taken, in part, from Magoon and others (1976) and Karlstrom (1964). 


\section{Bedrock Units}

\section{McHugh Complex}

Rocks in the study area assigned to the McHugh Complex (Clark, 1973) include sandstone, greenstone, chert, argillite, and melange. The sandstone is typically medium- to coarse-grained graywacke, rich in matrix, containing abundant chert and volcanic lithic fragments and somewhat less abundant quartz and feldspar. Owing to an absence of interbedded fine-grained rocks, or of amalgamation surfaces within sandstone bodies, bedding was not observed. Based on the size of outcrops consisting wholly of sandstone, beds are probably many tens of meters thick. Contorted veinlets of prehnite - a hallmark of McHugh Complex sandstone in the Seldovia and Anchorage quadrangles - are present in abundance. Greenstone was observed at a single outcrop and consists of altered, dark green, fine-grained basalt containing plagioclase laths that are visible under the hand lens. Several types, or "facies," of melange were observed; common to all is a phacoidally cleaved matrix of typically dark-gray argillite, which encloses fragments of various other rock types. One melange facies consists largely of matrix, and the "blocks" are dismembered beds of fine-grained, thin-bedded siliceous rocks and (or) siltstone that differ in competence only slightly from the matrix. A second facies contains a more diverse assemblage of blocks that are much more competent than the matrix, including sandstone, greenstone, chert, and limestone; this facies corresponds to what Bradley and Kusky (1992) referred to as mesoscale melange in the Seldovia quadrangle. No effort was made in the present reconnaissance study to map subunits of sandstone, chert, and basalt within the McHugh Complex, but this has proven to be possible in the Seldovia and Valdez quadrangles (Bradley and others, 1999; Winkler and others, 1980) (fig. 1).

Because no fossils have been recovered from the McHugh Complex in the Kenai quadrangle, its age must be extrapolated from areas along strike, particularly in the Seldovia quadrangle (see summary of older literature in Bradley and others, 1997). The best age control is from radiolarian cherts, which range in age from Ladinian (Middle Triassic) to Albian-Aptian (mid-Cretaceous). In the Seldovia quadrangle, chert depositionally overlies pillow basalt in several places; radiolaria from these particular chert sections are of Ladinian to Albian age, suggesting similar or slightly older ages for the pillow basalt. At one location in the Seldovia quadrangle, a Pleinsbachian (Early Jurassic) age is inferred for sandstone based on radiolaria of that age from chert immediately below sandstone (Bradley and others, 1997). A massive graywacke unit in Seldovia quadrangle is crosscut by a dike of basaltic andesite, which has a ${ }^{40} \mathrm{Ar} /{ }^{39} \mathrm{Ar}$ hornblende age of $115 \pm 2 \mathrm{Ma}$ (Bradley and others, this volume). Limestone blocks within melange have yielded Permian fusilinids (Stevens and others, 1997) and conodonts (A. Harris, written commun., 1994). The age of McHugh protoliths thus spans Permian to midCretaceous time; the age of melange formation is not well established but is likely to have spanned the Early Jurassic to mid-Cretaceous (Bradley and others, 1997).
Valdez Group

The Valdez Group, where we observed it, consists of medium-, thin-, and thick-bedded sandstone, siltstone, and slate, interpreted as turbidites. The medium-bedded turbidites consist of sandstone in graded beds a few centimeters to about $1 \mathrm{~m}$ thick. Interbedded slate is present in subordinate amounts. Thin-bedded turbidites consist of thinly interbedded slate and fine sandstone to siltstone, in roughly equal proportions. Bedding thicknesses range from less than one to a few centimeters. The thick-bedded turbidites consist of medium- to coarsegrained sandstone in beds ranging in thickness from a few meters to tens of meters. These beds have graded and (or) erosive bases and are rich in shale (now slate) rip-ups. The sandstone is subgraywacke, characterized by markedly less matrix and better sorting than sandstones of the McHugh Complex. Framework grains are predominantly quartz, feldspar, and lithic fragments; chert is rare. No fossils are known from the Valdez Group in the Kenai quadrangle; elsewhere, it has yielded bivalves of Maastrichtian (Late Cretaceous) age (Jones and Clark, 1973; Tysdal and Plafker, 1978).

In the Seldovia quadrangle, Kusky, Bradley, Haeussler, and Karl (1997) delineated a belt of tectonically disrupted Valdez Group. These rocks are informally referred to as the Iceworm melange, after exposures in the area of Iceworm Peak. The melange is readily distinguished from melanges of the McHugh Complex by its monomict clast assemblage: it consists of blocks, boudins, and dismembered beds of Valdez Group sandstone in a phacoidally cleaved matrix of Valdez Group slate. This belt of melange, which lies immediately east of and structurally beneath the McHugh Complex, was traced northward to the southern boundary of the Kenai quadrangle (Bradley and others, 1999; Kusky, Bradley, Haeussler, and Karl, 1997). In the present study, we encountered only one outcrop of tectonically disrupted Valdez Group, at the margin of Tustumena Glacier, on strike with the Iceworm melange mapped in the Seldovia quadrangle. This melange belt may or may not continue northward through the Kenai quadrangle. If it does, the outcrop belt is probably somewhat less than $1 \mathrm{~km}$ wide. In the Anchorage quadrangle, an equivalent melange belt, about $1 \mathrm{~km}$ in width, has been recognized just below the Eagle River fault along Turnagain Arm (Kusky, Bradley, and Haeussler, 1997).

\section{Kenai Group}

A small area of coal-bearing semiconsolidated silt, sand, and gravel near the snout of Tustumena Glacier was mapped as the Tertiary Kenai Group by Karsltrom (1964). The age of this outlier of Kenai Group is unknown; in the northern Seldovia quadrangle, comparable strata that flank the McHugh Complex along the mountain front are assigned to the Sterling Formation of Pliocene age (Magoon and others, 1976).

\section{Quaternary Geology}

The Quaternary geology of the area was not investigated in the present study, but a few anecdotal observations bear 
mentioning. Unconsolidated sediments include glacial deposits belonging to various Pleistocene glaciations (Karlstrom, 1964; Reger and Pinney, 1997), and Holocene fluvial, colluvial, and other surficial deposits. Tustumena, Skilak, and Indian glaciers have each receded about $1 \mathrm{~km}$ since the most recent 1:63,360scale topographic maps were published in the early 1980's. The snouts of Tustumena and Skilak Glaciers now face into lakes that are not shown on the topographic maps.

\section{Intrusive Rocks}

Nunataks in the extreme southeastern corner of the Kenai quadrangle are mapped as part of the Tustumena granodiorite pluton, a body that was unknown before the recently completed mapping in the Seldovia quadrangle (Bradley and others, 1999). The nunataks have not been visited, but in 1992 they were observed through binoculars from the northern edge of the Seldovia quadrangle and were seen to be made of granitic rocks. In the Seldovia quadrangle, the Tustumena pluton consists of medium- and coarse-grained, weakly foliated to unfoliated biotite granodiorite. It has yielded a ${ }^{40} \mathrm{Ar} /{ }^{39} \mathrm{Ar}$ biotite plateau age of 53.2 $\pm 1.1 \mathrm{Ma}$ (D. Lux, University of Maine, written commun., 1994; Bradley and others, this volume).

We located a small plug of fine-grained, light-gray dacite near the summit of Round Mountain, north of the Sterling Highway ("+" symbol in fig. 2). Several dacite dikes occur in the area a few kilometers west of this plug.

\section{Structure and Metamorphism}

Two principal tectonic elements make up the map area (fig. 2): Cook Inlet basin and the Chugach terrane. The Kenai lowland, in the northwestern part of the map area (fig. 2), is part of the Cook Inlet basin, the active forearc basin of the Aleutian arc. The lowlands are underlain by Tertiary sedimentary rocks of the Kenai Group, which have gentle dips and have not been penetratively deformed, and by a cover of Quaternary glacial and postglacial sediments.

The McHugh Complex and Valdez Group are part of a Mesozoic accretionary wedge - the Chugach terrane-and have been affected by subduction-related deformation and metamorphism. The principal fabric elements - phacoidal cleavage and compositional layering in the McHugh Complex and bedding and cleavage in the Valdez Group-strike north-northeast and dip moderately to steeply both to the northwest and southeast. Regionally, the contact between the McHugh Complex and the Valdez Group is a major west-dipping thrust fault, known as the Eagle River thrust in the Anchorage quadrangle, and as the Chugach Bay thrust in the Seldovia quadrangle (Kusky, Bradley, Haeussler, and Karl, 1997). In the present reconnaissance study, we did not examine the fault zone but have no reason to doubt its presence.

Metamorphism was not investigated in this brief study, but a few observations are warranted. Sandstone of the McHugh Complex is cut by abundant veinlets of prehnite related to low grade regional metamorphism. The Valdez Group appears to have been regionally metamorphosed to chlorite grade. Locally, some of the Valdez Group has been hornfelsed, suggesting the presence of unrecognized Tertiary intrusive rocks, either nearby or at depth.

\section{Summary of New Findings}

Our reconnaissance mapping produced the following results: (1) The compilation map of Magoon and others (1976) shows a problematic map pattern that has long defied explanation: a 75-km gap in the outcrop belt of the McHugh Complex, between the north end of Kachemak Bay in the Seldovia quadrangle and Skilak Lake in the Kenai quadrangle. Our results show that the gap does not exist and that the McHugh Complex is continuous through the Seldovia, Kenai, Seward, and Anchorage quadrangles. The resulting map pattern can be readily interpreted in terms of successive accretion of the McHugh Complex and the Valdez Group at a subduction zone. (2) Our mapping extends the Tustumena pluton at least $5 \mathrm{~km}$ northward into the Kenai quadrangle. (3) Three nunataks at the confluence of Indian Glacier and the Harding Icefield were not visited, but we were able to map them as the Valdez Group based on the overwhelming predominance of Valdez Group boulders at the snout of Indian Glacier. Some remote peaks at the edge of and within Harding Icefield remain unmapped; most likely, these areas are underlain by either granodiorite or the Valdez Group.

Acknowledgments.-Mapping was supported by the Mineral Resource Surveys Program of the U.S. Geological Survey. The manuscript benefited from careful reviews by Peter Haeussler, Julie Dumoulin, and Tim Kusky.

\section{References Cited}

Bradley, Dwight C., Kusky, Timothy M., Karl, Susan M., and Haeussler, Peter J., 1997, Field guide to the Mesozoic accretionary complex along Turnagain Arm and Kachemak Bay, south-central Alaska, in Karl, S.M., Vaughan, N.R., and Ryherd, T.J., eds., 1997 Guide to the Geology of the Kenai Peninsula, Alaska: Anchorage, Alaska Geological Society, p. 2-12.

Bradley, D.C., and Kusky, T.M., 1992, Deformation history of the McHugh Complex, Seldovia quadrangle, south-central Alaska: U.S. Geological Survey Bulletin 1999, p. 17-32.

Bradley, D.C., Kusky, T.M., Haeussler, P.J., Karl, S., and Donley, D.T., 1999, Geologic map of the Seldovia quadrangle, Alaska: U.S. Geological Survey Open-File Report 99-18, scale 1:250,000.

Clark, S.H.B., 1973, The McHugh Complex of south-central Alaska: U.S. Geological Survey Bulletin 1372-D, p. D1-D11.

Jones, D.L., and Clark, S.H.B., 1973, Upper Cretaceous (Maestrichtian) fossils from the Kenai-Chugach Mountains, Kodiak and Shumagin Islands, southern Alaska: U.S. Geological Survey Journal of Research, v. 1, no. 2, p. 125-136.

Karlstrom, T.N.V., 1964, Quaternary geology of the Kenai lowland and glacial history of the Cook Inlet region, Alaska: U.S. Geological Survey Professional Paper 443, 69 p.

Kusky, T., Bradley, D., Haeussler, P., and Karl, S.J., 1997, Controls on accretion of flysch and melange belts at accretionary margins: Evidence from the Chugach Bay thrust and Iceworm melange, Chugach accretionary wedge, Alaska: Tectonics, v. 16, p. 855-878. 
Kusky, T., Bradley, D., and Haeussler, P., 1997, Progressive deformation of the Chugach accretionary complex, Alaska, during a Paleogene ridge-trench encounter: Journal of Structural Geology, v. 19, p. 139157.

Magoon, L.B., Adkison, W.L., and Egbert, R.M., 1976, Map showing geology, wildcat wells, Tertiary plant fossil localities, K-Ar age dates, and petroleum operations, Cook Inlet area, Alaska, U.S. Geological Survey Miscellaneous Investigations Series Map I-1019, scale 1:250,000.

Martin, G.C., Johnson, B.L., and Grant, U.S., 1915, Geology and mineral resources of Kenai Peninsula, Alaska: U.S. Geological Survey Bulletin 587, $243 \mathrm{p}$.

Reger, R.D., and Pinney, D.S., 1997, Last major glaciation of Kenai lowland, in Karl, S.M., Vaughan, N.R., and Ryherd, T.J., eds., 1997 Guide to the Geology of the Kenai Peninsula, Alaska: Anchorage, Alaska Geological Society, p. 54-67.

Stevens, C.H., Davydov, V.I., and Bradley, D.C., 1997, Permian Tethyan fusilinids from the Kenai Peninsula, Alaska: Journal of Paleontology, v. 71, p. 985-994.

Tysdal, R.G., and Plafker, G., 1978, Age and continuity of the Valdez Group, southern Alaska, in Sohl, N.F., and Wright, W.B., eds., Changes in Stratigraphic Nomenclature by the U.S.Geological Survey, 1977: U.S. Geological Survey Bulletin 1457-A, p. A120-A124.

Winkler, G.R., Silberman, M.L., Grantz, Arthur, Miller, R.J., and MacKevett, E.M., Jr., 1980, Geologic map and summary geochronology of the Valdez quadrangle, southern Alaska: U.S. Geological Survey Open-File Report 80-892-A, scale 1:250,000, 2 sheets.

Reviewers: Peter Haeussler, Julie Dumoulin, Tim Kusky. 


\title{
Geologic Setting of the Fortymile River Area- Polyphase Deformational History within part of the Eastern Yukon-Tanana Uplands of Alaska
}

\author{
By Warren C. Day, Bruce M. Gamble, Mitchell W. Henning, and Bruce D. Smith
}

\section{Abstract}

The Fortymile River area lies within the Yukon-Tanana lithotectonic terrane of east-central Alaska. This terrane is a mosaic of several lithotectonic assemblages, each with a coherent lithologic, metamorphic, and deformational history. Previous workers have shown that the Fortymile River area is underlain by rocks of the Seventymile, Taylor Mountain, and Nisutlin assemblages. The Taylor Mountain tectonostratigraphic assemblage is the most widespread within study area and is made up of amphibolite-grade Paleozoic(?) metamorphosed supracrustal rocks that have been intruded by plutonic rocks. The protoliths for the supracrustal rocks include mafic volcanic(?) rocks, graywacke, sulfide-rich siliciclastic sediments, quartz-rich sandstone, pelite, and marble, all of which are cut by late sulfide-bearing quartz veins. The mafic metavolcanic(?) rocks are of both tholeiitic and calc-alkalic affinity and have distinctly different rare-earth-element abundances. The supracrustal rocks are interpreted to have been deposited on a continental margin and (or) distal to an island-arc complex in a back-arc basin.

The Steele Creek Dome Tonalite is defined herein as a composite body of foliated biotite-hornblende tonalitic orthogneiss containing country-rock rafts of paragneiss. The complex lies within the Taylor Mountain assemblage and has been tectonized and presumably recrystallized during regional Early Jurassic ductile deformation. The tonalite is compositionally similar to other volcanic-arc granites. The entire sequence was intruded by a Early Jurassic(?) hornblende monzodioritediorite-quartz diorite suite.

The area has been subjected to at least three phases of deformation. The first $\left(\mathrm{D}_{1}\right)$ produced a strong regional $\mathrm{S}_{1}$ schistosity and local mineral lineations. The second $\left(\mathrm{D}_{2}\right)$ deformation generated tight to isoclinal $F_{2}$ folds, folding the $S_{1}$ schistosity and $\mathrm{L}_{1}$ mineral lineations, and was accompanied by a weak axial-planar $\mathrm{S}_{2}$ cleavage and both $\mathrm{L}_{2}$ mineral and stretching lineations. The question remains if the $\mathrm{D}_{1}$ and $\mathrm{D}_{2}$ tectonic fabrics either (1) record end members of a continuous, relatively long lived, progressive ductile deformation associated with the peak regional metamorphism and northward-directed thrusting; or (2) were separate and distinct pulses of tectonism. The youngest deformation recognized $\left(\mathrm{D}_{3}\right)$ folded the ductile fabric elements about south-plunging, east-vergent, open folds and records east-west-directed tectonic shortening.

\section{Introduction}

This study is part of an ongoing effort by the U.S. Geological Survey and Alaska Department of Natural Resources to establish the baseline geology (Day and others, 1998), geochemistry, soil, plant, and surface water quality of the Fortymile River gold placer mining district of east-central Alaska. Recent concern has arisen over the impact of suction dredge and (or) mechanized mining techniques on the water quality of the Fortymile River, which is designated as a Wild and Scenic River Corridor. Regionally, similar placer districts, such as those around Fairbanks, Alaska, have elevated arsenic concentrations in the surface and ground water (Hawkins and others, 1982). This report discusses the character, origin, and deformation of the major bedrock units within the study area. Wanty and others (this volume) address the affects of suction dredge placer mining on the water quality of the Fortymile River.

The new geologic map developed for this report benefited from the new airborne geophysical survey (aeromagnetic and electromagnetic data) recently flown by the Alaska Division of Geological and Geophysical Surveys (1998). These data were extremely valuable in helping delineate geologic contacts in an area with poorly exposed bedrock.

The new geologic map discussed in this report was developed in part from interpretation based on airborne geophysical surveys. The most recent survey contracted by the Alaska Division of Geological and Geophysical Surveys (DGGS, 1998) covered the study area south of 64 degrees 15 minutes. This survey consists of both electromagnetic and magnetic data flown with 440 meter ( 0.25 mile) line spacing at an altitude of 100 meters. The northern part of the area is covered by an earlier (DGGS, 1973) airborne total field magnetic survey. This survey was flown at an altitude of 300 meters (1,000 feet above terrain) with a flight line spacing of 


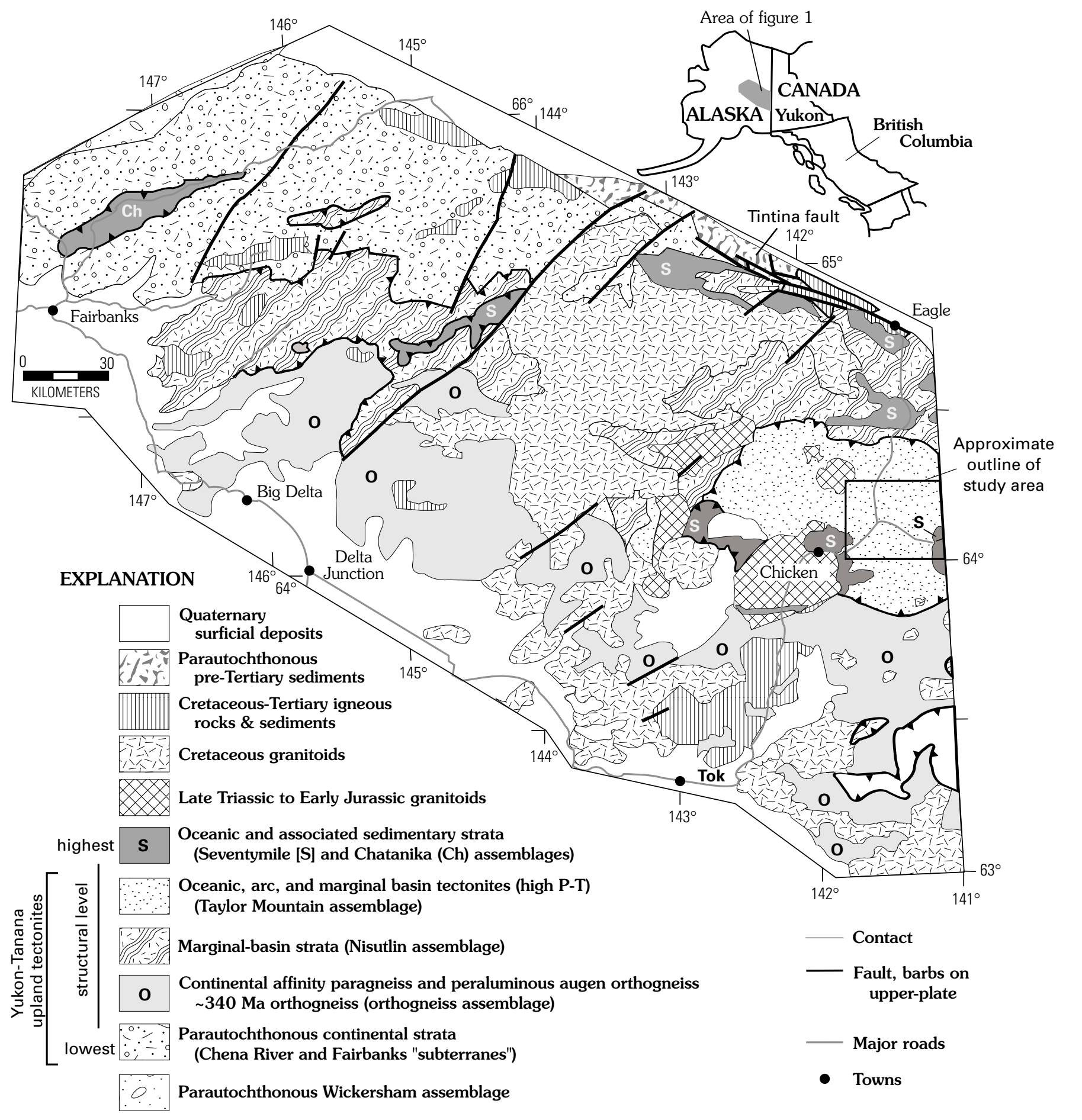

Figure 1. Regional map showing lithotectonic assemblages of the Yukon-Tanana terrane of east-central Alaska. Modified after Hansen and Dusel-Bacon (1998).

1,320 meters (0.75 mile). Digital data for the earlier survey was taken from a compilation of Alaska aeromagnetic data (Saltus and others, 1999).

The study area lies within the remote lower part of the Fortymile River drainage, which is underlain by metamorphic rocks of the Yukon-Tanana uplands of east-central Alaska (fig. 1). The area is northeast of the village of Chicken and south of Eagle, Alaska. Our new mapping extended from Wade Creek along the Taylor Highway east along the Top of the World Highway to near Boundary, Alaska, and north to the main stem of the
Fortymile River (fig. 2). Data for the remaining area were compiled from Foster (1976). Fieldwork was conducted during June of 1997 and 1998.

Access to the study area was via boat, helicopter, all-terrain vehicle, and foot. Limited access, coupled with the relatively sparse outcrop, has restricted this study to reconnaissance-level detail. Previous field notes and geologic maps of H.L. Foster and coworkers (Foster, 1969, 1976, 1992) as well as the study of Yeend (1996) were incorporated to compile the bedrock geologic map (fig. 2). 


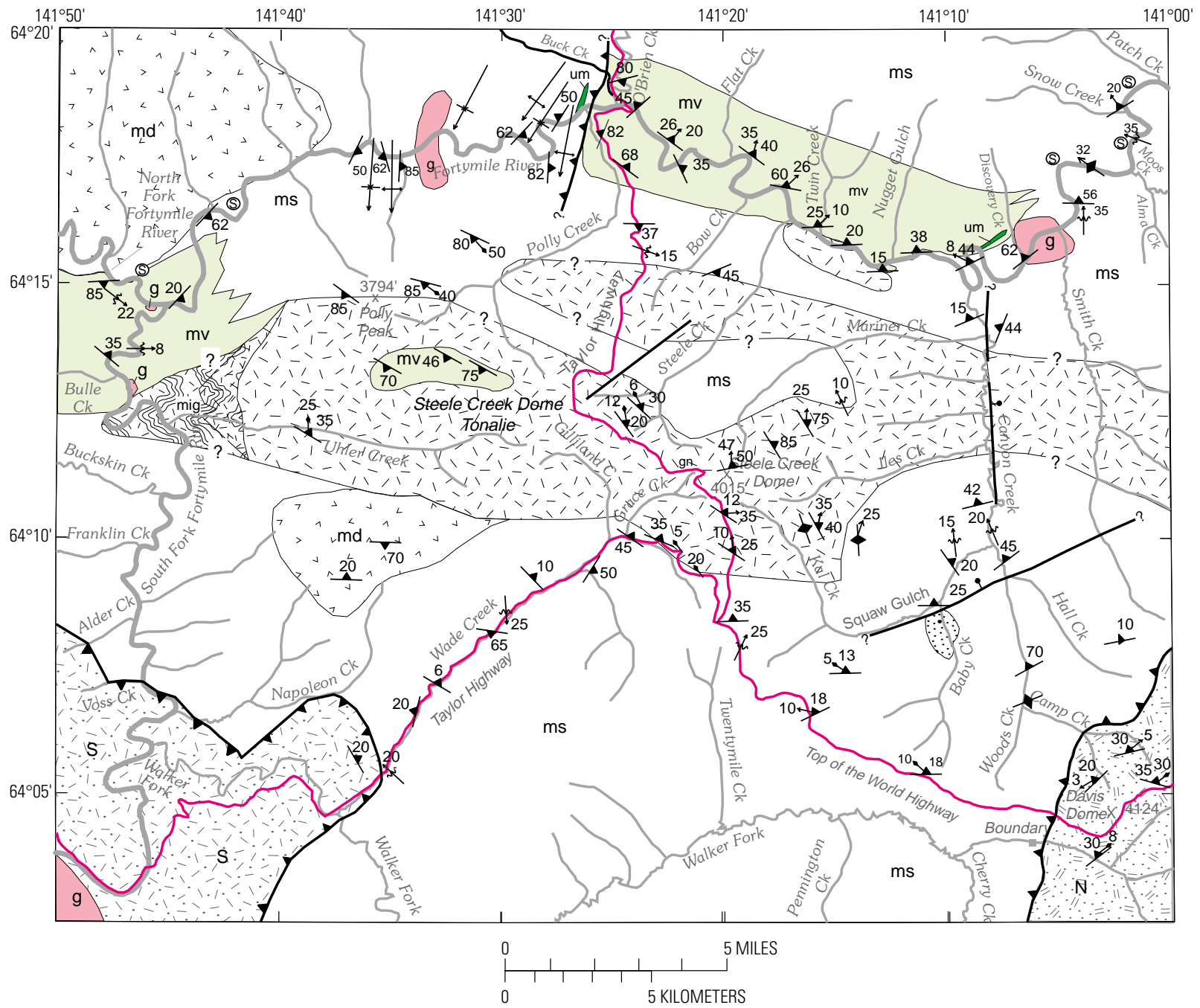

\section{TERTIARY ROCKS}

Detrital rocks of Baby Creek

\section{INTRUSIVE ROCKS}

Post-tectonic intrusive rocks

Pre- to syn-tectonic intrusive rocks

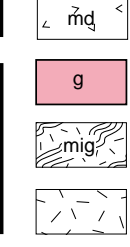

Monzodiorite to quartz diorite-Foliated hornblende monzodiorite to quartz diorite

Leucogranite to trondhjemite-Foliated peraluminous biotite-muscovite granodiroite, granite, and trondhjemite

Migmatite Supracrustal rocks invaded by biotite-hornblende tonalte to granite neosome

Steele Creek Dome Tonalite-Hornblende-biotite tonalitic orthogneiss with local enclaves of paragneiss country rock

um Ultramafic intrusion-Metmorphosed pyroxenite, peridotite intrusion

\section{MAP SYMBOLS}

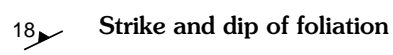

\. Strike of vertical foliation

10- Trend and plunge of mineral lineation 15 Trend and plunge of stretching lineation

$\longleftarrow$ Trace and plunge of axis of antiform

$\longleftrightarrow$ Trace and plunge of axis of synform

$\nLeftarrow 25$ Trend and plunge of minor fold

Contact-Approximate

Normal fault-Bar and ball on downthrown side

ـ__ Thrust fault-Teeth on upper plate

\section{SUPRACRUSTAL ROCKS}

Taylor Mountain Assemblage

$\mathrm{mv}$ Metabasalt-Hornblende-biotite schist

(5) Outcrop of sulfide-rich siliciclastic metasediment horizon within metasedimentary rock unit

$\mathrm{ms}$ Metasedimentary rocks-Biotite schist, marble, quartzite, metapelite, sulfide-bearing siliciclastic metasediment, and minor hornblene-biotite schist s. Seventymile assemblage-Dominantly metamorphosed marine mafic volcanic with minor sedimentary rocks

$\mathrm{N}$ Nisutlin assemblage-Metamorphosed ultramafic intrusive and siliclastic rocks

Figure 2. Simplified bedrock geologic map of the Fortymile River study area. 
Yeend (1996) presented a thorough review of the placer mining history, discussed the character of the placer gold deposits and their geologic setting, and suggested possible sources of gold for the area. Placer gold is present in gravels, alluvial material along the riverbanks, and in high terrace gravels on the Tertiary benches perched above the Fortymile River. Total production of gold from the Fortymile mining district has been estimated at about 500,000 troy ounces (Yeend, 1996).

Possible lode sources for the placer gold have not yet been identified. The metamorphic bedrock for the area hosts numerous, small, discontinuous quartz veins that are as much as $2-3 \mathrm{~m}$ long and $10 \mathrm{~cm}$ wide; these crosscut the tectonic fabrics. These minor veins may have been the ultimate source of the placer gold (Mertie, 1938; Yeend, 1996). Foster and O'Leary (1982) identified gold in sheared and altered diorite in an outcrop in the Lost Chicken placer gold mine (southwest of this study area). Some gold also occurs in sheared granite west of our study area also, near Chicken, Alaska (Foster and O’Leary, 1982).

\section{Regional Geologic Setting}

Regional syntheses by Coney and Jones (1985), Churkin and others (1982), Foster (1992), Dusel-Bacon and others (1995), and Hansen and Dusel-Bacon (1998) recognized that the Yukon-Tanana terrane contains several coherent lithotectonic packages (fig. 1). Hansen and Dusel-Bacon (1998) divided the terrane into five such packages. These include (1) the Seventymile assemblage of oceanic volcanic and sedimentary rocks; (2) the Taylor Mountain and Chatanika assemblages of oceanic and marginal-basin rocks; (3) the Nisutlin assemblage of siliciclastic marginal-basin strata; (4) paragneisses and peraluminous orthogneisses of continental affinity (the so-called orthogneiss assemblage); and, (5) the Chena River and Fairbanks subterranes, which are made up of parautochthonous continentally derived metasedimentary rocks. Rocks of the Seventymile, Taylor Mountain, and Nisutlin assemblages are present in the Fortymile River study area.

\section{Seventymile Assemblage}

Rocks of the Seventymile assemblage crop out in the southwestern part of the study area (fig. 2). The assemblage is an allochthonous group of oceanic pillowed basalts, alpine-type ultramafic rocks, and associated sedimentary rocks (Foster and others, 1994) that have experienced low-grade regional metamorphism (Dusel-Bacon and others, 1993). The Seventymile assemblage is exposed along the Taylor Highway northeast of the village of Chicken, Alaska, where greenschist-facies pillowed basalt is interlayered with metachert, metapelite, marble, and mafic meta-tuffaceous rocks. Foster and others (1994) observed Early Permian and Mississippian radiolarians and conodonts of Triassic age.

\section{Taylor Mountain Assemblage}

Rocks of the Taylor Mountain lithotectonic assemblage (fig. 2) dominate the Fortymile River study area. Within the study area, the assemblage is composed of high-grade metamorphic, polydeformed supracrustal rocks that were variously intruded by orthogneiss, trondhjemite, ultramafic rocks, and monzodiorite-diorite-quartz diorite. The supracrustal rocks consist of epiclastic metasedimentary strata and marble interlayered with hornblende-biotite schist that are interpreted to have been mafic metabasalt. The metasedimentary rocks include biotite schist, metachert, hornblende-biotite schist, metaquartzite, metapelite, sulfide-bearing epiclastic rocks, and marble.

The age of the protolith for the Taylor Mountain assemblage is poorly known. The fossil record for the metasedimentary rocks has been nearly obliterated by regional amphibolitefacies metamorphism (Dusel-Bacon and others, 1995). Foster (1976) surmised that the metasedimentary rocks were probably Paleozoic and found scarce, poorly preserved crinoid columns at one locality in similar metasedimentary rocks (unit Pzb of Foster, 1976) to the west of the study area. Aleinikoff and others (1987, their table 1) noted that the metasedimentary and meta-igneous rocks of the Yukon-Tanana terrane (Taylor Mountain assemblage of Hansen and Dusel-Bacon, 1998) are cut by Devonian and Mississippian plutons.

${ }^{40} \mathrm{Ar} /{ }^{39} \mathrm{Ar}$ dates are reported by Cushing (1984) for metamorphic minerals within the Taylor Mountain assemblage in the Fortymile area. Cushing's ${ }^{40} \mathrm{Ar} /{ }^{39} \mathrm{Ar}$ analysis showed that metamorphic hornblende ranged in age from $204 \mathrm{Ma}$ to $187 \mathrm{Ma}$, muscovite from $191 \mathrm{Ma}$ to $185 \mathrm{Ma}$, and biotite yielded dates that ranged from $186 \mathrm{Ma}$ to $188 \mathrm{Ma}$. Hansen and others (1991) analyzed hornblende and biotite samples from the Fortymile study area from rocks in the Taylor Mountain assemblage and reported resulting ${ }^{40} \mathrm{Ar} /{ }^{39} \mathrm{Ar}$ ages for hornblende of approximately $187 \mathrm{Ma}$ and for biotite of approximately $186 \mathrm{Ma}$. These data indicate that the Taylor Mountain assemblage underwent dynamic metamorphism and recrystallization (Dusel-Bacon and others, 1995) and then cooled past the ${ }^{40} \mathrm{Ar} /{ }^{39} \mathrm{Ar}$ hornblende and mica blocking temperatures by about $185 \mathrm{Ma}$ (Middle Jurassic).

\section{Nisutlin Assemblage}

Rocks of the Nisutlin assemblage are present in the southeastern part of the study area near Boundary, Alaska (fig. 2). Rocks of the Nisutlin assemblage exposed near Boundary (fig. 2) include strongly tectonized carbonaceous metapelite, metaquartzite, and biotite-muscovite schist (Foster and others, 1985). The age of the protoliths for the Nisutlin assemblage, like that for the other adjacent assemblages, is poorly known within the immediate study area. However, Foster and others (1985) speculated that the protoliths for the metasedimentary rocks in the assemblage range in age from middle to late Paleozoic.

Dynamic recrystallization of the metasedimentary rocks has produced S-C mylonites as well as L-S tectonites (Lister and Snoke, 1984). The tectonic fabric within the rocks of the Nisutlin assemblage near Boundary dips moderately to the northwest (fig. 2) and projects beneath the Taylor Mountain assemblage. The asymmetric shear-sense of the S-C mylonitic fabrics, as well as stretching lineations, indicate a top-to-thenorthwest direction (down-dip) of tectonic transport. Hansen and Dusel-Bacon (1998) first noted that this northwest-directed 
tectonic transport implies the amphibolite-facies Taylor Mountain assemblage rocks were thrust over greenschist-facies Nisutlin assemblage rocks during regional Jurassic thermaltectonism.

\section{Taylor Mountain Batholith}

The Taylor Mountain batholith is a composite body made up of reportedly unfoliated granodiorite, quartz diorite, and diorite (Foster and others, 1976) and cuts rocks of both the Seventymile and Taylor Mountain assemblages (fig. 1) (see DuselBacon and Hansen, 1991). Their observations imply that the emplacement of the batholith records the minimum age of metamorphism and regional ductile deformation and assembly of these lithotectonic assemblages. Zircon analyzed by Aleinikoff and others (1979) from the Taylor Mountain batholith yielded an imprecise upper intercept with concordia on a ${ }^{207} \mathrm{~Pb} /{ }^{206} \mathrm{~Pb}$ plot that ranged from 234 to $264 \mathrm{Ma}$. An U-Pb date on sphene from the Taylor Mountain intrusion yielded a concordant age of 212 Ma. The 212-Ma age approximately reflected the time of primary crystallization of the pluton, whereas the zircon date represented inheritance of radiogenic lead by the Mesozoic pluton (Aleinikoff and others, 1979).

\section{Detailed Bedrock Geology of the Fortymile River Area}

The supracrustal rocks of the Taylor Mountain assemblage in the Fortymile River area are made up of both metavolcanic(?) and metasedimentary rocks. These rocks were variously intruded by the pre- to syn-tectonic Steele Creek Dome Tonalite (fig. 2), small two-mica garnet-bearing leucogranite bodies as well as sills and plugs of trondhjemite (unit g, fig. 2), and ultramafic rocks (unit um, fig. 2). A hornblende monzodioritediorite-quartz diorite suite forms large plutons within both the supracrustal rocks and the Steele Creek Dome Tonalite.

\section{Supracrustal Rocks}

The metavolcanic(?) rocks (unit mv, fig. 2) have been recrystallized into fine- to medium-grained, dark-green, foliated, mafic hornblende-biotite-plagioclase schist. Dynamic recrystallization has obliterated the primary structures. Therefore, it is not possible to determine if the protolith was deposited as lava flows, as tuffaceous zones, or as sills intruded into the metasedimentary rocks. Metachert, metapelitic, and marble horizons are commonly interlayered with the mafic schist and are interpreted to have been interflow sediments in sequences of mafic volcanic or volcaniclastic rocks. However, an intrusive origin as either dikes or sills for the protolith of some of the mafic schists cannot be ruled out.

Basalt (unit mv, fig. 2) is the dominant composition of the metavolcanic(?) rock type recognized to date in the Fortymile River area (fig. 3) — only one sample of andesitic composition was identified. No felsic compositions for the metavolcanic(?) rocks have been recognized. The absence of felsic volcanic

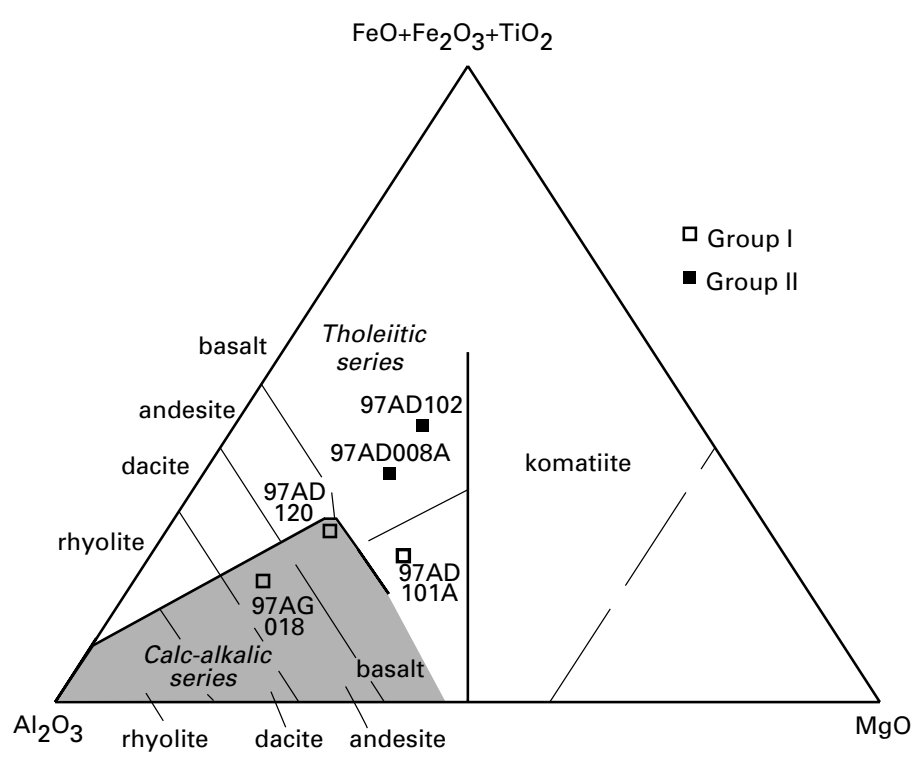

Figure 3. Jensen (1976) diagram characterizing metavolcanic(?) rocks from the Taylor Mountain assemblage rocks within the Fortymile River area. Diagram shows ranges for tholeiitic- and calc-alkalic-series volcanic rocks.

rocks is important in estimating the paleoenvironmental setting of the Taylor Mountain assemblage.

Reconnaissance geochemical data given in Crock and others (1999) show that there are two groups (at least) of basaltic compositions in the study area-a tholeiitic series characterized by light-rare-earth-element (REE) depletion (group I; figs. 3 and $4 A$ ) and a tholeiitic to calc-alkalic series characterized by lightREE enrichment (group II; figs. 3 and 4B). Inasmuch as both groups of metavolcanic rocks are interbedded with layers of marble, metachert, and metapelite, the primary environment was subaqueous and, presumably, coeval for both groups I and II. However, the exact timing and specific structural relationship between the samples from the two groups is unknown. The group-I metabasalt(?) has $\mathrm{TiO}_{2}$ abundances greater than 2 weight percent, whereas group II has $\mathrm{TiO}_{2}$ concentrations of less than 2 weight percent. The intense dynamic recrystallization and small sample population of the metavolcanic(?) rocks restricts a more detailed comparison of the major-element data. The relatively less mobile REE's allow a more reliable comparison of the metavolcanic groups. The trace-element composition of the group-I metabasalt has slightly depleted light-REE concentrations ( $\sim 10-22 \times$ chondrites) and relatively flat middle- to heavy-REE concentrations ( 20-30 $\times$ chondrites), and no appreciable europium anomaly (fig. $4 A$ ). In contrast, the group-II metavolcanic samples (fig. 4B) are relatively light-REE enriched ( 20-48 $\times$ chondrites), with a steadily decreasing negative sloping REE pattern. Similarly, the group-II heavy-REE concentrations ranges from approximately 12 to $22 \times$ chondrites.

Metasedimentary rocks (unit ms, fig. 2) of the Fortymile River area include biotite schist, sulfide-bearing siliciclastic metasedimentary rocks, metapelite, quartzite, and marble. The biotite schist is fine-grained, light-gray, layered, equigranular biotite-muscovite \pm hornblende \pm garnet quartzofeldspathic schist. Locally, relict bedding typical of graywacke in turbidite 

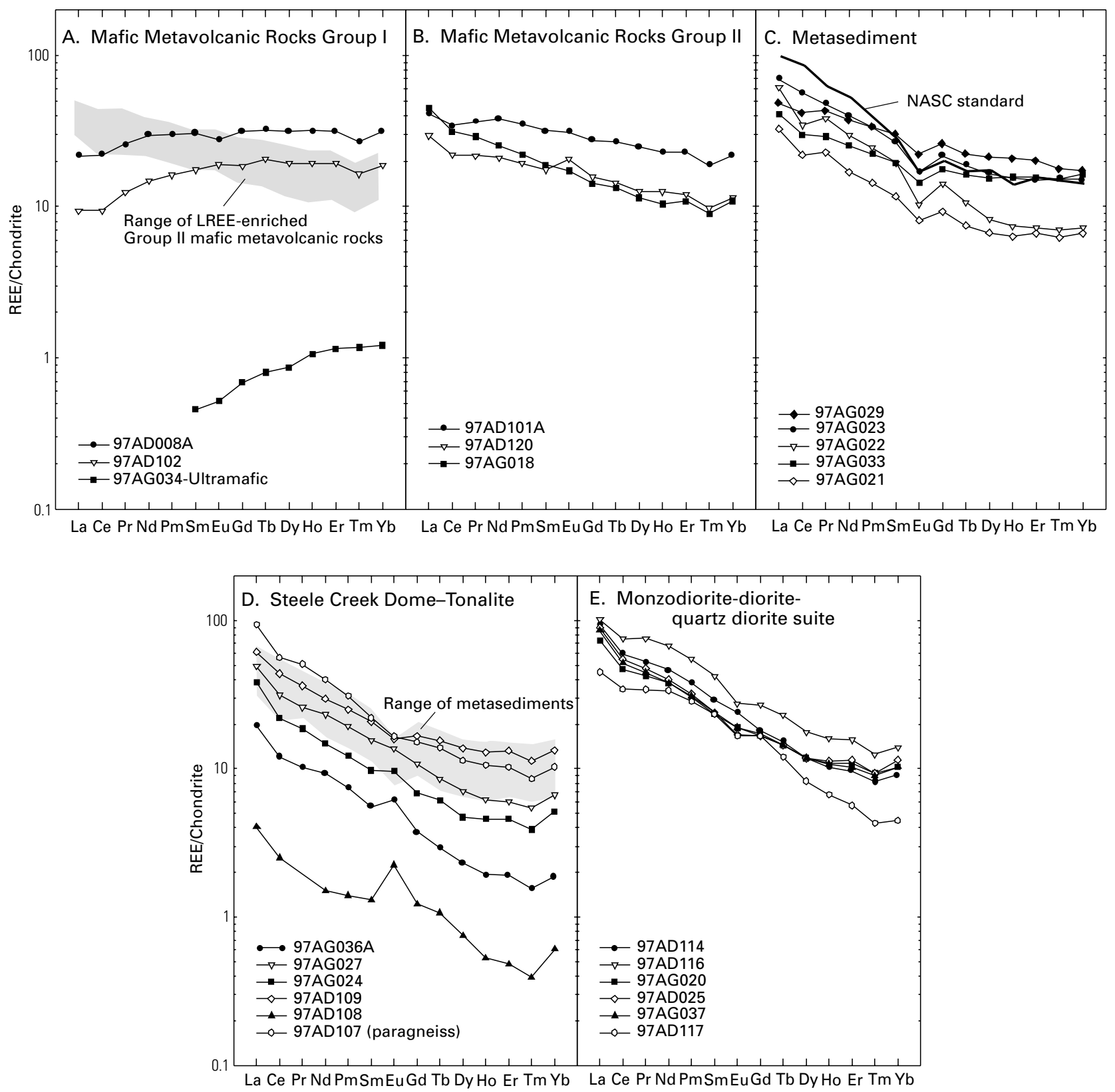

Figure 4. Chondrite-normalized rare earth element diagrams for rocks of the Taylor Mountain assemblage in the Fortymile River area. A shows the range for the group-I mafic metavolcanic(?) rocks; $B$ shows the range for the group-II mafic metavolcanic(?) rocks; $C$ shows the range for the metagraywacke (98AG023) and sulfide-rich siliclastic metasediments; $D$ shows the ranges for the Steele Creek Dome Tonalite, a paragneiss inclusion, and the metasedimentary rocks (shaded area); $E$ shows the range for rocks of the monzodiorite-diorite-quartz diorite suite. Sample numbers correspond to data given in Crock and others (1999). NASC, North American shale composite (Haskin and Paster, 1979).

sequences is preserved. The protolith probably varied between turbidite (graywacke) and pelagic oceanic sediment. However, only the recrystallized equivalents of the plane-parallel laminae (layers B and D of Bouma, 1962) are preserved.

The sulfide-bearing siliciclastic metasedimentary rocks crop out as 5- to 75-m-thick beds along the main stem of the Fortymile River downstream from the confluence of the North and South Forks as well as downstream near the AlaskaCanada border. These rocks are fine grained, light gray, and weather to a characteristic rusty brown as a result of oxidation of the contained sulfide minerals. The unit is dominantly quartz-it contains less than 10 percent mafic minerals (biotite \pm hornblende), feldspar, and graphite; accessory clinopyroxene, clino-amphibole, and zoisite; and approximately 5 percent disseminated sulfides (pyrite, pyrrhotite, makinawite?). The protolith was probably "dirty" sandstone or wacke.

The REE abundances are shown in figure $4 C$ for the biotite schist (or metagraywacke) (samples 97AG023 and 97AG029) and the sulfide-bearing siliciclastic metasediments (samples 97AG021, 97AG022, and 97AG033). Plotted for comparison also is the North American shale composite (NASC) standard analyzed by Haskin and Paster (1979). Both the metagraywackes and sulfide-bearing siliciclastics are light-REE enriched, have a negative europium anomaly, and 
flat heavy-REE concentrations (fig. $4 C$ ), similar to the typical NASC standard.

One continuous, highly folded marble unit, approximately 200-300 m thick, is exposed for more than $14 \mathrm{~km}$ along the Fortymile River, upstream from the Taylor Highway bridge. It extends just east of the confluence of the North and South Forks of the Fortymile River. Three distinct sedimentary facies are recognized based on color and texture of the marble. One facies, exposed in the structurally lower part of the unit, is darkto light-gray, laminated marble that is thinly interbedded with metaquartzite layers. Relic bedding preserved in one sample consists of thin laminations (1-3 mm thick) with no internal structure, as well as thin beds with preserved crossbedding. The slab sample contains a 5-cm-long, elliptical clast with fine internal layers, which are not concentric and truncate each other. This clast may represent a recrystallized oncolite deposited in carbonate mud. As such, the paleoenvironment may have been a high-energy intertidal zone.

The second facies variant in the marble unit is a massive white to buff-tan material interbedded with quartz-rich layers as thick as $2.5 \mathrm{~cm}$. In slab sections, relic bedding is preserved, with the quartz-rich interlayers suggesting cyclic sequences of siliciclastic deposition separated by periods of carbonate deposition. The protolith for this variant was probably carbonate mud with thin cyclic beds of quartz sand that were deposited in a medium- to low-energy environment.

The third facies variant is exposed within the (structurally) upper part of the unit; it is a massive, white to buff-tan marble. Slabs of samples from this facies reveal relic planar features (bedding?) as well as thin laminations (aglal mats?) and small clasts (as large as $0.5 \mathrm{~cm}$ in diameter) of presumably carbonate lithoclasts. The clasts are surrounded by a finegrained groundmass, which may have been carbonate mud. The protolith was probably a lithoclastic wackstone, with some possible algal beds, that was deposited in a medium-energy environment.

\section{Intrusive Rocks}

\section{Steele Creek Dome Tonalite}

The Steele Creek Dome Tonalite (fig. 2), named herein, is a composite body of biotite-hornblende foliated tonalitic to granodioritic orthogneiss containing rafts of paragneiss of supracrustal country rocks. The unit lies within the central part of the study and along the main stem of the Fortymile River downstream from the Taylor Highway (fig. 2). Rocks of the unit form several high ridges south of the Fortymile River, including Steele Creek Dome, Polly Peak, and the east-trending ridges that bound Uhler Creek (fig. 2).

The orthogneiss is primarily a light-gray, medium-grained, and strongly foliated biotite-hornblende tonalite (samples 97AG036A, 97AG027, 97AG024, 97AD109, and 97AG108; table 1). Xenoliths of metasedimentary and metavolcanic rocks occur as enclaves throughout the Steele Creek Dome Tonalite. One such mafic metavolcanic(?) raft is preserved within the center of the complex and is interpreted to be a roof(?) pendant within the tonalitic orthogneiss (fig. 2). The western margin of the complex, which is exposed along the South Fork of the Fortymile River, is a migmatite having a neosome of lightgray biotite tonalite and a paleosome of mafic metavolcanic(?)

Table 1. Percent modal mineral content for rocks from the Steele Creek Dome Gneiss Complex and small bodies within the Taylor Mountain assemblage rocks in the Fortymile River area.

[tr $=$ trace mineral, $*=$ sphene, $* *=$ pyrite. Modal analysis by P.K. Sims.]

\begin{tabular}{|c|c|c|c|c|c|c|c|c|c|}
\hline Sample no. & & 1 & 2 & 3 & 4 & 5 & 6 & 7 & 8 \\
\hline \multicolumn{10}{|l|}{ Mineral } \\
\hline Plagioclase & & 69 & 51 & 50 & 57 & 59 & - & 83 & 90 \\
\hline Quartz & & 19 & 32 & 33 & 13 & 32 & 57 & 15 & 10 \\
\hline Alkali feldspar & & - & 5 & - & - & 6 & - & - & - \\
\hline Hornblende & & - & 7 & - & - & - & - & - & - \\
\hline Biotite & & 10 & 4 & 5 & 28 & 2 & - & - & - \\
\hline Muscovite & & 1 & - & 6 & 1 & - & 6 & 1 & $\mathrm{tr}$ \\
\hline Chlorite & & - & - & - & 1 & - & 6 & - & - \\
\hline Epidote & & - & 1 & 6 & - & 0.5 & 17 & - & - \\
\hline Calcite & & - & - & $\operatorname{tr}$ & - & - & 7 & $\operatorname{tr}$ & $\operatorname{tr}$ \\
\hline Opaque & & - & - & - & - & - & 7 & $1 * *$ & $\operatorname{tr} * *$ \\
\hline Accessory & & 1 & $\operatorname{tr}$ & $\operatorname{tr}$ & $1 *$ & 0.5 & $\operatorname{tr}$ & - & $* *$ \\
\hline Number of counts & & 500 & 500 & 500 & 500 & 500 & 200 & 500 & 250 \\
\hline Sample no. & Latitude & \multicolumn{2}{|c|}{ Longitude } & \multicolumn{2}{|c|}{ Field number } & \multicolumn{4}{|c|}{ Rock name } \\
\hline 1 & 64.181 & \multicolumn{2}{|c|}{-141.464} & \multicolumn{2}{|c|}{ 97AG036A } & \multicolumn{4}{|c|}{ foliated biotite tonalite (orthogneiss) } \\
\hline 2 & 64.228 & \multicolumn{2}{|c|}{-141.642} & \multicolumn{2}{|c|}{ 97AG027 } & \multicolumn{4}{|c|}{ foliated hornblende-biotite tonalite (orthogneiss) } \\
\hline 3 & 64.295 & \multicolumn{2}{|c|}{-141.532} & \multicolumn{2}{|c|}{ 97AG024 } & \multicolumn{4}{|c|}{ mylonitic tonalite gneiss (orthogneiss) } \\
\hline 4 & 64.232 & \multicolumn{2}{|c|}{-141.353} & \multicolumn{2}{|c|}{ 97AD109 } & \multicolumn{4}{|c|}{ biotite diorite gneiss (orthogneiss) } \\
\hline 5 & 64.232 & \multicolumn{2}{|c|}{-141.404} & \multicolumn{2}{|c|}{ 97AD108 } & \multicolumn{4}{|c|}{ foliated biotite tonalite (orthogneiss) } \\
\hline 6 & 64.250 & \multicolumn{2}{|c|}{-141.398} & \multicolumn{2}{|c|}{ 97AD107 } & \multicolumn{4}{|c|}{ foliated metapelite (paragneiss) } \\
\hline 7 & 64.217 & \multicolumn{2}{|c|}{-141.777} & \multicolumn{2}{|c|}{ 97AD041 } & \multicolumn{4}{|c|}{ trondhjemite } \\
\hline 8 & 64.244 & \multicolumn{2}{|c|}{-141.768} & \multicolumn{2}{|c|}{ 97AG015 } & \multicolumn{4}{|c|}{ mylonitic trondhjemite } \\
\hline
\end{tabular}


rocks. The northern margin is a zone of high tectonic strain in which both the country rock and orthogneiss have a moderate $\left(30^{\circ}-40^{\circ}\right)$ south-dipping protomylonitic fabric near the Taylor Highway; the fabric steepens $\left(55^{\circ}-85^{\circ}\right.$ south) to the west near Polly Peak (fig. 2). The southern margin, as exposed near the Taylor Highway east of Grace Creek, is a dark-gray biotite tonalite with L-S tectonic fabric that dips moderately $\left(20^{\circ}-30^{\circ}\right)$ to the north.

The protolith for the orthogneiss of the Steele Creek Dome Tonalite was dominantly a light-gray, medium-grained biotite tonalite (samples 97AG036A, 97AG027, 97AG024, 97AD109, and 97AG1081; table 1). The strong regional metamorphism and penetrative deformation $\left(\mathrm{D}_{1}\right.$; see Structural Evolution section below) has recrystallized the primary igneous textures and minerals of the tonalite to produce the current gneissic fabric. Dusel-Bacon and others (1995) found that high-pressure ( 9 to $10 \mathrm{kbar})$ and temperature $\left(665^{\circ}\right.$ to $\left.730^{\circ} \mathrm{C}\right)$ dynamic metamorphism affected the supracrustal rocks that are both adjacent to, as well as those that form xenoliths within, the gneiss complex. Locally, greenschist-facies metamorphic mineralschlorite, epidote, and calcite (table 1) — subsequently overprinted the peak amphibolite-facies metamorphic mineral assemblage reported by Dusel-Bacon and others (1995). The primary age of crystallization is unknown. However, inasmuch as the gneiss is deformed by the regional $\mathrm{D}_{1}$ tectonism (see Structural Evolution section below), the protolith age is older than the Middle Jurassic ${ }^{40} \mathrm{Ar} /{ }^{39} \mathrm{Ar}$ ages reported by Hansen and others (1991) for metamorphic hornblende, biotite, and muscovite contained in the adjoining country rocks.

The tonalite is variable in mineralogy as well as in majorand trace-element concentrations. Modal data show that some parts of the unit contains both biotite and hornblende or biotite and muscovite; alkali feldspar is a minor constituent (table 1). Major-element data provided in Crock and others (1999) show that the tonalitic gneiss is transitional from metaluminous to peraluminous. The REE data also show a wide variation in total concentrations (fig. 4D). For example, the most leucocratic sample (97AD108), made up of approximately 75 percent feldspar with very minor biotite (table 1), has the lowest total REE concentration (fig. 4D) and mimics a common feldspar REE pattern from igneous rocks (Leeman and Phelps, 1981; Nash and Crecraft, 1985). The more typical tonalites (samples

97AG036A, 97AG027, 97AG024, and 97AD109) are light-REE enriched, with negatively sloping patterns, and a small, fluctuating (both positive and negative) europium anomaly (fig. 4D).

One sample of an enclave of paragneiss (97AD107) has a similar range in total REE's and pattern shape compared with the metagraywacke (figs. $4 C$ and $4 D$ ), except it has slightly higher lightREE concentrations. Moreover, the REE data show that the tonalite is not a recrystallized metasediment, arguing against a sedimentary protolith or paragneiss origin. The REE patterns are distinctly different from the sediment types observed throughout the area (fig. 4D).

There are two possible modes of the final emplacement of the gneissic Steele Creek Dome Tonalite. It was either emplaced as thrust sheets interleaved with the supracrustal rocks of the Taylor Mountain assemblage or as a pre- to syn-tectonic intrusion modified during the regional Middle Jurassic deformation and metamorphism. Support for the thrust mode comes from exposures along the northern and southern margins, in which the gneiss and adjacent country rock are highly tectonized and contain a strong mylonitic fabric. In fact, asymmetric S-C fabrics in the L-S tectonite, as well as northwest-plunging stretching (elongation) lineations, indicate a northwestward transport direction for tonalitic gneiss emplaced over the country rock. Also, the tectonic fabrics along the northern and southern margins dip inward beneath the complex and, thus, could represent parts of a continuous mylonite zone (thrust?) beneath the complex.

Support for an intrusive mode of emplacement is seen on the southern margin near Grace Creek just north of the Taylor Highway, where thin stringers of tonalite cut metabasaltic supracrustal country rock and are cut by a penetrative L-S tectonic fabric (fig. 5A). The inferred map pattern (fig. 2) also supports an intrusive origin. In addition, several stringers cut the country rock adjacent to smaller gneissic tonalite body exposed along the Fortymile River near Twin Creek (fig. 2).

The above, seemingly contradictory, observations lead to an interpretation that the Steele Creek Dome Tonalite intruded the metasedimentary country rocks prior to (or possibly during) the early phases of regional ductile Middle Jurassic deformation (early $\mathrm{D}_{1}$ to syn- $\mathrm{D}_{2}$; see Structural Evolution section below). The orthogneiss entrained rafts and screens of the country rock in the central part of the complex (roof zone?) as well as created lit-par-lit migmatite along the western margin. Subsequent northwest-vergent regional compression thrust the body over the supracrustal country rock along its southern margin, developing the stretching (elongation) lineations. The northern margin, which has a prominent, steeply dipping protomylonitic fabric as well as southwest-dipping stretching lineations, represents the tectonic leading edge as the main body was thrust to the northwest over the supracrustal rocks. The high-strain zones along the margins of the main body probably reflect areas of high contrasts in competency in which the more ductile metamorphosed supracrustal rocks flowed along the margins of the more competent orthogneiss during the Middle Jurassic tectonism.

\section{Leucogranite and Trondhjemite Bodies}

Leucogranite and trondhjemite form small plugs and sills within the rocks of the Taylor Mountain assemblage exposed along the Fortymile River (unit g, fig. 2). The leucogranite occurs as foliated to massive muscovite-biotite \pm garnet plutons whose size is uncertain, but most are estimated to be approximately $1-2 \mathrm{~km}^{2}$ in area. The leucogranite is white to light gray, medium grained, and, although they are penetrated by the regional $S_{1}($ ?) ductile foliation, they lack a strong mineral or stretching lineations. Small, relatively minor bodies of trondhjemite (as much as $50 \mathrm{~m}$ thick) are intercalated with metabasalt (unit mv, fig. 2) in the western part of the study area. One body is located along the eastern bank of the South Fork of the Fortymile River about $1.3 \mathrm{~km}$ south of the confluence with the Fortymile River (sample 97AG015, table 1). Another is located approximately $2.6 \mathrm{~km}$ south of the confluence of the South and North Forks of the Fortymile River (sample 97AD041, table 1). These small tabular intrusions 
form distinct ochre-colored outcrops due to the presence of weathered pyrite. They are generally massive but are cut by local brittle to ductile $\left(\mathrm{D}_{1}\right)$ shear zones. Their mode of
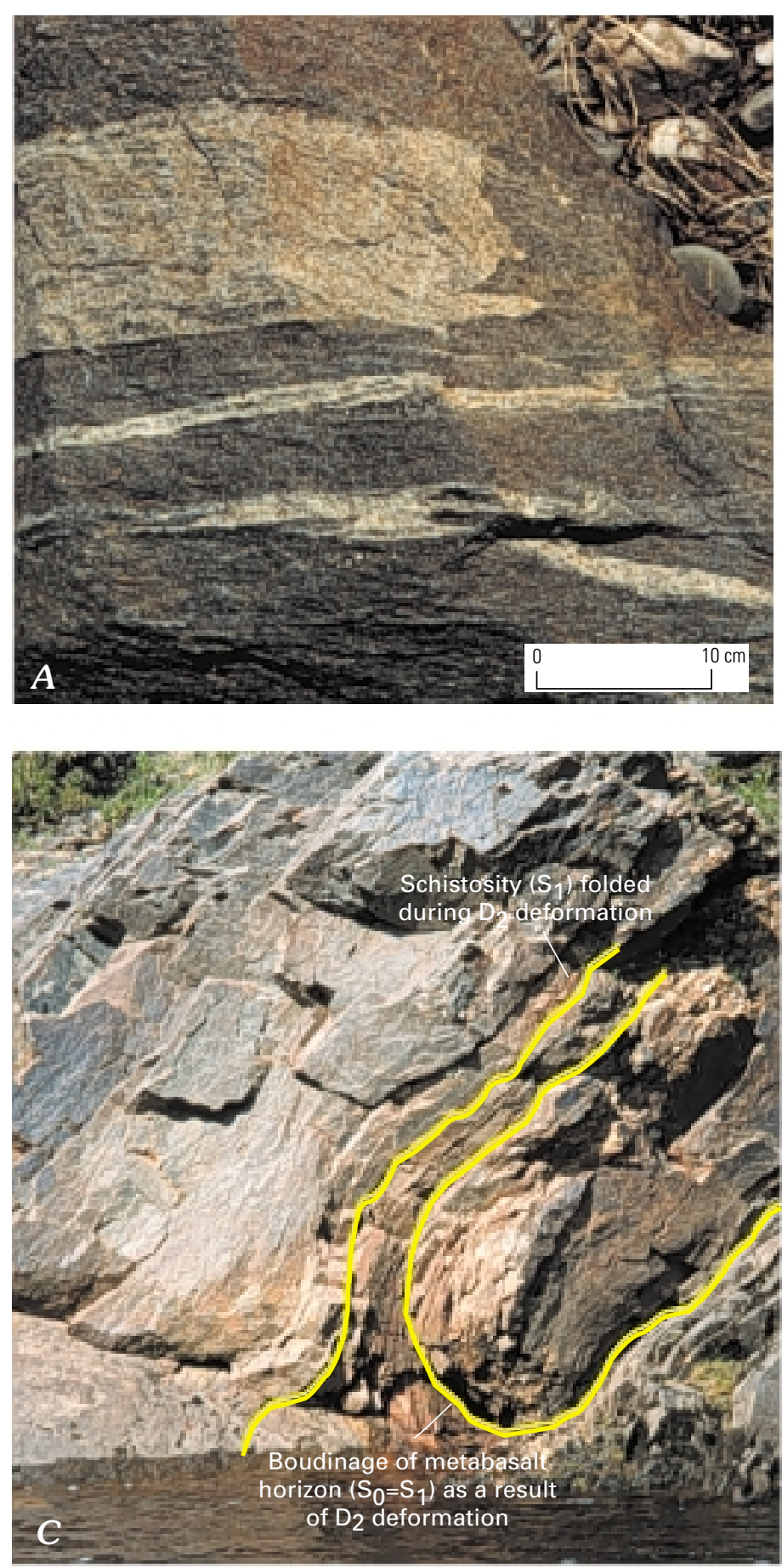

emplacement is speculated to be either as small pre-tectonic plugs or sills intruded along the foliation planes of the surrounding metamorphic country rock.
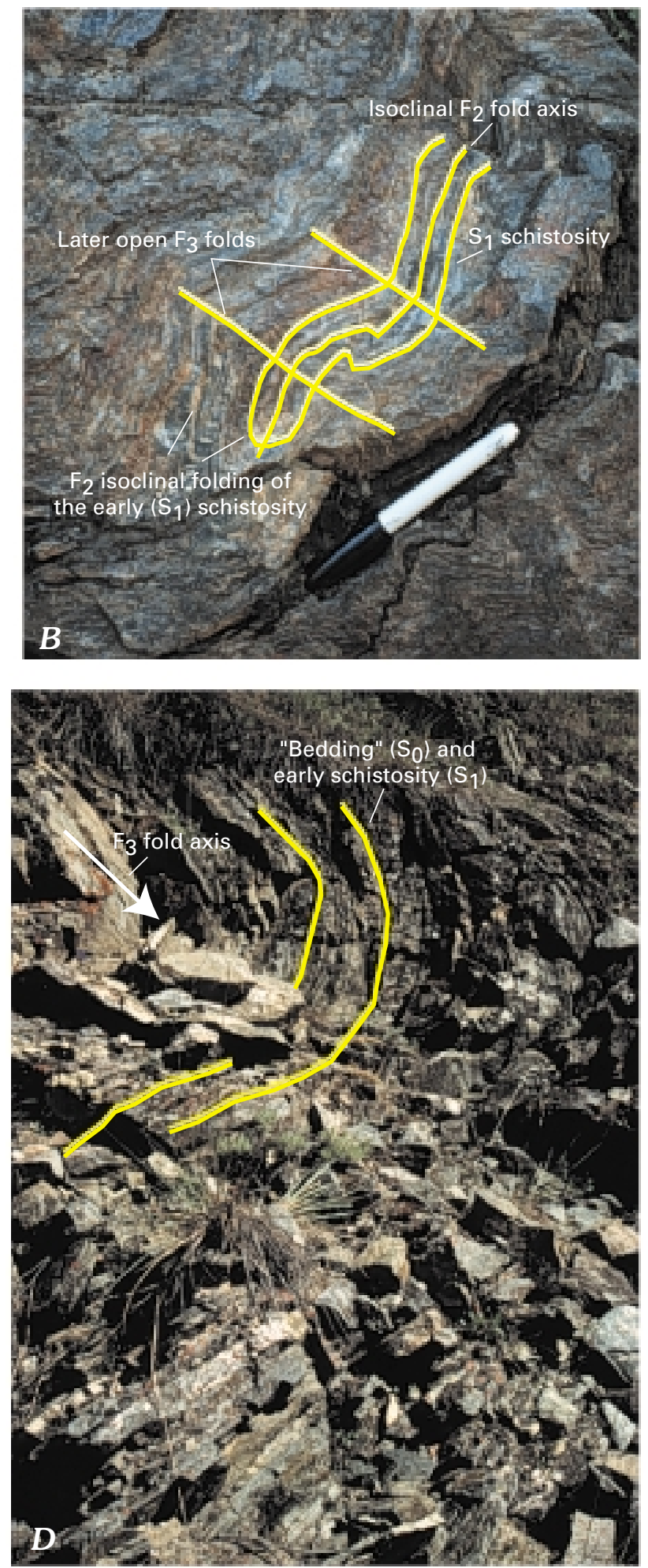

Figure 5. Photographs showing structural elements within rocks of the Taylor Mountain assemblage in the Fortymile River area. $A$ shows deformed stringers of biotite-hornblende tonalite on the southern margin of the Steele Creek Dome Tonalite (along Grace Creek north of the Taylor Highway) invading hornblende-biotite schist (metabasalt) of the supracrustal sequence within the Taylor Mountain assemblage. The tonalite intruded the supracrustal rocks prior to or during the ductile $D_{1}$ deformation; $B$ shows isoclinal $F_{2}$ folds refolded by open $F_{3}$ folds and $F_{2}$ fold strong $S_{1}$ schistosity developed in hornblende-biotite schist (metavolcanic); $C$ displays isoclinal $F_{2}$ fold and boudinage of $S_{1}$ layering within hornblende-biotite schist (metabasalt) horizons along the Fortymile River; $D$ illustrates open $F_{3}$ folding of bedding-parallel schistosity $\left(S_{0}=S_{1}\right)$ within hornblende-biotite schist metabasalt interlayered with chert horizons (light-colored layers). 


\section{Ultramafic Rocks}

Small ultramafic bodies (unit um, fig. 2) intrude both biotite schist (metagraywacke) and mafic metavolcanic rocks(?) (fig. 2). The intrusions are dark-green, coarse-grained meta-peridotite to meta-pyroxenite bodies that maintain compositional layering that is parallel to the schistosity in the surrounding country rocks. The REE pattern for one sample (97AG034) is shown in figure $4 A$ together with the samples from the group-I mafic metavolcanic(?) rocks. The ultramafic rock has a much lower total REE content than group-I metabasalt but has a similar depleted light-REE pattern. As such, they may be cogenetic with the group-I mafic metavolcanic rocks.

\section{Monzodiorite-Diorite-Quartz Diorite Suite}

A widespread intrusive suite invades the supracrustal and gneissic rocks of the Taylor Mountain assemblage in the Fortymile River area. This monzodiorite-diorite-quartz diorite suite (unit md, fig. 2) is well exposed just north of the confluence of the North and South Forks of the Fortymile River, as well as on the main east-trending ridge that separates Uhler and Wade Creeks (fig. 2). The suite is a coarse-grained, equigranular, foliated, dark-green to dark-gray monzodiorite to quartz diorite. Hornblende is the most common mafic mineral; it is commonly pseudomorphic after primary clinopyroxene, which is absent in the alkali-feldspar-bearing samples (table 2). Apatite and sphene are common accessory minerals.

In the areas of poor exposure, the contacts of the map unit were delineated on the basis of a pronounced aeromagnetic high.
The unit intruded the supracrustal rocks, forming skarn that is exposed along the easternmost margin of the body on the Fortymile River. A moderate foliation and ductile shear bands are seen within the unit. Although limited in exposure, the strong regional schistosity $\left(\mathrm{S}_{1}\right)$ within the country rocks appears to wrap around the southern and eastern margins of the body along the Fortymile River (fig. 2), but does not cut the diorite body. Although there are no published age data to suggest the primary ages for this suite, based on the structural fabrics the suite appears to be syn- to late-kinematic and, therefore, was emplaced during the waning stages of the regional Middle Jurassic tectonism.

The geochemical data show that the suite is metaluminous (Crock and others, 1999). The chondrite-normalized REE patterns are distinctive in that they are enriched and convex-shaped for the light REE, have a slight negative europium anomaly, and have relatively flat heavy REE shapes (fig. 4E). The overall range of light REE enrichment varies from 50-100 $\times$ chondritic values, decreasing to 5-15 $\times$ chondrites for the heavy-REE. In contrast, tonalite samples from the Steele Creek Dome Tonalite have less steep REE patterns but a considerably wider range in overall concentration. The tonalitic differs in that it has a variable europium anomaly, ranging from negative for the samples with the highest total REE abundance to positive for samples with the lowest total REE content (fig. $4 E$ ).

\section{Structural Evolution}

Regional Middle Jurassic polyphase deformation (Foster and others, 1985; Hansen and others, 1991; and Hansen and

Table 2. Percent modal mineral content for rocks from the monzonite-diorite-quartz diorite suite. [tr=trace amounts of mineral present. Modal analyses by P.K. Sims.]

\begin{tabular}{|c|c|c|c|c|c|c|c|}
\hline Sample no. & & 1 & 2 & 3 & 4 & 5 & 6 \\
\hline \multicolumn{8}{|l|}{ Mineral } \\
\hline Plagioclase & & 40 & 44 & 50 & 53.5 & 49 & - \\
\hline Quartz & & 3 & 8 & 11 & 7 & 6 & - \\
\hline Alkali feldspar & & 37 & 21 & - & - & $\operatorname{tr}$ & - \\
\hline Hornblende & & 18.5 & 20 & 16 & 21 & 32 & 7.5 \\
\hline Biotite & & $\operatorname{tr}$ & - & 10 & 5 & 1 & 46 \\
\hline Clinopyroxene & & - & - & 11 & 13.5 & 12 & 34 \\
\hline Muscovite & & - & - & 1 & - & - & - \\
\hline Chlorite & & - & 3 & - & - & - & - \\
\hline Epidote & & - & 3 & - & - & - & - \\
\hline Opaque & & 0.5 & 1 & 1 & - & - & 6 \\
\hline Sphene & & 1 & - & - & $\operatorname{tr}$ & $\operatorname{tr}$ & 2 \\
\hline Apatite & & $\operatorname{tr}$ & - & $\operatorname{tr}$ & $\operatorname{tr}$ & $\operatorname{tr}$ & 4.5 \\
\hline Accessory & & - & $\operatorname{tr}$ & - & - & - & - \\
\hline Number of counts & & 500 & 500 & 500 & 500 & 500 & 500 \\
\hline Sample no. & Latitude & \multicolumn{2}{|c|}{ Longitude } & \multicolumn{2}{|c|}{ Field number } & \multicolumn{2}{|c|}{ Rock name } \\
\hline 1 & 64.164 & \multicolumn{2}{|c|}{-141.534} & \multicolumn{2}{|c|}{ 97AD114 } & \multicolumn{2}{|c|}{ nonfoliated hornblende monzonite } \\
\hline 2 & 64.153 & \multicolumn{2}{|c|}{-141.616} & \multicolumn{2}{|c|}{ 97AD116 } & \multicolumn{2}{|c|}{ nonfoliated hornblende diorite } \\
\hline 3 & 64.269 & \multicolumn{2}{|c|}{-141.733} & \multicolumn{2}{|c|}{ 97AG020 } & \multicolumn{2}{|c|}{ foliated biotite-hornblende diorite } \\
\hline 4 & 64.232 & \multicolumn{2}{|c|}{-141.353} & \multicolumn{2}{|c|}{ 97AD025 } & \multirow{2}{*}{\multicolumn{2}{|c|}{$\begin{array}{l}\text { nonfoliated biotite-hornblende diorite } \\
\text { nonfoliated diorite }\end{array}$}} \\
\hline 5 & 64.337 & \multicolumn{2}{|c|}{-141.84} & \multicolumn{2}{|c|}{ 97AG037 } & & nonfoliated diorite \\
\hline 6 & 64.616 & \multicolumn{2}{|c|}{-141.149} & \multicolumn{2}{|c|}{ 97AD117 } & biot & -clinopyroxene diorite \\
\hline
\end{tabular}


Table 3. Summary of tectonic-fabric elements for rocks of the Taylor Mountain assemblage in the Fortymile River area.

\begin{tabular}{ll}
\hline & \multicolumn{1}{c}{ Planar Fabrics } \\
\hline $\mathrm{S}_{0}$ & Original bedding or compositional layering \\
$\mathrm{S}_{1}$ & Strong schistosity (main regional flattening fabric) \\
$\mathrm{S}_{2}$ & Weak axial planar cleavage (locally present on $\mathrm{F}_{2}$ folds) \\
\hline \multicolumn{1}{c}{ Linear Fabrics } \\
\hline $\mathrm{L}_{1}$ & Mineral lineations (local) \\
$\mathrm{L}_{2}$ & Strong mineral and stretching lineations \\
& Parallel with $\mathrm{F}_{2}$ fold axes, which fold $\mathrm{S}_{1}$ \\
$\mathrm{~L}_{3}$ & Mineral lineations developed on $\mathrm{F}_{3}$ folds (local) \\
\hline & \multicolumn{1}{c}{ Folds } \\
\hline $\mathrm{F}_{1}$ & Folds $\mathrm{S}_{0}$ bedding or compositional layering \\
$\mathrm{F}_{2}$ & Folds $\mathrm{S}_{1}$ schistosity, forming shallowly west and east plunging open folds \\
$\mathrm{F}_{3}$ & Refolds $\mathrm{S}_{1}$ and $\mathrm{F}_{2}$ folds to south-plunging open folds \\
\hline
\end{tabular}

Dusel-Bacon, 1998) has produced several discernable tectonic fabric elements, which, when sorted into their relative sequence of formation, elucidate the deformational history of the study area. Although Hansen and Dusel-Bacon (1998) provided a regional framework by numbering the tectonic phases, direct correlation with their three phases of deformation is not implied. Correlation with their phases of deformation is discussed below.

\section{Phases of Deformation}

The supracrustal rocks of the Taylor Mountain assemblage have undergone at least three phases of deformation. The earliest two phases $\left(D_{1}\right.$ and $\left.D_{2}\right)$ produced mesoscopic ductile-fabric elements throughout the area, whereas the latest $\left(D_{3}\right)$ phase was primarily a regional fold event that was not accompanied by development of a regional penetrative fabric. Table 3 summarizes the basic identifiable fabric elements, and figure 6 is a simplified sketch that highlights the spatial relationships between the fabric elements. The oldest planar feature is the original bedding $\left(\mathrm{S}_{\mathrm{O}}\right)$ in the metasedimentary rocks, which has been overprinted by structures of the earliest deformation phase $\left(D_{1}\right)$. $D_{1}$ was primarily a ductile flattening (or oblate) strain event and formed S-tectonites. The original bed$\operatorname{ding}\left(\mathrm{S}_{\mathrm{o}}\right)$ was overprinted by the strong regional $\mathrm{S}_{1}$ schistosity. An early mineral lineation $\left(\mathrm{L}_{1}\right)$, commonly demonstrated by biotite and (or) hornblende, forms within the $\mathrm{S}_{1}$ plane parallel to the $\mathrm{F}_{1}$ fold axes. Locally, where metamorphic recystallization is not complete (for example, in the metagraywacke) $S_{o}$ is folded along isoclinal $F_{1}$ folds characterized by bedding-parallel folds whose axes are planar with the $\mathrm{S}_{1}$ schistosity.

The second deformation $\left(\mathrm{D}_{2}\right)$ was a more constrictional (or prolate) ductile strain phase. Both mineral $\left(\mathrm{L}_{2}\right)$ and stretching lineations are coaxial with the hinge lines of younger $F_{2}$ folds, which folded the older $S_{1}$ schistosity (fig. 6). Interestingly, the axial planar cleavage $\left(S_{2}\right)$ within the $F_{2}$ folds is only moderately to weakly developed and is only present locally. However, flattening did occur during $\mathrm{D}_{2}$, inasmuch as the earlier strong $\mathrm{S}_{1}$ schistosity is folded into isoclinal folds (fig. $5 B$ ) and, locally, both $\mathrm{S}_{0}$ and $\mathrm{S}_{1}$ are boudinaged by the later ductile deformation (fig $5 C$ ).

The youngest recognized phase of deformation $\left(D_{3}\right)$ was a regional fold event that formed broad, open folds manifest by the $\mathrm{S}_{1}$ schistosity (fig. $5 D$ ); it also reoriented the older linear fabric elements $\left(\mathrm{L}_{1}\right.$ and $\left.\mathrm{L}_{2}\right)$ (fig. 6). Although a weak axial planar cleavage $\left(\mathrm{S}_{3}\right)$ is locally developed, no regionally recognizable penetrative fabric is present. However, low-grade (greenschist facies) metamorphic mineral assemblages are developed as retrograde products on the kyanite-bearing, highpressure, amphibolite-facies assemblages (Dusel-Bacon and others, 1995) in the supracrustal rocks as well as the Steele Creek Dome Tonalite; possibly, the retrograde metamorphism reflects metamorphism related to $\mathrm{D}_{3}$.

\section{Regional Variations in Tectonic-Fabric Elements}

The tectonic-fabric elements vary systematically in orientation throughout the study area. Three broad structural domains

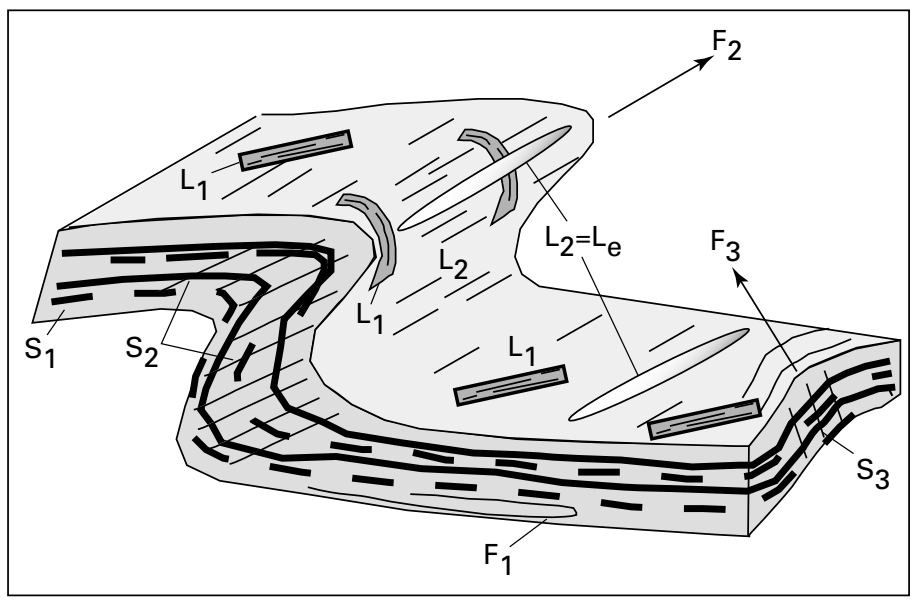

Figure 6. Sketch showing the relative superposition of mesoscopic tectonic fabric elements for rocks of the Taylor Mountain assemblage in the Fortymile River Study area. 
are defined to facilitate discussion of the deformational history within rocks of the Taylor Mountain assemblage in the study area (fig. 7). The first two domains contain supracrustal rocks and are (1) a western domain that extends from just east of the junction of O'Brien Creek and the Fortymile River to the southwest toward Uhler Creek, and (2) a central and eastern domain that extends from the western domain eastward to the International border. Rocks of the Steele Creek Dome Tonalite form a third structural domain and share similarities in tectonic fabrics with those of the domains made up of supracrustal rocks.

In the western part of the study area (fig. 7) the early $S_{1}$ schistosity varies considerably; a significant part of the data show a shallow southeast dip (fig. $8 A$ ). A crude great circle can be drawn having a strike of $218^{\circ}$ and dip of $49^{\circ}$ to the northwest, which would indicate regional folding about moderately southeast plunging tectonic axes. Additionally, the $\mathrm{D}_{2}$ folds and mineral lineations are also folded about this southeast-plunging tectonic trend (fig. $8 E$ and $8 F$ ). Subsequently, post- $\mathrm{D}_{2}$ folding affected the western part of the study area in the form of the south-plunging open $\mathrm{F}_{3}$ folds mapped along the Fortymile River (fig. 2). The axial planes of these $F_{3}$ folds dip west - the east-dipping limbs consistently dip more steeply $\left(50^{\circ}-85^{\circ}\right)$ than the more shallowly west dipping limbs $\left(35^{\circ}-75^{\circ}\right)$. Therefore, these $\mathrm{F}_{3}$ folds are interpreted as east-vergent and are associated with regional $\mathrm{D}_{3}$ shortening. It is reasonable to assume that the east-west-oriented $\mathrm{D}_{3}$ shortening is kinematically associated with the thrust fault mapped along the Fortymile River (fig. 2). The western side of the thrust fault displayed on figure 2 is interpreted to be the hanging wall. However, the relative ages of rocks on either side of the fault are unknown, and the fault plane in the area of the mapped thrust is inferred to lie beneath a rubble zone. The mesoscopic-scale $\mathrm{F}_{3}$ folds and mineral lineations are rare (fig. $8 H$ and $8 I$ ) in the supracrustal rocks in the western part of the area.

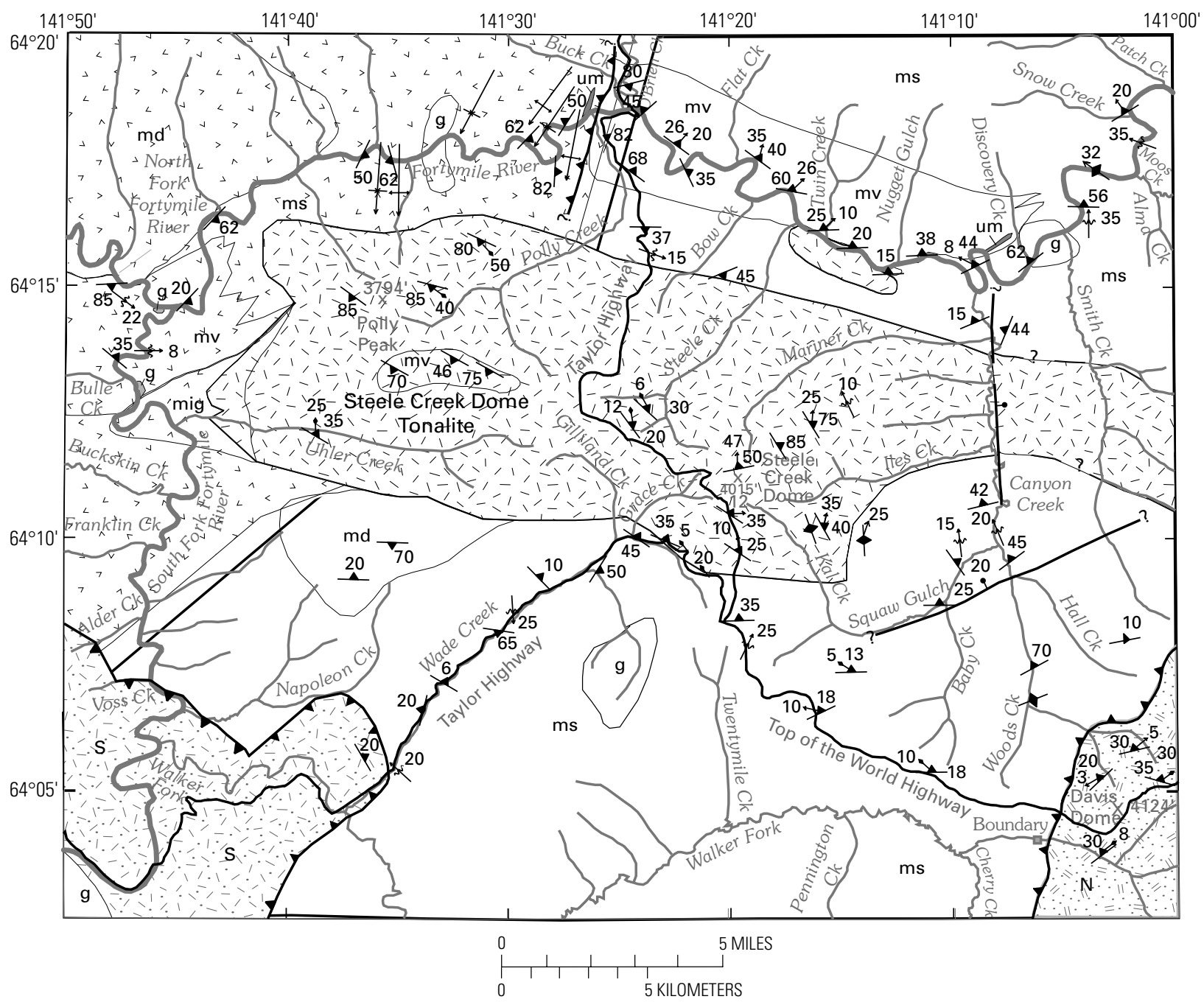

STRUCTURAL DOMAINS

Area of Steele Creek Dome Tonalite

Area of central and eastern structural domain

Area of western structural domain

Figure 7. Outline of structural domains for rocks within the Taylor Mountain assemblage in the Fortymile River area. Unit labels and symbols are same as in figure 2. 

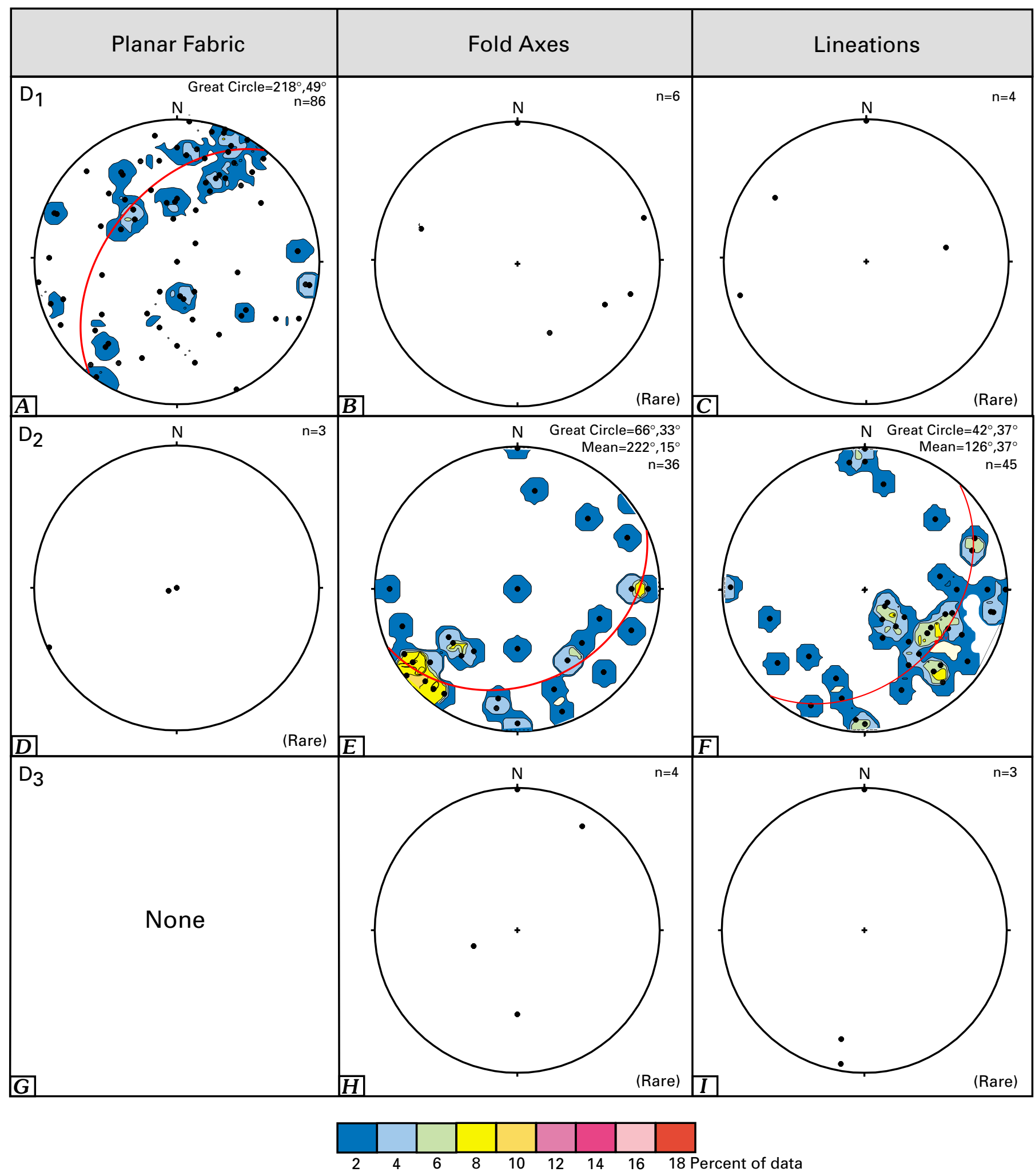

Figure 8. Tectonic-fabric elements in the supracrustal rocks within the Taylor Mountain assemblage in the western part of the Fortymile River area. Dots represent individual measurements and colored regions represent areas containing a given percentage of the data within the stereonet. Equal-area stereographic projection of lower hemisphere.

The orientation of tectonic-fabric elements in supracrustal rocks from the central and eastern parts of the Fortymile River study area (fig. 7) differs from that of the western part (figs. $9 \mathrm{~A}$ I). The strong $\mathrm{S}_{1}$ schistosity of the central and eastern regions consistently dips to the north and shows much less large scale post- $\mathrm{D}_{2}$ folding (fig. $9 A$ ). Additionally, unlike the western part of the study area, the $\mathrm{L}_{1}$ and $\mathrm{L}_{2}$ lineations define two populations, plunging both to the northwest and northeast (figs. $9 C$ and $9 F$ ). The $\mathrm{L}_{1}$ lineations are distinguished from the $\mathrm{L}_{2}$ lineations in that $\mathrm{L}_{1}$ can be folded by the $\mathrm{F}_{2}$ folds (fig. $9 E$ ). The $\mathrm{D}_{2}$ 

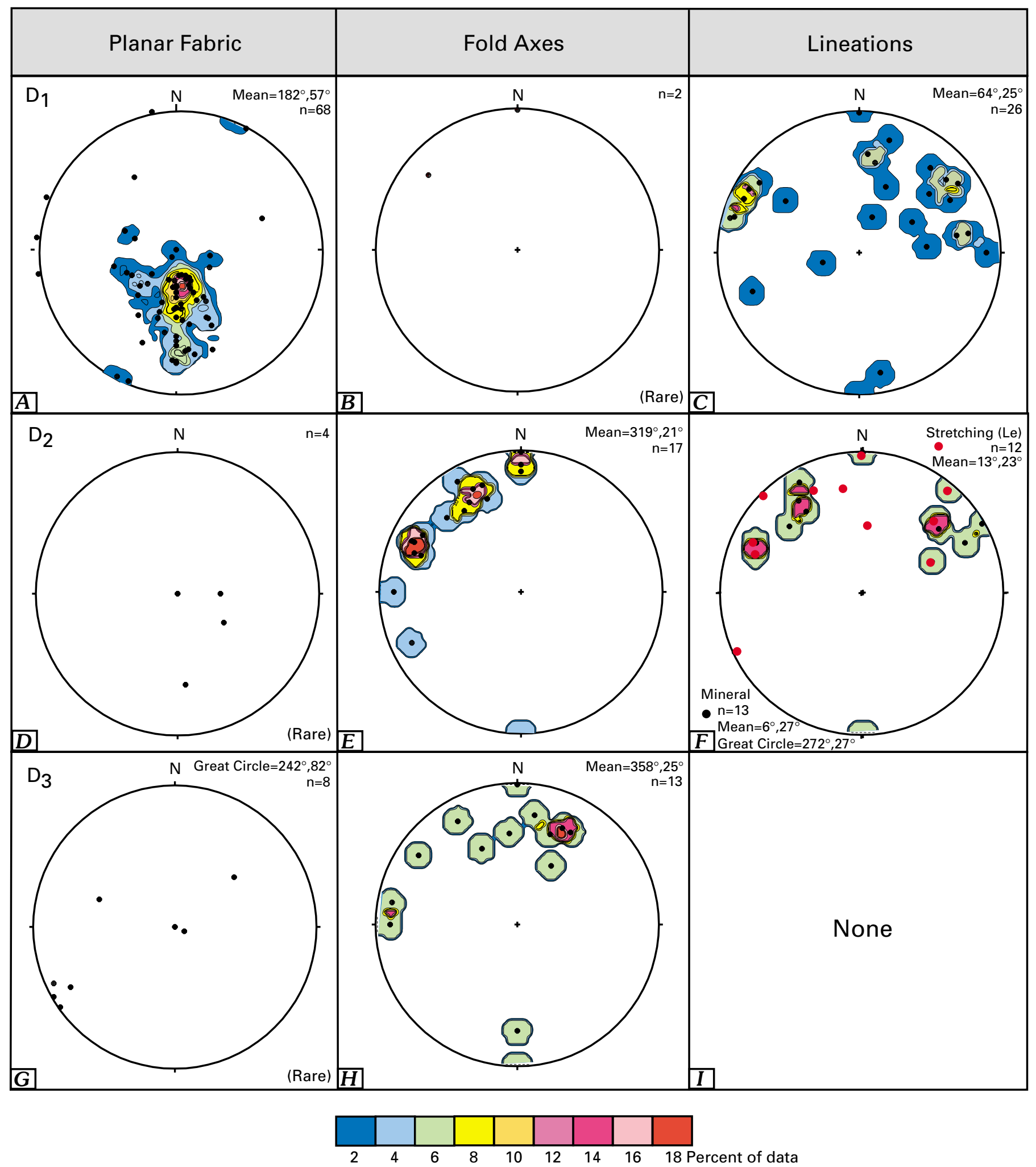

Figure 9. Tectonic-fabric elements in the supracrustal rocks within the Taylor Mountain assemblage in the central and eastern part of the Fortymile River area. Dots represent individual measurements and colored regions represent areas containing a given percentage of the data within the stereonet. Equal-area stereographic projection of lower hemisphere.

elongation lineations ("Le" of Hansen and Dusel-Bacon, 1998) fall into the two general populations, having northwest and northeast plunges. The relative timing of development of these two lineations is equivocal. Both appear to be $\mathrm{D}_{2}$ structures, but their absolute age is currently unknown.
The central and eastern parts of the study area have been locally affected by the $\mathrm{D}_{3}$ folding, which formed rare, albeit broad, open, north-plunging folds (fig. $9 H$ ). Locally, an axialplanar $\mathrm{S}_{3}$ cleavage is present within the $\mathrm{F}_{3}$ folds, but distinct mineral lineations are absent (figs. $9 G, 9 H$, and $9 I$ ). 


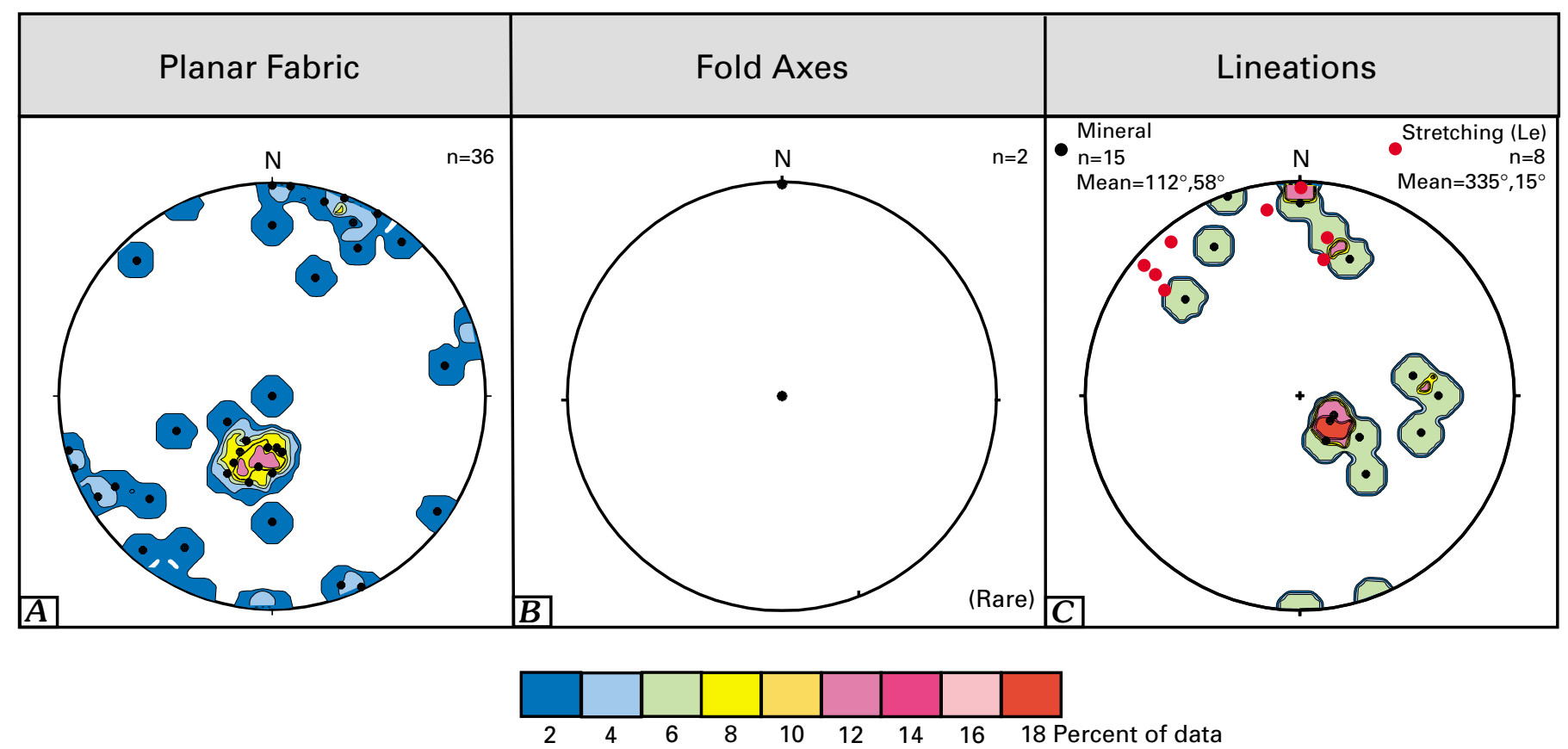

Figure 10. Tectonic-fabric elements in the Steele Creek Dome Tonalite within the Fortymile River area. Dots represent individual measurements and colored regions represent areas containing a given percentage of the data within the stereonet. Equal-area stereographic projection of lower hemisphere.

The tectonic fabrics preserved within the Steele Creek Dome Tonalite (fig. 7) share some similarities with both domains of the surrounding supracrustal rocks. As seen in the central and eastern parts of the supracrustal structural domain (fig. 9A), a relatively shallow dipping, north-northwest-striking schistosity exists throughout the area (figs. 2 and 10A). Also, the steep southwest-dipping, northwest-striking gneissic fabric is parallel to that in the western supracrustal structural domain (fig. 8A).

Mineral lineations within the gneiss form two populations; one trends north-northwest and has shallow plunges; the other trends east-southeast with steep plunges (fig. 10C). The orientations of the stretching (elongation) lineations (Hansen and Dusel-Bacon, 1998) within the gneiss complex overlap the north-northwest-trending mineral lineation (fig. 10C). Only one fold hinge was observed within the gneissic fabric. This may indicate that either (1) the $\mathrm{F}_{2}$ folds did not affect the gneiss complex inasmuch as the gneiss was a more competent rigid body caught up in the regional folding, or (2) the dynamic recrystallization associated with $\mathrm{D}_{2}$ was so intense that only rare hinges are preserved. Regardless, L-S tectonites were developed within the complex and surrounding supracrustal country rocks.

\section{Discussion}

The paleoenvironment for the supracrustal rocks of the Taylor Mountain assemblage within the Fortymile River area can be reconstructed if the entire lithologic package is considered. Protoliths for the sedimentary rocks include graywacke, pelite, siliciclastic sediments ("dirty" sandstones), orthoquartzite, chert, and limestone, which are interbedded with basalt and (or) are cut by mafic sills. Felsic volcanic rocks appear to be lacking. The turbidites lack significant relict graded bedding (layer A of the Bouma sequence). Where present, regional metamorphism has commonly preserved primary structures in graded turbidites (A layer) as "reverse grading," where the primary upper fine-grained silt-sized fraction is recrystallized into coarse-grained biotite-rich zones and the lower sand-sized fraction remains about the same in grain size. The lack of relict graded bedding in the turbidites, coupled with the presence of interlayers of metapelite, argue for a pelagic or low-flow-regime paleoenvironment distal from the source of the density currents.

Carbonate (now marble) units that are several tens to hndreds of meters thick are interlayed within both the metabasalt(?)-dominant units and the siliciclastic metasedimentary unit (fig. 2). The primary environment of deposition was probably an open-marine platform (Wilson, 1975). Typically, these rocks are deposited in shallow waters (as deep as tens of meters) with moderate circulation within straits, open lagoons, and bays behind the edge of an outer platform (Wilson, 1975). Intense dynamic recrystallization of the marble has destroyed any primary fauna that may have been present. Stratigraphic correlation of the marble is tenuous because of a lack of fossils. However, similar rock types are contained in the Upper Silurian to Middle Devonian Skajit Formation in the Brooks Range, as described by Henning (1982). Albeit a correlation is highly speculative, the marbles within the Fortymile River area may be lithologic equivalents to those of the Skajit Formation.

The presence of basalt compositions (and rare metaandesite) and the lack of felsic volcanic rocks indicate that the area was not close to a felsic to andesitic volcanic center, common to either modern island arcs or continental-rift environments involving concomitant bimodal volcanism. Therefore, the supracrustal rocks in this part of the Taylor Mountain assemblage were deposited in a marine environment either distal from an island arc or within a shallow marginal basin, which had 
syndepositional mafic volcanism and (or) basaltic dike emplacement. This interpretation agrees with that of previous workers for the assemblage (Mortensen, 1992; Foster and others, 1994; Dusel-Bacon and others, 1995).

The Steele Creek Dome Tonalite has trace-element abundances similar to modern volcanic arc granites (fig. 11). Coeval felsic volcanic rocks with chemistry equivalent to the tonalites were not observed. Therefore, the tonalite, which may have formed within a subduction zone, intruded the supracrustal rocks after their deposition, probably during the onset of compressional $\mathrm{D}_{1}$ deformation during the early stages of the tectonic assembly of the Taylor Mountain assemblage.

The $\mathrm{D}_{1}$ and $\mathrm{D}_{2}$ deformational phases may represent either (1) end-members of long-lived progressive ductile deformation, or (2) distinct and separate pulses of ductile deformation.

Regardless, both the $\mathrm{D}_{1}$ and $\mathrm{D}_{2}$ phases were probably part of the regional Middle Jurassic dynamic metamorphic recrystallization discussed by Dusel-Bacon and others (1995). $\mathrm{L}_{2}$ stretching lineations as well as $F_{2}$ folds are superimposed on $S_{1}$, and, thus, their formation followed the regional flattening of $\mathrm{D}_{1}$. Microscopic textures and the similarity of high-pressure amphibolitefacies metamorphic mineral assemblages developed for both phases argue for an evolving tectonic environment in which the progressive, ductile, tectonic-strain regime changed from a dominantly flattening to a constrictional-strain environment.

Hansen and Dusel-Bacon (their fig. 7, 1998) discuss two phases of ductile compressive deformation older than $185 \mathrm{Ma}$ (pre-early Middle Jurassic; Hansen and others, 1991) and a regional extensional event between $135 \mathrm{Ma}$ and $109 \mathrm{Ma}$ (Early Cretaceous). The early Middle Jurassic dynamic metamorphism has been proposed to have accompanied obduction of the Taylor Mountain assemblage onto the continental margin (orthogneiss assemblage, fig. 1) by Hansen and others (1991) and Hansen and Dusel-Bacon (1998).

Our data indicate the rocks within the Taylor Mountain assemblage in the Fortymile River area experienced at least two phases of ductile deformation associated with the pre-early Middle Jurassic compressional tectonism $\left(\mathrm{D}_{1}\right.$ and $\left.\mathrm{D}_{2}\right)$. At present, evidence is inconclusive as to which of the two hypotheses for the development of $D_{1}$ and $D_{2}$ structures is valid - they could either be related to each other as end-members of a protracted progressive deformation, or they could represent unrelated cycles of deformation. The only constraint on the age of $\mathrm{D}_{2}$ is that it took place prior to $185 \mathrm{Ma}$ (pre-early Middle Jurassic), which was the ${ }^{39} \mathrm{Ar} /{ }^{40} \mathrm{Ar}$ closure age for biotite obtained by Cushing (1984) and Hansen and others (1991).

A third, previously unrecognized, phase of shortening $\left(\mathrm{D}_{3}\right)$ caused folding in the Taylor Mountain assemblage rocks in the Fortymile River area; however, it had only an associated minor penetrative fabric. No evidence for ductile crustal extension as prescribed by Hansen and Dusel-Bacon (1998) is recognized in the Fortymile River study area.

\section{Conclusions}

(1) As suggested by previous workers, the depositional environment for the Taylor Mountain assemblage within the

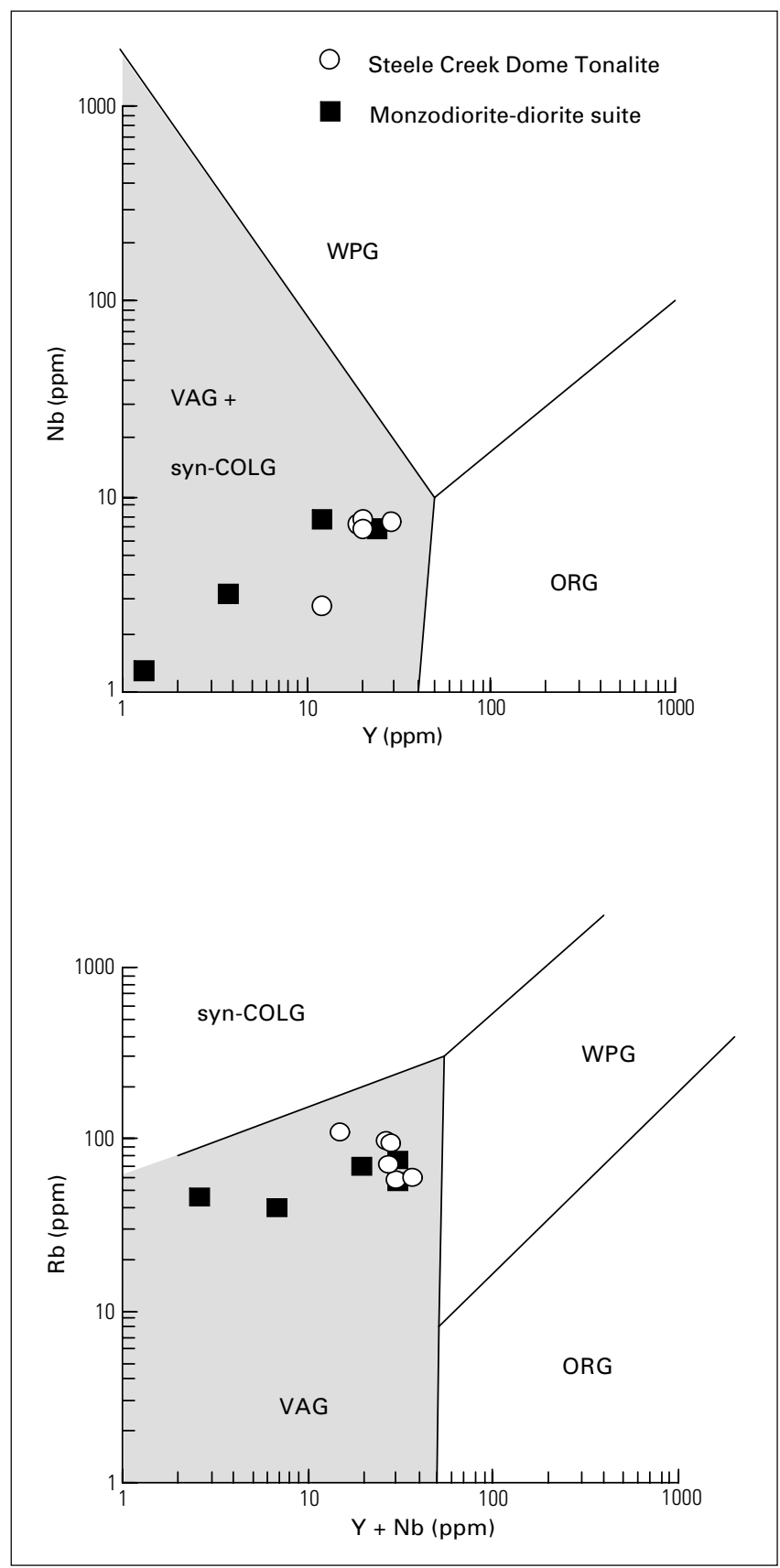

Figure 11. Diagram comparing samples of the tonalite from the Steele Creek Dome Tonalite (open circles) and monzodiorite-diorite suite (solid squares). Both sample suites fall within ranges seen for volcanic-arc granites (VAG). Fields for ranges in composition for within-plate granites (WPG), syn-collisional granites (syn-COLG), orogenic granites (ORG) are also included.

Fortymile River area was within a marine basin either adjacent to the continental margin or distal to an island-arc complex in a back-arc basin. Protoliths for the metasedimentary rocks within the area include graywacke, sulfide-rich and quartz-rich siliciclastic sediment, chert, limestone, and pelite. Hornblendebiotite schist is interlayered with the metasedimentary strata and is interpreted to have been mafic volcanic rocks whose composition was basaltic —one andesite sample is recognized. However, no felsic volcanic rocks have been identified within the supracrustal rocks of the study area. 
(2) Two groups of metabasalts are recognized, based on reconnaissance geochemical data; a tholeiitic, light-REEdepleted group and a calc-alkalic, light-REE-enriched group.

(3) The Steele Creek Dome Tonalite invaded the supracrustal rocks of the Taylor Mountain assemble prior to $184 \mathrm{Ma}$. Its absolute age is currently unknown. Mylonitic fabrics developed along the exposed northern and southern margins of the body indicates that ductile deformation and tectonism accompanied final emplacement of the body and could indicate that it is underlain by a thrust fault. No compositionally equivalent volcanic rock is recognized in the region, which suggests the plutonism was not coeval with volcanism and sedimentation represented by the supracrustal rocks. The tonalite underwent ductile deformation and recyrstallization during regional Middle Jurassic tectonism.

(4) The area was subjected to at least three major phases of deformation. The first $\left(D_{1}\right)$ produced a strong regional $S_{1}$ schistosity, bedding-parallel isoclinal folds, and local mineral lineations. The second $\left(\mathrm{D}_{2}\right)$ generated tight to isoclinal $\mathrm{F}_{2}$ folds (which folded the $\mathrm{S}_{1}$ schistosity) and produced weak axial-planar $S_{2}$ cleavage and both mineral and stretching lineations. $\mathrm{D}_{1}$ and $\mathrm{D}_{2}$ tectonic fabrics may record end members of a continuous, relatively long lived progressive ductile deformational event that was associated with peak regional Jurassic metamorphism and northward-directed thrusting. The youngest deformation $\left(\mathrm{D}_{3}\right)$ folded the ductile-fabric elements about south-plunging, east-vergent, open folds, and records eastdirected tectonic shortening. The regional extent of the $\mathrm{D}_{3}$ deformation is not known.

Acknowledgments.-Funding for this research was provided by the Mineral Resources Program of the U.S. Geological Survey for W.C. Day and B.M. Gamble and by the Alaska Department of Natural Resources for M.W. Henning. Field expenses were defrayed in part by a grant from the Alaska Science and Technology Foundation (grant \#98-1-079S). Laurel E. Burns of the Alaska Division of Geological and Geophysical Surveys was very helpful in providing the recent geophysical data flown by the State. Paul K. Sims and Benjamin F. Leonard graciously provided critical petrographic analysis and interpretations for rocks from the Fortymile River study area. The entire study would not have been possible without the continued hospitality of June and Larry Taylor. The unrivaled boating skills of Larry Taylor allowed access to difficult reaches of the Fortymile River. Discussions with Cynthia Dusel-Bacon concerning the mysteries of the Yukon-Tanana uplands were invaluable.

\section{References Cited}

Alaska Division of Geological and Geophysical Surveys, 1973, Aeromagnetic map, Eagle quadrangle: Alaska Division of Geological and Geophysical Surveys Open-File Report 18, 5 p., scale 1:250,000.

Alaska Division of Geological and Geophysical Surveys, 1998, Final data and plot files, southern Eagle and northern Tanacross quadrangles and part of the Livengood mining district, central Livengood quadrangle, Alaska: 4 CD-ROM set.

Aleinikoff, J.N., Dusel-Bacon, Cynthia, and Foster, H.L., 1979, Geochronologic studies in the Yukon-Tanana upland, east-central Alaska, in Albert, N.R.D., and Hudson, Travis, eds., The United States
Geological Survey in Alaska: Accomplishments During 1979: U.S. Geological Survey Circular 823-B, p. B34-B36.

Aleinikoff, J.N., Dusel-Bacon, Cynthia, Foster, H.L., and Nokleberg, W.J., 1987, Lead isotope fingerprinting of tectono-stratigraphic terranes, east-central Alaska: Canadian Journal of Earth Sciences, v. 24, p. 2089-2098.

Bouma, A.H., 1962, Sedimentology of some flysch deposits: Amsterdam, The Netherlands, Elsevier Publishing Company, 168 p.

Churkin, M.L., Jr., Foster, H.L., Chapman, R.M., and Weber, F.R., 1982, Terranes and suture zones in east-central Alaska: Journal of Geophysical Research, v. 87, p. 3718-3730.

Coney, P.J., and Jones, D.L., 1985, Accretion tectonics and crustal structure in Alaska: Tectonophysics, v. 119, p. 265-283.

Crock, J.G., Gough, L.P., Wanty, R.B., Day, W.C., Wang, B., Gamble, B.M., Henning, M., Brown, Z.A., and Meier, A.L., 1999, Regional geochemical results from the analyses of rock, water, soil, stream sediment, and vegetation samples-Fortymile River watershed, east-central, Alaska: U.S. Geological Survey Open-File Report 99-033.

Cushing, G.W., 1984, The tectonic evolution of the eastern Yukon-Tanana upland, Alaska: Albany, N.Y., State University of New York, M.S. thesis, $255 \mathrm{p}$.

Day, W.C., Wanty, R.B., Gamble, B.M., Henning, M.W., Crock, J., Gough, L., and Wang, B., 1998, Geology and regional surface-water quality of the Fortymile mining district, Yukon-Tanana uplands, Alaska [abs]: Geological Society of America, Abstracts with Programs, v. 30, no. 7, p. A-183.

Dusel-Bacon, C., Csejtey, B., Jr., Foster, H.L., Doyle, E.O., Nokleberg, W.J., and Plafker, G., 1993, Distribution, facies, ages, and proposed tectonic associations of regionally metamorphosed rocks in eastand south-central Alaska: U.S. Geological Survey Professional Paper 1497-C, 73 p., 2 plates.

Dusel-Bacon, C., and Hansen, V.L., 1991, High-pressure amphibolitefacies metamorphism and deformation within the Yukon-Tanana and Taylor Mountain terranes, eastern Alaska, in Bradley, D.C., and Dusel-Bacon, Cynthia, eds., Geological Studies in Alaska by the U.S. Geological Survey, 1991: U.S. Geological Survey Bulletin 2041, p. 140-159.

Dusel-Bacon, C., Hansen, V.L., and Scala, J.A., 1995, High-pressure amphibolite facies dynamic metamorphism and the Mesozoic tectonic evolution of an ancient continental margin, east-central Alaska: Journal of Metamorphic Geology, v. 15, p. 9-24.

Foster, H.L., 1969, Reconnaissance geology of the Eagle A-1 and A-2 quadrangles, Alaska: U.S. Geological Survey Bulletin 1271-G, 30 p., 1 plate.

Foster, H.L., 1976, Geologic map of the Eagle quadrangle, Alaska: U.S. Geological Survey Miscellaneous Investigations Map I-922, scale $1: 250,000$.

Foster, H.L., 1992, Geologic map of the Yukon-Tanana region, Alaska: U.S. Geological Survey Open-File Report 92-213, 26 p., 1 plate.

Foster, H.L., Albert, N.R.D., Barnes, D.F., Curtin, G.C., Griscom, Andrew, Singer, D.A., and Smith, J.G., 1976, The Alaska Mineral Resource Assessment Program-Background information to accompany folio of geologic and mineral resources maps of the Tanacross quadrangle, Alaska: U.S. Geological Survey Circular 734, 23 p.

Foster, H.L., Cushing, G.W., and Keith, T.E.C., 1985, Early Meozoic tectonic history of the Boundary Area, east-central Alaska: Geophysical Research Letters, v. 12, p. 553-556.

Foster, H.L., Keith, T.E.C., and Menzie, W.D., 1994, Geology of the YukonTanana area of east-central Alaska, in Plafker, George, and Berg, H.C., eds., The Geology of Alaska: Geological Society of America, Geology of North America, v. G-1, p. 205-240. 
Foster, H. L., and O'Leary, R.M., 1982, Gold found in bedrock of Lost Chicken Creek gold placer mine, Fortymile area, Alaska: U.S. Geological Survey Circular 844, p. 62-63.

Hansen, V.L., Heizler, M.T., and Harrison, T.M., 1991, Mesozoic thermal evolution of the Yukon-Tanana composite terrane-New evidence from ${ }^{40} \mathrm{Ar} /{ }^{39} \mathrm{Ar}$ data: Tectonics, v. 10 , no. 1, p. 51-76.

Hansen, V.L., and Dusel-Bacon, Cynthia, 1998, Structural and kinematic evolution of the Yukon-Tanana upland tectonites, east-central Alaska-A record of late Paleozoic to Mesozoic crustal assembly: Geological Society of America Bulletin, v. 110, p. 211-230.

Haskin, L.A., and Paster, T.P., 1979, Geochemistry and mineralogy of the rare earths, in Handbook Physical Chemistry of Rare Earths, v. 3, chapter 21, p. 1-80: Amsterdam, Netherlands, North-Holland Publishing Company.

Hawkins, D.B., Forbes, R.B., Hok, C.I., and Dinkel, D., 1982, Arsenic in water, soil, bedrock, and plants of the Ester dome area of Alaska: University of Alaska, Fairbanks Institute of Water Resources, Report IWR-103, $82 \mathrm{p}$.

Henning, M.W., 1982, Geology and stratigraphy, Skajit Formation, Wiseman B-5 quadrangle: Alaska Division of Geological and Geophysical Surveys AOF 158.

Jensen, L.S., 1976, A new cation plot for classifying subalkalic volcanic rocks: Ontario Ministry of Natural Resources Miscellaneous Paper $66,22 \mathrm{p}$.

Reviewers: E.H. Dewitt, Cynthia Dusel-Bacon, K.V. Evans, and P.K. Sims
Leeman, W.R., and Phelps, D.W., 1981, Partitioning of rare earths and other trace elements between sanidine and coexisting volcanic glass: Journal of Geophysical Research, v. 86, no. B11, p. 10193-10199.

Lister, G.S., and Snoke, A.W., 1984, S-C mylonite: Journal of Structural Geology, v. 6, p. 617-638.

Mertie, J.B., Jr., 1938, Gold placers of the Fortymile, Eagle, and Circle districts, Alaska: U.S. Geological Survey Bulletin 897-C, p. 133-261.

Mortensen, J., 1992, Pre-mid-Mesozoic tectonic evolution of the YukonTanana terrane: Tectonics, v. 11, p. 836-853.

Nash, W.P., and Crecraft, H.R., 1985, Partition coefficients for trace elements in silicic magmas: Geochimica et Cosmochimica Acta, v. 49, p. 2309-2322.

Saltus, R.W., 1975, Carbonate facies in geologic history: New York, Springer-Verlag, $471 \mathrm{p}$.

Saltus, R.W., Connard, G.G., and Hill, P.W., 1999, Alaska aeromagnetic compilation-Digital grids and survey data: U.S. Geological Survey Open-File Report 99-502, CD-ROM.

Wilson, J.L., Connard, G.G., and Hill, P.W., 1999, Alaska Aeromagnetic Compiliation-Digital Grids and Survey Data, U.S. Geological Survey Open-File Report 99-502, CD-ROM.

Yeend, W.E., 1996, Gold placers of the historical Fortymile River region, Alaska: U.S. Geological Survey Bulletin 2125, 75 p., 1 plate. 


\title{
Stratigraphic Variation in Petrographic Composition of Nanushuk Group Sandstones at Slope Mountain, North Slope, Alaska
}

\author{
By Mark J. Johnsson and Nikolas K. Sokol
}

\begin{abstract}
Fluvial, deltaic, and marine sediments of the Nanushuk Group (Albian to Cenomanian), North Slope, Alaska, record Early Cretaceous orogenic events in the Brooks Range to the south. The 1,060-m section at Slope Mountain is part of the Lower Cretaceous Umiat Delta, shed from the Endicott and De Long Mountains subterranes in the central Brooks Range. These sandstones are litharenites dominated by metasedimentary lithic fragments. Subtle and previously unrecognized stratigraphic variations in composition (up-section increases in metasedimentary lithic fragments, volcanic lithic fragments, and quartz interpreted to be of metamorphic origin) reflect a combination of facies migration and changes in provenance associated with unroofing of the ancestral Brooks Range. We recognize stratigraphic variation in sandstone composition at Slope Mountain whereas previous workers have not, probably because of our use of finely subdivided point-counting categories. The source of the volcanic lithic fragments in the Nanushuk Group remains enigmatic; the most likely candidate is a now-eroded volcanic arc, perhaps a volcanic superstructure to granitic rocks of the Ruby terrane to the south.
\end{abstract}

\section{Introduction}

The Albian to Cenomanian Nanushuk Group is a laterally extensive series of fluvial/deltaic/marine deposits shed into the central and western parts of the Colville Basin (North Slope of Alaska) in response to uplift in the Brooks Range orogen to the south (fig. 1). The unit represents the second of three principal Mesozoic pulses of coarse clastic sediments shed into the basin. The lower part of each sedimentation pulse is characterized by marine shale and interbedded turbidite sandstone, grading upward to shelf sandstone and shale. These rocks in turn grade upward to nonmarine, coal-bearing sandstone, shale, and conglomerate (Howell and others, 1992). Each cycle thins and fines to the north-northeast, indicating the direction of basin filling
(Molenaar, 1983, 1988; Molenaar and others, 1987). The Nanushuk Group represents the upper portion of the middle sedimentation pulse of orogenic sedimentation and provides a record of ancestral Brooks Range uplift in the Early Cretaceous (Bird and Molenaar, 1992) .

As a target of hydrocarbon exploration, the Nanushuk Group has seen considerable study. Early workers (Brosgé and Wittington, 1966; Chapman and others, 1964; Chapman and Sable, 1960; Detterman and others, 1963, 1975; Gryc and others, 1951; Smiley, 1966, 1969a, 1969b) concentrated on placing the unit in a regional context. Building on these studies, the U.S. Geological Survey began an exploration of the Naval Petroleum Reserve in Alaska (NPRA) in the mid 1970's and considered the Nanushuk Group a potential hydrocarbon reservoir. These studies, summarized in Ahlbrandt (1979b), Huffman (1985), and Gryc (1988), provided more detailed sedimentologic, petrographic and paleogeographic information. More recently, the Nanushuk Group has been placed in a regional sequence-stratigraphic context (Morrow, 1985, 1987; Myers and others, 1993, 1995; Noonan, 1987; Schenk and Bird, 1993), and newer petrographic data has been obtained from limited areas in the central North Slope (Meier, 1995).

The purpose of this study is to reevaluate stratigraphic variations in composition within the Nanushuk Group at a wellexposed section at Slope Mountain, central North Slope, in light of the recent sequence-stratigraphic context provided by Schenk and Bird (1993). A secondary goal is to compare the petrographic data of previous workers. This is a preliminary investigation undertaken to lay groundwork for a regional paleoclimatic study utilizing variations in the compositions of fluvial/deltaic sandstones of the North Slope to assess changing climate in northern Alaska. In addition, the reservoir quality of the Nanushuk Group sandstones is of interest for hydrocarbon potential on the North Slope. Petrographic data, especially the distribution of framework components whose presence tends to be negatively correlated with porosity (e.g., ductile lithic fragments), may be of use in assessing hydrocarbon reservoir potential of the Nanushuk Group sandstones. 


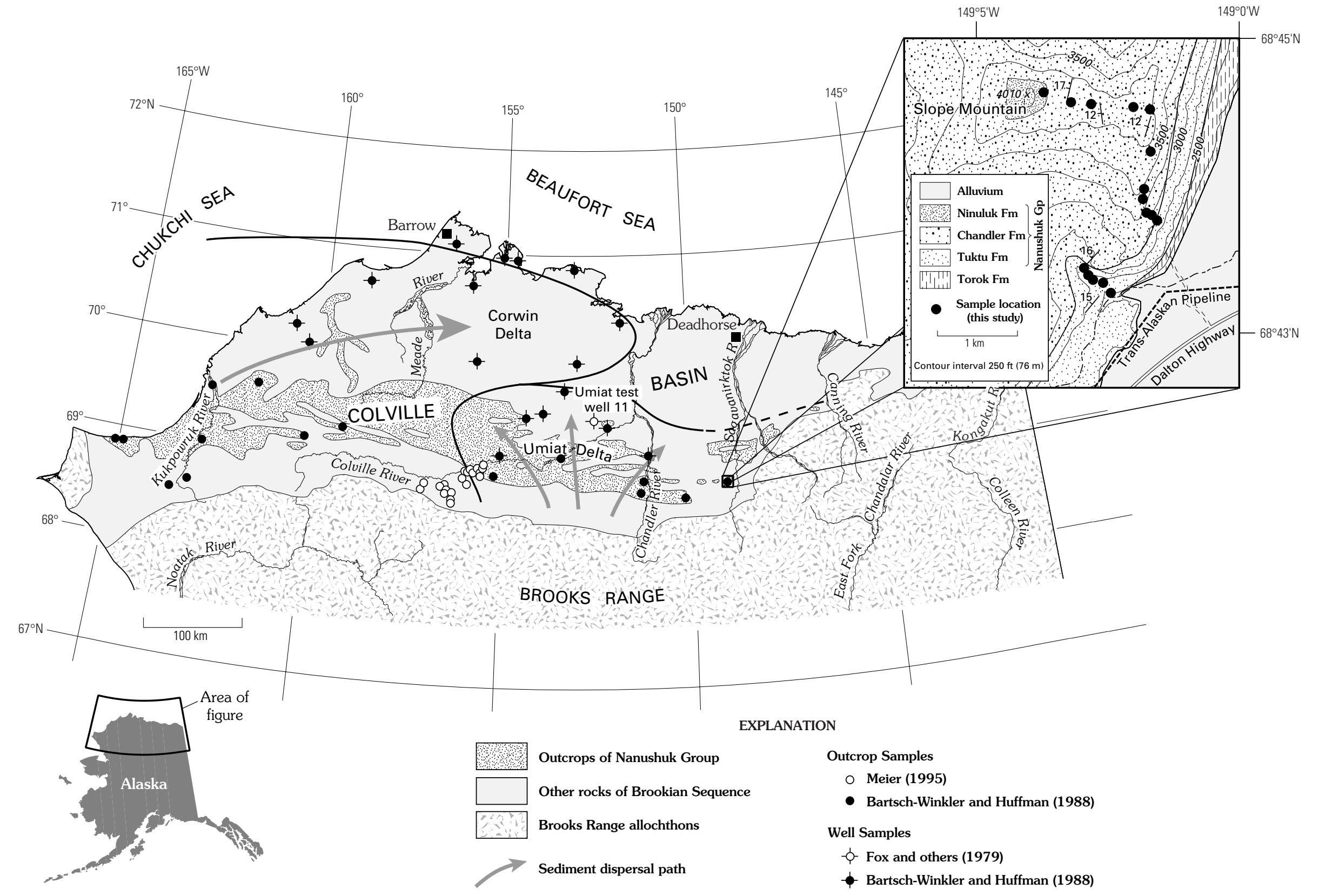

Figure 1. Map of the North Slope of Alaska showing outcrop pattern of the Nanushuk Group (adapted from Mull, 1985) and estimated extent of Corwin and Umiat Deltas (adapted from Ahlbrandt, 1979b; Huffman and others, 1985). Also shown are locations of outcrop and well samples from the Nanushuk Group and Torok Formation from Fox and others (1979), Bartsch-Winkler and Huffman (1988), and Meier (1995). Inset shows geologic map of Slope Mountain area (adapted from Reifenstuhl and others, 1994), showing locations of samples examined in this study. 


\section{Regional Geology}

Collision between the Arctic-Alaska plate and an oceanic island arc during Late Jurassic to Early Cretaceous time initiated the Brooks Range orogeny (Moore and others, 1994). The resultant tectonic loading and imbrication of the earlier existing margin sequence (Ellesmerian sequence) caused the subsidence that resulted in the Colville Basin. This basin has been a trap for sediments eroded from the Brooks Range orogen since the beginning of the Brookian orogeny (Bird and Molenaar, 1992).

The Brooks Range orogen consists of a package of imbricate thrust sheets, or allochthons, that have been grouped into terranes and subterranes on the basis of tectonic affinity (Moore and others, 1994). Although there is some variation in the stratigraphic makeup of these terranes along the strike of the orogen, the tectonic stratigraphy throughout the Brooks Range is roughly similar. The structurally highest allochthons (Misheguk Mountain, Kanuti, Copter Peak, and Narvak allochthons) are assigned to the Angayucham terrane (Silberling and others, 1994) and consist of gabbro, mafic volcanics, cherts, and shales of oceanic affinity (Loney, 1989; Moore and others, 1994; Pallister and Budahn, 1989; Patton and others, 1994). The Angayucham terrane, which is believed to represent obducted oceanic crust (Pallister and Budahn, 1989; Patton and others, 1994), is underthrust by a series of allochthons making up the Arctic Alaska terrane. Structurally highest in the Arctic Alaska terrane are the Slate Creek, Coldfoot, and Hammond allochthons, each assigned to a distinct subterrane of the Arctic Alaska terrane. These subterranes contain greenschist- and locally blueschistand amphibolite-facies phyllites, schists, and marbles of mostly lower Paleozoic age (Silberling and others, 1994). These medium- to high-grade metamorphic rocks, commonly showing penetrative deformation (especially in the Slate Creek and Coldfoot subterranes), are underthrust by a series of allochthons at lower metamorphic grade, making up the Endicott and De Long Mountains subterranes. These subterranes consist of rocks belonging to the Ellesmerian passive margin sequence (Moore and others, 1994). The oldest rocks belonging to the Ellesmerian sequence and preserved within the Endicott and De Long Mountains subterranes belong to the Endicott Group. This group consists of lower greenschist facies phyllites and unmetamorphosed shales (Devonian Hunt Fork Shale) overlain by the shallow-marine Noatak Sandstone, a thick series of fluvial chertpebble conglomerates (Devonian-Lower Mississippian Kanayut Conglomerate), and the shallow-marine Kayak Shale, of Mississippian age. The Endicott Group is overlain by thick platform carbonates (Lisburne Group) and laterally equivalent deep-water shales (Kuna Formation) of Mississippian-Pennsylvanian age, and a Permian to Lower Cretaceous condensed section made up of shales and cherty shales (Etivuluk Group and Ipewik Unit; Moore and others, 1994). The Mississippian through Cretaceous sediments are equivalent to those found in the North Slope subterrane to the north.

North of the orogen lies the North Slope subterrane of the Arctic Alaska terrane. Three stratigraphic sequences, reflecting the changing depositional setting of the North Slope over time (Bird and Molenaar, 1992), are developed on the North Slope. The oldest stratigraphic sequence is the Franklinian assemblage, which consists of pre-Mississippian metacarbonates, cherts, slates, quartzites, and some granitic and volcanic rocks that were complexly deformed and metamorphosed by a poorly understood orogenic event that occurred prior to the Middle Devonian (Anderson and others, 1994). The unconformably overlying Ellesmerian sequence consists, on the North Slope, of Carboniferous through Jurassic marine-shelf or platform-carbonate rocks and shale that is about $1,250 \mathrm{~m}$ thick. In the Endicott and De Long Mountains subterranes of the Brooks Range orogen to the south, these units also are present, but they overlie the Upper Devonian southward-prograding clastic wedge (Hunt Fork Shale, Noatak Sandstone, and Kanayut Conglomerate). The Ellesmerian sequence is the product of uplift and erosion related to the Ellesmerian orogeny of Lerand (1973). The third and youngest stratigraphic sequence found in the North Slope subterrane is the Brookian sequence, which dates from the Late Jurassic/Early Cretaceous through the late Tertiary. Sediments of the Brookian sequence were shed into the Colville Basin in three distinct pulses in response to the ongoing Brookian orogeny to the south. The Nanushuk Group represents the coarse, upper portion of the middle (Early Cretaceous) pulse. The timing of this pulse is roughly coincident with the collapse of the Brooks Range orogen by south-verging detachment faulting on the southern flank of the orogen (Miller and Hudson, 1991).

\section{Sedimentology of the Nanushuk Group}

\section{Depositional Environments and Paleogeography}

Abundant evidence, summarized in Ahlbrandt (1979b), Huffman (1985), and Gryc (1988), points to fluvial, deltaic, and marine environments for the Nanushuk Group. In the Aptian and earliest Albian, the Colville Basin was a deep-water basin receiving shales and sparse turbidites from the south (lower to middle Albian Torok Formation; Huffman and Ahlbrandt, 1979). Into this basin prograded two geographically and sedimentologically distinct delta systems (fig. 1), both assigned to the Nanushuk Group (Ahlbrandt, 1979a). The western delta system, the Corwin Delta of Ahlbrandt and others (1979), prograded to the northeast, suggesting a western or southwestern source. In the central North Slope, however, east-west facies trends and isopach data suggest northward progradation of a second delta complex (Mull, 1985), referred to by Ahlbrandt and others (1979) as the Umiat Delta. Although paleocurrent data are widely scattered in these fluvial/deltaic systems (see data below, and Ahlbrandt and others, 1978), sand-percentage contours, incised valley fill, and the area of coastal barrier sandstone build-up are all consistent with the presence of two distinct delta systems operating on the North Slope in Albian time (Huffman and others, 1985).

Petrographic data also support the existence of two distinct delta systems. The sediments deposited into the Umiat Delta are phyllarenites as compared to the more varied litharenite composition of the western and much larger Corwin Delta (BartschWinkler and Huffman, 1988). Although both delta systems originated in the ancestral Brooks Range, the Corwin Delta was additionally fed by the Herald arch-Tigara uplift to the west 
(Mull, 1985), whereas the Umiat Delta likely was fed only by rocks exposed within the ancestral Brooks Range immediately to the south (Ahlbrandt and others, 1979). In addition to a more limited source of sediment, the rapid northward facies change to the basinal shales of the Torok Formation suggest that sediments of the Umiat Delta were not transported as far as were those in the Corwin Delta. This inference is born out by petrographic data; sandstones of the Corwin delta tend to be more highly altered and matrix rich than those from the Umiat Delta (Bartsch-Winkler and Huffman, 1988). The Corwin Delta appears to be a river-dominated system, whereas the Umiat Delta is marine-dominated (Ahlbrandt, 1979a).

\section{Stratigraphy}

The Nanushuk Group conformably overlies the lower part of the shaley Torok Formation in the central North Slope (fig. 2) but is coeval with and laterally equivalent to the upper part of the Torok Formation in the east (Molenaar, 1988). The Nanushuk Group is unconformably overlain by the Upper Cretaceous Seabee and Prince Creek Formations. Stratigraphic terminology within the Nanushuk Group is complex. In the study area (the Umiat Delta), the group is divided, from bottom to top, into the largely marine Tuktu Formation, the estuarine to fluvial Chandler Formation, and the marine Ninuluk Formation (fig. 2). The Chandler Formation can be subdivided into the Killik and the overlying Niakogon Tongues. Upper and lower divisions of the Killik tongue are recognized on the basis of depositional environments; fluvial rocks make up the upper part, whereas transitional (fluvial-marine) rocks make up the lower part. These units are well displayed at an easily accessible outcrop on Slope Mountain, central North Slope (fig. 1), the study area of this report. This outcrop was first described by Keller and others (1961) who measured the section and reported Aptian megafossils from the Torok Formation. It was later measured in more detail by Huffman and others (Huffman, Ahlbrandt, Pasternook, Stricker, and others, 1981), and samples resulting from these efforts were examined by Bartsch-Winkler and Huffman (1988). More recent work at this outcrop includes geologic mapping by Reifenstuhl and others (1994) and sequence stratigraphic analysis by Myers and others (1993, 1995) and Schenk and Bird (1993).

The age of the Nanushuk Group is coarsely constrained by megafossils as early Albian (or late Aptian, see Scott and Smiley, 1979) to early Cenomanian (Elder and others, 1989), or approximately 121 to $99 \mathrm{Ma}$. The unit appears to become younger to the north and east (Huffman and others, 1988; Scott and Smiley, 1979), consistent with the interpretation that it represents a prograding fluvial-deltaic system (Huffman and others, 1988). The age span of the Slope Mountain section itself is poorly constrained as Aptian-Albian (Reifenstuhl and Plumb, 1993). The only published date that is more specific is based on a single sample yielding a middle to late Albian pollen (Reifenstuhl and Plumb, 1993). This, together with correlations with nearby Nanushuk sections reported in Elder and others (1989),

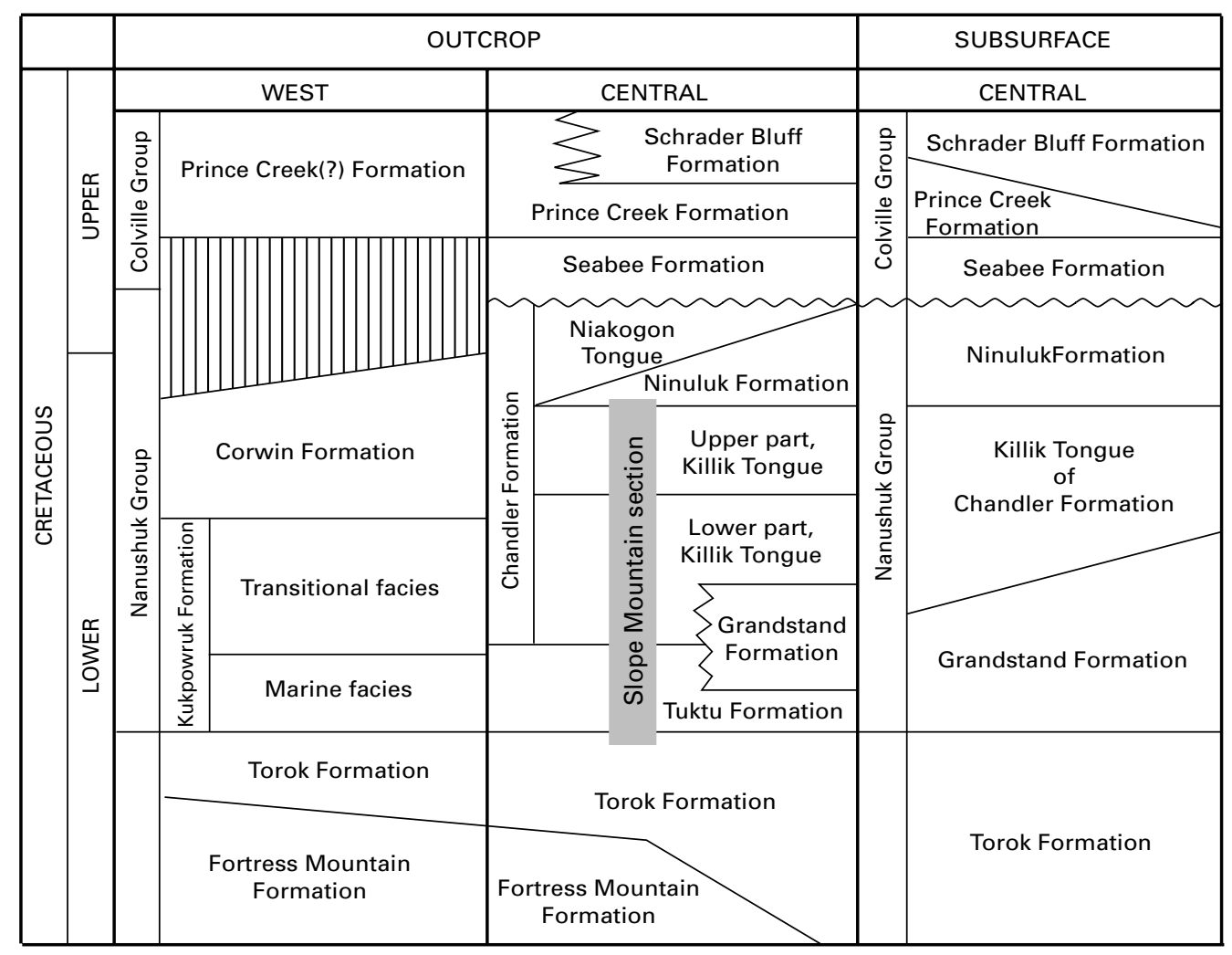

Figure 2. Stratigraphic nomenclature of Nanushuk Group and surrounding units, western and central North Slope, showing interval covered by Slope Mountain section. Adapted from Ahlbrandt and others (1979a). 
suggests that the Slope Mountain section could span most of the Aptian and Albian and, according to the latest Mesozoic time scale (Gradstein and others, 1994), may record between 8 and 14 million years of sedimentation.

\section{Previous Petrographic Work}

As part of the U.S. Geological Survey's study of petroleum potential in NPRA, Bartsch-Winkler and Huffman undertook the analysis of sandstones of the Nanushuk Group and the Torok Formation from several measured sections and numerous scattered outcrop and well samples in northern Alaska (Bartsch-Winkler, 1979; Bartsch-Winkler, 1985; Bartsch-Winkler and Huffman, 1981a, 1981b); these data are summarized in Bartsch-Winkler and Huffman (1988). The Corwin and Umiat Delta complexes, which represent separate transport and sedimentation units (Ahlbrandt, 1979b), are petrographically distinct as well, reflecting their different source areas. Nanushuk Group samples from the Corwin Delta are sedimentary litharenites and are markedly more feldspathic and much richer in sedimentary lithic fragments relative to metamorphic lithic fragments than are those from the Umiat Delta, which are classified as phyllarenites (fig. 3A). Sandstones of the Torok Formation from beneath both deltas are, in general, somewhat more feldspathic than Nanushuk Group sandstones, and lithic fragments tend to be mostly sedimentary in composition (fig. $3 A$ ). Using the provenance fields of Dickinson (1985), all of the sandstones from both formations are consistent with a recycled orogen source.

Meier (1995) examined a smaller set of Nanushuk and Torok sandstones from the overlap region between the Corwin and Umiat Deltas, in a position more proximal to the Brooks Range than most of the samples examined by Bartsch-Winkler and Huffman (1988). These samples are uniformly less quartzose than those examined by Bartsch-Winkler and Huffman (1988) (fig. 3A). Torok Formation sandstones are richer in lithic fragments than Nanushuk Group samples but, unlike those examined by Bartsch-Winkler and Huffman (1988), are not appreciably more feldspathic (fig. 3A). The largest differences between the studies of Bartsch-Winkler and Huffman (1988) and Meier (1995) are in the compositions of lithic fragments (fig. 3A); Meier (1995) found far fewer volcanic lithic fragments in all samples and a far lower metamorphic/sedimentary lithic fragment ratio than did Bartsch-Winkler and Huffman (1988) for their Umiat Delta samples (fig. 3A). These differences are difficult to resolve with existing models for the development of the Umiat Delta system and may, in fact, be partly procedurali.e., stemming from different point-counting criteria between the two studies.

Bartsch-Winkler and Huffman (1988) found very little systematic stratigraphic variation in the proportions of various framework components in most of the measured sections they examined. Fox (1979) and Fox and others (1979), however, detected a fairly pronounced systematic variation among sandstones of the Grandstand (equivalent to lower Tuktu Formation; fig. 2), Chandler, and Ninuluk Formations in Umiat test well 11 (fig. 1): overall lithic fragments increase dramatically up-section at the expense of total quartz (fig. $3 B$ ).
Bartsch-Winkler and Huffman (1988) examined Nanushuk Group sandstones from the Slope Mountain section that is the object of this study. They found stratigraphic variation among the grain types recognized to be subtle at best (fig. 3C). Most compositional parameters show wide fluctuation, but there nevertheless is a slight up-section increase in the abundance of volcanic lithic fragments, and the ratio of metamorphic lithic fragments to sedimentary lithic fragments decreases slightly in an up-section direction. Polycrystalline quartz relative to total quartz also shows wide variation but does show an overall slight decrease up-section from about 40 percent to around 30 percent (fig. 3C).

These subtle stratigraphic trends led us to speculate that a finer subdivision of grain varieties might reveal stratigraphic trends not recognized by previous studies. Further, in light of recent sequence-stratigraphic models for this section (Morrow, 1985, 1987; Myers and others, 1993, 1995; Noonan, 1987; Schenk and Bird, 1993), compositional data may be placed in a more complex depositional model than previously attempted. Finally, additional petrographic data and models for controls on sandstone composition within the Nanushuk Group might have important reservoir-quality implications. Accordingly, we undertook a reexamination of stratigraphic variation in petrographic components in part of the Umiat Delta by resampling and reanalyzing samples from the readily accessible and very complete section exposed at Slope Mountain.

\section{Methods and Results}

We collected 16 medium-grained sandstones from the Tuktu, Chandler, and Ninuluk Formations at Slope Mountain, keying them into the measured section of Huffman, Ahlbrandt, Pasternook, Fox, and others (1981) and Huffman, Ahlbrandt, Pasternook, Stricker, and others (1981) (figs. 1 and 4). In conjunction with Christopher Schenk and Donald Gautier (U.S. Geological Survey), we measured the portion of the section straddling a suspected sequence boundary between the lower and upper parts of the Killik Tongue (Chandler Formation) and collected a limited set of paleocurrent data from foreset beds on trough crossbedding (fig. 4). Standard thin sections were prepared from the sandstones and were stained for both plagioclase and potassium feldspars according to the methods of Houghton (1980). Petrographic analysis was performed with sample numbers covered in order to insure objective classification of grain types. At least 300 framework grains per sample were identified using the Gazzi-Dickinson method, by which data are assigned to categories based on subgrains larger than $63 \mu \mathrm{m}$. This procedure helps normalize for compositional differences due solely to grain size (Dickinson, 1970; Gazzi, 1966; Gazzi and Zuffa, 1970).

Because one object of this study was to investigate the power of finely discriminated grain varieties to elucidate stratigraphic variations not apparent in gross grain types, 33 framework-grain categories were recognized in the Slope Mountain sandstones. These varieties were later combined and assigned to the 19 framework categories listed in table 1; see the caption of that table for the definition of categories and the criteria used to discriminate between grain types. 


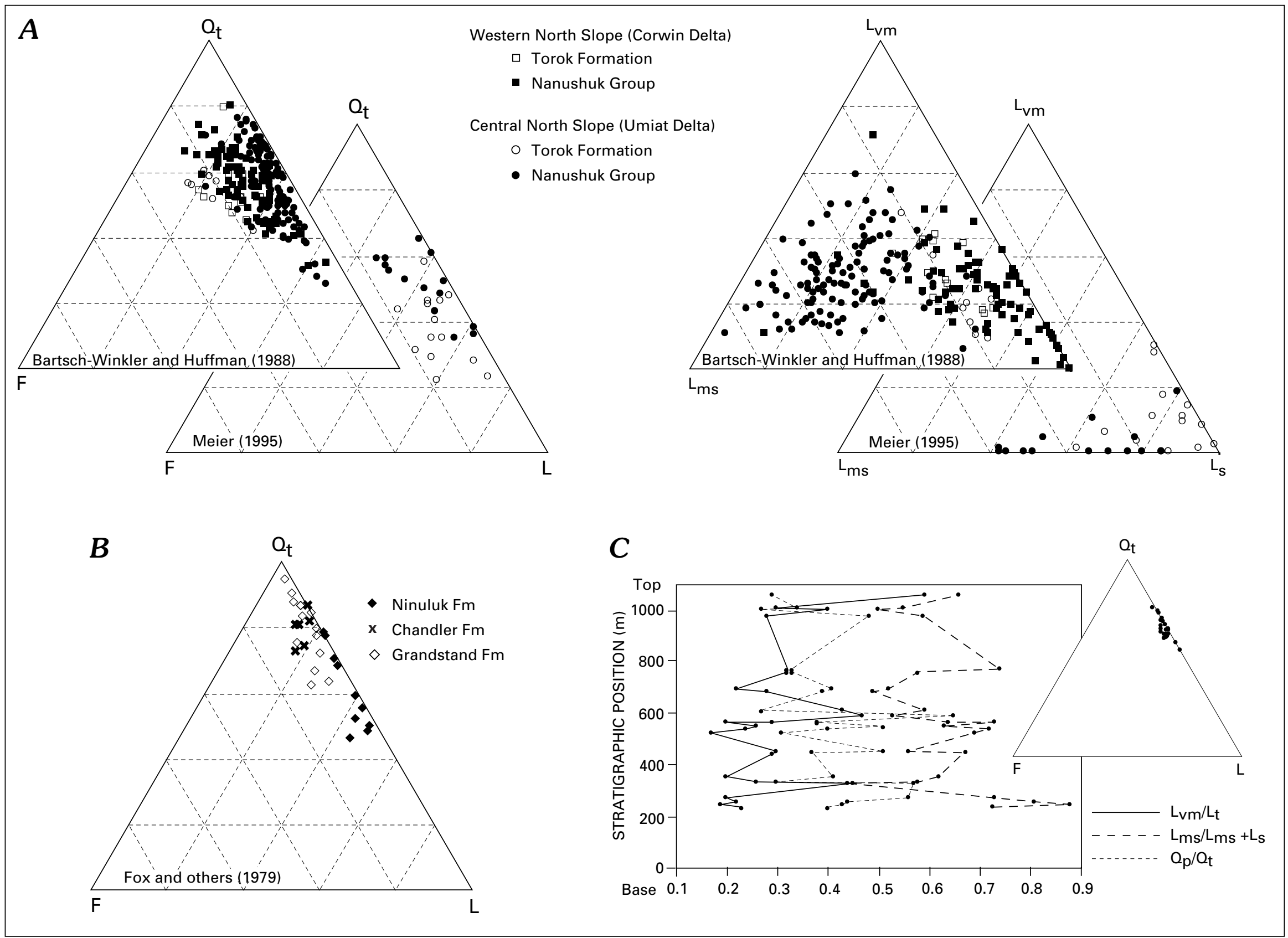

Figure 3. Previously reported petrographic data from the Nanushuk Group and Torok Formation. $A$, Comparison of $\mathrm{Q}_{\mathrm{t}} \mathrm{FL}$ and $\mathrm{L}_{v m} \mathrm{~L}_{\mathrm{ms}} \mathrm{L}_{s}$ compositions of western North Slope (Corwin Delta) samples and central North Slope (Umiat Delta) samples, as reported by Bartsch-Winkler and Huffman (1988), and Meier (1995). B, Stratigraphic variation in $0_{f} F L$ composition of Nanushuk Group samples from Umiat test well 11 (see fig. 1) as reported by Fox and others (1979). $C$, Stratigraphic variation in $L_{v m} / L_{t}, Q_{p} / Q_{t}$, and $L_{m s} / L_{m s} L_{s}$ at Slope Mountain (Marmot syncline) section, as reported by Bartsch-Winkler and Huffman (1988). Inset shows $\mathrm{Q}_{\mathrm{F}} \mathrm{FL}$ composition of Slope Mountain samples. See table 1 for explanation of petrographic abbreviations. 


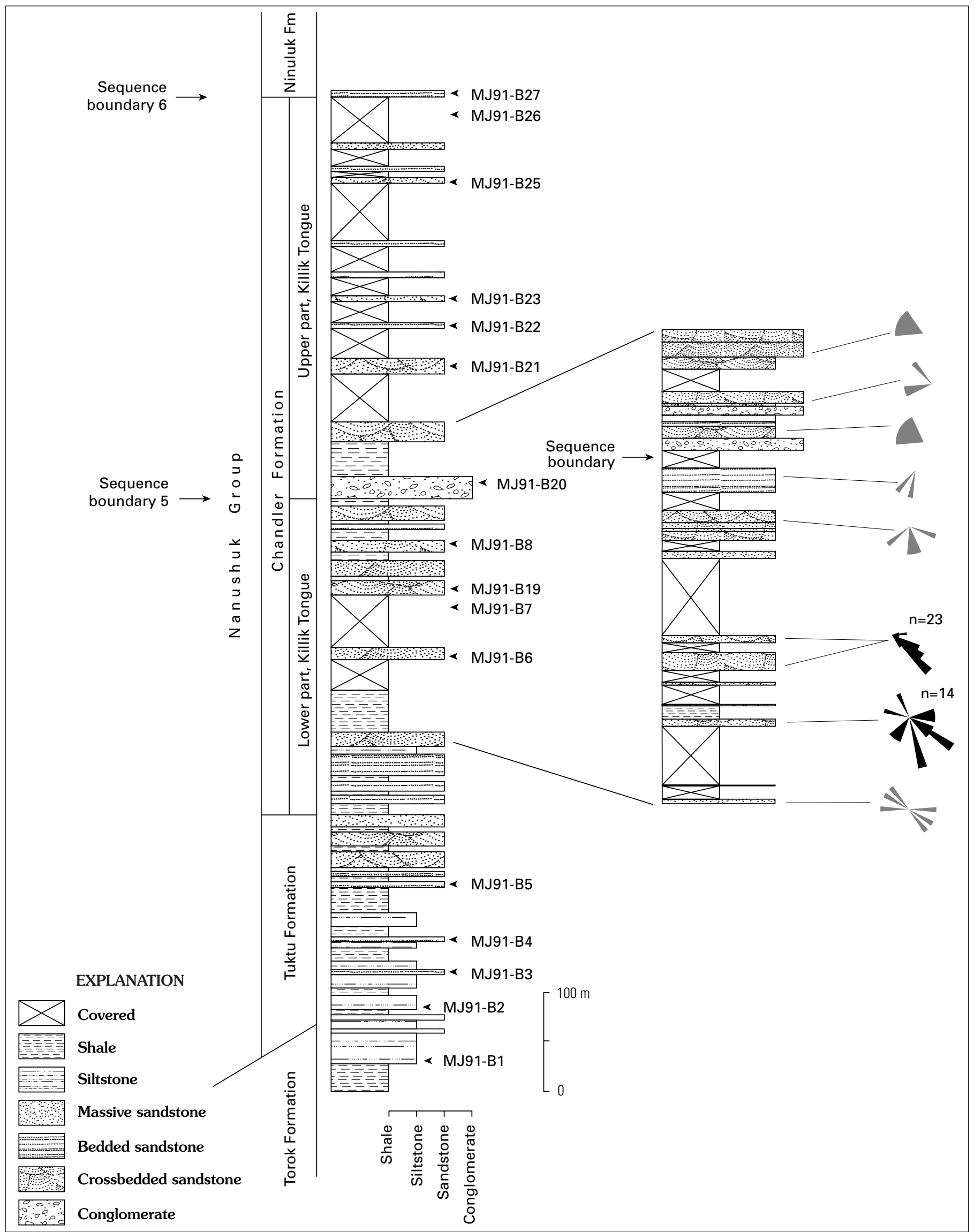

Figure 4. Stratigraphic section of Slope Mountain outcrop, as adapted from Huffman, Ahlbrandt, Pasternook, Fox, and others (1981) and Huffman, Ahlbrandt, Pasternook, Stricker, and others (1981), showing approximate locations of samples collected during this study. Expanded section, measured during this study, courtesy of Christopher Schenk. Paleocurrent roses (true north to top of page) are shown in black if the number of measurements exceeds 10, in gray otherwise. Formation picks from Huffman (1989); sequence boundaries from Schenk and Bird (1993). 
Table 1. Summary petrographic data of principal framework and nonframework components of Nanushuk Group sandstones ${ }^{1}$ as a percentage of total rock.

\begin{tabular}{|c|c|c|c|c|c|c|c|c|c|c|c|c|c|c|c|c|c|c|c|c|c|c|c|c|c|}
\hline Sample & Position $^{2}$ & $\mathrm{Q}_{\mathrm{ms}}$ & $\mathrm{Q}_{\mathrm{mu}}$ & $\mathrm{Q}_{\mathrm{ps}}$ & $\mathrm{Q}_{\mathrm{pu}}$ & $\mathrm{Q}_{\mathrm{pf}}$ & $\mathrm{Q}_{\mathrm{pc}}$ & $\mathrm{F}_{\mathrm{k}}$ & $\mathrm{F}_{\mathrm{p}}$ & Musc & Chlo & Calc & Opaq & $\mathrm{L}_{\text {smud }}$ & $\mathrm{L}_{\text {ssilt }}$ & $\mathrm{L}_{\mathrm{msf}}$ & $\mathrm{L}_{\mathrm{msm}}$ & $\mathrm{L}_{\mathrm{vm}}$ & $\mathrm{L}_{\text {other }}$ & Alt & Mat & Pseudo & $\mathrm{Cem}$ & Rep & Por \\
\hline MJ91-B27 & $1069 \mathrm{~m}$ & 21.3 & 12.6 & 10.5 & 0.6 & 2.3 & 8.5 & 0.0 & 0.3 & 1.8 & 0.0 & 0.0 & 0.9 & 7.3 & 0.0 & 16.1 & 1.2 & 1.5 & 0.0 & 4.4 & 3.8 & 3.2 & 2.9 & 0.9 & 0.0 \\
\hline MJ91-B26 & 996 & 4.4 & 14.7 & 18.9 & 3.1 & 6.7 & 2.5 & 0.0 & 0.0 & 1.7 & 1.4 & 0.0 & 0.3 & 5.6 & 0.0 & 21.1 & 1.4 & 0.6 & 0.8 & 2.8 & 3.9 & 6.7 & 2.8 & 0.8 & 0.0 \\
\hline MJ91-B25 & 918 & 14.6 & 10.7 & 16.4 & 1.5 & 3.0 & 3.6 & 0.0 & 0.9 & 1.8 & 0.0 & 0.0 & 0.3 & 8.1 & 0.3 & 22.7 & 1.8 & 0.9 & 0.0 & 4.8 & 3.3 & 2.4 & 2.4 & 0.0 & 0.0 \\
\hline MJ91-B23 & 797 & 12.0 & 24.8 & 8.5 & 2.0 & 2.3 & 8.5 & 7.3 & 1.7 & 0.3 & 0.0 & 0.9 & 0.3 & 5.5 & 0.0 & 6.4 & 0.0 & 8.7 & 0.0 & 2.3 & 4.1 & 2.3 & 0.9 & 0.6 & 0.0 \\
\hline MJ91-B22 & 762 & 2.5 & 25.8 & 6.7 & 12.9 & 6.1 & 9.5 & 0.0 & 0.0 & 0.3 & 0.0 & 0.0 & 0.6 & 5.5 & 0.0 & 9.2 & 11.7 & 2.5 & 0.0 & 0.0 & 0.9 & 5.2 & 0.6 & 0.0 & 0.0 \\
\hline MJ91-B21 & 720 & 5.4 & 30.6 & 11.0 & 4.0 & 4.8 & 1.9 & 1.6 & 0.0 & 0.0 & 0.3 & 0.3 & 0.0 & 3.2 & 0.0 & 9.9 & 0.3 & 5.1 & 0.0 & 8.9 & 1.3 & 4.0 & 5.9 & 1.3 & 0.0 \\
\hline MJ91-B20 & 622 & 3.8 & 22.7 & 10.7 & 1.9 & 2.1 & 1.7 & 0.0 & 0.2 & 0.5 & 0.0 & 0.0 & 0.0 & 5.5 & 0.0 & 18.4 & 1.7 & 4.5 & 0.0 & 10.3 & 2.9 & 6.0 & 3.3 & 3.8 & 0.0 \\
\hline MJ91-B8 & 524 & 4.5 & 22.0 & 13.8 & 3.7 & 4.2 & 5.9 & 0.0 & 0.0 & 0.0 & 0.0 & 0.0 & 0.3 & 2.0 & 1.4 & 21.1 & 2.0 & 4.5 & 0.3 & 3.1 & 1.1 & 9.0 & 0.8 & 0.3 & 0.0 \\
\hline MJ91-B19 & 489 & 6.3 & 18.9 & 5.7 & 11.1 & 4.2 & 3.3 & 0.0 & 0.0 & 0.0 & 0.0 & 0.0 & 0.0 & 0.9 & 0.0 & 24.9 & 9.3 & 5.4 & 0.3 & 4.2 & 2.1 & 3.3 & 0.0 & 0.3 & 0.0 \\
\hline MJ91-B7 & 460 & 6.6 & 16.1 & 0.6 & 7.2 & 5.2 & 13.2 & 0.0 & 0.0 & 0.0 & 0.0 & 0.0 & 0.0 & 4.3 & 0.3 & 19.8 & 12.1 & 3.4 & 0.0 & 4.3 & 2.6 & 4.3 & 0.0 & 0.0 & 0.0 \\
\hline MJ91-B6 & 407 & 3.7 & 9.3 & 5.9 & 31.9 & 5.1 & 1.7 & 0.0 & 0.0 & 0.6 & 0.0 & 0.0 & 0.8 & 0.6 & 0.0 & 16.1 & 4.5 & 4.2 & 0.0 & 4.0 & 1.7 & 8.2 & 0.0 & 0.0 & 1.4 \\
\hline MJ91-B4 & 116 & 6.6 & 25.4 & 2.3 & 13.3 & 5.2 & 7.2 & 0.0 & 0.0 & 0.3 & 0.0 & 0.0 & 0.3 & 2.9 & 0.0 & 13.3 & 7.5 & 4.6 & 0.0 & 2.3 & 0.9 & 7.2 & 0.6 & 0.3 & 0.0 \\
\hline MJ91-B3 & 96 & 6.9 & 18.4 & 0.9 & 15.7 & 5.4 & 11.2 & 0.0 & 0.0 & 0.0 & 0.0 & 0.0 & 0.3 & 5.7 & 0.0 & 15.4 & 7.9 & 3.3 & 0.0 & 0.9 & 0.9 & 4.5 & 0.3 & 2.1 & 0.0 \\
\hline MJ91-B2 & 50 & 5.3 & 16.5 & 4.7 & 16.5 & 6.8 & 5.3 & 0.3 & 0.0 & 0.0 & 0.0 & 0.0 & 1.2 & 0.3 & 0.0 & 23.2 & 4.7 & 3.2 & 0.0 & 0.3 & 1.8 & 9.7 & 0.0 & 0.3 & 0.0 \\
\hline MJ91-B1 & 0 & 5.1 & 19.4 & 4.8 & 16.9 & 5.1 & 1.7 & 0.0 & 0.0 & 0.8 & 0.3 & 0.0 & 0.6 & 1.1 & 0.0 & 22.5 & 3.1 & 5.1 & 0.0 & 0.8 & 2.8 & 9.3 & 0.0 & 0.8 & 0.0 \\
\hline
\end{tabular}

${ }^{1}$ All samples from the Slope Mountain section, North Slope, Alaska. See figure 1 for map location of section and samples.

${ }^{2}$ As measured above base of section.

Explanation of abbreviations and definitions of categories:

Framework Grains

Monomineralic grains ( $>95 \%$ of grain made up of a single mineral species) $\mathrm{Q}_{\mathrm{t}}=$ Total quartz

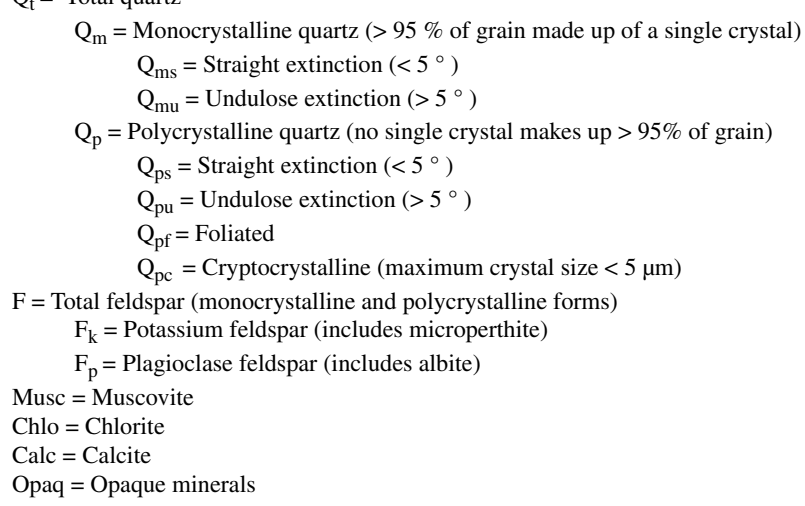

$\mathrm{L}=$ Lithic fragments (no single mineral species makes up $>95 \%$ of grain) $\mathrm{L}_{\mathrm{s}}=$ Sedimentary rock fragments

$\mathrm{L}_{\mathrm{smud}}=$ Mudstone or shale fragments (detrital subgrains not resolvable) $\mathrm{L}_{\text {ssilt }}=$ Siltstone or sandstone fragments (detrital subgrains resolvable)

$\mathrm{L}_{\mathrm{ms}}=$ Metasedimentary rock fragments (birefringent micas)

$$
\mathrm{L}_{\mathrm{msf}}=\text { Foliated }
$$$$
\mathrm{L}_{\mathrm{msm}}=\text { Massive }
$$

$\mathrm{L}_{\mathrm{vm}}=$ Volcanic and metavolcanic rock fragments

$\mathrm{L}_{\text {other }}=$ Other rock fragment, or ambiguous mineral assemblage

$\mathrm{L}_{\mathrm{t}}=$ Total rock fragments $\left(\mathrm{L}+\mathrm{Q}_{\mathrm{p}}\right)$

Alt $=$ Alterites (grain altered sufficiently to preclude identification of precursor)

Nonframework Components

Mat $=$ Matrix (co-deposited with framework grains)

Psuedo $=$ Pseudomatrix (compacted lithic fragments)

$\mathrm{Cem}=$ Cement (clay, calcite, and quartz)

Rep $=$ Calcite replacement of primary components

Por = Porosity 
Grain types of particular interest are quartz, sedimentary lithic fragments, and metamorphic lithic fragments because we hypothesize that, among the Umiat Delta sandstones, these grain types may document stratigraphic variations reflecting differences in provenance and in susceptibility to chemical weathering (Johnsson, 1993). Accordingly, we discriminated not only between monocrystalline and polycrystalline quartz varieties, but also on the basis of whether individual grains or subgrains showed undulose extinction. A separate category was created for polycrystalline quartz with evident foliation. Subdividing quartz varieties in this way allows us to construct an interpretive "metamorphic quartz" category, consisting of foliated polycrystalline quartz as well as mono- and polycrystalline quartz showing undulose extinction (Folk, 1974). Unfoliated cryptocrystalline quartz, commonly containing radiolarian or sponge-spicule ghosts, was assigned to "chert" and interpreted to be of solely sedimentary origin (Folk, 1974). We feel that the provenance of other quartz varieties is ambiguous (Folk, 1974). Sand-size framework grains consisting of sedimentary lithic fragments were separated into mudstone fragments ( $>8$ percent of subgrains not resolvable by an optical microscope) and siltstone/ sandstone fragments ( $>20$ percent of subgrains can be resolved); the interpretation of these categories is that the mudstone fragments are likely to be dominated by intrabasinal fragments, whereas the siltstone/sandstone fragments are likely to be mostly extrabasinal. Finally, in order to provide some constraints on metamorphic grade of the detritus, metasedimentary lithic fragments were subdivided into foliated versus nonfoliated varieties with the underlying assumption that foliated varieties would reflect greater contributions from high-grade sources than massive varieties. Volcanic lithic fragments are a minor constituent of these sandstones and were not subdivided, although most show andesitic textures.

The sandstones we examined contain as much as 10 percent pseudomatrix, as defined by Dickinson (1970). Pseudomatrix is differentiated from depositional matrix by its heterogeneous character and petrographic similarity to lithic fragments (mostly mudstone). As demonstrated by Cox and Lowe (1996), assessing sandstone composition based solely on framework composition when pseudomatrix is abundant can lead to large errors in provenance interpretation. The continuum between sedimentary lithic fragments, compacted sedimentary lithic fragments, and pseudomatrix, together with the overall paucity of other framework components that could have contributed to pseudomatrix, leads us to the interpretation that lithic fragments (predominantly sedimentary lithic fragments) are the dominant source of the pseudomatrix in these sandstones.

In terms of overall framework composition, the Nanushuk Group sandstones at Slope Mountain occupy a limited range of compositions between sublitharenite and litharenite (fig. 5). Very little change in ternary composition occurs when pseudomatrix is reassigned to the lithic fragments and included in the framework composition (figs. 5A, 5B). Although the overall $\mathrm{Q}_{\mathrm{t}} \mathrm{FL}$ compositions we observe are strikingly similar to those reported by Bartsch-Winkler and Huffman (1988) (cf. figs. 3C, 5A) we, like Meier (1995), found far fewer volcanic lithic fragments than did those authors. Lithic fragments are dominated by metasedimentary grains (figs. $5 C, 5 D$ ), and the major framework varieties show very little stratigraphic variation on ternary diagrams (fig. 5).
When plotted against stratigraphic position, the dominant framework components do show some systematic stratigraphic trends (fig. 6). Most dramatic is the reduction in sedimentary lithic fragments (nearly all of which are mudstones and probably intrabasinal; see table 1) from about 8 percent of total framework grains to nearly zero and the increase in metamorphic lithic fragments from about 20 percent of framework grains to about 30 percent. Volcanic lithic fragments, which are never abundant, increase from near zero at the base of the section to about 6 percent of total framework grains at the top. These results are in qualitative, but not quantitative, agreement to those of Bartsch-Winkler and Huffman (1988) (fig. 3C) and may presage the abundant volcanic detritus found in the overlying Seabee Formation (Fox and others, 1979). Neither total quartz, nor the varieties monocrystalline, coarse polycrystalline, or chert, show any systematic stratigraphic variation, although the ratio of chert to total quartz does seem to reach a minimum near the middle of the stratigraphic sequences defined by sequence boundaries $5(600 \mathrm{~m})$ and $6(1,000 \mathrm{~m})$ of Schenk and Bird (1993) (fig. 7). The most pronounced stratigraphic trends are revealed by plotting ratios of components. Metamorphic quartz, as defined above, increases relative to total quartz from near zero at the base of the section to 40 percent at the top, with a correlation coefficient of 0.72 . Equally dramatic are a marked increase in both metamorphic and volcanic lithic fragments relative to sedimentary lithic fragments (fig. 7). Neither the ratio of mudstone to siltstone lithic fragments nor foliated to nonfoliated metamorphic lithic fragments show any significant stratigraphic variation (table 1 ).

\section{Discussion}

\section{Causes of Stratigraphic Variation in Petrographic Components}

Stratigraphic variations in sandstone composition indicate systematic changes over time in the parameters controlling the composition of sands delivered to the depositional basin. As outlined in Johnsson (1993), the system controlling the composition of sands is dynamic and interlinked, and the evaluation of potential causal mechanisms for stratigraphic variability must be made with the entire system in mind. Fundamentally, stratigraphic changes in sandstone composition might be related to differences in diagenetic history, changes in physical weathering during transport and deposition, changes in chemical weathering during pedogenesis and transport, or to changes in source material over time.

Evidence of diagenetic alteration of the Nanushuk Group sandstones at Slope Mountain includes compaction of lithic fragments and creation of pseudomatrix (sensu Dickinson, 1970), the presence of alterites (sensu Johnsson, 1990), some of which may be diagenetic, and the presence of quartz and calcite cements. Vitrinite reflectance values increase systematically from $R_{o}=0.47$ percent at the top of the section to 0.74 percent at the section's base, indicating only modest burial heating (Johnsson and Howell, 1996; Johnsson and others, 1992). Although there is some suggestion that alterites and 


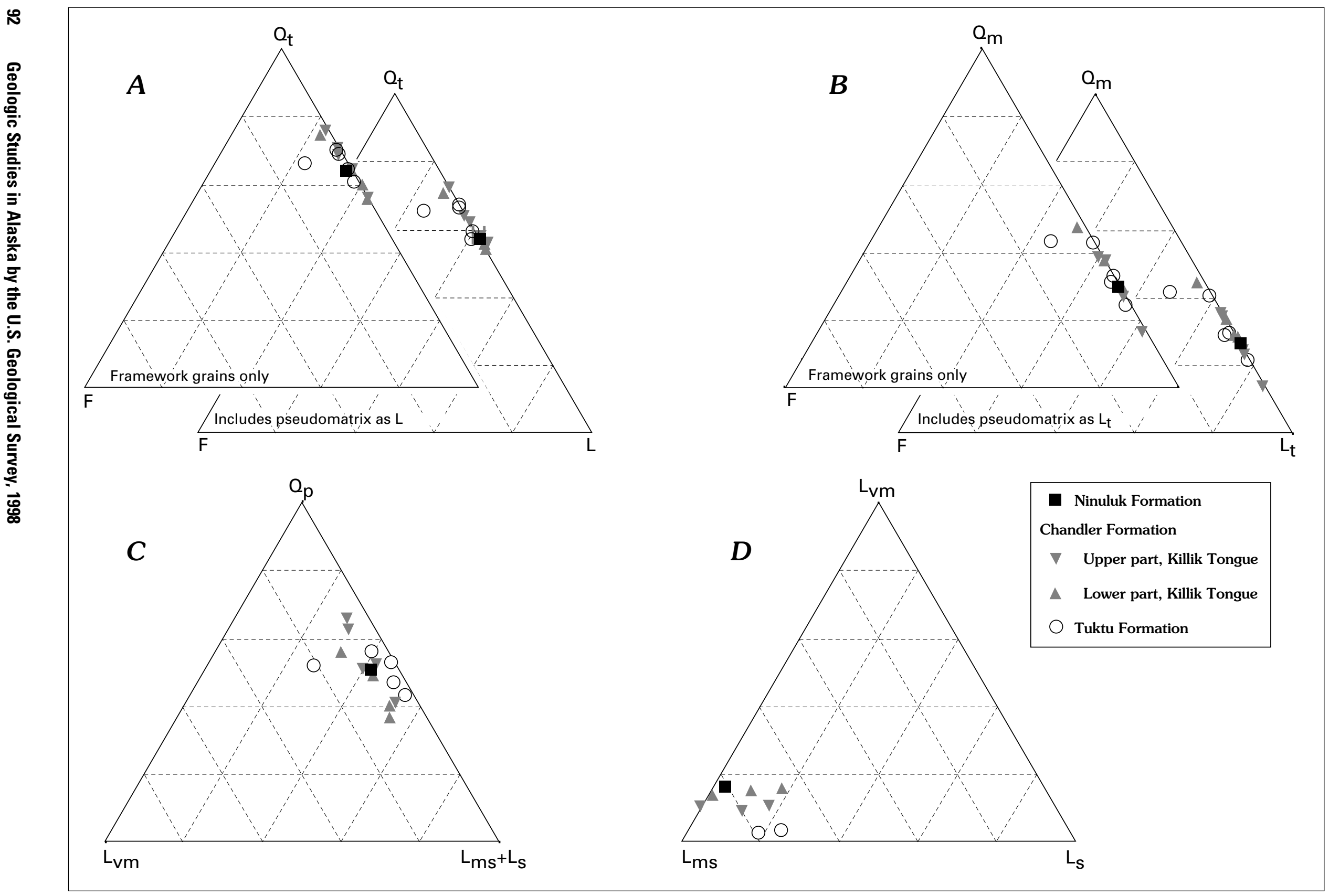

Figure 5. Ternary diagrams showing composition of Nanushuk Group sandstones from Slope Mountain (this study). $A, a_{\mathrm{t}} \mathrm{FL}, B_{,} a_{\mathrm{m}} \mathrm{FL}_{\mathrm{t}}, \mathrm{C}_{\mathrm{p}} \mathrm{a}_{\mathrm{p}} \mathrm{L}_{v m} \mathrm{~L}_{\mathrm{ms}}, \mathrm{D}_{\mathrm{v}} \mathrm{L}_{\mathrm{v}} \mathrm{L}_{\mathrm{ms}} \mathrm{L}_{\mathrm{s}}$. See table 1 for explanation of abbreviations and definitions of grain categories. 


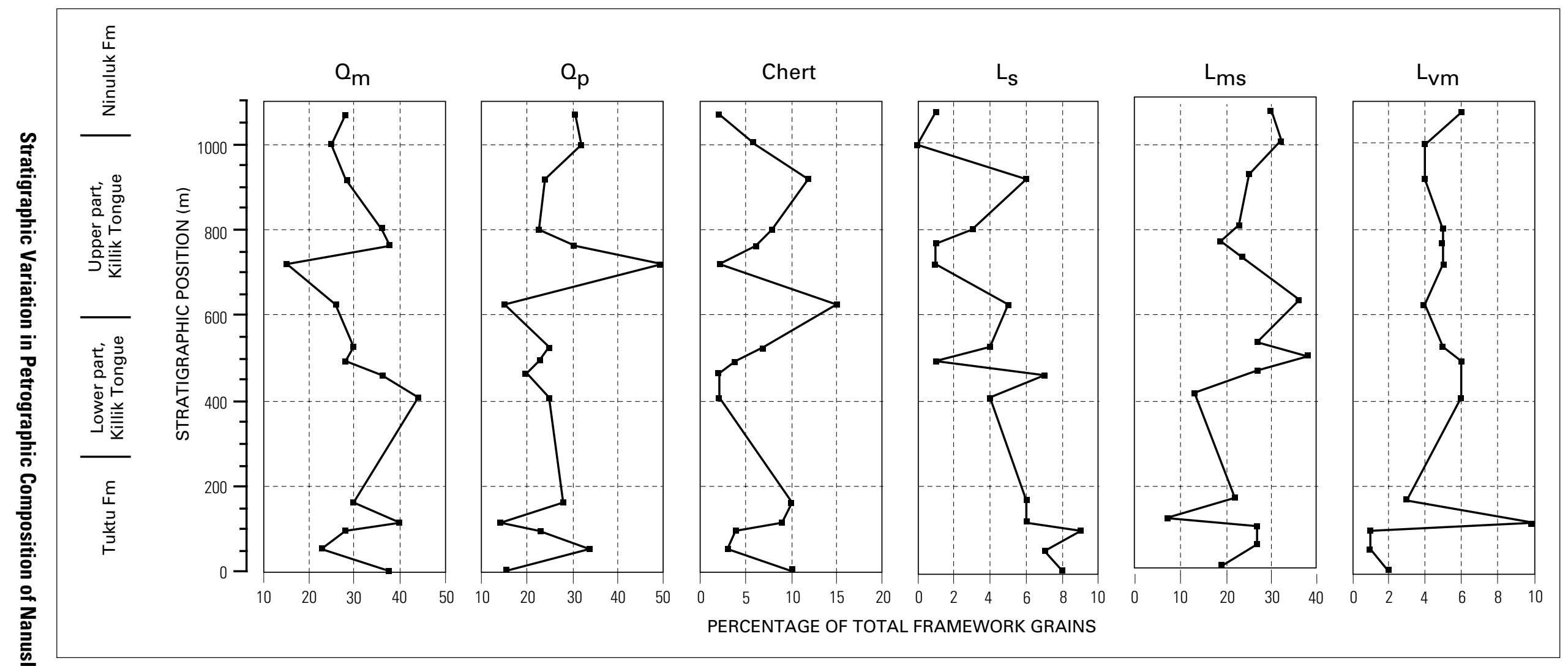

Figure 6. Stratigraphic variations in principal components of Nanushuk Group sandstones at Slope Mountain as a percentage of total framework grains. See table 1 for explanation of abbreviations and definitions of grain categories. 


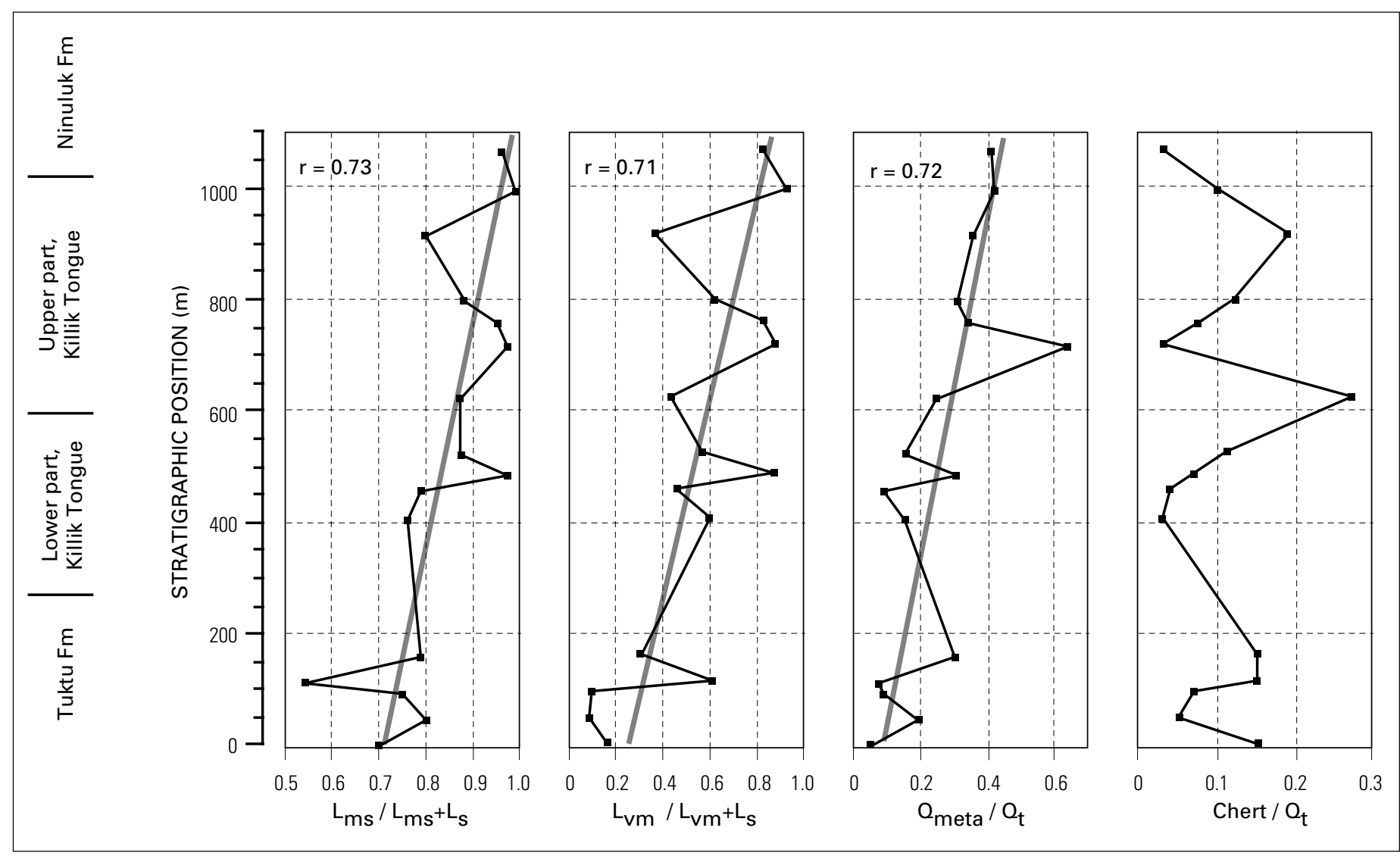

Figure 7. Stratigraphic variations in petrographic component ratios, Nanushuk Group sandstones at Slope Mountain. Gray lines are fitted by linear least-squares regression; regression coefficient indicated at top of diagram. See table 1 for explanation of abbreviations and definitions of grain categories.

cements are more abundant higher in the section (table 1), this is antithetic to the upward increase in more labile components (especially volcanic lithic fragments). Finally, sandstones are dominated by point and tangential grain contacts and show very few concavo-convex or sutured grain boundaries. All of these data suggest that, although these sandstones have undoubtedly been altered to some degree by diagenesis, the systematic compositional variations observed are not likely to have been produced diagenetically.

Stratigraphic variations in sandstone composition could be the result of changing amounts of physical weathering, owing to changes in the dynamics of the transport system over the time of deposition. Indeed, the Slope Mountain section shows reversals from a dominantly shallow marine system (Tuktu Formation) to a transitional (estuarine?) system (lower part of the Killik Tongue) to a fluvial system (upper part of the Killik Tongue), with a return to marine conditions at the very top of the section (Ninuluk Formation; Huffman, 1989). Schenk and Bird (1993) interpret the shift from estuarine to a fluvial system, and the shift back to a marine setting, to represent major sequence boundaries on the North Slope. Sequence boundary 5 (fig. 4) thus marks a major progradational episode, with the upper part of the Killik Tongue representing a lowstand system tract. Sequence boundary 6 (fig. 4) marks a transgression with the Ninuluk Formation comprising a highstand system tract. Neither sequence boundary, however, is apparent in the compositional trends (figs. 6 and 7), suggesting that migration of facies associated with regressive and transgressive events is not recorded in sandstone composition. Thus, differing physical weathering in the various depositional environments recorded in the Slope Mountain section appears not to have been recorded in the detrital signal. Moreover, at Slope Mountain, sandstone composition does not appear to be a useful tool for helping to define stratigraphic sequences.

A third possible mechanism for creating stratigraphic variations in sandstone composition is temporal differences in the chemical weathering regime. The level of alteration brought about by chemical weathering is a function both of weathering intensity and weathering duration (Johnsson, 1993). Although many factors can affect weathering intensity, climate is of primary importance; thus changing climate might yield stratigraphic variations in sandstone composition. The Early Cretaceous climate of the North Slope was long thought to have been warm temperate to subtropical on the basis of cycadophytes (Smiley, 1967), a dominance of gymnosperm pollen and spores in the Nanushuk Group (May and Shane, 1985), and the presence of a dinosaur fauna (Roehler and Stricker, 1984). More recent studies (Spicer and Chapman, 1990; Spicer and Corfield, 1992; Spicer and Parrish, 1986, 1987, 1990) have, however, established fairly conclusively that the Cretaceous climate of the North Slope was much cooler than previously believed and, based on paleobotanical evidence, these authors describe the Albian-Cenomanian climate as "cool temperate" with a mean annual temperature (MAT) of about $10^{\circ} \mathrm{C}$ (Spicer and Parrish, 1986). This is in general agreement with oxygen isotope data from belemnites in Svalbard, which yield a 
Valanginian MAT of about $8^{\circ} \mathrm{C}$ (Ditchfield, 1997). Somewhat warmer temperatures likely characterized the early to middle Late Cretaceous; for example, Herman and Spicer (1997) estimate a Coniacian MAT of $15^{\circ} \mathrm{C}$. Thus, during the deposition of the Nanushuk Group (Aptian to Cenomanian), mean annual temperatures on the North Slope were probably increasing, likely leading to increased precipitation and a possible increasing level of chemical-weathering intensity. The stratigraphic variation in sandstone composition does not, however, support any increase in chemical-weathering intensity over this interval. Bedrock components present in the Endicott and De Long Mountains subterranes (source rocks for the Umiat Delta) that are particularly susceptible to chemical weathering include calcite and feldspars; detritus of this composition is extremely rare throughout the Nanushuk sandstones at Slope Mountain and show no decrease up-section. Of the sandstone components found in these sandstones, volcanic lithic fragments are likely to be the most susceptible to chemical weathering - and these increase up-section. Thus, any increase in chemicalweathering intensity through time appears not to be recorded in the detrital signal.

Variations in the duration of chemical weathering also have the capacity to imprint a compositional signal on a stratigraphic succession. Sediments that are stored in alluvial deposits-such as point bars, mid-channel bars, flood plains, and terraces-prior to ultimate deposition are exposed to the weathering environment. Variations in the amount of time sediments spend in such deposits provide differing time periods of exposure to chemical weathering. Thus sediments may be altered to differing degrees relative to the "starting" composition of the sediment when it was released from soils and entered the fluvial system. Because sinuous rivers deposit and rework sediments on their flood plains during migration of river channels, they continually erode alluvial deposits and incorporate older sediment stored in those deposits with younger material being carried by the river. This incorporation of older sediment increases the relative proportion of the previously stored sediment in a downstream direction (Johnsson and Meade, 1990; Johnsson and others, 1991; Macaire, 1985; Morton and Johnsson, 1993; Rolfe and Hadley, 1964; Savage and others, 1988). Weathering of sediments during alluvial storage and reincorporation into river bedload during channel migration has a profound impact on sediment composition in intense chemical weathering environments, where first-cycle quartz arenites may result (Johnsson and others, 1991, 1988). This process has recently been demonstrated to significantly affect sediment composition in arctic weathering environments as well (Robinson and Johnsson, 1997). Thus, changes in the length of alluvial flood plains traversed by river systems provides a mechanism for varying the overall effects of chemical weathering on sediment composition. During deposition of the Nanushuk Group, the axis of sedimentation shifted northward due to progradation of the Umiat Delta (Mull, 1985). Such a northward progradation would bring to the Slope Mountain area more proximal portions of the alluvial system, especially in the regressive system tract between sequence boundaries 5 and 6 . Thus, less weathered sediments might overlie more weathered sediments at the Slope Mountain locality. This scenario is consistent with some aspects of the compositional data from the Slope Mountain samples. For example, more labile components, such as volcanic and metamorphic lithic fragments, do increase up-section. Moreover, sedimentary lithic fragments-largely intrabasinal in origin in these samples - decrease, consistent with a lower production of such materials within the fluvial system. Nonetheless, the most labile components expected, given the known source rocks (calcite, feldspar), do not increase up-section and are, in fact, nearly absent from all samples. Further, the increase in metamorphic quartz up-section is difficult to explain purely by chemical weathering.

Thus it appears that a portion of the detrital sandstone signal recorded at the Slope Mountain section records changing provenance, most likely as a result of progressive unroofing of the source terrain. It is reasonable to attribute the upsection increases in metamorphic lithic fragments (relative to sedimentary lithic fragments) and metamorphic quartz (relative to total quartz) to the erosion through Endicott Group sediments in the upper levels of the Endicott Mountains and De Long Mountain subterranes into underlying greenschist-facies rocks (Hunt Fork Shale). Alternatively, the higher grade detritus may represent contributions from the Slate Creek, Hammond, and Coldfoot subterranes to the south. The increase in volcanic clasts could be a result of variations in alluvial storage through facies migration as described above, or it could reflect an actual increase in the relative contribution of volcanic source rocks to the sediments. A source for coarse volcanic detritus in the Slope Mountain section and in the overlying Seabee Formation is somewhat problematic. Possible sources for such volcanic detritus are rare in the Slate Creek, Endicott Mountains, and De Long Mountains subterranes (very minor volcanic rocks within the Mississippian Kuna Formation), and possible sources are not much more abundant in the Coldfoot and Hammond subterranes (Devonian metavolcanic rocks of Ambler Sequence). The nearest known abundant source of volcanic detritus might be mafic rocks of the Angayucham terrane, but volcanic detritus in the Nanushuk Group and Seabee Formation appears to be more silicic (andesitic) than volcanic rocks in these ophiolites.

\section{Implications for Regional Geology}

The apparent unroofing history recorded at the Slope Mountain section is consistent with either erosion through the upper Endicott and (or) De Long Mountains subterranes into deeper, more heavily metamorphosed portions of the same subterranes or with contributions of metamorphic detritus from the Slate Creek, Hammond, and Coldfoot subterranes. The latter alternative might help explain the presence of volcanic lithic fragments higher in the section, as the Hammond and Coldfoot subterranes do contain minor amounts of volcanic rocks. The up-section increase in metamorphic and volcanic components might, then, reflect regional uplift of these subterranes with continued underthrusting. Till (1992) found blueschist detritus in heavy-mineral separates from Nanushuk Group and Torok sandstones in the western North Slope and concluded that blueschist-facies rocks exposed in the metamorphic core of the central and western Brooks Range were 
the likely source. This would seem to indicate exposure during contractional deformation related to Brooks Range orogenesis, rather than during later extensional collapse of the orogen as proposed by Miller and Hudson (1991). Mull and others (1997) examined conglomerate clasts in the Fortress Mountain Formation, a series of alluvial-fan and fan-delta deposits slightly older to coeval with the Nanushuk Group and proximal to the Brooks Range front (about $20 \mathrm{~km}$ south of Slope Mountain). Clasts are dominantly chert and mafic igneous rocks, which they interpret as being derived from the Picnic Creek and Ipnavik River allochthons (DeLong Mountain subterrane), with additional contributions from the Endicott Mountains subterrane. Reworking of these deposits could have contributed to the chert and volcanic clasts in the Nanushuk Group at Slope Mountain.

An alternative explanation for the volcanic contributions might be an island arc to the south or southwest. The Jurassic to Early Cretaceous Koyukuk arc has been hypothesized as the source of the Upper Jurassic to Neocomian Okpikruak Formation, most extensive in the western North Slope (Toro and others, 1998). Although this arc is probably too far removed and too old to contribute to the Nanushuk Group, evidence from east-central Alaska suggests that a similar arc, perhaps a superstructure of granitic rocks of the Ruby terrane to the south, may have been accreted to the central or eastern Brooks Range in Aptian-Albian time (Johnsson, in press).

This study thus supports previous views of the provenance of the Nanushuk Group, but it also provides some constraints on the source regions of the eastern Umiat Delta: it may have received sediments not only from the adjacent Endicott and De Long Mountains subterranes, but also from higher grade rocks in the Coldfoot, Slate Creek, and Hammond subterranes. Further, a volcanic source farther to the south may have become increasingly important through the deposition of the sediments, suggesting continued uplift far to the south within the Brooks Range orogen.

\section{Lessons for Evaluation of Stratigraphic Trends}

This study illustrates that relatively simple stratigraphic variations may be produced by multiple mechanisms. The upsection increase in volcanic lithic fragments, in particular, may reflect not only an increase in contributions of volcanic detritus to the river systems feeding the Umiat Delta, but also may reflect progradation of the delta. As portions of the fluvial system more proximal to sediment sources encroach on the depositional setting, the relative affects of chemical weathering on sediment composition are diminished. A similar argument may apply to the up-section reduction of sedimentary lithic fragments (especially mudstones), which are largely intrabasinal in origin. On the other hand, the increase in metamorphic quartz relative to total quartz is more difficult to explain without appealing to changing source terrain. This changing source may reflect unroofing of the sedimentary-metasedimentary packages within the Endicott and De Long Mountains subterranes, the addition of new sources (located within the Hammond, Coldfoot, and Slate Creek subterranes), or a combination thereof.

\section{Conclusions}

1. Sandstones of the Nanushuk Group at Slope Mountain are litharenites, the compositions of which are dominated by mono- and polycrystalline quartz and by low-grade metasedimentary lithic fragments. There exist only slight stratigraphic variations in the abundances of principal components-most notable is an up-section decrease in sedimentary lithic fragments, matched by increases in the relative proportions of volcanic and metasedimentary lithic fragments. Quartz grains interpreted to be of metamorphic origin (varieties showing undulose extinction, or with foliated subgrains) also increase up-section.

2. We recognized stratigraphic variation in sandstone composition at Slope Mountain whereas previous workers did not, probably because of our use of finely subdivided point-counting categories. Important stratigraphic trends may not be recognized from the major sandstone components alone.

3. We interpret the stratigraphic trends in sandstone composition to be due to a combination of two principal mechanisms. First, a general northward progradation of fluvial/deltaic facies resulted in more proximal facies being represented at the location of the Slope Mountain section relative to more northerly parts of the fluvial/deltaic system. Proximal facies contain a smaller proportion of reworked (and weathered) alluvium, so an up-section increase in labile components (primarily volcanic lithic fragments) may be, in part, the result of facies progradation. Second-order depositional cycles corresponding to a previously recognized sequence boundary within the section are not, however, recorded in sandstone composition. Second, the increase in metasedimentary detritus relative to sedimentary lithic fragments and the increase in quartz interpreted to be of metamorphic origin, likely reflects a change in provenance. One explanation is an unroofing of sedimentary cover of the Endicott and (or) De Long Mountains subterranes into their deeper metasedimentary core. Alternatively, the higher grade detritus may represent contributions from the Slate Creek, Hammond, and Coldfoot subterranes.

4. The source of the volcanic lithic fragments of andesitic texture in the Nanushuk Group remains enigmatic. The Angayucham terrane, an ophiolite structurally overlying the allochthons of the Arctic Alaska Terrane, is in the right geometry to be a source, but it is unlikely to provide abundant andesitic debris. Although minor volcanic detritus could have been contributed from the Hammond or Coldfoot subterranes, the most likely candidate is a now-eroded volcanic arc lying to the south.

\section{Acknowledgments}

Funding for this project was provided by the U.S. Geological Survey; we especially thank David Howell for his support. Assistance in the field was provided by Donald Gautier and Christopher Schenk. Thanks to Curt Huffman for help with his previous data from Slope Mountain, and to Kenneth J. Bird for valuable discussions and a thorough review. Thomas $\mathrm{S}$.

Ahlbrandt, Karen Kelley, Larry Gough, and Rick Scott also provided careful reviews, improving the quality of this paper immensely. 


\section{References Cited}

Ahlbrandt, T.S., 1979a, Introduction to geologic studies of the Nanushuk Group, North Slope, Alaska, in Ahlbrandt, T.S., ed., Preliminary Geologic, Petrologic, and Paleontologic Results of the Study of Nanushuk Group Rocks, North Slope, Alaska: U.S. Geological Survey Circular 794, p. 1-4.

Ahlbrandt, T.S., ed., 1979b, Preliminary Geologic, Petrologic, and Paleontologic Results of the Study of Nanushuk Group Rocks, North Slope, Alaska: U.S. Geological Survey Circular 794, 163 p.

Ahlbrandt, T.S., Fox, J.E., Huffman, A.C., May, F.E., Mull, C.G., Pasternack, I., Scott, R.A., and Winkler, S., 1978, Paleotransport directions in Nanushuk Group: U.S. Geological Survey Professional Paper 1100, p. 81.

Ahlbrandt, T.S., Huffman, A.C., Jr., Fox, J.E., and Pasternack, I., 1979, Depositional framework and reservoir-quality studies of selected Nanushuk Group outcrops, North Slope, Alaska, in Ahlbrandt, T.S., ed., Preliminary Geologic, Petrologic, and Paleontologic Results of the Study of Nanushuk Group Rocks, North Slope, Alaska: U.S. Geological Survey Circular 794, p. 14-31.

Anderson, A.V., Wallace, W.K., and Mull, C.G., 1994, Depositional record of a major tectonic transition in northern Alaska: Middle Devonian to Mississippian rift-basin margin deposits, upper Kongahat River region, eastern Brooks Range, Alaska, in Thurston, D.K., and Fujita, K., eds., 1992 Proceedings, International Conference on Arctic Margins, Anchorage, Alaska: Mineral Management Service OCS Study MMS 94-0040, p. 71-76.

Bartsch-Winkler, S., 1979, Textural and mineralogical study of some surface and subsurface sandstones from the Nanushuk Group, western North Slope, Alaska, in Ahlbrandt, T.S., ed., Preliminary Geologic, Petrologic, and Paleontologic Results of the Study of Nanushuk Group Rocks, North Slope, Alaska: U.S. Geological Survey Circular 794, p. 61-76.

Bartsch-Winkler, S., 1985, Petrography of sandstones of the Nanushuk Group from four measured sections, central North Slope, Alaska, in Huffman, A.C., Jr., ed., Geology of the Nanushuk Group and Related Rocks, North Slope, Alaska: U.S. Geological Survey Bulletin 1614, p. 75-95.

Bartsch-Winkler, S., and Huffman, A.C., 1988, Sandstone petrography of the Nanushuk Group and Torok Formation, in Gryc, G., ed., Geology and Exploration of the National Petroleum Reserve in Alaska, 1974 to 1982: U.S. Geological Survey Professional Paper 1399, p. 801-831.

Bartsch-Winkler, S.R., and Huffman, A.C., 1981a, Compositional variation in sandstones of the Nanushuk Group, Arctic North Slope, in Albert, N.R., and Hudson, T., eds., The United States Geological Survey in Alaska, Accomplishments During 1979: U.S. Geological Survey Circular 823-B, p. 6-8.

Bartsch-Winkler, S.R., and Huffman, A.C., 1981b, Petrography of the Nanushuk Group and Torok Formation: U. S. Geological Survey Open-File Report 81-1222, 60 p.

Bird, K.J., and Molenaar, C.M., 1992, The North Slope foreland basin, Alaska, in Macqueen, R., and Leckie, D., eds., Foreland Basins and Foldbelts: American Association of Petroleum Geologists Memoir 55, p. 363-393.

Brosgé, W.P., and Wittington, C.L., 1966, Geology of the Umiat-Maybe Creek region, Alaska, Exploration of Naval Petroleum Reserve No. 4 and adjacent areas, northern Alaska, 1944-53; Part3, Areal geology: U.S. Geological Survey Professional Paper 303-H, p. 501-638.

Chapman, R.M., Detterman, R.L., and Mangus, M.D., 1964, Geology of the Killik-Etivluk Rivers region, Alaska, Exploration of Naval Petroleum
Reserve No. 4 and adjacent areas, northern Alaska, 1944-53; Part 3, Areal geology: U.S. Geological Survey Professional Paper 303-F, p. 325-407.

Chapman, R.M., and Sable, E.G., 1960, Geology of the Utukok-Corwin region, northwestern Alaska, Exploration of Naval Petroleum Reserve No. 4 and adjacent areas, northern Alaska, 1944-53, Part 3, Areal geology: U.S. Geological Survey Professional Paper 303-C, p. 47-174.

Cox, R., and Lowe, D.R., 1996, Quantification of the effects of secondary matrix on the analysis of sandstone composition, and a petrographic-chemical technique for retrieving original framework grain modes of altered sandstones: Journal of Sedimentary Research, v. 66, no. 3, p. 548-558.

Detterman, R.L., Bickel, R.S., and Gryc, G., 1963, Geology of the Chandler River region, Alaska, Exploration of Naval Petroleum Reserve No. 4 and adjacent areas, northern Alaska, 1944-53; Part 3, Areal geology: U.S. Geological Survey Professional Paper 303-E, p. 223-324.

Detterman, R.L., Reiser, H.N., Brosgé, W.P., and Dutro, J.T., Jr., 1975, Post-Carboniferous stratigraphy, northeastern Alaska: U.S. Geological Survey Professional Paper 886, 46 p.

Dickinson, W.R., 1970, Interpreting detrital modes of graywacke and arkose: Journal of Sedimentary Petrology, v. 40, no. 2, p. 695-707.

Dickinson, W.R., 1985, Interpreting provenance from detrital modes of sandstones, in Zuffa, G.G., ed., Provenance of Arenites: Dordrecht, The Netherlands, Reidel, p. 333-362.

Ditchfield, P.W., 1997, High northern palaeolatitude Jurassic-Cretaceous palaeotemperature variation: New data from King Karls Land, Svalbard: Palaeogeography, Palaeoclimatology, Palaeoecology, v. 130, no. 1-4, p. 163-175.

Elder, W.P., Miller, J.W., and Adam, D.P., 1989, Maps showing fossil localities and checklists of Jurassic and Cretaceous macrofauna of the North Slope of Alaska: U.S. Geological Survey Open-File Report $89-556,7 \mathrm{p}$.

Folk, R.L., 1974, Petrology of sedimentary rocks: Austin, Texas, Hemphill, $182 \mathrm{p}$.

Fox, J.E., 1979, A summary of reservoir characteristics of the Nanushuk Group, Umiat Test Well 11, National Petroleum Reserve in Alaska, in Ahlbrandt, T.S., ed., Preliminary Geologic, Petrologic, and Paleontologic Results of the Study of Nanushuk Group Rocks, North Slope, Alaska: U.S. Geological Survey Circular 794, p. 42-53.

Fox, J.E., Lambert, P.W., Pitman, J.K., and Wu, C.H., 1979, A study of reservoir characteristics of the Nanushuk and Colville Groups, Umiat Test Well 11, National Petroleum Reserve in Alaska: U.S. Geological Survey Circular 820, $47 \mathrm{p}$.

Gazzi, P., 1966, Le arenarie del flysch sopracretaceo dell'Appennino modenese; correlazioni con il flysch di Monghidoro: Mineralogica et Petrographica Acta, v. 12, p. 69-97.

Gazzi, P., and Zuffa, G.G., 1970, Le arenarie paleogeniche dell'Appennino emiliano: Mineralogica et Petrographica Acta, v. 16, p. 97-137.

Gradstein, F.M., Agterberg, F.P., Ogg, J.G., Hardenbol, J., van Veen, P., Thierry, J., and Huang, Z., 1994, A Mesozoic time scale: Journal of Geophysical Research, v. 99, no. 12, p. 24051-24074.

Gryc, G., ed., 1988, Geology and Exploration of the National Petroleum Reserve in Alaska, 1974 to 1982: U.S. Geological Survey Professional Paper 1399, 940 p.

Gryc, G., Patton, W.W., Jr., and Payne, T.G., 1951, Present Cretaceous stratigraphic nomenclature of northern Alaska: Washington Academy of Sciences Journal, v. 41, no. 5, p. 159-167. 
Herman, A.B., and Spicer, R.A., 1997, New quantitative palaeoclimatic data for the Late Cretaceous Arctic: Evidence for a warm polar ocean: Palaeogeography, Palaeoclimatology, Palaeoecology, v. 128, no. 1-4, p. 227-251.

Houghton, H.F., 1980, Refined techniques for staining plagioclase and alkali feldspars in thin section: Journal of Sedimentary Petrology, v. 50, p. 629-631.

Howell, D.G., Bird, K.J., Lu Huafu, and Johnsson, M.J., 1992, Tectonics and petroleum potential of the Brooks Range fold-and-thrust beltA progress report, in Bradley, D.C., and Ford, A., eds., Geologic Studies in Alaska by the U.S. Geological Survey, 1990: U.S. Geological Survey Bulletin 1999, p. 112-126.

Huffman, A.C., Jr., ed., 1985, Geology of the Nanushuk Group and related rocks, North Slope, Alaska: U.S. Geological Survey Bulletin 1614, $129 \mathrm{p}$.

Huffman, A.C., Jr., 1989, The Nanushuk Group, in Mull, G.C., and Adams, K.E., eds., Dalton Highway, Yukon River to Prudhoe Bay, Alaska: Bedrock Geology of the Eastern Koyukuk Basin, Central Brooks Range, and East-Central Arctic Slope: Alaska Division of Geological and Geophysical Surveys Guidebook 7, p. 303-309.

Huffman, A.C., and Ahlbrandt, T.S., 1979, The Cretaceous Nanushuk Group of the western and central North Slope, Alaska, in Johnson, K.M., and Williams, J.R., eds., The United States Geological Survey in Alaska: Accomplishments During 1978: U.S. Geological Survey Circular 804-B, p. B46-B50.

Huffman, A.C., Jr., Ahlbrandt, T.S., and Bartsch-Winkler, S., 1988, Sedimentology of the Nanushuk Group, North Slope, in Gryc, G., ed., Geology and Exploration of the National Petroleum Reserve in Alaska, 1974 to 1982: U.S. Geological Survey Professional Paper 1399, p. 281-298.

Huffman, A.C., Jr., Ahlbrandt, T.S., Pasternack, I., Fox, J.E., BartschWinkler, S., May, F.E., Scott, R.A., and Materna, W.L., 1981, Measured sections of the Cretaceous Nanushuk Group undivided, western North Slope, Alaska: U.S. Geological Survey Open-File Report 81-0176, 1 microfilm roll.

Huffman, A.C., Jr., Ahlbrandt, T.S., Pasternack, I., Stricker, G.D., BartschWinkler, S., Fox, J.E., May, F.E., Scott, R.A., and Materna, W.L., 1981, Measured sections in the Cretaceous Nanushuk and Colville groups undivided, central North Slope, Alaska: U.S. Geological Survey Open-File Report 81-0177, 1 microfilm roll.

Huffman, A.C., Jr., Ahlbrandt, T.S., Pasternack, I., Stricker, G.D., and Fox, J.E., 1985, Depositional and sedimentologic factors affecting reservoir potential of the Cretaceous Nanushuk Group, central North Slope, Alaska, in Huffman, A.C., Jr., ed., Geology of the Nanushuk Group and Related Rocks, North Slope, Alaska: U.S. Geological Survey Bulletin 1614, p. 61-74.

Johnsson, M.J., 1990, Overlooked sedimentary particles from tropical weathering environments: Geology, v. 18, no. 2, p. 107-110.

Johnsson, M.J., 1993, The system controlling the composition of clastic sediments, in Johnsson, M.J., and Basu, A., eds., Processes Controlling the Composition of Clastic Sediments: Geological Society of America Special Paper 284, p. 1-19.

Johnsson, M.J., in press, Tectonic assembly of east-central Alaska: Evidence from Cretaceous-Tertiary sandstones of the Kandik River terrane: Geological Society of America Bulletin.

Johnsson, M.J., and Howell, D.G., 1996, Generalized thermal maturity map of Alaska: U.S. Geological Survey Miscellaneous Geologic Investigations Map I-2494, 1 sheet, scale 1:2,500,000.

Johnsson, M.J., and Meade, R.H., 1990, Chemical weathering of fluvial sediments during alluvial storage: The Macuapanim Island point bar, Solimões River, Brazil: Journal of Sedimentary Petrology, v. 60 , no. 6, p. 827-842.

Johnsson, M.J., Pawlewicz, M.J., Harris, A.G., and Valin, Z.C., 1992, Vitrinite reflectance and conodont color alteration index data from Alaska: Data to accompany the thermal maturity map of Alaska: U.S. Geological Survey Open-File Report 92-409, 3 diskettes.

Johnsson, M.J., Stallard, R.F., and Lundberg, N., 1991, Controls on the composition of fluvial sands from a tropical weathering environment: sands of the Orinoco River drainage basin, Venezuela and Colombia: Geological Society of America Bulletin, v. 103, p. 1622-1647.

Johnsson, M.J., Stallard, R.F., and Meade, R.H., 1988, First-cycle quartz arenites in the Orinoco River basin, Venezuela and Colombia: Journal of Geology, v. 96, no. 3, p. 263-277.

Keller, A.S., Morris, R.H., and Detterman, R.L., 1961, Geology of the Shaviovik and Sagavanirktok Rivers region, Alaska: U.S. Geological Survey Professional Paper 303-D, p. 169-222.

Lerand, M., 1973, Beaufort Sea, in McCrossan, R.G., ed., The Future Petroleum Provinces of Canada-Their Geology and Potential: Canadian Society of Petroleum Geologists Memoir 1, p. 315-386.

Loney, R.A., 1989, The Kanuti Ophiolite, Alaska: Journal of Geophysical Research, v. 94, no. B11, p. 15869-15900.

Macaire, J.J., 1985, Relations entre les altérites formées sur les roches endogènes du Massif central français et les épandages détritiques périphériques, au Cénozoïque récent: Géologie de la France, v. 1985 , no. 2, p. 201-212.

May, F.E., and Shane, J.D., 1985, An analysis of the Umiat Delta using palynologic and other data, North Slope, Alaska, in Huffman, A.C., Jr., ed., Geology of the Nanushuk Group and Related Rocks, North Slope, Alaska: U.S. Geological Survey Bulletin 1614, p. 97-120.

Meier, J.M., 1995, Petrographic evaluation of foreland basin sandstones, Brooks Range, north-central Alaska: University of Missouri, unpub. M.S. thesis, $253 \mathrm{p}$.

Miller, E.L., and Hudson, T.L., 1991, Mid-Cretaceous extensional fragmentation of a Jurassic-Early Cretaceous compressional orogen, Alaska: Tectonics, v. 10, no. 4, p. 781-796.

Molenaar, C.M., 1983, Depositional relations of Cretaceous and lower Tertiary rocks, northeastern Alaska: American Association of Petroleum Geologists Bulletin, v. 67, no. 7, p. 1066-1080.

Molenaar, C.M., 1988, Depositional history and seismic stratigraphy of Lower Cretaceous rocks in the National Petroleum Reserve in Alaska and adjacent areas, in Gryc, G., ed., Geology and Exploration of the National Petroleum Reserve in Alaska, 1974 to 1982: U.S. Geological Survey Professional Paper 1399, p. 593-621.

Molenaar, C.M., Bird, K.J., and Kirk, A.R., 1987, Cretaceous and Tertiary stratigraphy of northeastern Alaska, in Tailleur, I., and Weimer, P., eds., Alaskan North Slope Geology: Bakersfield, Calif., and Anchorage, Alaska, Pacific Section, Society of Economic Paleontologists and Mineralogists and Alaska Geological Society, p. 513-528.

Moore, T.E., Wallace, W.K., Bird, K.J., Karl, S.M., Mull, C.G., and Dillon, J.T., 1994, Geology of northern Alaska, in Plafker, G., and Berg, H.C., eds., The Geology of Alaska: Geological Society of America Decade of North American Geology Volume G-1, p. 49-140.

Morrow, H.B., 1985, Seismic subsequences in Foothills foldbelt, National Petroleum Reserve in Alaska (NPRA), Alaska: American Association of Petroleum Geologists Bulletin, v. 69, p. 671.

Morrow, H.B., 1987, Seismic subsequences in the Foothills fold belt, NPRA, Alaska, in Tailleur, I.L., and Weimer, P., eds., Alaskan 
North Slope Geology: Field Trip Guidebook, Pacific Section, Society of Economic Paleontologists and Mineralogists: Los Angeles, Calif., Society of Economic Paleontologists and Mineralogists, Pacific Section, p. 479.

Morton, A.C., and Johnsson, M.J., 1993, Factors influencing the composition of detrital heavy mineral suites in Holocene sands of the Apure River drainage basin, Venezuela, in Johnsson, M.J., and Basu, A., eds., Processes Controlling the Composition of Clastic Sediments: Geological Society of America Special Paper 284, p. 171-185.

Mull, C.G., 1985, Cretaceous tectonics, depositional cycles, and the Nanushuk Group, Brooks Range and Arctic Slope, Alaska, in Huffman, A.C., Jr., ed., Geology of the Nanushuk Group and Related Rocks, North Slope, Alaska: U.S. Geological Survey Bulletin 1614, p. 7-36.

Mull, C.G., Glenn, R.K., and Adams, K.E., 1997, Tectonic evolution of the central Brooks Range mountain front: Evidence from the Atigun Gorge region: Journal of Geophysical Research, v. 102, no. B9, p. 20749-20772.

Myers, M., Smith, T.N., Krouskop, D.L., and Ryherd, T.J., 1993, Sequence stratigraphy of the Cretaceous Nanushuk Group, central North Slope, Alaska; Slope Mountain outcrop to the Lupine Well [abs.]: American Association of Petroleum Geologists 1993 Annual Convention, p. 151.

Myers, M.D., Smith, T.N., Krouskop, D.L., and Ryherd, T.J., 1995, Paleogeographic and sequence stratigraphic reconstruction of the Cretaceous Nanushuk Group, central North Slope, Alaska; Slope Mountain outcrop to the Lupine Well [abs.]: Geological Society of America, Abstracts with Programs, v. 27, p. 67.

Noonan, W.G., 1987, Post-Ellesmerian depositional sequences of the North Slope subsurface, in Tailleur, I., and Weimer, P., eds., Alaskan North Slope Geology, Bakersfield, Calif., and Anchorage, Alaska, Pacific Section, Society of Economic Paleontologists and Mineralogists and Alaska Geological Society, p. 459-477.

Pallister, J.S., and Budahn, J.R., 1989, Pillow basalts of the Angayucham terrane: 0 ceanic plateau and island crust accreted to the Brooks Range: Journal of Geophysical Research, v. 94, no. B11, p. 15901-15923.

Patton, W.W., Jr., Box, S.E., and Grybeck, D.J., 1994, Ophiolites and other mafic-ultramafic complexes in Alaska, in Plafker, G., and Berg, H.C., eds., The Geology of Alaska: Geological Society of America Decade of North American Geology Volume G-1, p. 671686.

Reifenstuhl, R.R., Mull, C.G., Harris, E.E., Plumb, E.W., and Clough, J.G., 1994, Preliminary bedrock geologic map of the Philip Smith Mountains D-3 quadrangle, northeastern Brooks Range, Alaska: Alaska Division of Geological and Geophysical Surveys Public-Data File 93-80, 1 sheet.

Reifenstuhl, R.R., and Plumb, E.W., 1993, Micropaleontology of 38 outcrop samples from the Chandler Lake, Demarcation Point, Mt. Michelson, Philip Smith Mountains, and Sagavanirktok quadrangles, northeast Alaska: Alaska Division of Geological and Geophysical Surveys Public-Data File 93-30b, 15 p., 4 sheets, scale $1: 250,000$.

Robinson, R.S., and Johnsson, M.J., 1997, Chemical and physical weathering of fluvial sands in an Arctic environment: Sands of the Sagavanirktok River, North Slope, Alaska: Journal of Sedimentary Research, v. 67, no. 3, p. 560-570.

Roehler, H.W., and Stricker, G.D., 1984, Dinosaur and wood fossils from the Cretaceous Corwin Formation in the National Petroleum
Reserve, North Slope, Alaska: Alaskan Geological Society Journal, v. 4, p. 35-41.

Rolfe, B.N., and Hadley, R.F., 1964, Weathering and transport of sediment in the Cheyenne River basin, eastern Wyoming, in Bradley, W.F., ed., Clays and Clay Minerals: New York: Macmillan, Proceedings of the Twelfth National Conference on Clays and Clay Minerals, p. 649-670.

Savage, K.M., De Cesero, P., and Potter, P.E., 1988, Mineralogic maturity of modern sand along a high-energy tropical coast: Baixada de Jacarepaguá, Rio de Janeiro, Brazil: Journal of South American Earth Sciences, v. 1, no. 4, p. 317-328.

Schenk, C.J., and Bird, K.J., 1993, Depositional sequences in Lower Cretaceous rocks, Atigun syncline and Slope Mountain areas, Alaskan North Slope, in Dusel-Bacon, C., and Till, A.B., eds., Geologic Studies in Alaska by the U.S. Geological Survey, 1992: U.S. Geological Survey Bulletin 2068, p. 48-58.

Scott, R.A., and Smiley, C.J., 1979, Some Cretaceous plant megafossils and microfossils from the Nanushuk Group, northern Alaska: A preliminary report, in Ahlbrandt, T.S., ed., Preliminary Geologic, Petrologic, and Paleontologic Results of the Study of Nanushuk Group Rocks, North Slope, Alaska: U.S. Geological Survey Circular 794, p. 89-111.

Silberling, N.J., Jones, D.L., Monger, J.W.H., Coney, P.J., Berg, H.C., and Plafker, G., 1994, Lithotectonic terrane map of Alaska and adjacent parts of Alaska, in Plafker, G., and Berg, H.C., eds., The Geology of Alaska: Geological Society of America Decade of North American Geology Volume G-1, scale 1:2,500,000.

Smiley, C.J., 1966, Cretaceous floras from Kuk River area, Alaska; stratigraphic and climatic interpretations: Geological Society of America Bulletin, v. 77, p. 1-13.

Smiley, C.J., 1967, Paleoclimatic interpretations of some Mesozoic floral sequences: American Association of Petroleum Geologists Bulletin, v. 51, p. 849-863.

Smiley, C.J., 1969a, Cretaceous floras of Chandler-Colville region, Alaska-Stratigraphy and preliminary floristics: The American Association of Petroleum Geologists Bulletin, v. 53, p. 482-502.

Smiley, C.J., 1969b, Flora zones and correlations of Cretaceous Kukpowruk and Corwin Formations, northwestern Alaska: American Association of Petroleum Geologists Bulletin, v. 53, p. 2079-2093.

Spicer, R.A., and Chapman, J.L., 1990, Climate change and the evolution of high-latitude terrestrial vegetation and floras: Trends in Ecology and Evolution, v. 5, no. 9, p. 279-284.

Spicer, R.A., and Corfield, R.M., 1992, A review of terrestrial and marine climates in the Cretaceous with implications for modelling the “Greenhouse Earth:" Geological Magazine, v. 129, no. 2, p. 169-180.

Spicer, R.A., and Parrish, J.T., 1986, Paleobotanical evidence for cool North Polar climates in middle Cretaceous (Albian-Cenomanian) time: Geology, v. 14, no. 8, p. 703-706.

Spicer, R.A., and Parrish, J.T., 1987, Plant megafossils, vertebrate remains, and paleoclimate of the Kogosukruk Tongue (Late Cretaceous), North Slope, Alaska, in Hamilton, T.D., and Galloway, J.P., eds., Geologic Studies in Alaska by the U.S. Geological Survey During 1986: U.S. Geological Survey Circular 998, p. 47-48.

Spicer, R.A., and Parrish, J.T., 1990, Late Cretaceous-early Tertiary palaeoclimates of northern high latitudes: A quantitative view: Journal of the Geological Society of London, v. 147, p. 329-341.

Till, A.B., 1992, Detrital blueschist-facies metamorphic mineral assemblages in Early Cretaceous sediments of the foreland basin of the 
Brooks Range, Alaska, and implications for orogenic evolution: Tectonics, v. 11, p. 1207-1223.

Toro, J., Cole, F., and Meier, J., 1998, ${ }^{40} \mathrm{Ar} /{ }^{39} \mathrm{Ar}$ ages of detrital minerals in Lower Cretaceous rocks of the Okpikruak Formation:
Evidence for upper Paleozoic metamorphic rocks in the Koyukuk arc, in Gray, J.E., and Riehle, J.R., eds., Geologic Studies in Alaska by the U.S. Geological Survey, 1996: U.S. Geological Survey Professional Paper 1595, p. 169-182.

Reviewers: Thomas S. Ahlbrandt and Kenneth J. Bird 


\title{
Regional Baseline Geochemistry and Environmental Effects of Gold Placer Mining Operations on the Fortymile River, Eastern Alaska
}

\author{
By Richard B. Wanty, Bronwen Wang, Jim Vohden, Paul H. Briggs, \\ and Allen L. Meier
}

\section{Abstract}

A systematic water-quality study of the Fortymile River and many of its major tributaries in eastern Alaska was conducted in June of 1997 and 1998. Surface-water samples were collected for chemical analyses to establish regional baseline geochemistry values and to evaluate the possible environmental effects of suction-dredge placer gold mining and bulldozeroperated placer gold mining (commonly referred to as "cat mining"). In general, the water quality of the Fortymile River is very good, with low total dissolved solids and only two cases in which the concentration of any element exceeded primary or secondary drinking-water quality standards. In both cases, iron exceeded secondary drinking-water limits. At the time this work was conducted, only a handful of suction dredges were operating on the lower Fortymile River, and cat mining was being conducted along Uhler Creek and Canyon Creek, two major tributaries to the river. Based on the water-quality and turbidity data, the suction dredges have no apparent impact on the Fortymile River system, although possible effects on biota have not been evaluated in this study. In contrast, the cat-mining operations in Canyon Creek appear to have a dramatic impact on water quality and stream-bed morphology, based on the field water-quality and turbidity measurements, on comparisons to adjacent unmined drainages, and on field observations of stream-bed morphology. The cat mining in Uhler Creek appears to have had less impact, perhaps because the main stream channel was not as heavily disrupted by the bulldozers, and the stability of the channel was mostly preserved.

\section{Introduction}

The U.S. Geological Survey (USGS) and the Alaska Department of Natural Resources (AKDNR) are conducting a cooperative investigation of the environmental geochemistry of the Fortymile River drainage system in eastern Alaska. This river is designated a Wild and Scenic Corridor by the Alaska National Interest Lands Conservation Act. Current users of the river include placer mine operators and recreational users such as canoeists and rafters. Regulators at the State and Federal levels are thus challenged with responsible land management that accommodates these varied interests. Although USGS is not a regulatory agency, its role in this study is to provide objective scientific data that can be used by the regulatory community to develop reasonable guidelines that balance environmental protection and resource development. By conducting regional geochemical surveys, we hope to provide objective information on the variation of natural chemistry in the area, as well as sitespecific information on potential mining impacts. The term "natural chemistry" refers to the variation in chemical quality and chemical character of surface water that results from natural water-rock interactions, not from any mining impact.

Along the North Fork of the Fortymile River, and below its confluence with the South Fork to the Canadian border (fig. 1), mining is limited to a few small suction dredges that produce a total of a few hundred ounces of gold per year. At this writing, mining is conducted only during the summer months. Along Canyon Creek, a major tributary that enters the Fortymile approximately 19 river kilometers (12 miles) above the Canadian border, extensive "cat mining" is conducted using bulldozers (or Caterpillar tractors) to move river sediments into a sluice to process the gravel and extract gold. Cat mining also is conducted in the Uhler Creek basin. Some potential environmental concerns have been raised associated with the mining activities, including increased turbidity of the river water, adverse impact on the overall chemical quality of the river water, and potential additions of specific toxic elements, such as arsenic, to the river during mining operations.

The current research effort by the USGS and the AKDNR was initiated to provide data to address the potential miningrelated environmental concerns and to provide regional geochemical baseline data for the Fortymile River system 


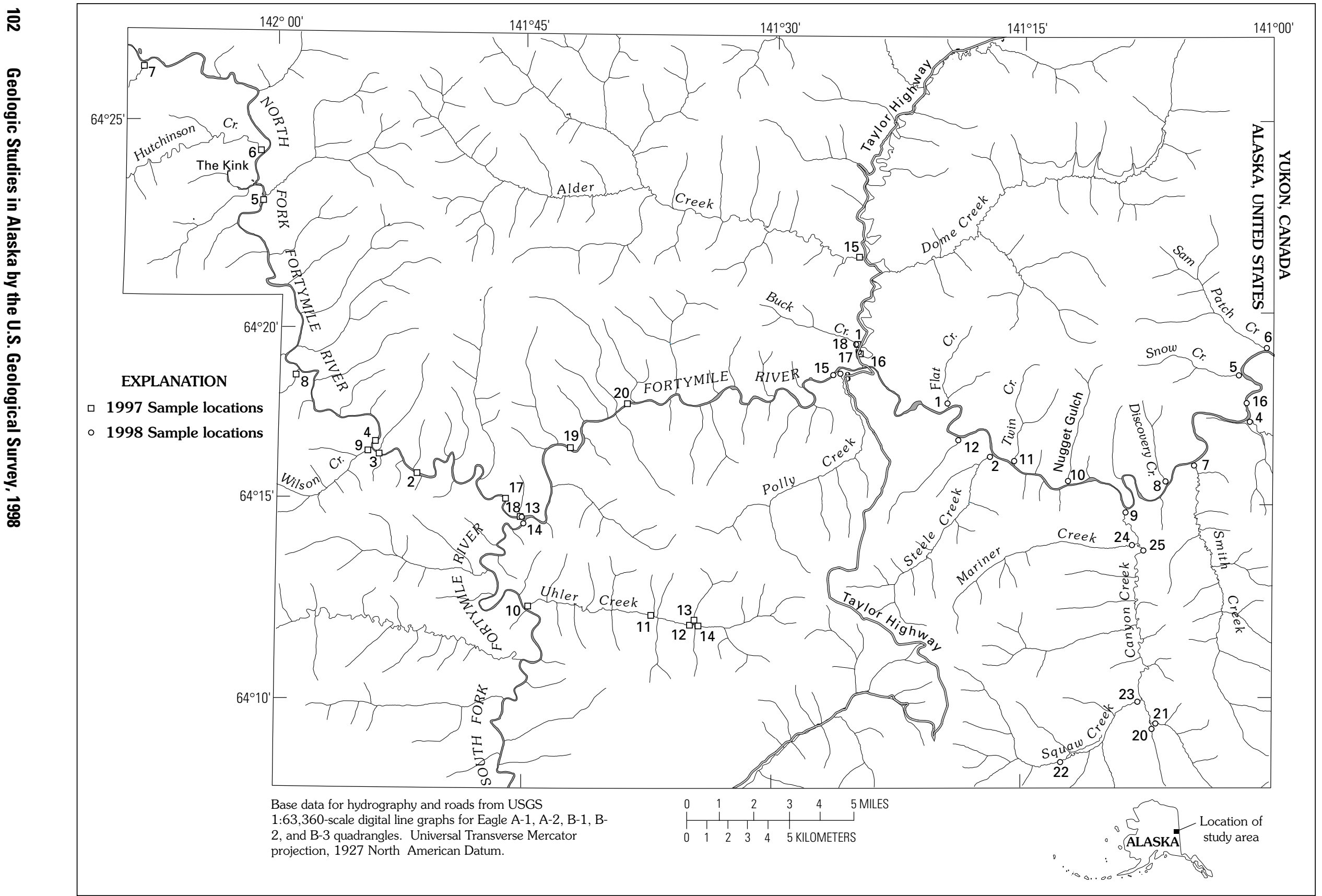

Figure 1. Map of the Fortymile River study area. 
(Gough and others, 1997). Fieldwork was conducted in June of 1997 and 1998. This paper summarizes some of the results of this ongoing study. At this writing, chemical analyses are complete for the 1997 samples, but are still in progress for the 1998 samples. The 1997 sampling campaign focused on the North Fork of the Fortymile and the main stem to the Taylor Highway, Uhler Creek, and the suction-dredge operations. The 1998 fieldwork focused on the main stem of the Fortymile from the Taylor Highway to the border with Canada, including Canyon Creek and several of its tributaries. The following discussion presents regional geochemical baseline data for the Fortymile River and examines the possible environmental effects of the suction dredges and the cat-mining placer operations. The interpretations and discussions in this paper are based on examinations of surface-water chemistry, geology, and hydrology. Biota were not examined in this study.

\section{Regional Geology}

Day and others (this volume) describe the geology of the study area in detail. The major rock units in the area comprise a supracrustal sequence of metamorphosed volcanic and sedimentary rocks that have been intruded by Mesozoic plutonic rocks. The metamorphic rocks include mafic volcanic rocks, graywacke, quartzite, pelite, marble, and sulfide-rich siliciclastic sediments, all of which are cut by late sulfidebearing quartz veins. The supracrustal rocks were deposited on a continental margin and (or) distal to an island-arc complex. The entire sequence was intruded by a post-tectonic Jurassic hornblende tonalite suite, whose chemistry is similar to other volcanic-arc granites.

At least three episodes of deformation affected the rocks in the Fortymile area. The first produced a strong regional schistosity and local mineral lineations. The second deformation generated tight to isoclinal folds and was accompanied by a weak axial-planar cleavage and both mineral and stretching lineations. The youngest deformation that is recognized folded the ductile fabric elements about south-plunging, east-vergent, open folds. As a result of this youngest regional folding, the Fortymile River cuts through each individual rock unit many times between the Kink (fig. 1) and the Canada border, alternatively rising and descending through the stratigraphic sequence.

\section{Regional Baseline Geochemistry}

Water samples were collected at a number of points along the Fortymile River (fig. 1), from below the Kink on the North Fork and along the main stem of the Fortymile to the Canada border. Samples also were collected at all major tributaries to the North Fork (including two above the Kink) and the main stem of the river, and from Uhler Creek, which enters the South Fork of the Fortymile (fig. 1). At each sampling site, discharge was measured by integrating a cross section of components of flow across the river or stream channel. Water samples were collected either at equal-width or equal-discharge intervals at each site. In most cases, five sample points comprised the integrated water-quality sample.
Field analyses were conducted for $\mathrm{pH}$, electrical conductivity, temperature, and turbidity-in some cases, dissolved oxygen and iron also were measured. Sampling and analytical methods followed established standard procedures (Wood, 1976; Fishman and Pyen, 1979; Lichte and others, 1987; Meier and others, 1994). For $\mathrm{pH}$ measurements, the $\mathrm{pH}$ meter was calibrated with three standard $\mathrm{pH}$ buffers at each sample site to provide greater precision and accuracy. At each site, samples were collected for chemical analyses for major cations and trace metals by USGS laboratories in Denver, Colo. Cations and trace metals were analyzed by inductively coupled plasmamass spectrometry (ICP-MS; Meier and others, 1994). This method provides improved sensitivity, precision, and accuracy for the trace elements and heavy metals as compared to other analytical techniques. Anions were analyzed by ion chromatography, following the techniques of Fishman and Pyen (1979).

In general, the quality of water in the Fortymile River and its tributaries is very good. All water samples had low electrical conductivity $(<220 \mu \mathrm{mhos} / \mathrm{cm})$ and calculated total dissolved solids less than 210 milligrams per liter $(\mathrm{mg} / \mathrm{L})$. As seen in the Piper plot for the 1997 samples (fig. 2), water in the Fortymile River and its tributaries is primarily of the $\mathrm{Ca}-\left(\mathrm{HCO}_{3}-\mathrm{SO}_{4}\right)$ type, typical of dilute meteoric waters (Edmunds and others, 1982; Back and others, 1993). The low total dissolved solids and the predominant chemical character of the waters indicate that the waters that comprise the discharge of the Fortymile River system have not undergone extensive chemical reactions with the rocks or sediments of the region. This chemical character is consistent with the discontinuous permafrost coverage in the area, which limits the depth of percolation of water and also limits the residence time of water in the ground (Sloan and van Everdingen, 1988). Permafrost decreases the hydraulic conductivity of soils and decreases the rate and depth of penetration of meteoric waters into the ground (Sloan and van Everdingen, 1988). In the Fortymile River region, the permafrost causes

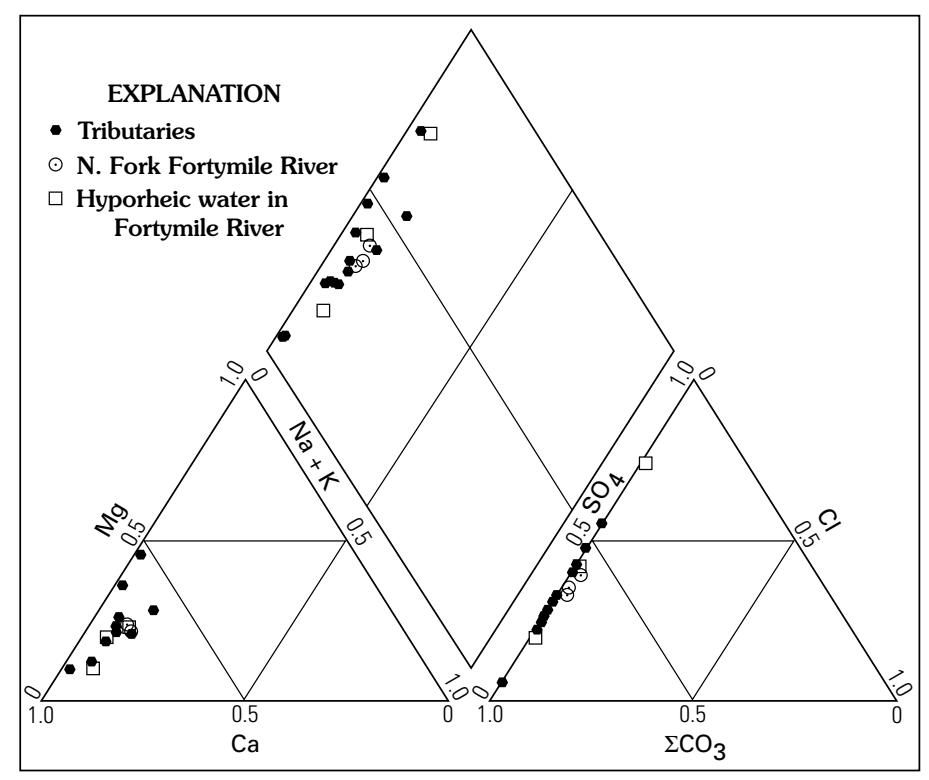

Figure 2. Piper plot of the water samples collected in 1997 from the Fortymile River and many of its major tributaries. Sample locations are shown in figure 1. See text for explanation of hyporheic water samples. 
Table 1. Summary data for chemical analyses of samples collected in June 1997, compared with the U.S. EPA's recommended primary and secondary drinking-water quality standards (Environmental Protection Agency, 1999).

[All data shown are for $0.45-\mu \mathrm{m}$ filtered samples. A total of 33 samples was collected from the 20 sites shown in figure 1 . All concentrations are given in micrograms per liter $(\mu \mathrm{g} / \mathrm{L})$ except sulfate, which is given in milligrams per liter $(\mathrm{mg} / \mathrm{L})$, and $\mathrm{pH}$, which is given in standard units. Complete chemical analyses appear in Crock and others (1999)]

\begin{tabular}{|c|c|c|c|c|c|}
\hline Element & $\begin{array}{l}\text { Minimum observed } \\
\text { concentration }\end{array}$ & $\begin{array}{c}\text { Maximum observed } \\
\text { concentration }\end{array}$ & $\begin{array}{c}\text { Geometric } \\
\text { mean }\end{array}$ & $\begin{array}{l}\text { Primary drinking- } \\
\text { water standard }\end{array}$ & $\begin{array}{l}\text { Secondary drinking- } \\
\text { water standard }\end{array}$ \\
\hline $\mathrm{pH}$ & 7.05 & 8.25 & $7.66^{*}$ & & 6.5 to 8.5 \\
\hline Arsenic & $<0.2$ & 0.5 & 0.31 & 50 & \\
\hline Antimony & 0.04 & 0.58 & 0.10 & 6.0 & \\
\hline Cadmium & $<0.02$ & 0.07 & n.c. & 5.0 & \\
\hline Chromium & 2 & 6 & 3.7 & 100 & \\
\hline Copper & 2 & 10 & 2.4 & 1300 & 1000 \\
\hline Iron & 53 & 440 & 134 & & 300 \\
\hline Lead & $<0.05$ & 0.2 & n.c. & 15 & \\
\hline Manganese & .34 & 23 & 1.5 & & 50 \\
\hline Nickel & 0.6 & 3.3 & 1.1 & $100 * *$ & \\
\hline Selenium & $<0.2$ & 1 & .33 & 50 & \\
\hline Sulfate & 6.2 & 56 & 18 & & 250 \\
\hline Zinc & $<0.5$ & 3 & .81 & & 5000 \\
\hline Cobalt & 0.03 & 0.4 & 0.08 & n.a. & n.a. \\
\hline Molybdenum & 0.06 & 2.3 & .26 & n.a. & n.a. \\
\hline Thorium & 0.02 & 0.15 & 0.07 & n.a. & n.a. \\
\hline Uranium & 0.07 & 0.71 & 0.31 & n.a. & n.a. \\
\hline \multicolumn{6}{|c|}{$\begin{array}{l}\text { Notes: } \\
* \text { For } \mathrm{pH} \text { only, the arithmetic mean, rather than the geometric mean, is shown in the table. } \\
* * \text { The primary drinking-water standard for nickel is promulgated by the State of Alaska, Department of Environmental Conservation. } \\
\text { n.c.- For cadmium, geometric mean was not calculated because only one sample had a measurable concentration; all others were less than } 0.02 \\
\mu \mathrm{g} / \mathrm{L} \text {. For lead, geometric mean was not calculated because only } 3 \text { analyses were above the detection limit of } 0.05 \mu \mathrm{g} / \mathrm{L} \text {. } \\
\text { n.a.- For cobalt, molybdenum, thorium, and uranium, no drinking-water quality standards have been issued by EPA as of this writing. }\end{array}$} \\
\hline
\end{tabular}

decreased residence times of water in the ground, as evidenced by the dilute chemical character of the waters and by the rapid increase of stream flows following storms.

Table 1 shows summary chemical data for the 1997 samples, compared to the established EPA primary or secondary drinking-water standards (Environmental Protection Agency, 1999). These samples include regional chemical samples as well as samples collected near operating suction dredges. Only two instances were found in which any single chemical parameter exceeded drinking-water standards. Neither of these samples appears to have been affected by any mining activities. In both cases, iron in filtered water samples exceeded the recommended secondary drinking-water quality standard of $300 \mu \mathrm{g} / \mathrm{L}$. One sample was from a small (discharge approximately 20 liters per second at time of sample), unmined tributary to Uhler Creek $(440 \mu \mathrm{g} / \mathrm{L} \mathrm{Fe})$. The other was a sample of hyporheic water of the Fortymile River in an area where pyrite-rich metamorphic rocks are exposed at the surface $(370 \mu \mathrm{g} / \mathrm{L} \mathrm{Fe})$. The hyporheic (literally, "underflow") zone is defined as the narrow subsurface sediment layers through which stream water flows for short distances (Winter and others, 1998). The hyporheic zone is the active zone of ground water-surface water interactions.

Nearly all samples for which dissolved oxygen (DO) measurements were made had DO concentrations indicative of atmospheric saturation. The only exceptions to this were the three samples of hyporheic water (1997 sample sites 17, 19, and 20; fig. 1) that were sampled from the bed of the Fortymile River.
During changes in river stages, water may exit or enter the hyporheic zone, or the hyporheic zone may be a consistent zone of ground-water recharge or discharge. Water from this zone was sampled in the Fortymile River bed using a metal pipe driven by hand into the sediments through which a length of polyethylene tubing was threaded, modeled after the minipiezometer design of Winter and others (1988). A diagram of the sampling device is shown in figure 3. The loop of tubing allows for a direct comparison of the hydraulic head of the subsurface water with the river surface, so a determination can be made whether the subsurface water has a tendency to enter the river, or if the flow is downward into the sediments. In all three of the sample sites, the subsurface rocks consisted of a pyrite-rich metasedimentary unit (Day and others, this volume). All three samples exhibited characteristics consistent with reaction of oxygenated surface water with pyrite, namely, the subsurface waters had been nearly depleted of dissolved oxygen, had lower $\mathrm{pH}$ (by as much as 1 unit), and higher specific conductivity than the river water at the same location. Two of the three hyporheic water samples had higher sulfate concentrations than the river water. In most cases, the concentrations in the hyporheic water of the trace elements listed in table 1 are greater than the geometric mean of all the samples. A notable exception to this observation is arsenic, which was lower in the hyporheic water samples. At two of the three sites, there was a slight $(0.5 \mathrm{~cm}-$ $1.5 \mathrm{~cm}$ ) positive hydraulic head in the subsurface water relative to the river surface, indicating a tendency for water to flow from 


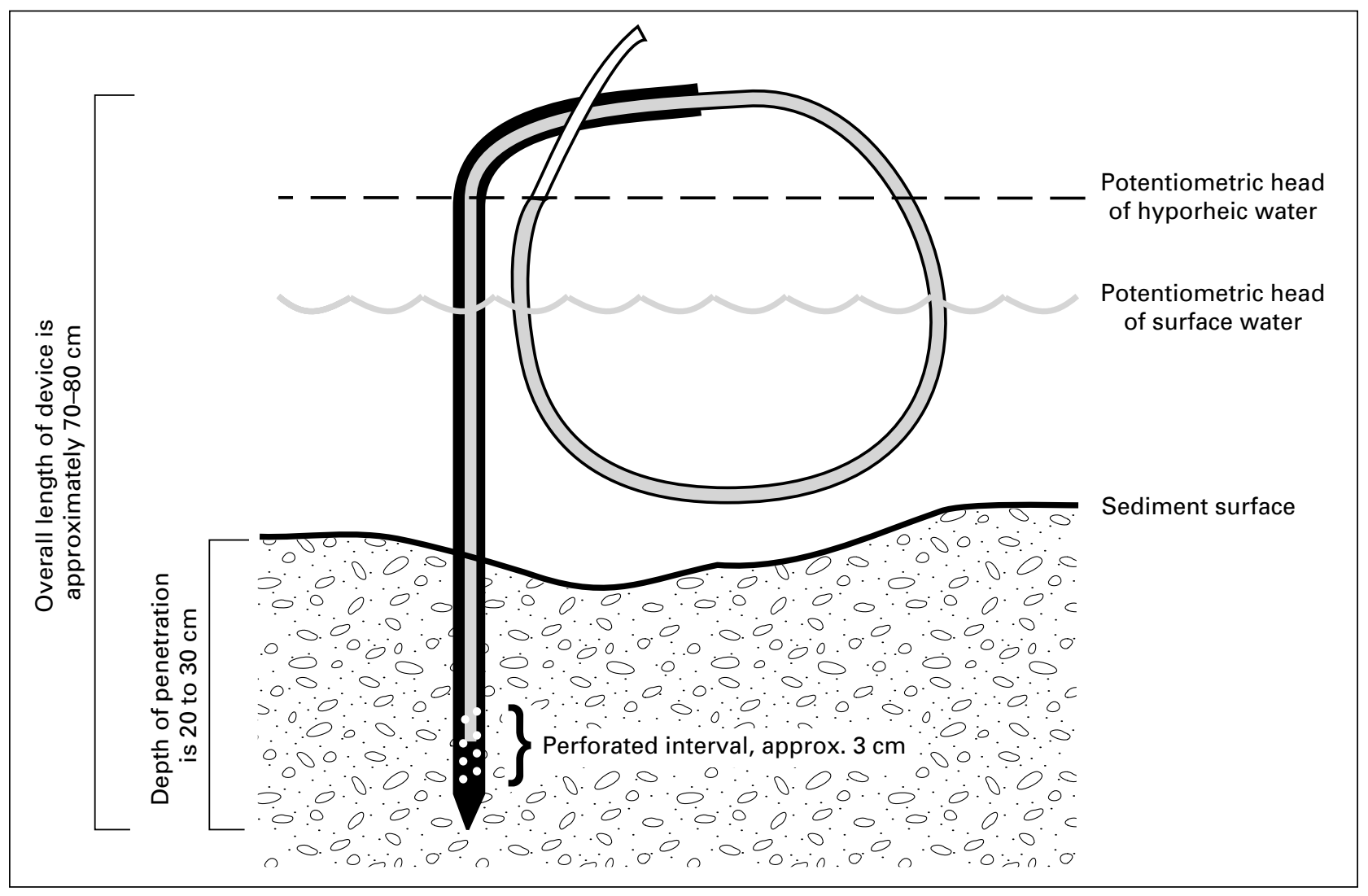

Figure 3. Schematic drawing of the device used to sample hyporheic water and to compare hydraulic head levels between the hyporheic water and the Fortymile River. As shown in the figure, there is a positive hydraulic head in the hyporheic water, which indicates a tendency for the hyporheic water to discharge to the surface water. If the water level in the open end of the tube were below the surface-water level, then the indicated tendency would be for surface water to recharge the hyporheic water.

the subsurface into the river. Regionally, this ground-water discharge may be a source of solutes to the Fortymile River system if the river intersects enough outcrops of this metasedimentary unit and if the subsurface hydraulic heads remain positive throughout the year. However, to quantify this possible natural input, more thorough surveys would need to be done of the ground-water chemistry and hydrogeology in the area.

\section{Effects of Suction-Dredge Mining}

Suction dredges consist of a floating platform bearing an engine that drives a suction pump. The dredges operate by pulling river gravels through an intake hose to a sluice box, where the gold is trapped (Yeend, 1996). The dredge works like a large vacuum cleaner, creating a depression in the river bottom at its advancing end. Material that passes the sluice creates a pile at its trailing end, usually filling the previously created hole as the dredge proceeds upstream. The fine particles that pass the sluice create a zone of increased turbidity that is transported downstream from the dredge. This turbidity zone is the most obvious effect of the operating dredges. State regulations require that suction dredges may not increase the turbidity of the river by more than 5 nephelometric turbidity units (NTU; the standard unit for turbidity measurement) 500 feet $(\approx 150 \mathrm{~m})$ downstream. The impact of the suction dredges on stream-bed morphology is limited to the holes and piles that are created as the dredge moves along the stream bottom. However, the breakup of ice along the river each spring also is a powerful physical event that reshapes the bed morphology, commonly erasing many of the effects of suction dredging from the previous year.

Two suction dredges were studied while they were operating on the North Fork of the Fortymile River in June 1997. Samples were collected on a grid extending downstream from the dredges as they were operating and compared to measurements made upstream of the dredges. All measurements were made using a Hach 2100P turbidity meter. One dredge had a 25$\mathrm{cm}$ (10 inch) diameter intake hose and was working relatively fine sediments on a smooth but fast section of the river. The other dredge had a $20-\mathrm{cm}$ (8 inch) intake and was working coarser sediments in a shallower reach of the river. The sampling grid was set up with transects at 30-m (100 ft) intervals behind the dredge extending perpendicular to the bank. Each transect was sampled at fixed 6-m (20 ft) intervals from the bank (objective samples) with an additional subjective sample collected within the plume along each transect. The plume location was determined visually as the samples were collected. Samples were collected as far from the bank as could be safely waded, usually 20 to $25 \mathrm{~m}$.

The results of the turbidity survey for the two dredges are shown in figures $4 A$ and $4 B$. Turbidity values behind the smaller dredge (fig. $4 A$ ) were generally lower because the smaller intake 
was moving less sediment material and because that dredge was working in an area with coarser sediments that settled more rapidly. Background turbidities measured upstream of the dredges or prior to when the dredges were operating were usually around 2 NTU or less. Our data indicate that both dredges created a narrow (few meters or less) plume of turbidity that was attenuated within approximately 90 to $120 \mathrm{~m}$ behind the dredge. At some of the more distal sampling locations ( $>90 \mathrm{~m}$ downstream) it was difficult to determine the plume location for the subjective sample. Both dredges were well within compliance with the State turbidity regulation.

The turbidity values found in the detailed dredge studies fall within the range of turbidity values found elsewhere along the Fortymile River and many of its unmined or historically mined tributaries. The highest turbidity value measured in 1997 was from an unmined tributary to Uhler Creek (site 13 on fig. 1; $21 \mathrm{NTU}$ ); the lowest values were from a number of unmined tributaries to the North Fork (all less than 2 NTU). There is no discernible difference in the range of turbidity values between areas that were mined by suction dredges and unmined areas (Wanty and others, 1997).

Water-quality samples were collected $60 \mathrm{~m}$ downstream of each of the two operating suction dredges. Three samples were collected: one from either side of the plume, and one in the center of the plume. The samples were passed through a filter with a nominal pore size of $0.45 \mu \mathrm{m}$ and acidified to a $\mathrm{pH}$ near 1 .

Results are listed in table 2. Samples 2A, 2C, 3A, and 3C are from either side of the plume behind the dredges shown in figures $4 A$ and $4 B$, respectively. Samples $2 B$ and $3 B$ are from the center of each plume.

The data show similar water-quality values for samples collected within and on either side of the dredge plumes. Further, the values shown in the table are not significantly different than the regional average concentrations for each dissolved metal, based on the 25 analyses that have been completed so far. Therefore, suction dredging appears to have no measurable

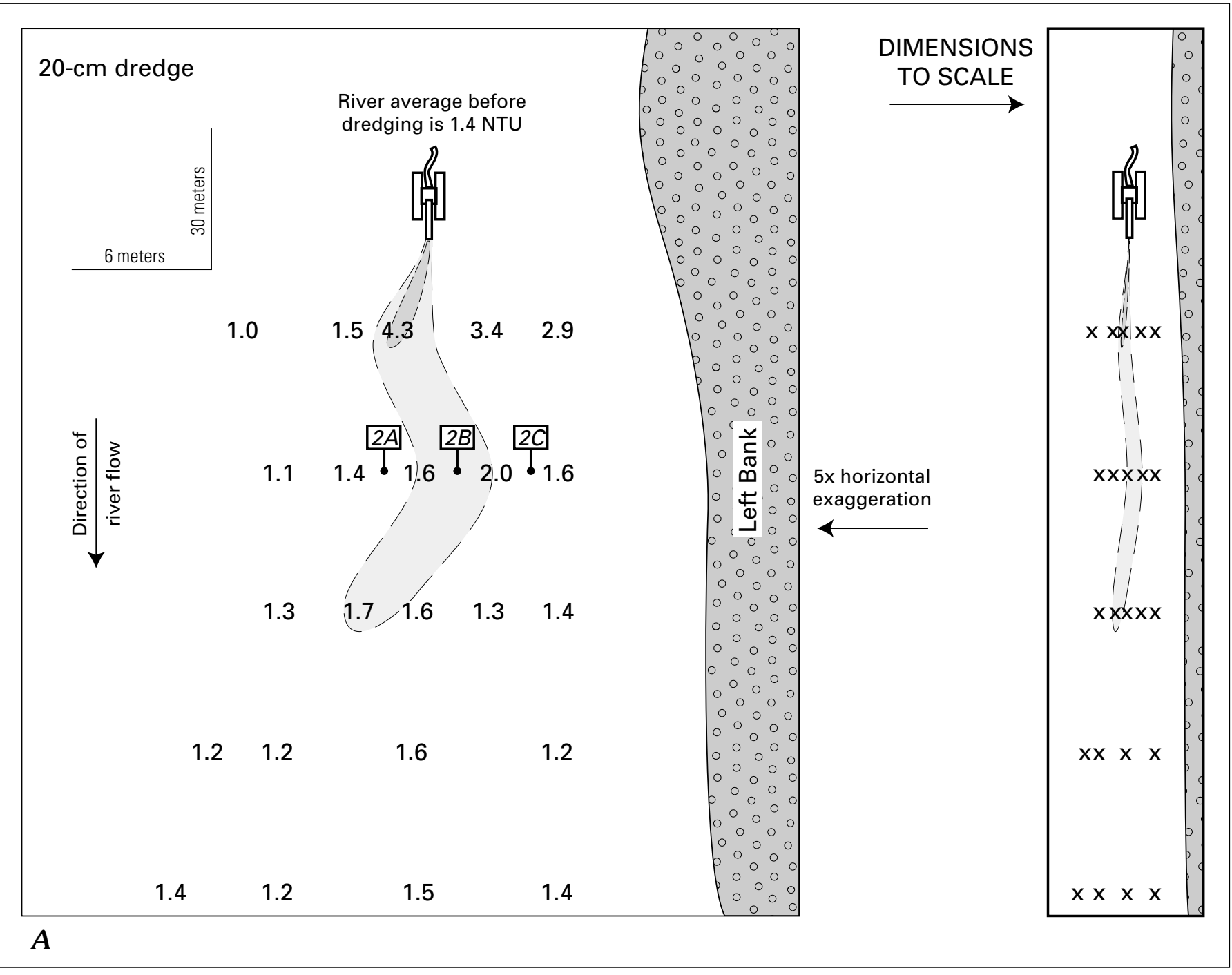

Figure 4 (above and next page). Results of turbidity survey behind two operating suction dredges (sites 2 and 3 from 1997 on fig. 1). $A$, results behind a dredge with a $20-\mathrm{cm}(8 \mathrm{inch})$ intake. $B$, results behind a dredge with a $25-\mathrm{cm}(10 \mathrm{inch})$ intake. All numbers shown are in NTU (nephelometric turbidity units), the standard unit of turbidity. Sample sites $2 \mathrm{~A}, 2 \mathrm{~B}$, and $2 \mathrm{C}$ are shown in $4 \mathrm{~A}$; sites $3 \mathrm{~A}, 3 \mathrm{~B}$, and $3 \mathrm{C}$ are shown in $4 B$. Refer to table 2 for chemical analyses of these samples. The right bank of the river is off the edge of both figures. The approximate shapes of the plumes are shown in gray. The figures on the left are exaggerated $5 x$ horizontally for clarity, and companion figures on the right are shown in which the dimensions are not distorted. 


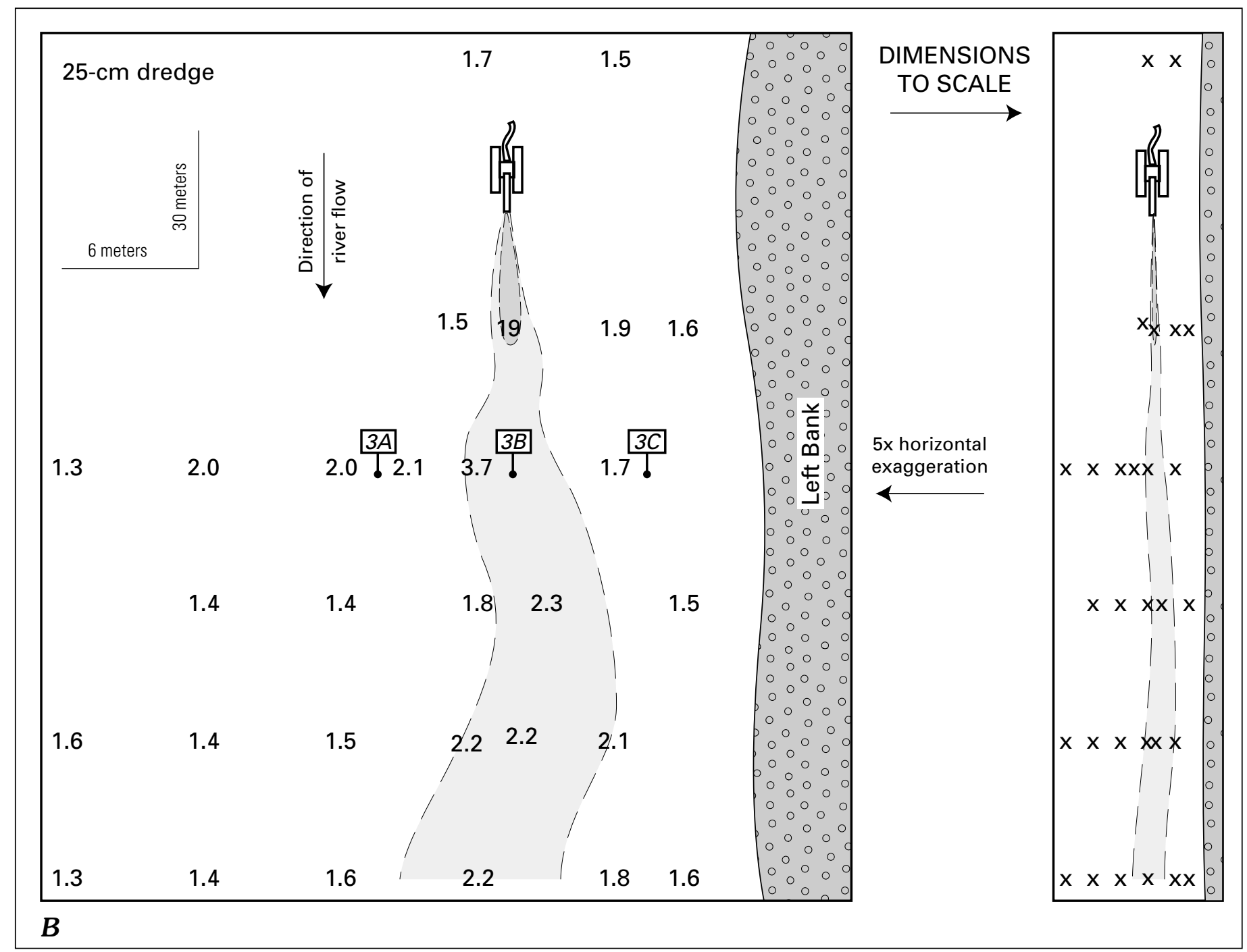

effect on the chemistry of the Fortymile River within this study area. We have observed greater variations in the natural stream chemistry in the region than in the suction-dredge areas. Again it should be noted that aquatic biota were not sampled as part of this study, so no conclusions can be drawn with respect to the health of benthic organisms in the river.

\section{Effects of Cat-Mining Operations}

Cat-mining operations are also referred to as placer mines since the object is to extract gold and other minerals from the placer, or riverine, gravels found in active or historic stream beds. This is accomplished through the use of heavy equipment that removes the overburden of non-mineralized ground and exposes the pay streak or gold-bearing material below. This material is extracted and washed in a screen plant or a trommel to separate the fine from the coarser material. The smaller material is passed over a sluice box where heavy minerals, including gold, are trapped. Settling ponds isolate sediment-laden process water from any active stream channel. Ideally, when mining is completed, streams are re-channelized to approximate the original configuration and the land is reclaimed such that a stable basin remains and vegetation can become reestablished.

Cat mining is being carried out in three places in the study area: along the upper reaches of Canyon Creek, along Squaw Creek (a tributary to upper Canyon Creek), and along the central part of Uhler Creek (fig. 1). All three sites were actively being mined at the time of sampling. The upper Canyon Creek area (including Squaw Creek) was studied and sampled in June 1998, and samples were collected for field and laboratory analyses. The lab analyses are not yet complete, so the interpretations given here are based on field measurements and observations. Our sampling in 1998 was conducted a few days after a major storm event, so stream discharges were greater than they had been in previous days. To some extent, the timing of the storm relative to our sampling indicates a worst-case scenario for parameters that might be impacted by higher flow rates, especially turbidity. On the other hand, the data from mined sections of the creek can be compared to adjacent, geologically similar, unmined tributaries that were sampled the same day to draw comparisons. For this purpose, we make the reasonable assumption that the nearby stream catchments received similar amounts of rainfall during the widespread storm event as did the upper reaches of Canyon Creek itself. The Canyon Creek drainage and the sample sites 
Table 2. Comparison of surface-water quality within the turbidity plumes behind two operating suction dredges, to the water quality on either side of the plume in non-turbid water.

[Samples labeled 2A, B, or C correspond to the suction dredge shown in figure $4 A$; those labeled $3 \mathrm{~A}, \mathrm{~B}$, or $\mathrm{C}$ correspond to figure $4 B$. All concentrations are given in micrograms per liter, except sulfate, which is given in milligrams per liter. Complete chemical analyses for these samples appear in Crock and others (1999). There is no sample 3C with "RU" of "RA" treatment.

Treatment: "FA" means filtered through a $0.45-\mu \mathrm{m}$ filter and acidified to $\mathrm{pH}$ approx. 1 with nitric acid; "RU" means unfiltered and unacidified; and "RA" means unfiltered, but acidified to $\mathrm{pH}$ approx. 1 with nitric acid. The column labeled "Regional data" gives the geometric mean for the other 25 samples collected in the study area in 1997 (NMF means "not a meaningful figure" because of the preponderance of non-detected concentrations)]

\begin{tabular}{|c|c|c|c|c|c|c|}
\hline \multirow[b]{2}{*}{ Element } & \multicolumn{6}{|c|}{ Field number } \\
\hline & $\begin{array}{c}\text { 97AK-2A } \\
\text { FA }\end{array}$ & $\begin{array}{c}\text { 97AK-2B } \\
\text { FA }\end{array}$ & $\begin{array}{c}\text { 97AK-2C } \\
\text { FA }\end{array}$ & $\begin{array}{c}\text { 97AK-3A } \\
\text { FA }\end{array}$ & $\begin{array}{c}\text { 97AK-3B } \\
\text { FA }\end{array}$ & $\begin{array}{c}\text { 97AK-3C } \\
\text { FA }\end{array}$ \\
\hline $\mathrm{Cr}$ & 2 & 2 & 3 & 3 & 3 & 3 \\
\hline $\mathrm{Fe}$ & 110 & 110 & 110 & 100 & 97 & 100 \\
\hline Mn & 1.0 & 0.98 & 0.76 & 0.65 & 0.63 & 0.65 \\
\hline $\mathrm{Co}$ & 0.07 & 0.07 & 0.06 & 0.06 & 0.05 & 0.05 \\
\hline $\mathrm{Ni}$ & 1.1 & 1.1 & 1.1 & 1.1 & 1.1 & 1.1 \\
\hline $\mathrm{Cu}$ & 2 & 2 & 2 & 2 & 2 & 2 \\
\hline $\mathrm{Zn}$ & 0.8 & 0.6 & 0.8 & 1 & 1 & 1 \\
\hline As & 0.3 & 0.3 & 0.3 & 0.3 & 0.3 & 0.3 \\
\hline $\mathrm{Se}$ & 0.3 & 0.3 & 0.2 & 0.2 & 0.3 & 0.3 \\
\hline Mo & 0.3 & 0.3 & 0.3 & 0.3 & 0.3 & 0.3 \\
\hline $\mathrm{Cd}$ & $<0.02$ & $<0.02$ & $<0.02$ & $<0.02$ & $<0.02$ & $<0.02$ \\
\hline $\mathrm{Sb}$ & 0.1 & 0.1 & 0.09 & 0.1 & 0.1 & 0.08 \\
\hline $\mathrm{Pb}$ & $<0.05$ & $<0.05$ & $<0.05$ & $<0.05$ & $<0.05$ & $<0.05$ \\
\hline $\mathrm{Th}$ & 0.08 & 0.08 & 0.08 & 0.07 & 0.07 & 0.06 \\
\hline $\mathrm{U}$ & 0.42 & 0.40 & 0.40 & 0.40 & 0.40 & 0.41 \\
\hline & \multicolumn{6}{|c|}{ Field number } \\
\hline Element & $\begin{array}{c}\text { 97AK-3A } \\
\text { FA }\end{array}$ & $\begin{array}{c}\text { 97AK-3B } \\
\text { FA }\end{array}$ & & $\begin{array}{c}\text { 97AK-3A } \\
\text { FA }\end{array}$ & $\begin{array}{c}\text { 97AK-3B } \\
\text { FA }\end{array}$ & $\begin{array}{c}\text { Regional } \\
\text { data }\end{array}$ \\
\hline $\mathrm{SO}_{4}$ & 17 & 16 & & & & 17 \\
\hline $\mathrm{Cr}$ & 6 & 6 & & 6 & 6 & 3.3 \\
\hline $\mathrm{Fe}$ & 120 & 83 & & 150 & 150 & 140 \\
\hline Mn & 0.94 & 0.89 & & 1.2 & 1.4 & 1.6 \\
\hline Co & 0.06 & 0.05 & & 0.07 & 0.07 & 0.09 \\
\hline $\mathrm{Ni}$ & 0.9 & 0.9 & & 1.0 & 1.0 & 1.2 \\
\hline $\mathrm{Cu}$ & 2 & 2 & & 2 & 2 & 2.5 \\
\hline $\mathrm{Zn}$ & $<0.5$ & $<0.5$ & & $<0.5$ & $<0.5$ & 0.81 \\
\hline As & 0.4 & 0.3 & & 0.4 & 0.4 & 0.31 \\
\hline $\mathrm{Se}$ & 0.3 & 0.3 & & 0.2 & 0.2 & 0.34 \\
\hline Mo & 0.4 & 0.3 & & 0.2 & 0.2 & 0.26 \\
\hline $\mathrm{Cd}$ & $<0.02$ & $<0.02$ & & $<0.02$ & $<0.02$ & $\mathrm{NMF}$ \\
\hline $\mathrm{Sb}$ & 0.2 & 0.2 & & 0.09 & 0.08 & 0.10 \\
\hline $\mathrm{Pb}$ & $<0.05$ & $<0.05$ & & $<0.05$ & $<0.05$ & NMF \\
\hline $\mathrm{Th}$ & 0.11 & 0.08 & & 0.06 & 0.05 & 0.07 \\
\hline $\mathrm{U}$ & 0.34 & 0.36 & & 0.35 & 0.40 & 0.29 \\
\hline
\end{tabular}

are shown in figure 1. Several lines of observation demonstrate the negative impact that cat mining has had on the riparian environment in upper Canyon Creek, including the streamwater turbidity and the stream-bed and bank morphology. The turbidity of Canyon Creek within the cat-mining area was the highest we measured in this study, at approximately 320 NTU. For comparison, the average turbidity of the three unmined triutaries to Canyon Creek was 17 NTU; these were sampled on the same day as the main Canyon Creek samples, under similar flow conditions. The increased turbidity is a direct result of the destabilization of the stream channel that has occurred as the channel was moved during cat mining. The new channel has an immature bed, lacking the large anchor rocks that help stabilize the bed. Without these anchors, the bed load increases 
dramatically as material is carried downstream. Also a result of the bed destabilization is the undercutting and mass wasting of the stream banks as the channel migrates laterally. Mass wasting of the bank exacerbates the already high turbidity. We observed several long $(>10 \mathrm{~m})$ and dilated $(>10 \mathrm{~cm})$ longitudinal fractures in the banks, indicating large sections of the bank were about to fall into the stream. In addition to undercutting, the stability of the bank also is decreased because of the removal of riparian vegetation, redirection of the stream channel, and failure to regrade the banks, all of which occur during cat mining activity in Canyon Creek. Because gold-bearing sediments commonly flank the contemporary stream channel, riparian vegetation often is disturbed in a cat-mining operation.

Two other cat-mining operations are ongoing at Squaw Creek and Uhler Creek (fig. 1). These operations do not seem to have had the destructive effect on stream-bed morphology that the upper Canyon Creek operations have. At this writing, we are unsure of the reason for this observation, but it may be that these two operations are simply taking place at a smaller scale and less material has been moved. Alternatively, perhaps there is a greater abundance of large (anchor) rocks in these two areas; the permafrost may be less disturbed; or the original stream channel may have been less disturbed by mining in these two locations. If the Squaw Creek and Uhler Creek operations did not disturb the original mature stream bed, then no increase in turbidity is expected. Even though the Squaw Creek and Uhler Creek cat-mining operations do not appear to have affected their stream channels as the Canyon Creek operations have, the surface disturbance of cat mining on the stream banks destroys riparian vegetation that may take decades to reestablish and mature, although successional growth occurs more quickly.

In any case, the environmental impacts of cat mining can be minimized by following locally established best management practices (BMP's). BMP's are designed to minimize nonpoint-source pollution and to promote and enhance the natural recovery of a mine site (Rundquist and others, 1986). BMP's should be incorporated into all phases of mine operation from the formation of a mining plan, through design and construction of temporary and permanent structures, to site closure and reclamation. The mining plan outlines the existing site features and describes overall site preparation, operation, and rehabilitation. The design of permanent and temporary structures takes into account the mitigation of turbidity, suspended sediment, and siltation resulting from erosion. Site rehabilitation covers design flows, stream patterns and placement, hydraulic design, and channel stability. The level to which the BMP's are adhered often determines the overall success of mine operations with respect to environmental effects.

\section{Conclusions}

The data collected for this study help establish regional background geochemical compositions and turbidity for the surface waters in the Fortymile River system. In general, the quality of the surface waters in the Fortymile River system is very good. The waters are quite dilute $(<210 \mathrm{mg} / \mathrm{L}$ total dissolved solids) and have low concentrations of heavy metals. The primary factors causing natural variations in surface-water quality are probably variations in bedrock geology and mineral content. Even though the extent of chemical interactions between ground or surface waters and bedrock are limited, as evidenced by the dilute nature of the waters, it is likely that geologic and mineralogic variations in bedrock and stream sediment result in the observed chemical variations in surface and ground-water samples.

Within the study area, some sites are mined by suction dredges along the main river, and some sites are mined by bulldozers. One of the main objectives of this study was to evaluate the potential environmental effects of these two goldplacer-mining techniques, as measured in the surface-water quality. Chemical and turbidity data show that any variations in water quality due to the suction dredging technique fall within the natural variations in water quality of the river. This conclusion is further supported by similarities between waterquality data from dredged areas with that from other samples collected throughout the region, at the sites shown in figure 1. Conversely, some cat-mining operations have a pronounced impact, leading to increased turbidity values, stream-channel destabilization, mass-wasting of stream banks, and destruction of riparian vegetation.

\section{References Cited}

Back, W., Baedecker, M.J., and Wood, W.W., 1993, Scales in chemical hydrogeology: A historical perspective, in Alley, W.M., ed., Regional Ground-Water Quality: New York, Van Nostrand Reinhold, p. 111129.

Crock, J.G., Gough, L.P., Wanty, R.B., Day, W.C., Wang, B., Gamble, B.M., Henning, M., Brown, Z.A., and Meier, A.L., 1999, Regional geochemical results from the analyses of rock, water, soil, stream sediment, and vegetation samples-Fortymile River watershed, east-central Alaska: U.S. Geological Survey Open-File Report 99-33, $82 \mathrm{p}$.

Edmunds, W.M., Bath, A.H., and Miles, D.L., 1982, Hydrochemical evolution of the East Midlands Triassic sandstone aquifer, England: Geochimica et Cosmochimica Acta, v. 46, no. 11, p. 2069-2081.

Environmental Protection Agency [USEPA], 1999, Current drinking-water standards: National primary and secondary drinking-water regulations: accessible at the USEPA website: http://www.epa.gov/ OGWDW/wot/appa.html.

Fishman, M.J., and Pyen, G., 1979, Determination of selected anions in water by ion chromatography: U.S. Geological Survey WaterResources Investigations Report 79-101.

Gough, L., Day, W., Crock, J., Gamble, B., and Henning, M., 1997, Placergold mining in Alaska- Cooperative studies on the effect of suction dredge operations on the Fortymile River: U.S. Geological Survey Fact Sheet FS-155-97

Lichte, F.E., Golightly, D.W., and Lamothe, P.J., 1987, Inductively coupled plasma-atomic emission spectrometry, in Baedecker, P.A., ed., Geochemical Methods of Analysis: U.S. Geological Survey Bulletin 1770, p. B1-B10.

Meier, A.L., Grimes, D.J., and Ficklin, W.H., 1994, Inductively coupled plasma mass spectrometry; a powerful analytical tool for mineral resource and environmental studies: U.S. Geological Survey Circular 1103-A, p. 67-68. 
Rundquist, L.A., Bradley, N.E., Baldrige, J.E., Hampton, P.D., Jennings, T.R., and Joyce, M.R., 1986, Best management practices for placer mining-Technical report: Juneau, Alaska, Alaska Department of Fish and Game.

Sloan, C.E., and van Everdingen, R.0., 1988, Region 28, Permafrost region, in Back, W., Rosenshein, J.S., and Seaber, P.R., eds., Hydrogeology: Boulder, Colo., Geological Society of America, p. 263-270.

Wanty, R.B., Wang, B., and Vohden, J., 1997, Studies of suction dredge gold-placer mining operations along the Fortymile River, eastern Alaska: U.S. Geological Survey Fact Sheet, FS-154-97, 2 p.

Winter, T.C., LaBaugh, J.W., and Rosenberry, D.0., 1988, The design and use of a hydraulic potentiometer for direct measurement of differences in hydraulic head between ground water and surface water: Limnology and Oceanography, v. 33, no. 5, p. 1209-1214.

Winter, T., Harvey, J.W., Franke, O.L., and Alley, W.M., 1998, Ground water and surface water: A single resource: U.S. Geological Survey Circular 1139, $79 \mathrm{p}$.

Wood, W.W., 1976, Guidelines for the collection and field analysis of ground-water samples for selected unstable constituents: Techniques of Water-Resources Investigations of the U.S. Geological Survey, Book 1, Ch. D2, 24 p.

Yeend, W., 1996, Gold placers of the historical Fortymile River region, Alaska: U.S. Geological Survey Bulletin 2125, 75 p.

Reviewers: Geoffrey S. Plumlee and Robert Eppinger 


\title{
Bedrock Assemblages of the Bering Strait Region: Implications for Offshore Metal Sources in the Marine Environment
}

\author{
By Travis L. Hudson and R.W. Saltus
}

\section{Abstract}

The Bering Strait region is important habitat for Pacific walrus (Odobenus rosmarus divergens). Elevated metal levels in tissues of some walrus have raised concerns about the sources of these metals. This study synthesizes and integrates onshore geology, regional gravity and magnetic data, and information about mineral deposits and the natural processes that weather, erode, and disperse metals in the Bering Strait region. In this region (Seward Peninsula, St. Lawrence Island, Chukotsk Peninsula, and intervening areas of the Bering Sea shelf), six bedrock assemblages can be defined and extended from onshore to offshore areas. These assemblages include (1) Paleozoic sedimentary and low-grade metasedimentary rocks, (2) upper Paleozoic to Triassic sedimentary and related mafic igneous rocks, (3) Mesozoic high-pressure, low-temperature metamorphic rocks, (4) Cretaceous amphibolite-facies metamorphic rocks, (5) Cretaceous volcanic and related intrusive rocks, and (6) Tertiary sedimentary and volcanic rocks. Cretaceous plutonic rocks are widely scattered and locally intrude all of the pre-Tertiary bedrock assemblages. The distribution and thickness of Tertiary sedimentary rocks can be approximated in offshore areas using satellite gravity data. The resulting new map shows that about 40 percent of the offshore Bering Strait region may have bedrock at or near the sea floor. Some mineral deposits and rock units with high background metal contents are associated with specific bedrock assemblages whereas other mineral deposits are more regionally distributed. The mineral deposits of the region are mostly types that contain $\mathrm{Cu}, \mathrm{Pb}, \mathrm{Zn}, \mathrm{Ag}, \mathrm{Mo}, \mathrm{Sn}$, or $\mathrm{Au}$ (or certain combinations of these metals) and elevated concentrations of associated elements, such as $\mathrm{As}, \mathrm{Bi}, \mathrm{Be}, \mathrm{B}, \mathrm{Sb}$, and $\mathrm{F}$. The mineral deposits have been physically and chemically weathered and eroded by both subaerial and marine processes. Marine processes have been particularly important as the region has experienced several sea-level fluctuations that have alternately exposed and submerged the Bering Sea shelf. The marine transgressions and regressions that accompanied sea-level fluctuations have eroded mineral deposits and reworked and redistributed metals and associated element suites derived from them. The distribution of natural metal sources and the natural processes responsible for dispersal of metals from them to the environment have existed in the Bering Strait region throughout a large part of the Quaternary. As a consequence, the nearshore and offshore areas have served as an accumulation region for metals for at least many hundreds of thousands of years.

\section{Introduction}

The northern Bering Sea and adjacent coasts of Seward Peninsula, St. Lawrence Island, and Chukotsk Peninsula (the Bering Strait region, fig. 1) are important habitat for Pacific walrus (Odobenus rosmarus divergens). Walrus live or migrate through this entire region during all months of the year (Fay, 1982, p. 8-20). Local shorelines of St. Lawrence Island and the Chukotsk Peninsula are popular places where walrus come ashore (hauling-out areas) and the sea floor in the Bering Strait region, mostly at water depths of $50 \mathrm{~m}$ or less, is everywhere within the known feeding depths of walrus (as deep as $80 \mathrm{~m}$ ).

Walrus feed on invertebrates and crustaceans that live on or within sediment on the sea floor. Bivalve mollusks are a mainstay of their diet. In the process of finding and eating their food, walrus come in contact with and ingest bottom sediment. Fine sand and small stones make up nearly 2 percent of the stomach contents that have been examined (Fay, 1982, p. 153). As a result of these feeding habits, walrus are exposed to the chemical character of the sea floor, either directly by contact and ingestion of bottom sediments, or indirectly by consumption of the biota that live on or in the bottom sediment.

Recent studies have identified walrus in the Bering Strait region that have elevated metal contents in their internal organs (Taylor and others, 1989; Warburton and Seagars, 1993).

These elevated metal contents have raised concerns about the potential roles of anthropogenic and natural metal sources on walrus habitat.

Exposed land areas in the Bering Strait region are locally highly mineralized. Several bedrock assemblages have welldefined suites of associated natural mineral deposits. The 


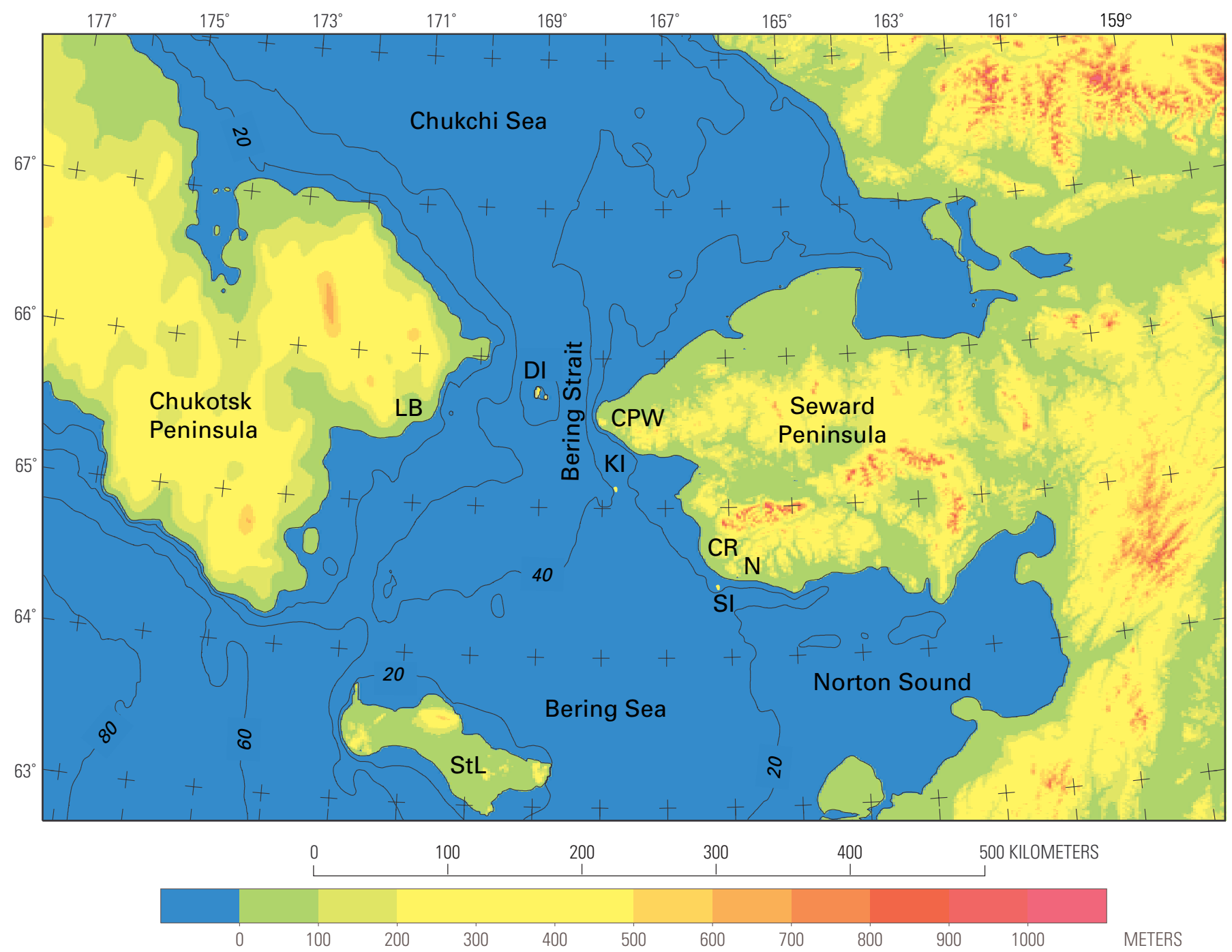

Figure 1. Map showing topography/bathymetry and geographic locations in the Bering Strait region. Offshore lines are $20 \mathrm{~m}$ bathymetric contours. Geographic location abbreviations: CPW, Cape Prince of Wales; CR, Cape Rodney; DI, Diomede Islands; KI, King Island; LB, Lawrence Bay; N, Nome; SI, Sledge Island; StL, St. Lawrence Island.

chemical character of these mineral deposits is generally predictable. The distribution of the bedrock assemblages can therefore be a guide to the types and distribution of associated natural metal sources in the Bering Strait region.

This report defines six bedrock assemblages that extend from onshore to offshore areas in the Bering Strait region. The continuity of these bedrock assemblages can be interpreted using gravity and magnetic data and regional geologic relationships. Parts of the offshore Bering Strait region have bedrock assemblages at or near the sea floor. In these areas, local metal sources are to be expected. Mobilization and dispersal of metals and associated elements to the marine environment from these sources has probably occurred, especially during the marine transgressions and regressions on the shallow Bering Sea shelf that accompanied Quaternary sea-level fluctuations.

\section{Data and Methods}

Three regional data sets have been compiled to define bedrock assemblages onshore and offshore in the Bering Strait region. These include 1:1,000,000-scale geology, gravity, and magnetic maps. The regional onshore geology was compiled from Till and others (1986), Sainsbury (1972), Sainsbury and others (1972), Patton and Csejtey (1980), and Worrall (1991). The results of recent geologic fieldwork on the Chukotsk Peninsula (Bering Strait Field Party, 1997) were also helpful. The onshore geology compilation maps lithologic assemblages potentially useful in interpreting regional magnetic and gravity data (fig. 2).

The regional gravity map (fig. 3) combines onshore (Alaska) and offshore data. Onshore gravity data are primarily reconnaissance in nature and helpful for regional 


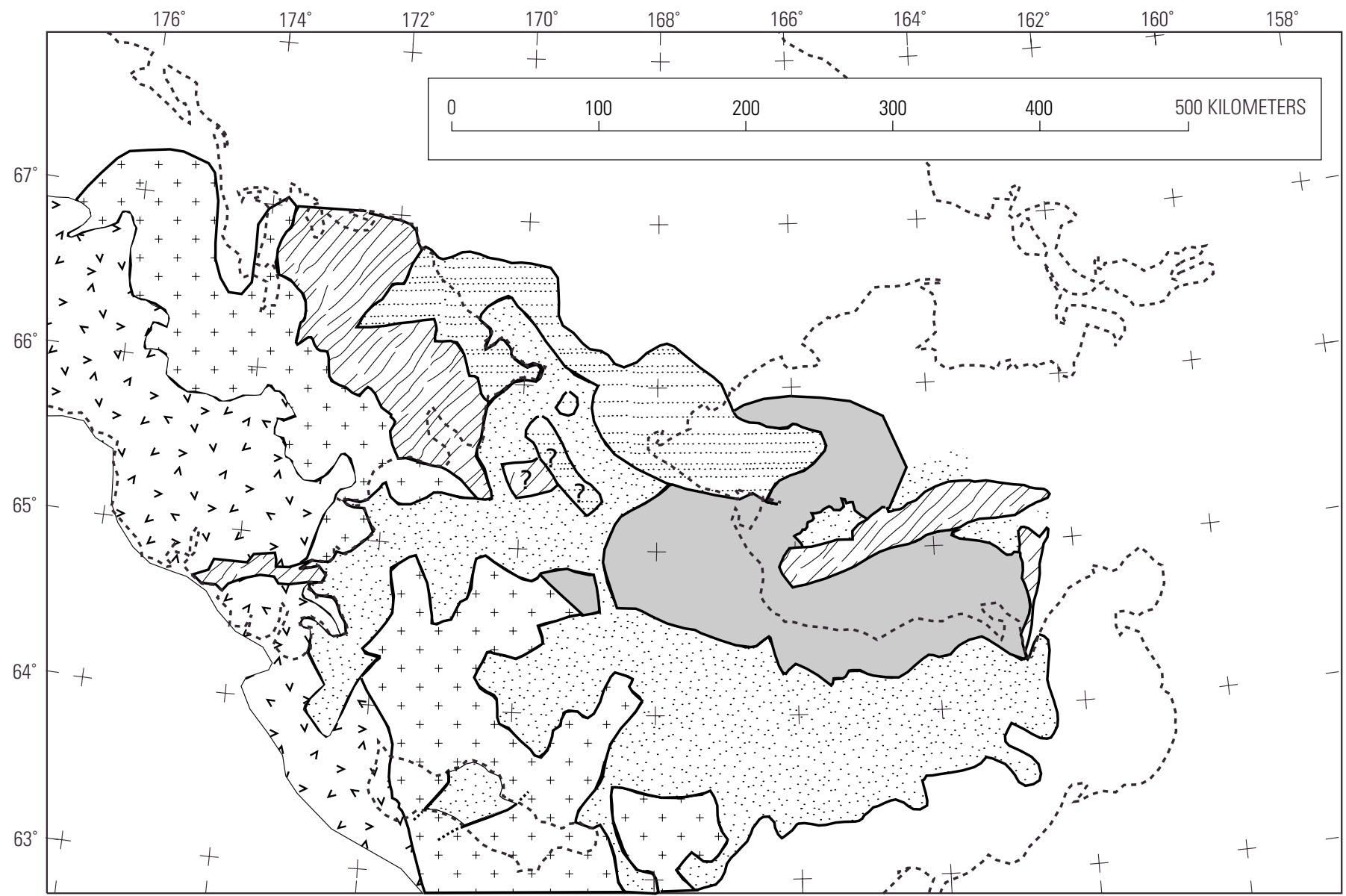

EXPLANATION

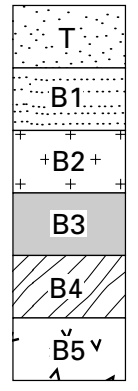

Tertiary sedimentary and volcanic rocks

Paleozoic sedimentary and low-grade metasedimentary rocks

Upper Paleozoic to Triassic sedimentary and mafic igneous rocks

Mesozoic high-pressure, low-temperature metasedimentary and metavolcanic rocks

Cretaceous amphibolite-facies metamorphic rocks

Cretaceous volcanic and associated intrusive rocks

Figure 2. Map showing distribution of bedrock assemblages in the Bering Strait region. These bedrock assemblages are inferred using offshore using gravity and magnetic data (figs. 3,4 ) and regional geologic trends. Area shown is approximately the same as on figure 1.

interpretations of Seward Peninsula geology (Barnes and Hudson, 1977; Barnes and others, 1994). Offshore gravity data, derived throughout the region from satellite measurements (Sandwell and Smith, 1997), are useful in delineating sedimentary basins and the intervening areas where bedrock is at or near the sea floor. A conversion of gravity anomaly to sediment thickness produces the offshore contour lines of figure 3. This conversion was calibrated by seismic thickness estimates shown by Kirschner (1994). This calibration leads to lateral density contrasts of the basinal sediments that range from $-0.3 \mathrm{~g} / \mathrm{cm}^{3}$ for shallow sediments to $-0.05 \mathrm{~g} / \mathrm{cm}^{3}$ for sediments thicker than $4 \mathrm{~km}$.

Regional magnetic data (fig. 4) are complete for the Seward Peninsula (Saltus and Simmons, 1997) and available but less detailed for the Chukotsk Peninsula (National Geophysical Data Center, 1996). Magnetic data are not available for the St. Lawrence Island quadrangle (onshore or offshore). Offshore magnetic data are limited in coverage and do not tie well to onshore data; therefore they are not included in our compilation.

In general the geologic data define the major bedrock assemblages. Gravity data show where bedrock may be at or near the sea floor and also permit extrapolation of bedrock outcrops on the Seward Peninsula to offshore areas. Magnetic data permit extrapolation of some bedrock assemblages on the Chukotsk Peninsula to adjacent offshore areas. In specific areas, combinations of the regional data sets are useful in delineating bedrock assemblages. The delineation of bedrock 

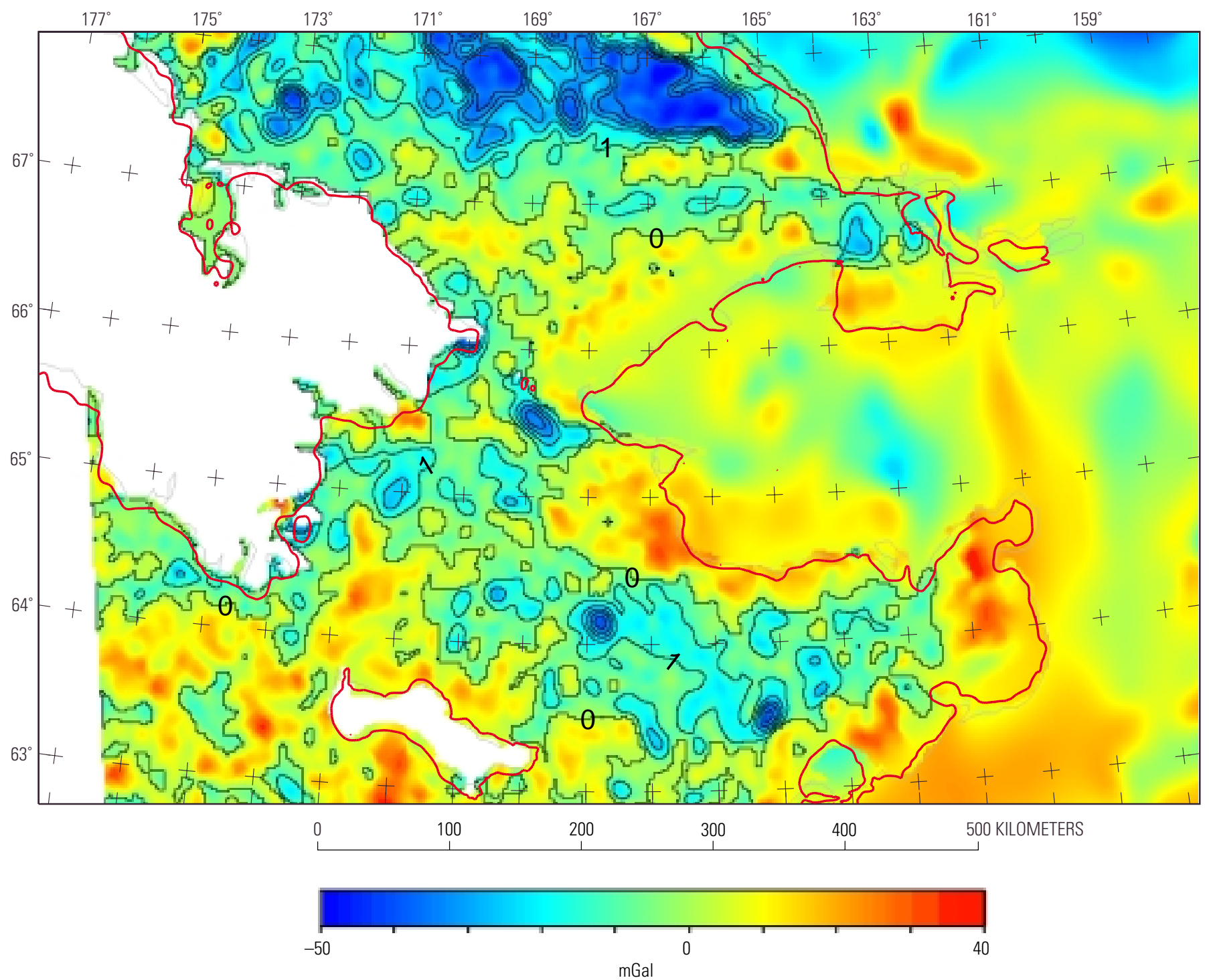

Figure 3. Map showing onshore and offshore gravity data for the Bering Strait region. Alaska onshore data are isostatic residual anomalies from Barnes and others (1994). Offshore data are free-air anomalies derived from satellite altimetry (Sandwell and Smith, 1997). Offshore contour lines are 1-km levels of inferred sediment thickness from the gravity data (details given in text). Depths exceed $5 \mathrm{~km}$ in the deepest basins. White areas are where gravity data are not available.

assemblages, combined with information about the mineral deposits that are known within them (Hudson and others, 1977; Hudson and DeYoung, 1978; Hudson, 1998a; 1998b; 1999; Nokleberg and others, 1996), enables interpretations of the sinificance of natural metal sources in the offshore Bering Straits region.

\section{Regional Delineation of Bedrock Assemblages}

Six bedrock assemblages have been defined and carried from onshore to offshore in the Bering Strait region (fig. 2). These include Tertiary sedimentary and volcanic rocks (map unit T), Paleozoic sedimentary and low-grade metasedimentary rocks (map unit B1), upper Paleozoic to Triassic sedimentary and related mafic igneous rocks (map unit B2),
Mesozoic high-pressure, low-temperature metamorphic rocks (map unit B3), Cretaceous amphibolite-facies metamorphic rocks (map unit B4), and Cretaceous volcanic and associated intrusive rocks (map unit B5). Certain Cretaceous plutonic rocks are widely scattered and locally intrude all of the preTertiary bedrock assemblages. These Cretaceous plutonic rocks are not shown separately on figure 2 .

\section{Tertiary Sedimentary and Volcanic Rocks (Map Unit T)}

Tertiary sedimentary and volcanic rocks are locally developed onshore and more widely distributed offshore. Onshore, these rocks include (1) local occurrences and fault-bounded depocenters to 3 or more $\mathrm{km}$ thick of coal-bearing sandstone and shale on the Seward Peninsula (Barnes and Hudson, 1977), St. Lawrence Island (Patton and Csejtey, 1980), and the 


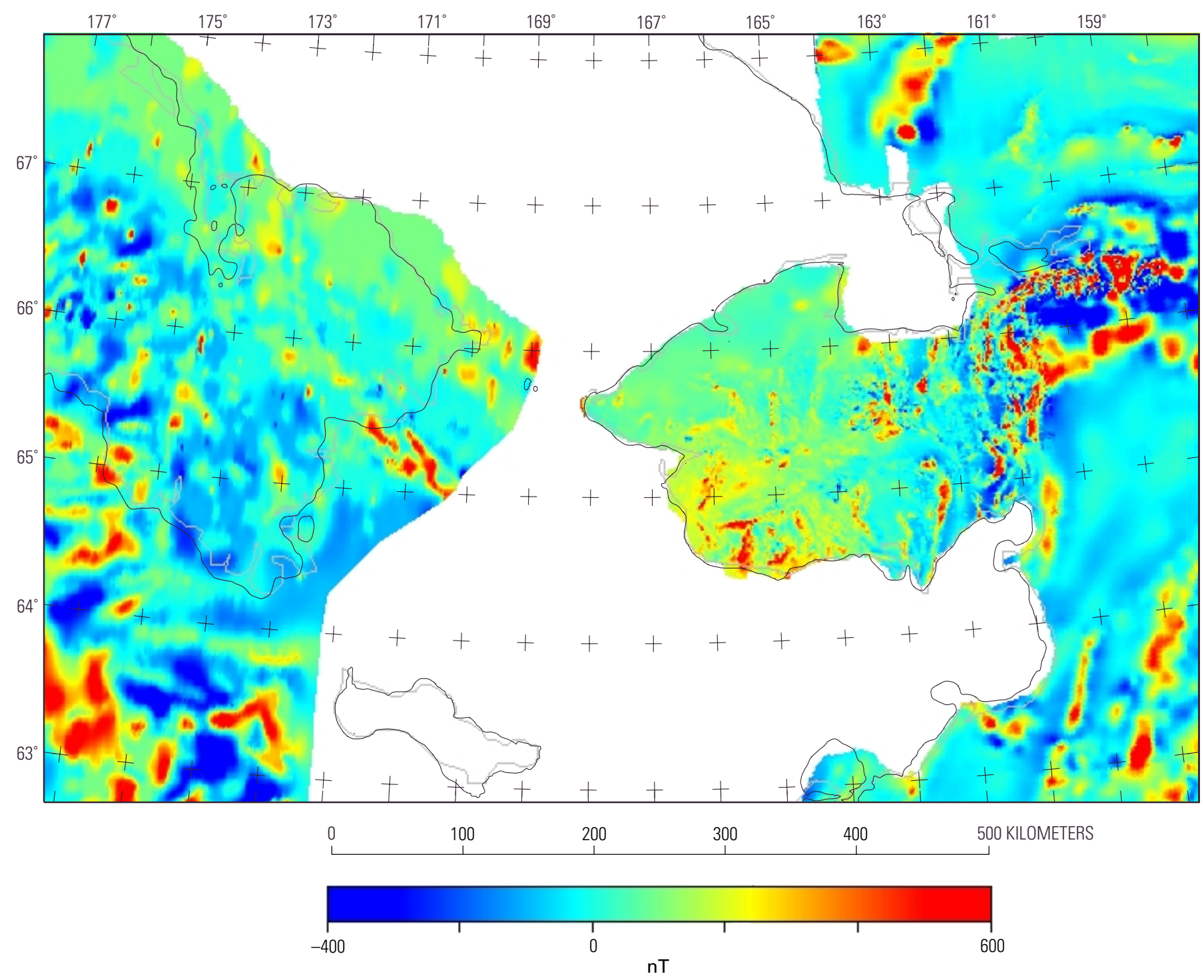

Figure 4. Map showing aeromagnetic data for the Bering Strait region. Alaska data are from a recent U.S. Geological Survey compilation (Saltus and Simmons, 1997). Russian data were digitized from 1:2,500,000 scale maps and are available from the National Geophysical Data Center (1996). White areas do not have aeromagnetic data, the available data are not satisfactory, or they are beyond the area of this study.

Chukotsk Peninsula (Nelson and Hopkins, 1972) that are, in places, as old as Eocene (Dickinson and others, 1987); (2) subaerial (and locally submarine) basalt fields on all three emergent land areas of the region (parts of the Bering Sea volcanic province of Moll-Stalcup, 1994) that are late Cenozoic and, in many places, Quaternary in age (not shown separately on fig. 2); and (3) Tertiary mafic to felsic volcanic rocks (especially on St. Lawrence Island, fig. 2) (Patton and Csejtey, 1980).

Tertiary volcanic rocks are probably also present locally offshore but areas of Tertiary sediments are prevalent. The Norton (offshore southern Seward Peninsula; Worrall, 1991; Kirschner, 1994) and Chirikov (offshore east Chukotsk Peninsula; Nelson and Hopkins, 1972) basins are the principal Tertiary depocenters, but gravity data (fig. 2) and some seismic data (Kirschner, 1994) indicate that these depocenters are part of a larger, interconnected basin system covering much of the offshore area. The Tertiary sedimentation in these basins started in the early Tertiary, probably in the Eocene (Dickinson and others, 1987; Worrall, 1991). Tertiary sediment thickness has been estimated by calibrating gravity data to known sediment thickness (fig. 2). As interpreted from satellite gravity data, at least 60 percent of the offshore Bering Strait region has a Tertiary sediment mantle that could isolate pre-Tertiary bedrock from the marine environment.

The offshore areas of average to slightly above average gravity values are where sediment accumulations are thinner and preTertiary bedrock assemblages can be near or at the sea floor. The principal areas where Tertiary sediment is thin or absent include the Bering Strait (offshore Cape Prince of Wales), western Seward Peninsula, north and south of St. Lawrence Island, and near Lawrence Bay on the eastern Chukotsk Peninsula. The distribution of pre-Tertiary, near-sea-floor bedrock is also indicated locally by seismic data (Grim and McManus, 1970; Fisher and others, 1982), the distribution of coarse bottom sediment and particulate gold (Creager and McManus, 1967; Nelson and Hopkins, 1972; McManus and others, 1997), and the location of subaerial bedrock exposures in the offshore such as on Sledge, King, and Diomede Islands. 


\section{Paleozoic Sedimentary and Metasedimentary Rocks (Map Unit B1)}

Low-grade metasedimentary rocks, structurally overlain by a few thousand meters of less deformed and metamorphosed Ordovician to Silurian limestone and dolostone, are the principal bedrock assemblage of northwest Seward Peninsula (the York terrane of Till and Dumoulin, 1994). The metasedimentary rocks, locally intruded by metadiabase, include pelite-rich sections (slate, phyllite, fine-grained metasandstone, locally calcareous semischist, and minor gray metachert) and coarser grained sections with more abundant fine-grained metasandstone and minor impure calcareous beds. Till and Dumoulin (1994) report one Ordovician conodont age from metasandstone that is considered a maximum age.

The low-grade metaclastic rocks and the structurally overlying carbonate rocks appear to represent lower Paleozoic sedimentary successions that are the least metamorphosed Paleozoic rocks on the Seward Peninsula. This assemblage on the Seward Peninsula has long been correlated with lower Paleozoic metasedimentary and sedimentary rocks on northeast Chukotsk Peninsula and the Brooks Range (Churkin, 1972; Worrall, 1991) (fig. 2). The Chukotsk Peninsula rocks include greenschist-facies phyllite and schist whose protoliths are Paleozoic in age (Bering Strait Field Party, 1997) and shelf-facies Cambrian to Carboniferous rocks deposited on crystalline basement (Worrall, 1991).

Extrapolation of the Paleozoic sedimentary and metasedimentary bedrock assemblage from northwest Seward Peninsula, across Bering Strait to northeast Chukotsk Peninsula, is constrained by satellite gravity data and some aeromagnetic data. Gravity lows suggest that sediment depocenters flank the Chukotsk Peninsula to the east and northeast; however, neutral to slightly positive gravity values north and west of the Diomede Islands suggest that western Seward Peninsula sedimentary and low-grade metasedimentary rocks extend offshore through Bering Strait to northeast Chukotsk Peninsula. On Chukotsk Peninsula, the boundary between Paleozoic shelf-facies rocks and amphibolite-facies metamorphic rocks coincides with a boundary between a magnetic domain of low values and one with average and locally high values. This boundary in the magnetic data extends offshore to the southeast about $100 \mathrm{~km}$ and further constrains the distribution of bedrock assemblages in the area of Bering Strait.

\section{Upper Paleozoic to Triassic Sedimentary and Associated Mafic Igneous Rocks (Map Unit B2)}

Sedimentary rocks on St. Lawrence Island include Devonian dolostone and dolomitic limestone, Mississippian limestone, and Triassic black shale, thin-bedded limestone, and chert that have been correlated with similar rocks of the Brooks Range and Chukotsk Peninsula (Patton and Dutro, 1969). The Triassic rocks represent a condensed section similar to the Shublik Formation of the Brooks Range (Patton and Dutro, 1969).

A clastic sequence containing carbonaceous graywacke, shale, some chert, and impure clastic limestone, thought to be of Triassic and Permian age (Patton and Csejtey, 1980), is also present on St. Lawrence Island. This sequence, commonly associated with diabase and gabbro intrusions, appears to be in structural contact with the more calcareous Paleozoic to Triassic section. Central and northwest Chukotsk Peninsula contain Triassic shaley rocks and flysch spatially associated with mafic (and some ultamafic) rocks (Worrall, 1991) that are considered similar to these St. Lawrence Island rocks (Patton and Csejtey, 1980).

The Paleozoic to Triassic sedimentary and associated mafic igneous rocks on Chukotsk Peninsula are in contact on the south with Cretaceous volcanic and associated intrusive rocks of the Okotsk-Chukotsk volcanic belt (see below). This complicated boundary is here considered to be the southern limit of Paleozoic and Triassic rocks on the Chukotsk Peninsula (fig. 2). The boundary trends irregularly southeast through the central part of the Chukotsk Peninsula and comes to the coast at the southeast headland closest $(150 \mathrm{~km})$ to St. Lawrence Island. On St. Lawrence Island, a comparable south-southeast-trending boundary between Paleozoic and Triassic rocks and Cretaceous volcanic and associated intrusive rocks (considered the extension of the Okotsk-Chukotsk volcanic belt) is on the westernmost part of the island (fig. 2) (Patton and Csejtey, 1980). The gravity and magnetic data are not sufficiently detailed to characterize these two contrasting assemblages. Therefore, the offshore boundary between Paleozoic to Triassic sedimentary and associated mafic igneous rocks and Cretaceous volcanic and associated intrusive rocks of the Okotsk-Chukotsk volcanic belt is simply projected across the strait between Chukotsk Peninsula and St. Lawrence Island.

\section{Mesozoic High-Pressure, Low-Temperature Metamorphic Rocks (Map Unit B3)}

A large part of Seward Peninsula is underlain by high-pressure, low-temperature (including blueschist facies) metamorphic rocks of the Nome Group (part of the Seward terrane; Till and Dumoulin, 1994). The protoliths for many of these metamorphic rocks are lower Paleozoic clastic and carbonate sedimentary rocks and mafic and felsic volcanic rocks representing a variety of depositional environments (Till and others, 1986). Parts of the Nome Group may be in depositional contact with Precambrian rocks and are locally intruded by Devonian metagranitic rocks. High-pressure, low-temperature metamorphism (Sainsbury and others, 1970; Thurston, 1985; Patrick, 1988; Patrick and Evans, 1989; Hannula and others, 1995) took place in the Jurassic and (or) Early Cretaceous (Forbes and others, 1984; Armstrong and others, 1986; Hannula and McWilliams, 1995). Later deformation, uplift, and higher temperature metamorphism accompanied regional extension that affected these rocks in the mid-Cretaceous (Miller and Hudson, 1991; Dumitru and others, 1995; Hannula and others, 1995).

High-pressure, low-temperature metamorphic rocks are the dominant bedrock assemblage on southern Seward Peninsula adjacent to the Bering Sea. Correlative assemblages are not known from St. Lawrence Island or the Chukotsk Peninsula. The offshore extensions of the high-temperature, lowpressure metamorphic rocks are indicated by gravity data. The satellite gravity (Sandwell and Smith, 1997) and onshore 
gravity (Barnes and Hudson, 1977; Barnes and others, 1994) merge remarkably well along the southern Seward Peninsula. The high-pressure, low-temperature metamorphic rocks here are characterized by average to slightly positive gravity values that extend offshore from areas along the southern coast of the Seward Peninsula. High-pressure, low-temperature metamorphic rocks host the most important gold deposits in the region including the large gold-producing district at Nome. The distribution and character of particulate gold and other heavy minerals (Nelson and Hopkins, 1972; McManus and others, 1977) in bottom sediments is consistent with the western offshore extension of high-pressure, low-temperature metamorphic rocks based on gravity values.

\section{Cretaceous Amphibolite-Facies Metamorphic Rocks (Map Unit B4)}

High-grade metamorphic rocks make up important parts of the Seward and Chukotsk Peninsulas. These rocks include metasedimentary and metaigneous components that are mostly of amphibolite facies but range up to granulite facies in one area of the Seward Peninsula (Kigluaik Mountains; Till, 1980). On the Seward Peninsula, amphibolite-facies rocks are localized in structural culminations bound by Cenozoic normal faults (Kigluaik, Bendeleben, and Darby Mountains). The high-grade metamorphism is mid-Cretaceous in age and accompanied by development of migmatitic complexes and granitic plutonism (Sainsbury, 1972; Till and others, 1986; Hudson, 1994; Amato and others, 1994; Amato and Wright, 1997a). Amphibolitefacies metamorphism and related magmatism and deformation are interpreted to reflect regional extension that was widespread in Alaska during the mid-Cretaceous (Miller and Hudson, 1991; Hudson, 1994). On the Chukotsk Peninsula, there are two areas of amphibolite-facies metamorphic rocks comparable to those on the Seward Peninsula. These are the Senyavin uplift on the southeast peninsula and the Koolen-Neshkin uplift of the northeast peninsula (Bering Strait Field Party, 1997).

Only one area of amphibolite-facies metamorphic rocks is adjacent to a coastline in the Bering Strait region. The Koolen metamorphic complex (Bering Strait Field Party, 1997) makes up the headlands around the mouth of Lawrence Bay (fig. 1) (Petrov, 1967, fig. 1; Lavrentiya Bay, Bering Strait Field Party, 1997) on the northeast coast of the Chukotsk Peninsula (figs. 1, 2). A well-developed gravity low along the north headland of the bay indicates that a Cenozoic basin is present just offshore. The continuation of average to slightly positive gravity values offshore of the southern headland suggests that pre-Tertiary bedrock continues about $50 \mathrm{~km}$ to the southeast of the coastline. Aeromagnetic data for the Chukotsk Peninsula, although very reconnaissance in nature, show that the amphibolite-facies metamorphic rocks have generally smooth, low-amplitude magnetic values. These rocks are flanked to both the northeast and southwest by magnetic domains with distinctly more internal variation, which include local magnetic highs. The boundaries of these magnetic domains coincide with contacts of the amphibolite-facies metamorphic rocks with Paleozoic to Triassic sedimentary and associated mafic igneous rocks to the south and with Paleozoic sedimentary and low-grade metasedimentary rocks to the north. These magnetic-domain boundaries can be traced offshore for a distance of about $100 \mathrm{~km}$ and are the principal basis for extrapolating amphibolite-facies metamorphic rocks offshore of the Chukotsk Peninsula.

\section{Cretaceous Volcanic and Related Intrusive Rocks (Map Unit B5)}

The southern half of the Chukotsk Peninsula is underlain by volcanic, volcaniclastic, hypabyssal, and plutonic rocks that range in composition from basalt to rhyolite but include large volumes of intermediate-composition igneous rocks (Popeko, 1995). These igneous rocks are the easternmost part of the large, elongate, and continuous Okhotsk-Chukotsk volcanic belt (Popeko, 1995; Worrall, 1991) that is mid-Cretaceous in age (Popeko, 1995). On the Chukotsk Peninsula, the northern boundary of the Okhotsk-Chukotsk volcanic belt is diffuse and, for the purposes of this report, is taken to be the southern limit of Paleozoic and Mesozoic sedimentary rocks on the peninsula. South of this limit, mid-Cretaceous volcanic and related intrusive rocks make up the principal bedrock assemblage on the Chukotsk Peninsula.

Cretaceous volcanic and related intrusive rocks border the coastline along the southern half of the Chukotsk Peninsula and extend offshore in the general direction of St. Lawrence Island (fig. 2), about $100 \mathrm{~km}$ to the southeast. The westernmost part of St. Lawrence Island has large areas of mid-Cretaceous volcanic and plutonic rocks (Patton and Csejtey, 1980). These mid-Cretaceous volcanic rocks, intruded by shallow-seated intermediate to felsic plutons (Csejtey and others, 1971), are in contact to the east with Devonian and Mississippian sedimentary rocks and Permian to Triassic mafic rocks (Patton and Csejtey, 1980).

\section{Cretaceous Plutonic Rocks}

Although not shown separately on figure 2, certain Cretaceous plutonic rocks are widespread in the Bering Strait region. Those on Seward Peninsula and St. Lawrence Island have counterparts on Chukotsk Peninsula and include 113- to 99-Ma subsilicic and potassium-rich rocks (Csejtey and others, 1971; Csejtey and Patton, 1974; Miller, 1972; Patton and Csjetey, 1980; Amato and Wright, 1997a, 1997b), 105- to about 80-Ma granodiorite and granite (Miller and Elliot, 1969; Csjetey and others, 1971; Miller and Bunker, 1976; Patton and Csejtey, 1980; Amato and Wright, 1997a), and 80- to about 70-Ma granite (Hudson, 1979; Hudson and Arth, 1983). Some of these plutonic rocks are exposed offshore on King and the Diomede Islands.

Controls on the distribution of these plutonic suites are not clear, but components of all three are emplaced in the preTertiary bedrock assemblages of the region. A possible exception is the amphibolite-facies metamorphic rock assemblage where shallow-seated, early Upper Cretaceous granites are not known. Amphibolite-facies metamorphic rocks, metamorphosed at the time of much of the mid-Cretaceous plutonism, are structurally deep seated and, in general, not highly mineralized. 


\section{Mineral Deposits and their Bedrock Associations}

The onshore areas of the Bering Strait region have many known mineral deposits and some lithologic suites that have high background levels of certain elements. With the exception of amphibolite-facies metamorphic rocks, all bedrock assemblages of the Bering Strait region contain mineral deposits that could be significant sources of metals if they are exposed to the marine environment. Most of the mineral deposits are sulfide-bearing. Pyrite in particular is very common in mineral deposits of the region. Although varied in character, the mineral deposits contain (1) base metals $(\mathrm{Cu}, \mathrm{Pb}$, and $\mathrm{Zn}$ and associated metals such as $\mathrm{Ag}$ and $\mathrm{Bi}$ ), (2) $\mathrm{Au}$ (and associated metals such as As, $\mathrm{Sb}, \mathrm{Ag}$, and $\mathrm{Hg}$ ), (3) $\mathrm{Sn}$ (and associated elements such as W, base metals, Ag, As, F, B, Li, and $\mathrm{Be}$ ), or (4) Mo (and associated metals such as $\mathrm{Cu}$ ). The general character of these mineral deposits and metalliferous lithologies and their associations with the major bedrock assemblages of the region are described below.

\section{Lithologic Suites with Elevated Background Metal Contents}

There are at least three lithologic suites that may have elevated background metal contents. These are (1) certain midCretaceous plutonic rocks, (2) Permian to Triassic mafic igneous rocks, and (3) Paleozoic to Triassic sedimentary rocks.

Mid-Cretaceous alkaline plutonic rocks such as the Kachauik pluton (Miller and Bunker, 1976) contain above average $\mathrm{U}$ and Th contents (5.7 ppm and $22.5 \mathrm{ppm}$, respectively). A large granodiorite and granite pluton (Darby pluton, Miller and Bunker, 1976) also contains above-average amounts of $U$ and Th (11.2 ppm and $58.7 \mathrm{ppm}$, respectively). The Darby pluton is considered the source for $\mathrm{U}$ that was released to ground water and subsequently deposited nearby in a sandstone-type $\mathrm{U}$ deposit that contains at least 1 million pounds of $\mathrm{U}_{3} \mathrm{O}_{8}$ (Dickinson and others, 1987).

Mafic igneous rocks, including gabbro, diabase, and basalt, locally make up important parts of the Paleozoic to Triassic sedimentary and mafic igneous rock assemblage on St. Lawrence Island and the Chukotsk Peninsula. Gabbro and diabase intrusions in this assemblage contain disseminated chalcopyrite, ilmenite, magnetite, and pyrite. A gabbro sample contained 700 ppm Cu and stream sediment samples collected along a 13-km drainage across these rocks have low but anomalous levels of $\mathrm{Cu}$ (150 ppm), V (1,000 ppm), Ni (100 ppm), and Mn (5,000 ppm) on St. Lawrence Island (Patton and Csejtey, 1971, 1972; Hudson, 1998b). These widespread, slightly elevated, metal values in the stream sediments probably reflect the general geochemical character of the mafic igneous bedrock. Local high $\mathrm{Cr}$ values in some stream-sediment samples on St. Lawrence Island may indicate that this igneous suite includes some ultramafic rocks (Patton and Csejtey, 1971).

The Paleozoic to Triassic sedimentary rocks on St. Lawrence Island may include some sections that have elevated metal concentrations. The highest and most consistently anomalous $\mathrm{Ag}$ and $\mathrm{Pb}$ values in stream-sediment samples from St. Lawrence Island are from streams draining these rocks. Stream-sediment samples, collected over a drainage length of 1.5 miles, contain anomalous concentrations of $\mathrm{Ag}(1.5 \mathrm{ppm})$, $\mathrm{Pb}$ (500 ppm), Zn (700 ppm), and Ba (500 ppm) (Patton and Csejtey, 1972; Hudson, 1998b). These elevated metal concentrations in stream sediments could reflect either the background metal content of the Paleozoic to Triassic sedimentary rocks or unrecognized mineral deposits in the area.

\section{Sandstone Uranium Deposits}

The Death Valley sandstone uranium deposit of the southwest Seward Peninsula is the farthest north deposit of its type in the world (Dickinson and others, 1987). The Death Valley deposit contains coffinite, small amounts of pyrite, and trace amounts of sphalerite in early Eocene continental sediments that were unconformably deposited on deeply weathered granitic rocks of the Darby pluton (Miller and Bunker, 1976). The proximity of the Death Valley uranium deposit to the slightly uraniferous Darby pluton seems to be an important control on its development. This deposit has an average grade of 0.27 percent $\mathrm{U}_{3} \mathrm{O}_{8}$ and a calculated resource of 453,500 $\mathrm{kg}(1,000,000$ pounds) of $\mathrm{U}_{3} \mathrm{O}_{8}$ (Dickinson and others, 1987). The epigenetic mineralization is considered to be early Eocene in age, a time when the climate was temperate or subtropical; processes producing supergene uranium mineralization may be ongoing here today (Dickinson and others, 1987). The Eocene sedimentary rocks that host the Death Valley uranium deposit are probably typical of the basal parts of the Tertiary offshore basins (fig. 2). This type of uranium deposit could be present in sedimentary rocks of the offshore basins but, because development of this type of deposit requires the host sedimentary rocks to be somewhat proximal to uraniferous pre-Tertiary bedrock, they may be only locally developed. If any deposits like the Death Valley deposit are located offshore, they may be overlain by a significant thickness of younger Tertiary sedimentary rocks.

\section{Tertiary(?) Gold Deposits}

One area of Tertiary(?) gold mineralization is known in the Bering Strait region. A $3-\mathrm{km}^{2}$, highly altered Tertiary(?) quartz latite and latite stock is intruded along the east side of the Myghapowit pluton in east-central St. Lawrence Island (Patton and Csejtey, 1971; Patton and Csejtey, 1980; Hudson, 1998b). The stock is altered to an assemblage of sericite, chlorite, clay minerals, and secondary silica. The altered rocks are highly oxidized, and pyrite remnants are the only sulfide mineral that has been identified in hand specimens. Rock and soil samples from the altered stock (Patton and Csejtey, 1972) have low to moderately anomalous contents of several metals including $\mathrm{Au}$ (to $0.6 \mathrm{ppm}$ ), As (to 3,000 ppm), $\mathrm{Sb}$ (to 300 $\mathrm{ppm}$ ), Mo (to $700 \mathrm{ppm}$ ), Bi (to $300 \mathrm{ppm}$ ), and Sn (to 150 $\mathrm{ppm})$. Although this is the only known epithermal gold occurrence in the region, it is important for two reasons: (1) it shows that Tertiary(?) igneous rocks of St. Lawrence Island can host significant metal concentrations, and (2) it was affected by 


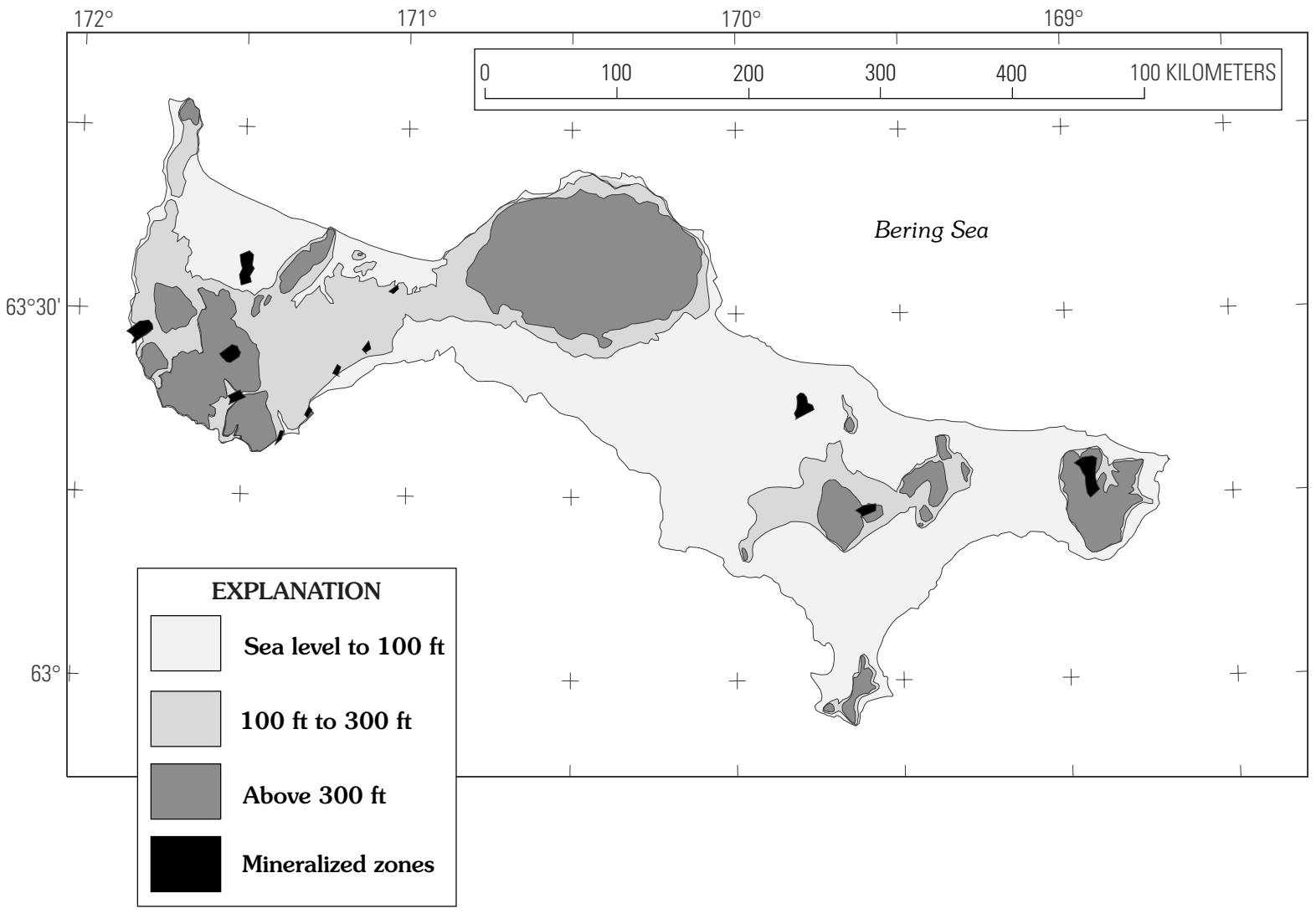

Figure 5. Map showing wave-cut terraces of St. Lawrence Island. Two principal terraces, one at elevations of as much as $100 \mathrm{ft}$ and one between elevations of 100 and $300 \mathrm{ft}$, developed on St. Lawrence Island. Mineralized zones (Hudson, 1998a) are areas of metal concentration; several were exposed on the sea floor at former times of higher sea level.

coastal processes and dispersed metals to the marine environment during former high sea-level stands (fig. 5).

\section{Seward Peninsula Gold Deposits}

Seward Peninsula has been a major gold-producing area since about 1900. The most important gold district is at Nome, along the southwest coast, where almost 5 million ounces have been produced from beach and alluvial placer deposits on the coastal plain and nearby offshore areas (Goldfarb and others, 1997). The lode sources of the Seward Peninsula placer gold are quartz veins in high-pressure, low-temperature metamorphic rocks of the Seward terrane (Till and Dumoulin, 1994). One lode deposit in the Nome area (Rock Creek) is a sheeted network of quartz veins in schist that contains more than 1 million ounces of gold at grades of about 0.07 ounces per ton (Bundzten and others, 1994). The lode gold deposits formed as a result of higher temperature mid-Cretaceous metamorphism (Apodoca, 1994; Ford, 1993; Ford and Snee, 1996; Goldfarb and others, 1997) that accompanied regional extension (Miller and Hudson, 1991) and crustal melting (Hudson, 1994) superimposed on the high-pressure, low-temperature metamorphic rocks of the Seward Peninsula. The veins commonly contain arsenopyrite, pyrite, and locally stibnite. Anomalous concentrations of As (to more than 1,000 ppm) are common, and anomalous concentrations of $\mathrm{Sb}$ (a few to several tens of ppm) and $\mathrm{Hg}$ (to several hundreds of ppb) can also be present in mineralized and altered rocks associated with the Seward Peninsula gold deposits.
Alteration (quartz, pyrite, arsenopyrite, carbonate minerals, and mica veining and replacement) can be widespread and significantly increase the volume of anomalous metal sources. For example, the Nome gold district contains several lode gold deposits in a belt extending $19 \mathrm{~km}$ and anomalous As concentrations are common throughout this belt (C. C. Hawley, written commun., 1998). The Nome gold district has been a major source of gold to the marine environment. Marine placer deposits (Kaufman and Hopkins, 1989) are present on the coastal plain and nearby offshore areas. The nearshore lode deposits at Nome, and probably others in offshore areas to the northwest, have contributed to weakly elevated background gold concentrations in sediments over large areas of the sea floor in the Bering Strait region (Nelson and Hopkins, 1972).

\section{Porphyry Copper Deposits}

At least two porphyry copper deposits are hosted by midCretaceous plutonic rocks on western St. Lawrence Island (Hudson, 1998b) - rocks considered to be part of the eastward extension of the Okotsk-Chukotsk volcanic belt of the Russian Far East. One example is a stock of quartz monzonite porphyry that contains disseminated chalcopyrite, malachite, pyrite, and minor molybdenite; highly oxidized rock samples contain as much as 3,000 ppm Cu (Patton and Csejtey, 1971). The Cretaceous volcanic rocks peripheral to the quartz monzonite porphyry are heavily pyritized and extensively oxidized. The only sulfide mineral identified in the volcanic rocks is pyrite; a grab sample 
of massive pyritized rock contained 1,500 ppm Cu, $10 \mathrm{ppm} \mathrm{Ag}$, and $30 \mathrm{ppm}$ Mo. Stream-sediment samples collected over about $2 \mathrm{~km}$ of the nearby drainages (Patton and Csejtey, 1972) contained anomalous to highly anomalous concentrations of $\mathrm{Cu}$ (1,500 ppm), Mo (70 ppm), and Ag (1.5 ppm). The porphyry copper deposits of St. Lawrence Island were sources of dispersed metals to the marine environment at former times of high sea level (fig. 5).

\section{Porphyry Molybdenum Deposits}

At least two porphyry molybdenum deposits are also hosted by mid-Cretaceous plutonic rocks of western St. Lawrence Island-rocks considered to be part of the eastward extension of the Okotsk-Chukotsk volcanic belt of the Russian Far East. Molybdenite occurs as disseminations and as scaly fracture and joint coatings (Anderson, 1947) in biotite quartz monzonite and in thin veinlets cutting highly oxidized pyritiferous biotite quartz monzonite (Hudson, 1998b). Small amounts of chalcopyrite and pyrite locally accompany the molybdenite. Channel samples contained as much as 0.71 percent $\mathrm{MoS}_{2}$ and grab samples as much as 7,500 ppm Mo and $700 \mathrm{ppm} \mathrm{Cu}$ at one locality along the present coastline (Anderson, 1947; Patton and Csejtey, 1971). Stream-sediment samples from western St. Lawrence Island locally contain anomalous concentrations of Mo (as much as $70 \mathrm{ppm}$ ) (Patton and Csejtey, 1972). The porphyry molybdenum deposits have been sources of metals to the marine environment (fig. 5).

\section{Tin Deposits}

Tin and related deposits are known to be present in all the pre-Tertiary bedrock assemblages of the Bering Strait region except amphibolite-facies metamorphic rocks. A variety of tin deposits, associated with Cretaceous granite complexes (Hudson and Arth, 1983), are present on the northwest Seward Peninsula (Hudson and Reed, 1997), St. Lawrence Island (Hudson, 1998b), and the Chukotsk Peninsula (Popeko, 1995). The most common tin deposits are cassiterite and sulfide-bearing greisens that may contain one percent or more tin. In general, these deposits and their associated alteration zones are polymetallic in character and contain anomalous to significant concentrations of W, Cu, Pb, Zn, Ag, As, F, B, Li, and Be (Hudson and Reed, 1997; Hudson, 1998a). Associated skarn deposits and hydrothermal alteration zones significantly expand the volume of metallized rock peripheral to the greisen deposits. Several of these deposits have been eroded to produce placer tin deposits, and, in several places, metals from these deposits have been dispersed to the marine environment at times of former high sea level (Hudson and Reed, 1997; Hudson, 1998b).

\section{Skarn Deposits}

Cretaceous plutonic rocks on Seward Peninsula, St. Lawrence Island, and Chukotsk Peninsula have base-metalbearing skarn deposits developed primarily in carbonate rocks. The skarns include massive magnetite with minor chalcopyrite (e.g., the Billiken prospect; Hudson, in press), and many pyrite-, sphalerite-, galena-, and chalcopyrite-bearing deposits. The base-metal skarn deposits most commonly contain as much as several percent $\mathrm{Pb}$ and $\mathrm{Zn}$ and significant $\mathrm{Ag}$ and $\mathrm{Bi}$ (Nokleberg and others, 1996).

\section{Massive Sulfide Deposits}

Two types of massive sulfide deposits are known in highpressure, low-temperature metamorphic rocks of Seward Peninsula. Volcanogenic massive sulfide deposits, such as the HOM and Big Bar prospects (Hudson, 1999), contain combinations of chalcopyrite, pyrite, sphalerite, and galena in felsic metavolcanic rocks. This type of deposit can contain from a few to several percent $\mathrm{Cu}, \mathrm{Pb}$, and $\mathrm{Zn}$ and a few ounces per ton silver. Metasedimentary rocks (including carbonates) also host massive sulfide deposits; an example is the Harry's Creek prospect (Hudson, 1999). These deposits commonly contain concentrations of galena, sphalerite, and pyrite; they may contain a few to several percent $\mathrm{Pb}$ and $\mathrm{Zn}$ and a few to several ounces per ton Ag.

Metavolcanic- or metasedimentary-hosted massive sulfide deposits are not known on St. Lawrence Island. However, the Paleozoic to Triassic sedimentary rocks there are permissible for the occurrence of sedimentary-exhalative deposits. Such a deposit is a possible source for the anomalous $\mathrm{Pb}$ and $\mathrm{Ag}$ contents in stream-sediment samples, as noted above. Barite could also be present in high concentrations in parts of this sedimentary section.

\section{Other Deposits}

Polymetallic sulfide deposits, ranging from small isolated veins to large areas of intensely hydrothermally altered volcanic rocks, are locally important metal sources. For example, stream-sediment samples peripheral to a large gossanous area in Cretaceous volcanic rocks on St. Lawrence Island contain as much as 150 ppm $\mathrm{Pb}, 2$ ppm Ag, 50 ppm Mo, 700 ppm Cu, and 30 ppm Sn (Hudson, 1998b). Polymetallic sulfide deposits on the Seward Peninsula, such as those in the Omilak area (Mulligan, 1962), contain as much as several percent $\mathrm{Pb}$, hundreds of ounces per ton $\mathrm{Ag}$, and lesser amounts of $\mathrm{Zn}, \mathrm{Cu}, \mathrm{Sb}$, $\mathrm{Sn}$, and $\mathrm{Au}$.

\section{Factors Influencing Metal Dispersal in the Bering Strait Region}

The dispersal of metals from mineral deposits to the environment takes place through weathering and erosion processes. There are many examples of metal dispersal by weathering and erosion on land in the Bering Strait region, but marine erosion processes are also important. The shallow continental shelf in this part of the Bering Sea (mostly less than 50-m water depth; fig. 1), the location of some mineral deposits (such as those of the Nome gold district) at the present coastline, and Quaternary 
sea-level fluctuations are all factors that can be important to metal dispersal in the Bering Sea.

Chemical and physical weathering processes are important in the Bering Strait region. Chemical weathering involves the alteration and dissolution of minerals. In the Bering Strait region, the dominance of sulfide-bearing mineral deposits makes them especially susceptible to oxidation processes; extensive oxidation of Seward Peninsula sulfide deposits is known to depths of more than 100 m (Mulligan, 1962). Oxidation of sulfide minerals, especially pyrite, is a very important chemical weathering process that develops acidic surficial materials and waters. The acidic conditions and the abundance of oxidized iron enables further sulfide mineral breakdown, precipitation of secondary iron oxides and hydroxides, and dissolution of metals in surface and ground water. In the natural surficial environments of the Bering Strait region, metal-bearing waters are quickly diluted and any potentially toxic conditions are expected to be very local and short-lived. Even though some metals are dissolved and released through oxidation, oxidized mineral deposits may still be a source of significant metal concentrations.

Although virtually all mineral deposits exposed at or near the surface in the Bering Strait region are at least partly oxidized, it is physical weathering processes that ensure dispersal of metals. Physical weathering has been dominated in the region by frost action and related periglacial processes. These processes effectively break up near-surface bedrock and create a mantle as much as several meters thick of soil and regolith. The mantle of surficial material moves slowly downslope to nearby lowlands and valleys where it can be eroded by streams. Stream erosion and transport creates alluvial deposits that incorporate the surficial materials and bedrock debris. In places, mineral deposits are eroded directly by waves along the present shoreline. Examples include the Booshu porphyry molybdenum deposit on St. Lawrence Island (Patton and Csjetey, 1971) and the Bluff gold deposit on the Seward Peninsula (Ford, 1993).

Heavy minerals such as cassiterite (tin oxide) and gold that are relatively stable in surficial environments form placer deposits as a result of physical weathering and erosion processes. The beach and alluvial gold placers at Nome, the alluvial gold placers at many other places on the Seward Peninsula, and the tin placers of the western Seward Peninsula are examples. Even though metal concentrations can be high in these deposits, the relatively inert character of the minerals forming them leads to little environmental concern. However, the presence of placer deposits is an excellent indication that significant erosion and transport of mineral deposits has occurred and that large amounts of associated elements, such as As in the case of Seward Peninsula gold deposits, have probably also been dispersed to the environment.

Shoreline processes are very important in the erosion and dispersal of metals in offshore areas of the Bering Strait region. Evidence for several former high sea-level stands, in the form of elevated beaches and wave-cut terraces, is present on the Seward Peninsula (Hopkins, 1967, 1973; Sainsbury, 1967a, 1967b; Kaufman and Hopkins, 1989), the Chukotsk Peninsula (Petrov, 1967), and St. Lawrence Island (Patton and Csejtey, 1971). In addition, offshore studies at Nome show that shorelines, formed at times of lower sea level, are still preserved at water depths as much as $24 \mathrm{~m}$ (Nelson and Hopkins, 1972). Perhaps the best examples of the erosion of mineral deposits by marine processes that accompanied sea-level changes are on St. Lawrence Island. Quaternary wave-cut terraces have long been recognized on St. Lawrence Island (Patton and Csejtey, 1971), but they have received little study. Based on reconnaissance mapping of their planar surfaces and the location of their shoreline angles, there appear to be at least two major wave-cut surfaces on the island (fig. 5). The younger one, with shoreline angles at elevations of about $30 \mathrm{~m}$, covers most of central and eastern St. Lawrence Island (fig. 5). An older wave-cut surface, locally preserved around uplands and more widely spread on western parts of the island, has shoreline angles at about 100-m elevation (fig. 5). The wave-cut surfaces show that most of St. Lawrence Island was formally below sea level and an archipelago of small islands. Furthermore, many mineral deposits here (Hudson, 1998b) eroded at times of high sea level directly into the marine environment. Marine sediments preserved on the terraces could be analogs for today's offshore marine environment. In other words, what may have been former walrus feeding grounds are now subaerially exposed over a large part of St. Lawrence Island.

There is additional evidence from offshore areas for the importance and impact of marine processes during the Quaternary (e.g., Hess, 1985). The sandy and gravelly relict character of bottom sediments in areas where bedrock can be at or near the sea floor (Creager and McManus, 1967; McManus and others, 1969), the distribution and character of detrital heavy minerals including gold (Nelson and Hopkins, 1972; McManus and others, 1977), and the extensive reworking of bottom sediments over thicknesses of $20 \mathrm{~m}$ (Kaufman and Hopkins, 1989) all attest to the importance and impacts of former sea-level fluctuations in the Bering Strait region.

\section{Discussion}

This synthesis and integration of information about bedrock assemblages, associated mineral deposits, and factors important to dispersal of metals to the environment are first steps toward understanding the environmental baseline conditions in offshore areas of the Bering Strait region. Where magnetic data are complete and detailed, as on the Seward Peninsula, much more specific information can be discerned about the potential distribution of mineral deposits (e.g., Reed and others, 1989). In the future, the availability of complete and detailed magnetic data, complemented by similar-quality gravity data, would assist geologic mapping of the internal character of the bedrock assemblages in offshore areas. In particular, refined geologic and geophysical mapping would be expected to constrain the distribution of igneous rocks and their thermal aureoles. This would be especially valuable because Cretaceous igneous rocks are a principal control on specific types of mineral deposits throughout the region.

The available geophysical data permit the extrapolation of the five pre-Tertiary bedrock assemblages of the region from onshore to offshore areas. The offshore distribution of bedrock assemblages is reasonably well constrained along southwest Seward Peninsula and between St. Lawrence Island and 
Chukotsk Peninsula. Also, because extensive reworking of as much as $20 \mathrm{~m}$ of sea-floor sediment has been identified (Kaufman and Hopkins, 1989), the offshore areas where bedrock can be at or near the sea floor as indicated by the gravity data is considered adequate for the scale of this study. It is encouraging that the distribution of gravel and coarser detrital gold in offshore bottom sediments and local bedrock exposures such as at King Island are consistent with the inferred offshore distribution of pre-Tertiary bedrock (fig. 2).

The mapping (fig. 2) shows that two bedrock assemblages dominate the offshore areas. Paleozoic to Triassic sedimentary and related igneous rocks are expected to cover large areas north and northwest of St. Lawrence Island. High-pressure, low-temperature metamorphic rocks are expected to cover large areas offshore of the southwest Seward Peninsula. Both assemblages have significant metal sources associated with them. The Paleozoic to Triassic sedimentary and igneous rock assemblage contains certain mafic igneous rocks with high background $\mathrm{Cu}$ contents, perhaps some unidentified ultramafic rocks with elevated Cr (Patton and Csejtey, 1971), and the potential for massive sulfide deposits in sedimentary rocks. The highpressure, low-temperature metamorphic rock assemblage is associated with the major gold districts of the Seward Peninsula. The Seward Peninsula gold deposits typically contain elevated concentrations of $\mathrm{As}, \mathrm{Sb}$, and, in some cases, $\mathrm{Hg}$. Metallized systems (porphyry copper, porphyry molybdenum, and polymetallic deposits, see above) in the Cretaceous volcanic and related igneous assemblage are potentially important in offshore areas to the south and southwest of western St. Lawrence Island.

Several types of mineral deposits of the region contain characteristic element suites. For example, trace-element suites in offshore bottom sediments could be helpful in evaluating and distinguishing metal sources related to Seward Peninsula gold deposits, tin-metallized systems, mafic igneous rocks of the Paleozoic to Triassic bedrock assemblage, and porphyry molybdenum deposits. The element suites may have their own environmental importance, and their dispersal can be broader than the primary metal of interest in the related mineral deposit. For example, from an environmental perspective, it may be more helpful to think of Seward Peninsula gold deposits as an arsenic deposit with trace amounts of gold rather than vice versa.

The role of sea-level fluctuations is expected to be significant in the erosion and dispersal of metals and associated elements in the Bering Strait region. Marine transgressions and regressions that affected the region several times during the Quaternary would have eroded mineral deposits on the sea floor and reworked any previous metal accumulations in bottom sediments. Metals dispersed to the marine environment would have long residence times as a result of this reworking and recycling through the bottom sediment system. In a way, the sea floor of the Bering Strait region has served as a collecting area (sink) for metals. The environmental setting of this prime walrus habitat is, therefore, one where the natural distribution of mineral deposits and the natural processes affecting the dispersal of metals from them have combined to increase the likelihood that walrus may be exposed to metal concentrations.

\section{Conclusions}

The Bering Strait region is important habitat for Pacific walrus. Elevated metal contents in some walrus liver and kidney tissues have raised concerns about the environmental character of this habitat. This synthesis and integration of onshore geology; regional gravity and magnetic data; information about known mineral deposits; and the natural processes that weather, erode, and disperse metals from them to the environment has led to the following general conclusions:

(1) Offshore parts of the region include large areas (about 40 percent of the sea floor) where bedrock assemblages can be present at or near the sea floor.

(2) Six regional bedrock assemblages can be defined and extended from onshore to offshore areas on the basis of gravity, magnetic, and geologic trends.

(3) Mineral deposits of several types are common and widespread in four of the five pre-Tertiary bedrock assemblages. Some of the mineral-deposit types and certain rock units with high background metal concentrations are associated with specific bedrock assemblages. Other mineral-deposit types are present in all four of the highly mineralized pre-Tertiary bedrock assemblages.

(4) Weathering and erosion processes that can effectively disperse metals to both marine and nonmarine environments have affected mineral deposits and rocks with high background metal concentrations.

(5) The role of sea-level fluctuations is particularly significant in dispersing metals in the nearshore and offshore areas of the Bering Strait region. Several episodes of subaerial exposure and subsequent marine transgression and regression associated with sea-level fluctuations have eroded mineral deposits and reworked and redistributed materials derived from them.

(6) Offshore data, such as bottom sediment coarseness and detrital gold character and distribution, are consistent with the inferred distribution of bedrock assemblages and the mineral deposits that can be present in them.

(7) Several mineral-deposit types in the region have characteristic minerals and associated suites of elements. The mineralogy and trace element character of these deposits can serve as guides to their occurrence in offshore areas. Trace-element suites in walrus may also be helpful in evaluating their exposure to metal-bearing materials.

(8) The distribution of natural metal sources and the natural processes responsible for the dispersal of metals from them to the environment have been in place in the Bering Strait region throughout a large part of the Quaternary. The nearshore and offshore areas here have served as a sink for metals for many hundreds of thousands of years.

\section{Acknowledgments}

Cynthia Parnow helped compile much of the literature important to this study. Elizabeth Miller kindly provided 
geologic information developed for the multi-institutional Bering-Chukchi crustal transect. Technical reviews by Warren Day, Jeanine Schmidt, Larry Gough, and Karen Kelley were very helpful.

\section{References Cited}

Amato, J.M., and Wright, J.E., 1997a, Geochronologic investigations of magmatism and metamorphism within the Kigluaik Mountains gneiss dome, Seward Peninsula, Alaska, in Short Notes in Alaskan Geology: Fairbanks, Alaska Division of Geological and Geophysical Surveys.

Amato, J.M., and Wright, J.E., 1997b, Potassic mafic magmatism in the Kigluaik gneiss dome, northern Alaska: A geochemical study of arc magmatism in an extensional tectonic setting: Journal of Geophysical Research, v. 102, no. B4, p. 8065-8084.

Amato, J.M., Wright, J.E., Gans, P.B., and Miller, E.L., 1994, Magmatically induced metamorphism and deformation in the Kigluaik gneiss dome, Seward Peninsula, Alaska: Tectonics, v. 13, p. 515527.

Anderson, Eskil, 1947, Mineral occurrences other than gold deposits in northwestern Alaska: Alaska Department of Mines Pamphlet 5-8, $48 \mathrm{p}$.

Apodoca, L.E., 1994, Genesis of lode gold deposits of the Rock Creek area, Nome mining district, Seward Peninsula, Alaska: Boulder University of Colorado, Ph.D. dissertation, $208 \mathrm{p}$.

Armstrong, R.L., Harakal, J.E., Forbes, R.B., Evans, B.W., and Thurston, S.P., 1986, Rb-Sr and K-Ar study of metamorphic rocks of Seward Peninsula and southern Brooks Range, Alaska, in Evans, B.W., and Brown, E.H., eds., Blueschists and Eclogites: Geological Society of America Memoir 176, p. 185-203.

Barnes, D. F., and Hudson, T., 1977, Bouguer gravity map of Seward Peninsula, Alaska: U. S. Geological Survey Open-File Report 77-796C, 1 sheet, scale 1:1,000,000.

Barnes, D.F., Mariano, John, Morin, R.L., Roberts, C.W., and Jachens, R.C., 1994, Incomplete isostatic gravity map of Alaska, in Plafker, G., and Berg, H.C., eds., The Geology of Alaska, Geology of North America, v. G-1: Boulder, Geological Society of America, scale $1: 2,500,000,1$ sheet.

Bering Strait Field Party, 1997, Koolen metamorphic complex, NE Russia: Implications for the tectonic evolution of the Bering Strait region: Tectonics, v. 16, no. 5, p. 713-729.

Bundzten, T.K., Reger, R.D., Laird, G.M., Pinney, D.S., Clautice, K.H., Liss, S.A., and Cruse, G.R., 1994, Progress report on the geology and mineral resources of the Nome mining district: Alaska Division of Geological and Geophysical Surveys Public Data File 94-39, 19 p.

Churkin, M., Jr., 1972, Western boundary of the North American continental plate in Asia: Geological Society of America Bulletin, v. 83, p. 1027-1036.

Creager, J.E., and McManus, D.A., 1967, Geology of the floor of Bering and Chukchi Seas-American studies, in Hopkins, D.M., ed., The Bering Land Bridge: Stanford, Calif., Stanford University Press, p. 7-31.

Csejtey, Bela, Jr., and Patton, W.W., Jr., 1974, Petrology of the nepheline syenite of St. Lawrence Island, Alaska: U.S. Geological Survey Journal of Research, v. 2, no. 1, p. 41-47.

Csejtey, Bela, Jr., Patton, W.W., Jr., and Miller, T.P., 1971, Cretaceous plutonic rocks of St. Lawrence Island, Alaska-A preliminary report: U.S. Geological Survey Professional Paper 750-D, p. D68-D76.
Dickinson, K.A., Cunningham, K.D., and Ager, T.A, 1987, Geology and origin of the Death Valley uranium deposit, Seward Peninsula, Alaska: Economic Geology, v. 82, no. 6, p. 1558-1574.

Dumitru, T.A., Miller, E.L., O'Sullivan, P.B., Amato, J.M., Hannula, K.A., Calvert, A.T., and Gans, P.B., 1995, Cretaceous to Recent extension in the Bering Strait region, Alaska: Tectonics, v. 14, no. 3, p. 549563.

Fay, F.H., 1982, Ecology and biology of the Pacific walrus, Odobenus rosmarus divergens: North American Fauna 74, U.S. Fish and Wildlife Service, Washington, D.C., 279 p.

Fisher, M.A., Patton, W.W., Jr., and Holmes, M.L., 1982, Geology of Norton basin and continental shelf beneath northwestern Bering Sea, Alaska: American Association of Petroleum Geologists Bulletin, v. 66, no. 3, p. 255-285.

Forbes, R.B., Evans, B.W., and Thurston, S.P., 1984, Regional progressive high-pressure metamophism, Seward Peninsula, Alaska: Journal of Metamorphic Geology, v. 2, p. 43-54.

Ford, R.C., 1993, Geology, geochemistry, and age of gold lodes at Bluff and Mt. Distin, Seward Peninsula, Alaska: Golden, Colorado School of Mines, Ph.D. dissertation, $302 \mathrm{p}$.

Ford, R.C., and Snee, L.W., 1996, ${ }^{40} \mathrm{Ar} /{ }^{39} \mathrm{Ar}$ thermochronology of white mica from the Nome district, Alaska: The first ages of lode sources to placer gold deposits in the Seward Peninsula: Economic Geology, v. 91, p. 213-220.

Goldfarb, R.J., Miller, L.D., Leach, D.L., and Snee, L.W., 1997, Gold deposits in metamorphic rocks of Alaska: Economic Geology Monograph 9, p. 151-190.

Grim, M.S., and McManus, D.A., 1970, A shallow seismic-profiling survey of the northern Bering Sea: Marine Geology, v. 8, p. 293-320.

Hannula, K.A., and McWilliams, M.O., 1995, Reconsideration of the age of blueschist-facies metamorphism on the Seward Peninsula, Alaska, based on phengite ${ }^{40} \mathrm{Ar} /{ }^{39} \mathrm{Ar}$ results: Journal of Metamorphic Petrology, v. 13, p. 125-139.

Hannula, K.A., Miller, E.L., Dumitru, T.A., Lee, Jeffery, and Rubin, C.M., 1995, Structural and metamorphic relations in the southwest Seward Peninsula, Alaska: Crustal extension and the unroofing of blueschists: Geological Society of America Bulletin, v. 107, no. 5, p. 536-553.

Hess, R.G., 1985, Quaternary stratigraphy and sedimentation-Northern Bering Sea, Alaska: Stanford, Calif., Stanford University, Ph.D. dissertation, $89 \mathrm{p}$.

Hopkins, D.M., 1967, Quaternary marine transgressions in Alaska, in Hopkins, D. M., ed., The Bering Land Bridge: Stanford, Calif., Stanford University Press, p. 47-90.

Hopkins, D.M., 1973, Sea level history in Beringia during the past 250,000 years: Quaternary Research, v. 3, p. 520-540.

Hudson, T.L., 1979, Igneous and metamorphic rocks of the Serpentine Hot Springs area, Seward Peninsula, Alaska: U.S. Geological Survey Professional Paper 1079, $27 \mathrm{p}$.

Hudson, T.L. 1994, Crustal melting events in Alaska, in Plafker, G., and Berg, H. C., eds., The Geology of Alaska: Boulder, Colo., Geological Society of America, The Geology of North America, v. G-1, p. 657670.

Hudson, T.L., 1998a, Alaska Resource Data File-Teller quadrangle: U.S. Geological Survey Open-File Report 98-328, 235 p.

Hudson, T.L., 1998b, Alaska Resource Data File-St. Lawrence quadrangle: U. S. Geological Survey Open-File Report, 51 p.

Hudson, T.L., 1999, Alaska Resource Data File-Bendeleben quadrangle: U.S. Geological Survey Open-File Report 99-332, 301 p. 
Hudson, T.L., and Arth, J.G., 1983, Tin granites of Seward Peninsula, Alaska: Geological Society of America Bulletin, v. 94, p. 768-790.

Hudson, Travis, and DeYoung, J.H., Jr., 1978, Map and tables describing areas of mineral resource potential, Seward Peninsula, Alaska: U.S. Geological Survey Open-File Report 78-1-C, 62 p., one sheet, scale $1: 1,000,000$.

Hudson, Travis, Miller, M.L., and Pickthorn, W.J., 1977, Map showing metalliferous and selected nonmetalliferous mineral deposits, Seward Peninsula, Alaska: U.S. Geological Survey Open-File Report 77-796-B, 46 p., one sheet, scale 1:1,000,000.

Hudson, T.L., and Reed, B.L., 1997, Tin deposits in Alaska: Economic Geology Monograph 9, p. 450-465.

Kaufman, D.S., and Hopkins, D.M., 1989, Late Cenozoic geologic controls on placer-gold distribution in the Nome nearshore area, inDover, J.H., and Galloway, J.P., eds., Geologic Studies in Alaska by the U. S. Geological Survey, 1988: U.S. Geological Survey Bulletin 1903, p. 26-45.

Kirschner, C.E., 1994, Map showing sedimentary basins in Alaska, in Plafker, G., and Berg, H.C., eds., The Geology of Alaska: Boulder, Colo., Geological Society of America, The Geology of North America, v. G-1, plate 7, 1 sheet, scale 1:2,500,000.

McManus, D.A., Kelley, J.C., and Creager, J.S., 1969, Continental shelf sedimentation in an arctic environment: Geological Society of America Bulletin v. 80, p. 1961-1984.

McManus, D.A., Venkatarathnam, K, Hopkins, D.M., and Nelson, C.H., 1977, Distribution of bottom sediments on the continental shelf, northern Bering Sea: U.S. Geological Survey Professional Paper 759-C, p. C1-C31.

Miller, T.P., 1972, Potassium-rich alkaline intrusive rocks of western Alaska: Geological Society of America Bulletin, v. 83, p. 2111-2128.

Miller, T.P., and Bunker, C.M., 1976, A reconnaissance study of the uranium and thorium contents of plutonic rocks of the southeastern Seward Peninsula, Alaska: U.S. Geological Survey Journal of Research, v. 4, no. 3, p. 367-377.

Miller, T.P., and Elliott, R.L., 1969, Metalliferous deposits near Granite Mountain, eastern Seward Peninsula, Alaska: U.S. Geological Survey Circular 614, $19 \mathrm{p}$.

Miller, E.L., and Hudson, T.L., 1991, Mid-Cretaceous extensional fragmentation of a Jurassic-Early Cretaceous compressional orogen, Aaska: Tectonics, v. 10, p. 781-796.

Moll-Stalcup, E.J., 1994, Late Cretaceous and Cenozoic magmatism of mainland Alaska, in Plafker, G., and Berg, H.C., eds., The Geology of Alaska: Boulder, Colo., Geological Society of America, The Geology of North America, v. G-1, p. 589-619.

Mulligan, J.J., 1962, Lead-silver deposits in the Omilak area, Seward Peninsula, Alaska: U.S. Bureau of Mines Report of Investigations 6018, $44 \mathrm{p}$.

National Geophysical Data Center, 1996, Magnetic Anomaly Data in the Former Soviet Union: Product \#1149-A27-001, 1 CD-ROM.

Nelson, C.H., and Hopkins, D.M., 1972, Sedimentary processes and distribution of particulate gold in the northern Bering Sea: U.S. Geological Survey Professional Paper 689, 27 p.

Nokleberg, W. J., Bundtzen, T.K., Dawson, K.M., Eremin, R.A., Goryachev, N.A., Koch, R.D., Ratkin, V.V., Rozenblum, I.S., Shpikerman, V.I., Frolov, Y.F., Gorodinskiy, M.E., Melnikov, V.D., Ognyanov, N.V., Petrachenko, E.D., Petrachenko, R.I., Pozdeev, A.I., Ross, K.V., Wood, D.H., Grybeck, D.J., Khanchuk, A.I., Kovbas, L.I., Nekrasov, I.Y.., Siderov, A.A, 1996, Significant metalliferous and selected non-metalliferous lode deposits and placer districts for the Russian Far East, Alaska, and the Canadian Cordillera: U.S. Geological Survey Open-File Report 96-513-A.
Patrick, B.E., 1988, Synmetamorphic structural evolution of the Seward Peninsula blueschist terrane, Alaska: Journal of Structural Geology, v. 10, no. 6, p. 555-565.

Patrick, B.E., and Evans, B.W., 1989, Metamorphic evolution of the Seward Peninsula blueschist terrane: Journal of Petrology, v. 30, p. 531-556.

Patton, W.W., Jr., and Csejtey, Bela, Jr., 1971, Preliminary geologic investigations of western St. Lawrence Island, Alaska: U.S. Geological Survey Professional Paper 684-C, p. C1-C15.

Patton, W.W., Jr., and Csejtey, Bela, Jr., 1972, Analyses of stream sediment and rock samples from St. Lawrence Island, Alaska, 19661971: U.S. Geological Survey Open-File Report 72-293, 78 p.

Patton, W.W., Jr., and Csejtey, B., Jr., 1980, Geologic map of St. Lawrence Island, Alaska: U.S. Geological Survey Map I-1203, 1 sheet, scale 1:250,000.

Patton, W.W., Jr., and Dutro, J.T., Jr., 1969, Preliminary report on the Paleozoic and Mesozoic sedimentary sequence on St. Lawrence Island, Alaska: U.S. Geological Survey Professional Paper 650-D, p. D138-D143.

Petrov, 0.M., 1967, Paleogeography of Chukotka during late Neogene and Quaternary time, in Hopkins, D.M., ed., The Bering Land Bridge: Stanford, Calif., Stanford University Press, p. 141-171.

Popeko, V.A. 1995, Magmatic formations and mineralization in the Okhotsk-Chukotka volcanic belt, in Bundzten, T.K., Fonseca, A.L., and Mann, R, eds., Geology and Mineral Deposits of the Russian Far East: Anchorage, Alaska, Alaska Miners Association.

Reed, B.L., Menzie, W.D., McDermott, M., Root, H., Scott, W, and Drew, L.J., 1989, Undiscovered lode tin resources of the Seward Peninsula, Alaska: Economic Geology, v. 84, p. 1936-1947.

Sainsbury, C.L., 1967a, Quaternary geology of western Seward Peninsula, Alaska, in Hopkins, D.M., ed., The Bering Land Bridge: Stanford, Calif., Stanford University Press, p. 121-143.

Sainsbury, C.L., 1967b, Upper Pleistocene features in the Bering Strait area, in Geological Survey Research 1967: U.S. Geological Survey Professional Paper 575-D, p. D203-D213.

Sainsbury, C.L., 1972, Geologic map of the Teller quadrangle, western Seward Peninsula, Alaska: U.S. Geological Survey Map I-685, scale $1: 250,000$.

Sainsbury, C.L., Hummel, C.L., and Hudson, T.L., 1972, Reconnaissance geologic map of the Nome quadrangle, Seward Peninsula, Alaska: U.S. Geological Survey Open-File Report 72-326, 28 p., scale $1: 250,000$.

Sainsbury, C.L., Coleman, R.G., and Kachadoorian, R., 1970, Blueschist and related greenschist facies rocks of the Seward Peninsula, Alaska, in Geological Survey Research: U.S. Geological Survey Professional Paper 750-C, p. C52-C57.

Saltus, R.W., and Simmons, G.C., 1997, Composite and merged aeromagnetic data for Alaska-A web site for distribution of gridded data and plot files: U.S. Geological Survey Open-File Report 97-520, 15 p.

Sandwell, D.T., and Smith, W.M., 1997, Marine gravity anomaly from Geosat and ERS-1 satellite altimetry: Journal of Geophysical Research B, v. 102, p. 10039-10054.

Taylor, D.L., Schleibe, Scotts, and Metsker, Howard, 1989, Contaminants in blubber, liver, and kidney tissue of Pacific walruses: Marine Pollution Bulletin, v. 20, no. 9, p. 465-468.

Thurston, S.P., 1985, Structure, petrology, and metamorphic history of the Nome Group blueschist terrane, Seward Peninsula, Alaska: Geological Society of America Bulletin, v. 96, p. 600-617.

Till, A.B., 1980, Crystalline rocks of the Kigluaik Mountains, Seward Peninsula, Alaska: Seattle, University of Washington, M.S. thesis, 97 p. 
Till, A.B., and Dumoulin, J.A, 1994, Geology of Seward Peninsula and St. Lawrence Island, in Plafker, G., and Berg, H.C., eds., The Geology of Alaska: Boulder, Colo., Geological Society of America, The Geology of North America, v. G-1, p. 141-152.

Till, A.B., Dumoulin, J.A., Gamble, B.M., Kaufman, D.S., and Carroll, P.I., 1986, Preliminary geologic map and fossil data, Solomon, Bendeleben, and southern Kotzebue quadrangles, Seward Peninsula,

Reviewers: Warren Day and Jeanine Schmidt
Alaska: U.S. Geological Survey Open-File Report 86-276, 10 p., appendix, 3 plates, scale 1:250,000.

Warburton, Janet, and Seagars, D.J., 1993, Metal concentrations in liver and kidney tissues of Pacific walrus: U.S. Fish and Wildlife Service Technical Report R7/MMM 93-1, 23 .

Worrall, D.M., 1991, Tectonic history of the Bering Sea and the evolution of Tertiary strike-slip basins and the Bering Shelf: Geological Society of America, Special Paper 257, 120 p., 4 plates. 


\section{An Evaluation of Methods for Identifying and Interpreting Buried Soils in Late Quaternary Loess in Alaska}

\author{
By Daniel R. Muhs, Thomas A. Ager, Josh M. Been, \\ Joseph G. Rosenbaum, and Richard L. Reynolds
}

\section{Abstract}

The presence of buried soils in Alaskan loess is controversial, and therefore criteria for identifying buried soils in these deposits need to be evaluated. In this paper, morphologic and chemical criteria for identifying buried soils are evaluated by studying modern soils developed mostly in Holocene loess under tundra, boreal forest, and transitional coastal-boreal forest vegetation in different parts of Alaska. Data from modern Alaskan soils that developed under vegetation similar to that of the present indicate that soil morphology, organic-matter concentrations, and $\mathrm{P}$ concentrations can be useful diagnostic tools for identifying buried soils. Soil morphologic criteria, particularly horizon colors and horizon sequences, are essential for identifying buried soils, but some minimally developed soils may resemble organic-rich alluvial, colluvial, or lacustrine deposits. Organic matter and total $\mathrm{P}$ contents and distributions can aid in such studies because in well-drained soils these constituents show rapid declines with depth. However, neither of these techniques may work if the upper genetic horizons of buried soils are eroded.

If buried soils are present in Alaskan loess, it would also be desirable to have techniques for determining the dominant vegetation under which the soils formed. Such techniques could then be used to reconstruct former vegetation types and paleoclimates in Alaska. A previous study suggested that tundra and boreal forest vegetation have distinctive carbon isotopic compositions, although both are dominated by $\mathrm{C}_{3}$ plants. If this is the case, then the carbon isotopic composition of organic matter in buried soils could be used to reconstruct former vegetation types. A larger suite of modern soils from Alaskan tundra and forest were analyzed to test this hypothesis. Results indicate that modern soil $\mathrm{O}$ horizons in these two biomes have the same range of $\delta^{13} \mathrm{C}$ values, and therefore carbon isotope compositions cannot be used to reconstruct former tundra or boreal forest.

\section{Introduction}

Interest in loess stratigraphy has increased greatly over the past decade because loess sequences contain detailed records of Quaternary environmental conditions and could be the closest terrestrial equivalent to the oxygen isotope record in deep-sea sediments (Hovan and others, 1989). In Europe and the North American Midcontinent, most loess deposits accumulated during glacials or stadials, whereas buried soils developed during interglacials or interstadials. In China, loess records are more complex because loess is deposited during both glacials and interglacials. The same is true for Alaska, as loess deposition took place during the last glacial period but continues today (Péwé, 1975).

There have been conflicting interpretations of loess stratigraphy in Alaska. Although Alaskan loess has been studied for decades (see summary in Péwé, 1975), prior to the 1980's there was little or no mention of buried soils in these deposits. More recent studies, however, report the existence of numerous buried soils in Alaskan loess sections, suggesting that episodes of loess fall alternated with periods of landscape stability characterized by little or no loess deposition (Hamilton and others, 1988; Begét and Hawkins, 1989; Begét and others, 1990; Begét, 1990, 1996; Hamilton and Brigham-Grette, 1991; Muhs, Ager, and others, 1997; Muhs and others, in press). Nevertheless, Péwé and others (1997, p. 29-34) question the existence of buried soils in the loess record of interior Alaska, and McDowell (1997) points out some of the difficulties in interpreting organic-rich zones in Alaskan loess sections. In order to resolve these conflicting interpretations, it is essential to establish which criteria can be used to identify buried soils in the Alaskan loess record.

Recognition of buried soils is often difficult. Birkeland (1999) outlines some of the field and laboratory criteria that are potentially useful, but many of these rely on the presence of well-developed subsoil Bt or Bk horizons, which are extremely 
rare in present-day Alaskan soils (Rieger and others, 1979). Organic-rich, surface-soil $\mathrm{O}$ and A horizons are found in Alaskan soils, and the challenge is to find methods of using these horizons for the identification of buried soils in the Alaskan loess record. However, organic-rich alluvial, colluvial, or lacustrine deposits can be mistaken for buried soil $\mathrm{O}$ horizons and vice versa. In addition, if the $\mathrm{O}$ or $\mathrm{A}$ horizons are removed by erosion prior to burial, it may be extremely difficult to identify the remaining parts of a buried soil.

In order to address these problems, it is necessary to characterize modern loess-derived soils that developed in diverse climatic and vegetation settings in Alaska. One purpose of this paper, therefore, is to evaluate methods for identifying buried soils in the Alaskan loess record. If it can be determined that key soil properties show depth-related changes caused by pedogenesis, then identification of buried soils is possible. Morphologic and chemical data are evaluated for modern Alaskan loess or loess-and-till-derived soils that are potentially useful in identifying buried soils in loess sections.

A second purpose of the paper is to evaluate a method for interpreting past vegetation types by looking at buried soils. Certain soil properties reflect the vegetation type under which they form, and therefore such properties in buried soils can be keys to past vegetation types (Jenny, 1980; Birkeland, 1999).

Because much of Quaternary climate change in Alaska results in shifts in the dominance of boreal forest versus tundra (Ager, 1983; Ager and Brubaker, 1985), buried soils in loess sections could record these different vegetation regimes. However, as will be shown later, morphologic criteria alone may not be sufficient to identify the type of vegetation under which a buried soil formed. Carbon isotopes have been employed extensively for reconstruction of past vegetation types from buried soils (Cerling and others, 1989; Holliday, 1995; Fredlund and Tieszen, 1997; Muhs, Stafford, and others, 1997). This method was tested as a tool for distinguishing soils developed under boreal forest and tundra.

\section{Methods}

Modern Alaskan soils, developed in either loess or loess over till of either Holocene or latest Pleistocene age, were investigated in three climatically and biogeographically distinct parts of Alaska (figs. 1, 2): (1) Gelisols (Histoturbels, Haploturbels, Aquorthels, and Historthels) and Inceptisols

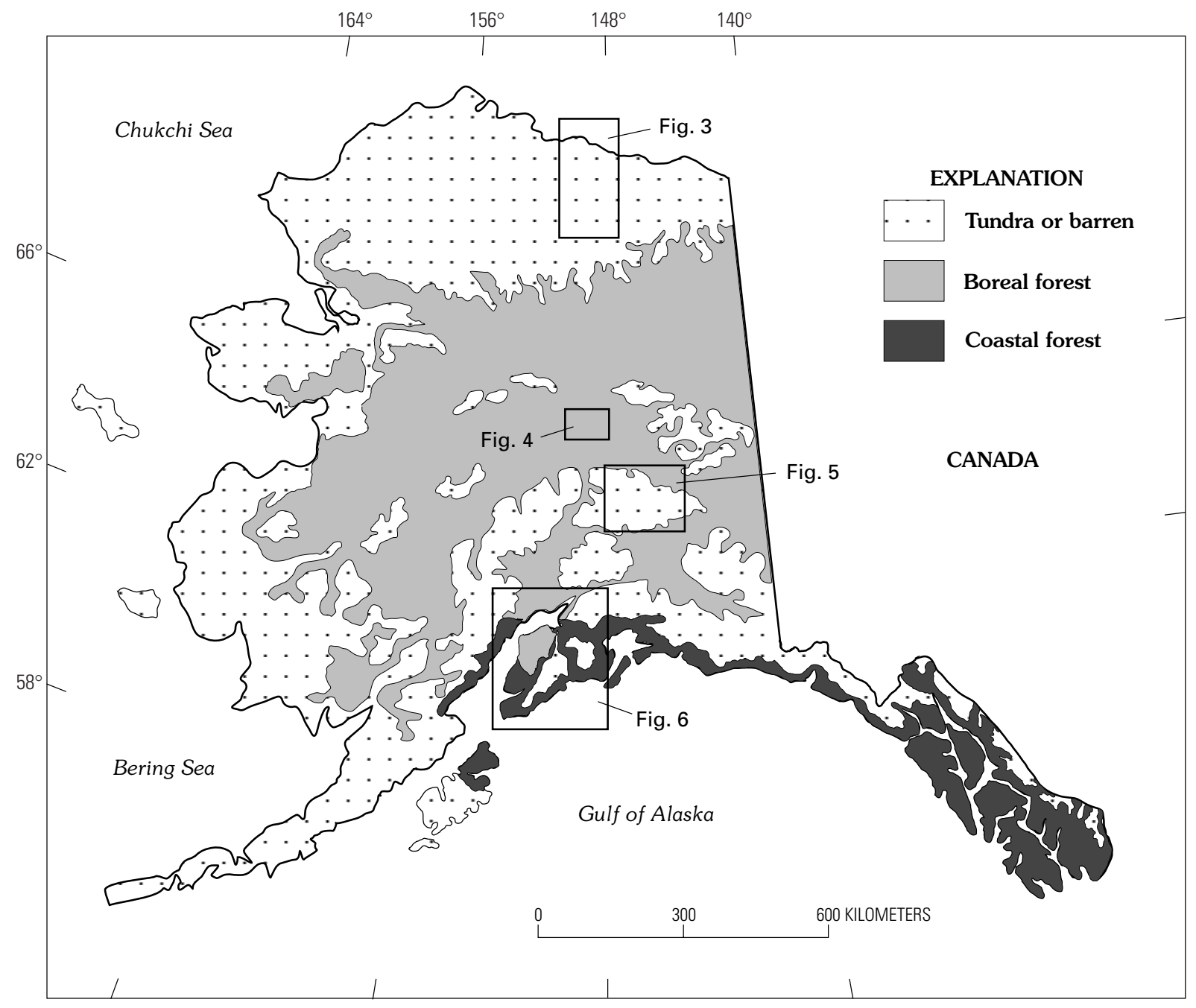

Figure 1. Map showing study areas and the present distribution of vegetation communities in Alaska (from Viereck and Little, 1972, as modified and redrawn by Ager and Brubaker, 1985). 

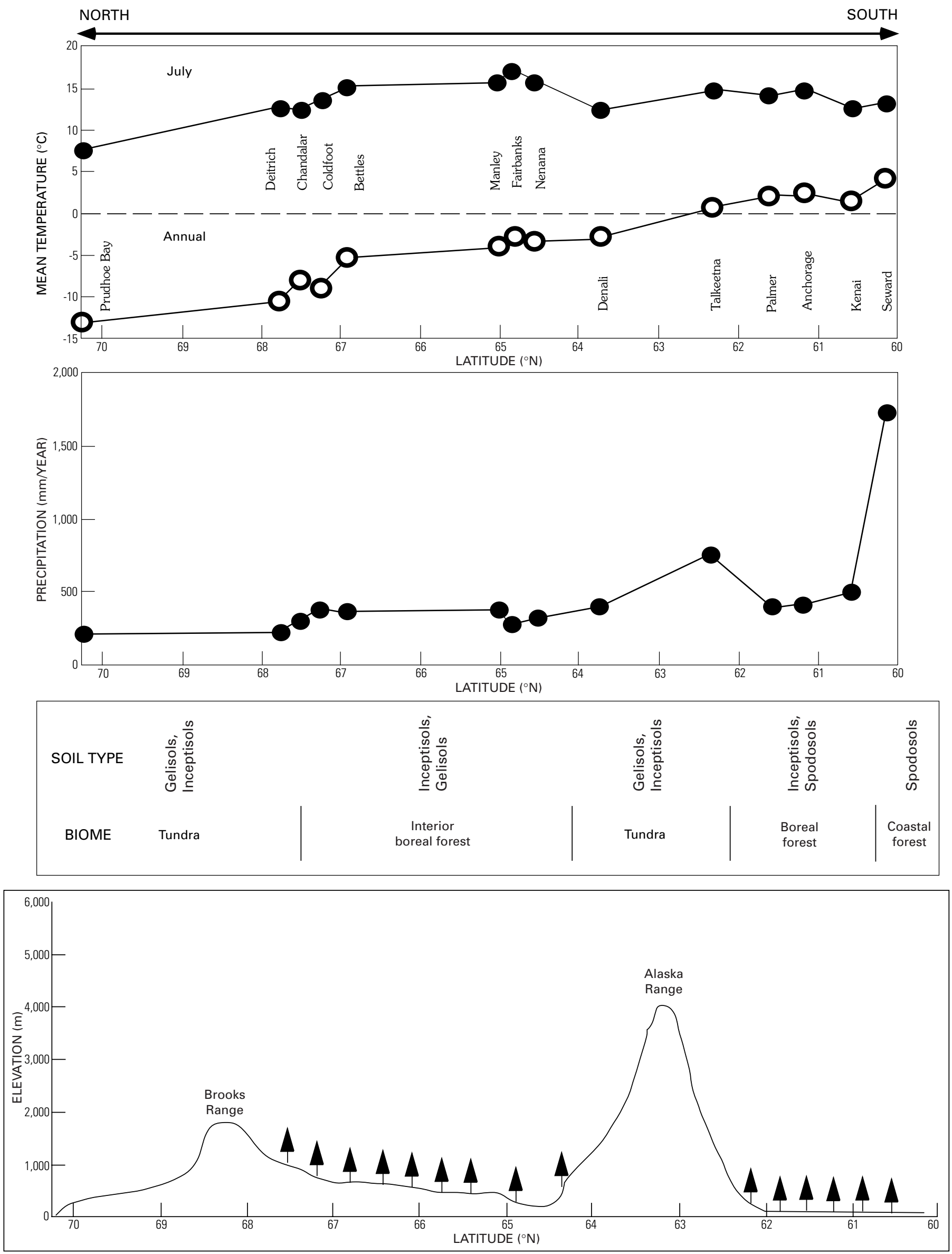

Figure 2. Transect of climates, major soil types, biomes, and topography from north to south across Alaska. Climate data are 1961-1990 means, except for localities where only shorter records exist (Prudhoe Bay, Deitrich Camp, and Coldfoot). 
(Typic and Aquic Dystrocryepts) developed under moist or wetmoist tundra vegetation of the extremely cold, dry environment of the Arctic Coastal Plain, the Arctic Foothills, and the Alaska Range; (2) Inceptisols (Typic and Aquic Dystrocryepts) developed under boreal forest in interior Alaska near Fairbanks, where mean annual temperatures are higher and precipitation is greater than in tundra regions; and (3) Spodosols (Typic Haplocryods) developed under either boreal forest or transitional coastal-boreal forest near Kenai in southern Alaska, where precipitation and mean annual temperatures are higher than in the interior (fig. 2).

Organic-matter concentrations were estimated by weight loss on ignition at $950^{\circ} \mathrm{C}$ for 1 hour, slightly modified from the methods described in Ball (1964) and Nelson and Sommers (1982). As pointed out by Davies (1974), Dean (1974), and Nelson and Sommers (1982), some of the weight loss by this method is derived from structural water loss in clay minerals and $\mathrm{CO}_{2}$ loss from carbonates. However, Nelson and Sommers (1982) note that estimation of organic matter content by the classical Walkley-Black method requires corrections both for unoxidized organic carbon and for conversion of organic carbon values to organic matter values. Janitzky (1986) reported a high correlation between organic carbon measured by the drycombustion and Walkley-Black methods. We compared loss-onignition and Walkley-Black methods for soils near Fairbanks that have organic matter contents of less than 7 percent (as estimated by the Walkley-Black method). Results show that the relation between the two methods is linear with a high degree of explanation $\left(\mathrm{r}^{2}=0.73\right)$. However, loss-on-ignition values are consistently higher than Walkley-Black-derived values, even though the samples are not calcareous, suggesting some structural water loss from clay minerals. Therefore, loss-on-ignition estimates, of organic matter content less than $\sim 10$ percent reported here, should be interpreted as maxima. Certain soils studied on the Arctic Coastal Plain are calcareous; organicmatter estimates of these soils, derived from loss-on-ignition, are certainly maxima. Based on the estimated carbonate content, however, the error introduced does not affect interpretations.

Concentrations of $\mathrm{P}_{2} \mathrm{O}_{5}$, which are examined in some detail here, were determined by wavelength-dispersive X-ray fluorescence. Analyses of this element by this method have analytical uncertainties of \pm 0.01 percent.

Only noncalcareous soil horizons were analyzed for carbon isotopes. Splits of samples from each soil horizon were combusted in an automated Dumas combustion device at $\sim 1,000^{\circ} \mathrm{C}$. Resulting combustion gases were passed through a series of chemical scrubbers to remove interfering species, leaving the $\mathrm{CO}_{2}$ and $\mathrm{He}$ carrier. Gases were passed directly into the ionization source and the $\mathrm{CO}_{2}$ was analyzed on a triple-collecting gassource mass spectrometer. Results are reported in delta notation relative to the Peedee belemnite (PDB) standard.

\section{Soil Properties Useful in Identifying and Interpreting Buried Soils in Alaskan Loess}

In the field, soil morphology (color, texture, structure, consistence, horizonation) is what distinguishes modern soils in
Alaska and elsewhere from unaltered sediments or other parent materials. In different climates and biomes of Alaska, soils with well-developed horizons are distinct from unaltered loess, primarily because of different-colored horizons, although there can also be subtle changes in texture, structure, and the abundance of roots. However, recognition of buried soils on the basis of morphology alone may be difficult in fresh exposures of perennially frozen loess.

Organic matter shows consistent depth relations in modern, well-drained soils from a wide variety of climates and biomes, and the trends have been summarized by Jenny (1980). Soil organic matter content is a function of the competing processes of organic-matter production by living organisms and destruction by decomposition. Because production rates are usually highest at the soil surface in well-drained soils, organic matter contents tend to be highest in surface horizons and diminish rapidly with depth: this is therefore a characteristic "depth function" found in many soils. For most well-drained soils, Jenny (1980) suggests that organic-matter-content depth functions are best approximated by exponential curves. In contrast, poorly drained soils frequently have monotonically high organic matter contents to considerable depths, resulting in linear depth functions. Organic matter production rates and decomposition rates in coastal southern Alaska soils are relatively high (Burt and Alexander, 1996). In contrast, both organic matter production rates and decomposition rates are relatively low in tundra and boreal-forest environments in other parts of Alaska (Chapin and others, 1980; Van Cleve and others, 1991). The characteristic exponential depth function of soil organic matter, commonly found in mid-latitude and low-latitude environments, may be a key property used to identify buried soils. However, cryoturbation processes are common in many Alaskan tundra soils and even some boreal-forest soils (Everett and Parkinson, 1977; Bockheim and Tarnocai, 1998; Bockheim and others, 1997, 1998). These mechanisms could produce highly irregular organic matter-depth functions. Nevertheless, the few published studies of organic-matter concentrations in Alaskan soils show depth functions similar to mid-latitude and low-latitude soils (Rieger and others, 1979; Michaelson and others, 1996; Bockheim and others, 1998).

Phosphorus, an important plant nutrient in soils, is derived chiefly from the weathering of apatite $\left[\mathrm{Ca}_{5}\left(\mathrm{PO}_{4}\right)_{3}(\mathrm{~F}, \mathrm{Cl}, \mathrm{OH})\right]$. The $\mathrm{P}$ released by apatite weathering can enter several pools: small amounts can be leached, some can be taken up in secondary $\mathrm{P}$ minerals, some can be taken up by plants and converted to organic forms (many of which are insoluble), some becomes part of the soil labile (exchangeable) pool, and some becomes part of what has been referred to as the occluded (encapsulated in other minerals) pool (Smeck, 1985). Although P is considered to be relatively immobile in soils (Smeck, 1973), soil chronosequence studies have shown that total $\mathrm{P}$ decreases in soils over time (Walker and Syers, 1976). For the present study, however, it is important to note that much of the $\mathrm{P}$ released by apatite weathering is taken up by plants, converted to organic forms, and returned to soil surface horizons after dieback. Studies of soils in the United States, Canada, and New Zealand show a characteristic total $\mathrm{P}$ depth function as follows: (1) enrichments in surface horizons due to biocycling, (2) depletions in subsurface horizons where plants have removed $\mathrm{P}$ or it has been 
leached, and (3) relative enrichments below the zone of depletion where there has been neither plant uptake nor leaching (Smeck, 1973; Runge and others, 1974; Walker and Syers, 1976; Letkeman and others, 1996). Runge and others (1974) successfully used this characteristic total-P depth function to identify buried soils in loess sequences in New Zealand. Studies have shown that, under both tundra (Gersper and others, 1980; Chapin and others, 1980) and boreal forest (Van Cleve and others, 1993), soil P is found largely in organic forms; Bockheim and others (1998) provide some of the few published P depth functions.

Carbon isotopes potentially can be used to infer past vegetation regimes under which buried soils formed. The use of carbon isotopes for paleoecological reconstructions is reviewed by Tieszen (1991). Two types of photosynthetic pathways, $C_{3}$ and $\mathrm{C}_{4}$, fractionate carbon isotopes in distinctly different ways. Plants following the $\mathrm{C}_{3}$ pathway, which include cool-season grasses, all trees, and most tundra plants, have $\delta^{13} \mathrm{C}$ values that range from -22 to $-34 \%$ and average about $-26 \%$. In contrast, $\mathrm{C}_{4}$ plants, which include most warm-season grasses, range from -9 to $-20 \%$ and average $-12 \%$ (O'Leary, 1988). Because Alaska presently has only forest and tundra vegetation (both dominated by $\mathrm{C}_{3}$ plants), it could be assumed that carbon isotopes would be of little use in interpreting past vegetation types. However, there is a considerable range of variability of carbon isotopic composition even within the realm of $\mathrm{C}_{3}$ plants.

Ugolini and others (1981) reported that tundra litter at one locality in Alaska showed a range of $\delta^{13} \mathrm{C}$ values from about -21.8 to $-24.0 \%$, whereas boreal forest litter at lower elevations showed a range of values from -25.5 to $-27.1 \%$. Although the number of samples ( 6 of each biome) was limited in this study, the reported differences in carbon-isotope composition are much greater than typical analytical uncertainty and suggest that the technique has promise for differentiating tundra- and forestderived buried soils.

\section{Vegetation in the Study Areas}

In northern Alaska, the Brooks Range is dominated by alpine tundra, whereas the Arctic Foothills and Arctic Coastal Plain have moist tundra that grades into wet tundra (fig. 3). At most of the localities we studied in the Arctic Foothills and on the Coastal Plain, the vegetation can be characterized as moist tundra. In the interior near Fairbanks, soils studied are found in upland Picea-Betula-Populus forest (fig. 4) dominated by white spruce (Picea glauca), as well as more poorly drained sites dominated by black spruce (Picea mariana). The vegetation above $~ 900-1,000 \mathrm{~m}$ in the Alaska Range consists of both alpine tundra and moist tundra (fig. 5). Moist tundra (low sedge tussock/shrub tundra) is the characteristic vegetation on two soil catenas that were studied. The dominant shrubs are birch (Betula glandulosa) and willow (Salix pulchra). On the Kenai Peninsula, both interior-type boreal forest and coastal forest are found (fig. 6). However, there is also a transitional community, particularly along a narrow (less than $1 \mathrm{~km}$ wide) strip on the west coast near the city of Kenai. This transitional community is dominantly boreal forest, but its understory has some of the elements of coastal forest such as devil's club (Oplopanax

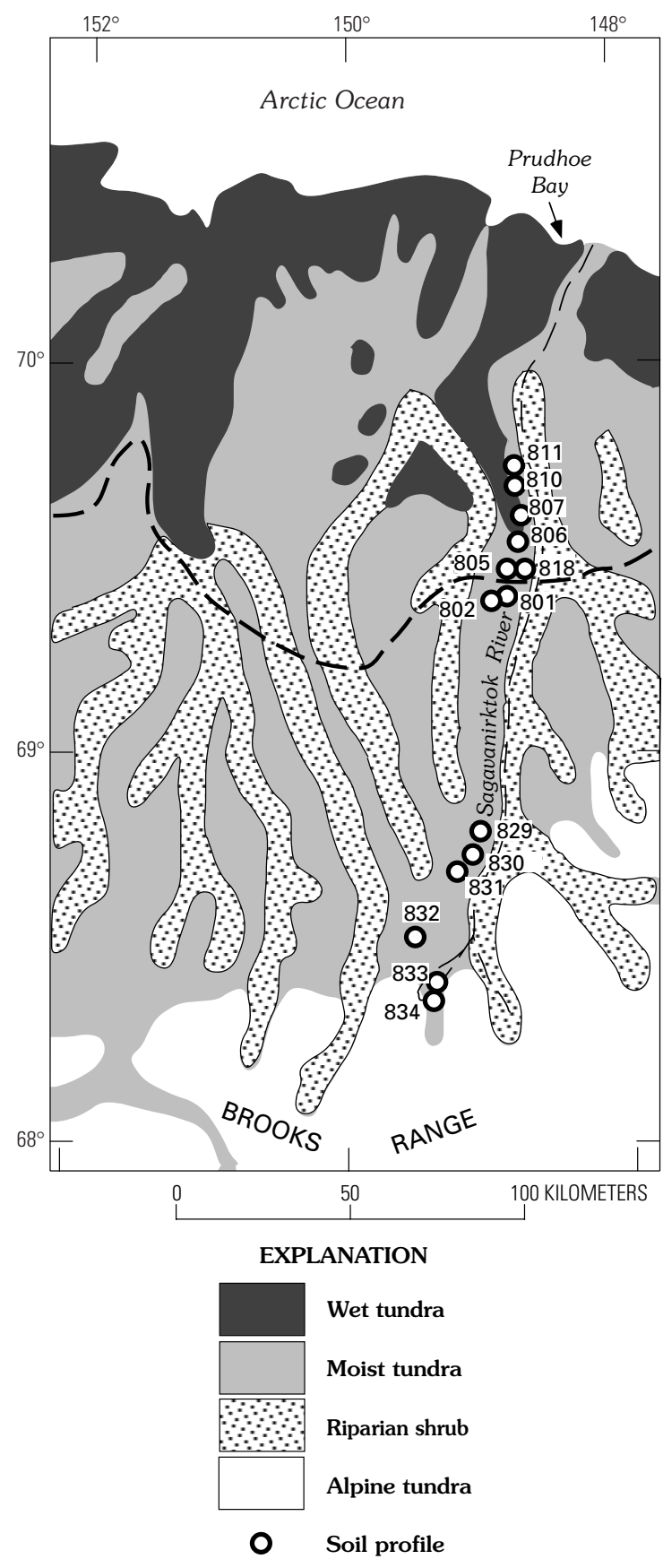

Figure 3. Major ecosystem types in the northern Brooks Range, Arctic Foothills, and Arctic Coastal Plain regions of Alaska, and location of pedons (soil profiles) studied. Dashed line indicates approximate boundary between the Arctic Foothills and the Arctic Coastal Plain. Vegetation distribution from Joint Federal-State Land Use Planning Commission for Alaska (1973).

horridum), Sorbus sp., and abundant ferns. Many of the upperstory trees are hybrids of Sitka spruce (Picea sitchensis) and white spruce (Picea glauca). Most of the Spodosols sampled in the Kenai area are developing under what is presently boreal forest, but two pedons were sampled in the transitional coastalboreal forest community.

Geochronological studies indicate that most of the modern soils studied on the Arctic Coastal Plain, in the interior near 


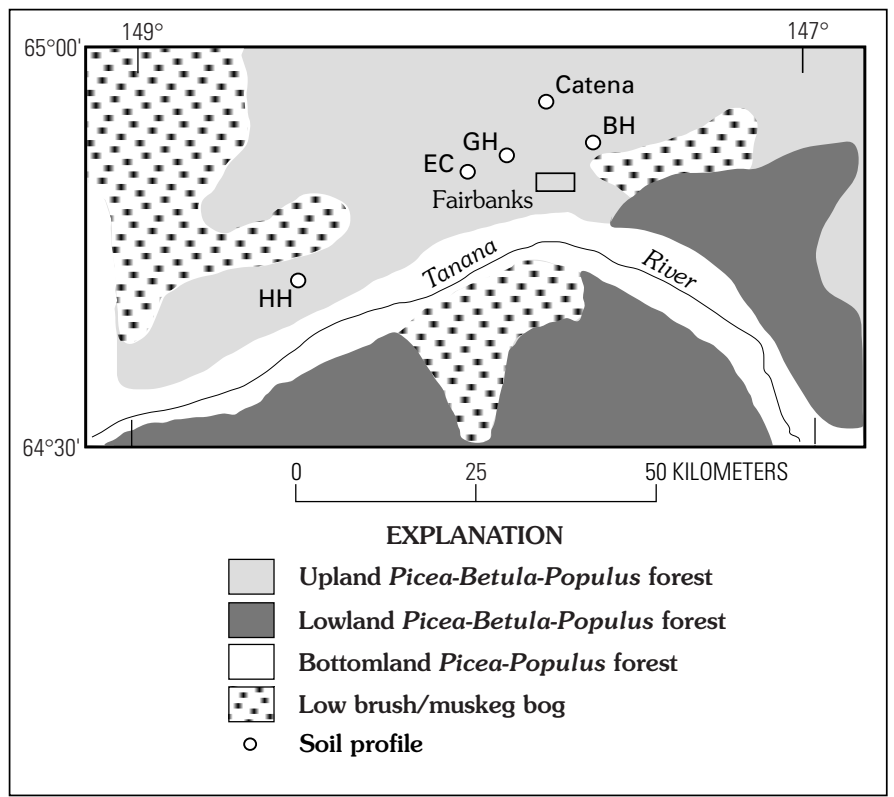

Figure 4. Major ecosystem types in the Fairbanks, Alaska, area and location of soil catena and other pedons studied. $\mathrm{HH}$, Halfway House; EC, Eva Creek; GH, Gold Hill; BH, Birch Hill. Vegetation distribution from Joint Federal-State Land Use Planning Commission for Alaska (1973).

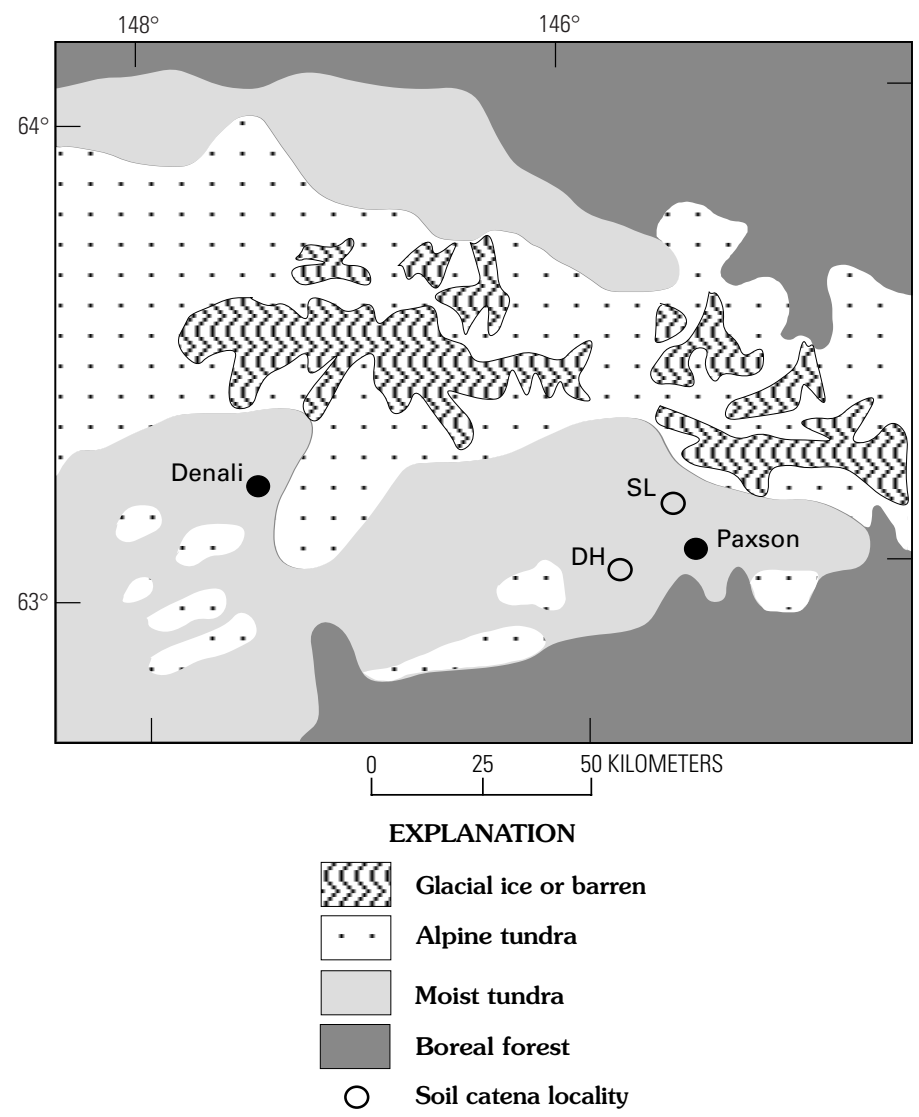

Figure 5. Major ecosystem types in the central part of the Alaska Range and surrounding areas, and location of soil catenas near Summit Lake (SL), and on the Denali Highway (DH) near Ten Mile Lake. Vegetation distribution from Joint Federal-State Land Use Planning Commission for Alaska (1973).

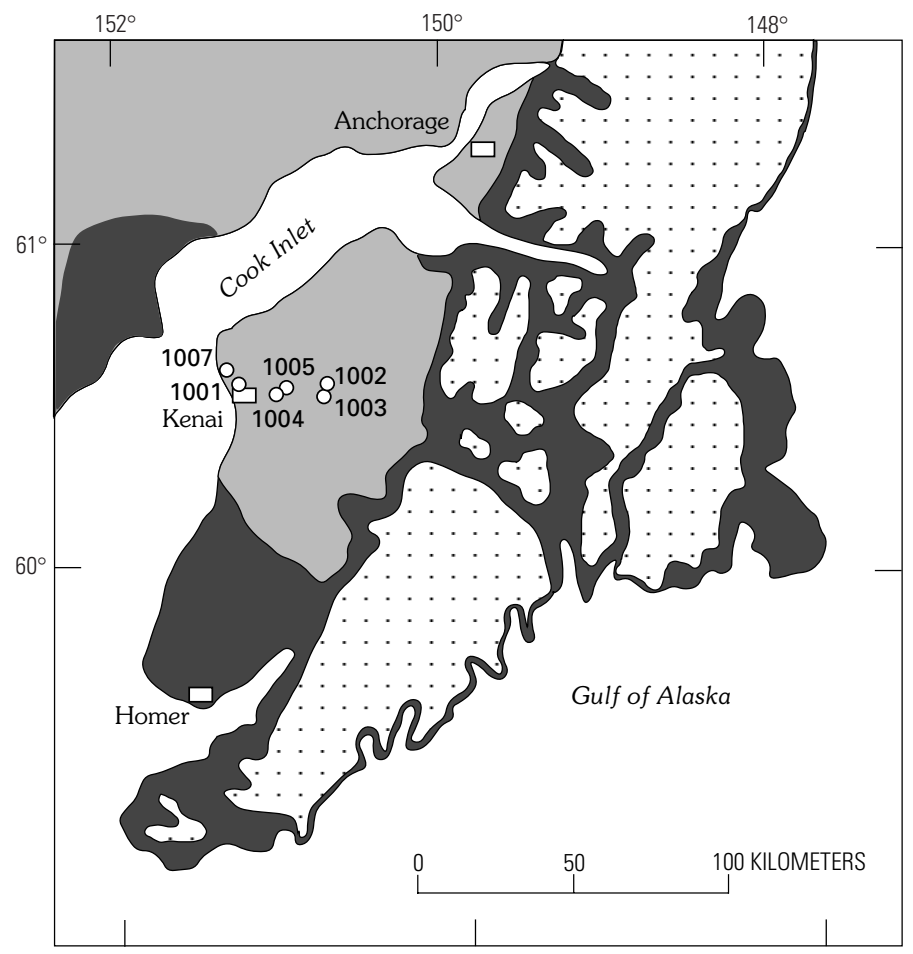

EXPLANATION

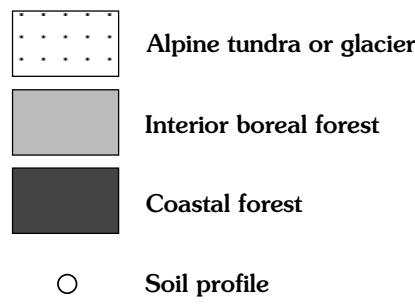

Figure 6. Major ecosystem types in the Kenai Peninsula area and location of pedons studied. Vegetation distribution slightly modified from Joint Federal-State Land Use Planning Commission for Alaska (1973).

Fairbanks, and near Kenai have formed in loess of Holocene or latest Pleistocene age (Everett and Brown, 1982; Brown and Krieg, 1983; Walker and others, 1998; Hamilton and others, 1983, 1988; Begét, 1990; Péwé and others, 1997; Muhs, Ager, and others, 1997; Reger and others, 1996). Pedons in both the Arctic Foothills and the Alaska Range have developed in thin loess over glacial till or outwash that dates to the last glacial period between 24 and $11.5 \mathrm{ka}$ (Coulter and others, 1965; Hamilton, 1978, 1994; Anderson and others, 1994). Pollen studies from all these regions indicate that modern soils have developed primarily under vegetation that is little different from that found in those regions today (Ager, 1983; Ager and Brubaker, 1985; Ager and Sims, 1982; Anderson and Brubaker, 1994; Anderson and others, 1994).

\section{Properties of Soils in the Study Areas}

\section{Soil Morphology}

Soil morphological properties are what distinguish individual soil horizons from one another. In this paper, terminology for soil horizons and pedon (soil profile) 


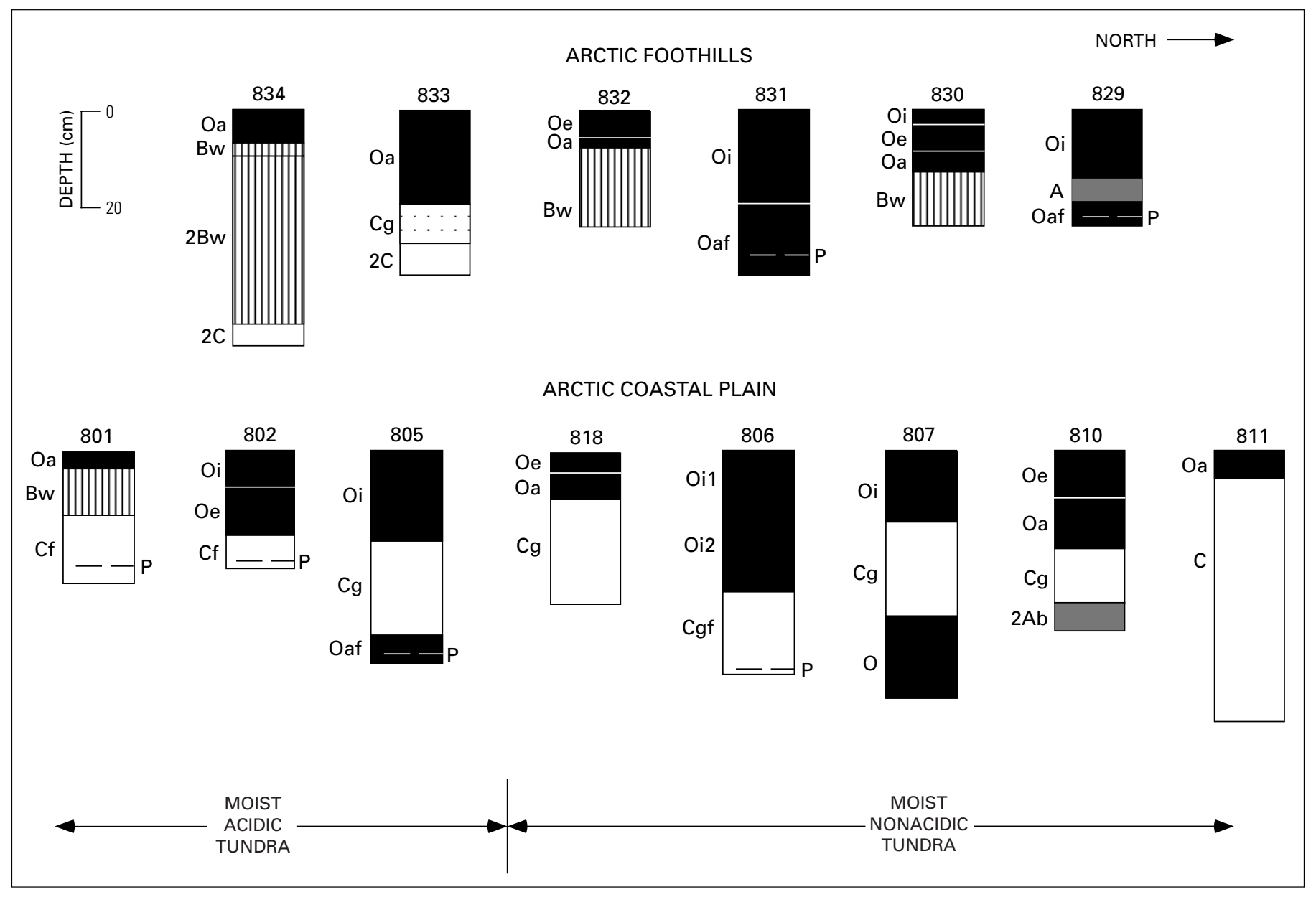

Figure 7. Soil morphology in pedons studied in the Arctic Foothills and Arctic Coastal Plain regions, developed under moist acidic and nonacidic tundra (terminology from Bockheim and others, 1998, and Walker and others, 1998). "P" symbol with dashed line indicates depth of permafrost at time of sampling (July 1996). Pedon numbers keyed to figure 3.

classification follows definitions given by the Soil Survey Staff (1998). On the Arctic Coastal Plain, Gelisols (permafrostaffected soils) occur where permafrost occurs within $100 \mathrm{~cm}$ of the surface or within $200 \mathrm{~cm}$ of the surface if there is gelic material within $100 \mathrm{~cm}$ of the surface (Bockheim and others, 1997; Soil Survey Staff, 1998). Many of the soils studied in this area qualify as Gelisols because permafrost was encountered at depths of $\sim 20-50 \mathrm{~cm}$ at the time of sampling in July 1996 (fig. 7). Some of the soils with evidence of cryoturbation are likely classified as Histoturbels (profiles 805 and 806) or Haploturbels (profiles 801 and 802). Other soils without evidence of cryoturbation are most likely Aquorthels (profile 807 ) or Historthels (profile 810). Soils that do not have permafrost at the requisite depths are Inceptisols.

Most of the Arctic Coastal Plain soils studied have $\mathrm{O} / \mathrm{Cg}$ profiles, whether developed under moist acidic or nonacidic (terminology from Bockheim and others, 1998 and Walker and others, 1998) tundra (fig. 7). Many soils are poorly drained, and $\mathrm{O}$ horizon thicknesses are quite variable. Several pedons studied have buried $\mathrm{O}$ or A horizons, similar to other Arctic Coastal Plain soils studied by Michaelson and others (1996) and Bockheim and others (1998). No E horizons were observed in any of these soils, and only one pedon studied (801) had a B horizon.
Soils formed in loess over till or outwash of last glacial age in the Arctic Foothills generally have a greater degree of profile differentiation than soils on the Arctic Coastal Plain (fig. 7). At least two of these pedons (829 and 831) are Gelisols, but others with deeper permafrost are likely Dystrocryepts (830 and 834). No E horizons or Bt horizons were observed in Arctic Foothills soils.

In the Alaska Range, soils developed in loess over till show variability as a function of slope position (fig. 8). Some of these soils may qualify as Gelisols, but the depth to permafrost is not known in most of our study sites. Relatively well drained soils on crest and shoulder positions and even upper footslope positions have thin $\mathrm{O}$ horizons and brown or yellowish-brown Bw horizons. At poorly drained lower footslope positions, soils have minimally developed grayish-brown B horizons or lack B horizons altogether. As in soils in the Coastal Plain and the Arctic Foothills, E horizons were not observed in tundra soils of the Alaska Range, except possibly in the ridge-crest position soil in the Summit Lake catena (fig. 8). This thin, light-colored horizon may be unaltered loess, but given a possibility of slightly higher treeline in this area in the early Holocene (Anderson and others, 1994), we cannot exclude the possibility that it is an E horizon that developed under a former forest cover. 


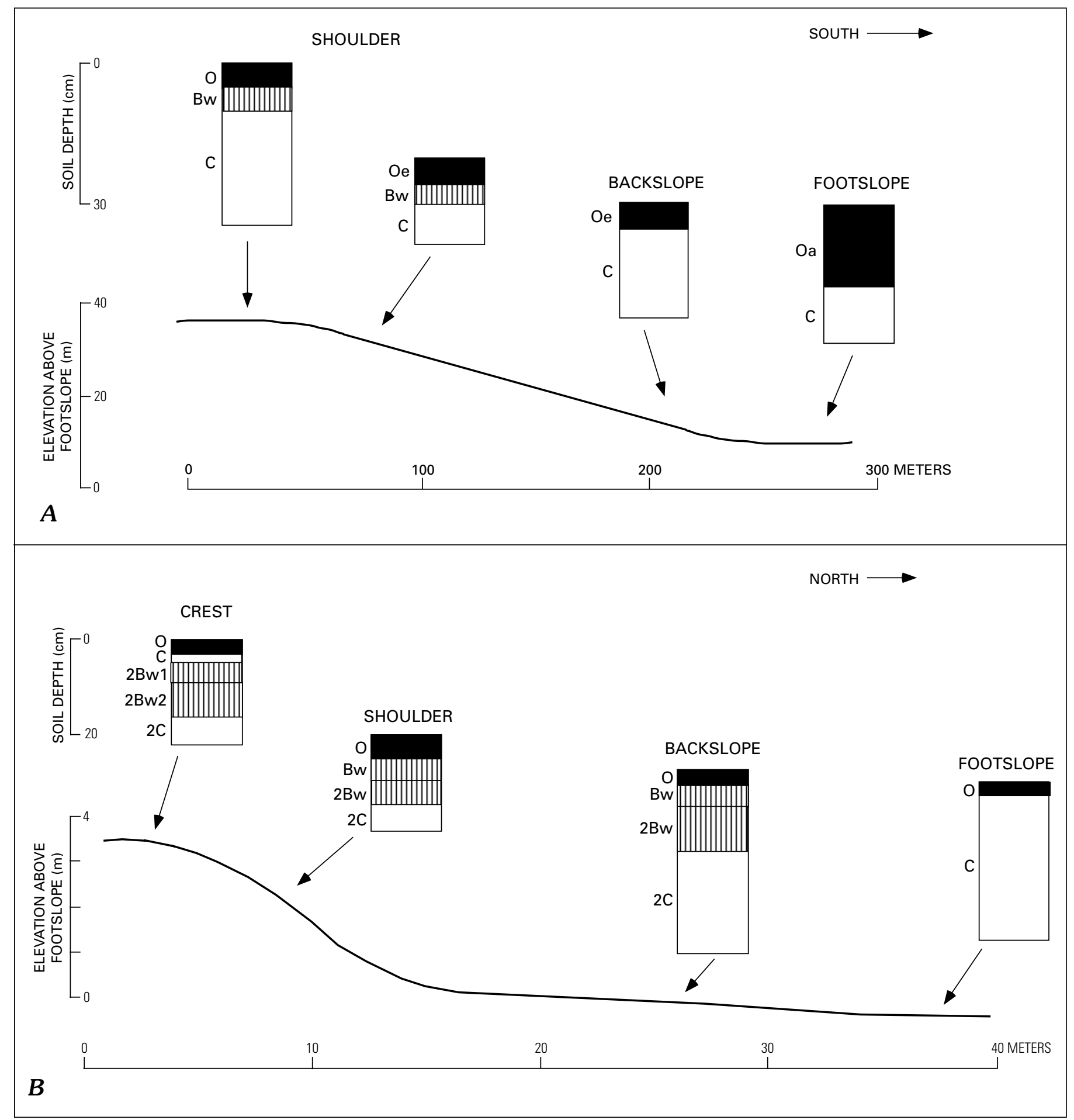

Figure 8. Soil morphology along catenas on $A$, the Denali Highway near Ten Mile Lake and $B$, near Summit Lake in the Alaska Range. Locations on figure 5 .

Inceptisols and Gelisols developed under interior boreal forest near Fairbanks show distinct horizonation that varies with slope position (fig. 9). The greatest degree of profile differentiation is at the shoulder and upper backslope positions, where soils have $\mathrm{A} / \mathrm{E} / \mathrm{Bw} / \mathrm{Bt} / \mathrm{C}$ or $\mathrm{A} / \mathrm{E} / \mathrm{Bw} / \mathrm{C}$ profiles. All soils at lower backslope or higher positions are Typic Dystrocryepts that lack shallow permafrost. In all soils downslope of the lower backslope position, E horizons are absent. At upper footslope positions, soils are Aquic Dystrocryepts with $\mathrm{O} / \mathrm{Bw} / \mathrm{C}$ profiles, and poorly drained soils at the lower footslope position are Aquic Historthels with $\mathrm{Oi} / \mathrm{Cg}$ profiles. Permafrost was encountered at depths of 70-90 cm in lower footslope soils at the time of sampling (September 1996).

Spodosols (Haplocryods) developed under coastal-boreal forest or boreal forest near Kenai (Rieger and others, 1979) have very distinct horizons (fig. 10). O horizons are very dark (10YR $2 / 1$ or $2 / 2$ ) even when dry. All Spodosols studied have E horizons that are more distinct than under interior boreal forest and 


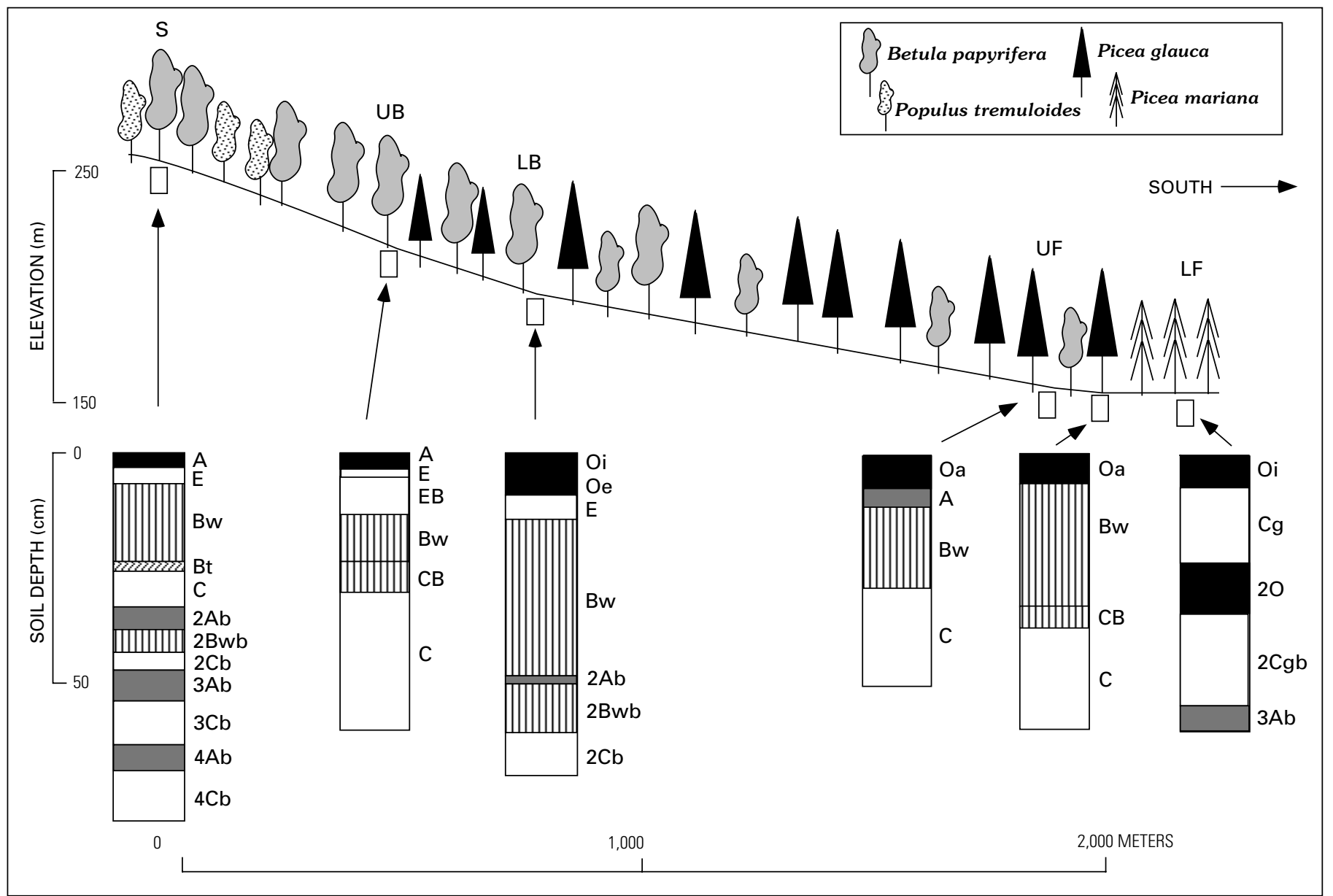

Figure 9. Soil morphology along a catena north of Fairbanks and dominant boreal forest taxa. Slope positions: S, shoulder; UB, upper backslope; LB, lower backslope; UF, upper footslope; LF, lower footslope. Location on figure 4.

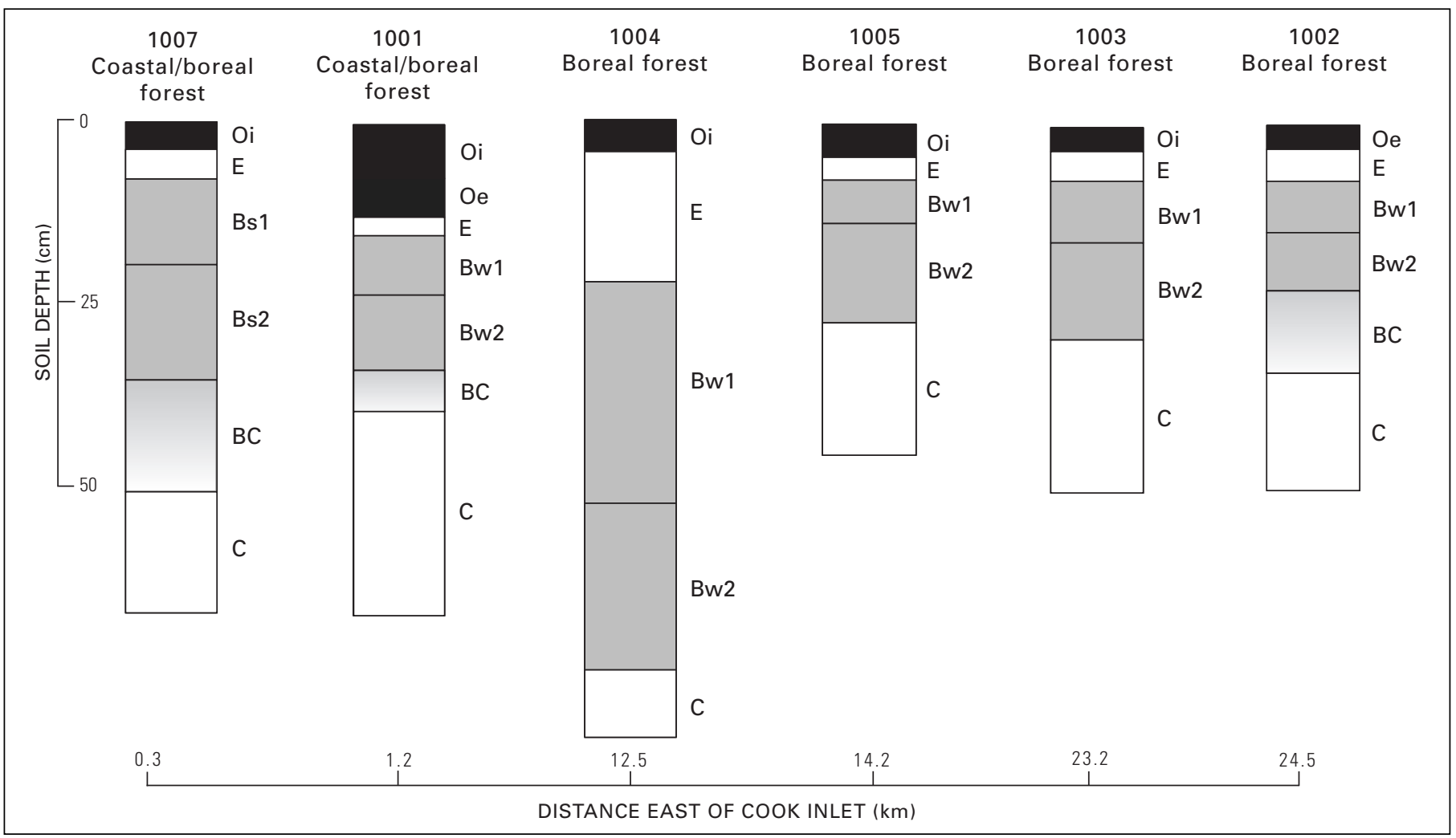

Figure 10. Soil morphology in pedons studied in a transect from Cook Inlet to $\sim 24 \mathrm{~km}$ inland on the Kenai Peninsula. Profile numbers keyed to figure 6. 
are underlain by Bw horizons. Near the coast, under transitional coastal-boreal forest, Spodosols have Bs horizons that are much higher in total $\mathrm{Fe}_{2} \mathrm{O}_{3}$ content than the parent loess or overlying $\mathrm{E}$ horizon (Muhs and others, in press). Although all Spodosols studied have Bw or Bs horizons, no Bt horizons were observed.

Studies of modern, well-drained Alaskan soils indicate that morphological characteristics, particularly horizon sequences with their distinctive colors, can be used to identify buried soils in unfrozen, dry exposures of loess. Unaltered loess in Alaska typically has light brownish gray $(2.5 \mathrm{Y} 6 / 2$, dry), light yellowish brown (2.5Y 6/3, dry) or grayish-brown (2.5Y 5/2, dry) colors. Soil O or A horizons generally have 10YR or 7.5YR hues and much lower values and chromas (usually 1 or 2 ) that distinguish them from unaltered loess. Well-drained soils with $\mathrm{Bw}$ and Bs horizons generally have redder hues (10YR or 7.5YR) and higher chromas (3-6) than unaltered loess. In forests, soil E horizons are very distinctive features (10YR or 7.5YR 6/1 or 6/2 colors) in Spodosols and well-drained Inceptisols that contrast with dark, overlying $\mathrm{O}$ horizons - these E horizons ought to be identifiable in loess-derived buried soils.

Organic-rich alluvial, colluvial, or lacustrine deposits that could be mistaken for buried soils in a stratigraphic section may superficially resemble $\mathrm{O}$ or A horizons of soils. However, these deposits are unlikely to have horizon sequences that would be mistaken for a soil $\mathrm{O} / \mathrm{E} / \mathrm{Bw} / \mathrm{C}$ horizon sequence. On the other hand, buried soils with only $\mathrm{O} / \mathrm{Cg}$ profiles that developed under poorly drained conditions could be mistakenly identified as organic-rich sediments, and, in such cases, other criteria

(discussed below) need to be included for positive identification as a buried soil.

It is more difficult to interpret past vegetation type on the basis of buried soil morphology. Dark soil O horizons, frequently of similar thicknesses, are present under tundra, boreal forest, and coastal-boreal forest, so surface horizons say little about vegetation type. Tundra soils lack E horizons, whereas these horizons are found in all Spodosols and well-drained Inceptisols that developed under forest. However, boreal forest soils that developed in poorly drained landscape positions lack E horizons. Therefore, while the presence of an E horizon in a buried soil implies a past forest vegetation, the lack of an E horizon in a buried soil does not necessarily imply tundra vegetation, unless there is certainty that the former land surface was well drained. In well-drained landscape positions, both tundra and forest soils can have Bw horizons; thus, Bw horizons cannot be used to infer past vegetation type.

\section{Organic Matter}

Organic matter distributions in both acidic and nonacidic tundra soils from the Arctic Coastal Plain and Arctic Foothills show depth functions typical of well-drained mid-latitude and low-latitude soils in some cases, but not in others (fig. 11). Organic matter contents are extremely high ( $>70$ percent in some soils) in surface $\mathrm{O}$ horizons, and many of these are thick enough to qualify as histic epipedons. Concentrations of organic matter diminish rapidly as a function of depth in some soils (e.g., profiles $801,810,830,834$ ), but less so in others (profiles 805 , $806,807)$. The soils that do not show rapid organic matter decreases with depth are those that are very poorly drained and have relatively thick Oi horizons. Some of the latter soils were saturated and had standing water at the time of sampling.

In modern boreal forest soils in the Fairbanks area, $\mathrm{O}$ horizons are generally thinner than those developed under tundra and, in some cases, notably at better drained positions, have organic matter contents that are lower than those in tundra soils (fig. 12). Organic matter depth functions in boreal forest soils show the characteristic exponential decreases as described by Jenny (1980). A buried O horizon, identifiable by its very dark grayish brown (10YR 3/2, moist) or black (10YR 2/1, moist) color in the lower footslope position is also clearly marked by its higher organic matter content (fig. 12). However, thin buried soils that were identified in the field at both backslope and shoulder positions by their darker colors do not have increases in organic matter. Therefore, at well-drained slope positions, organic matter content sometimes may be a poor indicator of the presence of a buried soil.

Modern tundra soils at the Summit Lake catena in the Alaska Range also show relatively rapid declines in organic matter as a function of depth (fig. 13). As is the case with boreal forest soils in the Fairbanks area, organic matter contents are highest at lower slope positions (backslope and footslope), but the forms of depth functions at all slope positions are similar.

Spodosols under either boreal forest or transitional coastal-boreal forest have $\mathrm{O}$ horizons with organic matter contents of 30-70 percent that decrease very rapidly with depth (fig. 14). Two Spodosols (profiles 1001 and 1007) that developed under transitional coastal-boreal forest and one that developed under boreal forest (profile 1005) have very distinct decreases in organic matter content in their E horizons, but they show slight enrichments in the upper Bs or Bw horizons. Such translocation of organic matter is characteristic of some Spodosols (Rieger, 1983).

Overall, the depth functions observed here suggest that organic matter concentration is a valuable property for identifying buried soils in loess sections. All forest soils and most tundra soils show decreases in organic matter content as a function of depth, very similar in form to the characteristic organic matter depth functions that have been described for well-drained mid-latitude and low-latitude soils. Organic-rich colluvial, alluvial, or lacustrine deposits found in a stratigraphic section are more likely to show irregular changes in organic matter content as a function of depth. However, some buried boreal forest soils that were identified on the basis of morphology could not be detected by organic matter trends, and some poorly drained tundra soils do not show rapid decreases in organic matter with depth. Finally, because organic matter in most well-drained Alaskan soils decreases rapidly with depth, buried soils whose $\mathrm{O}$ or A horizons have been partially or wholly eroded might not be detected in a stratigraphic section. Therefore, organic matter content should be used in conjunction with other properties to identify buried soils.

\section{Phosphorus}

Phosphorus distributions in tundra soils of the Arctic Coastal Plain and Arctic Foothills show trends that generally 
ORGANIC MATTER CONTENT (\%)

MOIST ACIDIC TUNDRA
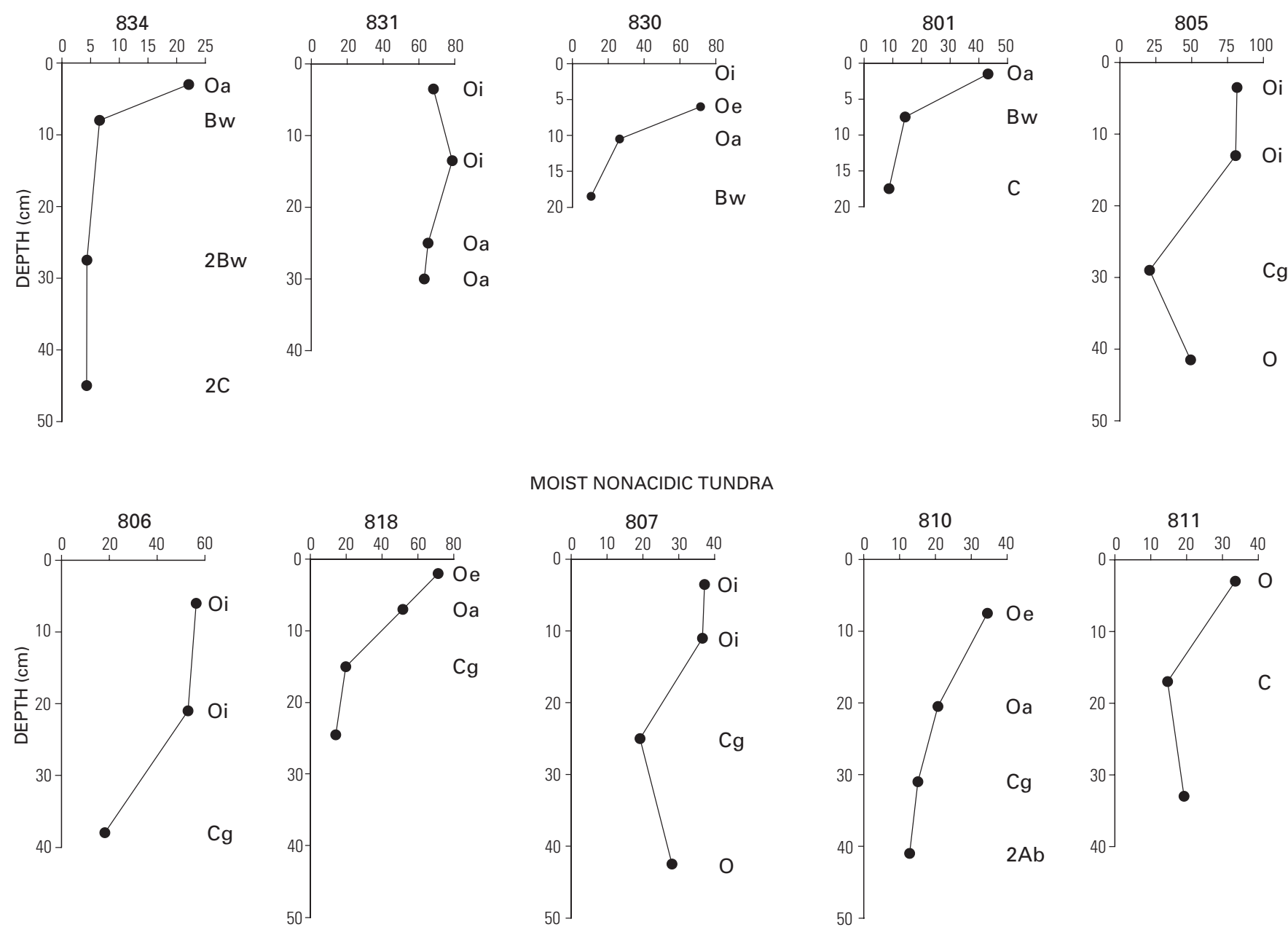

MOIST NONACIDIC TUNDRA
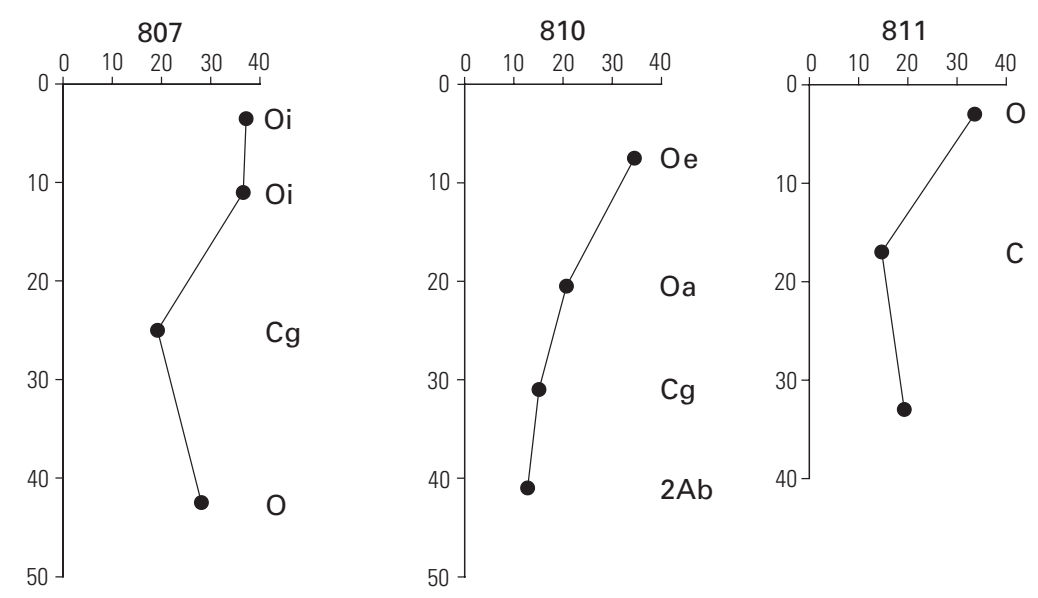

Figure 11. Organic matter content vs. depth in Gelisols and Inceptisols from the Arctic Foothills and Arctic Coastal Plain, developed under moist acidic and nonacidic tundra. Pedon numbers keyed to figures 3 and 7.

parallel organic matter distributions (fig. 15). The same is true for tundra soils in the Summit Lake catena of the Alaska Range, with the exception of the $\mathrm{O}$ horizon at the backslope position (fig. 13). Concentrations of $\mathrm{P}$ are highest in surface $\mathrm{O}$ horizons and diminish rapidly with depth, supporting earlier interpretations (Gersper and others, 1980; Chapin and others, 1980) that $P$ in Alaskan tundra soils is largely in organic forms. Buried $\mathrm{O}$ or $\mathrm{A}$ horizons in these soils show slight $\mathrm{P}$ enrichments compared to overlying $\mathrm{C}$ horizons. None of the tundra soils examined show the "high-low-high" surface-tosubsurface depth functions of $\mathrm{P}$ concentrations described by Runge and others (1974) and other workers studying midlatitude soils.

Modern boreal forest soils from the Fairbanks area, on the other hand, show $\mathrm{P}$ distributions that are similar to those reported for mid-latitude soils in North America and New Zealand (fig. 12). The highest $\mathrm{P}$ values are found in the $\mathrm{O}$ or $\mathrm{A}$ horizons. The lowest values are found just below the surface horizons and values increase again slightly in the lower B or upper $\mathrm{C}$ horizons. The high values associated with the $\mathrm{O}$ or $\mathrm{A}$ horizons (including the buried $\mathrm{O}$ horizon in the lower footslope soil) support the suggestion of Van Cleve and others (1993) that $\mathrm{P}$ in boreal forest soils, like tundra soils, is found mainly in organic forms. Spodosols from the Kenai area also show distinct enrichments in $\mathrm{P}$ in surface horizons (fig. 14). Most pedons studied show relatively rapid decreases as a function of depth; only two profiles (1007 and 1005) have E horizons with lower values than all other subsurface horizons. In the case of profiles 1007 and 1005 (and perhaps in the lower backslope soil near Fairbanks), it appears that $\mathrm{P}$ has been translocated downward in the profile, perhaps in association with organic matter.

Our studies indicate that $\mathrm{P}$ concentrations can be a valuable tool in identifying buried soils in Alaska. Although only the interior boreal forest soils show similarities to the "high-lowhigh" depth function reported for mid-latitude soils, all pedons, whether developed under tundra or forest, show greatest $\mathrm{P}$ concentrations in $\mathrm{O}$ or $\mathrm{A}$ horizons. The importance of these findings to stratigraphy is that $\mathrm{P}$ enrichments (succeeded at depth by depletions) should mark surface horizons of buried soils. However, the same problem associated with organic matter depth functions applies to $\mathrm{P}$ trends: buried soils with eroded $\mathrm{O}$ or $\mathrm{A}$ horizons may go undetected. 


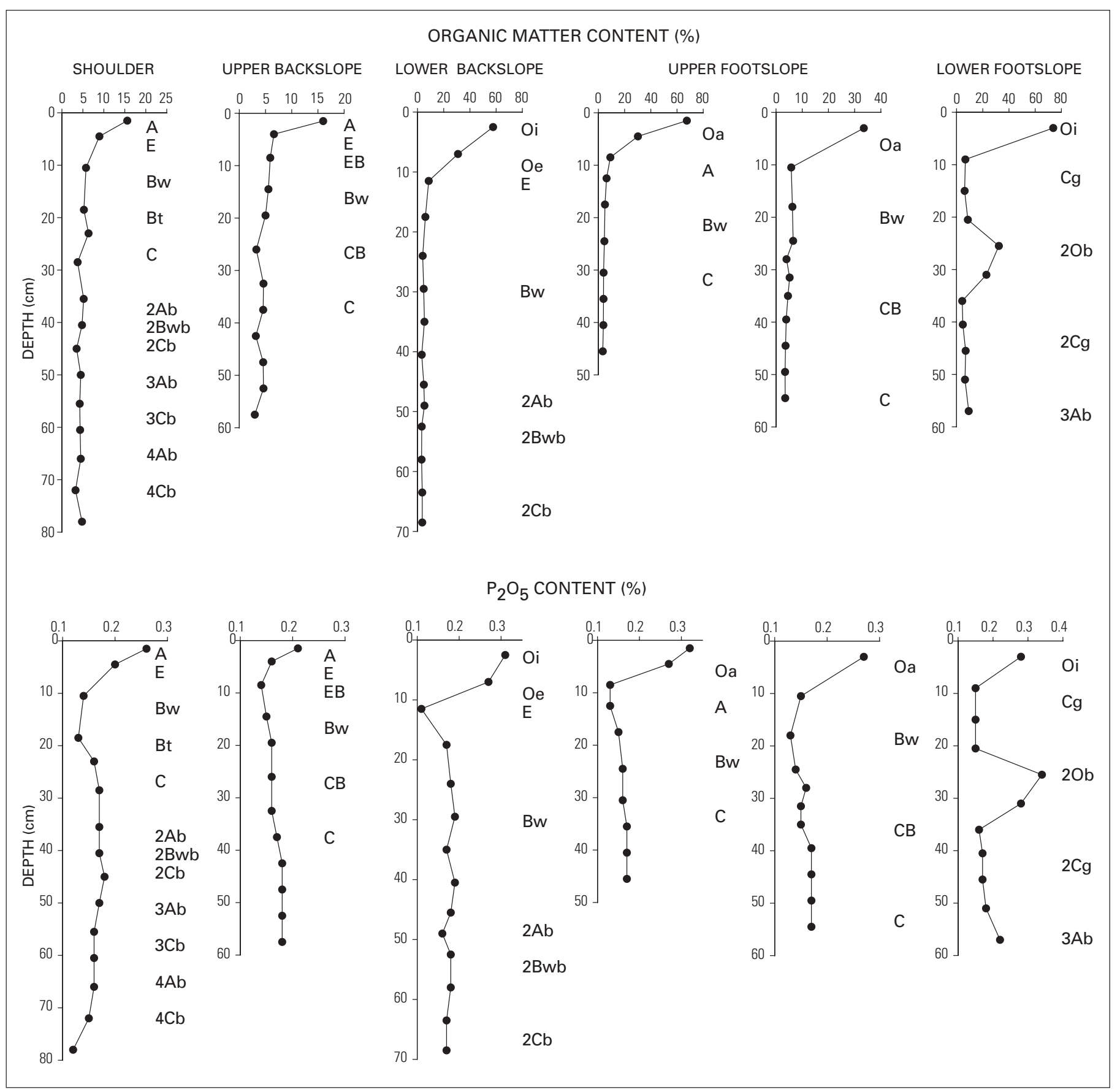

Figure 12. Organic matter and $\mathrm{P}_{2} \mathrm{O}_{5}$ content vs. depth in Inceptisols along a catena in the Fairbanks area. Slope Positions keyed to figure 9.

\section{Carbon Isotopes}

Because buried soil morphology alone often does not permit identification of the dominant vegetation at the time of soil formation, the use of carbon isotopes in vegetation reconstruction from buried soils is tested here. Surface or near-surface $\mathrm{O}, \mathrm{A}$, and $\mathrm{E}$ horizons should have $\delta^{13} \mathrm{C}$ values that are most closely related to modern vegetation. Values from $\mathrm{C}$ horizons can reflect the isotopic composition of detrital or in situ vegetation that was in the region during loess deposition, rather than vegetation present during the period of pedogenesis.
Tundra soils from the Arctic Coastal Plain and the Arctic Foothills give $\delta^{13} \mathrm{C}$ values ranging from -25.5 to $-27.1 \%$ (fig. 16). The uppermost parts of the $O$ horizons have a rather narrow range of values from -26.0 to $-26.9 \%$. For some pedons, herbaceous tundra vegetation itself, primarily grasses and sedges, was also analyzed. These materials gave $\delta^{13} \mathrm{C}$ values of $-25.5 \%$ (profiles 801 and 802 ) and $-26.5 \%$ (profiles 805 and 806) and are similar to $\delta^{13} \mathrm{C}$ values of the subjacent horizons. There are no apparent depth-related trends in carbon isotopic composition.

Tundra soils in the Alaska Range have $\delta^{13} \mathrm{C}$ values that are very similar to tundra soils in the Arctic Foothills and the Arctic 


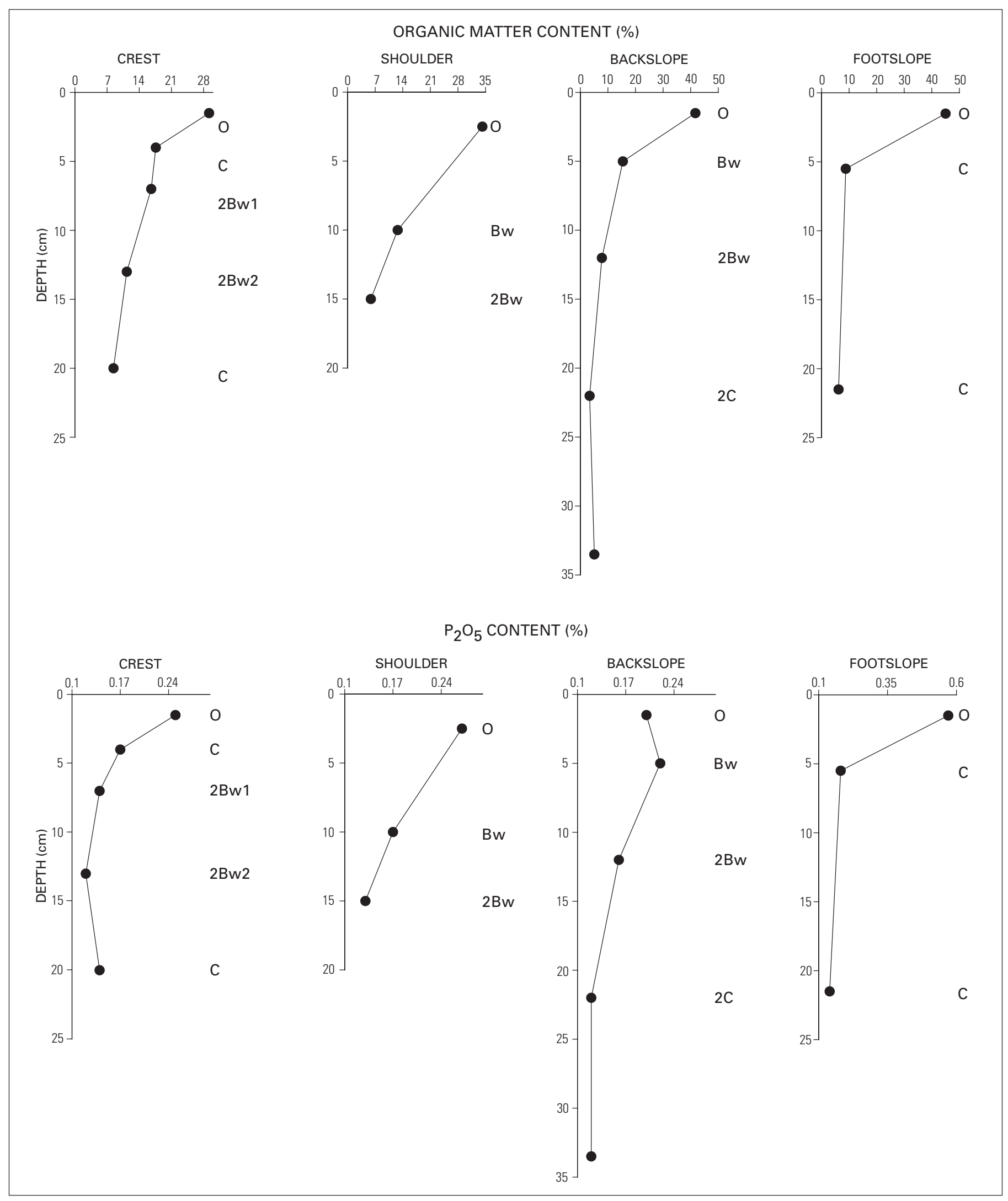

Figure 13. Organic matter and $\mathrm{P}_{2} \mathrm{O}_{5}$ content vs. depth in soils in the Summit Lake catena in the Alaska Range. Slope Positions keyed to figure 8.

Coastal Plain (fig. 17). The overall range of $\delta^{13} \mathrm{C}$ values at both the Summit Lake and Denali Highway catenas is greater than in the Arctic Foothills and Coastal Plain soils ( -23.9 to $-27.8 \%$ ), but values are judged not to be significantly different. There are no consistent depth-related trends in carbon isotopic values in the Alaska Range catenas. Although pollen evidence suggests the possibility that some of these soils may have developed partly under a brief period of open boreal forest or forest-tundra 


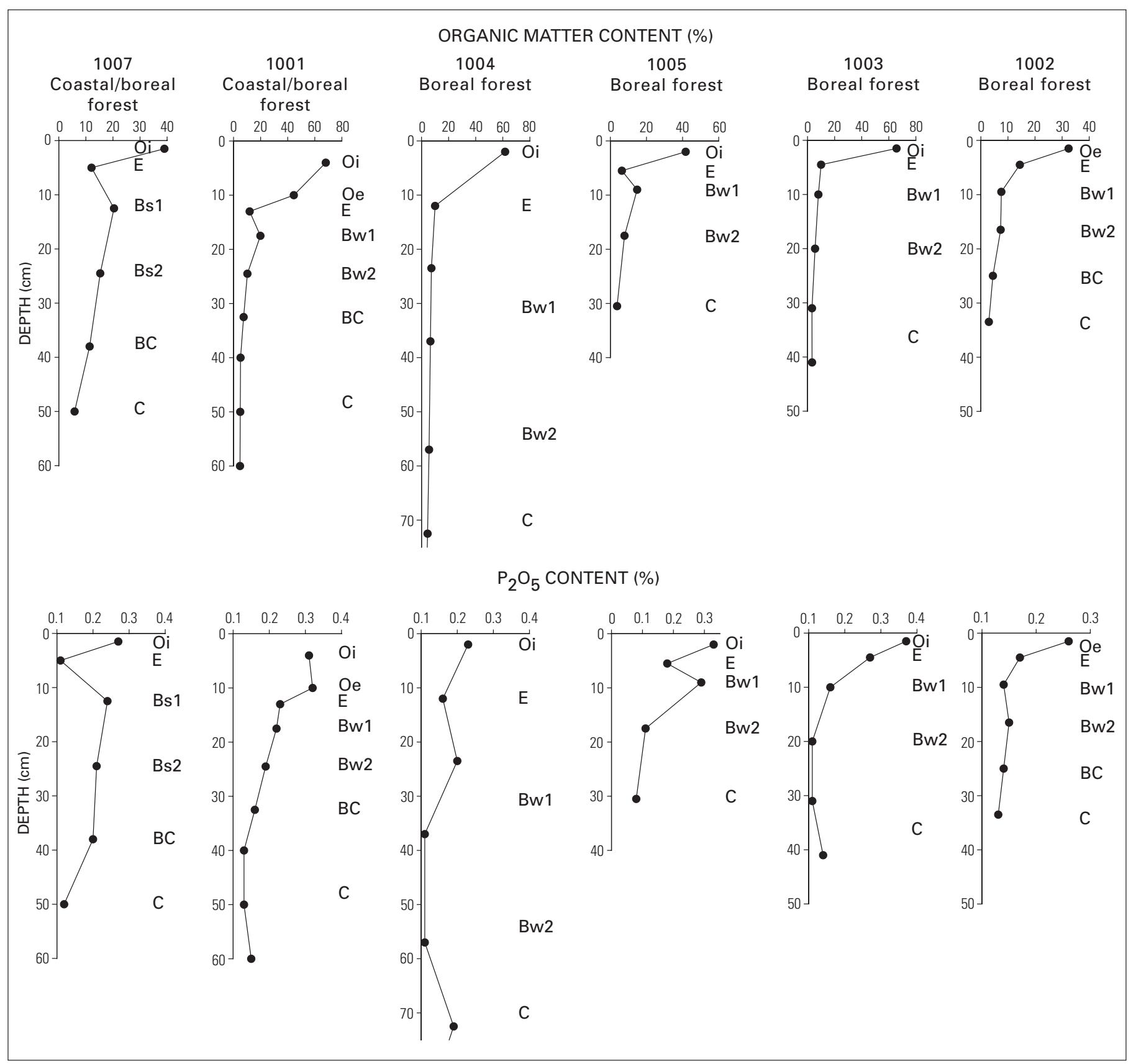

Figure 14. Organic matter and $\mathrm{P}_{2} \mathrm{O}_{5}$ content vs. depth in Spodosols in the Kenai Peninsula area. Pedon numbers as in figures 6 and 10.

(Anderson and others, 1994), the $\delta^{13} \mathrm{C}$ values of the uppermost horizons almost certainly reflect the dominant shrub tundra vegetation that is growing in the area now.

In the Fairbanks area, five modern soils in an upland spruce-birch forest setting were analyzed (localities shown in fig. 4). Carbon isotope values for these soils range from about -25.4 to $-27.7 \%$ o (fig. 18) and differ little from the values within the uppermost $\mathrm{C}$ horizons. As is the case with the tundra soils in the Alaska Range, there are no obvious depthrelated changes in carbon isotopic composition.

Spodosols from the Kenai area show the greatest range of carbon isotope values of any of the soils studied. Values range from -24.0 to $-29.3 \%$, and $\mathrm{O}$ horizons alone span most of this range (fig. 19). Unlike soils from the other regions, Spodosols show a possible trend of isotopically heavier values with greater depth in the profile.

Comparison of the four study areas indicates that carbon isotopes cannot be used to distinguish forest from tundra vegetation in Alaskan buried soils. Uppermost $\mathrm{O}$ horizons of tundra soils from all areas studied range from -24.8 to $-27.4 \%$, similar to the range of -25.5 to $-28.6 \%$ for the uppermost $\mathrm{O}$ horizons from all forest soils studied. The results presented here differ from those of Ugolini and others (1981), who found that tundra litter (O horizons) had values of -21.8 to $-24.0 \%$ and boreal forest litter had values of -25.5 to $-27.1 \%$. Carbon isotope values for both tundra and forest soils in the present study are closest to Ugolini and others' (1981) boreal forest values. However, some Inceptisols and Spodosols that developed under forest 


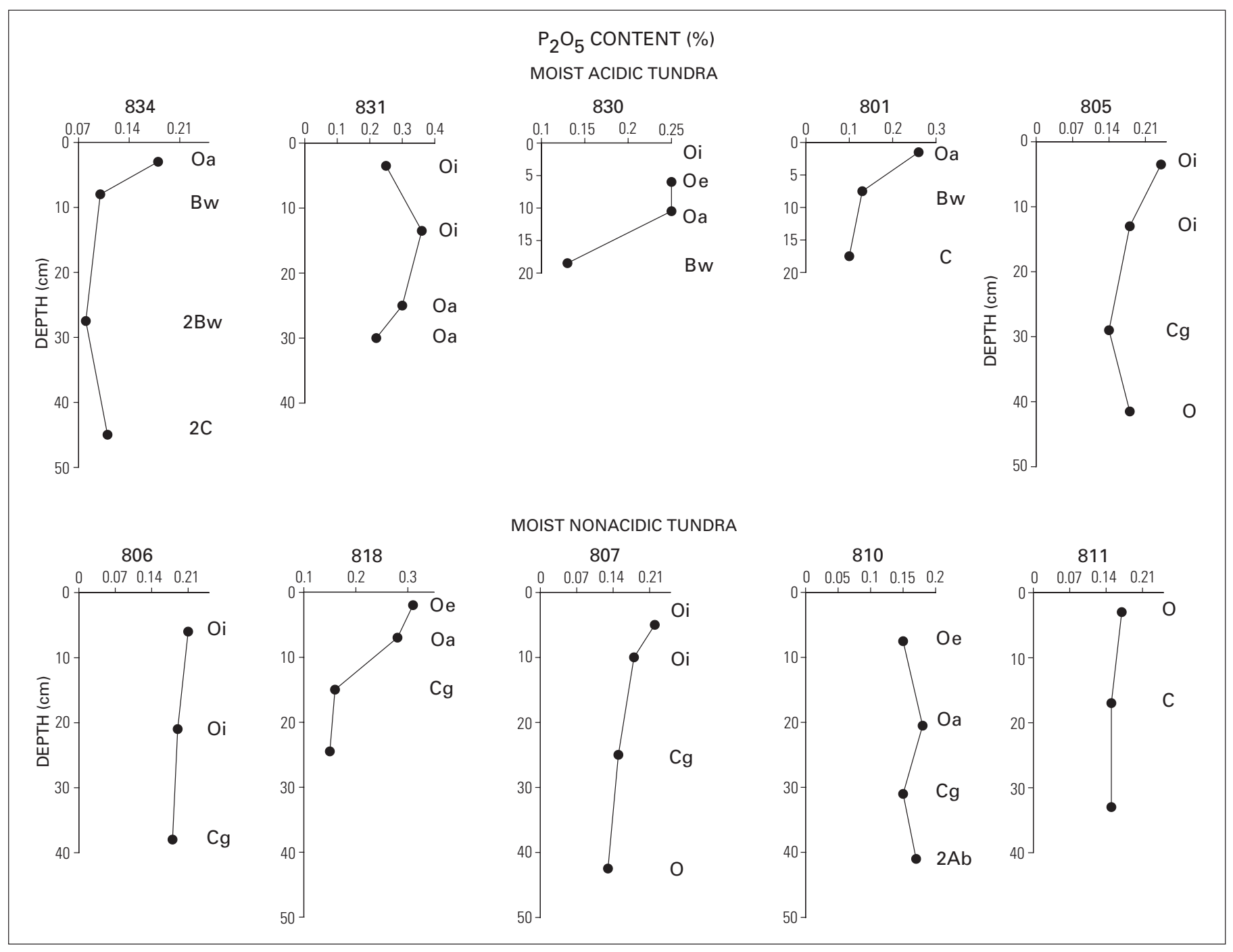

Figure 15. $\mathrm{P}_{2} \mathrm{O}_{5}$ content vs. depth in Gelisols and Inceptisols from the Arctic Foothills and Arctic Coastal Plain, developed under moist acidic and nonacidic tundra. Pedon numbers as in figures 3 and 7.

vegetation have values greater than $-25.0 \%$, which falls within the range of values that Ugolini and others (1981) reported for tundra. None of tundra soils in the present study have $\delta^{13} \mathrm{C}$ values as heavy as the tundra values reported in the earlier study, and most have values within the range of what Ugolini and others report for boreal forest. However, the study by Ugolini and others (1981) was based on a very limited number of samples in one local area. The larger sample size reported here shows that the carbon isotope values of soils developed under the two ecosystems are judged not to be significantly different.

\section{Conclusions}

Our studies indicate that soil morphology, organic matter concentrations, and $\mathrm{P}$ concentrations can be useful diagnostic tools for identifying buried soils. Soil-horizon colors are significantly different from loess parent material, and soil-horizon sequences (e.g., O/Bw/C and $\mathrm{O} / \mathrm{E} / \mathrm{Bw} / \mathrm{C}$ profiles) are important clues for identifying buried soils. Nevertheless, soils with only $\mathrm{O} / \mathrm{C}$ profiles could be misidentified as organic-rich alluvial, colluvial, or lacustrine deposits, and other criteria should be used in conjunction with field data in studying such soils. Furthermore, soil morphology may not be particularly useful for identifying the type of vegetation under which a buried soil may have formed. Although certain soil horizons, such as E and Bs horizons, seem to form only under forest, not all modern forest soils have such horizons. In addition, both well-drained tundra and boreal forest soils can have similar $\mathrm{O} / \mathrm{Bw} / \mathrm{C}$ horizon sequences.

Organic matter concentrations in well-drained Alaskan tundra and forest soils show the rapid decline with depth that is typical of many mid-latitude and low-latitude soils, and this decline is therefore a potentially useful characteristic in identifying buried soils. However, some poorly drained tundra soils show only gradual declines in organic-matter concentrations with depth and thus may be difficult to distinguish from organic-rich sediments in a loess section. Furthermore, because of the rapid decline of organic-matter content with depth, partly eroded buried soils may go undetected in stratigraphic sections. We conclude, therefore, that organic matter trends are a helpful but insufficient tool for identifying buried soils in loess sections. 


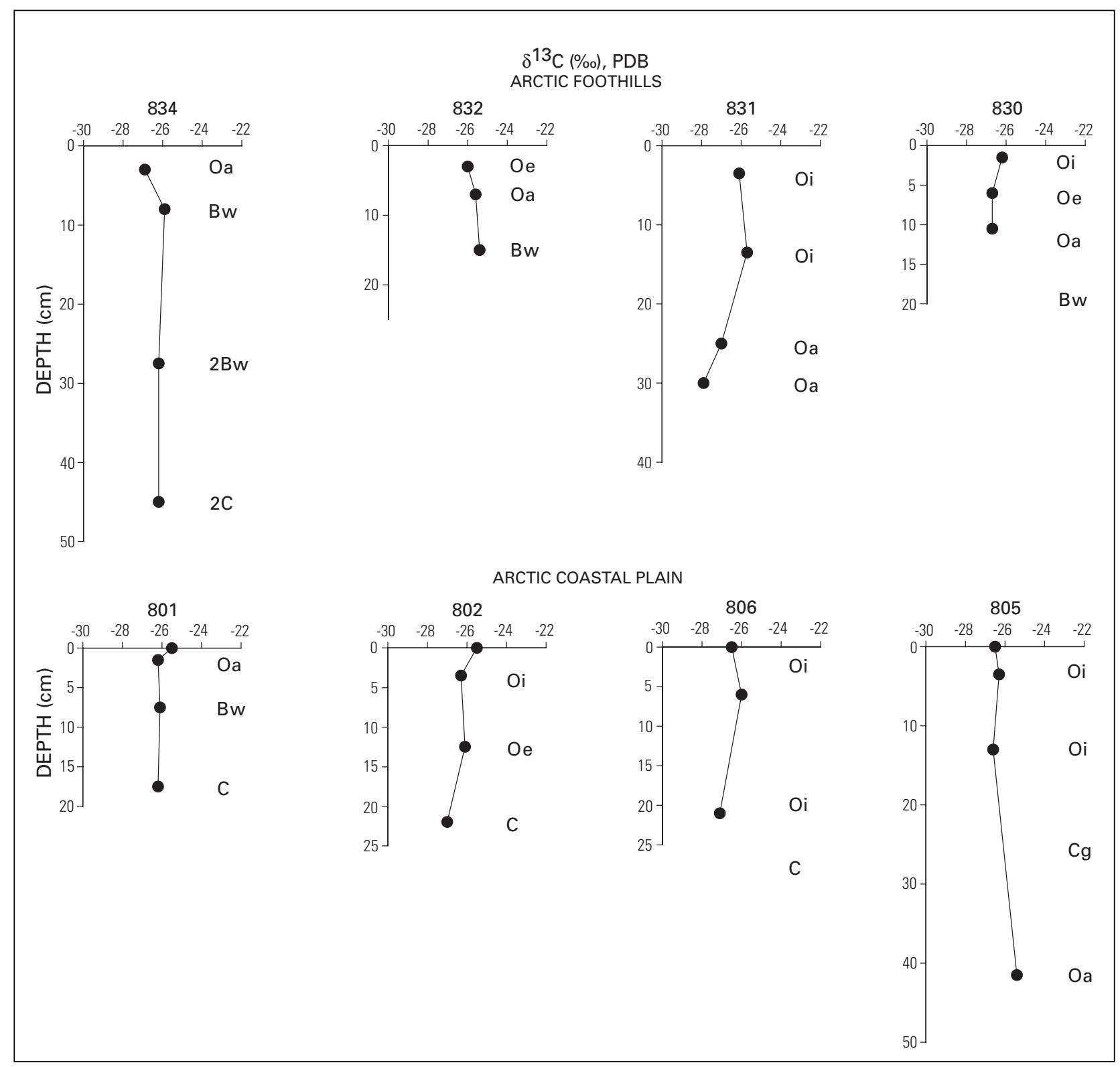

Figure 16. Carbon isotopic composition of soil organic matter vs. depth in Gelisols and Inceptisols from the Arctic Foothills and Arctic Coastal Plain, developed under moist acidic and nonacidic tundra. Pedon numbers as in figures 3 and 7.

In general, concentrations of $\mathrm{P}$ follow the organic matter trends, supporting earlier conclusions that $\mathrm{P}$ in Alaskan soils is largely in organic forms. In interior Alaska, boreal forest soils show $\mathrm{P}$ depth distributions similar to those of mid-latitude soils, with distinct enrichments in surface horizons, depletions immediately below the surface, and slight enrichments again at depth. In contrast, tundra soils and Spodosols show P enrichments in O horizons, but tend to decline consistently with depth. A few poorly drained tundra soils that were studied show no particularly diagnostic depth functions. We conclude that $\mathrm{P}$ depth functions are useful tools for identifying buried soils, particularly when used in conjunction with soil morphology and organic matter-depth functions.

Carbon isotope values do not support findings from a previous study that tundra and boreal forest soils can be differentiated using this property. Results from the present study show that carbon isotope values of soil organic matter in tundra and forest soils are not significantly different. Other soil properties need to be investigated to see if they are diagnostic of pedogenesis under forest vs. tundra. Shroba and Birkeland (1983), studying soils developed in late Wisconsin till in the Rocky Mountains, found that vermiculite and other pedogenic clay minerals form under spruce-fir forest, but not under alpine tundra at higher elevations. Bozarth (1993) has shown that boreal forest vegetation has a distinctive assemblage of opal phytoliths that may differentiate it from tundra vegetation. Grass and sedge-dominated tundra may be distinguished from boreal forest using lignin phenols and if these components of organic matter are preserved in soils, may be a fruitful approach for the interpretation of buried soils (Ugolini and others, 1981; Orem and others, 1993, 1997). Finally, fractions of soil organic acids may have a distinctive signature that would allow differentiation of forest from tundra (Ping and others, 1997). 


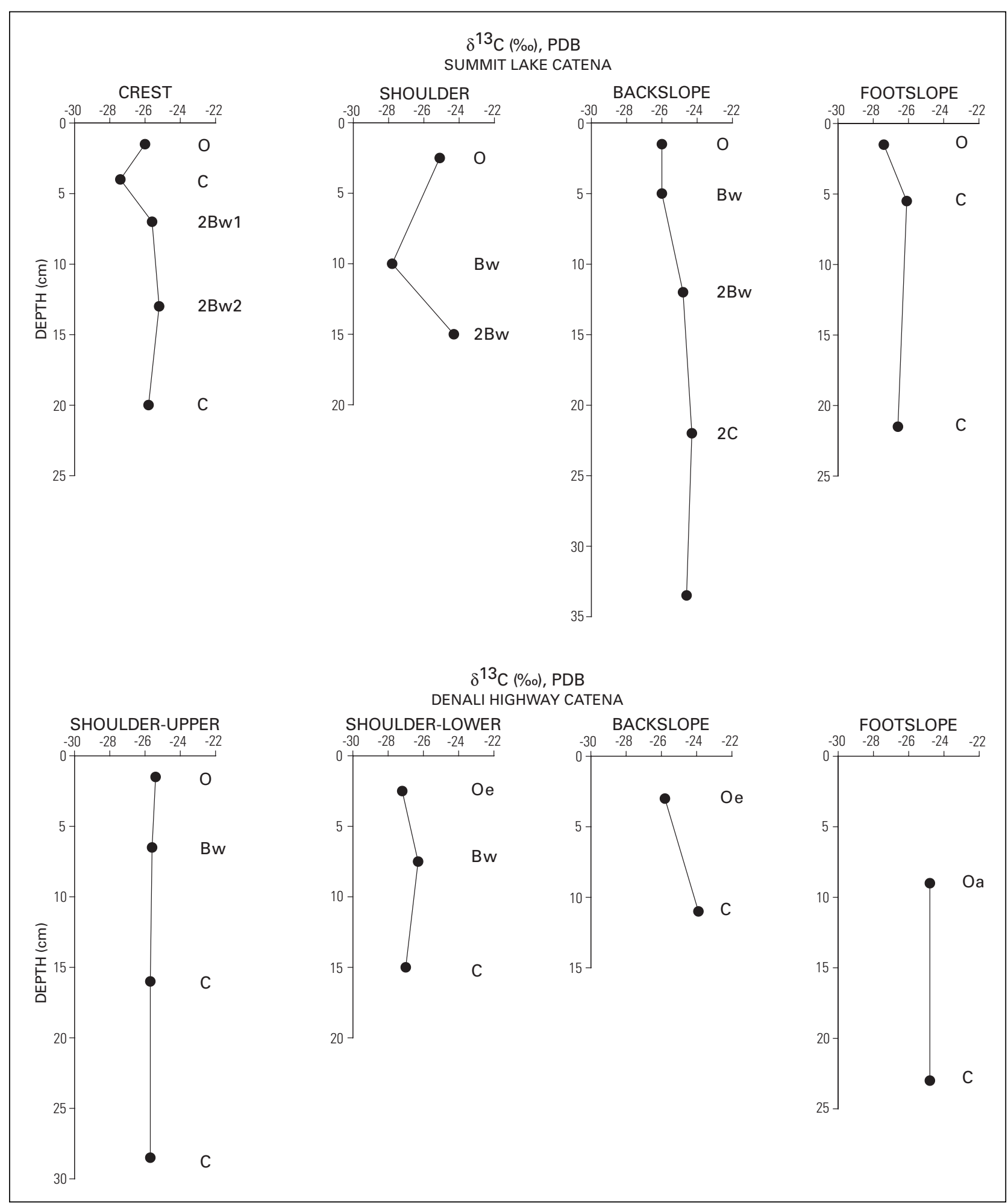

Figure 17. Carbon isotopic composition of soil organic matter vs. depth in tundra soils from catenas in the Alaska Range. Slope positions as in figure 8. 


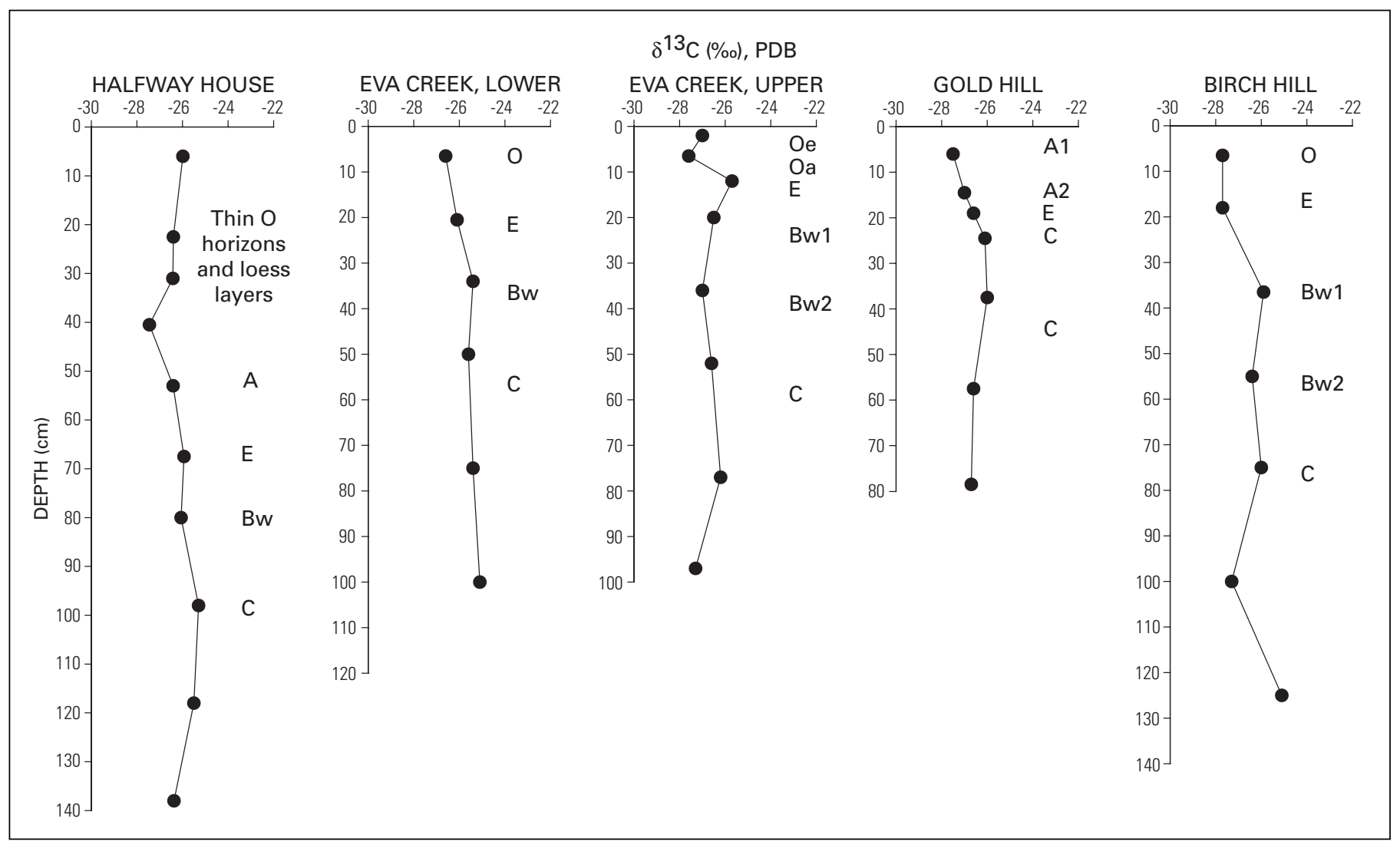

Figure 18. Carbon isotopic composition of soil organic matter vs. depth in five upland boreal forest Inceptisols in the Fairbanks area (localities shown in figure 4).

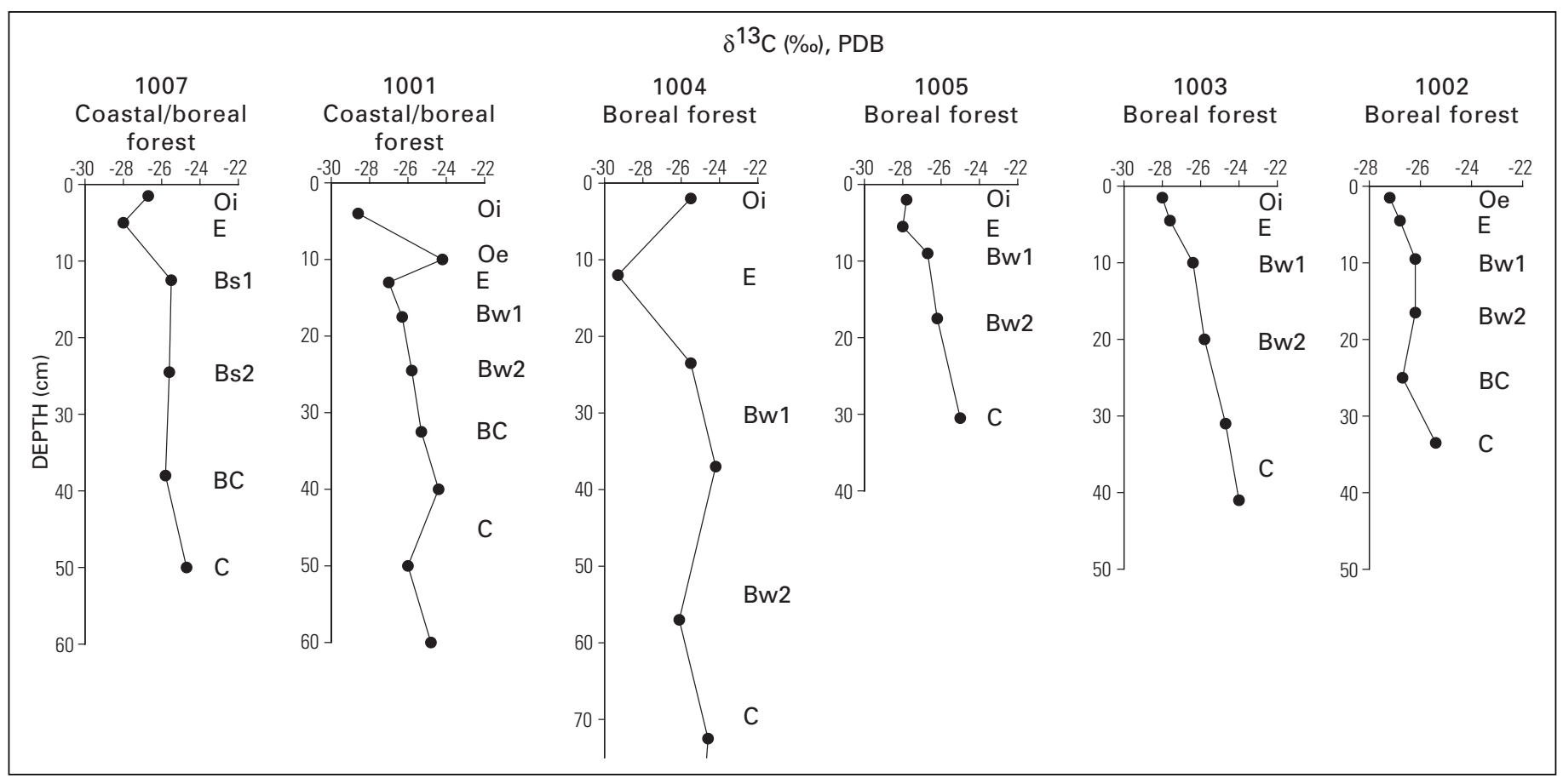

Figure 19. Carbon isotopic composition of soil organic matter vs. depth in Spodosols in the Kenai Peninsula area. Pedon numbers as in figures 6 and 10. 


\section{Acknowledgments}

Matt Emmons performed the carbon isotopic analyses. We thank James Bockheim, Marith Reheis, and Art Bettis for helpful comments on an earlier draft of the paper.

\section{References Cited}

Ager, T.A., 1983, Holocene vegetational history of Alaska, in Wright, H.E., Jr., and Porter, S.C., eds., Late Quaternary Environments of the United States, Volume 2: The Holocene: Minneapolis, University of Minnesota Press, p. 128-141.

Ager, T.A., and Brubaker, L., 1985, Quaternary palynology and vegetational history of Alaska, in Bryant, V.M., Jr., and Holloway, R.G., eds., Pollen Records of Late-Quaternary North American Sediments: Dallas, Tex., American Association of Stratigraphic Palynologists Foundation, p. 353-383.

Ager, T.A., and Sims, J.D., 1982, Late Quaternary pollen record from Hidden Lake, Kenai Peninsula, Alaska: Palynology, v. 6, p. 271-272.

Anderson, P.M., and Brubaker, L.B., 1994, Vegetation history of northcentral Alaska: A mapped summary of late-Quaternary pollen data: Quaternary Science Reviews, v. 13, p. 71-92.

Anderson, P.M., Lozhkin, A.V., Eisner, W.R., Kozhevnikova, M.V., Hopkins, D.M., Brubaker, L.B., and Colinvaux, P.A., 1994, Two late Quaternary pollen records from south-central Alaska: Géographie Physique et Quaternaire, v. 48, p. 131-143.

Ball, D.F., 1964, Loss-on-ignition as an estimate of organic matter and organic carbon in non-calcareous soils: Journal of Soil Science, v. 15, p. 84-92.

Begét, J.E., 1990, Middle Wisconsin climate fluctuations recorded in central Alaskan loess: Géographie Physique et Quaternaire, v. 44, p. 3-13.

Begét, J.E., 1996, Tephrochronology and paleoclimatology of the last interglacial-glacial cycle recorded in Alaskan loess deposits: Quaternary International, v. 34-36, p. 121-126.

Begét, J.E., and Hawkins, D.B., 1989, Influence of orbital parameters on Pleistocene loess deposition in central Alaska: Nature, v. 337, p. 151-153.

Begét, J.E., Stone, D.B., and Hawkins, D.B., 1990, Paleoclimatic forcing of magnetic susceptibility variations in Alaskan loess during the Quaternary: Geology, v. 18, p. 40-43.

Birkeland, P.W., 1999, Soils and geomorphology: New York, Oxford University Press, $430 \mathrm{p}$.

Bockheim, J.G., and Tarnocai, C., 1998, Recognition of cryoturbation for classifying permafrost-affected soils: Geoderma, v. 81, p. 281-293.

Bockheim, J.G., Tarnocai, C., Kimble, K.M., and Smith, C.A.S., 1997, The concept of gelic materials in the new Gelisol order for permafrostaffected soils: Soil Science, v. 162, p. 927-939.

Bockheim, J.G., Walker, D.A., Everett, K.R., Nelson, F.E., and Shiklomanov, N.I., 1998, Soils and cryoturbation in moist nonacidic and acidic tundra in the Kuparuk River Basin, Arctic Alaska, U.S.A.: Arctic and Alpine Research, v. 30, p. 166-174.

Bozarth, S., 1993, Biosilicate assemblages of boreal forests and aspen parklands, in Pearsall, D.M., and Piperno, D.R., eds., Current
Research in Phytolith Analysis: Applications in Archaeology and Paleoecology: Philadelphia, The University Museum of Archaeology and Anthropology, p. 95-105.

Brown, J., and Kreig, R.A., 1983, Elliott and Dalton Highways, Fox to Prudhoe Bay, Alaska: Alaska Geological and Geophysical Surveys Guidebook 4, $230 \mathrm{p}$.

Burt, R., and Alexander, E.B., 1996, Soil development on moraines of Mendenhall Glacier, southeast Alaska. 2. Chemical transformations and soil micromorphology: Geoderma, v. 72, p. 19-36.

Cerling, T.E., Quade, J., Wang, Y., and Bowman, J.R., 1989, Carbon isotopes in soils and palaeosols as ecology and palaeoecology indicators: Nature, v. 341, p. 138-139.

Chapin, F.S., III, Miller, P.C., Billings, W.D., and Coyne, P.I., 1980, Carbon and nutrient budgets and their control in coastal tundra, in Brown, J., Miller, P.C., Tieszen, L.L., and Bunnell, F.L., eds., An Arctic Ecosystem: The Coastal Tundra at Barrow, Alaska: Stroudsburg, $\mathrm{Pa}$.: Dowden, Hutchinson \& Ross, Inc., p. 458-482.

Coulter, H.W., Hopkins, D.M., Karlstrom, T.N.V., Péwé, T.L., Wahrhaftig, C., and Williams, J.R., 1965, Map showing extent of glaciations in Alaska: U.S. Geological Survey Miscellaneous Geologic Investigations Map I-415, scale 1:2,500,000.

Davies, B.E., 1974, Loss-on-ignition as an estimate of soil organic matter: Soil Science Society of America Proceedings, v. 38, p. 150-151.

Dean, W.E., 1974, Determination of carbonate and organic matter in calcareous sediments and sedimentary rocks by loss on ignition: comparison with other methods: Journal of Sedimentary Petrology, v. 44 , p. $242-248$.

Everett, K.R., and Brown, J., 1982, Some recent trends in the physical and chemical characterization and mapping of tundra soils, Arctic slope of Alaska: Soil Science, v. 133, p. 264-280.

Everett, K.R., and Parkinson, R.J., 1977, Soil and landform associations, Prudhoe Bay area, Alaska: Arctic and Alpine Research, v. 9, p. 1-19.

Fredlund, G.G., and Tieszen, L.L., 1997, Phytolith and carbon isotope evidence for late Quaternary vegetation and climate change in the southern Black Hills, South Dakota: Quaternary Research, v. 47, p. 206-217.

Gersper, P.L., Alexander, V., Barkley, S.A., Barsdate, R.J., and Flint, P.S., 1980, The soils and their nutrients, in Brown, J., Miller, P.C., Tieszen, L.L., and Bunnell, F.L., eds. An Arctic Ecosystem: The Coastal Tundra at Barrow, Alaska, Stroudsburg, Pa.: Dowden, Hutchinson \& Ross, Inc., p. 219-254.

Hamilton, T.D., 1978, Surficial geologic map of the Philip Smith Mountains quadrangle, Alaska: U.S. Geological Survey Miscellaneous Field Studies Map MF-879A, scale 1:250,000.

Hamilton, T.D., 1994, Late Cenozoic glaciation of Alaska, in Plafker, G., and Berg, H.C., eds., The Geology of Alaska: Boulder, Colorado, Geological Society of America, The Geology of North America, v. G1, p. 813-844.

Hamilton, T.D., Ager, T.A., and Robinson, S.W., 1983, Late Holocene ice wedges near Fairbanks, Alaska, U.S.A.: Environmental setting and history of growth: Arctic and Alpine Research, v. 15, p. 157-168.

Hamilton, T.D., and Brigham-Grette, J., 1991, The last interglaciation in Alaska: Stratigraphy and paleoecology of potential sites: Quaternary International, v. 10-12, p. 49-71.

Hamilton, T.D., Craig, J.L., and Sellmann, P.V., 1988, The Fox permafrost tunnel: A late Quaternary geologic record in central Alaska: Geological Society of America Bulletin, v. 100, p. 948-969. 
Holliday, V.T., 1995, Stratigraphy and paleoenvironments of late Quaternary valley fills on the Southern High Plains: Geological Society of America Memoir 186, 136 p.

Hovan, S.A., Rea, D.K., Pisias, N.G., and Shackleton, N.J., 1989, A direct link between the China loess and marine $\delta^{18} 0$ records: Aeolian flux to the north Pacific: Nature, v. 340, p. 296-298.

Janitzky, P., 1986, Organic carbon (Walkley-Black method), in Singer, M.J., and Janitzky, P., eds., Field and Laboratory Procedures Used in a Soil Chronosequence Study: U.S. Geological Survey Bulletin 1648, p. 34-36.

Jenny, H., 1980, The soil resource: Origin and behavior: New York, Springer-Verlag, $377 \mathrm{p}$.

Joint Federal-State Land Use Planning Commission for Alaska, 1973, Major ecosystems of Alaska, scale, 1:2,500,000.

Letkeman, L.P., Tiessen, H., and Campbell, C.A., 1996, Phosphorus transformations and redistribution during pedogenesis of western Canadian soils: Geoderma, v. 71, p. 201-218.

McDowell, P.F., 1997, Stratigraphy and genetic interpretation of a sequence of loess-related deposits in the Yukon Flats southern marginal upland near Circle, Alaska, in Edwards, M.E., Sher, A.V., and Guthrie, R.D., eds., Terrestrial Paleoenvironmental Studies in Beringia: Fairbanks, The Alaska Quaternary Center, University of Alaska, Fairbanks, p. 49-51.

Michaelson, G.J., Ping, C.L., and Kimble, J.M., 1996, Carbon storage and distribution in tundra soils of Arctic Alaska, U.S.A.: Arctic and Alpine Research, v. 28, p. 414-424.

Muhs, D.R., Ager, T.A., and Begét, J.E., in press, Vegetation and paleoclimate of the last interglacial period, central Alaska: Quaternary Science Reviews.

Muhs, D.R., Ager, T., Stafford, T.W., Jr., Pavich, M., Begét, J.E, and McGeehin, J.P., 1997, The last interglacial-glacial cycle in late Quaternary loess, central interior Alaska [abs.], in Elias, S.A. and Brigham-Grette, J., eds., Program and Abstracts: Beringian Paleoenvironments Workshop, Florissant, Colo., p. 109-112.

Muhs, D.R., Stafford, T.W., Jr., Been, J., Mahan, S., Burdett, J., Skipp, G., and Rowland, Z.M., 1997, Holocene eolian activity in the Minot dune field, North Dakota: Canadian Journal of Earth Sciences, v. 34, p. 1442-1459.

Nelson, D.W., and Sommers, L.E., 1982, Total carbon, organic carbon, and organic matter, in Page, A.L., ed., Methods of Soil Analysis: Part 2 Chemical and Microbiological Properties (2nd ed.): Madison, Wis., American Society of Agronomy, p. 539-579.

O'Leary, M.H., 1988, Carbon isotopes in photosynthesis: BioScience, v. 38, p. 328-336.

Orem, W.H., Colman, S.M., and Lerch, H.E., 1997, Lignin phenols in sediments of Lake Baikal, Siberia: Application to paleoenvironmental studies: Organic Geochemistry, v. 27, p. 153-172.

Orem, W.H., Lerch, H.E., and Kotra, R.K., 1993, Lignin oxidation products in sediments of Lake Baikal: Indicators of late Quaternary paleovegetation and paleoclimate change in north-central Asia: Russian Geology and Geophysics, v. 34, p. 89-100.

Péwé, T.L., 1975, Quaternary geology of Alaska: U.S. Geological Survey Professional Paper 835, $145 \mathrm{p}$.

Péwé, T.L., Berger, G.W., Westgate, J.A., Brown, P.M., and Leavitt, S.W., 1997, Eva Interglaciation forest bed, unglaciated east-central
Alaska: Global warming 125,000 years ago: Geological Society of America Special Paper 319, $54 \mathrm{p}$.

Ping, C.L., Michaelson, G.J., Loya, W.M., Chandler, R.J., and Malcolm, R.L., 1997, Characteristics of soil organic matter in Arctic ecosystems of Alaska, in Lal, R., Kimble, J.M., Follett, R.F., and Stewart, B.A., eds., Soil Processes and the Carbon Cycle: Boca Raton, CRC Press, p. 157-167.

Reger, R.D., Pinney, D.S., Burke, R.M., and Wiltse, M.A., 1996, Catalog and initial analyses of geologic data related to middle to late Quaternary deposits, Cook Inlet region, Alaska: State of Alaska Division of Geological and Geophysical Surveys Report of Investigations 95$6,188 \mathrm{p}$.

Rieger, S., 1983, The genesis and classification of cold soils: New York, Academic Press, $230 \mathrm{p}$.

Rieger, S., Schoephorster, D.B., and Furbush, C.E., 1979, Exploratory soil survey of Alaska: Washington, U.S. Government Printing Office, Soil Conservation Service, $213 \mathrm{p}$.

Runge, E.C.A., Walker, T.W., and Howarth, D.T., 1974, A study of late Pleistocene loess deposits, South Canterbury, New Zealand. Part I. Forms and amounts of phosphorus compared with other techniques for identifying paleosols: Quaternary Research, v. 4, p. 76-84.

Shroba, R.R., and Birkeland, P.W., 1983, Trends in late-Quaternary soil development in the Rocky Mountains and Sierra Nevada of the Western United States, in Porter, S.C., ed., Late-Quaternary Environments of the United States, v. 1: The Late Pleistocene: Minneapolis, University of Minnesota Press, p. 145-156.

Smeck, N.E., 1973, Phosphorus: An indicator of pedogenetic weathering processes: Soil Science, v. 115, p. 199-206.

Smeck, N.E., 1985, Phosphorus dynamics in soils and landscapes: Geoderma, v. 36, p. 185-199.

Soil Survey Staff, 1998, Keys to Soil Taxonomy (8th ed.): Washington, D.C., U.S. Department of Agriculture, Natural Resources Conservation Service, $325 \mathrm{p}$.

Tieszen, L.L., 1991, Natural variations in the carbon isotope values of plants: Implications for archaeology, ecology, and paleoecology: Journal of Archaeological Science, v. 18, p. 227-248.

Ugolini, F.C., Teanier, R.E., Rau, G.H., and Hedges, J.I., 1981, Pedological, isotopic, and geochemical investigations of the soils at the boreal forest and alpine tundra transition in northern Alaska: Soil Science, v. 131, p. 359-374.

Van Cleve, K., Chapin, F.S., III, Dyrness, C.T., and Viereck, L.A., 1991, Element cycling in taiga forests: State-factor control: BioScience, v. 41, p. 78-88.

Van Cleve, K., Dyrness, C.T., Marion, G.M., and Erickson, R., 1993, Control of soil development on the Tanana River floodplain, interior Alaska: Canadian Journal of Forest Research, v. 23, p. 941955.

Viereck, L.A., and Little, E.L., Jr., 1972, Alaska trees and shrubs: U.S. Department of Agriculture Handbook 410, 265 p.

Walker, D.A., Auerbach, N.A., Bockheim, J.G., Chapin, F.S., III, Eugster, W., King, J.Y., McFadden, J.P., Michaelson, G.J., Nelson, F.E., Oechel, W.C., Ping, C.L., Reeburg, W.S., Regli, S., Shiklomanov, N.I., and Vourlitis, G.L., 1998, Energy and trace-gas fluxes across a soil pH boundary in the Arctic: Nature, v. 394, p. 469-472.

Walker, T.W., and Syers, J.K., 1976, The fate of phosphorus during weathering: Geoderma, v. 15, p. 1-19.

Reviewers: James Bockheim, Marith Reheis, and Art Bettis 


\title{
Postglacial Vegetation History of the Kachemak Bay Area, Cook Inlet, South-Central Alaska
}

\author{
ByThomas A. Ager
}

\section{Abstract}

Pollen records from two sites on the north shore of Kachemak Bay, south-central Alaska, provide the first radiocarbondated histories of postglacial vegetation development for southern Cook Inlet. During the late Wisconsin glacial interval, glaciers covered most of Cook Inlet. Deglaciation of Kachemak Bay began prior to 13,000 yr B.P. Pollen evidence indicates that a pioneering herbaceous tundra began to develop by 12,800 yr B.P., but was soon replaced by a shrub tundra of dwarf birch (Betula), Ericales (Ericaceae and Empetrum) and willows (Salix).

By 9,500 yr B.P., a shrub-dominated vegetation of alders (Alnus) and willows, with some deciduous trees (Populus spp.) quickly developed and persisted until late Holocene time. By about 4,000-3,800 yr B.P., spruce trees (Picea glauca and (or) $P$. mariana) from the interior boreal forests reached the northern Kachemak Bay area from upper Cook Inlet and began to displace the alder-dominated vegetation. A coastal forest of Sitka spruce (Picea sitchensis) began to colonize Kachemak Bay more recently, about 1,650 yr B.P. (minimum age), apparently from sources in Prince William Sound to the east. Where Sitka spruce came into proximity with boreal white spruce (Picea glauca), hybridization occurred, ultimately influencing the spruce forests over a large area of the Kenai Lowland. Some key findings of this study are: (1) the Kachemak Bay-area pollen records do not display persuasive evidence for a "Younger Dryas" cold, dry interval ca. 11,000-10,000 yr B.P. that has been reported from pollen records on Kodiak Island (Gulf of Alaska) and Pleasant Island (southeastern Alaska); (2) at least one species of alder may have survived in refugia in south-central Alaska during the last glacial interval; (3) coastal forests appear to be still migrating west along the coast of south-central Alaska, but their spread northward is being limited by drier, colder winter climates; (4) the mountainous topography of south-central Alaska, coupled with varying degrees of maritime climate influence, create complex patterns of climates and vegetation in the region, in both the past and present.

\section{Introduction}

A series of palynological investigations of Alaskan Quaternary deposits in recent decades have led to a general understanding of the late Quaternary vegetation history of many areas of the State. Investigations of sites in interior Alaska (Ager, 1975, 1983; Ager and Brubaker, 1985; Anderson and Brubaker, 1988; Hopkins and others, 1981; Barnosky and others, 1987) indicate that, during the late Wisconsin glacial interval, the unglaciated interior of Alaska (north of the Alaska Range and south of the Brooks Range) was vegetated by mostly herbaceous tundra communities. Herb tundra growing even in low-elevation areas now covered by vast boreal forests implies that climate was substantially colder and dryer than today. By about 14,000 to 13,000 yr B.P. (ages given in radiocarbon years throughout this paper), herbaceous tundra communities across much of Alaska were replaced by shrub tundra composed of dwarf birch (Betula nana, B. glandulosa), Ericales (Ericaeae, Empetraceae), and willows (Salix), in response to warmer, moister climates. Shrub tundra communities at lower elevations were invaded by poplar trees (Populus spp.) and willows by about 10,500 yr B.P. Spruce (Picea) trees, which may have been eliminated from Alaska by glacial climates of the late Wisconsin interval, first appeared in the Tanana Valley in east-central Alaska about 9,400 yr B.P. This population was most likely derived from boreal spruce forests spreading northward across western Canada following deglaciation (Ager, 1975, 1983) (fig.1).

Alder (Alnus) populations began to expand rapidly across interior Alaska by about 8,400 yr B.P. Boreal spruce-dominated forests then spread westward, northward, and southward into other areas of Alaska.

In contrast with interior Alaska, the history of late Quaternary vegetation development in southcentral Alaska is not as well known, although several key sites have been investigated (e.g., Ager, 1983, 1989; Ager and Brubaker, 1985; Ager and Sims, 1984; Anderson and others, 1994; Heusser, 1960, 1983, 1985). Unlike arid interior Alaska, mountainous south-central 


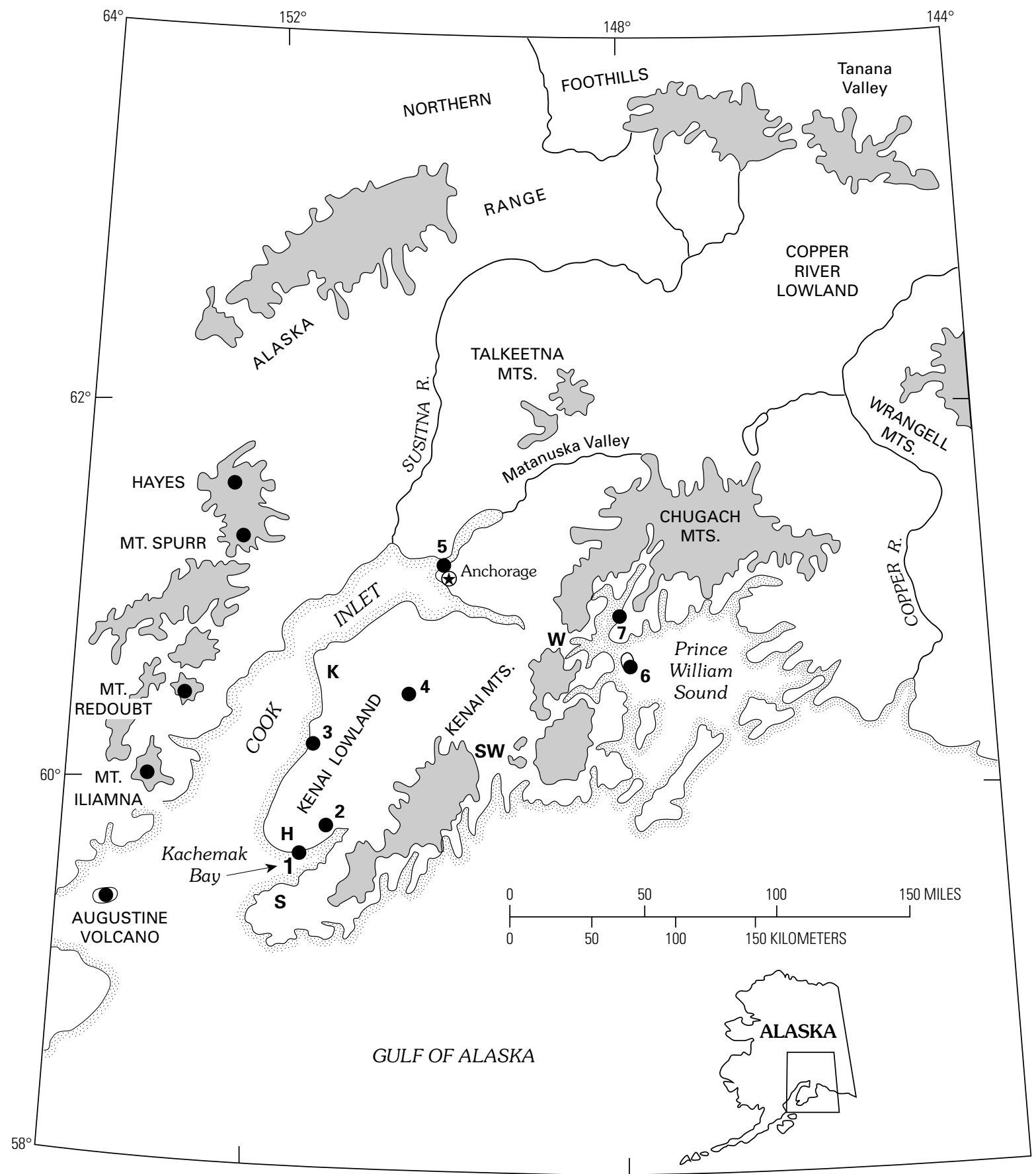

Figure 1. Map of Cook Inlet region showing major geographic features and sites mentioned in this paper. Labeled peaks on the west side of Cook Inlet are volcanoes, several of which have erupted repeatedly during postglacial time. Augustine Volcano is the apparent source of most tephras found in peat sections and at Circle Lake in Kachemak Bay (Riehle, 1985). Map also shows the locations of the two sites discussed in this paper: 1, Homer Spit peat section; and 2, Circle Lake. Several sites where previous palynological research has been done in the region are also shown: 3, Clam Gulch (Ager, unpub. data); 4, Hidden Lake (Ager, 1983); 5, Point Woronzof (Ager, 1983); 6, Parry Island (Heusser, 1960); 7, Golden, in Port Wells (Heusser, 1983). Also shown are cities mentioned in this paper: K, Kenai; W, Whittier; SW, Seward; H, Homer; and S, Seldovia.

Alaska was heavily glaciated during the late Wisconsin glacial interval (Hamilton and Thorson, 1983). The topographic complexity of the south-central region, coupled with varying degrees of maritime climatic influence along the southern coast, resulted in widely differing conditions of temperature, precipitation, wind exposure, and soil from area to area. All of these environmental parameters influence vegetation development. Therefore, vegetation histories tend to differ substantially from site to site within south-central Alaska, compared to the more predictable regional patterns of vegetation development seen in the interior.

This paper presents the results of pollen analyses of two late Quaternary deposits on the north shore of Kachemak Bay in southern Cook Inlet: the Homer spit peat section and the Circle Lake coring site (fig.1). These records provide the first dated postglacial vegetation histories for southern Cook Inlet in 
south-central Alaska and provide useful examples of postglacial vegetation development under the partial influence of a maritime climate. The high degree of variability of vegetation histories that can now be demonstrated in south-central Alaska provide a basis for caution when broad-scale paleoenvironmental reconstructions are attempted based on atmospheric general circulation model (AGCM) simulations.

During the late Wisconsin glacial maximum, nearly all of Cook Inlet and adjacent land areas were covered by glacial ice (Karlstrom, 1964; Reger, Cobellick and Brigham-Grette, 1995; Reger and Pinney, 1996, 1997). At that time, expanding glaciers from the Kenai Mountains of the southern Kenai Peninsula filled Kachemak Bay with ice to an altitude of about $480 \mathrm{~m}$ above present-day sea level in the upper bay (Karlstrom, 1964; Reger and Pinney, 1996, 1997) (fig. 2).

Radiocarbon-dated marine invertebrate fossils from the glaciomarine facies of the Bootlegger Cove Formation indicate that deglaciation of Cook Inlet was under way by $16,000 \mathrm{yr}$ B.P., but glacial retreat was interrupted by a less extensive glacial readvance (Elmendorf stade of Reger and Pinney, 1996, 1997) about $14,300-13,500$ yr B.P.

The details of the deglaciation history of Kachemak Bay are not well known, but results from this paper indicate that local ice retreat was well under way before 13,000 yr B.P. In addition, studies of the glacial history of the southern Kenai Mountains indicate that ice had retreated more than $10 \mathrm{~km}$ upvalley from the present upper Kachemak Bay shoreline by $10,240 \pm 70$ yr B.P. (fig. 2) (Wiles and Calkin, 1994). Pollen data and radiocarbon dates from Hidden Lake in the northern Kenai Lowlands indicate that this area was deglaciated by about 14,000 yr B.P. (Rymer and Sims, 1982; Ager, 1983). Similarly, pollen records and radiocarbon dates from southwestern Kodiak Island, south of Cook Inlet in the Gulf of Alaska, indicate that late Wisconsin glaciers had retreated in that area prior to 14,000 yr B.P. (Mann and Peteet, 1994; Peteet and Mann, 1994).

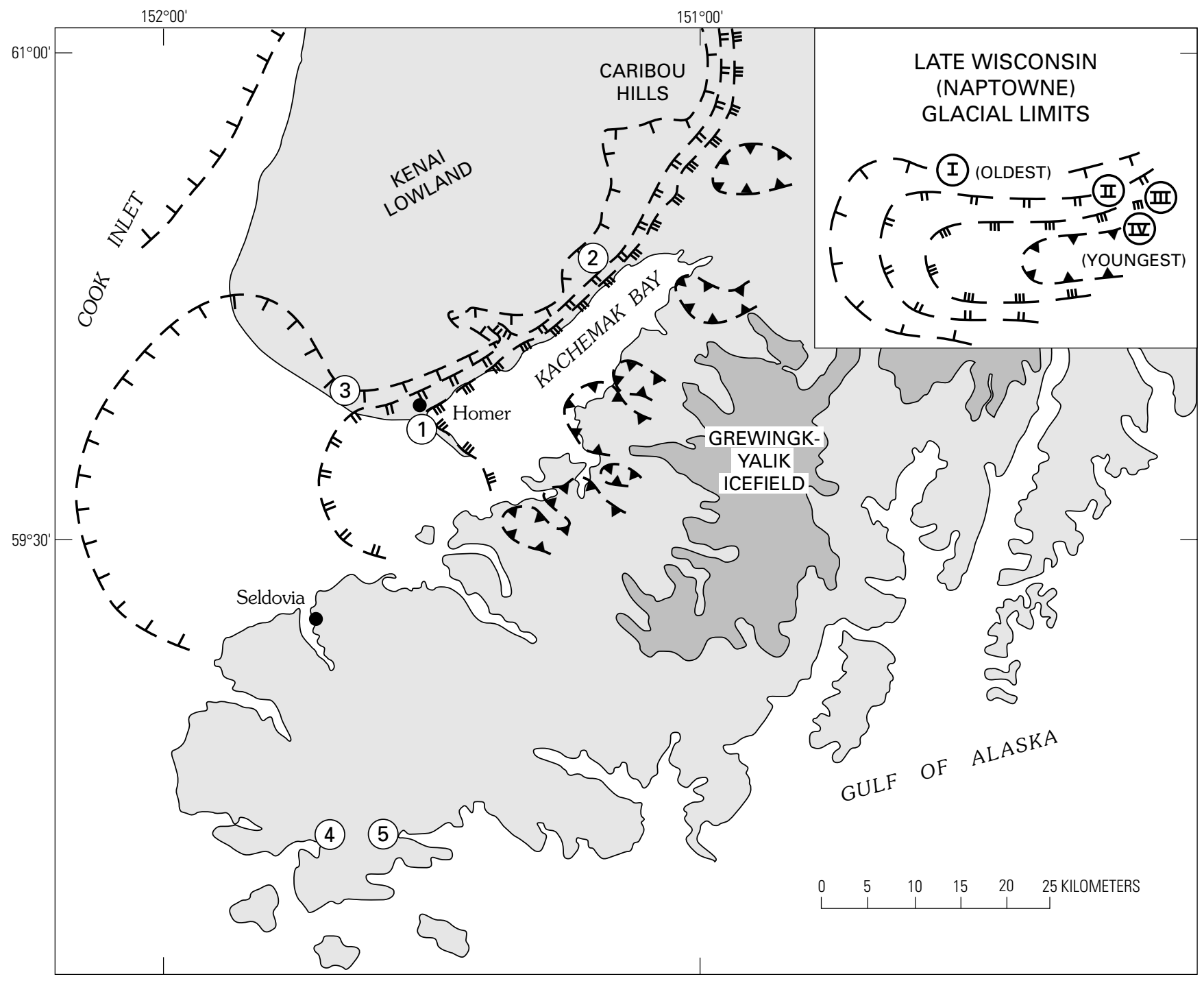

Figure 2. Map of southern Kenai Peninsula showing the position of glacial ice during four stades during the late Wisconsin (Naptowne) glaciation (modified from Karlstrom, 1964; and Reger and Pinney, 1997). Also shown on the map are the locations of the cities of Homer and Seldovia, and the pollen coring sites discussed in this paper: 1, Homer Spit peat section (this paper); 2, Circle Lake (this paper); 3, peat core Homer 1 of Heusser (1960); 4, Port Chatham peat core of Heusser (1960); 5, Windy Bay peat core of Heusser (1960). 
Extensive glacial ice may have persisted in valleys in the Kenai Mountains until the beginning of the Holocene, ca. 10,000 yr B.P., as suggested by young basal dates from peat sections in western Prince William Sound and within the Kenai Mountains (Heusser, 1983; Ager, 1983, Ager, unpub. data). Recent investigations of the Holocene history of glaciation in the southern Kenai Mountains indicate that at least three Neoglacial ice advances occurred ca. 3,600 yr B.P., 1,400 yr B.P., and between 700 and $150 \mathrm{yr}$ B.P. At the present time, extensive icefields (e.g., the Harding, Sargent, and GrewingkYalik icefields) persist in several areas of the Kenai Mountains, but they are of minor extent compared with late Wisconsin glaciers (fig. 2).

\section{Modern Climates of the Cook Inlet Region}

The southern coast of south-central Alaska bordering the Gulf of Alaska (fig.1) has a maritime climate characterized by heavy precipitation (especially in autumn), cool summers, and relatively warm winters (e.g., climate data for Seward and Whittier, table 1). Moist maritime air masses penetrate far into Cook Inlet, carrying abundant precipitation to the mountains to the west and northwest of the Inlet, but much of eastern and northern Cook Inlet is partly influenced by precipitation shadows from the Kenai Mountains (e.g., climate data for Kenai and Anchorage, table 1). Much of Cook Inlet, therefore, has a transitional climate between coastal maritime and interior continental climates. The Kenai Peninsula has highly varied climates, again reflecting the influences of maritime climates on the outer coast, and precipitation shadow effects of the Kenai Mountains in the Kenai Lowland (fig.1; table 1). The Kenai Peninsula's mountains also introduce additional local influences of altitude, slope aspect, and wind exposure, which also contribute to the complexity of vegetation patterns.

\section{Modern Vegetation}

The Kachemak Bay area is located within a vegetation transition zone between boreal forest and coastal forest vegetation types (fig. 3) (Viereck and Little, 1972, 1975; Pojar and MacKinnon, 1994). The southern coastal areas of Kachemak
Bay are blanketed with coastal forests of Sitka spruce. Within these forests are also rare occurrences of western hemlock (Tsuga heterophylla), which appears to have begun colonizing the area only recently (Viereck and Little, 1975). Mountain hemlock (Tsuga mertensiana) has invaded the northern Kenai Mountains but has apparently not yet reached the Kachemak Bay area (Viereck and Little, 1975; Hultén, 1968). On the north shore of Kachemak Bay, Sitka spruce stands can be found, especially near the shoreline, but the slopes and uplands north of the bay are forested by white spruce-Sitka spruce hybrids (Picea glauca $\times$ sitchensis), occasional stands of black spruce (Picea mariana) in boggy settings, Kenai birch (Betula papyrifera var. kenaica), cottonwood (Populus trichocarpa), balsam poplar (Populus balsamifera), aspen (Populus tremuloides), alders, and willows. In the Kachemak Bay area, the altitudinal limit of tree growth varies between about 370 to $500 \mathrm{~m}$, depending on slope steepness, avalanche frequency, and slope aspect.

The differences in modern vegetation communities, even within the relatively small area of the western Kenai Peninsula, raise interesting questions about the history of vegetation development. When did components of the boreal forest flora first arrive in the northern Kachemak Bay area? When did coastal shrub taxa first appear in the Kachemak Bay area and from what source areas? When did coastal forest trees first arrive? Do local variations in climatic conditions within the region significantly influence distribution of vegetation types? This paper attempts to address these questions by interpretation of pollen records from two key localities in the area and placing them into a larger regional context of postglacial vegetation and climate history. These pollen records provide useful examples of how maritime and transitional climate influences have shaped vegetation development in this topographically varied coastal region.

\section{Previous Studies of Vegetation History in the Cook Inlet Region}

The earliest study of the pollen record of the Kachemak Bay area was by W.S. Benninghoff (unpublished, but cited by Karlstrom, 1964, p. 50). He collected samples from a coastal exposure near the base of Homer Spit in 1951 (figs. 1, 2). The sampled deposit was a peat-filled kettle depression overlying

Table 1. Modern climate data from selected weather stations in south-central Alaska.

[MAT, mean annual temperature; MJulT, mean July temperature; MJanT, mean January temperature; MAP, mean annual precipitation. From Leslie (1989)]

\begin{tabular}{|c|c|c|c|c|c|c|}
\hline & \multicolumn{6}{|c|}{ Location } \\
\hline & Anchorage & Kenai & Whittier & Seward & Homer & Seldovia \\
\hline Latitude .................... & $61^{\circ} 10^{\prime} \mathrm{N}$ & $60^{\circ} 34^{\prime} \mathrm{N}$ & $60^{\circ} 46^{\prime} \mathrm{N}$ & $60^{\circ} 07^{\prime} \mathrm{N}$ & $59^{\circ} 38^{\prime} \mathrm{N}$ & $59^{\circ} 26^{\prime} \mathrm{N}$ \\
\hline Longitude.................... & $150^{\circ} 01^{\prime} \mathrm{W}$ & $151^{\circ} 15^{\prime} \mathrm{W}$. & $148^{\circ} 41^{\prime} \mathrm{W}$ & $149^{\circ} 27^{\prime} \mathrm{W}$ & $151^{\circ} 30^{\prime} \mathrm{W}$ & $151^{\circ} 42^{\prime} \mathrm{W}$. \\
\hline Altitude .................... & $35 \mathrm{~m}$ & $26 \mathrm{~m}$ & $18 \mathrm{~m}$ & $11 \mathrm{~m}$ & $27 \mathrm{~m}$ & $9 \mathrm{~m}$ \\
\hline 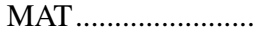 & $2.06^{\circ} \mathrm{C}$ & $0.83^{\circ} \mathrm{C}$ & $4.00^{\circ} \mathrm{C}$ & $4.17^{\circ} \mathrm{C}$ & $2.89^{\circ} \mathrm{C}$ & $2.78^{\circ} \mathrm{C}$ \\
\hline MJulT ........................ & $14.50^{\circ} \mathrm{C}$ & $12.33^{\circ} \mathrm{C}$ & $13.39^{\circ} \mathrm{C}$ & $13.17^{\circ} \mathrm{C}$ & $11.67^{\circ} \mathrm{C}$ & $12.33^{\circ} \mathrm{C}$ \\
\hline 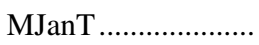 & $-9.56^{\circ} \mathrm{C}$ & $-10.94^{\circ} \mathrm{C}$ & $-0.36^{\circ} \mathrm{C}$ & $-3.89^{\circ} \mathrm{C}$ & $-5.17^{\circ} \mathrm{C}$ & $-7.11^{\circ} \mathrm{C}$ \\
\hline 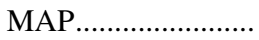 & $39.04 \mathrm{~cm}$ & $47.98 \mathrm{~cm}$ & $480.52 \mathrm{~cm}$ & $171.98 \mathrm{~cm}$ & $63.32 \mathrm{~cm}$ & $90.60 \mathrm{~cm}$ \\
\hline
\end{tabular}




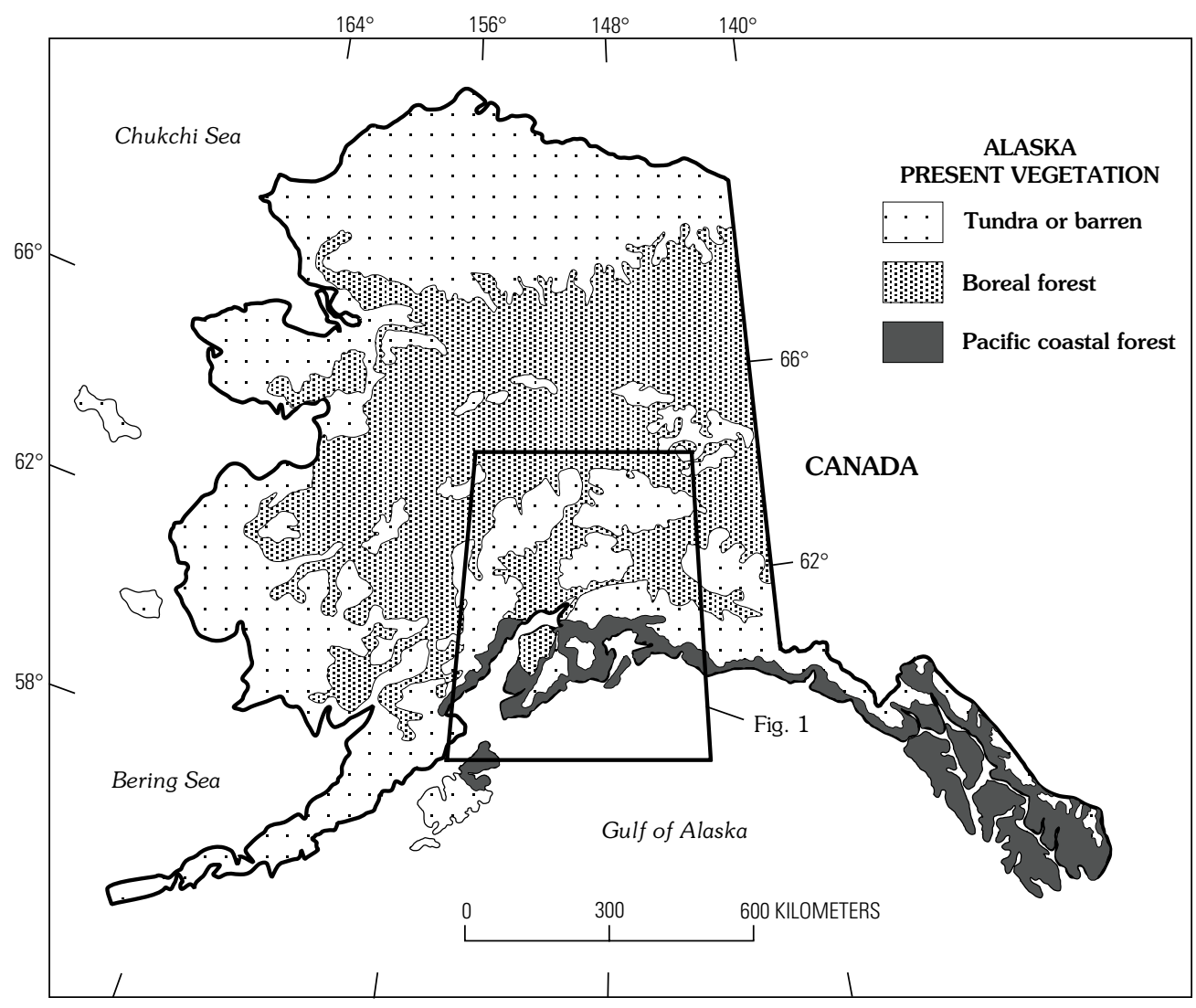

Figure 3. Map of Alaska showing present-day distribution of the three major vegetation types: Pacific coastal forest, boreal forest, and tundra (alpine and lowland tundra). Within the areas mapped as tundra are included extensive areas of barren bedrock, glaciers, and icefields. Vegetation map modified from Viereck and Little (1972). glacial sediments. A single solid-carbon radiocarbon age on wood fragments collected near the base of the peat section yielded an age of $9,000 \pm 750 \mathrm{yr}$ B.P. (L-137W). Many early radiocarbon dates using the solid-carbon method have proven to be unreliable, so the date reported by Benninghoff may only be an approximation of the actual sample age. Benninghoff's pollen record suggests that a long interval of essentially treeless vegetation existed in the Homer area prior to the invasion of spruce trees.

C.J. Heusser (1960) cored three peat bogs in the northwest Kachemak Bay area and two bogs on the southwest of the bay, but none of these five peat sections were radiocarbon-dated. Therefore, the chronology of vegetation changes recorded in those profiles was based on Heusser's correlations with a few radiocarbon-dated sites along the coast of south-central Alaska (Heusser, 1960). The longest, and apparently oldest of Heusser's cores penetrated to $5.5 \mathrm{~m}$ in a bog near Homer (fig.2). Two pollen samples from the basal peat contain a fossil assemblage interpreted by Heusser to represent a late glacial-age vegetation dominated by Betula (probably dwarf birch), Salix, Cyperaceae, and fern spores of the Polypodiaceae type (e.g., Dryopteris). Pollen assemblages from higher in Heusser's Homer 1 peat bog core suggest that the vegetation that developed after early postglacial time was composed largely of alder and birch shrubland (an Alnus-Betula pollen zone) between $4.2 \mathrm{~m}$ to $3.5 \mathrm{~m}$ core depth, followed by a spruce-alder-birch forest (Picea-AlnusBetula-Ericales pollen zone) indicated in the upper $1.5 \mathrm{~m}$ of the core. Heusser's two shorter peat cores, also from the vicinity of Homer, contain basal pollen assemblages that are similar to what appears in the upper parts of the Homer 1 core, with local minor variations. Heusser's undated sites from south of Kachemak Bay (fig. 2) record an apparent recent arrival of spruce in that area (Heusser, 1960).

\section{Methods}

Samples for pollen analysis and radiocarbon dating for this investigation were obtained from the Homer peat section exposed in a coastal bluff, and from a road-accessable kettle pond (Circle Lake) on a lateral moraine east of Homer (figs. 1, 2 ). The peat exposure is located in the Seldovia (C-5) quadrangle at lat $59^{\circ} 38^{\prime}$ N., long $151^{\circ} 30.75^{\prime}$ W. The Homer Spit peat section is probably a remnant of a larger peat bog once exposed in cross section at this locality. The site was first sampled by W.S. Benninghoff in 1951, as discussed earlier in the text, and in Karlstrom (1964), although the deposit described by him was substantially thicker than the section sampled in this study. Coastal erosion has apparently removed much of the original peat deposit, but sediments and peat in the upper part of the bluff were sampled in 5-cm-thick blocks. The peat samples were screened to remove coarse fibrous plant material, and the fine fraction was processed using standard maceration techniques to concentrate pollen and spores.

Circle Lake is a kettle pond that formed on the highest, oldest lateral moraine deposited during the late Wisconsin glacial interval (figs.1, 2) (Karlstrom, 1964; Reger and Pinney, 1997). The lake is located within Seldovia (D-4) quadrangle at lat $59^{\circ} 48.17^{\prime} \mathrm{N}$., long $151^{\circ} 09.5^{\prime} \mathrm{W}$., at an altitude of about $418 \mathrm{~m}$ above sea level. In spite of its name, Circle Lake is oval-shaped 
and has an area of less than 1.5 ha. The maximum water depth in the lake is only $2.2 \mathrm{~m}$. A field measurement of the lake water yielded a $\mathrm{pH}$ of 6.6 (moderately acidic).

Circle Lake was sampled using a modified Livingstone piston corer lowered into the central lake bottom from an anchored floating platform. The 5-cm-diameter, 1-m-length cores were sealed with corks within aluminum-alloy tubes for transport and temporary storage. In the laboratory, the cores were extruded, split, measured and described, then sampled for pollen analysis, tephra analysis, and radiocarbon dating. Methods and results of the tephra analysis are presented in Riehle (1985). Pollen samples from the Circle Lake core were generally taken every 10 $\mathrm{cm}$ within the upper $4.0 \mathrm{~m}$ of the core. From $4.0 \mathrm{~m}$ to the base of the core, samples were taken every $5 \mathrm{~cm}$. Bulk sediment samples were taken from the core for conventional radiocarbon dating from core intervals of $375-385 \mathrm{~cm}$ and $440-460 \mathrm{~cm}$. Low organic content of sediments near the base of the core required sampling relatively large segments for conventional dating.

Pollen percentages for samples from both sites were calculated on the basis of a pollen sum that included all pollen types found in the samples (terrestrial, semi-aquatic, and aquatic). A minimum count of 300 pollen grains was used whenever possible. Spore percentages were calculated on the basis of the pollen sum plus the spore sum.

\section{Homer Spit Peat Section}

\section{Modern Vegetation near the Homer Spit Peat Section}

Trees observed near the Homer Spit peat section appear to be Picea sitchensis, but some Picea glauca $\times$ sitchensis hybrids may also be present. The understory vegetation within this Sitka spruce forest includes Betula nana, Ledum decumbens, Vaccinium uliginosum, V. vitis-idaea, V. ovalifolium, Equisetum sylvaticum, and abundant Empetrum nigrum. Mosses such as the feathermoss Hylocomium splendens contribute significantly to the present-day ground cover in the area. The local vegetation can therefore be characterized as a mixture of coastal, boreal forest and cosmopolitan plant species that commonly occur in both interior and coastal forest environments (Hultén, 1968).

\section{Description of the Homer Spit Peat Section}

The exposure reveals a cross section of a sediment- and peat-filled depression near the top of the 5-m-high bluff. The uppermost $112 \mathrm{~cm}$ of the Homer Spit peat section consists mostly of coarsely fibrous peat derived from sedges (Cyperaceae), mosses, and roots. Numerous diffuse tephras were observed within the peat deposits, appearing as white to gray coatings on compressed peat-forming plant detritus. These ashy zones were generally $1-2 \mathrm{~cm}$ thick but were not sampled for tephra analysis at this site. Most of the tephras found in postglacial deposits in the Kachemak Bay area appear to have been derived from eruptions of Augustine Volcano in lower Cook Inlet (fig.1) (Riehle, 1985; J.R. Riehle, oral commun., 1984). The postglacial eruptive history of Augustine Volcano is not yet well understood, so the tephrochronological potential of these numerous tephras has not yet been fully developed, although some recent progress has been made (Reger, Pinney, and others, 1995).

Below the peat unit is a 15-cm-thick deposit of sandy silt containing plant detritus. This silty unit appears to have been deposited within a shallow pond prior to the accumulation of peat that later filled in the depression. The sediments underlying the pond deposits consist of a bouldery till with a sandy matrix that is partially cemented by iron oxide. About 6 to $7.5 \mathrm{~m}$ of glacial till are exposed in the bluff at this locality below the peat deposits capping the section.

Homer Spit is composed in part of postglacial marine sediments, but is underlain by deposits that are probably part of a late-Wisconsin-age tidewater glacial moraine (Karlstrom, 1964; Reger and Pinney, 1996) (fig.2). The contorted glacial deposits exposed in the bluff where the peat was sampled are located about $1 \mathrm{~km}$ west of Homer Spit and therefore were deposited somewhat earlier than the morainal deposits that underlie the spit, based on mapping in the area by Reger and Pinney (1996, 1997). Their map indicates that the areas immediately west of Homer Spit along the north coast of Kachemak Bay were ice covered during an earlier late Wisconsin ice advance.

\section{Description of the Homer Spit Peat Section Pollen Diagram}

The pollen percentage diagram (figs. $4 A$ and $4 B$ ) for the Homer peat section has been subdivided into four pollen zones defined on the basis of major shifts in percentages of key taxa. The diagram is constructed from data derived from analyses of 26 peat and silt samples collected from the upper part of the bluff exposure near Homer (figs. 1 and 2).

The basal zone, H-4 (125 cm to $77.5 \mathrm{~cm}$ depth) is characterized by high percentages of birch (Betula) pollen and significant percentages of sedge (Cyperaceae) pollen. Percentages of grass (Poaceae) pollen are higher in the lower part of this zone (100 to $125 \mathrm{~cm}$ depth) than in any other part of the entire profile. Poaceae pollen percentages decline toward the upper part of zone $\mathrm{H}-4$ as percentages of Sphagnum spores increase.

Other taxa represented in the pollen samples from zone H-4 include aquatic plants such as Nuphar, Menyanthes, Myriophyllum and Sparganium. Sphagnum spore percentages increase in the upper part of pollen zone $\mathrm{H}-4$, coinciding with the transition from an open-water pond to peat bog. Other taxa of note within zone H-4 include Salix, very small amounts of Ericales pollen (Ericaceae and Empetrum), Sanguisorba, Potentilla, Artemisia, Asteraceae (Subfamily Asteroideae). Ferns are represented by small amounts of Polypodiaceae-type spores and occasional occurrences of Cryptogramma spores. Equisetum and Lycopodium spores are also present in small amounts within pollen zone $\mathrm{H}-4$.

Pollen zone H-3 (77.5 to $62.5 \mathrm{~cm}$ depth) is characterized by significantly lower percentages of Betula pollen (in comparison with zone $\mathrm{H}-4$ ), high percentages of Cyperaceae pollen, and relatively high percentages of other herb taxa shown in figures $4 A$ and $4 B$. Percentages of Apiaceae pollen reach their highest 
percentages within this zone. Polypodiaceae-type fern spore percentages rise to $>50$ percent of the pollen + spore sum within this zone. Pollen of aquatic and semi-aquatic plants occur consistently in the samples within this zone, as they do occur in zone $\mathrm{H}-4$.

Zone H-2 ( 62.5 to $27.5 \mathrm{~cm}$ depth) is characterized by slightly higher percentages of Betula pollen than in zone $\mathrm{H}-3$ and an abrupt rise in Alnus abundance. Alnus percentages rise from less than 2 percent in zone $\mathrm{H}-3$ to $>50$ percent of the pollen sum within zone H-2. Ericales pollen abundances rise to $>30$ percent of the pollen sum at the base of this zone, and then fall off to about 10-15 percent of the pollen sum between a core depth of $45 \mathrm{~cm}$ and the top of the H-2 zone. Rubus

chamaemorus is well represented in pollen samples within this zone, in contrast to zones $\mathrm{H}-4$ and $\mathrm{H}-3$, where this pollen type was not observed. Polypodiaceae-type fern spores are well represented within zone $\mathrm{H}-2$, but the percentages are substantially lower than in zone H-3. Spores of Sphagnum moss vary in abundance substantially within zone $\mathrm{H}-2$ and are relatively abundant in comparison with zones $\mathrm{H}-4$ and $\mathrm{H}-3$. Aquatic and semiaquatic plants are absent from the pollen samples in zone $\mathrm{H}-2$, but the bog plant Drosera (sun-dew) appears in three samples within this zone, but nowhere else in the section.

Zone $\mathrm{H}-1(27.5 \mathrm{~cm}-0 \mathrm{~cm})$ is characterized by rising percentages of Picea pollen, moderate percentages of Betula and Alnus pollen, high percentages of Ericales pollen (rising to $>30$ percent of the pollen sum in several samples), and relatively low percentages of herbaceous taxa and Polypodiaceae spores. Sphagnum spores vary substantially within zone H-1, ranging from $<10$ percent (e.g., samples from $0-5,10-18$, and $20-25 \mathrm{~cm}$ depths) to $>40$ percent of the pollen + spore sum (18-20 cm depth).

\section{Chronology for the Homer Spit Peat Section}

Two bulk conventional radiocarbon ages are available from the Homer peat section. The lowermost sample is from near the base of pollen zone H-4, from sediments collected between 115 to $120 \mathrm{~cm}$ depths within the section. The dated material is fine plant detritus in a sandy silt, and the age is $11,800 \pm 300 \mathrm{yr}$ B.P. (W-5521). The uppermost sample is from depths of $25-30 \mathrm{~cm}$ within the section and provides an age for the $\mathrm{H}-2 / \mathrm{H}-1$ pollenzone boundary, which is $4,190 \pm 200$ yr B.P. (W-5574).

Additional age control for the section can be obtained by correlation between pollen zone boundaries in the Homer Spit peat section and the Circle Lake core to be discussed below. The abrupt rise in Alnus percentages (Zone H-2 at the Homer Spit peat section) has been radiocarbon-dated in the Circle Lake core at 9,550 $\pm 200 \mathrm{yr}$ B.P. (W-5905). Evidence for this major regional expansion of alder populations has also been dated to more than 9,440 $\pm 350 \mathrm{yr}$ B.P. in northwestern Prince William Sound (fig.1) on Parry Island (Heusser, 1960), and at Golden in Port Wells (fig.1) soon after 10,015 \pm 125 yr B.P. (Heusser, 1983). In the Hidden Lake core in the northern Kenai Lowland (fig.1) (Ager, 1983), the age of the alder rise can be approximated by extrapolating from adjacent dated core segments. The alder rise at Hidden Lake occurred about 9,350 yr B.P., assuming a constant sedimentation rate between adjacent radiocarbondated intervals.

\section{Interpretation of Postglacial Vegetation History}

The record begins about 12,000 yr B.P., which may be as much as several thousand years after local glacial retreat. A delay of that magnitude could have been caused by localized slow melting of a buried glacial ice block following local glacial retreat. The resulting depression on the surface of newly exposed glacial deposits then began to accumulate fine sediments.

The Homer Spit peat section provides insights into both the regional and local vegetation history of the northern coastal area of Kachemak Bay. The earliest flora recorded by pollen assemblages at this site was a shrub tundra composed of Betula (probably B. nana), Salix, Cyperaceae and Poaceae, with small amounts of Polypodiaceae-type ferns. Peat-forming mosses such as Sphagnum were present, but the relative rarity of Sphagnum spores suggests that mosses probably did not yet cover much of the local land surface. The basal sample from the section contains no pollen of aquatic plants, but the next sample above the base of the section (depth $120 \mathrm{~cm}$ ) contains Nuphar (pond lily) pollen. Early postglacial colonization of freshwater ponds and lakes in Cook Inlet by aquatic plants was rapid and probably was expedited by migratory waterfowl, which often carry seeds of aquatic plants on their feet, feathers, and within their guts. Large seeds, such as those of Nuphar, are likely candidates for transport from lake to lake by birds.

At a depth of $112 \mathrm{~cm}$ within the section, the sediments are rich in plant detritus, suggesting that the area surrounding the lake had become completely covered with shrub tundra vegetation, and detritus from aquatic plants and surrounding vegetation began to accumulate in the pond. The persistence of aquatic pollen throughout zones $\mathrm{H}-4$ and $\mathrm{H}-3$ indicates that open-water conditions persisted in this part of the basin until the early Holocene.

In pollen zone H-4, abundances of Poaceae pollen decline to $<2$ percent of the pollen sum above $100 \mathrm{~cm}$ depth within the section. This decline in Poaceae pollen overlaps slightly with an increase in percentages of Sphagnum spores. This suggests the beginnings of a shift from a dwarf shrub-herb meadow vegetation to shrub vegetation with more widespread mossy, peatforming, ground-covering vegetation.

The boundary between zones H- 4 and $\mathrm{H}-3$ is marked by the beginning of significant shifts in percentages of Betula (decline), Cyperaceae (increase), and Polypodiaceae ferns (increase). This suggests the invasion of at least the nearshore areas of the shallowing pond by emergent sedges (probably Carex). The major increase in fern spore percentages in this part of the profile suggests a possible climatic shift toward wetter conditions. This fern-spore increase is not dated directly at this site, but an estimate of the age can be made by extrapolating between radiocarbon ages in the section and by comparison with similar increases in Polypodiacae-type fern-spore percentages at other sites on the Kenai Peninsula. By extrapolation, the estimated age of the H-4/H-3 pollen zone boundary is about 10,267 yr B.P. At Hidden Lake, in the northern Kenai Lowland, the beginning of the fern-spore increase is radiocarbon-dated at about $10,380 \pm 80$ yr B.P. (Ager, 1983; Ager, unpub. data). In the Circle Lake record, this event is not directly dated, but the extrapolated age for this event is older than at Hidden Lake, about 11,600 yr 


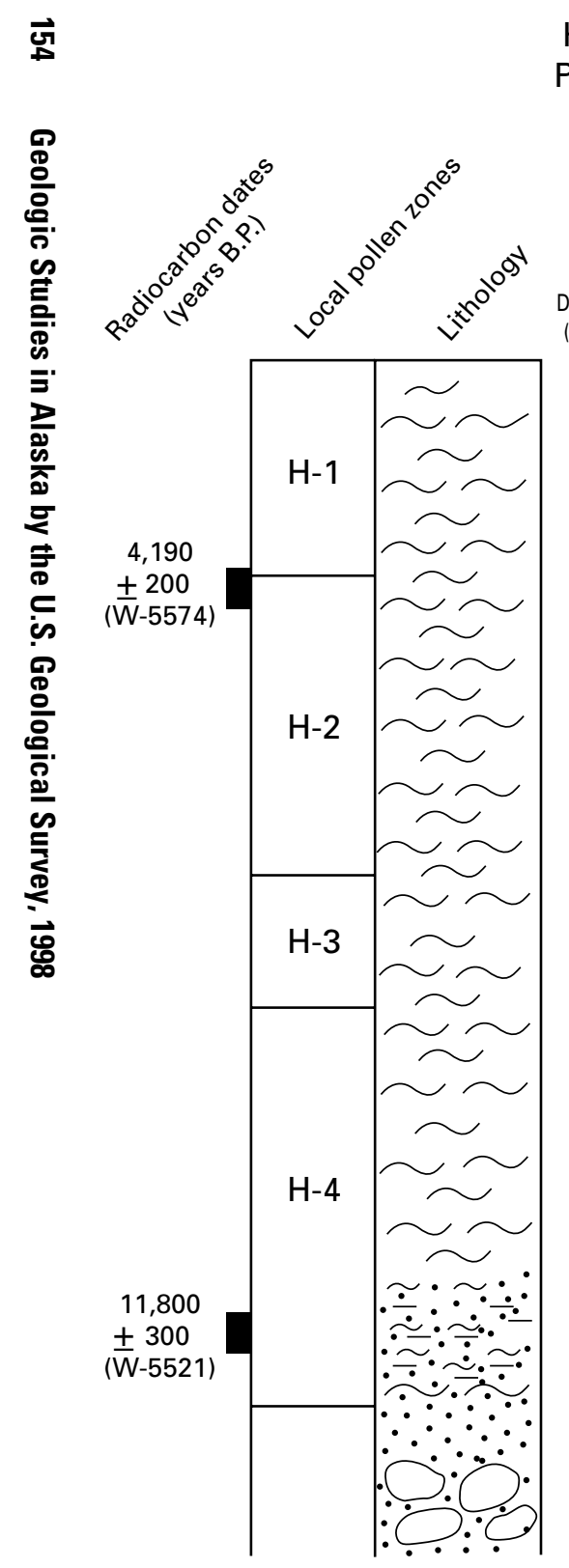

A
Homer Spit

Peat Section

POLLEN TYPES

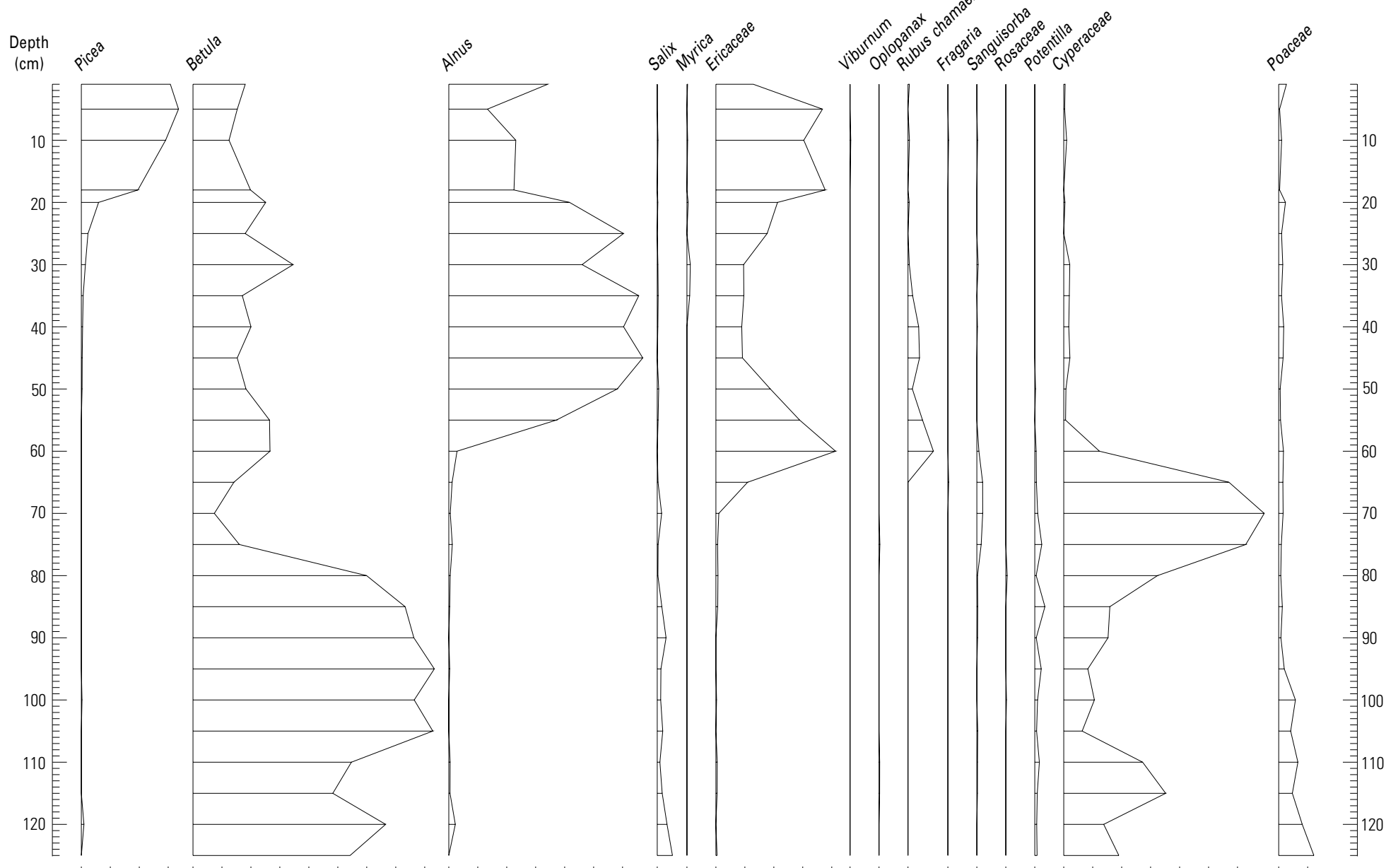

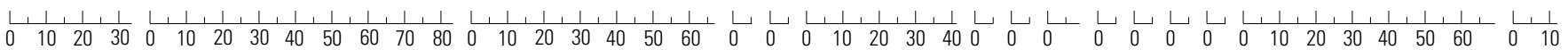
PERCENT

INCLUDED IN POLLEN SUM

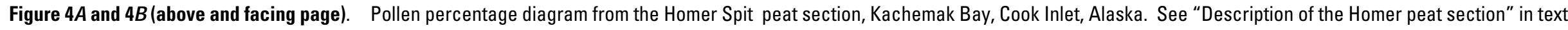
for interpretation of section lithology. 


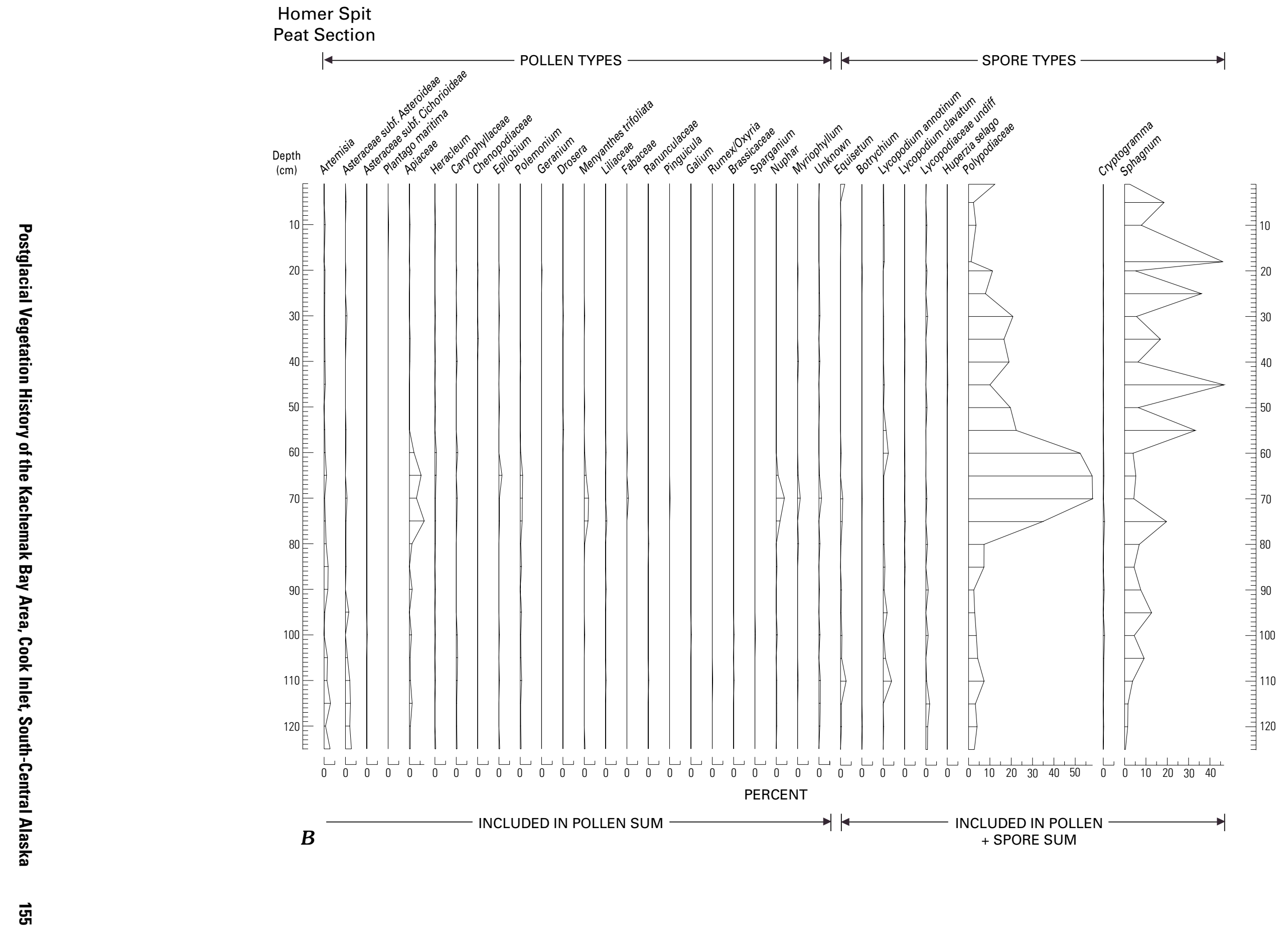


B.P. However, it may be incorrect to assume a constant sedimentation rate near the base of the Circle Lake core.

Vegetation changes within zone $\mathrm{H}-2$ are dramatic and abrupt. Alnus very quickly colonized Kachemak Bay in the early Holocene, beginning about 9,500 yr B.P. This was very slightly preceded by expansion of Ericales (probably including Empetrum, Vaccinium, Ledum, and other genera). Sphagnum expanded as a peat-forming ground cover at least locally at this time. This suggests the development of a shrubby vegetation with a peaty ground surface that may have been rather similar to what is now found in the understory of the spruce forests that grow along the northern coast of Kachemak Bay.

Zone $\mathrm{H}-1$ records the invasion of the northern Kachemak Bay area by spruce beginning about 4,200-3,800 yr B.P. Picea pollen percentages begin to rise within the radiocarbon-dated peat sample that overlaps the $\mathrm{H}-2 / \mathrm{H}-1$ zone boundary, but the percentages of Picea do not exceed 10 percent of the pollen sum until the 15-20 cm section depth. This suggests that, although spruce trees were approaching northern Kachemak Bay by ca. $4,200 \mathrm{yr}$ B.P., they may not have begun growing in the area of Homer Spit until perhaps ca. 2,600 yr B.P. Because white spruce-Sitka spruce hybrids (Picea glauca $\mathrm{x}$ sitchensis), black spruce (P. mariana), and Sitka spruce (Picea sitchensis) all grow today along the north side of Kachemak Bay, it is not yet entirely certain which species of spruce first invaded the area. The early arrival of boreal spruce (probably white spruce, followed by black spruce) at Hidden Lake (Ager, 1983) and Longmere Lake (Ager, unpub. data), in the northern Kenai Lowland about 7,8008,000 yr B.P., suggests that boreal spruce had the earliest opportunity to invade the southern Kenai Peninsula.

Pollen records along the North Pacific coast of Alaska reported by Heusser $(1960,1983,1985)$ and Peteet $(1986,1991)$ document the progressive postglacial invasion of Sitka spruce along the coast from the Pacific Northwest (Washington State) into coastal south-central Alaska during the Holocene. Initially, the spread of coastal forests into southeastern Alaska was very rapid, then slowed as forest vegetation spread west along the southern Alaska coast. Currently available data suggest that Sitka spruce probably arrived in western Prince William Sound (fig. 1) during the late Holocene, ca. 2,500 yr B.P. (Heusser, 1983, 1985). In the southern Kenai Mountains (figs. 1, 2), stumps of Sitka spruce trees have been found that have been overridden by advancing ice during Neoglacial events. The trees were identified on the basis of wood characteristics and large trunk diameters. The oldest radiocarbon date obtained so far on wood from the outermost tree rings on one of these stumps is $1,440 \pm 70 \mathrm{yr}$ B.P. The tree trunk has an estimated 215 tree rings, so a probable minimum age estimate for the arrival of Sitka spruce in the southern Kachemak Bay area is about 1,650 yr B.P. (Wiles and Calkin, 1990, 1994). Given the pollen evidence that indicates an earlier arrival of spruce in the Kachemak Bay area, it is probable that Sitka spruce was not the first species of spruce to begin colonizing northern Kachemak Bay by ca. 4,000-3,800 yr B.P.

It is hypothesized, based on all lines of evidence, that boreal spruce species probably were the first invaders of northern Kachemak Bay, followed by Sitka spruce perhaps 2,0002,200 years or so later. It is not yet known if both species of boreal spruce (Picea glauca, P. mariana) invaded Kachemak
Bay simultaneously. Boreal spruce have similar climatic tolerances for mean January, mean July, and mean annual temperatures; and mean annual precipitation (Thompson and others, in press; Hogg 1994; Muhs and others, in press). They tend to occupy different habitats, however, with Picea glauca occupying sites with better drained soils and south-facing slopes, whereas Picea mariana tolerates nutrient-poor, peaty, wetter soils and can grow on cool north-facing slopes (Viereck and Little, 1972). Neither species of boreal spruce appears to be able to tolerate the wet, relatively warm winters that typify the southern coast of Alaska. Kachemak Bay area lies in the partial rain shadow of the Kenai Mountains, so the winters are not as warm and wet as on the outer coast (table 1). The Kachemak Bay area does have somewhat wetter, warmer winters than sites in upper Cook Inlet, such as Kenai and Anchorage (table 1). Therefore, the late arrival of boreal spruce in the Kachemak Bay area may have been caused by winter climates marginally favorable to their survival and successful reproduction.

The apparent absence of pure strains of Picea glauca in the Kachemak Bay area today resulted from extensive hybridization between closely related Picea glauca and P. sitchensis when the two species came into contact during late Holocene time. These two species hybridize readily when populations come into proximity (Viereck and Little, 1972, 1975; Copes and Beckwith, 1977). Two scenarios are possible to explain the present distribution of $P$. glauca and $P$. glauca $\times$ sitchensis hybrids in the Kenai Lowlands and Kachemak Bay. In the first scenario, $P$. glauca reached the northern Kenai Lowland by ca. 8,000 yr B.P. (Ager and Brubaker, 1985) and then spread southward more slowly as warmer, wetter winter climates were encountered, reaching the vicinity of northern Kachemak Bay by ca. 4,000 yr B.P. When $P$. sitchensis colonized the southern Kenai Peninsula within the past 2,000-1,650 yr, hybridization with $P$. glauca proceeded rapidly, replacing pure strains of $P$. glauca wherever the hybrids could tolerate the climatic conditions, primarily in the southern Kenai Lowland.

The alternate scenario allows Picea glauca to colonize the northern Kenai Lowland beginning ca. 8,000 yr B.P., but perhaps it was unable to colonize the southern Kenai Lowland with its somewhat warmer, wetter winters until the arrival of $P$. sitchensis allowed hybrids to occupy areas that neither pure strain could. If this second scenario is correct, then P. mariana was the boreal spruce that initially colonized the northern Kachemak Bay area. Personal observations suggest that Picea mariana is relatively uncommon in the Kachemak Bay area today, so if that species was the first spruce to colonize the area, it probably formed open, patchy forests in poorly drained, peaty soils, while much of the landscape would have remained dominated by alders, poplars, willows, birches, and other shrubby vegetation. Apparently neither Picea glauca nor P. mariana has colonized the southern shores of Kachemak Bay, where P. sitchensis is the only common conifer in the forests (Viereck and Little, 1975).

It is likely that Alnus shrub thickets were the dominant vegetation on the southern shores of Kachemak Bay until the arrival of Sitka spruce within the past two millenia. The rarity of western hemlock in forested areas of the southern Kenai Mountains today (Viereck and Little, 1975) suggests that it has only recently begun to invade the region. The undated pollen record from a peat bog near Port Chatham (Heusser, 1960) (figs. 1, 2) 
shows traces of Tsuga heterophylla pollen near the top of the section, which suggests a recent arrival of that taxon in the southern Kenai Peninsula.

If either scenario outlined above about the invasion of spruce species is correct, it raises some intriguing questions about environmental factors that limit the distribution of boreal spruce species. In postglacial time, boreal spruce invaded southcentral Alaska from interior Alaska beginning about 9,100 yr B.P., and spruce populations spread rapidly southward via the Copper River basin and the Matanuska Valley (Ager, 1989). Spruce reached the Anchorage area by about 8,000 yr B.P. and quickly spread southward to the northern Kenai Lowland by about 8,000-7,800 yr B.P. (Ager, 1983; Ager and Brubaker, 1985). At that rapid rate of migration (about $0.4 \mathrm{~km} / \mathrm{yr}$ ), boreal spruce should have reached northern Kachemak Bay much earlier than the pollen evidence indicates. Given the lack of topographic barriers, boreal spruce should have reached Kachemak Bay by about 7,500 yr B.P., rather than ca. 3,800 yr B.P. Pollen and radiocarbon ages from a coastal peat section near Clam Gulch (fig. 1) indicate that spruce reached the vicinity of that site by about 6,900 yr B.P., about 800 years later than it should have arrived if the migration rate was still about $0.4 \mathrm{~km} / \mathrm{yr}(\mathrm{T}$. Ager, unpub. data). The migration rate for boreal spruce between northern and southern Kenai Lowland between about $8,000-4,000$ yr B.P. slowed to only about $0.03 \mathrm{~km} / \mathrm{yr}$. Was this entirely because boreal spruce were encountering less favorable climatic conditions as they spread south? Another factor that might have inhibited the spread of Picea glauca southward was the development of wet, peaty soils, which provide a less favorable seed bed for successful germination and seedling survival for Picea glauca than for P. mariana (Viereck and Little, 1972).

\section{Circle Lake Core}

\section{Description of the Circle Lake Core}

The piston corer recovered $467 \mathrm{~cm}$ of sediments from the central, deepest area of Circle Lake. The basal sediments are clayey gravel probably derived from glacial till (fig. 5A). These glacial sediments are overlain by fine silty lake sediments, which contain increasing amounts of plant detritus between 420 to $380 \mathrm{~cm}$ core depth. From $380 \mathrm{~cm}$ core depth to the top of the core, plant detritus is relatively abundant in the lake sediments. Sixteen tephras were identified within the core and have been described, analyzed, and discussed by Riehle (1985). They are shown in the sediment profile in figure $5 A$ and are labeled $\mathrm{A}$ through $\mathrm{P}$, from the top of the core to the lowest tephra near the base of the core.

\section{Modern Vegetation near Circle Lake}

In contrast to the mixture of coastal and boreal taxa along the north shoreline of Kachemak Bay, such as is seen in the Homer area, the modern vegetation in the immediate area around Circle Lake is dominated by boreal-forest species. The lake area has an open boreal forest of Picea glauca, although the large size of seed cones on some of the trees suggests that many may be Picea glauca $\times$ sitchensis hybrids. A single sapling of Betula papyrifera var. kenaica was seen near the lake. Larger shrubs growing near the lake include Salix pulchra, Alnus tenuifolia, and A. sinuata. Low-growing, woody plants observed near the lake include Vaccinium uliginosum, V. vitisidaea, Ledum palustre subsp. decumbens, Rubus chamaemorus, Empetrum nigrum, Andromeda sp., Ribes lacustre, and Betula nana.

Moist areas near the lake shore include Eriophorum sp., Carex spp., Spiranthes romanzoffiana, and Sanguisorba stipulata. Epilobium angustifolium subsp. macrophyllum grows near the lake in open-meadow sites. The pond is rimmed with a partially floating mat of Sphagnum moss, Potentilla palustris and Menyanthes trifoliata (fig. 6). Equisetum fluviatile grows in shallow waters along some parts of the lakeshore. Nuphar polysepalum grows in the lake, and Chara was recovered from a dredge sample of the lake bottom. Other vascular plants observed near the lake, some of which present a more coastal aspect to the local flora, include Heracleum lanatum, Lupinus nootkatensis, Sambucus racemosa, Spiraea beauverdiana, Castelleja caudata, Geranium erianthum, and Veratrum viride.

\section{The Circle Lake Pollen Record}

The Circle Lake pollen diagram (figs. $5 A$ and $5 B$ ) has been divided into three zones, $\mathrm{C}-1, \mathrm{C}-2$, and $\mathrm{C}-3$, on the basis of major changes in percentages of dominant pollen and spore types. Zones C-2 and C-3 have been further divided into subzones $\mathrm{C}-2 \mathrm{a}$ and $\mathrm{C}-2 \mathrm{~b}$, and $\mathrm{C}-3 \mathrm{a}$ and $\mathrm{C}-3 \mathrm{~b}$. Beginning with the base of the core, subzone C-3b (core depth $453 \mathrm{~cm}$ to $422 \mathrm{~cm}$ ) is characterized by relatively high percentages of Betula pollen, but significant amounts of pollen of Poaceae, Cyperaceae, Artemisia, and other herbaceous taxa are also present. The lowermost sample within this subzone contains only a few percent Betula pollen but also has unusually high percentages of Artemisia pollen and Equisetum spores (71.2 percent of the pollen + spore sum). This sample is sufficiently different from all other samples in the subzone (and all other samples in the core) that it could justifiably be assigned to a separate subzone. Because there is only one sample with these characteristics, however, it has been included in subzone C-3b.

Other pollen types represented in the lowermost part of the core include Epilobium, Caryophyllaceae, Polemonium, Ranunculaceae, and Polygonum persicaria type. The sample $5 \mathrm{~cm}$ above the basal zone boundary contains pollen of the aquatic plants yellow pond lily (Nuphar) and buckbean (Menyanthes). These taxa then occur in many samples throughout the rest of the core. Lycopodium spores (mostly Lycopodium annotinum and $L$. clavatum) are relatively abundant within subzone C-3b.

Subzone C-3a (core depths $422 \mathrm{~cm}$ to $383 \mathrm{~cm}$ ) differs in several ways from $\mathrm{C}-3 \mathrm{~b}$ assemblages. The former contains significantly higher percentages of pollen of Salix, Heracleum and other Apiaceae types. Also within this subzone, Polypodiaceaetype fern spores rise to very high percentages (50 to 80 percent of the pollen + spore sum). Alnus is represented within this zone by low amounts $(<2$ percent to $>10$ percent $)$ of the pollen sum. 


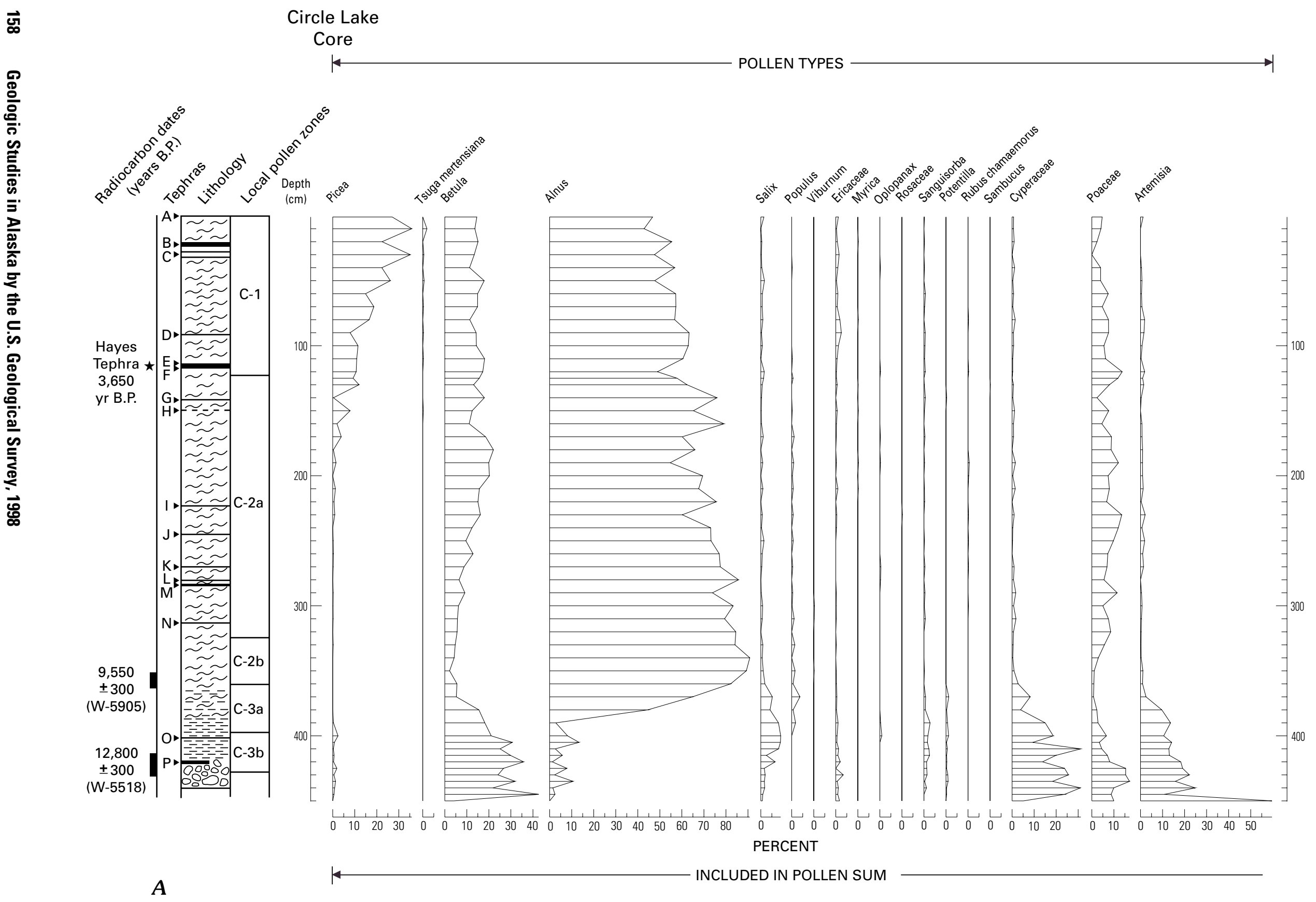

Figure 5Aand 5B (above and facing page). Pollen percentage diagram for the Circle Lake core, Kachemak Bay, Cook Inlet, Alaska. See "Description of the Circle Lake core" in text for interpretation of the lake sediment core lithology. 


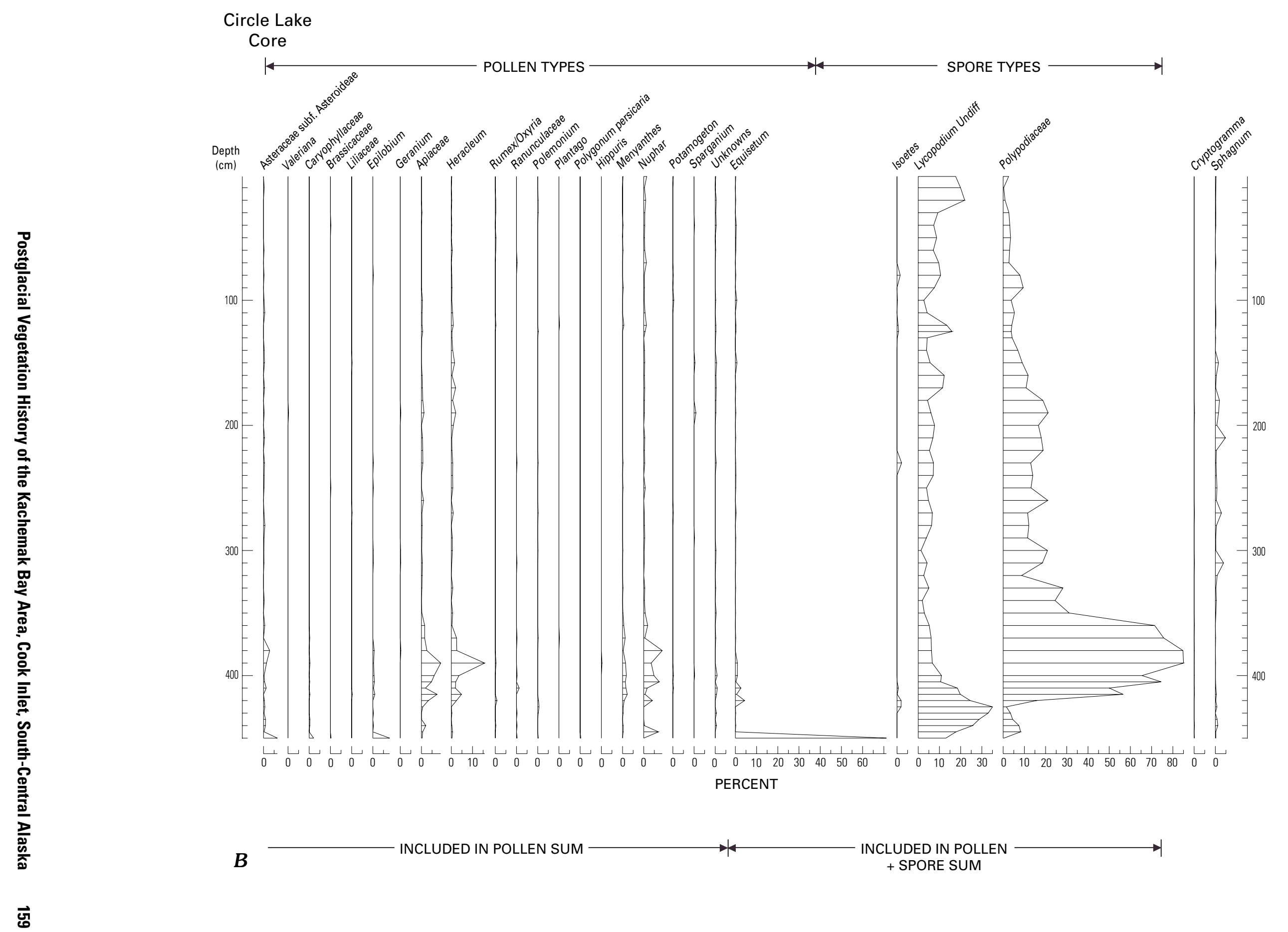




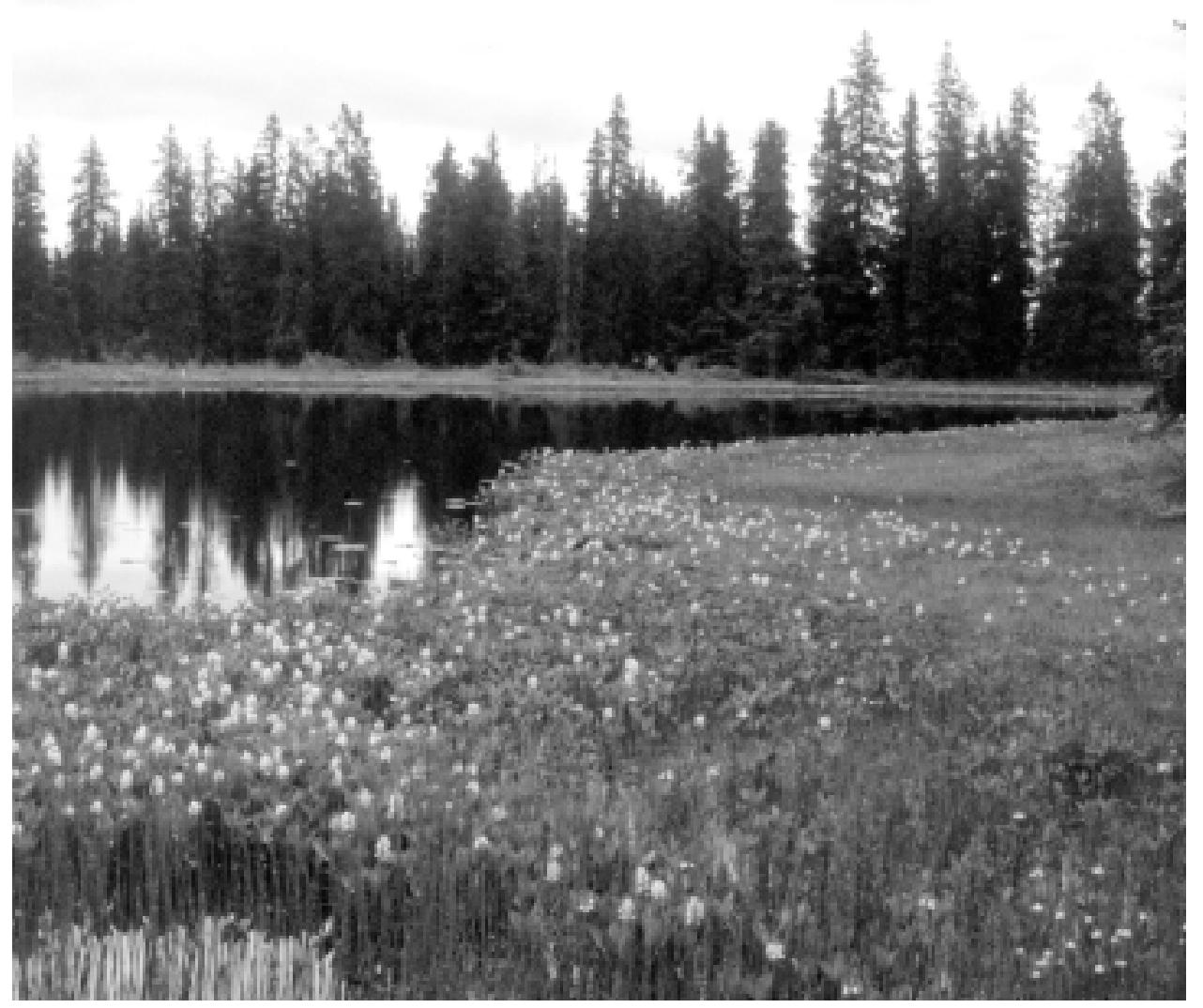

Figure 6. Vegetation of the Circle Lake area is open forest of probable white spruce-Sitka spruce hybrid trees (Picea glauca $\times$ sitchensis) and a shrub-and-herb assemblage that is predominantly of the boreal-forest type. Some coastal taxa do grow in the area of the lake, however. The photograph shows shoreline vegetation of Equisetum fluviatile, Menyanthes trifoliata, and Sphagnum moss.

Subzone C-2b (core depths of $383 \mathrm{~cm}$ to $348 \mathrm{~cm}$ ) is readily differentiated from subzone $\mathrm{C}-3 \mathrm{a}$ by the relatively abundant percentages of Alnus, coinciding with a relative decline in Betula percentages. Populus pollen (poplar, cottonwood and (or) aspen) first appears within this subzone, and, although represented by very small percentages of the pollen sum, its presence is highly significant. Populus pollen is usually poorly represented in most deposits, even where the trees are locally abundant, because of the vulnerability of its thin-walled grains to mechanical destruction and biological degradation by bacteria and fungi. Therefore, its presence here, while not abundant, attests to Populus becoming an important component of the pollen assemblage during the time represented by subzone $\mathrm{C}-2 \mathrm{~b}$.

Subzone C-2a (core depths $348 \mathrm{~cm}$ to $132 \mathrm{~cm}$ ) pollen assemblages are very similar to those in subzone $\mathrm{C}-2 \mathrm{~b}$, except that fern spores (Polypodiaceae-type) are far less abundant.

Subzone C-1 (core depths $132 \mathrm{~cm}$ to the top of the core) differs only slightly from the underlying subzone C-2a, but the difference is ecologically significant. Within subzone C-1, Picea percentages rise to $>10$ percent of the pollen sum. Other pollen types, which are relatively abundant in this zone, include Betula, Alnus, and Poaceae. Spore types that are most abundant in the zone include Lycopodium and Polypodiaceae-type fern spores. Ericales (Ericaceae and Empetrum) pollen is represented in every sample within this zone, sometimes in slightly higher amounts than in other Holocene-age samples in this core.

\section{Chronology of the Circle Lake Core}

Chronological control is provided by two conventional radiocarbon dates on organic matter in bulk sediment samples, plus a tephrochronological correlation of one of the tephras sampled in the Circle Lake core. Core interval $440-460 \mathrm{~cm}$, near the base of the core, yielded an age of $12,800 \pm 300 \mathrm{yr}$ B.P. (W-5518), the oldest radiocarbon date yet obtained from postglacial deposits in the Kachemak Bay area. This is about 1,000 years older than the basal age obtained from the Homer peat section. The deposits underlying Circle Lake appear to have been deposited during an earlier stadial of the late Wisconsin (Naptowne) glaciation (fig. 2), and, therefore, the buried ice mass that melted out to form the depression may have been exposed to thawing earlier in postglacial time than at the Homer site, located near present sea level. A second bulk sediment sample from 375 to $385 \mathrm{~cm}$ depth in the core yielded a radiocarbon date of $9550 \pm 300 \mathrm{yr}$ B.P. (W-5518). This core segment was sampled to date the initial rise of Alnus percentages at the base of subzone $\mathrm{C}-2 \mathrm{~b}$.

One of the tephras in the core proved to be useful for tephrochronologic correlation. Tephra $\mathrm{F}$ from a core depth of 127 $\mathrm{cm}$ matched closely with tephras from the Hayes volcanic eruptions (tephra set $\mathrm{H}$ ) dated elsewhere in Cook Inlet at about 3,650 yr BP (Riehle, 1985; Riehle and others, 1990; J.R. Riehle, oral commun., 1984).

\section{Interpretation of the Circle Lake Pollen Record}

The Circle Lake pollen record provides the second-longest available late Quaternary pollen record yet recovered from the Kenai Peninsula. The longest late Quaternary pollen record found thus far in the Cook Inlet region is from Hidden Lake in the northern Kenai Lowland, which begins more than 13,700 yr B.P. (Rymer and Sims, 1982; Ager and Sims, 1984; Ager, 1983). 
Hidden Lake is located near the range front of the western Kenai Mountains and was formed by a glacial advance into the Kenai Lowland during the late Wisconsin glacial interval.

The earliest postglacial pollen assemblage from the Kachemak Bay area is from the base of pollen subzone C-3b in the Circle Lake core and was taken within a core segment that was radiocarbon-dated at $12,800 \pm 300 \mathrm{yr}$ B.P. (W-5518). This basal sample differs substantially from the other samples within this subzone and indicates that the earliest known colonizing vegetation in this area consisted of Poaceae, Cyperaceae, Artemisia, and herbs such as Epilobium, Polygonum persicaria,

Polemonium, Caryophyllaceae, Ranunculaceae, and Chenopodiaceae, and spore-producing plants such as Equisetum and Lycopodium. Woody plants are minor components of this assemblage, with only small amounts of Betula (presumably dwarf birch, Betula nana) and Ericales (e.g., Vaccinium, Ledum, Empetrum).

The basal sample of subzone C-3b indicates that the earliest postglacial vegetation to develop around Circle Lake was herbaceous tundra. Glacial mapping of the Kenai Lowland and adjacent areas indicates that a large area of the southern Kenai Lowland north of Kachemak Bay was not overridden by glacial ice during the late Wisconsin glaciation, although it was surrounded by extensive icefields (fig. 2) (Reger and Pinney, 1996, 1997). This unglaciated area was a likely refugium at least for alpine and perhaps shrub tundra plants and aquatic vegetation during the late Wisconsin glacial interval. This refugium is the nearest likely seed source for tundra plants invading the Kachemak Bay area as the ice receded.

The abundance of Equisetum spores in the basal sample from the Circle Lake core suggests that the shallows of the lake that formed in this kettle depression some time after deglaciation were probably colonized initially by horsetails, perhaps Equisetum fluviatile, which grow in the area today (Hultén, 1968; Pojar and MacKinnon, 1994). Equisetum is known to colonize newly formed ponds soon after glacial retreat in Glacier Bay, southeastern Alaska (Goldthwait and others, 1966).

Soon after the pioneering stage of vegetation development, the character of the local vegetation changed significantly to a shrub-herb tundra, as Betula shrubs, Sanguisorba, Potentilla, Asteraceae subf. Asteroideae, and ferns colonized the area around Circle Lake. Within the lake, aquatic plants such as Nuphar and Menyanthes became established within this early postglacial stage of vegetation development.

Surprisingly, within Subzone C-3b, pollen of Alnus first appears, suggesting that Alnus was colonizing areas within the region in early postglacial time. In northwest Prince William Sound, Heusser $(1960,1983)$ reported early postglacial appearances of Alnus pollen from peat cores obtained at Golden, in Port Wells, and on Perry Island (fig. 2). However, the oldest radiocarbon date yet obtained from peat cores in western Prince William Sound is only 10,015 \pm 125 yr B.P. (Heusser, 1983). If the oldest peat ages are closely limiting ages for deglaciation, this suggests that extensive glacial ice may have persisted in the mountains surrounding Prince William Sound until the beginning of the Holocene. Therefore, the early appearance of Alnus pollen in the Circle Lake core, and in the early postglacial record from Hidden Lake in the northern Kenai Lowland (Ager, 1983), suggests two possibilities: (1) that some Alnus shrubs (perhaps A. tenuifolia) may have survived within south-central Alaska during the late Wisconsin glacial interval, then expanded their range quickly when postglacial warming permitted; or (2) Sitka alder (A. sinuata) invaded coastal south-central Alaska from southeastern Alaska in early postglacial time. Alnus pollen appears early (more than 12,000 yr B.P.) in the postglacial record from Pleasant Island in southeastern Alaska near Glacier Bay (Hansen and Engstrom, 1996). It is therefore possible that some early populations of Sitka alder reached the Kenai Peninsula quite early following deglaciation from coastal populations to the east.

Fern spores, and relatively abundant Lycopodium spores, appear within the lower part of subzone C-3b. Ferns are typical early colonizing plants in southern and southeastern coastal Alaska (Heusser, 1960, 1983, 1985). Fern-spore percentages remain relatively low within subzone $\mathrm{C}-3 \mathrm{~b}$, and decline to $<2$ percent of the pollen + spore sum at the top of the subzone before increasing dramatically within the overlying subzone C-3a samples. This is somewhat similar to an early postglacial decline in Polypodiaceae spores observed in cores from southwestern Kodiak Island (Peteet and Mann, 1994). They interpret this "fern-gap" to represent an interval of cool, dry climate associated with the Younger Dryas event, ca. 10,800 to 10,000 radiocarbon yr B.P. Their interpretations are strengthened by a restudy of the Kodiak Island evidence (Hajdas and others, 1998), which correlates the cold interval there with the Younger Dryas. In subzone C-3a of the Circle Lake core, however, the fern percentages prior to the "fern-gap" are far lower than seen in the record from Kodiak Island. This poorly defined "fern-gap" provides only ambiguous evidence that it might represent the Younger Dryas in Kachemak Bay. In the Circle Lake core, this "fern-gap" event is not directly dated, but an estimate can be made, assuming a constant sedimentation rate between radiocarbon-dated core intervals above and below this interval. By applying this assumption, the lowest Polypodiaceae percentage at the top of subzone C-3a was deposited about 11,600 yr B.P., which is somewhat older than the accepted radiocarbon ages for the Younger Dryas. However, it is doubtful that the sedimentation rate within Circle Lake was constant during this early stage of the lake history, when colonization by plants of the landscape around the lake was under way and extensive areas of bare soil were probably still exposed. Such unvegetated soils would have been more readily eroded during rainstorms and during spring melt season, and the lake sedimentation rates might have been more irregular than at later times, when vegetation cover was more complete. Additional research in the region will be needed to resolve this uncertainty about a possible Younger Dryas event influencing vegetation in the early postglacial record.

The Homer Spit peat record does not show evidence of a "fern-gap" in the early postglacial, so the currently available evidence suggests that the Younger Dryas event cannot be clearly discerned in the Kachemak Bay area. However, several postglacial pollen records in upper Cook Inlet do display convincing "fern-gaps" and at least one of them is dated sufficiently (Hidden Lake) to place the event within the supposed Younger Dryas (Ager, unpub. data). In most Alaskan late Quaternary pollen records, there is little to no indication of a cold, dry Younger Dryas interval, indicated by significant vegetation change. 
Clubmosses (Lycopodium spp.) are common elements of the ground cover of both forested and tundra regions of Alaska (Hultén, 1968) and are well adapted to colonization of mineral soils in newly deglaciated terrain. Spores of Lycopodium species are often common to abundant in early postglacial deposits along the southern coastal regions of Alaska (Heusser, 1960, 1983; Ager, unpub. data). At Circle Lake, Lycopodium was an important colonizer during the early postglacial period and was probably a significant component of the discontinuous ground cover. It persists as a component of the local vegetation throughout postglacial time.

Small percentages ( $<2$ percent of the pollen sum) of Picea pollen appear in all samples from subzone C-3a. The source of these pollen grains is unclear. Some may be fossil pollen redeposited from older Quaternary or even local coal-bearing Miocene deposits (Wolfe and others, 1966) eroded by glacial activity. An alternative explanation is long-distance windtransport of pollen grains from the expanding North Pacific coastal forests of southeastern Alaska and British Columbia. This is less likely, however, because, if those regions were the source, there should also be trace amounts of Tsuga mertensiana and Pinus contorta pollen appearing in the Circle Lake record for the early postglacial time. The pollen record from Pleasant Island indicates that those trees were growing in that coastal region of northern southeastern Alaska in early postglacial time (Hansen and Engstrom, 1996). Another possible source for pollen of spruce is from the interior, but the earliest known postglacial appearance of significant amounts of spruce pollen in interior Alaska occurred about 9,400 yr B.P. (Ager, 1983; Ager and Brubaker, 1985). However, trace amounts of spruce pollen occur in late Wisconsin-age deposits in the interior. The only remaining possibility is that some small population of boreal spruce survived in south-central Alaska during the late Wisconsin glaciation. A few areas did escape glaciation, such as Caribou Hills and part of the southern Kenai Lowland (Karlstrom, 1964; Reger and Pinney, 1996, 1997). If such a population had survived full glacial climates within south-central Alaska, however, the pattern of postglacial expansion of boreal spruce would have been far different than currently available records from the region suggest (Ager, 1983; Ager and Brubaker, 1985). Of the various hypotheses, reworking may be the most likely explanation for the early appearance of spruce pollen in small amounts in the early postglacial period.

The subzone $\mathrm{C}-3 \mathrm{~b} / \mathrm{C}-3 \mathrm{a}$ boundary marks the beginning of a significant vegetation change near Circle Lake that probably has climatic implications. Within subzone C-3a, pollen percentages of Salix, Heracleum, other Apiaceae, and other herbs increase substantially, and there is a rapid and major increase in Polypodiaceae-type fern spores. These events imply wetter climatic conditions during deposition of subzone C-3a than during deposition of subzone C-3b. This is similar to the early postglacial record from southwest Kodiak Island (Peteet and Mann, 1994), where fern-spore percentages in Phalarope Pond increased dramatically immediately after ca. 10,000 yr B.P. The Kodiak record was interpreted by those authors to be a vegetational response to warmer, wetter climates in the Gulf of Alaska region.

The pollen data from Subzone C-3a indicate that the vegetation around Circle Lake continued to be shrub-herb tundra, but the increases in Apiaceae, Heracleum, Salix, and ferns imply a richer, more mesic tundra with perhaps more complete ground cover by vegetation. Alnus pollen percentages increase slightly within subzone $\mathrm{C}-3 \mathrm{a}$, implying the continued colonization of southern Kenai Peninsula by alders that apparently began in the region during earlier postglacial time (subzone C-3b).

Subzone C-2b records a rapid and important expansion of Alnus populations in the Kachemak Bay area beginning about 9,550 yr B.P. Climatic conditions were relatively warm and moist during the earliest Holocene and therefore may have been ideal for Alnus to expand into the Cook Inlet region. Alternatively, this expansion may simply be the result of the arrival of Alnus sinuata from sources in the North Pacific coastal forest to the east. The modern distribution of Alnus sinuata suggests that it populated south-central Alaska from sources in southeastern Alaska (Viereck and Little, 1975). Populus spp. arrived in the Kachemak Bay area at about the same time as the Alnus populations began to rapidly expand. The available fossil evidence does not make clear which species of Populus first arrived, but three species are now found in the area today.

Within subzone $\mathrm{C}-2 \mathrm{~b}$ the increase of Alnus populations may account for declining percentages of herbaceous taxa such as Poaceae, Cyperaceae, Artemisia, Heracleum, and other Apiaceae types as alder shrub thickets spread over much of the landscape, decreasing the areas of open meadows near the lake. The continued abundance of fern spores during this rapid expansion of alders suggests that ferns were probably able to survive in abundance within the alder thickets, as they are often seen today in the coastal regions of southern Alaska. The decline of Betula pollen percentages within the subzone may reflect a loss of open habitat where dwarf birch could continue to be a common element of the shrub layer.

Subzone C-2a records a long interval (about 4,500 yr) of fairly stable vegetation, dominated by Alnus thickets, with small amounts of Betula, probably both minor Betula nana shrubs and paper birch (Betula papyrifera). Rising percentages of Betula pollen within subzone C-2a may reflect the gradual colonization of northern Kachemak Bay by paper birch trees during the mid-Holocene. Small amounts of Picea pollen within this subzone are probably derived from long-distance wind transport from distant sources to the north (northern Kenai Lowland).

Zone C-1 represents the past ca. 3,800 yr of record in the Kachemak Bay area during which Picea began to colonize the north shore. The initial colonization was probably by boreal spruce (Picea mariana and possibly some P. glauca) from the lowlands to the north (Ager, 1983). Alnus and Betula are important components throughout zone C-1, and, except for the important expansion of spruce populations in the area, there is little indication of vegetation change in this interval. Two small spruce needles found in sediments from 105-115 $\mathrm{cm}$ depth in the Circle Lake core indicate that Picea was growing in the vicinity of the lake by about 3,000 yr B.P. The rising percentages of spruce pollen percentages in the upper ca. $80 \mathrm{~cm}$ of the core may be the result of the arrival of Picea sitchensis populations in the Kachemak Bay area from Prince William Sound, by way of the Kenai Mountains within the past ca. 1,650-2,000 years. 


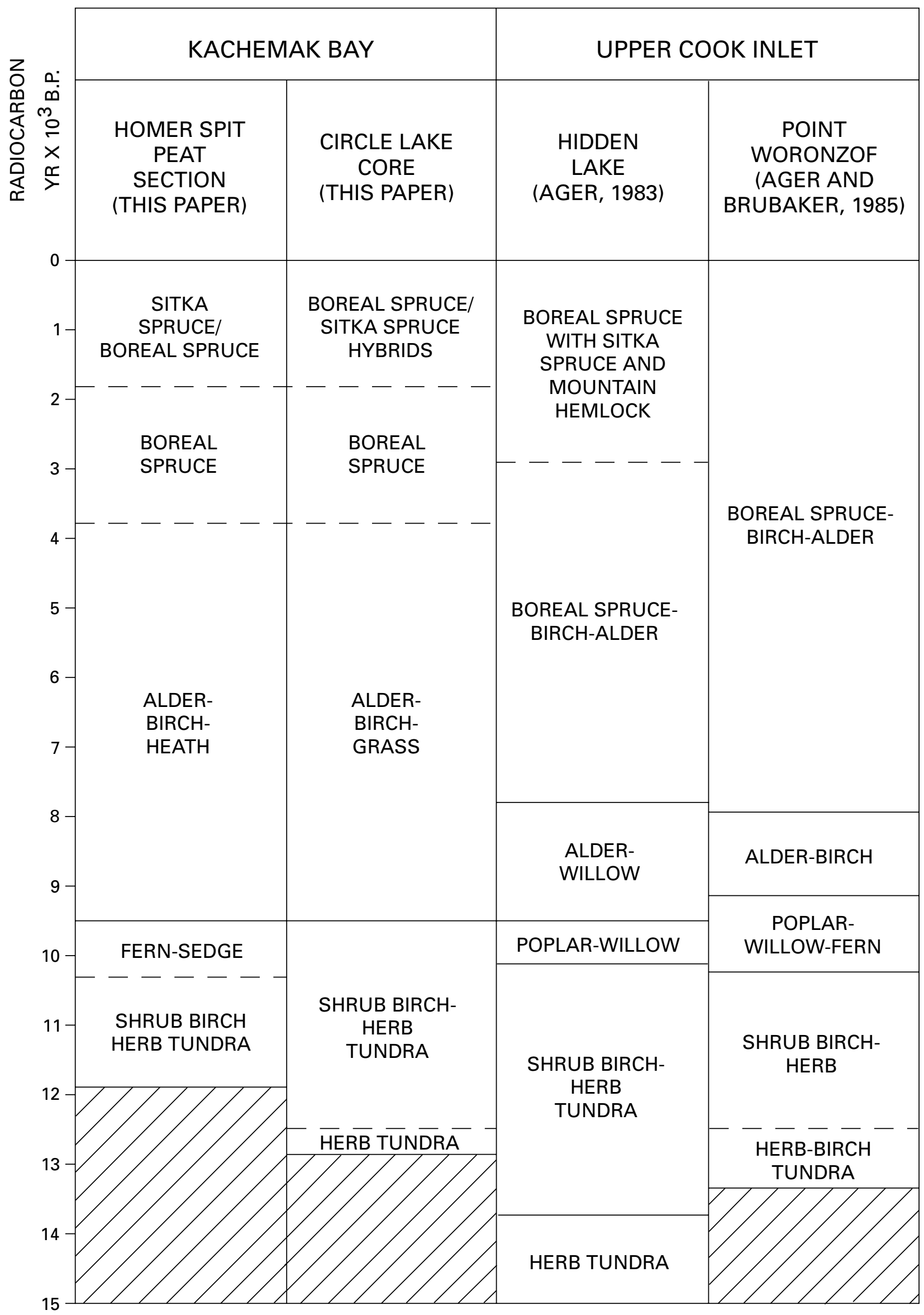

Figure 7. Summary and comparison of postglacial vegetation histories of Kachemak Bay and upper Cook Inlet based on pollen records from key sites discussed in this paper. Figure 1 shows locations of sites included in this chart. 


\section{Summary}

This paper presents the earliest radiocarbon ages yet obtained from the Kachemak Bay area, providing a minimum age of 12,800 yr B.P. for deglaciation of the southern Kenai Lowlands. The pollen records from Kachemak Bay (fig. 7) indicate that the earliest pioneering vegetation following the retreat of glacial ice was herbaceous tundra composed of grasses, sedges, willows, low herbs, and scouring rush (Equisetum). Herb tundra was apparently quickly replaced by shrub tundra of dwarf birch, Ericales, and willows that persisted for nearly 3,000 yr. Small amounts of alder pollen which appear in the Kachemak Bay area in the early postglacial deposits (pre-9,500 yr B.P.), hint at the possibility that at least one species (Alnus tenuifolia?) survived in refugia (e.g., north of the bay) during full glacial time. By about 9,500 yr B.P., alder populations (probably including Sitka alder, Alnus sinuata) expanded quickly around Kachemak Bay and, almost simultaneously, throughout the Cook Inlet region. The alder population explosion was probably in response to both postglacial climatic warming and the probable arrival of Sitka alder from coastal populations in southeastern Alaska. Poplars and perhaps aspens appeared in the Kachemak Bay area at about the same time as the alder expansion. Alder-dominated vegetation persisted in the Kachemak Bay area until about 3,800 yr B.P., when boreal spruce (white and (or) black spruce) first began to invade the north shore of the bay. The late Holocene arrival of boreal spruce in the northern Kachemak Bay area is difficult to explain because boreal spruce spread rapidly throughout much of lowland, interior south-central Alaska and much of upper Cook Inlet during the early Holocene. The migration rate by boreal spruce changed from about $0.4 \mathrm{~km} / \mathrm{yr}$ during the early Holocene in south-central Alaska to only about $0.03 \mathrm{~km} / \mathrm{yr}$ during the middle Holocene. This dramatic slowing of boreal spruce migration on southern Kenai Peninsula may have resulted from somewhat warmer, wetter winter climates near the southern coast of the Kenai Peninsula. Boreal spruce is poorly adapted to maritime climates. Sitka spruce began to invade the Kachemak Bay area, presumably from coastal forest sources in Prince William Sound, by ca. 1,650 yr B.P. or slightly earlier.

The Kachemak Bay pollen records differ in significant ways from those for the upper Cook Inlet, where boreal spruce forests developed earlier in the Holocene, and where the influence of maritime climate and the Pacific coastal forest flora was more limited. The use of pollen data as proxies for reconstructing regional paleoclimates in atmospheric general circulation models may result in erroneous climatic reconstructions if the topographic and climatic complexity of mountainous regions and the varied influences of maritime climate are not taken into consideration. In such complex terrain, it is necessary to compile paleovegetation records from as many sites as possible to capture the details of past vegetation patterns, especially if the data are to be used for paleoclimatic modeling.

\section{References Cited}

Ager, T.A., 1975, Late Quaternary environmental history of the Tanana Valley, Alaska: Columbus, Ohio, The Ohio State University Institute of Polar Studies Report 54, 107 p.

Ager, T.A., 1983, Holocene vegetational history of Alaska, in Wright, H.E., Jr., ed., Late-Quaternary Environments of the United States. Vol. 2. The Holocene: Minneapolis, University of Minnesota Press, p. 128 140.

Ager, T.A., 1989, History of late Pleistocene and Holocene vegetation in the Copper River basin, south-central Alaska, in Carter, L.D., Hamilton, T.D., and Galloway, J.P., eds., Late Cenozoic History of the Interior Basins of Alaska and the Yukon: U.S. Geological Survey Circular 1026, p. 89-92.

Ager, T.A., and Brubaker, L.B., 1985, Quaternary palynology and vegetational history of Alaska, in Bryant, V., and Holloway, R., eds., Pollen Records of Late-Quaternary North American Sediments: Dallas, Texas, American Association of Stratigraphic Palynologists Foundation, p. 354-384.

Ager, T.A., and Sims, J.D., 1984, Postglacial pollen and tephra records from lakes in the Cook Inlet region, southern Alaska, in Coonrad, W.L., and Elliott, R.L., eds., The United States Geological Survey in Alaska: Accomplishments During 1981: U.S. Geological Survey Circular 868, p. 103-105.

Anderson, P.M., and Brubaker, L.B., 1988, Vegetation history of northcentral Alaska: A mapped summary of the late-Quaternary pollen data: Quaternary Science Reviews, v. 13, p. 71-92.

Anderson, P.M., Lozhkin, A.V., Eisner, W.R., Kozhevnikova, M.V., Hopkins, D.M., Brubaker, L.B., and Colinvaux, P.A., 1994, Two late Quaternary pollen records from south-central Alaska: Géographie physique et Quaternaire, v. 44, p. 3-13.

Barnosky, C.W., Anderson, P.M., and Bartlein, P.J., 1987, The northwestern U.S. during deglaciation; Vegetational history and paleoclimatic implications, in Ruddiman, W.F., and Wright, H.E., Jr., eds., North America and Adjacent Oceans During the Last Glaciation: Boulder, Geological Society of America, The Geology of North America, v. K-3, p. 289-321.

Copes, D.L., and Beckwith, R.C., 1977, Isoenzyme identification of Picea glauca, $P$. sitchensis, and $P$. lutzii populations: Botanical Gazette, v. 138 , p. 512-521.

Goldthwait, R.P., Lowe, F., Ugolini, F.C., Decker, H.F., DeLong, D.M., Trautman, M.B., Good, E.E., Merrill, T.R., III, and Rudolph, E.D., 1966, Soil development and ecological succession in a deglaciated area of Muir Inlet, southeast Alaska: Columbus, Ohio, Institute of Polar Studies Report No. 20, The Ohio State University Research Foundation, $167 \mathrm{p}$.

Hajdas, I., Boden, G., Peteet, D.M., and Mann, D.H., 1998, Cold reversal on Kodiak Island, Alaska, correlated with the European Younger Dryas by using variations of atmospheric ${ }^{14} \mathrm{C}$ content: Geology, v. 26, no. 11, p. 1047-1050.

Hamilton, T.D., and Thorson, R.M., 1983, The Cordilleran ice sheet in Alaska, in Porter, S.C., ed., Late-Quaternary Environments of the United States, v. 1: Minneapolis, University of Minnesota Press, p. $38-52$.

Hansen, B.C.S., and Engstrom, D.R., 1996, Vegetation history of Pleasant Island, southeastern Alaska, since 13,000 yr b.p.: Quaternary Research, v. 46, p. 161-175. 
Heusser, C.J., 1960, Late-Pleistocene environments of North Pacific North America: American Geographical Society Special Publication $35,308 \mathrm{p}$.

Heusser, C.J., 1983, Holocene vegetation history of the Prince William Sound region, south-central Alaska: Quaternary Research, v. 19, p. 337-355.

Heusser, C.J., 1985, Quaternary pollen records from the Pacific Northwest coast: Aleutians to the Oregon-California boundary, in Bryant, V., and Holloway, R., eds., Pollen Records of Late Quaternary North American Sediments: Dallas, Texas, American Association of Stratigraphic Palynologists Foundation, p. 143-165.

Hogg, E.T., 1994, Climate and the southern limit of the western Canadian boreal forest: Canadian Journal of Forest Research, v. 24, p. 18351845.

Hopkins, D.M., Smith, P.A., and Matthews, J.V., Jr., 1981, Dated wood from Alaska and Yukon: Implications for forest refugia in Beringia: Quaternary Research, v. 15, p. 217-249.

Hultén, E., 1968, Flora of Alaska and neighboring territories: Stanford, California, Stanford University Press, 1008 p.

Karlstrom, T.N.V., 1964, Quaternary geology of the Kenai Lowland and glacial history of the Cook Inlet region, Alaska: U.S. Geological Survey Professional Paper 443, $69 \mathrm{p}$.

Leslie, L.D., 1989, Alaska climate summaries: Alaska Climate Data Center Technical Note No. 5, Arctic Environmental Information and Data Center, University of Alaska - Anchorage, Anchorage, $478 \mathrm{p}$.

Mann, D.H., and Peteet, D.M., 1994, Extent and timing of the last glacial maximum in southwestern Alaska: Quaternary Research, v. 42, no. 2, p. $136-148$.

Muhs, D.R., Ager, T.A., and Begét, J.E., in press, Vegetation and paleoclimate of the last interglacial period, central Alaska: Quaternary Science Reviews.

Peteet, D.M., 1986, Modern pollen rain and vegetational history of the Malaspina Glacier district, Alaska: Quaternary Research, v. 25, p. 100-120.

Peteet, D.M., 1991, Postglacial migration of lodgepole pine near Yakutat, Alaska: Canadian Journal of Botany, v. 69, p. 786-796.

Peteet, D.M., and Mann, D.H., 1994, Late-glacial vegetational, tephra, and climatic history of southwestern Kodiak Island, Alaska: Ecoscience, v. 1, no. 3, p. 255-267.

Pojar, A., and MacKinnon, A., eds., 1994, Plants of the Pacific Northwest coast: Washington, Oregon, British Columbia \& Alaska: Redmond, Washington, Lone Pine Publishing, $528 \mathrm{p}$.

Reger, R.D., Combellick, R.A., and Brigham-Grette, J., 1995, LateWisconsin events in the upper Cook Inlet region, south-central Alaska, in Combellick, R.A., and Tannian, F., eds., Short Notes

Reviewers: Dan R. Muhs, Robert S. Thompson, and William Workman on Alaska Geology, 1995: Fairbanks, Alaska, Alaska Division of Geological and Geophysical Surveys, Professional Report 117, p. 33-45.

Reger, R.D., Pinney, D.S., Burke, R.M., and Wiltse, M.A., 1995, Cata$\log$ and initial analyses of geologic data related to middle to late Quaternary deposits, Cook Inlet region, Alaska: State of Alaska Department of Natural Resources, Division of Geological \& Geophysical Surveys, Report of Investigations 95-6, 188 p., 5 plates.

Reger, R.D., and Pinney, D.S., 1996, Late Wisconsin glaciation of the Cook Inlet region with emphasis on Kenai Lowland and implications for early peopling, in Davis, N.Y., and Davis, W.E., eds., Adventures Through Time: Readings in the Anthropology of Cook Inlet, Alaska: Anchorage, Cook Inlet Historical Society, p. 15-35.

Reger, R.D., and Pinney, D.S., 1997, Last major glaciation of Kenai Lowland, in Karl, S.M., Vaughn, N.R., and Ryherd, T.J., eds., 1997 Guide to the Geology of the Kenai Peninsula, Alaska: Anchorage, Alaska Geological Society, p. 54-67.

Riehle, J.R., 1985, A reconnaissance of the major Holocene tephra deposits in the upper Cook Inlet region, Alaska: Journal of Volcanology and Geothermal Research, v. 26, p. 37-74.

Riehle, J.R., Bowers, P.M., and Ager, T.A., 1990, The Hayes tephra deposits, an upper Holocene marker horizon in south-central Alaska: Quaternary Research, v. 33, p. 276-290.

Rymer, M.J., and Sims, J.D., 1982, Lake-sediment evidence for the date of deglaciation of the Hidden Lake area, Kenai Peninsula, Alaska: Geology, v. 10, no. 6, p. 314-316.

Thompson, R.S., Anderson, K.H., and Bartlein, P.J., in press, Atlas of Relations Between Climatic Parameters and Distributions of Important Trees and Shrubs in North America: U.S. Geological Survey Professional Paper 1650.

Viereck, L.A., and Little, E.L., Jr., 1972, Alaska Trees and Shrubs: U.S. Department of Agriculture Forest Service Handbook 410, $265 \mathrm{p}$.

Viereck, L., and Little, E., 1975, Atlas of United States Trees. Vol. 2, Alaskan Trees and Common Shrubs: U.S. Department of Agriculture Forest Service, Miscellaneous Publication 1293, 127 p.

Wiles, G.C., and Calkin, P.E., 1990, Neoglaciation in the southern Kenai Mountains, Alaska: Annals of Glaciology, v. 14, p. 319-323.

Wiles, G.C., and Calkin, P.E., 1994, Late Holocene, high-resolution glacial chronologies and climate, Kenai Mountains, Alaska: Geological Society of America Bulletin, v. 106, p. 281-303.

Wolfe, J.A., Hopkins, D.M. and Leopold, E.B., 1966. Tertiary stratigraphy and paleobotany of the Cook Inlet region, Alaska: U.S. Geological Survey Professional Paper 398-A. 


\title{
The Chemical Characteristics of Ground Water near Fairbanks, Alaska
}

\author{
By G. Lang Farmer, Richard J. Goldfarb, Michael R. Lilly, Bob Bolton, \\ Allen L. Meier, and Richard F. Sanzolone
}

\section{Abstract}

Major- and trace-element abundances, and $\mathrm{Sr}$ and $\mathrm{Pb}$ isotopic compositions, of ground waters in and near Fairbanks, Alaska, were determined to characterize their chemical characteristics and to assess the factors controlling variations in dissolved arsenic concentrations. Collected samples show majorelement $(\mathrm{Ca}>\mathrm{Mg}>\mathrm{Na}>\mathrm{K})$ and strontium and lead isotopic compositions characteristic of waters that have interacted with lithologies comprising the Fairbanks Schist. Dissolved arsenic concentrations are not highly correlated with the abundances of other major and trace elements in these waters; however, waters with high arsenic concentrations (5.4 to 450 parts per billion) tend to have relatively high concentrations of antimony (as much as $1.7 \mathrm{ppb}$ ). The correlation between arsenic and antimony suggests that both elements were derived from the oxidation of hypogene sulfide minerals (arsenopyrite) that originally formed within the Fairbanks Schist during hydrothermal activity associated with the emplacement of Cretaceous granitic rocks. Variations in measured arsenic concentrations are due, in part, to the variations in the original abundance of upgradient sulfide minerals from a given well or spring. However, speciation studies on the ground water containing the highest concentration of arsenic in this study (450 ppb) demonstrate that the arsenic occurs primarily in its reduced form (As(III)). In agreement with previous studies, we conclude that relatively reducing ground waters have the highest potential for high arsenic concentrations due to greater mobility of As(III) relative to its oxidized counterpart $(\mathrm{As}(\mathrm{V}))$. In light of this conclusion, additional studies are being undertaken to determine how seasonal variations in ground-water redox affect arsenic mobility.

\section{Introduction and Previous Work}

In the mid-1970's, it was discovered that many domestic water wells in the Fairbanks region of east-central Alaska yielded waters with extremely high concentrations of dissolved arsenic-concentrations commonly far in excess of the 50-partsper-billion (ppb) recommended safe-drinking level (Johnson and others, 1978). High levels of arsenic were also found in the urine and hair of individuals exposed to waters with high levels of arsenic (Harrington and others, 1978). Given that spring and well water represent the main sources of drinking water for the city of Fairbanks, Alaska's second largest population center, these observations had obvious implications for local homeowners and prompted the installation of arsenic purification systems on household water supplies.

Because of the significance of ground-water quality for future population growth in the Fairbanks area, it is critical to understand the factors controlling arsenic levels in local ground waters. Early studies revealed that some of the uncased wells with high arsenic values had been drilled through, and contaminated by, highly mineralized placer dredge piles (Wilson and Hawkins, 1978). But many of the wells with high arsenic concentrations were distal to and (or) upstream from known mining activities (Johnson and others, 1978). Therefore, much of the high arsenic concentrations in ground waters in the Fairbanks area must reflect a naturally high regional background for this element. The arsenic concentrations in ground water are, however, spatially variable. For example, Johnson and others (1978), from a detailed sampling program conducted between February 1976 and September 1977, reported dissolved arsenic (as well as nitrate, iron, and hardness) data for hundreds of well waters from the Fairbanks area. Measured arsenic concentrations were as high as 10 parts per million (ppm) and varied greatly between wells. In some cases, wells within less than $100 \mathrm{~m}$ of each other contained water with arsenic contents varying from $<50 \mathrm{ppb}$ to hundreds of $\mathrm{ppb}$. Weddleton and others (1989), using arsenic-concentration data from Weber (1986), also showed that there is substantial variability in well-water arsenic concentrations in the Fairbanks area, but further demonstrated that the ground waters with the highest arsenic concentrations occur in a northeast-southwest-trending belt from Gilmore dome to Cripple Creek (fig. 1).

Determining the origin of the high, but variable, groundwater arsenic concentrations has proved problematic. Johnson and others (1978) hypothesized that the variability in arsenic concentrations observed in their study reflected varying well depths, with the wells intersecting different zones in bedrock aquifers. Hawkins and others (1982) further suggested that 


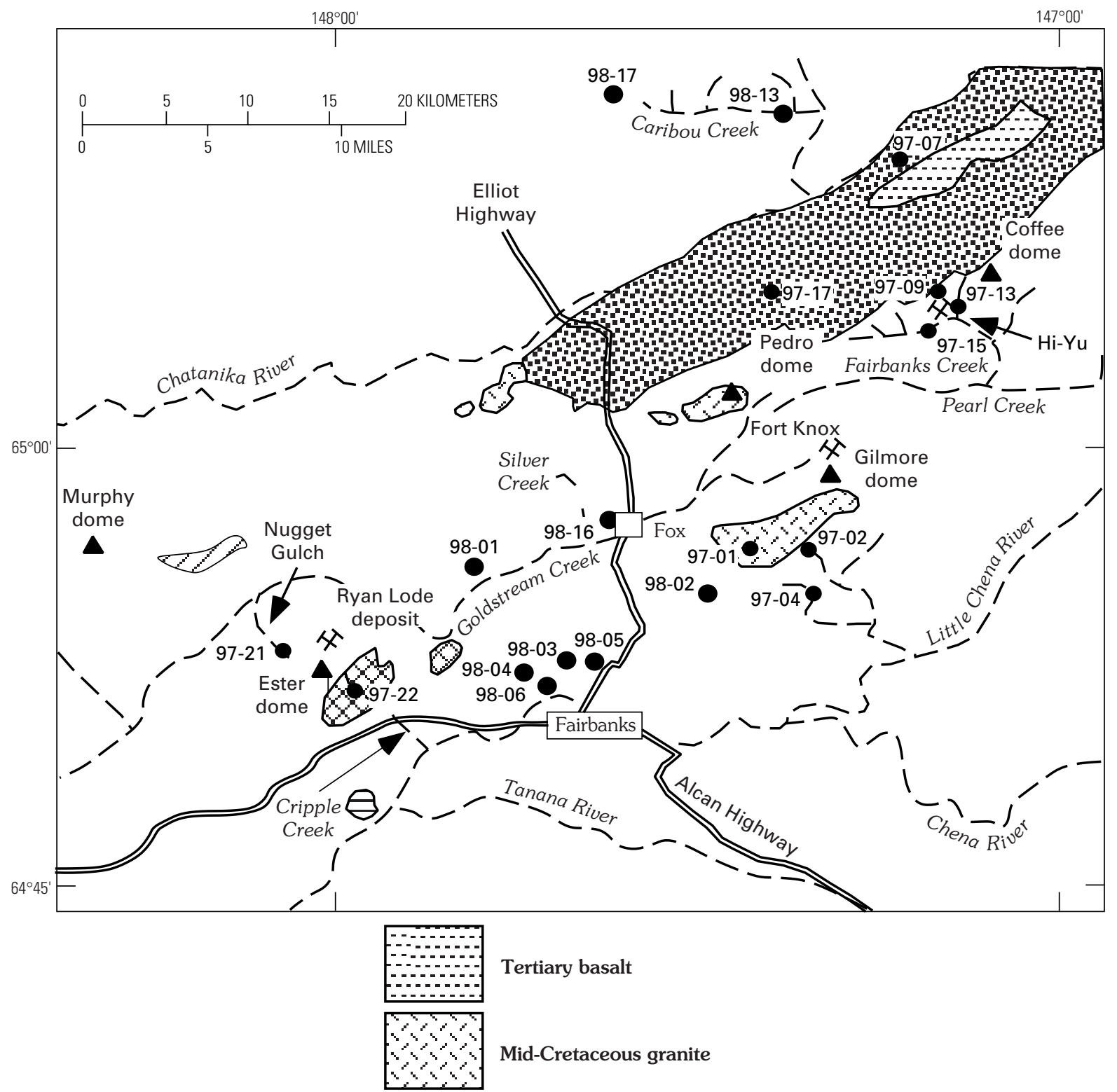

Devonian-Mississippian Chatanika assemblage
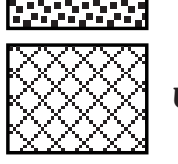

Upper Devonian Muskox Sequence

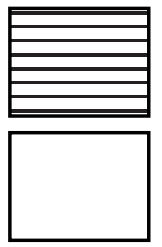

Devonian Birch Hill Sequence

97-13

Proterozoic Fairbanks Schist locally intruded by Mississippian orthogneiss

Sample site and number

Dome location

Figure 1. Site localities for ground-water samples collected during 1998 and previous surface-water samples from 1997 study. Bedrock geology generalized from Newberry and Bundtzen (1996).

highly sulfidized metasedimentary rocks immediately adjacent to wells containing ground waters with high arsenic concentrations were the cause of the significant arsenic enrichments. These workers also carried out laboratory experiments to suggest that much of the arsenic was leached from scorodite, an oxidation product of arsenopyrite. Hawkins and others (1982) speculated that the more reduced arsenic species (arsenite, As(III)) was a major component of the dissolved arsenic 
throughout the Fairbanks area. This suggestion was supported by the result of Brown and others (1982), who showed that arsenite was the more abundant arsenic species in the headwater regions of streams draining Ester dome, an area west of Fairbanks itself (fig. 1).

Even though these previous studies provide important insights into the source and distribution of arsenic in Fairbanks ground waters, questions remain regarding the factors controlling the highly variable arsenic ground-water concentrations. In this study, we present the initial results of major- and traceelement, and $\mathrm{Sr}$ and $\mathrm{Pb}$ isotope studies, of well water in the Fairbanks area. Our immediate aim was to build upon the existing studies and use the new, more detailed chemical data to (1) assess whether weathering of sulfide minerals associated with hypogene mineralization in schistose rocks is responsible for the release of arsenic into local aquifers, (2) determine if other elements commonly enriched in sulfidized bedrock (i.e., $\mathrm{Sb}, \mathrm{Te}, \mathrm{Bi}$, W) are also enriched in ground waters with high levels of arsenic, and (3) assess the role of secondary phases in controlling the amount of arsenic that is mobilized in ground water. These data represent the initial phase of a longer term study designed to better define the controls on spatial and seasonal variations of dissolved arsenic concentrations.

\section{Geologic Setting}

The geology of the Fairbanks area has been described by Robinson and others (1990), Foster and others (1994), and Newberry and Bundtzen (1996). The rocks are all part of the YukonTanana terrane, a displaced pericratonic block of late Paleozoic and older rocks that has undergone multiple episodes of deformation and metamorphism (Foster and others, 1994). The dominant lithologic unit of the Yukon-Tanana terrane exposed in the Fairbanks region is the Fairbanks Schist, a heterogeneous unit dominantly composed of quartzite and muscovitequartz \pm garnet \pm biotite \pm chlorite schist that is intruded in places by Mississippian orthogneiss (Foster and others, 1994). Minor lithologies of the Fairbanks Schist include amphibolite, magnetite-rich biotite schist, and marble (Newberry and Bundtzen, 1996). We note that the distribution of these minor units is not fully characterized, due to poor exposure throughout the region. Other important metasedimentary, volcanic, and metavolcanic units in the Fairbanks area (Newberry and Bundtzen, 1996) include (1) metamorphosed andesite, basalt, rhyolite, and sandstone of the Devonian Muskox Sequence, (2) slate, phyllite, quartzite, calcareous schist, impure marble, and minor metarhyolite tuff of the Birch Hill Sequence, (3) DevonianMississippian eclogite-bearing schist, amphibolite, and quartzite of the Devonian-Mississippian Chatanika assemblage, and (4) Tertiary basalt (Newberry and Bundtzen, 1996) (fig. 1). Bedrock units in the Fairbanks area are overlain discontinously by Quaternary Fairbanks loess (Preece and others, 1999).

Widely scattered granitic rocks intruded the Fairbanks Schist at $\sim 110 \mathrm{Ma}$ and $\sim 90 \mathrm{Ma}$ and form much of the domed upland surrounding the city of Fairbanks (fig. 1). The younger intrusive event is spatially and temporally associated with the formation of lode gold deposits in the Fairbanks area (McCoy and others, 1997). The auriferous quartz-vein deposits are hosted either by the granitic rocks (for example, the Fort Knox deposit), along granitic rock-schist contacts (Ryan Lode deposit), or solely in the schist itself (Hi-Yu deposit). Where hosted by the granitic rocks, the ores often show a Bi-Te-W enrichment, but have an extremely low sulfide content. Within the schist, however, sulfide-mineral abundances reach the percent level in many of the gold-bearing quartz-vein deposits, with arsenopyrite and stibnite being the dominant sulfide minerals.

\section{Methods}

\section{Sample-Collection and Field Methods}

Nine ground-water samples were collected from areas underlain by the Fairbanks Schist in the Fairbanks area during early June 1998 (fig. 1). The land surface is generally covered by a layer of eolian loess, but the wells penetrate the loess and intersect bedrock aquifers within the Fairbanks Schist. Six of the samples were from domestic water-supply wells along the margins of the Goldstream Creek valley (sites 98-01 to 98-06; fig. 1). This is the area characterized by Weddleton and others (1989) as the central part of the high-arsenic-concentration trend. An additional domestic water supply well was sampled from an isolated home about $15 \mathrm{~km}$ north of Fairbanks (site 9817). Two ground-water samples were also collected from natural springs. The first was taken from Fox Spring near the headwaters of Goldstream Creek (site 98-16). The second spring (site 98-13) was from the center of a pingo within the University of Alaska's Caribou Creek experimental watershed, located about $40 \mathrm{~km}$ north of Fairbanks along Caribou Creek (fig. 1).

Water temperature, $\mathrm{pH}$, and conductivity were measured at each of the sampled well and spring sites (table 1) using standard meters and probes and calibrating instruments at each site. Filtered water samples were collected in polyethylene bottles at each location using a $0.45-\mu \mathrm{m}$ filter and a portable batteryoperated pump. At each site, an acid-rinsed $60-\mathrm{mL}$ bottle was filled with filtered water for dissolved cation analyses, and the sample was acidified in the field to a $\mathrm{pH}<2$ with ultrapure concentrated nitric acid. An unacidified, filtered $125-\mathrm{mL}$ sample was collected for determination of anions. A third 60-ml sample, acidified with six drops of ultrapure hydrochloric acid and covered with aluminum foil to prevent exposure to sunlight, was also collected for arsenic speciation studies. A 1-L acid-rinsed bottle was filled with sample for isotopic analysis, and it too was acidified with ultrapure concentrated nitric acid. All samples were kept cool until they were returned to Denver, Colo., where they were then refrigerated prior to chemical analyses at the U.S. Geological Survey and the University of Colorado.

\section{Analytical Methods}

Concentrations for more than 60 trace, minor, and major elements were determined by inductively coupled plasma-mass spectrometry (ICP-MS) using the methodology of Meier and others (1994). This analytical method is characterized by analytical determination limits down to the parts per trillion level 
Table 1. Field measurements of ground waters and concentrations of dissolved cations and anions in collected, filtered ( $0.45 \mu \mathrm{m})$, acidified ground waters from the Fairbanks area.

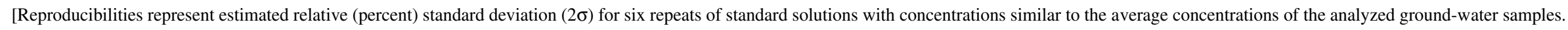
n.a., not analyzed]

\begin{tabular}{|c|c|c|c|c|c|c|c|c|c|c|}
\hline SITE & $98-01$ & $98-02$ & $98-03$ & $98-04$ & $98-05$ & $98-06$ & $98-13$ & $98-16$ & $98-17$ & Reproducibility \\
\hline Latitude & 64.924 & 64.933 & 64.896 & 64.855 & 64.899 & 64.888 & 65.15 & 64.964 & 65.127 & \\
\hline Longitude & 147.88 & 147.55 & 147.79 & 147.84 & 147.67 & 147.80 & 147.52 & 147.63 & 147.58 & \\
\hline $\mathrm{pH}$ & 7.64 & 7.66 & 7.36 & 6.96 & 7.18 & 7.31 & n.a. & 7.31 & 6.14 & \\
\hline cond $(\mathrm{mS} / \mathrm{cm})$ & 484 & 111 & 1060 & 547 & 558 & 1030 & 314 & 417 & 26 & \\
\hline $\mathrm{T}\left({ }^{\circ} \mathrm{C}\right)$ & 10 & 4.9 & 7.2 & 6.5 & 7.1 & 7.2 & 0.3 & 6.2 & 7.2 & \\
\hline \multicolumn{11}{|c|}{ MAJOR ELEMENTS (ppm) } \\
\hline $\mathrm{Ca}$ & 69 & 11 & 110 & 35 & 57 & 140 & 38 & 44 & 2.6 & 1.4 \\
\hline $\mathrm{K}$ & 5.8 & 0.7 & 6 & 0.6 & 1.1 & 0.7 & 1.4 & 3.5 & 0.2 & 1.3 \\
\hline $\mathrm{Mg}$ & 9 & 3.7 & 70 & 49 & 22 & 28 & 11 & 16 & 0.8 & 3.6 \\
\hline $\mathrm{Na}$ & 4.2 & 2.2 & 8.6 & 9.3 & 9.4 & 9.6 & 1.9 & 2.5 & 1.2 & 3.7 \\
\hline $\mathrm{SiO}_{2}$ & 13 & 14 & 9.4 & 11 & 11 & 15 & 5.9 & 7.8 & 9 & 0.8 \\
\hline \multicolumn{11}{|c|}{ TRACE ELEMENTS (ppb) } \\
\hline As & $<0.3$ & 2.3 & $<0.3$ & 450 & 6.9 & 5.4 & $<0.3$ & $<0.3$ & $<0.3$ & 1.6 \\
\hline $\mathrm{Ag}$ & 0.05 & 0.02 & $<0.01$ & $<0.01$ & $<0.01$ & $<0.01$ & $<0.01$ & $<0.01$ & $<0.01$ & n.a. \\
\hline $\mathrm{Al}$ & $<0.5$ & 1 & $<0.5$ & $<0.5$ & $<0.5$ & $<0.5$ & 26 & 52 & $<0.5$ & 3.5 \\
\hline $\mathrm{Ba}$ & 14 & 2 & 7.5 & 2 & 2 & 5.1 & 9.8 & 13 & $<0.02$ & 1.7 \\
\hline $\mathrm{Bi}$ & $<0.01$ & $<0.01$ & $<0.01$ & $<0.01$ & 0.02 & $<0.01$ & $<0.01$ & 0.01 & $<0.01$ & n.a. \\
\hline $\mathrm{Cd}$ & 0.08 & 0.04 & 0.19 & $<0.03$ & 0.04 & $<0.03$ & $<0.03$ & $<0.03$ & $<0.03$ & 3.7 \\
\hline $\mathrm{Cu}$ & 8 & 13 & 3 & 0.6 & 2 & $<0.5$ & $<0.5$ & 1 & 1 & 2.8 \\
\hline $\mathrm{Fe}$ & 81 & 14 & 190 & 550 & 55 & 5900 & 82 & 34 & $<10$ & 2.8 \\
\hline $\mathrm{Li}$ & 11 & 5 & 36 & 8.4 & 13 & 57 & 4 & 4 & 1 & 1.5 \\
\hline $\mathrm{Mn}$ & 4.6 & 0.9 & 17 & 48 & 1 & 120 & 22 & $<0.04$ & 0.5 & 2 \\
\hline Mo & 4.4 & 0.7 & 1.6 & 0.2 & 0.2 & 0.2 & 0.1 & 0.5 & $<0.06$ & 28 \\
\hline $\mathrm{Pb}$ & $<0.01$ & $<0.01$ & 0.02 & $<0.01$ & $<0.01$ & $<0.01$ & 0.02 & 0.05 & $<0.01$ & n.a. \\
\hline $\mathrm{Sb}$ & 0.08 & 0.05 & 0.02 & 1.7 & 0.7 & 0.2 & $<0.02$ & 0.03 & $<0.02$ & n.a. \\
\hline $\mathrm{Se}$ & 2 & $<0.5$ & 4.1 & 1 & 4.2 & $<0.5$ & $<0.5$ & $<0.5$ & $<0.5$ & 2 \\
\hline
\end{tabular}




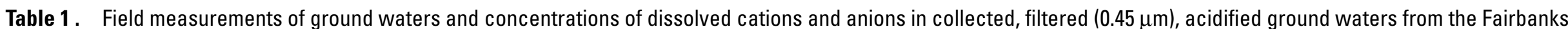
area-Continued.

\begin{tabular}{|c|c|c|c|c|c|c|c|c|c|c|}
\hline SITE & $98-01$ & $98-02$ & $98-03$ & $98-04$ & $98-05$ & $98-06$ & $98-13$ & $98-16$ & $98-17$ & Reproducibility \\
\hline $\mathrm{Sr}$ & 170 & 42 & 480 & 93 & 230 & 440 & 250 & 420 & 17 & 3.5 \\
\hline $\mathrm{Te}$ & $<1$ & $<1$ & $<1$ & $<1$ & $<1$ & $<1$ & $<1$ & $<1$ & $<1$ & n.a. \\
\hline $\mathrm{U}$ & 2.3 & 0.05 & 11 & 1.4 & 5.8 & 8.8 & 3 & 4.6 & 0.01 & 1.3 \\
\hline $\mathrm{W}$ & $<0.02$ & 4.2 & 0.4 & 0.09 & 0.02 & 0.02 & $<0.02$ & $<0.02$ & $<0.02$ & 2 \\
\hline $\mathrm{Zn}$ & 260 & 180 & 390 & 160 & 50 & 4 & 0.7 & 7 & 36 & 1.3 \\
\hline \multicolumn{11}{|c|}{ ANIONS (ppm) } \\
\hline $\mathrm{F}^{-}$ & 0.5 & 1.4 & 0.4 & 0.2 & 0.3 & 0.9 & $<0.1$ & 0.2 & $<0.1$ & n.a. \\
\hline $\mathrm{Cl}^{-}$ & 2 & 1.2 & 2.5 & 1.7 & 8.5 & 1.5 & 0.4 & 0.9 & 0.3 & n.a. \\
\hline $\mathrm{SO}_{4}{ }^{2-}$ & 56 & 4.3 & 260 & 57 & 42 & 330 & 49 & 49 & 2.3 & n.a. \\
\hline $\mathrm{NO}_{3}^{-}$ & 1.3 & 3.3 & 10 & 16 & 26 & $<0.4$ & 0.9 & 1 & 0.6 & n.a. \\
\hline Alkalinity $\left(\mathrm{ppm} \mathrm{CaCO}_{3}\right)$ & 210 & 48 & 330 & 240 & 220 & 260 & 130 & 170 & 15 & n.a. \\
\hline
\end{tabular}


for most elements. Anions were determined by ion chromatography as described in d'Angelo and Ficklin (1996). The cation and anion data are given in table 1 .

The procedure used to separate the dominant inorganic forms of dissolved arsenic, As(III) and As(V), was one based on a modification of the method by Ficklin (1983). The water samples were passed through ion-exchange columns packed with a strong anion-exchange resin (acetate form). In this technique, arsenite passes through the column while aresenate is retained until eluted with $0.12 \mathrm{M}$ hydrochloric acid. Arsenic concentrations were determined using graphite-furnace atomic absorption spectrometry with a detection limit of $3 \mathrm{ppb}$ for each species.

For the strontium isotopic analyses, $~ 50-\mathrm{mL}$ aliquots of each filtered water sample were dried in a Teflon beaker in a Class 100 clean-room environment, and the residues were passed through conventional cation-exchange columns to separate strontium. Total procedural blanks for strontium were approximately $1 \mathrm{ng}$, with ${ }^{87} \mathrm{Sr} /{ }^{86} \mathrm{Sr}=0.720$. Because greater than 1,000 ng of strontium were processed for each sample, the blank contribution to each measured ${ }^{87} \mathrm{Sr} /{ }^{86} \mathrm{Sr}$ ratio was inconsequential $(<0.00002)$. The strontium isotopic compositions were obtained using a 6-collector Finnigan MAT 261 thermal ionization mass spectrometer at the University of Colorado, Boulder. Repeated measurements of the NBS-987 strontium standard during the study period produced a mean ratio of $0.710312 \pm 2(2 \sigma ; \mathrm{n}=8)$, which is $\sim 0.00003$ higher than accepted values for this standard. As a result, the strontium isotopic data reported in table 2 have been corrected downward by this increment.

The lead isotope data were obtained from three of the wellwater samples analyzed in 1998 and 12 of the surface-water samples from the Fairbanks area collected in 1997 by Goldfarb and others (1999). The lead analyses reported in table 2 were corrected for mass discrimination by extrapolating the measured isotopic compositions to the time when heating procedure was initiated (resulting in a 0.1 to 0.5 percent downward correction in measured isotopic compositions). Repeated measurements of the NBS-981 Pb isotope standard $(\mathrm{n}=11)$ yielded a ${ }^{208} \mathrm{~Pb} /$ ${ }^{204} \mathrm{~Pb}=36.575 \pm 0.073,{ }^{207} \mathrm{~Pb} /{ }^{204} \mathrm{~Pb}=15.452 \pm 0.021$ and ${ }^{206} \mathrm{~Pb} /$ ${ }^{204} \mathrm{~Pb}=16.909 \pm 0.117$. These values are $\sim 2 \%$ o lower than accepted values, so the lead isotope ratios reported in table 2 have been corrected upward by this increment.

Table 2. Lead and strontium concentration and isotopic data from Fairbanks area well and surface waters. [Strontium isotopic and concentration data for surface-water samples from Goldfarb and others (1999)]

\begin{tabular}{|c|c|c|c|c|c|c|}
\hline SITE & $\operatorname{Sr}(p p b)^{1}$ & ${ }^{87} \mathrm{Sr} /{ }^{86} \mathrm{Sr}^{2}$ & $\mathrm{~Pb}\left(\mathrm{ppb}^{3}\right)$ & ${ }^{208} \mathrm{~Pb} /{ }^{204} \mathrm{~Pb}^{4}$ & ${ }^{207} \mathrm{~Pb} /{ }^{204} \mathrm{~Pb}$ & ${ }^{206} \mathrm{~Pb} /{ }^{204} \mathrm{~Pb}$ \\
\hline \multicolumn{7}{|c|}{ Well Waters } \\
\hline 98-01 & 201 & $0.71586 \pm 1$ & 0.3 & 37.958 & 15.552 & 18.225 \\
\hline $98-02$ & 48.5 & $0.72864 \pm 1$ & 0.2 & 39.470 & 15.810 & 20.458 \\
\hline $98-03$ & 588 & $0.72545 \pm 1$ & 0.2 & - & - & - \\
\hline 98-04 & 129 & $0.73395 \pm 3$ & $<0.05$ & - & - & - \\
\hline $98-05$ & - & - & 0.59 & - & - & - \\
\hline $98-06$ & - & - & $<0.05$ & - & - & - \\
\hline $98-17$ & 18.8 & $0.73438 \pm 1$ & 0.1 & 39.400 & 15.796 & 20.251 \\
\hline \multicolumn{7}{|c|}{ Surface Water } \\
\hline $97-02$ & 174 & 0.7251 & $<0.5$ & 38.859 & 15.661 & 19.312 \\
\hline $97-04$ & 102 & 0.7360 & $<0.5$ & 38.998 & 15.733 & 19.903 \\
\hline $97-05$ & 63 & 0.7182 & $<0.5$ & 38.956 & 15.684 & 19.967 \\
\hline $97-07$ & 126 & 0.7392 & $<0.5$ & 39.570 & 15.820 & 20.502 \\
\hline 97-09 & 37 & 0.7312 & $<0.5$ & 38.798 & 15.695 & 19.603 \\
\hline $97-13$ & 71 & 0.7364 & $<0.5$ & 38.510 & 15.679 & 18.844 \\
\hline $97-15$ & 70 & 0.7354 & 0.3 & 39.116 & 15.666 & 19.138 \\
\hline $97-17$ & 258 & 0.7231 & $<0.5$ & 38.663 & 15.657 & 19.374 \\
\hline $97-21$ & 39 & 0.7296 & $<0.5$ & 38.762 & 15.686 & 19.613 \\
\hline $97-22$ & 27 & 0.7249 & $<0.5$ & 38.818 & 15.703 & 19.568 \\
\hline \multicolumn{7}{|c|}{ Pingo } \\
\hline $98-13$ & 297 & $0.74071 \pm 1$ & $<0.05$ & - & - & - \\
\hline \multicolumn{7}{|c|}{$\begin{array}{l}{ }^{1} \text { Strontium concentration by isotope dilution. Strontium concentrations and isotopic compositions for surface waters re } \\
\text { in Goldfarb and others (1999). } \\
{ }^{2} \text { Errors on }{ }^{87} \mathrm{Sr} /{ }^{86} \mathrm{Sr} \text { are } 2-\sigma \text { (mean) and refer to last significant figures. } \\
{ }^{3} \text { Lead concentrations from table } 1 \text { (ICP-MS determinations). } \\
{ }^{4} \text { Based on repeated measurements of NBS- } 981 \text {, the measured lead isotopic compositions are considered to represent a } \\
0.1 \text { to } 0.2 \% \text { external reproducibility (see text for further discussion of lead isotope measurements). }\end{array}$} \\
\hline
\end{tabular}




\section{Results}

\section{Chemical Characteristics}

The major-element ( $\mathrm{Mg}, \mathrm{Ca}, \mathrm{K}, \mathrm{Na}$, and $\mathrm{SiO}_{2}$ ) contents of the ground-water samples vary over a wide range, particularly $\mathrm{Ca}$ (2.6 to $140 \mathrm{ppm})$ and $\mathrm{Mg}(0.8$ to $70 \mathrm{ppm}$ ) (table 1; fig. 2). In most samples, however, major-element abundances decrease in the order $\mathrm{Ca}>\mathrm{Mg}>\mathrm{Na}>\mathrm{K}$. The main exceptions are sample 9817 , which has a low conductivity $(26 \mu \mathrm{S} / \mathrm{cm})$ and low majorelement contents in the order $\mathrm{Ca}>\mathrm{Na} \sim \mathrm{Mg}>\mathrm{K}$, and 98-04, which has $\mathrm{Mg}>\mathrm{Ca}$.

Minor- and trace-element abundances in the ground waters also vary widely. For example, iron and sulfate from the wells along the Goldstream Valley range over about two orders of magnitude, despite relatively constant $\mathrm{pH}$ values $(\sim 7$; fig. 2). The State of Alaska maximum contaminant level (the maximum concentration allowable in public drinking-water systems) is $300 \mathrm{ppb}$ for iron and $250 \mathrm{ppm}$ for sulfate, and is thus exceeded by one or both species in waters from three of the Goldstream Valley domestic-water-supply wells (98-03, 9804, 98-06). Other elements with wide concentration ranges include U (0.05 to $8.8 \mathrm{ppb}), \mathrm{Sr}(17-480 \mathrm{ppb}), \mathrm{Mn}$ (0.1 to 120 $\mathrm{ppb})$, and $\mathrm{Cl}^{-}$(0.9 to $8.5 \mathrm{ppm}$; concentration ranges quoted exclude sample 98-17).

Arsenic concentrations are generally low $(<7 \mathrm{ppb})$, with the exception of the high arsenic content for sample 98-04 (450 ppb), a value that previous studies suggest may be common among other wells along Goldstream Creek. The high total arsenic content for this well water was measured in the HCl-preserved sample from site 98-04, which was analyzed for arsenic by furnace atomic absorption (AA) after inorganic species separation.

Almost all of the arsenic was present as the reduced arsenite species, with only about 10 percent $(\sim 20 \mathrm{ppm})$ of the total arsenic occurring as arsenate. Surprisingly, the sample acidified with nitric acid from site 98-04 and analyzed by ICP-MS contained only $140 \mathrm{ppb}$ As. This sample was subsequently rerun by hydride-generation AA, and a similar low arsenic concentration was measured. The discrepancy between the two samples, collected at the same time and from the same source, but preserved by two different acids, suggests that arsenic was "lost" in some unknown fashion from the nitric-preserved sample. In our ongoing multi-element ICP-MS studies of high-arsenic-content ground waters near Fairbanks, we are attempting to determine whether nitric acid fixed arsenic in solution, both for $\mathrm{As}(\mathrm{V})$ - and As(III)-rich samples, or whether an alternative technique, perhaps using hydrochloric acid, is necessary to preserve the water samples.

\section{Isotopic Compositions}

The isotopic compositions of strontium dissolved in the well waters range from 0.71586 to 0.73438 , with sample $98-01$ containing the least radiogenic Sr (fig. 3). Dissolved lead in sample 98-01 also has considerably lower ${ }^{206} \mathrm{~Pb} /{ }^{204} \mathrm{~Pb},{ }^{207} \mathrm{~Pb} /$ ${ }^{204} \mathrm{~Pb}$, and ${ }^{208} \mathrm{~Pb} /{ }^{204} \mathrm{~Pb}$ ratios (fig. 4) than lead from the other

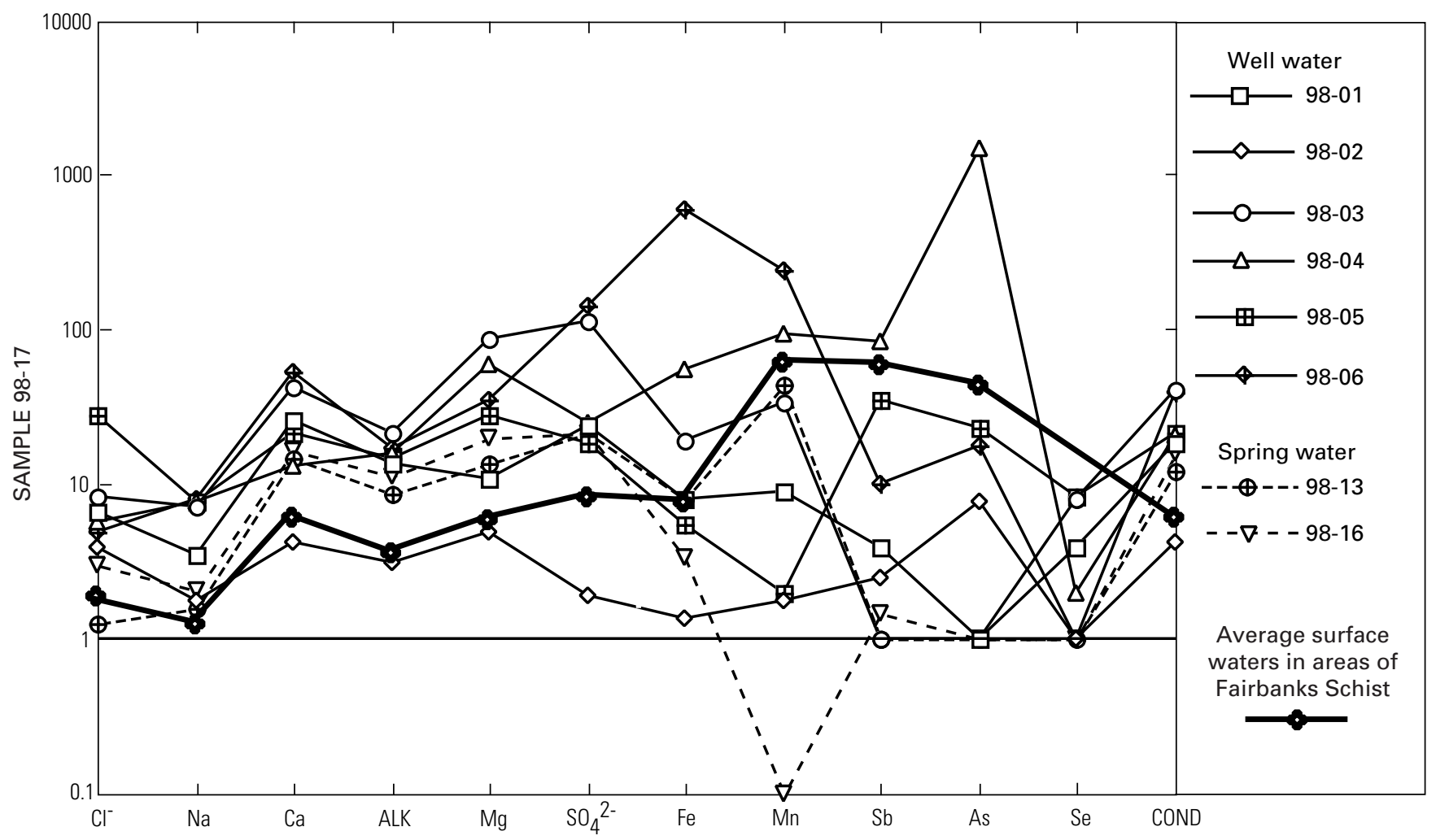

Figure 2. Selected major- and trace-element abundances of Fairbanks-area ground waters. The data have been normalized to the element abundances for sample 98-17, the ground water with the lowest conductivity and, presumably, the shortest residence time underground. ALK, alkalinity; COND, conductivity (see table 1). Average chemical composition of surface water in areas draining Fairbanks Schist calculated from data in Goldfarb and others (1999). 
two well waters analyzed in this study. The latter two (samples 98-02 and 98-17) contain radiogenic lead that lies to the right of the geochron, typical of upper crustal lead (Faure, 1986). Dissolved lead in individual surface-water samples studied by Goldfarb and others (1999) shares these same isotopic characteristics (fig. 4). For the surface-water samples, there is no obvious distinction between the isotopic compositions of dissolved lead in waters that interacted with different bedrock types (fig. 4).

\section{Discussion}

In general, the relatively high conductivities of the analyzed well waters indicate that they must have interacted considerably with the bedrock through which they traversed. The one exception is sample $98-01$ because the low conductivity $(26 \mu \mathrm{S} / \mathrm{cm})$ suggests that this water may have had a short residence time in the subsurface. This conclusion is consistent with the fact that this particular well was located at a relatively high elevation near a hilltop north of Fairbanks and may have tapped a local, perched water table (fig. 1). All of the sampled wells (including 98-17) tapped aquifers within the Fairbanks Schist and have similar major- and trace-element abundances, and strontium and lead isotopic compositions, as those of surface waters from areas underlain by Fairbanks Schist (figs. 2-4). The obvious conclusion is that chemical characteristics of most of the well waters were controlled by chemical weathering of the various lithologies comprising the Fairbanks Schist.

If the well water sampled at site $98-17$ is considered as the most "pristine" water sample analyzed, then it is appears that progressive interaction between meteoric water and Fairbanks Schist results in increases in ground-water $\mathrm{Na}, \mathrm{Ca}, \mathrm{Mg}$, and $\mathrm{SO}_{4}{ }^{2}$ contents. Without detailed information on the abundances and compositions of various mineral phases within the schist, we cannot yet reconstruct the weathering reactions that controlled the ground-water compositions. However, the high calcium content of most of the well and surface waters are most likely the result of calcite and plagioclase dissolution (see also Golfarb and others, 1999). Similarly, sodium and magnesium in the ground waters could reflect plagioclase and biotite \pm pyroxene weathering. Sulfide oxidation may play an important role in controlling the abundances of other elements. For example, the water sampled at site 98-06 contains a high concentration of $\mathrm{SO}_{4}{ }^{2-}(340 \mathrm{ppm})$ and almost $6 \mathrm{ppm}$ of dissolved iron, both of which are consistent with the breakdown of pyrite and (or) pyrrhotite. We note that dissolution of sulfides without any obvious acidic pH's indicates a high buffering capacity for the Fairbanks Schist, presumably as a result of calcite dissolution.

While the isotopic compositions of dissolved strontium and lead in most of the ground waters are consistent with the derivation of these elements from weathering of the Fairbanks Schist, well water from site 98-01 contains relatively nonradiogenic lead (fig. 4) and has a strontium isotopic compositions similar to that of surface waters draining Cretaceous granitic rocks (fig. 3). Nonetheless, granitic rocks are not known in the surface or subsurface immediately north of Goldstream Creek (fig. 1), so it seems unlikely that this ground water interacted with such rock types. The relatively high calcium content of the water from site 98-01 also argues against a granitic source for the dissolved load in these waters

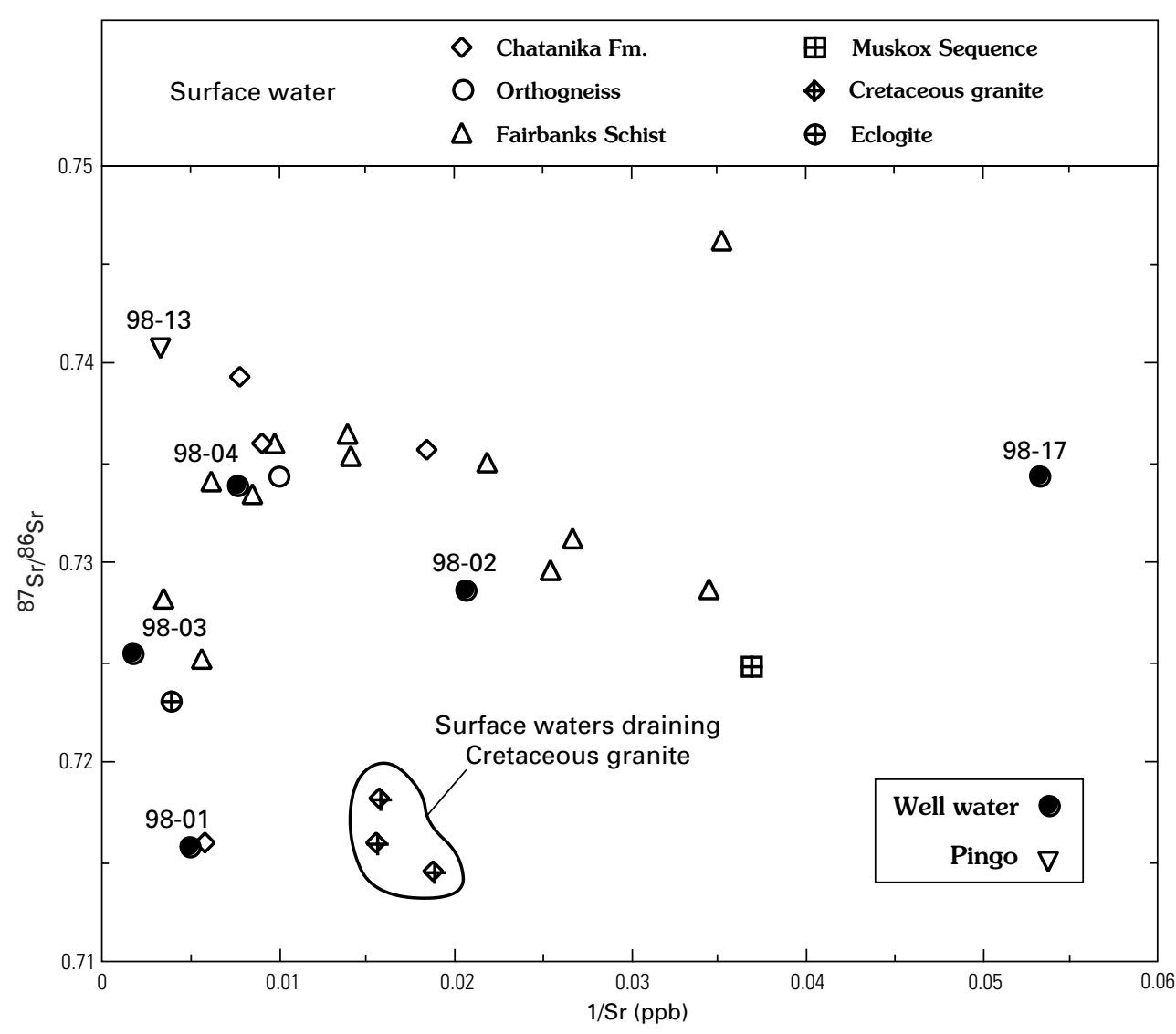

Figure 3. ${ }^{87} \mathrm{Sr} /{ }^{86} \mathrm{Sr}$ vs. $1 / \mathrm{Sr}(\mathrm{ppb})$ for ground-water samples. Data from individual surface-water samples from Goldfarb and others (1999). Sample numbers shown are those from this study. Two-sigma error bars for isotopic and concentration analyses are smaller than the symbol size. 


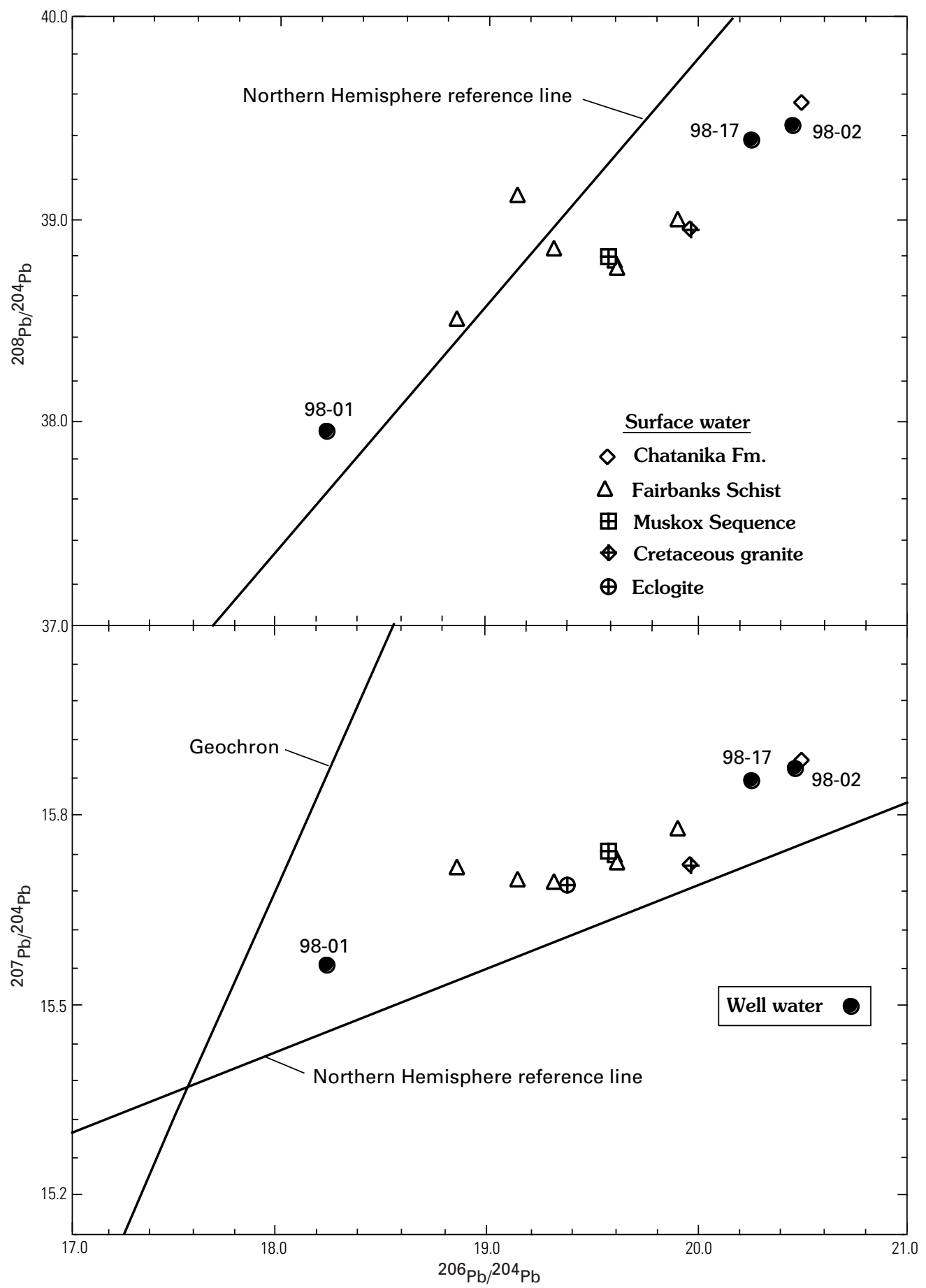

Figure 4. ${ }^{208} \mathrm{~Pb} /{ }^{204} \mathrm{~Pb}$ and ${ }^{207} \mathrm{~Pb} /{ }^{204} \mathrm{~Pb}$ for dissolved lead for ground waters (this study) and surface waters from Goldfarb and others (1999). Two-sigma error bars for isotopic data are approximately the same size as data symbols.

because waters draining the granitic rocks are characterized by calcium contents $<10$ ppm (fig. 5) (Goldfarb and others, 1999). A significant contribution of strontium from carbonate minerals within the Fairbanks Schist might account for both the high calcium and nonradiogenic strontium (and lead?) in 98-01, but no strontium or lead isotopic data are available from local carbonates to test this possibility.

\section{Origin of Arsenic in Ground Waters}

The arsenic contents of the analyzed ground waters vary widely, but only one sample, site 98-04, contains notably high dissolved arsenic (450 ppb). The water from this site contains strontium derived from the Fairbanks Schist and suggests that 


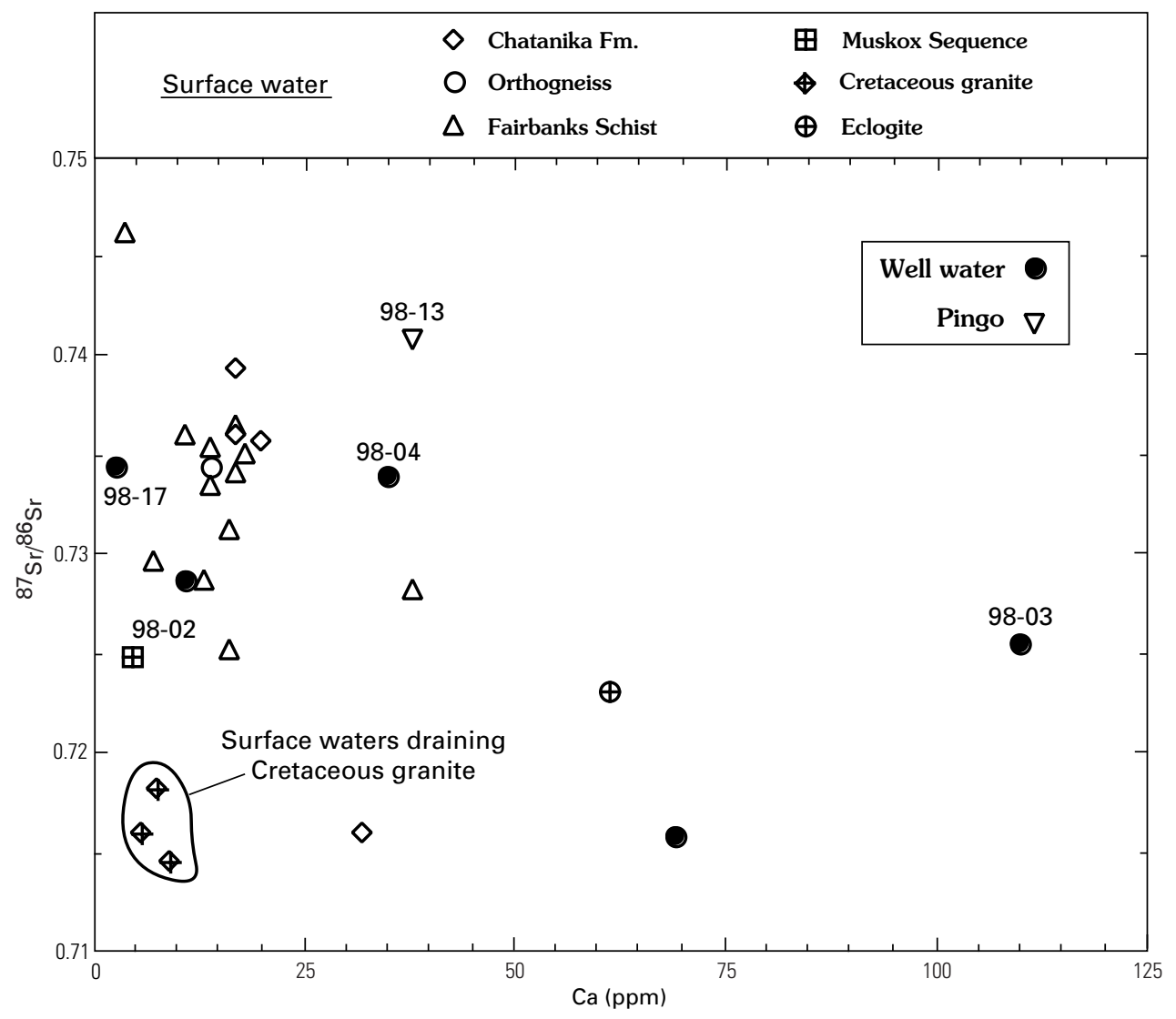

Figure 5. ${ }^{87} \mathrm{Sr} /{ }^{86} \mathrm{Sr}$ vs. calcium (ppm) for ground waters (this study) and surface waters (Goldfarb and others, 1999) in Fairbanks area.

weathering of the schist was the main source of dissolved constituents in this sample. It is reasonable to further suggest that the arsenic content of sample 98-04 is also ultimately related to weathering of this rock unit. Furthermore, even though the water from site 98-04 lacks anomalous Te, $\mathrm{W}$, and Bi (table 1) elements that along with arsenic are commonly associated with auriferous metal enrichments in the Fairbanks area-it does contain the highest antimony concentration $(1.7 \mathrm{ppb})$ of any of the analyzed water samples. As mentioned earlier, gold mineralization in the Fairbanks Schist is characterized by sulfides enriched in both arsenic and antimony (lodes hosted by granitic bodies are rich in $\mathrm{Te}, \mathrm{Bi}$, and $\mathrm{W}$ but not Sb; McCoy and others, 1997). The high concentrations of arsenic and antimony in the water from site 98-04 are consistent, therefore, with the ultimate derivation of these elements from the oxidation of sulfide minerals (arsenopyrite) within the bedrock schist. The general lack of anomalous arsenic in other ground waters could reflect the discontinuous distribution of arsenic-bearing sulfide phases within the schistose rocks, as suggested by Hawkins and others (1982).

We note, however, that the majority of the arsenic in the water at site 98-4 is in its reduced (III) form. The occurrence of As(III) in solution requires relatively reducing conditions, with Eh values less than $\sim 100 \mathrm{mV}$ (Brookins, 1988; Deutsch, 1997). In addition, even though the water at site 98-04 does contain a high iron content (550 ppb), it has a relatively low sulfate concentration $(59 \mathrm{ppm})$ that is similar to many of the ground waters with much lower arsenic concentrations (table 1; fig. 2). These observations suggest that the ground water present at site 98-04 is not capable of oxidizing primary arsenopyrite, in which case the arsenic present in the ground water must have been derived from the oxidation of arsenopyrite that occurs upgradient along the ground-water flow path. However, the relatively reducing conditions in the ground water could be responsible for the high dissolved arsenic content of this sample. In general, arsenite, in the form of $\mathrm{H}_{3} \mathrm{AsO}_{3}$, is relatively mobile in solution, whereas $\mathrm{As}(\mathrm{V})$ forms oxyanions that readily coprecipitate with, and (or) are adsorbed onto, the surfaces of secondary minerals such as ferrihydrite $\left(\mathrm{Fe}_{2} \mathrm{O}_{3} 2 \mathrm{H}_{2} \mathrm{O}\right.$; Fuller and others, 1993; Deutsch, 1997). Arsenate also forms secondary solids, such as $\mathrm{FeAsO}_{4} \mathrm{H}_{2} \mathrm{O}$ (scorodite) and $\mathrm{Mn}\left(\mathrm{AsO}_{4}\right)_{2}$ (Deutsch, 1997). Therefore, the high dissolved arsenic content of the sample from site 98-04 could reflect the enhanced mobility of arsenic under relatively reducing conditions and (or) the instability of mineral phases in which arsenic would otherwise be sequestered.

The key problem in understanding arsenic distribution in Fairbanks ground water, therefore, becomes the determination of the relative role of primary weathering reactions and varying ground-water redox conditions in controlling arsenic abundances. We have insufficient data to fully address this issue. Scorodite has been suggested as a concentration-limiting phase for arsenic in Fairbanks ground waters (Hawkins and others, 1982); however, this seems unlikely in light of more recent information suggesting that scorodite is stable only under acidic conditions ( $\mathrm{pH}=4-5$; Deutsch, 1997). The waters studied here all have near-neutral $\mathrm{pH}$, regardless of the dissolved arsenic concentration. In addition, there is no obvious relationship between $\mathrm{Fe}, \mathrm{Mn}$, and As levels in the waters. This fact also 
argues against an important role for arsenic-bearing secondary phases in controlling the concentration of dissolved arsenic, although waters with the highest arsenic-content do tend to contain significant dissolved iron concentrations (fig. 2). Such a correlation between increased iron and arsenic might be expected under relatively reducing conditions because at $\mathrm{pH}=7$ and $\mathrm{Eh}<100 \mathrm{mV}$, ferrihydrite become significantly soluble (Deutsch, 1997). An enhanced solubility of ferrihydrite would increase the iron (in the form of ferrous iron) and arsenic concentration in solution through dissolution and could also reduce the number of ferrihydrite sites for arsenic adsorption. Conversely, under oxidizing conditions, any As(V) would be readily adsorbed by ferrihydrite surfaces, resulting in low arsenic concentrations in ground water.

\section{Summary}

Based on the available chemical and isotopic data, we suggest that (1) the dissolved constituents in Fairbanks ground waters sampled were largely derived from weathering of schistose bedrock and (2) the arsenic concentration variations observed most likely reflect both the availability of arsenic in the form of arsenic-bearing sulfide minerals along a given groundwater flow path and variations in ground-water redox conditions, the latter controlling the arsenic oxidation state and mobility.

We cannot yet fully test the role of redox conditions in controlling the concentrations of arsenic, or other multivalent elements (such as iron), in the ground waters because we do not have estimates of Eh, dissolved oxygen, or ferrous/ferric ratios. We also have not tested whether arsenic mobilization is influenced by other factors, such as amount of organic material within the aquifer, or microbial action (Brown and others, 1982; Grantham and others, 1997). Of particular interest is the possibility that seasonal changes in the chemical characteristics of well waters may influence the mobilization of arsenic. During 1983 and 1984, McCrum (1985) conducted a ground-water sampling program to determine seasonal trends in arsenic levels. Results showed no consistent well-to-well arsenic patterns but did reveal that peaks in dissolved arsenic loads in late spring occurred in both years. This may suggest an important yearly flushing event for arsenic.

Additional studies will involve the acquisition of oxygen and deuterium isotope data and the seasonal collection of ground-water samples in order to address whether changes in sources and (or) redox conditions of ground water occur on a seasonal basis and how this affects arsenic mobility in the local aquifers. These data, along with major-element, trace- element, and radiogenic-isotope data, should allow more detailed geochemical modeling of the ground-water chemical variations than that attempted here.

\section{References Cited}

Brookins, D.G., 1988, Eh-pH diagrams for geochemistry: Berlin, SpringerVerlag, $176 \mathrm{p}$.
Brown, E.J., Luong, H.V., and Forshaug, J.M., 1982, The occurrence of Thiobacillus ferrooxidans and arsenic in subarctic streams affected by gold-mine drainage: Arctic, v. 35, p. 417-421.

d'Angelo, W.M., and Ficklin, W.H., 1996, Fluoride, chloride, nitrate, and sulfate in aqueous solution by chemically suppressed ion chromatography, in Arbogast, B.F., ed., Analytical Methods Manual for the Mineral Resource Surveys Program, U.S. Geological Survey: U.S. Geological Survey Open-File Report 96-525, p. 149-153.

Deutsch, W.J., 1997, Groundwater geochemistry—Fundamentals and applications to contamination: Boca Raton, Lewis Publishers, 221 p.

Faure, G.F., 1986, Principles of isotope geology: New York, John Wiley and Sons, $589 \mathrm{p}$.

Ficklin, W.H., 1983, Separation of arsenic (III) and arsenic (IV) in ground waters by ion-exchange: Talanta, v. 30, p. 371-373.

Foster, H.L., Keith, T.E.C., and Menzie, W.D., 1994, Geology of the YukonTanana area of east-central Alaska, in Plafker, G., and Berg, H.C., eds., The Geology of Alaska: Geological Society of America, Geology of North America, v. G-1, p. 205-240.

Fuller, C.C., Davis, J.A., and Waychunas, G.A., 1993, Surface chemistry of ferrihydrite: Part 2. Kinetics of arsenate adsorption and coprecipitation: Geochimica et Cosmochimica Acta, v. 57, p. 22712282.

Goldfarb, R.J., Farmer, G.L., Cieutat, B.A., and Meier, A.L., 1999, Majorelement, trace-element, and strontium-isotope systematics of natural waters in the Fairbanks mining district: Constraints from local geology, in Kelley, K.D., ed., Geological Studies in Alaska by the U.S. Geological Survey, 1997: U.S. Geological Survey Professional Paper 1614, p. 139-150.

Grantham, M.C., Dove, P.M, and DiChristina T.J., 1997, Microbially catalyzed dissolution of iron and aluminum hydroxide mineral surface coatings: Geochimica et Cosmochimica Acta, v. 61, p. 4467-4477.

Harrington, J.M., Middaugh, J.P., Morse, D.L., and Housworth, J., 1978, A survey of population exposed to high concentrations of arsenic in well water in Fairbanks, Alaska: American Journal of Epidemiology, v. 108, p. $377-385$.

Hawkins, D.B., Forbes, R.B., Hok, C.I., and Dinkel, D., 1982, Arsenic in water, soil, bedrock, and plants of the Ester Dome area of Alaska: Institute of Water Resources, University of Alaska, Fairbanks, Report IWR-103, $82 \mathrm{p}$.

Johnson, P.R., Wilcox, D.E., Morgan, W.D., Merto, J., and McFadden, R., 1978, Arsenic, nitrate, iron, and hardness in ground water, Fairbanks area, Alaska: U.S. Geological Survey Open-File Report 78-1034, 1 sheet.

McCoy, D., Newberry, R.J., Layer, P., DiMarchi, J.J., Bakke, A., Masterman, J.S., and Minehane, D.L., 1997, Plutonic-related gold deposits of interior Alaska, in Goldfarb, R.J., and Miller, L.D., eds., Mineral Deposits of Alaska: Economic Geology Monograph 9, p. 191-241.

McCrum, M.A., 1985, A chemical mass balance of the Ester Creek and Happy Creek watersheds on Ester Dome, Alaska: University of Alaska, Fairbanks, M.S. thesis, $141 \mathrm{p}$.

Meier, A.L., Grimes, D.J., and Ficklin, W.H., 1994, Inductively coupled plasma mass spectrometry-A powerful analytical tool for mineral resource and environmental studies [abs.], in Carter, L.M.H., Toth, M.I., and Day, W.C., eds., USGS Research on Mineral Resources1994, Part A-Program and Abstracts, Ninth V.E. McKelvey Forum on Mineral and Energy Resources: U.S. Geological Survey Circular 1103-A, p. 67-68. 
Newberry, R.J., and Bundtzen, T.K., 1996, Preliminary geologic map of the Fairbanks mining district, Alaska: Alaska Division of Geological and Geophysical Surveys, Public-Data File 96-12, 14 p., 2 sheets.

Preece, S.J., Westgate, J.A., Stemper, B.A., and Péwé, T.L., 1999, Tephrochronlogy of late Cenozoic loess at Fairbanks, central Alaska: Geological Society of America Bulletin, v. 111, p. 71-90.

Robinson, M.S., Smith, T.E., and Metz, P.A., 1990, Bedrock geology of the Fairbanks mining district, Alaska: Alaska Division of Geological and Geophysical Surveys Professional Report 106, 2 sheets, scale $1: 63,360$.
Weber, E.F., 1986, A stochastic model and risk analysis of arsenic, well depth, and well yield in the Fairbanks area, Alaska: University of Alaska, Fairbanks, unpub. M.S. thesis, 196 p.

Weddleton, J., Richards, H., and Seifert, R., 1989, A guide for assessing risks and costs of water well drilling in the Fairbanks area: University of Alaska Fairbanks, Institute of Northern Engineering, Water Research Center Publication IWR-111, 11 p.

Wilson, F.H., and Hawkins, D.B., 1978, Arsenic in streams, stream sediments, and ground water, Fairbanks area, Alaska: Environmental Geology, v. 2, p. 195-202.

Reviewers: Warren Day and Kathy Nagy 


\title{
Isotopic Ages from Intrusive Rocks near the Stuyahok Gold Placer Deposits, South-Central Holy Cross Quadrangle, Alaska
}

\author{
By Marti L. Miller, Robert D. Tucker, Paul W. Layer, \\ and Thomas K. Bundtzen
}

\section{Abstract}

In the Stuyahok area of the south-central Holy Cross quadrangle, Alaska, felsic to intermediate dikes and sills intrude Lower Cretaceous volcanic and volcaniclastic rocks of the Koyukuk terrane. These previously undated intrusions are the probable source of at least $933 \mathrm{~kg}(30,000 \mathrm{oz})$ of past placer gold production. Additional placer, and perhaps lode, resources are likely present at Stuyahok. New U/Pb and ${ }^{40} \mathrm{Ar} /{ }^{39} \mathrm{Ar}$ isotopic data indicate two of the dikes are early Tertiary in age (63.6 $\pm 0.2 \mathrm{Ma}$ and $60.4 \pm 1.1 \mathrm{Ma}$, respectively). In addition to helping constrain the age of gold mineralization, these early Tertiary ages suggest the Stuyahok dikes are part of a Late Cretaceous and early Tertiary belt of gold mineralized felsic dikes that lie in the Kuskokwim mineral belt. Also reported herein are previously unpublished conventional K-Ar ages of $69.4 \pm 2.1$ $\mathrm{Ma}$ and 69.3 $\pm 2.1 \mathrm{Ma}$ for two felsic intrusions from the western edge of this mineralized belt, the Marshall-Kako Creek area, which lies about $40 \mathrm{~km}$ west-southwest of the Stuyahok area.

\section{Introduction}

During 1995, the U.S. Geological Survey (USGS) performed geologic mapping and geochemical sampling of an approximately $142-\mathrm{km}^{2}$ area surrounding the Stuyahok placer gold deposits in the south-central part of the Holy Cross quadrangle (fig. 1). The work was performed under a Cooperative Research and Development Agreement (CRADA) with Calista Corporation (an Alaska Native regional corporation) to assess the mineral resources of this area. The Stuyahok area has produced about $933 \mathrm{~kg}(30,000 \mathrm{oz})$ of placer gold intermittently since the early part of the 20th century. Summaries describing the geology and mineral resources were provided in Miller and others $(1996,1998)$. Geochemical data for rock samples were published in Keith and others (1996) and data for streamsediment, heavy-mineral-concentrate, and soil samples were reported in Bailey and others (1996).

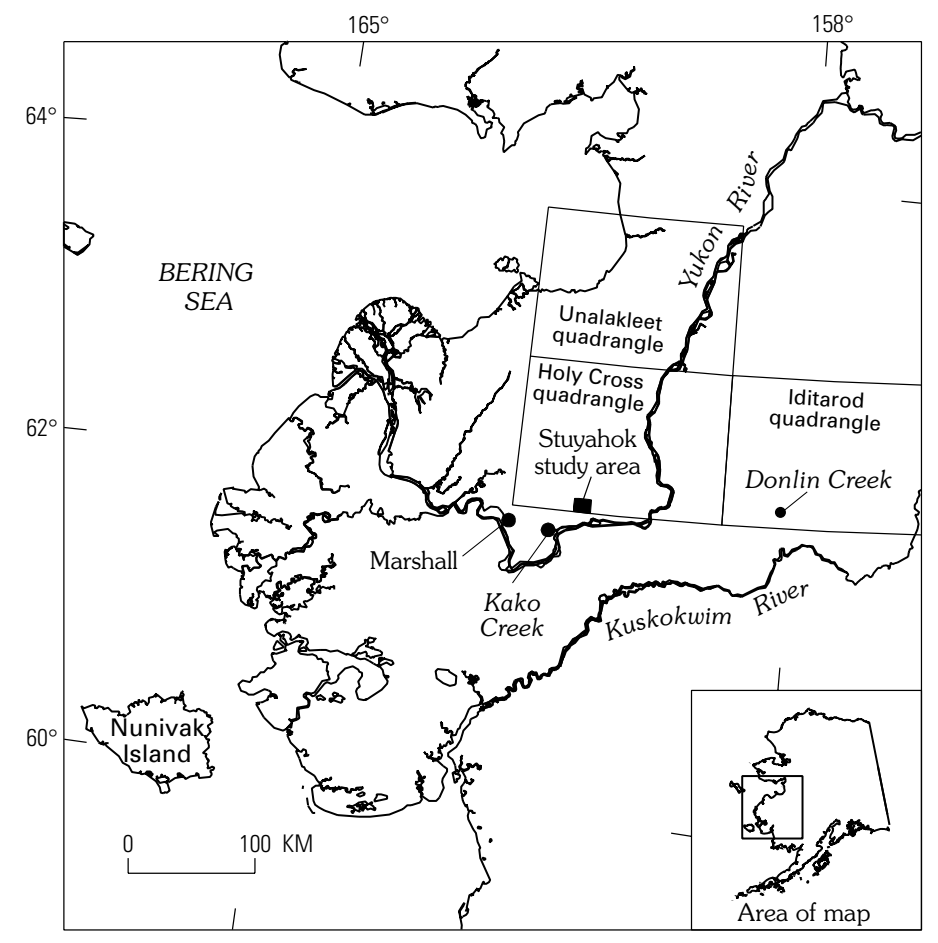

Figure 1. Map showing location of the Stuyahok study area and other areas of mineralized felsic dikes discussed in the text. 
The study area consists of rounded, largely bare, ridges (maximum elevation of $576 \mathrm{~m}$ ) separated by wide, sedimentfilled, heavily vegetated valleys (minimum elevation of $122 \mathrm{~m}$ ). It is primarily accessible by air, augmented during winter by overland access from the Yukon River. Placer gold was first mined in 1921 and, subsequently, various cabins and other structures have been built that constitute the small settlement known as Stuyahok. Most of the map area of figure 2 is either owned or selected by Calista Corporation. The remaining land within the map area (the southern quarter) is under selection by the State of Alaska.

\section{Geology}

The Stuyahok study area is primarily underlain by Lower Cretaceous volcaniclastic rocks and flows correlated by Miller and others $(1996,1998)$ with rocks of the Koyukuk terrane (Jones and others, 1987; Patton and others, 1994). These Lower Cretaceous lithologies are intruded by mafic to felsic dikes and sills, which are petrographically similar to the Late Cretaceous and early Tertiary dikes that are found in many parts of westcentral and southwestern Alaska (for example, Mertie, 1936; Bundtzen and Gilbert, 1983; Miller and Bundtzen, 1994; MollStalcup, 1994; Bundtzen and Miller, 1997). Unconsolidated late Tertiary(?) and Quaternary colluvial and alluvial deposits of variable thickness mantle the bedrock units (fig. 2). The Stuyahok area has not been glaciated.

Regionally, the Koyukuk terrane, as described by Patton and others (1994), contains two distinct assemblages: (1) Jurassic tonalite-trondhjemite plutonic rocks and older(?) volcanic and plutonic rocks, which are unconformably overlain by (2) Upper Jurassic(?) and Lower Cretaceous, andesitic volcanic and volcaniclastic rocks. The Upper Jurassic(?) and Lower Cretaceous volcanic and volcaniclastic rocks form the bulk of the Koyukuk terrane and record an episode of andesitic magmatism marked by the formation of voluminous pyroclastic and epiclastic deposits and subordinate flows of basaltic to dacitic composition (Patton and others, 1994). In the Unalakleet quadrangle (fig. 1), north of Stuyahok, andesitic volcaniclastic rocks of the Koyukuk terrane were assigned an Early Cretaceous age based on the presence of a Valanginian Buchia and radiolarians of possible Early Cretaceous (Valanginian) age (Patton and Moll-Stalcup, 1996). The volcaniclastic rocks and flows of the Stuyahok area are also assigned an Early Cretaceous age by correlation with the volcanic assemblage of the Unalakleet quadrangle (Miller and others, 1998).

Rocks of the Koyukuk terrane near Stuyahok are divided into three map units (Miller and others, 1996, 1998) as distinguished by sandstone-dominant, volcanic-dominant, and mixed sandstone and volcanic rocks (fig. 2). The sandstone-dominant unit (Ks, fig. 2) is volumetrically minor and primarily consists of lithic sandstone, but it also contains felsic tuff and minor siltstone. The volcanic-dominant unit (Ka, fig. 2) is characterized by volcanic agglomerate (vent facies) and lapilli tuff, but it also has some volcanic flow rocks, and minor felsic tuff and sedimentary rocks. The mixed unit (Kt, fig. 2), which underlies most of the study area, is composed dominantly of andesitic crystal lithic and lapilli tuffs that are closely interbedded with volcaniclastic sandstones and tuffaceous siltstones, and with minor felsic tuffs and andesitic to dacitic flow rocks. The Lower Cretaceous volcanic and volcaniclastic rocks of the Koyukuk terrane near Stuyahok have undergone low-grade regional metamorphism to laumontite and locally prehnite-pumpellyite facies (Miller and others, 1998).

Rocks of the Koyukuk terrane in the Stuyahok area are cut by two types of dikes-(1) felsic to intermediate, which are largely feldspar-quartz porphyry dikes, and (2) mafic to intermediate, which are largely clinopyroxene diabase dikes (Miller and others, 1998). The dikes are normally 1 to 3 m wide and are locally traceable along strike for as much as $100 \mathrm{~m}$.

The mafic to intermediate dikes are only found in the northwest corner of the map area shown in figure 2; they are more common to the west of this map area (Miller and others, 1996, 1998). These dikes are diabasic to subophitic in texture and are primarily composed of clinopyroxene, plagioclase, and accessory magnetite; locally they contain minor quartz. Chloritic alteration is common. No isotopic age data are available, but these dikes were assigned a Late Cretaceous and early Tertiary age by Miller and others (1998) because (1) they intrude Lower Cretaceous rocks of the Koyukuk terrane, and (2) they are petrographically similar to dated Late Cretaceous and early Tertiary mafic to intermediate dikes exposed $130 \mathrm{~km}$ to the east (Miller and Bundtzen, 1994).

East-west-striking dikes and sills of felsic to intermediate composition form a dense swarm on Chase Mountain (fig. 2). Felsic dikes are also concealed beneath the unconsolidated cover on the south side of Flat Creek (Miller and others, 1998). The felsic dikes exhibit porphyro-aphanitic textures and contain 5 to 25 percent quartz, plagioclase, and biotite phenocrysts in a microcrystalline groundmass. Clinopyroxene and hornblende phenocrysts are present locally. Granodiorite and granite are the most common compositions, but more intermediate varieties may be present locally. Alteration of the felsic dikes is extensive and includes assemblages of chlorite, sericite, calcite, and opaque minerals. Although no isotopic age data were available, Miller and others (1998) assigned these dikes a Late Cretaceous and early Tertiary age because (1) they intrude Lower Cretaceous rocks, and (2) they are petrographically similar to Late Cretaceous and early Tertiary peraluminous granite porphyry dikes mapped and dated to the southwest in the Marshall-Kako Creek area (Bundtzen and Miller, 1997) and to the west in the Iditarod quadrangle (Miller and Bundtzen, 1994) (fig. 1).

Volcaniclastic and flow rocks of the Koyukuk terrane on Chase Mountain (fig. 2) have been thermally metamorphosed (maximum grade of hornblende-hornfels facies), suggesting that the mountain is underlain by a buried pluton. Felsic dikes on Chase Mountain show no secondary minerals or textures indicative of thermal alteration, which suggests that the dikes postdate the inferred pluton intrusion (Miller and others, 1998). Hydrothermal alteration has affected both the felsic dikes and the enclosing volcaniclastic and flow rocks - the dikes are extensively altered to sericite (plus chlorite, calcite, and opaque minerals), and the enclosing country rock contains disseminated pyrite. 


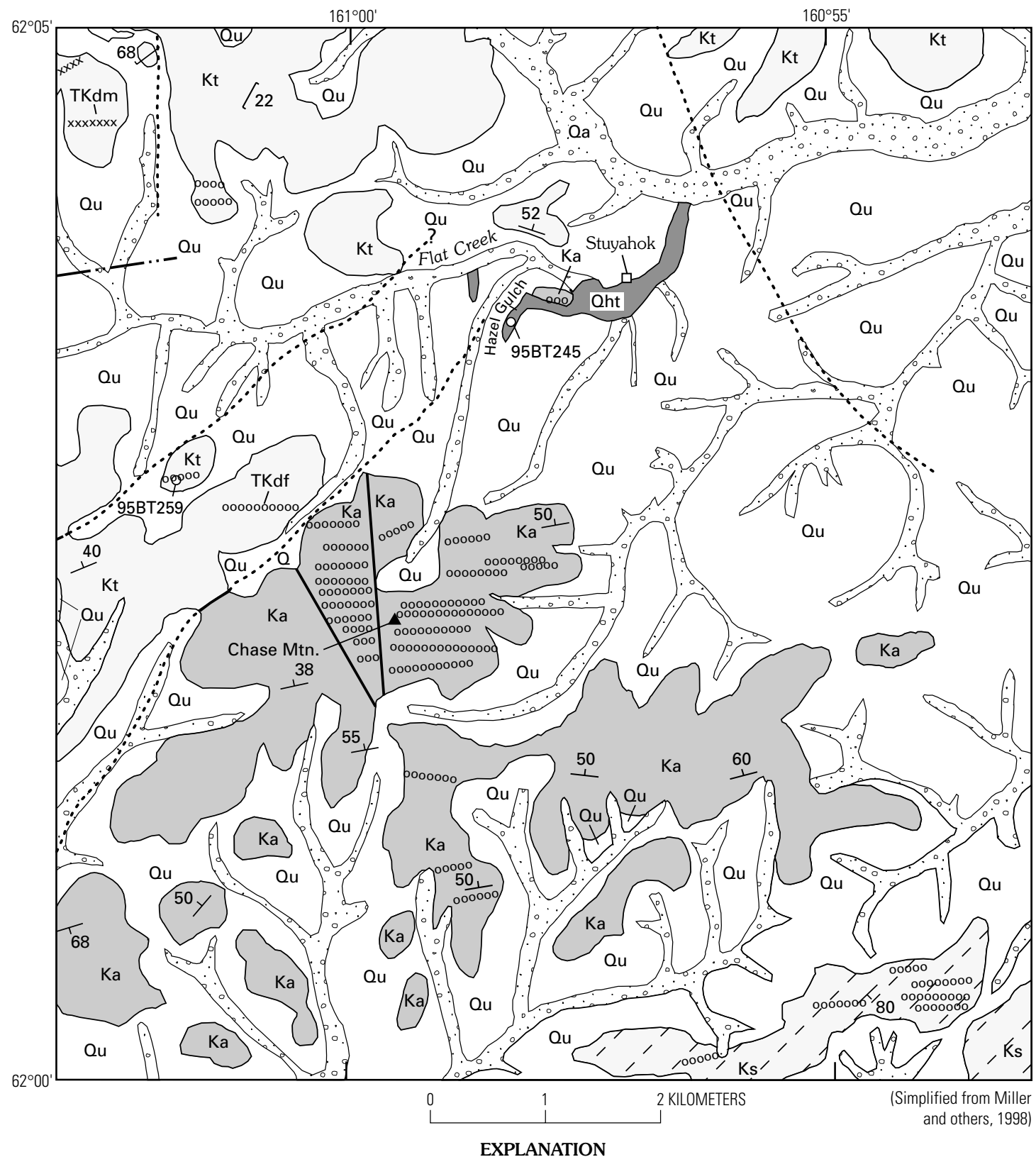

UNCONSOLIDATED DEPOSITS
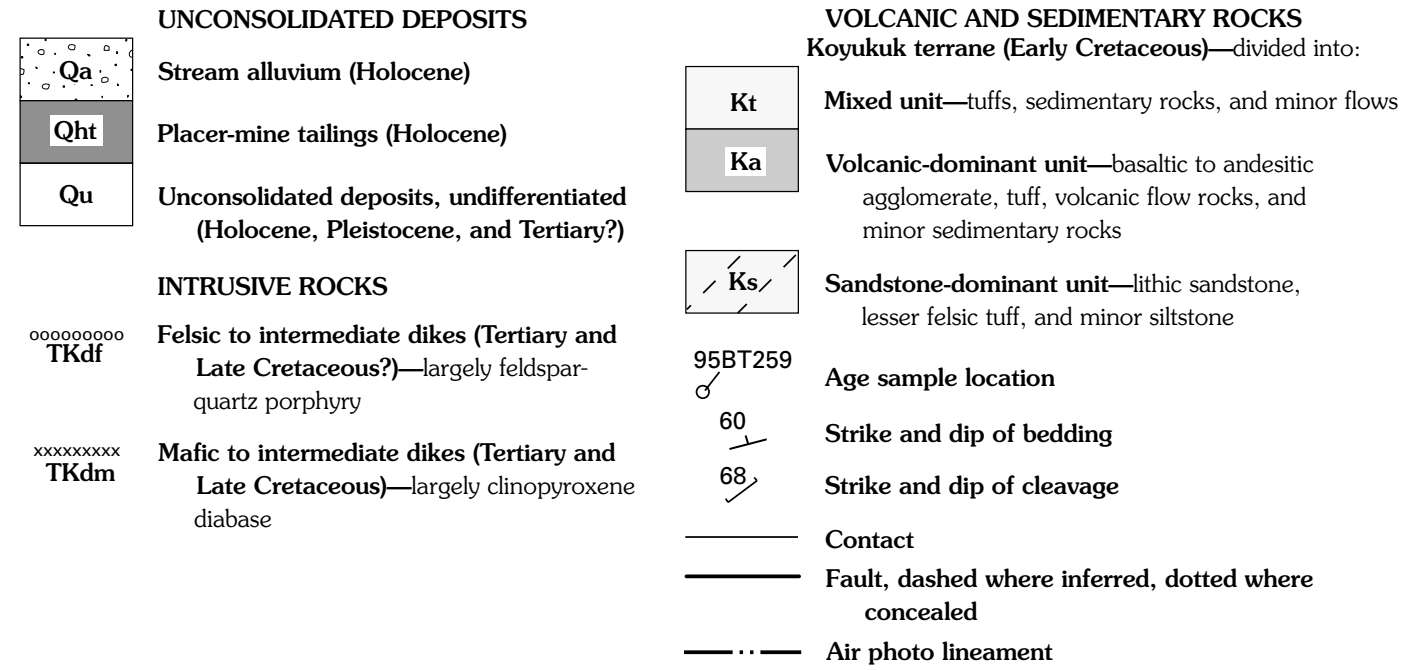

Figure 2. Simplified geologic map of part of the Stuyahok study area showing location of dike samples analyzed for isotopic age. 


\section{Gold Resources}

Placer gold was discovered in the Stuyahok area as early as 1916 (Harrington, 1918; Miller and others, 1996). Lower Flat Creek (fig. 2) and limited sections of its gold-bearing tributaries were mined from 1921 to 1940, and again from 1986 to 1997. An estimated $746 \mathrm{~kg}(24,000 \mathrm{oz})$ of placer gold was produced through 1940 (based on figures in Cobb, 1973), and at least 187 $\mathrm{kg}(6,000 \mathrm{oz})$ has been produced since 1986 (Miller and others, 1998).

Lode sources for the placer gold in the Stuyahok area are not known with certainty. In other parts of southwestern Alaska, placer gold is associated with several mineral deposit types (Bundtzen and Miller, 1997). The two main ones are (1) Late Cretaceous and early Tertiary plutonic-hosted copper-goldpolymetallic deposits associated with volcanic-plutonic complexes and (2) Late Cretaceous and early Tertiary peraluminous granite-porphyry-hosted gold-polymetallic deposits. In addition, some placer gold is derived from mid-Cretaceous granitic plutons; zoned Jurassic ultramafic complexes are a fourth, minor, source. Possible lode sources in the Stuyahok area

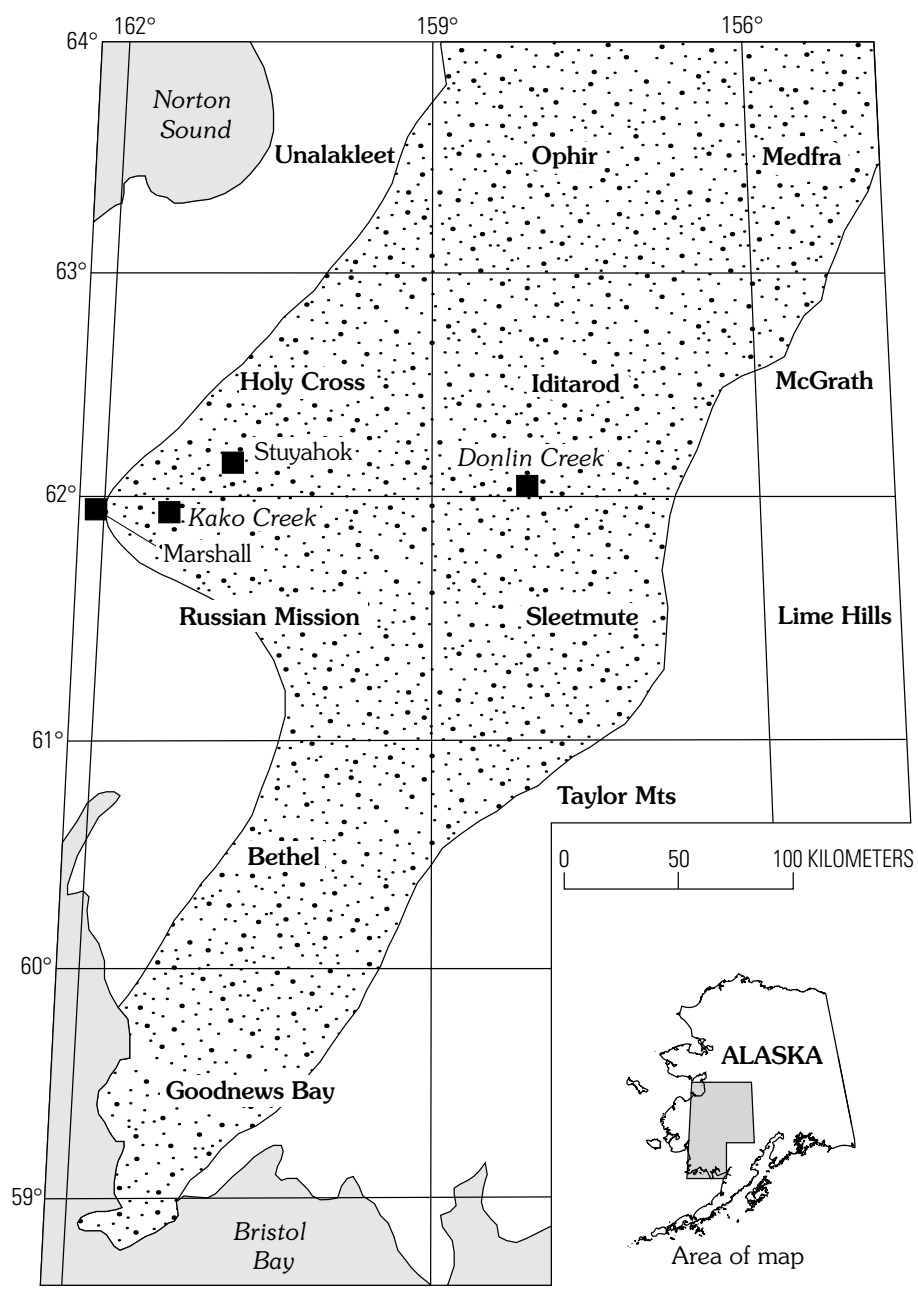

Figure 3. Map of the Kuskokwim mineral belt (stippled), 1:250,000 quadrangles, and areas discussed in the text. Modified from Bundtzen and Miller (1997, fig. 1). include feldspar-quartz porphyry dikes and mineralized veins of uncertain origin (possibly related to the postulated buried pluton) (Miller and others, 1998).

Late Cretaceous and early Tertiary peraluminous felsic dikes are interpreted to be the source of about 20 percent of the placer gold produced in the Kuskokwim mineral belt (fig. 3) and about 80 percent of the known lode gold resources (Bundtzen and Miller, 1997). Miller and others (1998) suggested that the most promising lode targets in the Stuyahok area are mineralized feldspar-quartz porphyry dikes and associated country rock that are geologically similar to the goldpolymetallic-bearing, peraluminous granite-porphyry dikes found in other parts of the Kuskokwim mineral belt. This conclusion was based mainly on the similarity between the geology and geochemistry of the Stuyahok placer deposits and those at Willow Creek (near Marshall), Kako Creek, and Donlin Creek (fig. 1), where, in each case, the gold is derived from peraluminous granite-porphyry dikes and associated country rock (Bundtzen and Miller, 1997). At both Willow Creek and Kako Creek, which lie west-southwest of the Stuyahok area, swarms of feldspar-quartz porphyry dikes of granodiorite to granite composition cut volcanic-dominant rocks of the Koyukuk terrane (Bundtzen and Miller, 1997), much like the geologic setting at Stuyahok. The prominent dike swarm of the MarshallKako Creek region projects east-northeast toward the Stuyahok area. At the Donlin Creek property, which lies about $150 \mathrm{~km}$ east of Stuyahok, at least three phases of mineralized felsic dikes and sills intrude Cretaceous flysch of the Kuskokwim Group (Miller and Bundtzen, 1994; Bundtzen and Miller, 1997). The Donlin Creek lode deposit is currently being explored by Placer Dome U.S., Inc.; they have outlined a resource of $358,000 \mathrm{~kg}$ ( 11.5 million oz) of gold consisting of $168,000 \mathrm{~kg}$ (5.4 million oz) in the measured and indicated categories and 190,000 $\mathrm{kg}$ (6.1 million oz) in the inferred category (Placer Dome, Inc., 1999).

\section{New Radiometric Age Data}

The felsic to intermediate dikes of the Stuyahok area were previously assigned a Late Cretaceous and early Tertiary age based on correlation with similar dated dikes elsewhere in southwestern Alaska (Miller and others, 1996, 1998). In the Stuyahok area, dike samples suitable for isotopic age determinations are rare due to their extreme alteration. However, two different dikes (fig. 2) did yield samples that appeared to be acceptable for analysis. One sample is from a biotite granite porphyry dike containing trace zircon that was exposed in an exploration trench near Hazel Gulch (95BT245, fig. 2; dike too small to show on map). A concordant $\mathrm{U} / \mathrm{Pb}$ age of $63.6 \pm 0.2$ $\mathrm{Ma}$ (average of three fractions) was obtained on the zircon. The biotite from this sample turned out to be heavily altered to chlorite. The ${ }^{40} \mathrm{Ar} /{ }^{39} \mathrm{Ar}$ dating of this altered biotite yielded an integrated age of $67.3 \pm 0.9 \mathrm{Ma}$, which, as will be discussed later, is less reliable than the zircon age. The other dike sample (95BT259, fig. 2) is hornblende granodiorite from a small knob $2 \mathrm{~km}$ northwest of Chase Mountain. Hornblende from this sample yielded a ${ }^{40} \mathrm{Ar} /{ }^{39} \mathrm{Ar}$ plateau age of $60.4 \pm 1.1 \mathrm{Ma}$. 


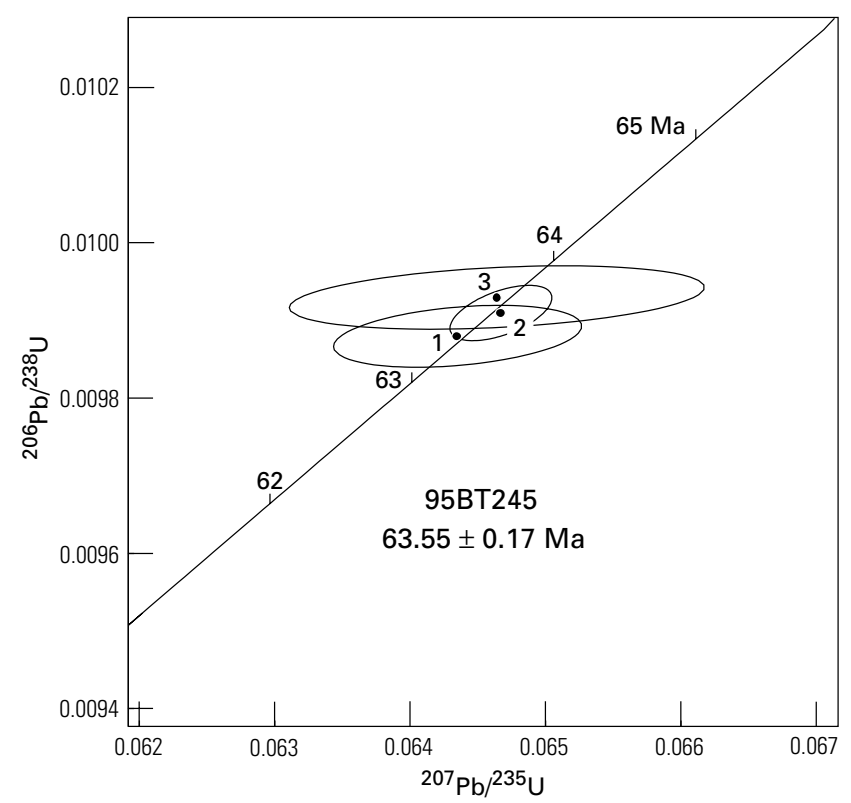

Figure 4. $\mathrm{U} / \mathrm{Pb}$ concordia diagram for sample 95BT245. Numbers 1-3 refer to fractions in table 1.

\section{$\mathrm{U} / \mathrm{Pb}$ Analytical Methods}

$\mathrm{U} / \mathrm{Pb}$ analyses (fig. 4 and table 1) were performed on zircons from sample 95BT245 at the geochronology laboratory at Washington University, St. Louis. Zircon was extracted using standard techniques of density and magnetic separation. Zircon grains were selected for analysis on the basis of size, color, clarity, and morphology. The grains analyzed were all clear, colorless, and long prismatic (table 1). Fractions ranged from 4 to 8 crystals. All zircons were air abraded (Krogh, 1982) and cleaned sequentially in warm $4 \mathrm{~N} \mathrm{HNO}_{3}$, water, and distilled acetone to remove components carrying common $\mathrm{Pb}$. Washed and weighed zircon fractions were then loaded in TFE Teflon bombs, spiked with a mixed ${ }^{205} \mathrm{~Pb}^{235} \mathrm{U}$ tracer solution, and digested in 48 percent $\mathrm{HF}$ and $7 \mathrm{~N} \mathrm{HNO}_{3}$ for 72 hours at $210^{\circ} \mathrm{C}$. Following digestion and conversion to chloride form, $\mathrm{Pb}$ and $\mathrm{U}$ were purified using ion-exchange techniques (Krogh, 1973). Total-procedure blanks for $\mathrm{Pb}$ and $\mathrm{U}$, measured during the period of analysis, ranged between $1-8 \mathrm{pg}$ and $<1 \mathrm{pg}$, respectively; total common- $\mathrm{Pb}$ abundances are reported for each analysis in table 1. Initial-Pb compositions result in insignificant changes to the calculated ages.

Isotope ratio measurements of $\mathrm{Pb}$ and $\mathrm{U}$ were made in a VG Sector-54 thermal ionization mass spectrometer. Lead and uranium were loaded on outgassed single-Re filaments with silica gel and phosphoric acid, and measurements were made by the method of peak-hopping in ion-counting mode. Additional details about the analytical procedure are discussed in Tucker and others (1998).

Errors for the ${ }^{238} \mathrm{U} /{ }^{206} \mathrm{~Pb},{ }^{235} \mathrm{U} /{ }^{207} \mathrm{~Pb}$, and ${ }^{207} \mathrm{~Pb} /{ }^{206} \mathrm{~Pb}$ ages were estimated using the method of Ludwig (1980); all age uncertainties are quoted at the 95-percent confidence level. Cited ages are the mean ${ }^{207} \mathrm{~Pb} /{ }^{206} \mathrm{~Pb}$ age of concordant or slightly discordant analyses weighted according to the inverse variance of each analysis (Ludwig, 1992); the quoted error is the standard error of the mean ${ }^{206} \mathrm{~Pb} /{ }^{238} \mathrm{U}$ age for each analysis. The reliability of all cited ages may be evaluated by the MSWD (mean square of the weighted deviates), which is a measure of the observed scatter to that predicted by the assigned errors to each analysis. In all cases, the MSWD is much less than one, indicating that assigned errors may be somewhat overestimated.

Table 1. $\mathrm{U} / \mathrm{Pb}$ isotope dilution analyses for sample $95 \mathrm{BT} 245$.

\begin{tabular}{|c|c|c|c|c|c|c|c|c|c|c|c|}
\hline \multicolumn{2}{|r|}{ FRACTIONS } & \multicolumn{5}{|c|}{ CONCENTRATIONS } & \multicolumn{4}{|c|}{ ATOMIC RATIOS } & \multirow{2}{*}{$\frac{\text { AGE (Ma) }}{{ }^{206} \mathrm{~Pb}}$} \\
\hline No. & Properties & Wt. & $\begin{array}{l}\mathrm{Pb} \\
\mathrm{rad}\end{array}$ & $U$ & $\begin{array}{c}\mathrm{Pb} \\
\text { common }\end{array}$ & $\mathrm{Th} / \mathrm{U}$ & ${ }^{206} \mathrm{~Pb}$ & $\begin{array}{l}{ }^{207} \mathrm{~Pb} \\
\end{array}$ & $\begin{array}{l}{ }^{207} \mathrm{~Pb} \\
\quad(+)\end{array}$ & $\begin{array}{l}{ }^{206} \mathrm{~Pb} \\
\end{array}$ & \\
\hline & & {$[\mu \mathrm{g}]$} & [ppm] & [ppm] & [pg] & & ${ }^{204} \mathrm{~Pb}$ & ${ }^{206} \mathrm{~Pb}$ & $235 \mathrm{U}$ & ${ }^{238} \mathrm{U}$ & ${ }^{238} \mathrm{U}$ \\
\hline & (1) & (2) & (2) & (2) & (3) & (4) & (5) & (6) & (6) & (6) & 6) \\
\hline 1 & $5 \mathrm{gr},-200, \mathrm{cl}, \mathrm{c}, \mathrm{l}-\mathrm{p}$ & 18 & 3.6 & 258 & 3.1 & 0.424 & 1,328 & $0.04723(26)$ & $0.06435(37)$ & $0.00988(2)$ & $63.39(0.15)$ \\
\hline 2 & $8 \mathrm{gr},-200, \mathrm{cl}, \mathrm{c}, \mathrm{l}-\mathrm{p}$ & 90 & 3.4 & 311 & 12.4 & 0.727 & 1,444 & 0.04733 (9) & $0.06467(15)$ & $0.00991(1)$ & $63.57(0.15)$ \\
\hline 3 & $4 \mathrm{gr},-200, \mathrm{cl}, \mathrm{c}, \mathrm{l}-\mathrm{p}$ & 20 & 2.0 & 195 & 6.3 & 0.570 & 415.4 & $0.04722(44)$ & $0.06464(63)$ & $0.00993(2)$ & $63.68(0.15)$ \\
\hline
\end{tabular}

Notes:

(1) Cardinal number indicates the number of zircon grains analyzed (e.g., 5 grains); all grains were selected from non-paramagnetic separates at $0^{\circ}$ tilt at full magnetic field in Frantz Magnetic Separator; $-200=$ size in mesh $(<75 \mu \mathrm{m})$; $\mathrm{cl}=$ clear; $\mathrm{c}=$ colorless; $1-\mathrm{p}=1$ long prismatic. All grains were air-abraded following Krogh (1982).

(2) Concentrations are known to $\pm 30 \%$ for sample weights of about $20 \mu \mathrm{g}$ and $\pm 50 \%$ for samples $\leq 5 \mu \mathrm{g}$.

(3) Corrected for 0.0215 mole fraction common- $\mathrm{Pb}$ in the ${ }^{205} \mathrm{~Pb}-{ }^{235} \mathrm{U}$ spike.

(4) Calculated $\mathrm{Th} / \mathrm{U}$ ratio assuming that all ${ }^{208} \mathrm{~Pb}$ in excess of blank, common- $\mathrm{Pb}$, and spike is radiogenic $\left(\lambda^{232} \mathrm{Th}=4.9475 \times 10^{-11} \mathrm{y}^{-1}\right)$.

(5) Measured, uncorrected ratio.

(6) Ratio corrected for fractionation, spike, blank, and initial common- $\mathrm{Pb}$ (at the determined age from Stacey and Kramers (1975)). $\mathrm{Pb}$ fractionation correction $=0.094 \% / \mathrm{amu}( \pm 0.025 \% 1 \sigma) ; \mathrm{U}$ fractionation correction $=0.111 \% / \mathrm{amu}( \pm 0.02 \% 1 \sigma)$. U blank $=0.2 \mathrm{pg} ; \mathrm{Pb}$ blank $\leq 10 \mathrm{pg}$. Absolute uncertainties $(1 \sigma)$ in the $\mathrm{Pb} / \mathrm{U}$ and ${ }^{207} \mathrm{~Pb} /{ }^{206} \mathrm{~Pb}$ ratios calculated following Ludwig (1980). U and Pb half-lives and isotopic abundance ratios from Jaffey and others (1971). 


\section{${ }^{40} \mathrm{Ar} /{ }^{39} \mathrm{Ar}$ Analytical Methods}

For ${ }^{40} \mathrm{Ar} /{ }^{39} \mathrm{Ar}$ analysis, samples 95BT245 and 95BT259 were crushed, then washed in deionized water, sieved, and 100to $250-\mu \mathrm{m}$ biotite and hornblende were selected. The samples were wrapped in aluminum foil and arranged in aluminum cans of $2.5-\mathrm{cm}$ diameter and $4.5-\mathrm{cm}$ height. Samples of hornblende MMHb-1, having an age of 513.9 Ma, were used to monitor the neutron flux. The samples were irradiated in the research reactor of McMaster University in Hamilton, Ontario, Canada.

After irradiation, the samples (5-20 crystals) and monitors were loaded in an ultra-high-vacuum extraction line. The monitors were fused, and samples step-heated using the technique described in York and others (1981) and Layer and others (1987). The samples were then analyzed in a VG-3600 mass spectrometer at the Geophysical Institute, University of Alaska, Fairbanks. The argon isotopes measured were corrected for system blank and mass discrimination, as well as calcium, potassium, and chlorine interference reactions following procedures outlined in McDougall and Harrison (1988). The ${ }^{40} \mathrm{Ar} /{ }^{39} \mathrm{Ar}$ results are given in table 2 ; all ages are quoted to the \pm 1 sigma level and calculated using the constants of Steiger and Jäger (1977). Age spectra for the two samples are shown in figure 5 .

\section{Discussion}

The $\mathrm{U} / \mathrm{Pb}$ concordia age of $63.6 \pm 0.2 \mathrm{Ma}$ (average of three fractions) is well constrained and is considered to be the crystallization age of the granite porphyry dike near Hazel Gulch. The ${ }^{40} \mathrm{Ar} /{ }^{39} \mathrm{Ar}$ age on altered biotite from this dike shows a disturbed age spectrum and no identifiable plateau (defined by three or more consecutive fractions whose ages are within 2 sigma of each other and total more than 50 percent of the ${ }^{39} \mathrm{Ar}$ gas released). An integrated age of $67.3 \pm 0.9$ Ma calculated for this biotite is 3.7 m.y. older than the crystallization age. The sample has a $\mathrm{Ca} / \mathrm{K}$ ratio of 3.7 that indicates alteration of the biotite; this was corroborated by the petrographic observation of chlorite alteration of the biotite phenocrysts. As biotite is altered, the $\mathrm{Ca} / \mathrm{K}$ ratio increases leading to a "hump-shaped" spectrum that has anomalously old ages at about 50 percent of gas release. We interpret this as being due to ${ }^{39} \mathrm{Ar}$ recoil and (or) potassium loss (Hess and others, 1987). Hence, the age of the dike is taken as the $\mathrm{U} / \mathrm{Pb}$ concordia age of $63.6 \pm 0.2 \mathrm{Ma}$.

${ }^{40} \mathrm{Ar} /{ }^{39} \mathrm{Ar}$ step heating of hornblende from the hornblende granodiorite dike exposed northwest of Chase Mountain yielded an eight-fraction plateau age of $60.4 \pm 1.1 \mathrm{Ma}$ (79 percent of ${ }^{39} \mathrm{Ar}$ gas released). The $\mathrm{Ca} / \mathrm{K}$ spectrum shows a ratio for the plateau part of the spectrum of approximately 25 , indicative of an unaltered amphibole. However, the first 20 percent of gas release had low $\mathrm{Ca} / \mathrm{K}$ and $\mathrm{Cl} / \mathrm{K}$ ratios, which we interpret as evidence of "biotitic" alteration (Layer and others, 1992). Excess argon (old ages) is also seen in this phase, but the plateau age is considered the age of hornblende crystallization.

The ages for felsic to intermediate dikes yielded by $\mathrm{U} / \mathrm{Pb}$ and ${ }^{40} \mathrm{Ar} /{ }^{39} \mathrm{Ar}$ techniques $(63.6 \pm 0.2 \mathrm{Ma}$ and $60.4 \pm 1.1 \mathrm{Ma}$, respectively) span 3 m.y. and suggest a history of multiple intrusions of dikes in the Stuyahok area. The older biotite granite porphyry dike (63.6 Ma) lies within an area that yields consistent gold anomalies in soil samples (Miller and others, 1998; Calista Corporation, unpub. data, 1996, 1997, 1998) and therefore is more clearly associated with the gold mineralization of the Stuyahok area. The younger hornblende granodiorite dike (60.4 Ma) may be part of a younger unmineralized intrusive event; however, based on available data, we cannot rule out that all felsic to intermediate dikes in the area were part of the gold-bearing suite and that the intrusive event spanned a several-million-year period.

\section{Summary and Regional Comparison}

The Stuyahok area is part of a large region defined by Bundtzen and Miller (1997) as the Kuskokwim mineral belt (fig. 3). Within this belt, granite porphyry dikes, stocks, and sills that are locally associated with gold mineralization range from 71 to $61 \mathrm{Ma}$ in age (Bundtzen and Miller, 1997). The Stuyahok area lies in the central part of this belt, as do goldmineralized dikes at Marshall, Kako Creek, and Donlin Creek. Two conventional K-Ar ages obtained by others for previous studies in the Marshall-Kako Creek area are reported here for comparative purposes (table 3 ). White mica (primary) from a mineralized felsic dike at Kako Creek yielded an age of $69.4 \pm 2.1 \mathrm{Ma}$, and biotite from a granite porphyry intrusion exposed near Marshall yielded an age of $69.3 \pm 2.1 \mathrm{Ma}$; both are part of the same east-west-striking felsic dike swarm. Near the Donlin Creek gold property, about $200 \mathrm{~km}$ east-northeast of the Marshall-Kako Creek area, granite porphyry intrusions yielded the following K/Ar ages: $69.5 \pm 2.1$ and $70.9 \pm 2.1 \mathrm{Ma}$ (biotite and muscovite, respectively, from the same dike) and a minimum of 65.1 $\pm 2.0 \mathrm{Ma}$ on biotite from another dike (Miller and Bundtzen, 1994). Hydrothermal sericite adjacent to mineralized veins at Donlin Creek yielded a ${ }^{40} \mathrm{Ar} /{ }^{39} \mathrm{Ar}$ isochron age of $69.5 \pm 1.1 \mathrm{Ma}$ (Gray and others, 1997). Given the sparsity of current data, the exact timing of gold mineralization at Donlin Creek is uncertain, but it was probably no more than 1-2 m.y. younger than dike emplacement.

Miller and others $(1996,1998)$ postulated that the felsic to intermediate dikes of the Stuyahok area were part of the Late Cretaceous and early Tertiary gold mineralized dike suite that contains the Marshall-Kako Creek area and Donlin Creek. Indeed, corroborating radiometric age data obtained at Stuyahok indicate an early Tertiary age of $64 \mathrm{Ma}$ for the mineralized dikes, but the data also indicate the felsic to intermediate dike suite includes dikes as young as $60 \mathrm{Ma}$, which may or may not be related to the gold. Including the Stuyahok data, the mineralized dikes in the central part of the Kuskokwim mineral belt (extending from Marshall $200 \mathrm{~km}$ east to Donlin Creek) range in age from possibly as young as $60 \mathrm{Ma}$ to $71 \mathrm{Ma}$, very nearly the same as the age range of the whole mineral belt.

Acknowledgments. - We thank William W. Patton, Jr. for contributing descriptive information on rocks of the Marshall area as well as allowing us to use $\mathrm{K}-\mathrm{Ar}$ data from a sample he collected in 1987. We also thank Jeff Foley and June McAtee, of Calista Corporation, for sharing additional information on the Stuyahok property that was acquired after completion of the CRADA and for their continuing helpful discussions on the geology of the property. 


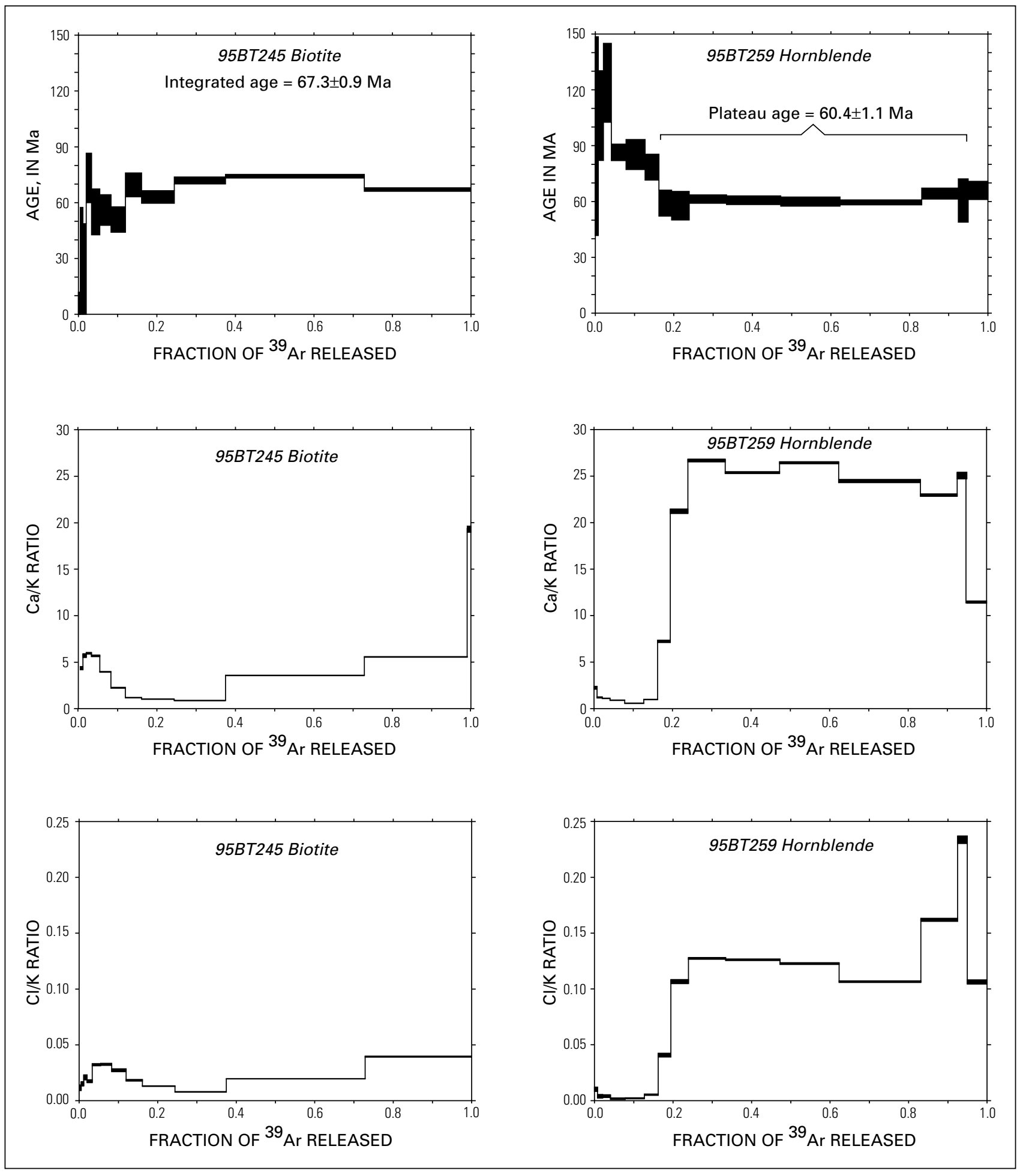

Figure 5. $\quad{ }^{40} \mathrm{Ar} /{ }^{39} \mathrm{Ar}$ age spectra for samples $95 \mathrm{BT} 245$ and 95BT259. Shown are age, $\mathrm{Ca} / \mathrm{K}$, and $\mathrm{Cl} / \mathrm{K}$ spectra. 
Table 2. ${ }^{40} \mathrm{Ar} /{ }^{39} \mathrm{Ar}$ data for samples 95BT259 and 95BT245.

[Weighted average of $\mathrm{J}$ from standards $=0.008755 \pm 0.000019$ ]

\begin{tabular}{|c|c|c|c|c|c|c|c|c|c|c|c|c|c|c|c|}
\hline $\begin{array}{l}\text { Laser } \\
\text { power } \\
(\mathrm{mW})\end{array}$ & $\begin{array}{l}\text { Cumula- } \\
\text { tive } \\
{ }^{39} \mathrm{Ar}\end{array}$ & $\begin{array}{c}{ }^{40} \mathrm{Ar} /{ }^{39} \mathrm{Ar} \\
\text { meas- } \\
\text { ured }\end{array}$ & $\begin{array}{c}+/- \\
(1 \sigma)\end{array}$ & $\begin{array}{c}{ }^{37} \mathrm{Ar} / \\
{ }^{39} \mathrm{Ar} \\
\text { meas- } \\
\text { ured }\end{array}$ & $\begin{array}{c}+/- \\
(1 \sigma)\end{array}$ & $\begin{array}{c}{ }^{36} \mathrm{Ar} / \\
{ }^{39} \mathrm{Ar} \\
\text { meas- } \\
\text { ured }\end{array}$ & $\begin{array}{c}+/- \\
(1 \sigma)\end{array}$ & $\begin{array}{l}\% \text { Atmos- } \\
\text { pheric } \\
{ }^{40} \mathrm{Ar}\end{array}$ & $\begin{array}{c}+/- \\
(1 \sigma)\end{array}$ & $\mathrm{Ca} / \mathrm{K}$ & $\begin{array}{c}+/- \\
(1 \sigma)\end{array}$ & $40 * / 39 \mathrm{~K}$ & $\begin{array}{c}+/- \\
(1 \sigma)\end{array}$ & $\begin{array}{l}\text { Age } \\
\text { (Ma) }\end{array}$ & $\begin{array}{c}+/- \\
\text { (Ma) } \\
(1 \sigma)\end{array}$ \\
\hline \multicolumn{16}{|c|}{ 95BT259 Hornblende } \\
\hline 150 & 0.0076 & 16.423 & 0.326 & 1.226 & 0.078 & 0.035 & 0.012 & 62.32 & 25.31 & 2.25 & 0.14 & 6.183 & 3.558 & 95.1 & 53.3 \\
\hline 200 & 0.0209 & 11.975 & 0.274 & 0.654 & 0.036 & 0.017 & 0.005 & 42.10 & 14.55 & 1.20 & 0.07 & 6.920 & 1.618 & 106.1 & 24.1 \\
\hline 300 & 0.0407 & 14.687 & 0.211 & 0.600 & 0.013 & 0.022 & 0.005 & 44.70 & 9.95 & 1.10 & 0.02 & 8.110 & 1.436 & 123.7 & 21.2 \\
\hline 450 & 0.0782 & 20.073 & 0.340 & 0.490 & 0.010 & 0.049 & 0.001 & 72.06 & 1.57 & 0.90 & 0.02 & 5.603 & 0.293 & 86.4 & 4.4 \\
\hline 600 & 0.1267 & 12.705 & 0.254 & 0.317 & 0.011 & 0.024 & 0.002 & 56.43 & 4.12 & 0.58 & 0.02 & 5.524 & 0.535 & 85.2 & 8.1 \\
\hline 750 & 0.1621 & 6.271 & 0.102 & 0.533 & 0.014 & 0.004 & 0.002 & 18.68 & 7.45 & 0.98 & 0.03 & 5.078 & 0.457 & 78.5 & 6.9 \\
\hline 900 & 0.1943 & 5.827 & 0.094 & 3.929 & 0.067 & 0.008 & 0.002 & 34.56 & 21.52 & 7.23 & 0.12 & 3.805 & 0.458 & 59.1 & 7.0 \\
\hline 1100 & 0.2393 & 6.108 & 0.070 & 11.487 & 0.129 & 0.011 & 0.002 & 39.35 & 24.88 & 21.24 & 0.24 & 3.715 & 0.500 & 57.7 & 7.7 \\
\hline 1300 & 0.3342 & 4.746 & 0.025 & 14.408 & 0.076 & 0.006 & 0.000 & 17.09 & 5.71 & 26.69 & 0.14 & 3.948 & 0.146 & 61.3 & 2.2 \\
\hline 1500 & 0.4725 & 4.786 & 0.024 & 13.712 & 0.053 & 0.006 & 0.001 & 18.63 & 4.02 & 25.39 & 0.10 & 3.906 & 0.154 & 60.7 & 2.3 \\
\hline 1800 & 0.6231 & 4.462 & 0.021 & 14.277 & 0.058 & 0.006 & 0.001 & 13.75 & 4.13 & 26.44 & 0.11 & 3.860 & 0.160 & 60.0 & 2.4 \\
\hline 2000 & 0.8313 & 4.214 & 0.032 & 13.226 & 0.089 & 0.005 & 0.000 & 9.24 & 2.55 & 24.48 & 0.17 & 3.832 & 0.086 & 59.5 & 1.3 \\
\hline 2500 & 0.9248 & 4.462 & 0.029 & 12.413 & 0.068 & 0.004 & 0.001 & 7.32 & 5.09 & 22.96 & 0.13 & 4.142 & 0.193 & 64.3 & 2.9 \\
\hline 3000 & 0.9495 & 4.436 & 0.087 & 13.540 & 0.190 & 0.005 & 0.003 & 12.40 & 31.42 & 25.07 & 0.36 & 3.895 & 0.760 & 60.5 & 11.6 \\
\hline 7000 & 1.0000 & 4.153 & 0.039 & 6.219 & 0.065 & 0.001 & 0.001 & -2.71 & 9.64 & 11.46 & 0.12 & 4.253 & 0.321 & 66.0 & 4.9 \\
\hline Integrated & & 6.017 & 0.016 & 10.719 & 0.026 & 0.009 & 0.000 & 29.71 & 1.31 & 19.81 & 0.05 & 4.239 & 0.079 & 65.7 & 1.2 \\
\hline \multicolumn{16}{|c|}{ 95BT245 Biotite } \\
\hline 150 & 0.0051 & 9.386 & 0.293 & 2.720 & 0.094 & 0.039 & 0.009 & 119.86 & 87.96 & 5.00 & 0.17 & -1.862 & 2.581 & -29.6 & 41.4 \\
\hline 200 & 0.0117 & 11.293 & 0.375 & 2.367 & 0.094 & 0.035 & 0.008 & 89.46 & 49.03 & 4.35 & 0.17 & 1.189 & 2.478 & 18.7 & 38.7 \\
\hline 300 & 0.0202 & 14.861 & 0.532 & 3.099 & 0.108 & 0.047 & 0.006 & 91.66 & 38.89 & 5.70 & 0.20 & 1.239 & 1.872 & 19.5 & 29.2 \\
\hline 450 & 0.0334 & 11.081 & 0.116 & 3.239 & 0.049 & 0.022 & 0.003 & 57.25 & 12.08 & 5.96 & 0.09 & 4.736 & 0.876 & 73.3 & 13.3 \\
\hline 600 & 0.0545 & 7.935 & 0.080 & 3.089 & 0.043 & 0.016 & 0.003 & 55.32 & 12.94 & 5.68 & 0.08 & 3.539 & 0.804 & 55.1 & 12.3 \\
\hline 750 & 0.0830 & 6.675 & 0.063 & 2.152 & 0.022 & 0.011 & 0.002 & 45.87 & 8.88 & 3.95 & 0.04 & 3.603 & 0.536 & 56.0 & 8.2 \\
\hline 900 & 0.1198 & 6.869 & 0.084 & 1.222 & 0.026 & 0.012 & 0.001 & 52.22 & 7.02 & 2.24 & 0.05 & 3.271 & 0.442 & 50.9 & 6.8 \\
\hline 1100 & 0.1610 & 7.059 & 0.071 & 0.645 & 0.012 & 0.009 & 0.001 & 36.18 & 6.01 & 1.18 & 0.02 & 4.489 & 0.421 & 69.5 & 6.4 \\
\hline 1300 & 0.2441 & 6.731 & 0.041 & 0.555 & 0.006 & 0.009 & 0.001 & 39.40 & 3.27 & 1.02 & 0.01 & 4.063 & 0.221 & 63.1 & 3.4 \\
\hline 1500 & 0.3747 & 5.878 & 0.027 & 0.478 & 0.005 & 0.004 & 0.000 & 20.58 & 2.07 & 0.88 & 0.01 & 4.647 & 0.124 & 71.9 & 1.9 \\
\hline 2000 & 0.7284 & 5.729 & 0.019 & 1.949 & 0.009 & 0.004 & 0.000 & 15.97 & 1.08 & 3.58 & 0.02 & 4.796 & 0.064 & 74.2 & 1.0 \\
\hline 3000 & 0.9909 & 4.739 & 0.019 & 3.023 & 0.016 & 0.002 & 0.000 & 8.40 & 1.28 & 5.56 & 0.03 & 4.323 & 0.062 & 67.0 & 0.9 \\
\hline 7000 & 1.0000 & 5.844 & 0.096 & 10.445 & 0.181 & 0.017 & 0.005 & 73.08 & 96.88 & 19.30 & 0.34 & 1.576 & 1.505 & 24.7 & 23.4 \\
\hline Integrated & & 5.947 & 0.012 & 1.984 & 0.005 & 0.006 & 0.000 & 26.69 & 0.98 & 3.65 & 0.01 & 4.344 & 0.059 & 67.3 & 0.9 \\
\hline
\end{tabular}


Table 3. K-Ar age data for samples from the Marshall-Kako Creek area.

[Samples were analyzed by D.L. Turner, University of Alaska, Fairbanks. Constants used in age calculations: $\lambda_{\varepsilon}+\lambda_{\varepsilon}=0.581 \times 10^{-10} \mathrm{yr}^{-1} ; \lambda_{\beta}=4.962 \times$ $10^{-10} \mathrm{yr}^{-1} ;{ }^{40} \mathrm{~K} / \mathrm{K}_{\mathrm{t}}=1.167 \times 10^{-4} \mathrm{~mol} / \mathrm{mol}$. The error assigned to each age is $3 \%$ of the calculated age.]

\begin{tabular}{|c|c|c|}
\hline Site name & Kako Creek & East of Marshall \\
\hline Sample number & 91BT210 & 87APa60 \\
\hline Rock type & Alaskite dike & Granite porphyry \\
\hline Latitude & $61^{\circ} 54.32^{\prime}$ & $61^{\circ} 54.89^{\prime}$ \\
\hline Longitude & $161^{\circ} 28.13^{\prime}$ & $161^{\circ} 55.69^{\prime}$ \\
\hline Mineral dated & White mica & Biotite \\
\hline $\mathrm{K}_{2} \mathrm{O}$ (wt \%) & 7.71 & 9.262 \\
\hline${ }^{40} \operatorname{Ar}\left(10^{-11} \mathrm{~mol} / \mathrm{g}\right)$ & 75.340 & 94.1654 \\
\hline${ }^{40} \mathrm{Ar}(\mathrm{mol} \%)$ & 53.4 & 89.17 \\
\hline${ }^{40} \mathrm{Ar} /{ }^{40} \mathrm{~K}\left(10^{-3}\right)$ & 4.136 & 4.1037 \\
\hline Age (Ma) & $69.4 \pm 2.1$ & $69.29 \pm 2.08$ \\
\hline
\end{tabular}

\section{References Cited}

Bailey, E.A., Keith, W.J., Bickerstaff, Damon, Dempsey, David, and Miller, M.L., 1996, Analytical results and sample locality maps of stream-sediment, panned-concentrate, stream-water, and soil samples from the Stuyahok study area, part of Holy Cross A-4 and A-5 quadrangles, Alaska: U.S. Geological Survey Open-File Report 96-505-C, $44 \mathrm{p}$.

Bundtzen, T.K., and Gilbert, W.G., 1983, Outline of geology and mineral resources of upper Kuskokwim region, Alaska, in Western Alaska Geology and Resource Potential: Alaska Geological Society Symposium, Anchorage, Alaska, 1982, Proceedings, p. 101-117.

Bundtzen, T.K., and Miller, M.L., 1997, Precious metals associated with Late Cretaceous-early Tertiary igneous rocks of southwestern Alaska, in Goldfarb, R.J., and Miller, L.D., eds., Mineral Deposits of Alaska: Economic Geology Monograph 9, p. 242-286.

Cobb, E.H., 1973, Placer deposits of Alaska: U.S. Geological Survey Bulletin 1374, $213 \mathrm{p}$.

Gray, J.E., Gent, C.A., Snee, L.W., and Wilson, F.H., 1997, Epithermal mercury-antimony and gold-bearing vein lodes of southwestern Alaska, in Goldfarb, R.J., and Miller, L.D., eds., Mineral Deposits of Alaska: Economic Geology, Monograph 9, p. 287-305.

Harrington, G.L., 1918, The Anvik-Andreafski region, Alaska: U.S. Geological Survey Bulletin 683, $70 \mathrm{p}$.

Hess, J.C., Lippolt, H. J., and Wirth, R., 1987, Interpretation of ${ }^{40} \mathrm{Ar} /{ }^{39} \mathrm{Ar}$ spectra of biotites: Evidence from hydrothermal degassing experiments and TEM studies: Chemical Geology [Isotope Geoscience Section], v. 66, p. 137-149.

Jaffey, A.H., Flynn, K.F., Glendenin, L.E., Bentley, W.C., and Essling, A.M., 1971, Precision measurement of half-lives and specific activities of ${ }^{235} \mathrm{U}$ and ${ }^{238} \mathrm{U}$ : Physical Review C: Nuclear Physics, v. 4, p. 1889-1906.

Jones, D.L., Silberling, N.J., Coney, P.J., and Plafker, George, 1987, Lithotectonic terrane map of Alaska, west of the 141st meridian; folio of the lithotectonic terrane maps of the North American Cordillera: U.S. Geological Survey Miscellaneous Field Studies Map MF-1874A, scale $1: 2,500,000$.
Keith, W.J., Miller, M.L., Bailey, E.A., Bundtzen, T.K., and Bickerstaff, Damon, 1996, Analytical results and sample locality maps of rock samples from the Stuyahok area, part of Holy Cross A-4 and A-5 quadrangles, Alaska: U.S. Geological Survey Open-File Report 96-505-B, $47 \mathrm{p}$.

Krogh, T.E., 1973, A low-contamination method for hydrothermal decomposition of zircon and extraction of $\mathrm{U}$ and $\mathrm{Pb}$ for isotopic age determinations: Geochimica et Cosmochimica Acta, v. 37, p. 485-494.

Krogh, T.E., 1982, Improved accuracy of U-Pb zircon dating by the creation of more concordant systems using air abrasion techniques: Geochimica et Cosmochimica Acta, v. 46, p. 637-649.

Layer, P.W., Hall, C.M., and York, D., 1987, The derivation of ${ }^{40} \mathrm{Ar} /$

${ }^{39} \mathrm{Ar}$ age spectra of single grains of hornblende and biotite by laser step heating: Geophysical Research Letters, v. 14, p. 757-760.

Layer, P.W., Kroner, A., and York, D., 1992, Pre-3000 Ma thermal history of the Archean Kaap Valley pluton, South Africa: Geology, v. 20, p. 717-720.

Ludwig, K.R., 1980, Calculation of uncertainties of U-Pb isotope data: Earth and Planetary Science Letters, v. 46, p. 212-220.

Ludwig, K.R., 1992, ISOPLOT_A plotting and regression program for radiogenic-isotope data, version 2.57: U.S. Geological Survey Open-File Report 91-445, $40 \mathrm{p}$.

McDougall, I., and Harrison, T.M., 1988, Geochronology and thermochronology by the ${ }^{40} \mathrm{Ar} /{ }^{39} \mathrm{Ar}$ method: New York, Oxford University Press, $212 \mathrm{p}$.

Mertie, J.B., Jr., 1936, Mineral deposits of the Ruby-Kuskokwim region, Alaska: U.S. Geological Survey Bulletin 864-C, p. 115-245.

Miller, M.L., and Bundtzen, T.K., 1994, Generalized geologic map of the Iditarod quadrangle, Alaska, showing potassium-argon, majoroxide, trace-element, fossil, paleocurrent, and archaeological sample localities: U.S. Geological Survey Miscellaneous Field Studies Map MF-2219-A, 48 p., scale 1:250,000.

Miller, M.L., Bundtzen, T.K., and Keith, W.J., 1998, Geology and gold resources of the Stuyahok area, Holy Cross quadrangle, southwestern Alaska, in Gray, J.E., and Riehle, J.R., eds., Geologic Studies in Alaska by the U.S. Geological Survey, 1996: U.S. Geological Survey Professional Paper 1595, p. 31-49.

Miller, M.L., Bundtzen, T.K., Keith, W.J., Bailey, E.A., and Bickerstaff, Damon, 1996, Geology and mineral resources of the Stuyahok area, part of Holy Cross A-4 and A-5 quadrangles, Alaska: U.S. Geological Survey Open-File Report 96-505-A, 30 p., scale $1: 63,360$.

Moll-Stalcup, E.J., 1994, Latest Cretaceous and Cenozoic magmatism in mainland Alaska, chap. 18 of Plafker, George, and Berg, H.C., eds, The Geology of Alaska: Boulder, Colo., Geological Society of America, The Geology of North America, v. G-1, p. 589-619.

Patton, W.W., Jr., Box, S.E., Moll-Stalcup, E.J., and Miller, T.P., 1994, Geology of west-central Alaska, chap. 7 of Plafker, George, and Berg, H.C., eds., The Geology of Alaska: Boulder, Colo., Geological Society of America, The Geology of North America, v. G-1, p. 241-269.

Patton, W.W., Jr., and Moll-Stalcup, E.J., 1996, Geologic map of the Unalakleet quadrangle, west-central Alaska: U.S. Geological Survey Miscellaneous Investigations Map I-2559, 39 p., scale $1: 250,000$.

Placer Dome, Inc., 1999, Placer Dome, the lowest-cost major gold producer, earns $\$ 105$ million in 1998: News release, February 18, 1999, http://portfolio@newswire.ca. 
Stacey, J.S., and Kramers, J.D., 1975, Approximation of terrestrial lead isotope evolution by a two-stage model: Earth and Planetary Science Letters, v. 26, p. 207-221.

Steiger, R.H., and Jäger, E., 1977, Subcommission on geochronology: Convention on the use of decay constants in geo and cosmochronology: Earth and Planetary Science Letters, v. 36, p. 359-362.

Reviewers: Dwight C. Bradley and Donald H. Richter
Tucker, R.D., Bradley, D.C., Ver Straeten, C.A., Harris, A.G., Ebert, J.R., and McCutcheon, S.R., 1998, New U-Pb zircon ages and the duration and division of Devonian time: Earth and Planetary Science Letters, v. 158, p. 175-186.

York, D., Hall, C.M., Yanase, Y., Hanes, J.A., and Kenyon, W.J., 1981, ${ }^{40} \mathrm{Ar} /{ }^{39} \mathrm{Ar}$ dating of terrestrial minerals with a continuous laser: Geophysical Research Letters, v. 8, p. 1136-1138. 


\title{
Sulfur-, Oxygen-, and Carbon-Isotope Studies of $\mathrm{Ag}-\mathrm{Pb}-\mathrm{Zn}$ Vein-Breccia 0ccurrences, Sulfide- Bearing Concretions, and Barite Deposits in the North-Central Brooks Range, with Comparisons to Shale-Hosted Stratiform Massive Sulfide Deposits
}

\author{
By Karen D. Kelley, David L. Leach, and Craig A. Johnson
}

\begin{abstract}
Stratiform shale-hosted massive sulfide deposits, sulfidebearing concretions and vein breccias, and barite deposits are widespread in sedimentary rocks of Late Devonian to Permian age in the northern Brooks Range. All of the sulfide-bearing concretions and vein breccias are hosted in mixed continentalmarine clastic rocks of the Upper Devonian to Lower Mississippian Endicott Group. The clastic rocks and associated sulfide occurrences underlie chert and shale of Mississippian-Pennsylvanian(?) age that contain large stratiform massive sulfide deposits like that at Red Dog. The relative stratigraphic position of the vein breccias, as well as previously published mineralogical, geochemical, and lead-isotope data, suggest that the vein breccias formed coevally with overlying shale-hosted massive sulfide deposits and that they may represent pathways of oreforming hydrothermal fluids. Barite deposits are hosted either in Mississippian chert and limestone (at essentially the same stratigraphic position as the shale-hosted massive sulfide deposits) or Permian chert and shale. Although most barite deposits have no associated base-metal mineralization, barite occurs with massive sulfide deposits at the Red Dog deposit.

Galena and sphalerite from most vein breccias have $\delta^{34} \mathrm{~S}$ values from -7.3 to $-0.7 \%$ o (per mil) and -5.1 to $3.6 \%$, respectively; sphalerite from sulfide-bearing concretions have $\delta^{34} \mathrm{~S}$ values of 0.7 and $4.7 \%$. This overall range in $\delta^{34} \mathrm{~S}$ values largely overlaps with the range previously determined for galena and sphalerite from shale-hosted massive sulfide deposits at Red Dog and Drenchwater. The Kady vein-breccia occurrence is unusual in having higher $\delta^{34} \mathrm{~S}$ values for sphalerite (12.1 to $12.9 \%$ ) and pyrite $(11.3 \%$ ) , consistent with previously published values for the shale-hosted Lik deposit. The correspondence in sulfur isotopic compositions between the stratiform and vein-breccia deposits suggests that they share a common source
\end{abstract}

of reduced sulfur, or derived reduced sulfur by similar geochemical processes. Most likely, the reduced sulfur was derived by biogenic sulfate reduction (BSR) or thermochemical sulfate reduction (TSR) of seawater sulfate during DevonianMississippian time.

The $\delta^{18} \mathrm{O}$ values of quartz from the vein breccias are between 16.6 and $19.9 \%$. Using the sphalerite-galena sulfur isotopic temperature of $188^{\circ} \pm 25^{\circ} \mathrm{C}$, the calulated hydrothermal fluids had $\delta^{18} \mathrm{O}$ values of 4.2 to $7.5 \%$. The calculated range of $\delta^{18} \mathrm{O}$ values of the fluids is similar to that of pore fluids in equilibrium with sedimentary rocks during diagenesis at $100^{\circ}-$ $190^{\circ} \mathrm{C}$.

\section{Introduction}

Stratiform shale-hosted massive sulfide deposits, sulfidebearing concretions, and sulfide-bearing vein-breccia ocurrences form an east-west-trending belt that extends across the northern Brooks Range (fig. 1). The stratiform deposits are hosted in chert, mudstone, and shale of MississippianPennsylvanian(?) age. Red Dog is the largest of these deposits, but other important stratiform occurrences include Su-Lik, Suds, and Drenchwater (fig. 1). The Ag-Pb- $\mathrm{Zn}$ vein breccias are discordant but stratabound in relatively older mixed continental-marine clastic rocks of the Lower Mississippian to Upper Devonian Endicott Group. Sulfide-bearing concretions also occur within rocks of the Endicott Group. Barite deposits are hosted either in Mississippian chert and limestone (at essentially the same stratigraphic position as the shale-hosted massive sulfide deposits) or Permian chert and shale. Although most barite deposits have no associated base-metal mineralization, barite occurs with massive sulfide deposits at the Red Dog deposit. 


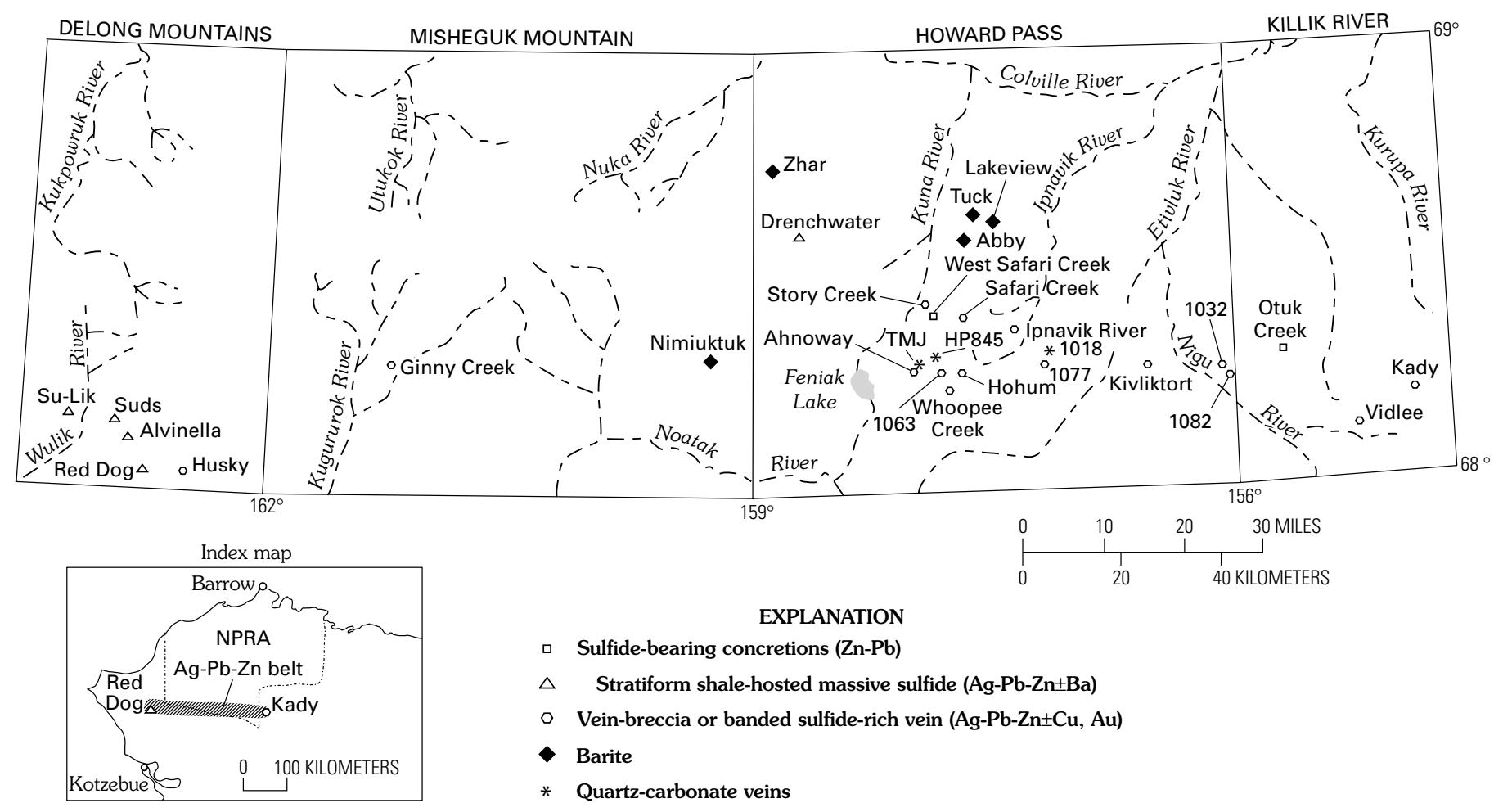

Figure 1. Locations of known Ag-Pb-Zn mineral occurrences and deposits in the northwestern and north-central Brooks Range. Unnamed localities are small, isolated occurrences that were found in stream float and not traced to outcrop (Kelley and others, 1997). Also shown are the locations of quartz-carbonate veins for which isotopic data were obtained; these veins are widespread throughout the Brooks Range. Inset shows locations of the regional $\mathrm{Ag}-\mathrm{Pb}-\mathrm{Zn}$ belt and of the National Petroleum Reserve in Alaska (NPRA).

In addition to the sulfide-rich vein-breccia occurrences, small quartz-carbonate veins, hosted primarily in weakly metamorphosed shale and siltstone of Late Devonian age, are widespread throughout the Brooks Range and are not confined to the $\mathrm{Ag}-\mathrm{Pb}-\mathrm{Zn}$ belt. Although these quartz-carbonate veins are typically barren of sulfide minerals, they locally contain pyrite and trace amounts of galena or sphalerite (Duttweiler, 1986).

It has been proposed that the vein breccias are either genetically related to the Carboniferous shale-hosted massive sulfide deposits (Young, 1989; Kelley and Mull, 1995; Young, 1995; Werdon, 1999) or to faulting that occurred during the Jurassic to Cretaceous Brooks Range orogeny (Ellersieck and others, 1982; Kurtak and others, 1995). The widespread quartz-carbonate veins are believed to have formed during metamorphism and deformation related to the Jurassic to Cretaceous Brooks Range orogeny (Duttweiler, 1986). Although the sulfide-bearing vein breccias and quartz-carbonate veins lack apparent economic value, understanding their genetic and temporal relations to the stratiform lead-zinc deposits can provide clues to regional hydrothermal events that formed the economically important stratiform ores. In order to evaluate a possible genetic relationship between the stratiform and vein-breccia occurrences, new sulfur-, oxygen-, and carbon-isotope data were obtained from sulfide-bearing concretions, vein-breccia occurrences, and spatially associated barite deposits in the north-central Brooks Range. Isotopic data were also acquired on samples of the widespread quartz-carbonate veins because they may provide an important comparison to the vein breccias and a means of testing the hypothesis that the sulfide-bearing vein breccias formed during the Mesozoic Brooks Range orogeny.

\section{Regional Geology}

The Brooks Range is an east-west-trending fold and thrust belt that formed during the Late Jurassic to Tertiary Brooks Range orogeny. This regionally extensive fold and thrust belt is made up of a series of thrust sheets or allochthons that consist dominantly of Devonian to Cretaceous sedimentary rocks (Mull, 1982). The allochthons are thought to represent parts of formerly continuous sedimentary basins that were juxtaposed during the orogenic event by multiple stages of thrusting and folding (Moore and others, 1994). The earliest Brooks Range deformational event occurred between 140 and $130 \mathrm{Ma}$ (Moore and others, 1994), with the major deformation ending by about $100 \mathrm{Ma}$ (Blythe and others, 1997). At least one minor compressional event continued into the Tertiary (O'Sullivan and others, 1997).

All of the Ag-Pb-Zn mineral occurrences and deposits are hosted in rocks of the Endicott Mountains allochthon (equivalent to the Brooks Range allochthon; Mayfield and others, 1988) (fig. 2), the structurally lowest of the formally named allochthons in the central Brooks Range. This allochthon contains an Upper Devonian to Lower Cretaceous sedimentary section that is probably as much as $4 \mathrm{~km}$ thick in the north-central Brooks Range (Killik River quadrangle) - this section thins to $1 \mathrm{~km}$ or less in the northwestern Brooks Range (Howard Pass quadrangle and farther west; Mull and Werdon, 1994; C.G. Mull, oral commun., 1998). It consists mostly of the Hunt Fork Shale, Noatak Sandstone, Kanayut Conglomerate, and Kayak Shale of the Endicott Group, which were deposited chiefly in a deltaic 


\begin{tabular}{|c|c|c|c|c|c|c|c|c|c|}
\hline 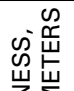 & 崖里 & & $\begin{array}{l}\text { MINERAL DE } \\
\text { OR OCCURI }\end{array}$ & $\begin{array}{l}\text { EPOSIT } \\
\text { RENCE }\end{array}$ & & & & & \\
\hline 兴告 & 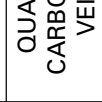 & Barite & $\begin{array}{l}\text { Stratiform } \\
\text { massive } \\
\text { sulfide }\end{array}$ & $\begin{array}{l}\text { Vein-breccia and } \\
\text { sulfide-bearing } \\
\text { concretions }\end{array}$ & TERIVD & & SIRAII & GRARTY & \\
\hline $7-$ & & 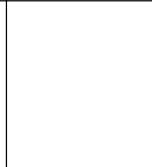 & $\begin{array}{c}1 \\
\vdots \\
\vdots \\
1 \\
1\end{array}$ & $\begin{array}{l}1 \\
1 \\
1 \\
1 \\
1\end{array}$ & $\begin{array}{c}\text { LOWER } \\
\text { CRETACEOUS }\end{array}$ & 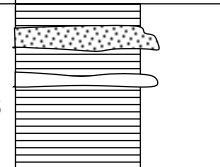 & Okpikrual & Formation (flysch) & \\
\hline 6 & & Zhar • & $i_{1}^{1}$ & 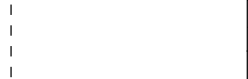 & \begin{tabular}{|l} 
JURASSIC \\
TRIASSIC \\
PERMIAN
\end{tabular} & 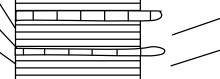 & $\begin{array}{l}\text { Otuk Forma } \\
\text { Siksikpuk F }\end{array}$ & $\begin{array}{l}\text { tion (mid-outer shelf) } \\
\text { ormation (mid-shelf) }\end{array}$ & $\begin{array}{l}\text { Etivluk } \\
\text { Group }\end{array}$ \\
\hline $5-$ & & $\begin{array}{l}\text { Abby, Tuck } \\
\text { Lakeview }\end{array}$ & $\begin{array}{l}\text { Red Dog, } \\
\text { ISu-Lik, } \triangle \text { ' }\end{array}$ & West Safari Creek, & PENN & 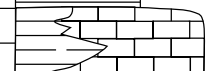 & Kuna Formation & $\begin{array}{l}\text { Alapah Limestone } \\
\text { (shallow marine) }\end{array}$ & Lisburne \\
\hline & & Nimiuktuk? & isater & $\begin{array}{l}\text { Otuk Creek } \\
-1\end{array}$ & MISSISSIPPIAN & & (deep marine) & $\begin{array}{c}\text { Wachsmuth Limestone } \\
\text { (shallow marine) }\end{array}$ & Group \\
\hline & HP845 & & 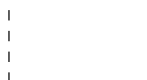 & Vidlop(?) & & 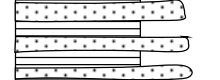 & $\begin{array}{l}\text { Noatak } \\
\text { (shallo }\end{array}$ & $\begin{array}{l}\text { Sandstone } \\
v \text { marine) }\end{array}$ & \\
\hline $1-$ & $*-$ & & $\begin{array}{l}1 \\
1 \\
1 \\
1 \\
1 \\
1\end{array}$ & Vidlee(?) ○ & & 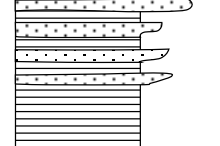 & $\begin{array}{r}\text { Hunt F } \\
\text { (shallow to }\end{array}$ & $\begin{array}{l}\text { ork Shale } \\
\text { deep marine) }\end{array}$ & \\
\hline
\end{tabular}

Figure 2. Generalized stratigraphic column of the Endicott Mountains allochthon (modified from Moore and others, 1994) showing approximate inferred stratigraphic position of mineral deposits and occurrences. Thicknesses are maximum except for the Kuna Formation (<100 $\mathrm{m}$ ), which is not drawn to scale. This stratigraphic column represents the central Brooks Range. In the Howard Pass quadrangle and westward, where most of the mineral deposits occur, the entire Endicott Group thins to $1 \mathrm{~km}$ or less (Mull and Werdon, 1994).

setting during the Late Devonian and Early Mississippian (Moore and others, 1994). The basal unit of the Endicott Group is the Upper Devonian Hunt Fork Shale, a prodelta sequence consisting of brown, fine-grained sandstone and grayish-black fissile shale (Brosgé and others, 1979). The Hunt Fork Shale grades upward into the shallow-marine Noatak Sandstone, a coarsening-upward package of fine- to medium-grained calcarous sandstone with interbedded dark-red siltstone and shale (Nilsen and Moore, 1984). The overlying Kanayut Conglomerate (Upper Devonian and Lower Mississippian?) represents a fluvial-deltaic sequence of interbedded sandstone, conglomerate, and shale (Nilsen and Moore, 1984). The Kanayut thins and fines southward and westward across the Brooks Range. Compositionally, the Kanayut consists primarily of chert and quartz clasts.

Feldspar is generally absent or is present only in small quantities. The sandstone cement is dominated by overgrowths of silica on quartz grains and by less abundant, but relatively coarse, phyllosilicate minerals that have grown interstitially. Other cements include calcite and local authigenic hematite (Brosgé and others, 1988). Zones of pyrite-rich sandstone and conglomerate are also common throughout the Brooks Range (Kelley, Barton, and others, 1993; Kelley and Mull, 1995).
During the Early Mississippian, the coarse clastic section was succeeded by shallow-water, fine-grained marine deposits of the Kayak Shale, which comprise black shale and minor fossiliferous limestone. The Kayak records submergence of the Kanayut clastic wedge and offshore deposition of fine-grained sediment prior to northward progradation of the Lisburne carbonate platform (Moore and others, 1994). At one locality in the central Brooks Range, the Kayak Shale differs markedly in having a basal section of reddish-brown-weathering, thin-bedded siltstone and fine-grained sandstone, interbedded locally with sandy limestone beds and overlain by typical black Kayak Shale; this basal unit has been termed the Isikut Member of the Kayak Shale (Mull and others, 1997).

Overlying the Kayak Shale is the Lisburne Group (Lower Mississippian to Lower Pennsylvanian), which in the central and eastern Brooks Range is characterized by thick platformcarbonate rocks. In the western Brooks Range, the Kayak Shale is overlain by black sooty shale, carbonate, and chert of the Kuna Formation (Mull and others, 1982), which is a basinal facies correlative with the platform carbonate rocks of the Lisburne Group farther east. The Permian Siksikpuk Formation, consisting of pyritic and baritic siltstone, mudstone, and chert, overlies the Carboniferous rocks. 


\section{Mineral-Deposit Types and their Stratigraphic Settings}

\section{Stratiform Shale-Hosted Massive Sulfide and Barite Deposits}

Stratiform massive sulfide deposits, consisting dominantly of sphalerite, galena, and pyrite or marcasite, are hosted in black sooty carbonaceous shale or mudstone of the Kuna Formation of the Lisburne Group (Nokleberg and Winkler, 1982; Forrest, 1983; Lange and others, 1985; Moore and others, 1986). The Kuna Formation, a deep-water (depths of $100 \mathrm{~m}$ or greater) assemblage, consists of less than $100 \mathrm{~m}$ of black shale interbedded with siliceous mudstone and black chert that is late Early Mississippian (Osagean) in age in the north-central Brooks Range and possibly younger (Late Mississippian to early Middle Pennsylvanian) farther west (Dumoulin and others, 1993). Preservation of fine laminae and the high organic carbon content suggest that anoxic or dysaerobic bottom-water conditions prevailed during its deposition (Dumoulin and others, 1993). The Kuna Formation may represent sponge-rich mud deposited in a partly oxygenated, starved-basin environment that lay southwest of the platform-carbonate facies of the Lisburne Group (Moore and others, 1994).

Stratiform barite deposits without associated base-metal mineralization, such as Abby, Tuck (fig. 3A), and Lakeview, are hosted in dominantly rhythmically bedded chert and minor limestone of middle Osage (late Early Mississippian) or early Meramecian (early Late Mississippian) age (Kelley, Tailleur, and others, 1993) (fig. 2). Farther west at the Red Dog deposit, barite of presumed similar age is abundant and is associated with massive sulfide mineralization (Moore and others, 1986). Rhythmic bedding in barite for some deposits suggests that the barite deposits are of syngenetic-diagenetic origin, similar to some in the Selwyn Basin (e.g., Pigage, 1983) and those in central Nevada (Rye and others, 1978).

Throughout the Brooks Range, barite also occurs as thin veins, lenses, and crystal aggregates in chert, siltstone, and mudstone of the Permian Siksikpuk Formation (Siok, 1985). Although most of the barite lenses are small ( $<1 \mathrm{~m}$ in length), one locality in the eastern part of the Killik River quadrangle has lenses that exceed $5 \mathrm{~m}$ in length (Kelley and Mull, 1995). Another previously undescribed occurrence at Zhar is north of the Drenchwater massive sulfide deposit in the Howard Pass quadrangle (fig. 1). At the Zhar occurrence, barite is hosted by green chert and shale of the Siksikpuk Formation (figs. 2 and $3 B$ ). Individual $10-\mathrm{cm}$-thick beds or layers of barite are interbedded with green chert and are exposed over an area of about $6 \mathrm{~m}$ laterally and $3 \mathrm{~m}$ vertically. As in the Mississippian barite deposits in the Howard Pass quadrangle, there are no associated sulfide minerals.

\section{Sulfide-Bearing Vein-Breccias}

Sulfide-rich vein-breccia occurrences are stratabound within clastic rocks of the Endicott Group. These occurrences are characterized primarily by banded sulfides in veins and sulfide-bearing breccias (figs. $3 C$ and $3 D$ ). The dominant gangue mineral is quartz. Where observed in outcrop, the veins are sharply discordant with host rocks (Kelley and others, 1997; Werdon, 1999). However, most occurrences are exposed only in frost boils and rubble-crop; it is therefore difficult to determine orientation or cross-cutting relations. Five of the more significant occurrences include Whoopee Creek (exposed over an area of at least 150 by $300 \mathrm{~m}$; Schmidt, this volume), Ahnoway (exposed over an area of about 25 by $30 \mathrm{~m}$ ), Hohum $(30 \mathrm{~m}$ lateral extent), Vidlee ( $25 \mathrm{~m}$ ), and Kady (about 8 zones, each $30 \mathrm{~m}$ wide or greater, exposed over a lateral distance of 6 kilometers) (Duttweiler, 1987; Kelley and Mull, 1995; Kelley and others, 1997; Werdon, 1999).

The vein breccias are particularly abundant in the western part of the Killik River quadrangle and farther west in the Brooks Range, which suggests that hydrothermal fluids were focused in this area. Nearly all of the vein-breccia occurrences are hosted either in the Noatak Sandstone or Kanayut Conglomerate of the Endicott Group (Kelley and Mull, 1995; Kurtak and others, 1995; Kelley and others, 1997) (fig. 2). Many vein-breccia zones exposed in outcrop (i.e., Kady) terminate at Mesozoic thrust faults, suggesting that they were present before Mesozoic deformation. However, there are also vein-breccia zones that are parallel to fold axes of anticlines; their orientation may suggest that minor sulfide remobilization accompanied Mesozoic deformation (Werdon, 1999).

The relative proportions of sulfide minerals in the vein breccias varies widely, even within a single vein-breccia zone; however, in general, the dominant sulfide mineral is sphalerite, with lesser amounts of galena, pyrite, and chalcopyrite (Jansons and Baggs, 1980; Jansons and Parke, 1981; Jansons, 1982; Kelley and Mull, 1995; Kurtak and others, 1995; Kelley and others, 1997). Rare grains of pyrrhotite in sphalerite and sulfosalt minerals as microscopic blebs within galena are reported at the Kady occurrence (Werdon, 1999). Where mineralized rocks are exposed in outcrop (i.e., Kady), the estimated maximum sulfide content of an entire vein-breccia zone (including barren quartz zones) is about 20 percent (Werdon, 1999). However, hand-sized samples of mineralized rock from many of the vein breccia occurrences contain as much as 50-60 percent sulfides (Kelley and others, 1997; Werdon, 1999).

Textures vary greatly within individual vein-breccia occurrences. Most common are host-rock breccias cemented by sulfides and quartz (fig. 3C), veins with color banded and (or) crustiform sphalerite with lesser banded quartz (fig. 3D), and complex sulfide-in-sulfide breccias (Werdon, 1999). In general, sulfide minerals show little textural evidence of deformation, with the exception of galena at the Vidlee occurrence, which shows curvature of crystal faces and cleavages.

The vein breccias are rich in silver (as much as $230 \mathrm{ppm}$ ) and commonly contain elevated gold (as much as $0.75 \mathrm{ppm}$ ) and copper (as much as 11 percent), but they characteristically lack significant amounts of barite (Duttweiler, 1987; Kelley and Mull, 1995; Kelley and others, 1997; Werdon, 1999). Shale-hosted stratiform deposits are dominated by sphalerite and galena, as are the vein breccias, but are generally not associated with anomalous concentrations of gold or copper and may contain abundant barite (Moore and others, 1986; Werdon, 1996). These geochemical differences between the stratiform 

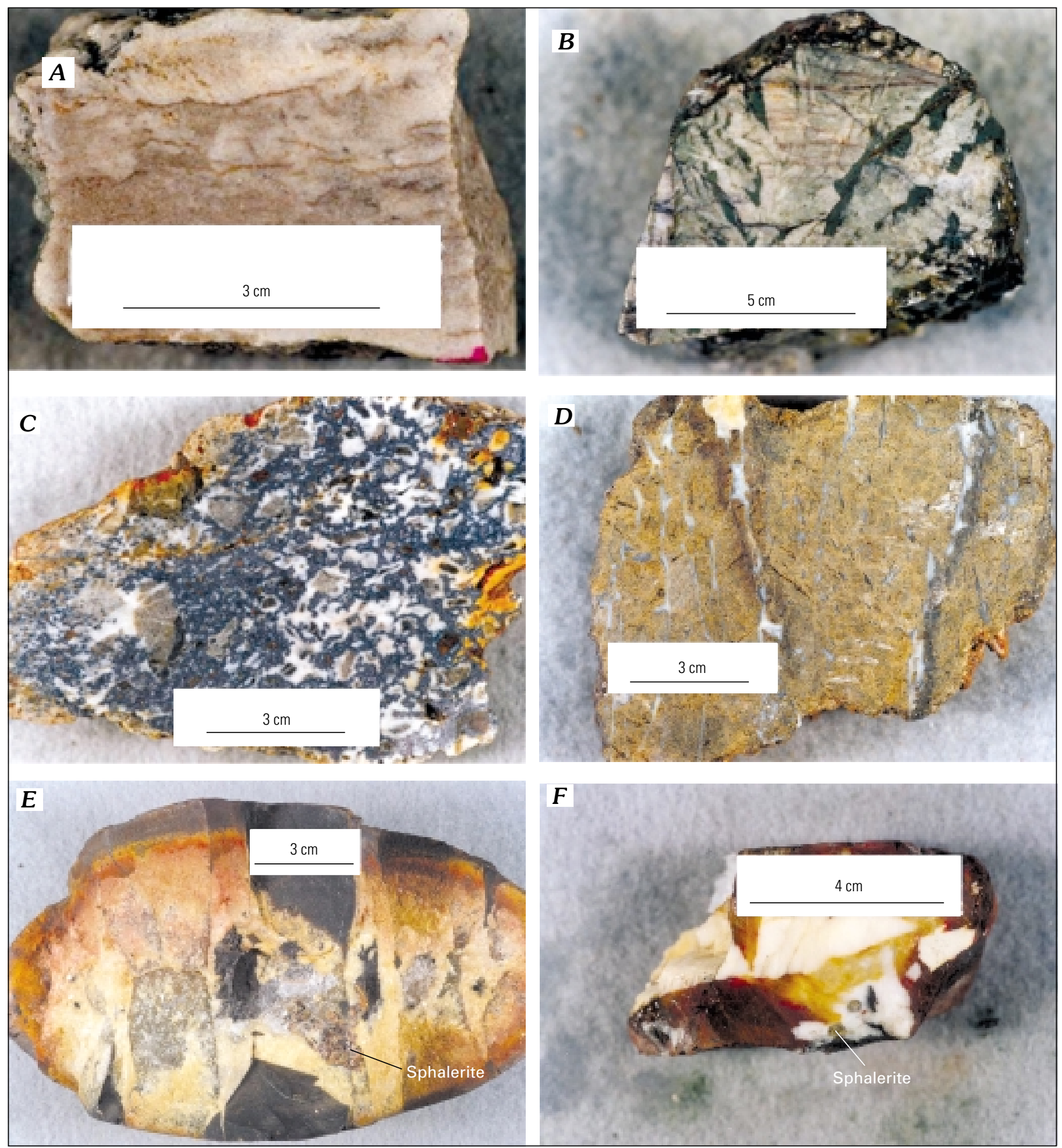

Figure 3. Examples of mineral-deposit types from the north-central Brooks Range. $A$, Massive barite hosted in Mississippian chert (Tuck); $B$, Barite intergrown with green chert of the Permian Siksikpuk Formation (Zhar); $C$, Typical mineralized vein-breccia occurrence showing clasts of siltstone rimmed by quartz with sulfide minerals (galena in this case but more commonly sphalerite) in the matrix (Whoopee Creek); $D$, Banded sphalerite-rich vein (Kady); $E$, Sphalerite-bearing concretion (Otuk Creek); $F$, typical quartz-carbonate vein with trace sphalerite (HP845).

shale-hosted deposits and the vein-breccia deposits in the Brooks Range may suggest that the vein-breccia occurrences represent feeder zones or dewatering pathways for overlying stratiform massive sulfide deposits (Young, 1989; Kelley and Mull, 1995). The presence of gold and copper in the vein breccias could reflect a geochemical zoning, with the feeder zones (i.e., the vein breccias) having a different geochemical signature than the overlying stratiform sulfides. Such a geochemical zonation (higher $\mathrm{Cu}$ and lower $\mathrm{Ba}$ concentrations in the feeder zone relative to the stratiform body) has been postulated for other stratiform sulfide deposits (Lydon, 1983; Goodfellow and others, 1993). 
Alternatively, it has been proposed that the vein breccias formed along faults and fractures during the Jurassic to Cretaceous Brooks Range orogeny (Ellersieck and others, 1982; Kurtak and others, 1995). However, recent ${ }^{40} \mathrm{Ar} /{ }^{39} \mathrm{Ar}$ isotopic dating of recrystallized detrital white mica in sandstone adjacent to a mineralized quartz vein at the Kady occurrence has documented a Mississippian age (324 Ma) for this mineralization (Werdon, 1999). In addition, previously obtained lead-isotope compositions of galenas from the vein breccias are within the range of compositions for galena in the shale-hosted Red Dog, Lik, and Drenchwater massive sulfide deposits (Gaccetta and Church, 1989; Young, 1995). The lead-isotope compositions of galena suggest that the lead in these deposits was derived from a similar or perhaps common crustal reservoir. Unless the lead reservoir for the vein breccias was depleted in uranium, the interval between Carboniferous to Jurassic-Cretaceous time would have produced significant radiogenic growth of lead that would be reflected in the lead isotope ratios of galena from the vein breccias. Although the uranium content of these rocks has not been established, it is unlikely that they are depleted in uranium. Therefore, any fluids that interacted with these rocks in Cretaceous to Jurassic time would have contained lead that is measurably more radiogenic than the lead present in these rocks during the Carboniferous.

\section{Sulfide-Bearing Concretions}

Iron-rich sulfide-bearing (sphalerite and galena) concretions are abundant locally in typical black shale of the Lower Mississippian Kayak Shale (Otuk Creek and West Safari Creek; fig. 2, fig. $3 E$ ). The concretions range in diameter from $7.6 \mathrm{~cm}$ to $20 \mathrm{~cm}$ and probably formed during compaction and diagenesis (Kelley and Mull, 1995; Kelley and others, 1997). They contain abundant calcite, minor amounts of red-brown sphalerite and pyrite, and trace amounts of galena. In addition to the sulfidebearing concretions that were found in the Kayak Shale at Otuk and West Safari Creeks, they were found in the Chandler Lake quadrangle to the east (Kurtak and others, 1995), indicating that they may be fairly common in the Kayak Shale (Kelley and Mull, 1995).

\section{Quartz-Carbonate Veins}

Small quartz-carbonate veins, which are widespread throughout the Brooks Range, are hosted by weakly metamorphosed shale and siltstone of the Hunt Fork Shale and Noatak Sandstone. Typically, these veins are $1-2 \mathrm{~cm}$ in width and contain pyrite with local trace amounts of galena or sphalerite (fig. $3 F$ ). The carbonate is either calcite, dolomite, or siderite. Chlorite and goethite are also common gangue minerals. Localities of two relatively large quartz-carbonate veins containing pyrite without other base-metal sulfide minerals include the TMJ and an unnamed occurrence (HP845; fig. 2) in the Howard Pass quadrangle. The formation of these veins has been attributed to metamorphism and fluid circulation during the Brooks Range orogeny (Duttweiler, 1986).
Quartz-carbonate veins from the central Brooks Range, similar to those sampled during this study, are described in Duttweiler (1986). Lead-isotope compositions of galena from these quartz-carbonate veins (Gaccetta and Church, 1989, p. 10, their table 1) are distinctly more radiogenic than galena in the vein breccias and shale-hosted deposits. Considering that the quartzcarbonate veins occur in the same shale-rich host rocks as the vein breccias, the more radiogenic character of the lead implies quartz-carbonate vein formation during a hydrothermal event considerably later than that which formed the vein breccias and the stratiform ores. These data suggest that formation of the quartz-carbonate veins occurred during the Brooks Range orogeny in Jurassic to Cretaceous time.

\section{Stable-Isotope Data}

\section{Analytical Methods}

Sulfur-isotope studies were performed to help identify possible sources of the sulfur in the various deposits and occurrences and to aid in defining the physiochemical conditions of ore deposition within these hydrothermal systems. Barite, galena, sphalerite, and pyrite were separated from occurrences and deposits in the Howard Pass and western Killik River quadrangles. The $\delta^{34} \mathrm{~S}$ values were determined by the methods of Yanagisawa and Sakai (1983) using a modified Nuclide 6-60 RMS mass spectrometer in laboratories at the U.S. Geological Survey in Denver, Colo. The data are reported in $\delta$-notation relative to the Cañn Diablo triolite (CDT) standard. Reproducibility of the analyses was generally within $\pm 0.2 \%$ o. Results are summarized in table 1 .

Oxygen- and carbon-isotope studies were initiated to help identify possible sources for the hydrothermal fluids. Quartz from vein breccias and quartz-carbonate veins was separated and oxygen-isotope compositions were measured using the methods of Clayton and Mayeda (1963). In addition, $\delta^{18} \mathrm{O}$ and $\delta^{13} \mathrm{C}$ values were determined for calcite from sulfide-bearing concretions at the Otuk Creek and West Safari Creek occurrences and for dolomite intergrown with quartz from a quartzcarbonate vein. Carbonate preparation procedures followed those given by McCrea (1950); fractionation factors were taken from Friedman and O'Neil (1977). The data are reported in standard $\delta$-notation relative to standard mean ocean water (SMOW) for oxygen and relative to Peedee belemnite (PDB) for carbon. Reproducibility of the oxygen isotopic analyses was generally within $\pm 0.2 \%$, and within $0.1 \%$ o for the carbonisotope analyses. Results are summarized in table 2.

\section{Sulfur-Isotope Compositions}

Sulfur-isotope compositions of the vein breccias and sulfide-bearing concretions are compared to published data for the Red Dog, Drenchwater, and Lik stratiform shale-hosted deposits in figure 4. With the exception of the Kady occurrence, galena and sphalerite separates from the vein-breccia occurrences have $\delta^{34} \mathrm{~S}$ values of -7.3 to $-0.7 \%$ and -5.1 to $3.6 \%$, respectively (table 1; fig. 4). Sphalerite from sulfide-bearing 
Table 1. Sulfur isotopic data for sulfide-bearing concretions, vein-breccia occurrences, barite deposits, and quartz-carbonate veins in the west-central Brooks Range.

[Mineral occurrence locations are shown on figs. 1 and 2; py, pyrite; gn, galena; sph, sphalerite; ba, barite]

\begin{tabular}{|c|c|c|c|c|c|c|c|}
\hline Field no. & Occurrence & Mineral & $\begin{array}{l}\text { Latitude } \\
\left(^{\circ}, \quad\right)\end{array}$ & $\begin{array}{l}\text { Longitude } \\
\left(^{\circ}, \prime\right)\end{array}$ & $\begin{array}{l}\delta^{34} S \\
(\% \circ)\end{array}$ & $\Delta$ sph-gn & $\begin{array}{c}\mathrm{T} \\
\left({ }^{\circ} \mathrm{C}\right)\end{array}$ \\
\hline \multicolumn{8}{|c|}{ Vein-breccia occurrences } \\
\hline 96KADY4 & Kady & sph & 681157 & 1550030 & 12.1 & & \\
\hline 96KADY6 & Kady & sph & 681157 & 1550030 & 12.9 & & \\
\hline AKD605E & Kady & py & 681157 & 1550030 & 11.3 & & \\
\hline 96VD001 & Vidlee & $\mathrm{sph}$ & 680730 & 1551700 & 0.8 & & \\
\hline 96VD001 & Vidlee & gn & 680730 & 1551700 & -2.7 & 1.9 & \\
\hline 96VD001 & Vidlee & py & 680730 & 1551700 & 0.3 & & \\
\hline 96HP1032 & Unnamed & $\mathrm{sph}$ & 681801 & 1560927 & -0.2 & & \\
\hline 96KV001 & Kivliktort & sph & 681800 & 1563753 & -0.2 & & \\
\hline 96WC001 & Whoopee Creek & gn & 681357 & 1575019 & -3.6 & & \\
\hline 96WC001 & Whoopee Creek & sph & 681357 & 1575019 & 0.8 & 2.8 & \\
\hline 961051 & Hohum & sph & 681557 & 1574535 & -4.6 & & \\
\hline 961051 & Hohum & gn & 681557 & 1574535 & -7.3 & 2.7 & \\
\hline AKD880 & Safari Creek & $\mathrm{sph}$ & 682100 & 1574330 & 3.6 & & \\
\hline AKD880 & Safari Creek & gn & 682100 & 1574330 & -0.8 & 2.8 & \\
\hline $96 \mathrm{SC} 001$ & Story Creek & gn & 682452 & 1573502 & -3.6 & & \\
\hline $96 \mathrm{SC} 001$ & Story Creek & sph & 682452 & 1573502 & -1.1 & 2.5 & \\
\hline 96AHN001 & Ahnoway & gn & 681547 & 1580658 & -0.7 & & \\
\hline 96AHN001 & Ahnoway & sph & 681547 & 1580658 & -4.1 & 3.4 & 188 \\
\hline 96HP615R2V & Ahnoway & sph & 681547 & 1580658 & -4.5 & & \\
\hline 96HP615R2D & Ahnoway & sph & 681547 & 1580658 & -4.1 & & \\
\hline 94HP1082 & Unnamed & gn & 681652 & 1560308 & -0.8 & & \\
\hline 4HP1063 & Unnamed & sph & 681615 & 1575428 & -4.9 & & \\
\hline 4HP1063 & Unnamed & sph & 681615 & 1575428 & -5.1 & & \\
\hline \multicolumn{8}{|c|}{ Sulfide-bearing concretions } \\
\hline 96НР610 & West Safari Creek & sph & 682226 & 1575436 & 0.7 & & \\
\hline $40 \mathrm{OC} 001$ & Otuk Creek & sph & 681927 & 1554145 & 4.7 & & \\
\hline \multicolumn{8}{|c|}{ Barite } \\
\hline 92AKD802 & Zhar & ba & 683906 & 1585421 & 22.1 & & \\
\hline 94TUCK & Tuck & ba & 683525 & 1573000 & 29.8 & & \\
\hline 94HP1090 & Lakeview & ba & 683520 & 1572940 & 27.3 & & \\
\hline \multicolumn{8}{|c|}{ Quartz-carbonate veins } \\
\hline 2HP845R1 & Unnamed & sph & 681838 & 1575308 & 17.7 & & \\
\hline 2TMJ001 & TMJ & py & 681829 & 1580456 & -22.9 & & \\
\hline 2TMJ003 & TMJ & py & 681829 & 1580456 & -23.0 & & \\
\hline
\end{tabular}

concretions have $\delta^{34} \mathrm{~S}$ values of 0.7 and $4.7 \%$. The overall range of $\delta^{34} \mathrm{~S}$ values for galena and sphalerite fall largely within the range of values determined by Zierenberg and Schmidt (1988) and Lange and others (1985) for galena and sphalerite from shale-hosted massive sulfide deposits at Red Dog and Drenchwater (fig. 4). Kady is characterized by higher $\delta^{34} \mathrm{~S}$ values for sphalerite (12.1 to $12.9 \%$ ) and pyrite (11.3\%o; table 1$)$; this is consistent with the sulfur-isotope compositions reported by Werdon (1999) for the Kady occurrence. The higher values at Kady fall within the range for sphalerite, galena, and pyrite from the Lik deposit (Forrest, 1983) and for pyrite in massive ore and pyrite veins at the Red Dog deposit (Schmidt and Zierenberg, 1987).

The correspondence of the sulfur-isotope values between the vein breccias and stratiform sulfides suggests that these different deposits derived reduced sulfur by similar geochemical processes or that they shared a common reservoir of reduced sulfur. However, to properly interpret the sulfur-isotope data for the deposits, it is necessary to understand the geochemical processes that produced the reduced sulfur on a regional or basin scale. In addition, it is important to understand the nature and distribution of sulfur in potential sulfur reservoirs (i.e., Devonian-Mississippian seawater and host rocks). Although we lack sufficient data to permit characterization of the various reservoirs of sulfur, it is possible to draw general observations from the existing data that provide some insights into possible sources of the reduced sulfur.

Data from Claypool and others (1980) show that late Carboniferous seawater sulfate had $\delta^{34} \mathrm{~S}$ values of $14-17 \%$, although the range extends from about $28 \%$ at the beginning of the Mississippian to $15 \%$ o by Late Mississippian time. Devonian seawater sulfate varied from about 15 to $24 \%$ o (fig. 4). Samples of barite from the Red Dog deposit have $\delta^{34} \mathrm{~S}$ values of about 10 to $30 \%$, with the majority falling between 16 and $19 \%$ (Lange and others, 1985; Schmidt and Zierenberg, 1987) (fig. 4). These values are consistent with the derivation of sulfate from 
Table 2. Oxygen and carbon isotopic data for sulfide-bearing concretions and vein-breccia occurrences in the north-central Brooks Range.

[Mineral occurrence locations are shown on figs. 1 and 2; qtz, quartz; cc, calcite; dol, dolomite; $\delta^{18} \mathrm{O}$, oxygen isotope composition (measured) of mineral; $\delta^{13} \mathrm{C}$, carbon isotope composition (measured) of mineral; $\delta^{18} \mathrm{O}_{\mathrm{f}}$, oxygen isotope composition (calculated) of fluid responsible for Lvein-breccia mineralization]

\begin{tabular}{|c|c|c|c|c|c|c|c|}
\hline Field no. & Occurrence & Mineral & $\begin{array}{l}\text { Latitude } \\
\left(^{\circ}, "\right)\end{array}$ & $\begin{array}{l}\text { Longitude } \\
\left(^{\circ}, "\right)\end{array}$ & $\begin{array}{r}\delta^{18} 0 \\
(\% 0)\end{array}$ & $\begin{array}{r}\delta^{13} \mathrm{C} \\
(\%)\end{array}$ & $\begin{array}{c}\delta^{18} 0_{f}^{*} \\
(\%)\end{array}$ \\
\hline \multicolumn{8}{|c|}{ Vein-breccia occurrences } \\
\hline 96KADY6 & Kady & qtz & 681157 & 1550030 & 17.2 & & 4.8 \\
\hline 96VD001 & Vidlee & qtz & 680730 & 1551700 & 16.6 & & 4.2 \\
\hline 96WC001 & Whoopee Creek & qtz & 681357 & 1575019 & 18.4 & & 6.0 \\
\hline 961051 & Hohum & qtz & 681557 & 1574535 & 18.4 & & 6.0 \\
\hline 96SC001 & Story Creek & qtz & 682452 & 1573502 & 19.9 & & 7.5 \\
\hline 96AHN001 & Ahnoway & qtz & 681547 & 1580658 & 18.1 & & 5.7 \\
\hline 2HP615R1 & Ahnoway & qtz & 681547 & 1580658 & 17.5 & & 5.1 \\
\hline 96HP615R2V & Ahnoway & qtz & 681547 & 1580658 & 17.4 & & 5.0 \\
\hline 96HP615R2D & Ahnoway & qtz & 681547 & 1580658 & 17.8 & & 5.4 \\
\hline 94HP1082 & Unnamed & qtz & 681652 & 1560308 & 19.2 & & 6.8 \\
\hline \multicolumn{8}{|c|}{ Sulfide-bearing concretions } \\
\hline 96НР610 & West Safari Creek & $\mathrm{cc}$ & 682226 & 1575436 & 0.7 & -3.7 & \\
\hline $40 \mathrm{OC} 001$ & Otuk Creek & $\mathrm{cc}$ & 681927 & 1554145 & 18.3 & -7.7 & \\
\hline \multicolumn{8}{|c|}{ Quartz-carbonate veins } \\
\hline 2HP845R1 & Unnamed & dol & 681838 & 1575308 & 16.0 & -2.5 & \\
\hline 2TMJ001 & TMJ & qtz & 681829 & 1580456 & 22.8 & & \\
\hline 4HP1018 & Unnamed & qtz & 681712 & 1572016 & 19.6 & & \\
\hline
\end{tabular}

Carboniferous seawater. However, some barites from Red Dog display relatively heavy sulfur of up to $50 \%$ (Schmidt and Zierenberg, 1987); barite $\delta^{34} \mathrm{~S}$ values from the Lakeview and Tuck deposits of late Early Mississippian age are 27.3 and 29.8\%o, respectively (table 1; fig. 4). These high values are consistent with bacterial sulfate reducion (BSR) in an anoxic environment within a closed, to nearly closed, basin (Ohmoto, 1986). During BSR, bacteria reduce the sulfate in seawater to form sulfide minerals. The earliest sulfide minerals formed during BSR will have extremely light sulfur-isotope compositions because bacteria preferentially incorporate ${ }^{32} \mathrm{~S}$, the lighter of the sulfur isotopes. This preference by bacteria for the light isotope will result in deposition of increasingly heavy $\left({ }^{34} \mathrm{~S}\right.$-rich) sulfides with time, and increasingly heavy seawater sulfate as BSR progresses. In closed systems, where there is no influx of sulfate, seawater sulfate $\delta^{34} \mathrm{~S}$ values can therefore become extremely heavy. The heavy sulfur reported for some Red Dog barites, and for barite from the Lakeview and Tuck deposits, probably records nearly closed system sulfate reduction in anoxic conditions during Mississippian time. At Red Dog and Drenchwater, the $\delta^{34} S$ values for galena and sphalerite show a narrow range from about -5 to +5\%o (Lange and others, 1985; Schmidt and Zierenberg, 1987), which is consistent with a BSR fractionation of $15-20 \%$ relative to the 16 to $19 \%$ o values of Red Dog barite, presumably reflecting the isotopic composition of the dissolved sulfate.

Sphalerite and galena from the Lik deposit have $\delta^{34} \mathrm{~S}$ values that range from -4 to $18 \%$ (fig. 4 ), with average values of about 9 and 6\%o, respectively (Forrest, 1983). These values are notably higher than those reported for the Red Dog deposit and are difficult to explain by BSR in the same seawater reservoir where Red Dog galena and sphalerite formed. As suggested by Forrest
(1983), the heavy values for sulfur isotopes at Lik can be explained by nearly quantitative reduction of seawater sulfate in an anoxic marine basin or sub-basin that was richer in ${ }^{34} \mathrm{~S}$ than the basin in which Red Dog formed. If this is true, then the Red Dog and Lik deposits obtained their reduced sulfur at different times and (or) from different basin sources.

The above discussion points out the broad range of sulfurisotope values observed in the stratiform deposits of the western and central Brooks Range and the complex and poorly understood processes that account for the range in isotope values. As discussed above, the lead-isotope data suggest that lead in galena from the vein-breccias and the stratiform ores was derived from a common reservoir and that the two types of ore formed broadly at the same time. If this is true, then the vein-breccias and stratiform ores probably are genetically related. It is reasonable to suggest that the sulfides in the vein-breccias obtained their reduced sulfur from the reduction of sulfate (as pore fluids) in the Devonian sedimentary rocks, which was ultimately derived from contemporaneous seawater (15 to 24\%o; Claypool and others, 1980). Reduced sulfur derived from Devonian seawater sulfate through BSR or thermochemical sulfate reduction (TSR) would yield isotopic values broadly similar to those observed in the vein breccias. Thus, metal-bearing fluids migrating through the Devonian rocks in Carboniferous time could have obtained reduced sulfur from local sources in the Devonian rocks to precipitate small amounts of sulfide minerals in the vein breccias. If this metal-bearing fluid ascended into the Carboniferous basinal environment and mixed with additional reduced sulfur, created through BSR of Carboniferous seawater sulfate, then the resulting sphalerite and galena would have sulfur isotopic compositions similar to those of the vein breccias. Thus, it is conceivable 


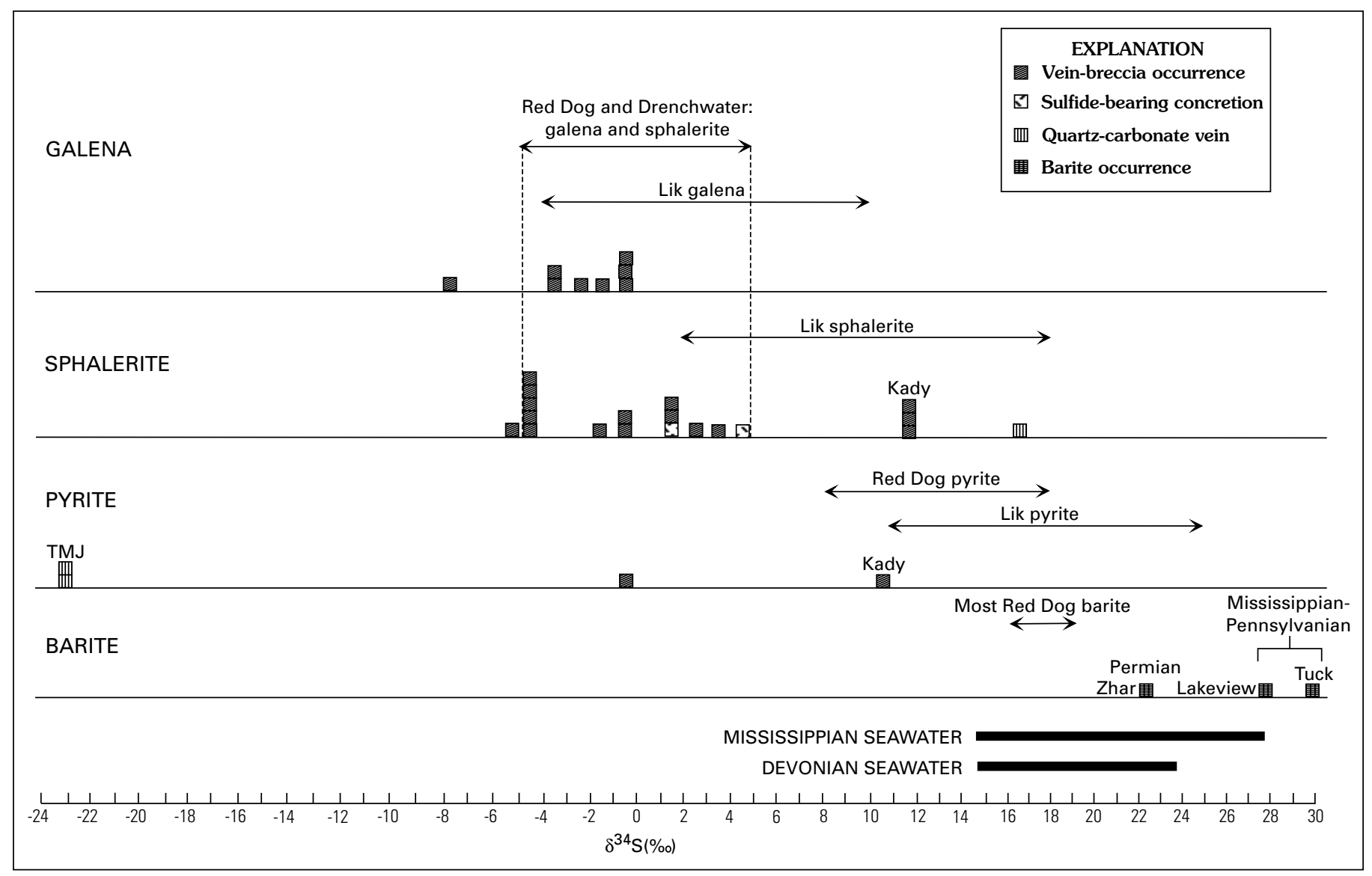

Figure 4. Sulfur-isotope data for sphalerite, galena, pyrite, and barite from sulfide-bearing concretions, vein-breccia and barite deposits, and quartz-carbonate veins in the north-central Brooks Range compared to sphalerite, galena, and pyrite data from Red Dog and Drenchwater (Lange and others, 1985; Zierenberg and Schmidt, 1988) and the Lik deposit (Forrest, 1983). Mississippian and Devonian seawater sulfate values are from Claypool and others (1980).

that reduced sulfur from Devonian seawater sulfate was the primary source of sulfur in the vein breccias and also provided one source (together with reduced sulfur from Carboniferous seawater) to form the shale-hosted deposits. Additional studies of sulfur isotopes in the host rocks of the region are needed to properly evaluate the different possibilities.

Only two samples of pyrite and one sphalerite sample from quartz-carbonate veins were analyzed for sulfur isotopes. The two samples of pyrite from the TMJ deposit have $\delta^{34} \mathrm{~S}$ values of $-23 \%$ and $-22.9 \%$, whereas sphalerite in sample 2HP845R has a value of $17.7 \%$. The light values of sulfur in the TMJ occurrence suggest remobilization of reduced sulfur that was originally fixed in the rocks by BSR. This remobilization probably occurred during low-grade metamorphism and deformation during the Brooks Range orogeny.

\section{Oxygen- and Carbon-Isotope Compositions}

All of the $\delta^{18} \mathrm{O}$ values for quartz from the vein breccias are between 16.6 and $19.9 \%$ (table 2, fig. 5). These results

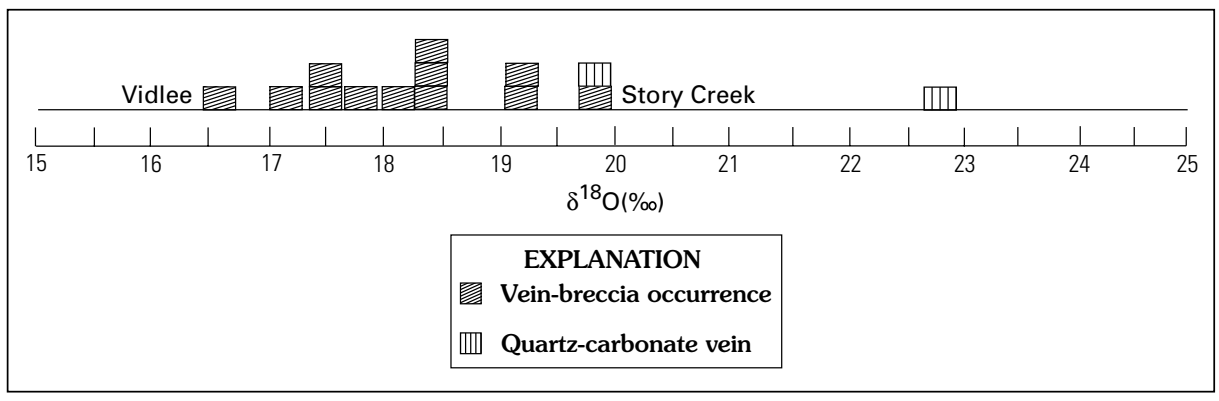

Figure 5. Oxygen-isotope data for quartz from vein-breccia occurrences and quartz-carbonate veins. 
conflict with the data obtained by Werdon (1999) for nine samples of quartz from the Kady occurrence that yielded a range of $\delta^{18} \mathrm{O}$ values from 10.8 to $15.4 \%$ (a single analysis from Kady analyzed during this study has a value of $17.2 \%$, table 2).

Quartz from vein-breccia occurrences that are unique in terms of their host-rock compositions yielded the lowest and highest oxygen-isotope values. For instance, quartz from the Story Creek occurrence, which yielded the highest $\delta^{18} \mathrm{O}$ value of $19.9 \%$, is hosted by reddish-brown siltstone of the Kayak Shale that locally contains scattered limestone beds. The occurrence at Vidlee, with the lowest value of $16.6 \%$, is within shaly siltstone of the Hunt Fork Shale. All of the others are hosted by siltstone or conglomerate of the Kanayut Conglomerate or Noatak Sandstone. This pattern suggests that the composition of the host rock played a dominant role in the oxygen-isotope compositions of quartz in the vein breccias, either due to differences in permeabilities (and thus, different water/rock ratios), or to differences in original oxygen-isotope compositions of the host rocks. For example, pelitic rocks have bulk $\delta^{18} \mathrm{O}$ values of around $18 \%$, whereas those of marine carbonate rocks are around 25-30\%o (e.g., Hoefs, 1997).

Fluid-inclusion studies were attempted for samples of sphalerite and quartz from the vein occurrences. Unfortunately, no primary fluid inclusions were observed. Therefore, we were unable to obtain homogenization temperatures for calculating $\delta^{18} \mathrm{O}$ values of the fluids in equilibrium with the quartz. However, sulfur-isotope values obtained for sulfides from the Ahnoway occurrence can be used to estimate the temperature of sulfide deposition using the sulfur-isotope fractionation equations of Ohmoto and Rye (1979). Sulfur-isotope geothermometry, based on the fractionation of sulfur isotopes between different sulfur-bearing compounds, assumes that equilibrium was established and preserved between two coprecipitated minerals. Sphalerite and galena in the Ahnoway vein are texturally intergrown and are interpreted to have coprecipitated. If isotopic equilibrium is assumed, $\delta^{34} \mathrm{~S}$ data for the sulfide pair indicate a temperature of $188^{\circ} \pm 25^{\circ} \mathrm{C}$. Similar temperatures $\left(209^{\circ} \pm 25^{\circ} \mathrm{C}\right)$ during sulfide deposition have been interpreted from sphaleritegalena data at the Kady occurrence by Werdon (1999). Assuming that all of the vein breccias formed at approximately the same temperature $\left(188^{\circ} \mathrm{C}\right)$, and using the quartz-water fractionation equation of Clayton and others (1972), which indicates a fractionation of 12.4 at $188^{\circ} \mathrm{C}$, the calulated hydrothermal fluids had $\delta^{18} \mathrm{O}$ values of 4.2 to $7.5 \%$ (table 2, fig. 6). The calculated range of $\delta^{18} \mathrm{O}_{\text {Fluid }}$ values provides insight into the character and origin of the hydrothermal fluid. It has been found that during diagenesis of sediments, pore waters in equilibrium with shale, mudstone, and clastic rocks have $\delta^{18} \mathrm{O}$ values of about 6 to $10 \%$ o at temperatures of about $100^{\circ}-190^{\circ} \mathrm{C}$ (for example, in Gulf Coast sediments; Longstaffe, 1987). Based on these data, it is reasonable to assume that the calculated compositions of fluids in equilibrium with the vein breccias may represent those of pore waters in the sediments (fig. 6).

Quartz from quartz-carbonate veins yields $\delta^{18} \mathrm{O}$ values (19.6-2.8\%o) that are relatively higher than most of those measured in the vein breccias. There are no direct temperature constraints on the formation of these veins. However, Harris and others (1987) suggested that temperatures in the north-central

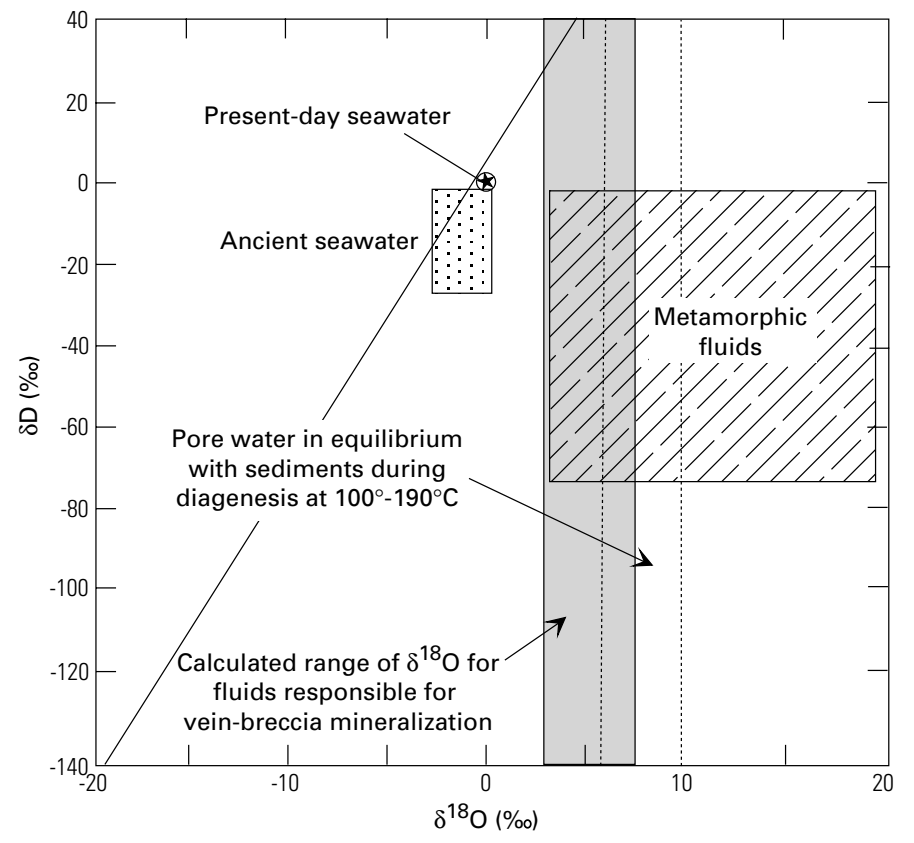

Figure 6. Calculated $\delta^{18} 0_{\text {fluid }}$ values for vein-breccia occurrences. Field boundaries from Ohmoto (1986), Sheppard (1986), and Longstaffe (1987). $\delta$ D refers to the isotopic composition of hydrogen in water.

Brooks Range did not exceed about $200^{\circ}-250^{\circ} \mathrm{C}$ during burial and metamorphism related to the Brooks Range orogeny. Using a temperature of $200^{\circ} \mathrm{C}$, calculated fluids in equilibrium with these quartz samples would have $\delta^{18} \mathrm{O}$ values of 7.9 and $11.1 \%$, respectively. At $250^{\circ} \mathrm{C}$, the fluids would have values of 10.6 and 13.81. These $\delta^{18} \mathrm{O}$ values are within the range reported for metamorphic fluids (fig. 6), but this interpretation is speculative due to our lack of hydrogen-isotope data and to uncertainties in the formational temperatures.

Two calcite samples from sulfide-bearing concretions at the West Safari Creek and Otuk Creek occurrences yield $\delta^{13} \mathrm{C}$ values of -3.7 and $-7.7 \%$, respectively. A third sample of dolomite from a quartz-carbonate vein has a value of $-2.5 \%$. The $\delta^{13} \mathrm{C}$ values for calcite from the concretions are consistent with carbonate that has formed during diagenesis. Sedimentary organic matter has a $\delta^{13} \mathrm{C}$ value of about $-25 \%$ o (Ohmoto and Goldhaber, 1997). Initial decomposition of this organic matter during diagenesis results in the formation of $\mathrm{CO}_{2}$ (aq) and $\mathrm{HCO}_{3}{ }^{-}$that are isotopically similar to this value. Addition of this $\delta^{13} \mathrm{C}$-depleted $\mathrm{HCO}_{3}{ }^{-}$to pore fluids of marine sediments may cause the pore fluids to become saturated with calcite. Consequently, diagnetic calcite formed in this way typically has $\delta^{13} \mathrm{C}$ values between -15 and $-5 \%$ (Ohmoto and Goldhaber, 1997).

\section{Summary}

There is abundant evidence to suggest that the vein-breccia occurrences formed at approximately the same time as the stratiform shale-hosted massive sulfide deposits. In addition to a 
Mississippian (324 Ma) ${ }^{40} \mathrm{Ar} /{ }^{39} \mathrm{Ar}$ isotopic age for recrystallized detrital white mica in sandstone adjacent to a mineralized quartz vein at the Kady occurrence (Werdon, 1999), lead-isotope compositions of galena from shale-hosted stratiform massive sulfide deposits are similar to those from the vein-breccia occurrences (Gaccetta and Church, 1989). This isotopic similarity suggests that the lead was derived from a common crustal reservoir. If the vein breccias had formed during the Brooks Range orogeny in Jurassic to Cretaceous time, the time interval between the Carboniferous and Jurassic-Cretaceous would have produced significant radiogenic growth of lead, resulting in more radiogenic lead in the vein-breccias compared to the shale-hosted deposits. However, this is clearly not the case. On the other hand, galena from small (1-2 cm wide) quartz-carbonate veins that are widespread throughout the Brooks Range is more radiogenic than the vein breccias and shale-hosted deposits. This pattern supports the interpretation that the quartz-carbonate veins formed during metamorphism and deformation related to the Jurassic to Cretaceous Brooks Range orogeny.

New sulfur-, oxygen-, and carbon-isotope data yield further evidence of a possible genetic association between the vein-breccias and shale-hosted massive sulfide deposits and provide insights about the reservoir of reduced sulfur in these hydrothermal systems. Galena and sphalerite from most veinbreccia occurrences have $\delta^{34} \mathrm{~S}$ values from -7.3 to $-0.7 \%$ and -5.1 to $3.6 \%$, respectively; sphalerite from sulfide-bearing concretions have $\delta^{34} \mathrm{~S}$ values of 0.7 and $4.7 \%$. These values fall largely within the range of previously determined values for galena and sphalerite from shale-hosted massive sulfide deposits at Red Dog and Drenchwater. The Kady vein-breccia occurrence has higher $\delta^{34} \mathrm{~S}$ values (11.3-12.9\%o), consistent with previously published data from the Lik deposit. The correspondence in sulfur isotopic compositions between the stratiform and vein-breccia occurrences suggests derivation of reduced sulfur by similar geochemical processes and (or) a shared reservoir of reduced sulfur. It is reasonable to suggest that the sulfides in the vein breccias obtained their reduced sulfur by the reduction of sulfate through BSR or TSR in Devonian rocks (as pore fluids), which was ultimately derived from Devonian seawater $\left(\delta^{34} S\right.$ of Devonian seawater=15 to $24 \%$; Claypool and others, 1980). Metal-bearing fluids migrating through Devonian rocks in Carboniferous time could have obtained reduced sulfur from local sources in the Devonian rocks to make small occurrences of sulfide minerals in the vein breccias. If this metal-bearing fluid ascended into the Carboniferous basinal environment and mixed with additional reduced sulfur, created through BSR of Carboniferous seawater sulfate, the resulting sphalerite and galena would have $\delta^{34} \mathrm{~S}$ values similar to those of the vein breccias. Additional studies of sulfur isotopes in the host rocks are needed to more definitively evaluate the possible sources of sulfur in the deposits.

The $\delta^{18} \mathrm{O}$ values of quartz from the vein breccias are between 16.6 and $19.9 \%$. Using a sulfur-isotope temperature of $188^{\circ} \pm 25^{\circ} \mathrm{C}$ calculated on the basis of sphalerite-galena mineral pairs, the hydrothermal fluids had $\delta^{18} \mathrm{O}$ values of 4.2 to $7.5 \%$. Although hydrogen-isotope data are not available for the veinbreccia occurrences, the calculated range of $\delta^{18} \mathrm{O}$ values of the fluids suggest the fluids may have been derived from pore fluids in the sediments during diagenesis.
Sulfide minerals in the quartz-carbonate veins yield sulfur and carbon isotopic values that are consistent with formation by BSR during diagenesis. This reduced sulfur could have been remobilized during low-grade metamorphism related to the Brooks Range orogeny. Oxygen-isotope compositions of quartz are heavier than those of the vein-breccia occurrences and may reflect the influence of a metamorphic fluid source. In addition, lead-isotope values for galena from some quartz-carbonate veins in the central Brooks Range are more radiogenic than those for the vein breccias or stratiform ores, suggesting that the quartzcarbonate veins are younger.

Acknowledgments.-We thank Carol Gent and Cyndi Brock for providing some of the sulfur- and oxygen-isotope analyses. We thank Erin Marsh for help with mineral separates and sample preparation. Discussions with Poul Emsbo were very helpful. Prompt and thorough reviews by Bob Rye and John Slack are greatly appreciated.

\section{References Cited}

Blythe, A.E., Murphy, J., and O'Sullivan, P.B., 1997, Tertiary cooling and deformation in the south-central Brooks Range: Evidence from zircon and apatite fission-track analyses: Journal of Geology, v. 105, p. 583-599.

Brosgé, W.P., Nilsen, T.H., Moore, T.E., and Dutro, J.T., Jr., 1988, Geology of the Upper Devonian and Lower Mississippian(?) Kanayut Conglomerate in the central and eastern Brooks Range, in Gryc, George, ed., Geology and Exploration of the National Petroleum Reserve in Alaska, 1974 to 1982: U.S. Geological Survey Professional Paper 1399, p. 299-316.

Brosgé, W.P., Reiser, H.N., Dutro, J.T., Jr., and Nilsen, T.H., 1979, Geologic map of Devonian rocks in parts of the Chandler Lake and Killik River quadrangles, Alaska: U.S. Geological Survey Open-File Report 79-1224, scale 1:200,000.

Claypool, G.E., Holser, W.T., Kaplan, I.R., Sakai, H., and Zak, I., 1980, The age curves of sulfur and oxygen isotopes in marine sulfate and their mutual interpretation: Chemical Geology, v. 28, p. 199-260.

Clayton, R.N., and Mayeda, T.K., 1963, The use of bromine pentafluoride in the extraction of oxygen from oxides and silicates for isotopic analysis: Geochimica et Cosmochimica Acta, v. 27, p. 43-52.

Clayton, R.N., O'Neil, J.R., and Mayeda, T.K., 1972, Oxygen isotope exchange between quartz and water: Journal of Geophysical Research, v. 77., p. 3057-3066.

Dumoulin, J.A., Harris, A.G., and Schmidt, J.M., 1993, Deep-water lithofacies and conodont faunas of the Lisburne Group, west-central Brooks Range, Alaska, in Dusel-Bacon, C., and Till, A.B., eds., Geologic Studies in Alaska by the U.S. Geological Survey, 1992: U.S. Geological Survey Bulletin 2068, p. 12-30.

Duttweiler, K.A., 1986, Sulfide occurrences in the Itkillik River region, southeast Chandler Lake quadrangle, Brooks Range, Alaska, in Bartsch-Winkler S., and Reed, K.M., eds., Geologic Studies in Alaska by the U.S. Geological Survey during 1985: U.S. Geological Survey Circular 978, p. 10-13.

Duttweiler, K.A., 1987, Use of factor analysis in locating base-metal mineralization in the Killik River quadrangle, in Hamilton, T.D., and Galloway, J.P., eds., Geologic Studies in Alaska by the U.S. Geological Survey During 1986: U.S. Geological Survey Circular 998, p. 27-30. 
Ellersieck, Inyo, Jansons, Uldis, Mayfield, C.F., and Tailleur, I.L., 1982, The Story Creek and Whoopee Creek lead-zinc-silver occurrences, western Brooks Range, Alaska, in Coonrad, W.L., ed., U.S. Geological Survey in Alaska-Accomplishments During 1980: U.S. Geological Survey Circular 844, p. 35-38.

Forrest, Kimball, 1983, Geologic and isotopic studies of the Lik deposit and the surrounding mineral district, DeLong Mountains, western Brooks Range, Alaska: Minneapolis, University of Minnesota, unpub. Ph.D. dissertation, $161 \mathrm{p}$.

Friedman, Irving, and O'Neil, J.R., 1977, Compilation of stable isotope fractionation factors of geochemical interest: U.S. Geological Survey Professional Paper 440-KK, p. 1-12.

Gaccetta, J.D., and Church, S.E., 1989, Lead isotope data base for sulfide occurrences in Alaska: U.S. Geological Survey Open-File Report 89$688,60 \mathrm{p}$.

Goodfellow, W.D., Lydon, J.W., and Turner, R.J.W., 1993, Geology and genesis of stratiform sediment-hosted (SEDEX) zinc-lead-silver sulfide deposits, in Kirkham, R.V., Sinclair, W.D., Thorpe, R.I., and Duke, J.M., eds., Mineral Deposit Modeling: Geological Association of Canada, Special Paper 40, p. 201-251.

Harris, A.G., Lane, H.R., Tailleur, I.L., and Ellersieck, I., 1987, Conodont thermal maturation patterns in Paleozoic and Triassic rocks, northern Alaska-Geologic and exploration implications, in Tailleur, I., and Weimer, P., eds., Alaskan North Slope Geology, v. 1, p. 181-192.

Hoefs, J., 1997, Stable isotope geochemistry (4th ed.), New York, Springer-Verlag, $236 \mathrm{p}$.

Jansons, Uldis, 1982, Zinc-lead occurrences in and near the National Petroleum Reserve in Alaska: U.S. Bureau of Mines Mineral Lands Assessment Report MLA 121-82, 55 p.

Jansons, Uldis, and Baggs, D.W., 1980, Mineral investigations of the Misheguk Mountain and Howard Pass quadrangles, Alaska: U.S. Bureau of Mines Open-File Report 38-80, 76 p.

Jansons, Uldis, and Parke, M.A., 1981, 1978 mineral investigations in the Misheguk Mountain and Howard Pass quadrangles, Alaska: U.S. Bureau of Mines Open-File Report 26-81, 195 p.

Kelley, J.S., Tailleur, I.L., Morin, R.L., Reed, K.M., Harris, A.G., Schmidt, J.M., and Brown, F.M., 1993, Barite deposits in the Howard Pass quadrangle and possible relations to barite elsewhere in the northwestern Brooks Range, Alaska: U.S. Geological Survey Open-File Report 93-215, $13 \mathrm{p}$.

Kelley, K.D., Barton, H.N., Sutley, S.J., and O'Leary, R.M., 1993, Maps showing geochemistry of sediment samples from the southern part of the Chandler Lake quadrangle, Alaska: U.S. Geological Survey Miscellaneous Field Studies Map MF-2144C, scale 1:250,000.

Kelley, K.D., and Mull, C.G., 1995, Maps showing areas of potential for mineral resources in the Killik River quadrangle, Brooks Range, Alaska: U.S. Geological Survey Miscellaneous Field Studies Map MF-2225-A, scale 1:250,000.

Kelley, K.D., Taylor, C.D., and Cieutat, B.A., 1997, Silver-lead-zinc mineral occurrences in the Howard Pass quadrangle, Alaska, in Dumoulin, J.A., and Gray, J.E., eds., Geologic studies in Alaska by the U.S. Geological Survey, 1995: U.S. Geological Survey Professional Paper 1574, p. 101-110.

Kurtak, J.M., Hicks, R.W., Werdon, M.B., Meyer, M.P., and Mull, C.G., 1995, Mineral investigations in the Colville mining district and southern National Petroleum Reserve in Alaska: U.S. Bureau of Mines Open-File Report 8-95, $217 \mathrm{p}$.

Lange, I.M., Nokleberg, W.J., Plahuta, J.T., Krouse, H.R., and Doe, B.R., 1985 , Geologic setting, petrology, and geochemistry of stratiform sphalerite-galena-barite deposits, Red Dog Creek and Drenchwater Creek areas, northwestern Brooks Range, Alaska: Economic Geology, v. 80, p. 1896-1926.

Longstaffe, F.J., 1987, Stable isotope studies of diagenetic processes, in Kyser, T.K., ed., Stable Isotope Geochemistry of Low Temperature Processes: Mineralogical Association of Canada Short Course, v. 13, p. 187-257.

Lydon, J.W., 1983, Chemical parameters controlling the origin and deposition of sediment-hosted stratiform lead-zinc deposits, in Sangster, D.F., ed., Sediment-Hosted Stratiform Lead-Zinc Deposits: Mineralogical Association of Canada Short Course Handbook, v. 8, p. $175-250$.

Mayfield, C.F., Tailleur, I.L., and Ellersieck, Inyo, 1988, Stratigraphy, structure, and palinspastic synthesis of the western Brooks Range, northwestern Alaska, in Gryc, George, ed., Geology and Exploration of the National Petroleum Reserve in Alaska, 1974-1982: U.S. Geological Survey Professional Paper 1399, p. 143-186.

McCrea, J.M., 1950, On the isotopic chemistry of carbonates and a paleotemperature scale: Journal of Chemical Physics, v. 18, p. 848857.

Moore, D.W., Young, L.E., Modene, J.S., and Plahuta, J.T., 1986, Geologic setting and genesis of the Red Dog zinc-lead-silver deposit, western Brooks Range, Alaska: Economic Geology, v. 81, p. 1696-1727.

Moore, T.E., Wallace, W.K., Bird, K.J., Karl, S.M., Mull, C.G., and Dillon, J.T., 1994, Geology of northern Alaska, in Plafker, George, and Berg, H.C., eds., The Geology of Alaska: Boulder, Colo., Geological Society of America, The Geology of North America, v. G-1, p. 49-140.

Mull, C.G., 1982, The tectonic evolution and structural style of the Brooks Range, Alaska-An illustrated summary, in Powers, R.B., ed., Geological Studies of the Cordilleran Thrust Belt: Denver, Colo., Rocky Mountain Association of Geologists, v. 1, p. 1-45.

Mull, C.G., Harris, A.H., and Carter, J.L., 1997, Lower Mississippian (Kinderhookian) biostratigraphy and lithostratigraphy of the western Endicott Mountains, Brooks Range, Alaska, in Dumoulin, J.A., and Gray, J.E., eds., Geologic Studies in Alaska by the U.S. Geological Survey, 1995: U.S. Geological Survey Professional Paper 1574, p. 221-242.

Mull, C.G., Tailleur, I.L., Mayfield, C.F., Ellersieck, Inyo, and Curtis, S., 1982, New upper Paleozoic and lower Mesozoic stratigraphic units, central and western Brooks Range, Alaska: Americal Association of Petroleum Geologists Bulletin, v. 66, p. 348-362.

Mull, C.G., and Werdon, M.B., 1994, Generalized geologic map of the western Endicott Mountains, central Brooks Range, Alaska: Alaska Division of Geological and Geophysical Surveys Public Data File 94-55.

Nilsen, T.H., and Moore, T.E., 1984, Stratigraphic nomenclature for the Upper Devonian and Lower Mississippian(?) Kanayut Conglomerate, Brooks Range, Alaska: U.S. Geological Survey Bulletin 1529-A, $64 \mathrm{p}$.

Nokleberg, W.J., and Winkler, G.R., 1982, Stratiform zinc-lead deposits in the Drenchwater Creek area, Howard Pass quadrangle, northwestern Brooks Range, Alaska: U.S. Geological Survey Professional Paper 1209, 22 p.

Ohmoto, H., 1986, Stable isotope geochemistry of ore deposits, in Valley, J.W., Taylor, H.P., and O'Neil, J.R., eds., Stable Isotopes and High Temperature Geological Processes: Reviews in Mineralogy, v. 16, Mineralogical Society of America, p. 460-491.

Ohmoto, H., and Goldhaber, M.B., 1997, Sulfur and carbon isotopes, in Barnes, H.L., ed., Geochemistry of Hydrothermal Ore Deposits (3rd ed.): John Wiley and Sons, New York, p. 517-612. 
Ohmoto, H., and Rye, R.O., 1979, Isotopes of sulfur and carbon, in Barnes, H.L., ed., Geochemistry of Hydrothermal Ore Deposits: New York, John Wiley and Sons, p. 509-567.

O'Sullivan, P.B., Murphy, J.M., and Blythe, A.E., 1997, Late Mesozoic and Cenozoic thermotectonic evolution of the central Brooks Range and adjacent North Slope foreland basin, Alaska: Including fission-track results from the Trans-Alaska Crustal Transect (TACT): Journal of Geophysical Research, v. 102, no. B9, p. 20821-20845.

Pigage, L.C., 1983, Geology of the Cirque barite-zinc-lead-silver deposits, northeastern British Columbia, in Morin, J.A., ed., Mineral Deposits of the Northern Cordillera: Canadian Institute of Mining and Metallurgy, Special Volume 37, p. 71-86.

Rye, R.O., Shawe, D.R., and Poole, F.G., 1978, Stable isotope studies of bedded barite at east Northumberland Canyon in Toquima Range, central Nevada: Journal of Research, v. 6, p. 221-229.

Schmidt, J.M., and Zierenberg, 1987, The Red Dog Pb-Zn-Ag deposit, Alaska: An example of non-exhalative processe in the formation of syngenetic massive sulfides [abs.]: U.S. Geological Survey Circular 995, p. 61.

Sheppard, S.M.F., 1986, Characterization and isotopic variations in natural waters, in Valley, J.W., Taylor, H.P. Jr., and O'Neil, J.R., eds., Stable Isotopes in High Temperature Geological Processes: Reviews in Mineralogy, v. 16, p. 165-183.

Siok, J.P., 1985, Geologic history of the Siksikpuk Formation on the Endicott Mountains and Picnic Creek allochthons, north central
Brooks Range, Alaska: University of Alaska, Fairbanks unpub. M.S. thesis, $253 \mathrm{p}$.

Werdon, M.B., 1996, Drenchwater, Alaska: Zn-Pb-Ag mineralization in a mixed black shale-volcanic environment, in Coyner, A.R., and Fahey, P.L., eds., Geology and Ore Deposits of the American Cordillera: Geological Society of Nevada Symposium Proceedings, Reno/ Sparks, Nevada, April 1995, p. 1341-1354.

Werdon, M.B., 1999, Geologic setting of Mississippian vein-breccias at the Kady $\mathrm{Zn}-\mathrm{Pb}-\mathrm{Cu}-\mathrm{Ag}$ occurrence: Plumbing system for a failed SEDEX deposit?, in Kelley, K.D., ed., Geologic studies in Alaska by the U.S. Geological Survey, 1997: U.S. Geological Survey Professional Paper 1614, p. 5-34.

Yanagisawa, F., and Sakai, H., 1983, Thermal decomposition of barium sulfate-vanadium pentoxide-silica glass mixtures for preparation of sulfur dioxide in sulfur isotope ratio measurements: Analytical Chemistry, v. 55, p. 985-987.

Young, L.E., 1989, Geology and genesis of the Red Dog deposit, western Brooks Range, Alaska: Canadian Institute of Mining and Metallurgy Bulletin, v. 82, p. 57-67.

Young, L.E., 1995, Empirical applications of common lead-isotope ratios to exploration: Society of Economic Geologists Newsletter, no. 22, p. 7-12.

Zierenberg, R.A., and Schmidt, J.M., 1988, Isotopic evidence for multiple sulfur sources at the Red Dog Zn-Pb-Ag deposit, Noatak district, Alaska [abs.]: Geological Society of America Abstracts with Programs, v. 20, p. A-37. 


\title{
Geology and Geochemistry of Zn-Pb-Ag Vein-Breccias at Whoopee Creek, Alaska
}

\author{
By Jeanine M. Schmidt
}

\section{Abstract}

$\mathrm{Zn}-\mathrm{Pb}-\mathrm{Ag}$ mineralization at the Whoopee Creek occurrence extends over an area of at least $150 \times 300 \mathrm{~m}$ with a very subtle surface expression. Sphalerite- and galena-bearing veinbreccias cut fine-grained sandstones, siltstones, and lesser shales of the Upper Devonian to Lower Mississippian Endicott Group, and possibly the Isikut Member of the Kayak Shale. Most samples of sulfide-bearing rock contain 2-38 percent combined $\mathrm{Pb}+\mathrm{Zn}$, with high Ag concentrations (as much as $380 \mathrm{ppm}$ ) and a few enriched Au values (as much as $1 \mathrm{ppm}$ ). Soils with 100>2000 ppm Zn, 100-10,000 ppm Pb, and elevated Ag and $\mathrm{Cd}$ concentrations define a broad belt overlying much, but not all, of the mineralized float.

The Whoopee Creek occurrence is a high-grade example of a series of vein-breccia prospects occurring in Endicott Group rocks across the central and western Brooks Range. Although they have few analogs worldwide, they appear to be the products of large-scale fluid transport, possibly related to dewatering of one or a series of sedimentary basins during a period of Mississippian extension and related high heat flow.

\section{Introduction}

The Whoopee Creek Zn-Pb-Ag occurrence (Howard Pass A-4 quadrangle), is one of at least 16 mineralogically simple vein-breccia prospects that occur in the northern Brooks Range and are hosted in Upper Devonian to Lower Mississippian finegrained sandstones and siltstones of the Endicott Group (Theobold and Barton, 1978; Schmidt and Werdon, 1993; Kelley and others, 1997; Werdon, 1999). This article describes soil and rock geochemistry, and the geologic setting at the Whoopee Creek site.

Whoopee Creek (figs. 1, 2) was first identified as having base-metal mineral potential during a joint U.S. Geological Survey (USGS) / U.S. Bureau of Mines (USBM) prospect evaluation in the National Petroleum Reserve of Alaska. A streamsediment sample, taken by the USGS in 1977 from the mouth of Whoopee Creek (stream H-448; Theobold and Barton, 1978) contained $50 \mathrm{ppm} \mathrm{Pb}$ and $70 \mathrm{ppm} \mathrm{Cu}$. The corresponding heavy-mineral-concentrate sample contained $1,000 \mathrm{ppm} \mathrm{Pb}$ and $300 \mathrm{ppm} \mathrm{Cu}$. Further prospecting in 1978 by the USBM identified mineralized float 2.1 miles upstream from this sample. Jansons and Parke (1981) reported abundant quartz-cemented sandstone breccias and lesser galena, sphalerite, and carbonatecemented siltstone breccias in float, and a 20-foot-wide, steeply dipping, N. $65^{\circ}$ W.-trending mineralized shear zone. Mineralized, but otherwise undescribed, rock samples yielded 70 to 1,700 ppm Cu, 0.02 to $4.4 \mathrm{ppm} \mathrm{Au,} 5.2$ to $460 \mathrm{ppm} \mathrm{Ag,} 20$ to 3,700 ppm $\mathrm{Cd}, 0.07$ to 44.0 percent $\mathrm{Pb}, 0.29$ to 46.0 percent $\mathrm{Zn}$, and 4.08 to 49.2 percent combined $\mathrm{Pb}+\mathrm{Zn}$ (Jansons and Parke, 1981; Jansons, 1982).

To investigate the mineralization at Whoopee Creek, 4 days were spent there in 1984 mapping along the north-northeastflowing (upper) section of the intermittent stream. A base line and grid (fig. 3) were surveyed with chain and compass to establish control for soil, sediment, and rock-geochemical samples.

\section{Geologic Setting}

Whoopee Creek is in a part of the unmetamorphosed foreland of the Brooks Range fold-and-thrust belt where geologic mapping has been limited (1:250,000 scale-Mull and Werdon, 1994). The Whoopee Creek area was assigned to the Key Creek sequence of the Brooks Range allochthon (the lowermost of seven, in the structural model of Mayfield and others, (1988). Mull and Werdon (1994) include the area in their newly designated "Aniuk River" sequence within the Endicott Mountains allochthon (equivalent in structural position to the Brooks Range allochthon of Mayfield and others, 1988). Moore and others (1994) considered this area part of the Endicott subterrane of the Arctic Alaska terrane (Moore and others, 1994).

Whoopee Creek crosscuts upland tundra with rare float and boulders (fig. 2). Outcrops are confined to the creek bed (fig. 4) and to high ridges south of the mineralized areas. The most common lithology at Whoopee Creek is a reddish- to orangebrown-weathering, fine-grained $(<0.5 \mathrm{~mm})$ gray sandstone to siltstone, usually with thin $(<2 \mathrm{~cm})$ lenticular to wavy bedding. The sand grains are dominantly quartz, with 1 to 2 percent black 


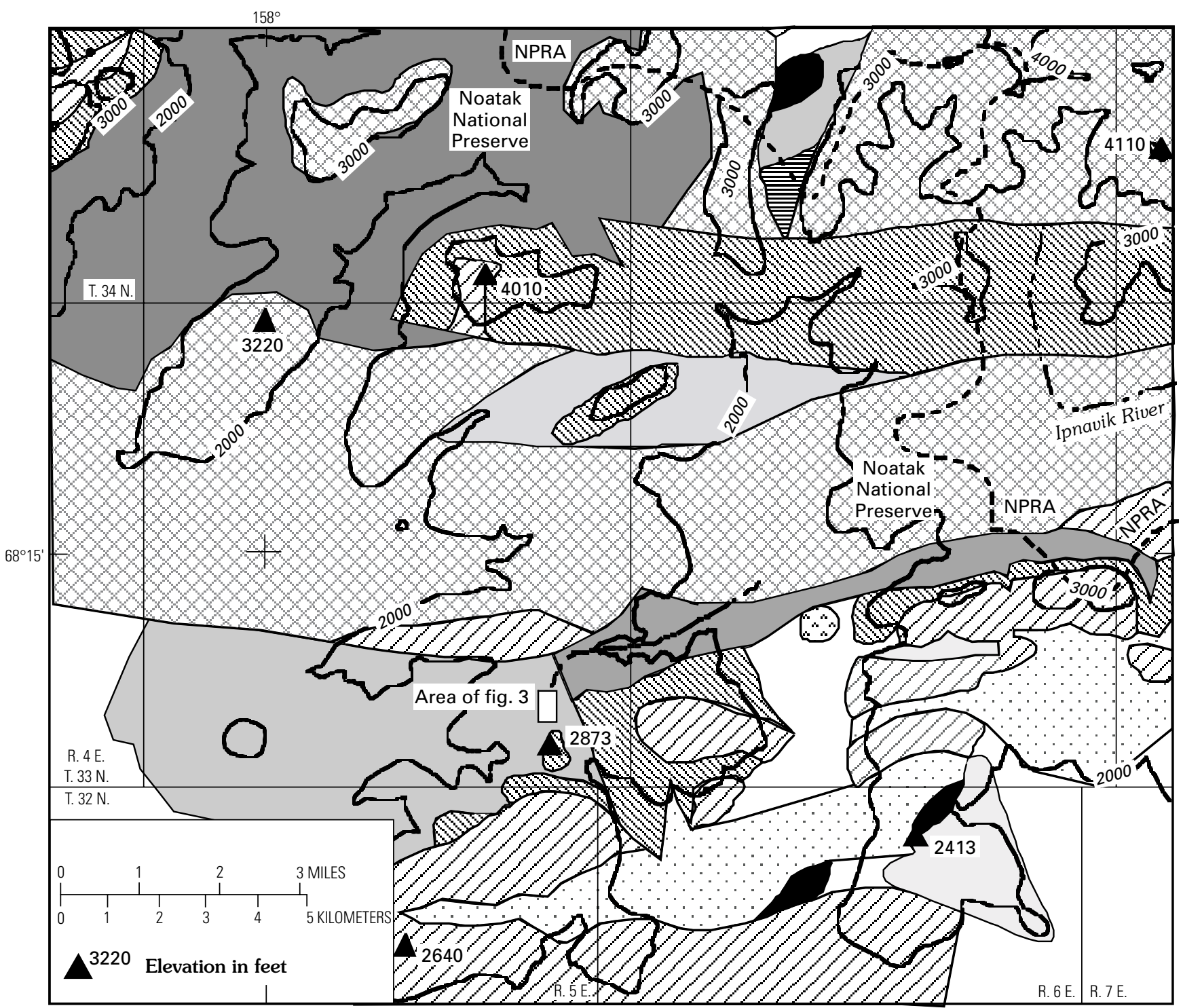

\section{EXPLANATION}

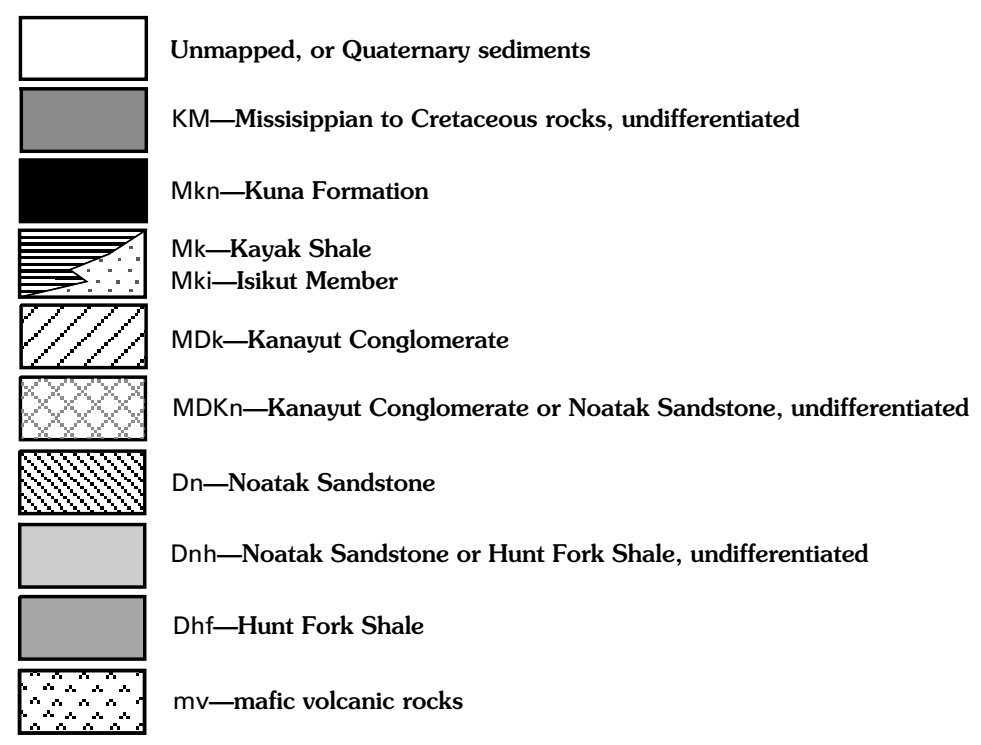

Figure 1. Generalized geologic map of part of the Howard Pass A-4 quadrangle, showing regional stratigraphic units modified from Mull and Werdon (1994). The white rectangle immediately north of hill 2873 indicates the location of the Whoopee Creek mineralized area and is the area shown in figures $3,4,7,8,9$, and 11 . 


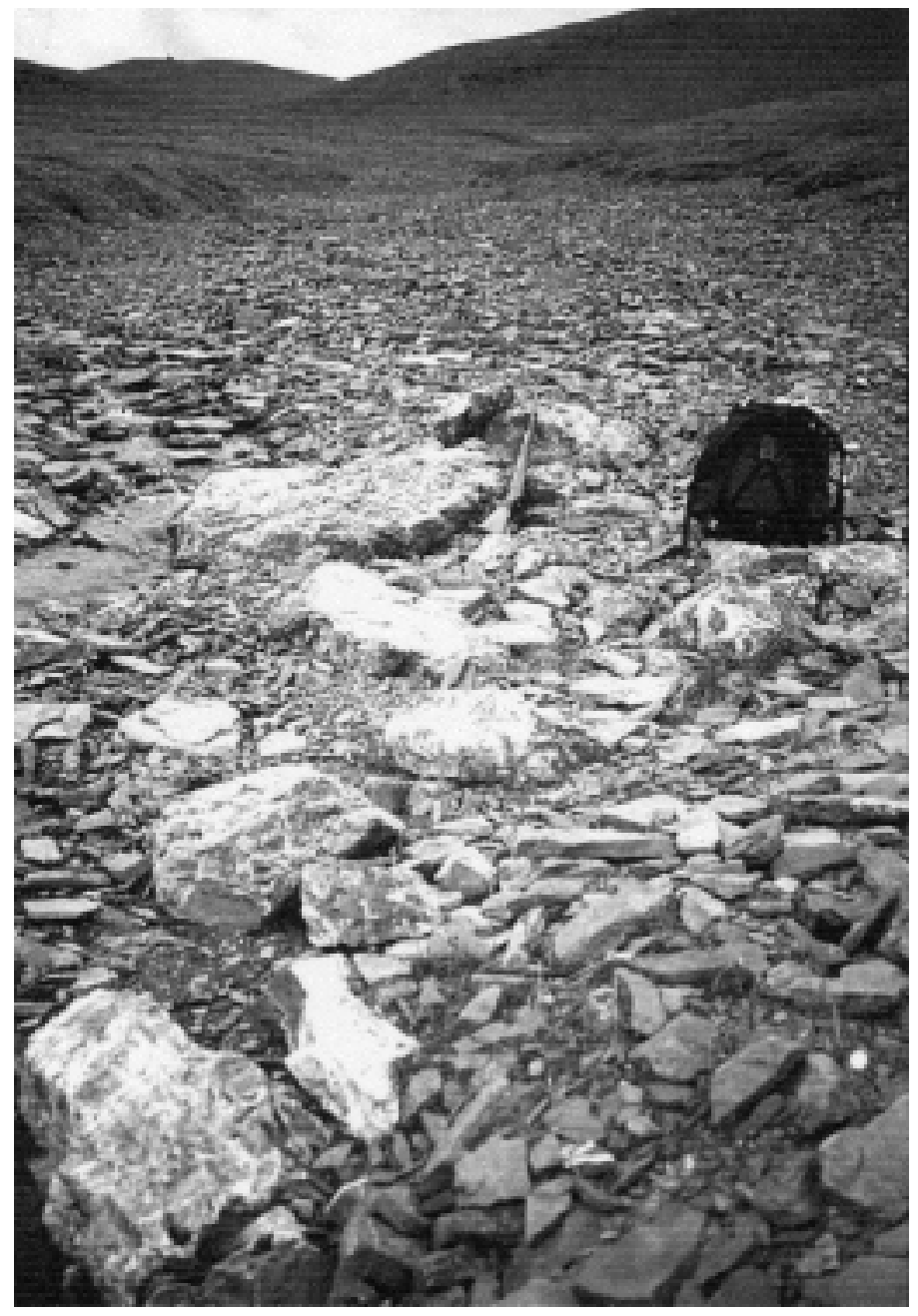

Figure 2. Photograph showing view toward the south-southwest along Whoopee Creek. Lighter colored boulders in foreground are mineralized and contain quartz (white-weathering), sphalerite and galena. Most boulders are of brown-weathering fine grained sandstone and siltstone.

chert, trace pyrite, and locally abundant shale chips. Two to fifteen percent small red specks indicate the weathering of Fecarbonate cement, minor pyrite, or, locally, sphalerite. Thin $(<1$ $\mathrm{mm}$ ) shale drapes weather prominently, although the ratio of shale to siltstone and sandstone is low overall. Ripple marks and trace fossils (possibly burrows?) are more common in dark-gray siltstone interbeds than in sandstone-rich intervals.

This orange-weathering, fine-grained sandstone-siltstone lithology is interbedded with lesser, medium-grained $(<1 \mathrm{~mm})$ tan-weathering quartzose sandstone, thin coal seams, and rare thin $(<2 \mathrm{~cm})$, reddish-orange-weathering calcareous, crinoidal, and (or) pyritic sandstone beds. The lithologies exposed at Whoopee Creek were probably deposited in a shallow-water, lagoonal to shallow-deltaic environment, with interfingering deposition of freshwater (coaly sediments) and marine (crinoid columnal-bearing and calcareous sandstone) facies.

Low outcrops along Whoopee Creek (fig. 4) have bedding orientations of $\mathrm{N} .75^{\circ} \mathrm{E}$. to S. $55^{\circ} \mathrm{E}$., with southward dips of $40^{\circ}$ to vertical, or, rarely, $80^{\circ} \mathrm{N}$. Many of the exposures show fold noses, and silty and shaly lithologies often exhibit a welldeveloped pencil cleavage or a lineation plunging $35^{\circ}$ to S. $60^{\circ}$ E. Some slickensided fracture surfaces are oriented north-south, and dip $70^{\circ}$ E.; the slickensides plunge $20^{\circ}$ to the south, but their direction of movement is not known. Overall, no distinctive stratigraphy, or sense of up-direction can be established because of poor exposures (fig. 2).

Rocks at Whoopee Creek were previously mapped as Mississippian or younger sedimentary rocks (unit Ms of Brosge and others, 1988) overlying the Endicott Group (Late Devonian to earliest Mississippian clastic rocks), or as part of the Mississippian Kayak Shale (Jansons and Parke, 1981; Jansons, 1982) at the top of the Endicott Group. Mull and Werdon (1994),

however, mapped the Whoopee Creek area as part of their Upper Devonian unit Dnh (undivided Noatak Sandstone and Hunt Fork Shale)— the lower part of the Endicott Group. They described unit Dnh as a brownish- to yellow-brown-weathering transitional facies containing limonitic and calcareous sandstone beds as much as $1 \mathrm{~m}$ thick interbedded with siltstone and gray, silty shales. Recent geologic mapping in the Howard Pass quadrangle (Mull and Werdon, 1994; unpublished data by USGS, 19901992) distinguished a siltstone-rich facies of Early Mississippian age, correlative with the lower part of the Kayak Shale, and overlying thin $(<400 \mathrm{~m})$ sandstones correlative with Kanayut Conglomerate and Noatak Sandstone of the middle Endicott Group. This distinctive red-weathering siltstone-rich facies (named the Isikut Member of the Kayak Shale; Mull and others, 1997) lacks the dark-gray shale and concretions typical of the Kayak Shale and is interpreted to represent a shallow-water depositional environment with less mud and more abundant and diverse fossils than the environment of typical Kayak Shale.

Because of the sandstone- and siltstone-dominant nature of the host rocks at Whoopee Creek, their red-brown weathering color, low percentage of shale, and lack of concretions, they are interpreted here as more similar to the Isikut Member of the Kayak Shale, than to the Kayak Shale proper or to undivided marine Noatak-Hunt Fork rocks (Dnh), as previously mapped.

\section{Description of the $\mathrm{Zn}-\mathrm{Pb}-\mathrm{Ag}$ Vein-Breccias}

Exposures at Whoopee Creek (fig. 2) are limited to a few small outcrops along the creek itself, boulders within the stream bed, and float in the upland tundra between drainages. Mineralized breccias, veins, and breccia veins (hereafter summarized as vein-breccias) were seen in boulders as large as $1 \mathrm{~m}$ in diameter. Neither mineralized outcrops, nor the "mineralized shear zone" discussed by Jansons and Parke (1981) were identified during 1984 field work. The maximum size of any single vein or breccia body, therefore, is unknown. Hand-sized samples containing as much as 60 percent sulfides (more commonly 10 to 40 percent) constitute 1 to 10 percent of the float material over an area of several hundred square meters (fig. 4). No disseminated mineralization or visible alteration associated with the vein-breccias were identified.

There is a continuum of veins and breccias at Whoopee Creek that includes: (A) barren quartz ladder veins; (B) quartz ladder veins with galena along centerlines; $(\mathrm{C})$ banded sphalerite-dominant veins; (D) quartz-galena-sphalerite veins with sharp walls and brecciated interiors (breccia veins); (E) barren breccias with terminated quartz rimming host-rock fragments; (F) breccias with galena rimming host rock fragments; 


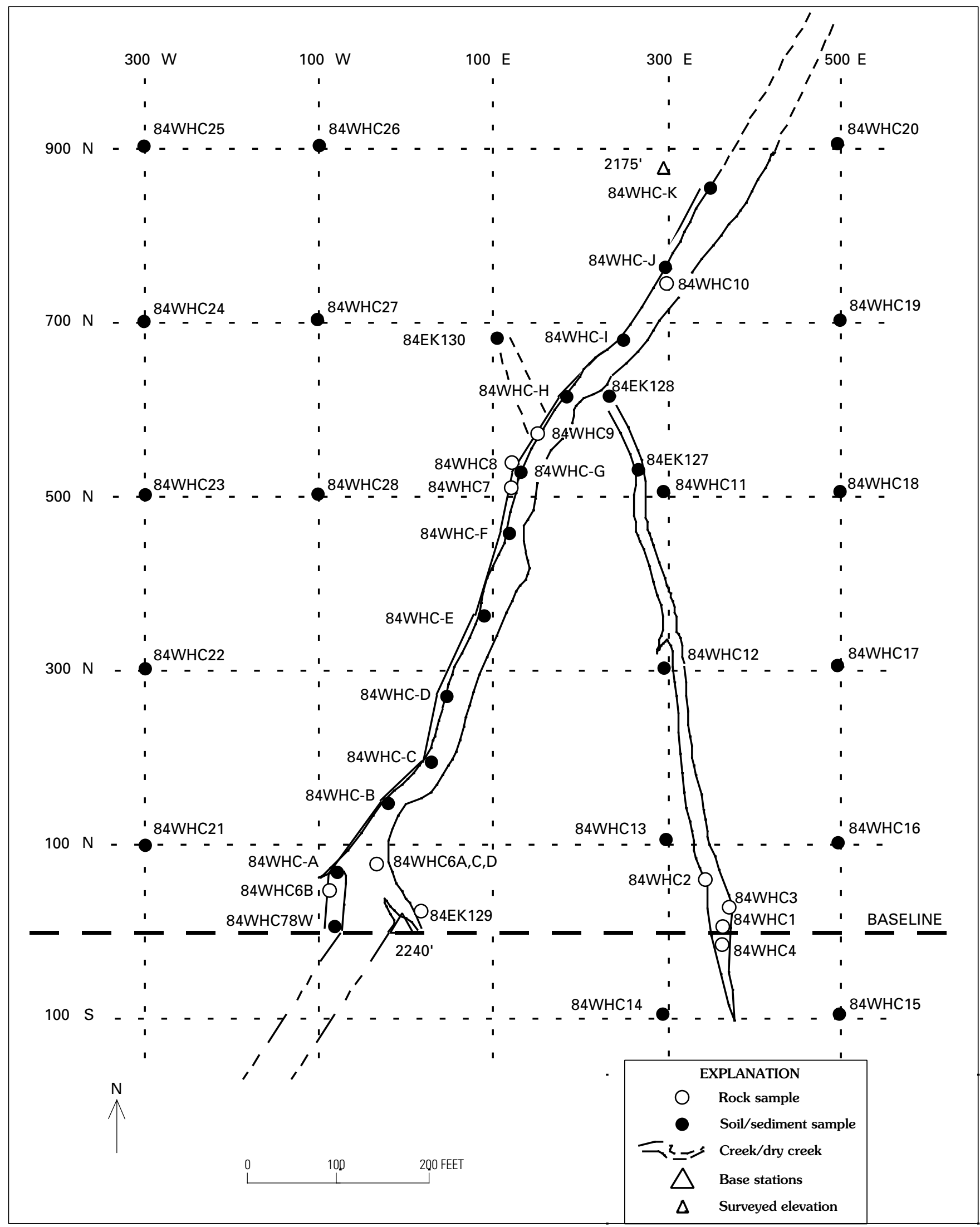

Figure 3. Map showing the survey grid established at Whoopee Creek (WHC-grid) and locations of rock, soil, and stream-sediment samples collected during this study. Area of map is shown by white rectangle in figure 1. 


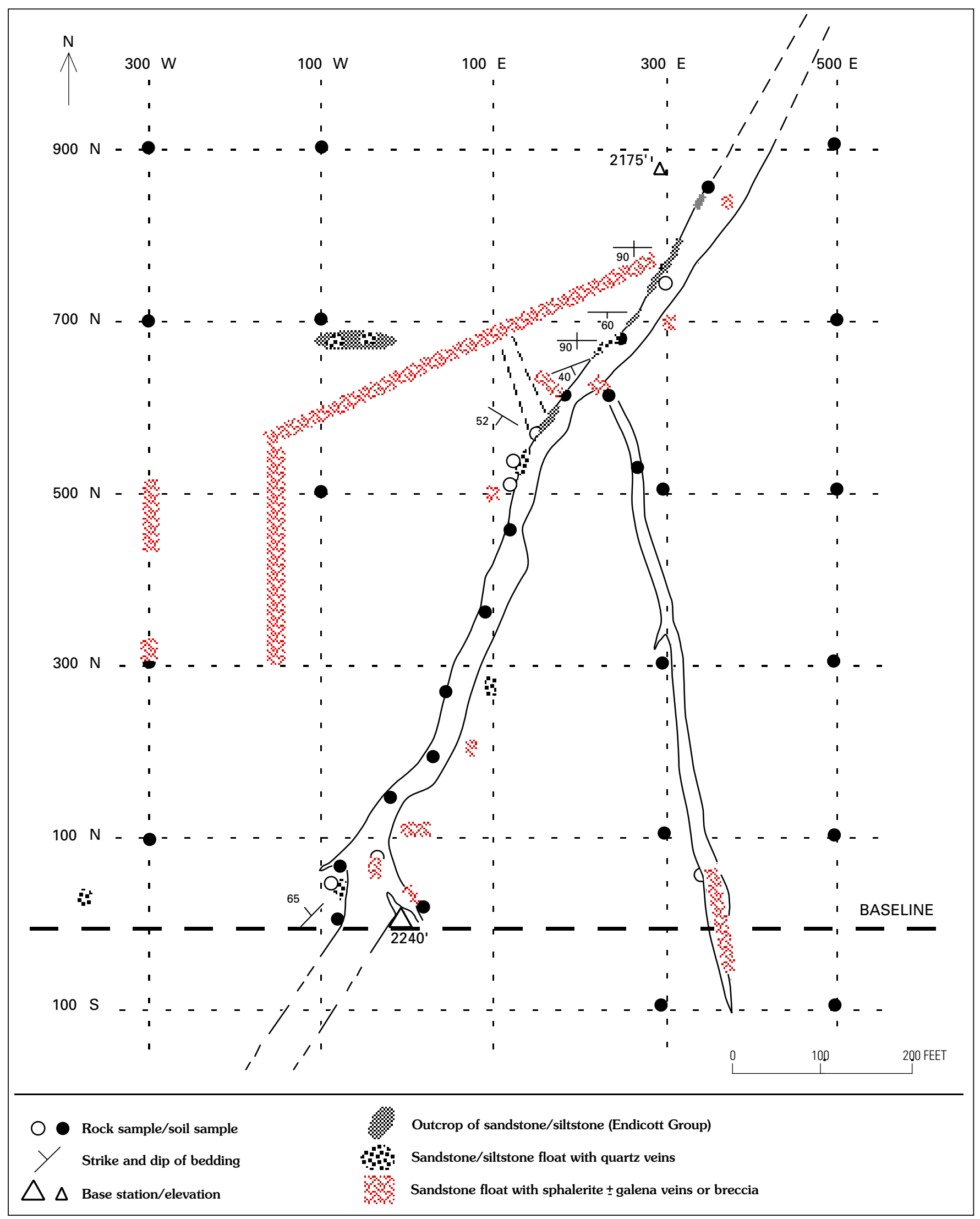

Figure 4. Map of WHC-grid area showing float and outcrop geology, and extent of mineralized rock. 
(G) breccias with fragments of host rock crosscut and surrounded by quartz, sphalerite, and galena (cockade ore); and $(\mathrm{H})$ complex breccias that incorporate mineralized clasts. Banded sphalerite-rich veins $(C)$ and mineralized breccias $(G)$ are the most common; vein-breccia types $\mathrm{B}, \mathrm{E}, \mathrm{F}$, and $\mathrm{H}$ are rare.

Fine-grained sandstone and siltstone host rocks at Whoopee Creek are locally cross-cut by 1 to 5 percent light-gray-weathering quartz veins (type A), a few millimeters to $2 \mathrm{~cm}$ wide, with sharp walls, no identifiable wallrock alteration, and variable development of a dark-gray ladder or comb texture perpendicular to the vein walls. Rarely, these veins include clots of galena along their centerlines (type B). Veins of color banded and (or) crustiform sphalerite with lesser banded quartz, minor galena, and trace pyrite and carbonate (type $\mathrm{C} ; 5 \mathrm{~mm}$ to at least $10 \mathrm{~cm}$ wide) are common. Small float samples composed entirely of banded sphalerite-galena-quartz (as much as 90 percent sulfide) may be fragments of these veins or of sphaleriterich breccias. The most spectacular mineralization at Whoopee Creek occurs as breccias and breccia veins. In the most common breccia type (fig. 5A; type $\mathrm{G}$ ), fragments of clastic wallrocks are rimmed by color-zoned, crustiform sphalerite, or, less commonly, quartz, and infilled by coarse-grained quartz, galena, and minor pyrite, sphalerite and sulfosalts (cockade ore). In some samples, host-rock fragments can be restored to the vein walls from which they were derived, suggesting a relatively passive (i.e., dissolution or crushing vs. explosion) mechanism of brecciation. In rare, complex breccias, angular fragments of vein and breccia ore are entrained in the matrix. All types of breccia at Whoopee Creek are matrix supported, but those that are galena rich (fig. $5 B$; type D) often contain more abundant and more angular fragments and a wider range of fragment sizes.
Sphalerite in vein-breccias at Whoopee Creek is medium red to red-brown to dark brown in color, suggesting a relatively high Fe and (or) Mn content. It weathers to a smooth brown surface only subtly different from the slightly rougher, orangebrown weathered surfaces of the host sandstones. Because of this subtle weathering, lack of oxidation, and the tundra cover, no color anomalies occur at Whoopee Creek, and the extent of mineralization is difficult to define.

\section{Rock Geochemistry}

The USBM analyzed mineralized rocks from Whoopee Creek that contained as much as 49.2 percent combined $\mathrm{Pb}+\mathrm{Zn}$ and 460 ppm Ag (Jansons and Parke, 1981; Jansons, 1982), with some elevated values of $\mathrm{Cu}, \mathrm{Au}$, and $\mathrm{Cd}$; however, USBM gave no description of the samples.

Geochemical analyses of rock samples collected in 1984 (table 1; fig. 3) were performed by a variety of methods in U.S. Geological Survey laboratories. Samples with no visible sphalerite or galena were analyzed by semiquantitative 6-step D.C. arc optical emission spectrography (Grimes and Marranzino, 1968) for 30 elements. Mineralized samples were analyzed by a variety of methods: $\mathrm{Ag}, \mathrm{As}, \mathrm{Cd}, \mathrm{Bi}$, and $\mathrm{Sb}$ were analyzed by atomic absorption spectrometry (O'Leary and Viets, 1986); Au was anlyzed by atomic absorption spectrophotometry (Thompson and others, 1968); $\mathrm{Ca}, \mathrm{Co}, \mathrm{Cu}, \mathrm{Fe}, \mathrm{Pb}$, $\mathrm{Si}$, and $\mathrm{Zn}$ were analyzed by quantitative emission spectroscopy; Ba was analyzed by energy-dispersive X-ray fluorescence spectrometry (Johnson and King, 1987); and S, total C, and inorganic $\mathrm{C}$ were analyzed by partial chemical analysis (Jackson and others, 1987).

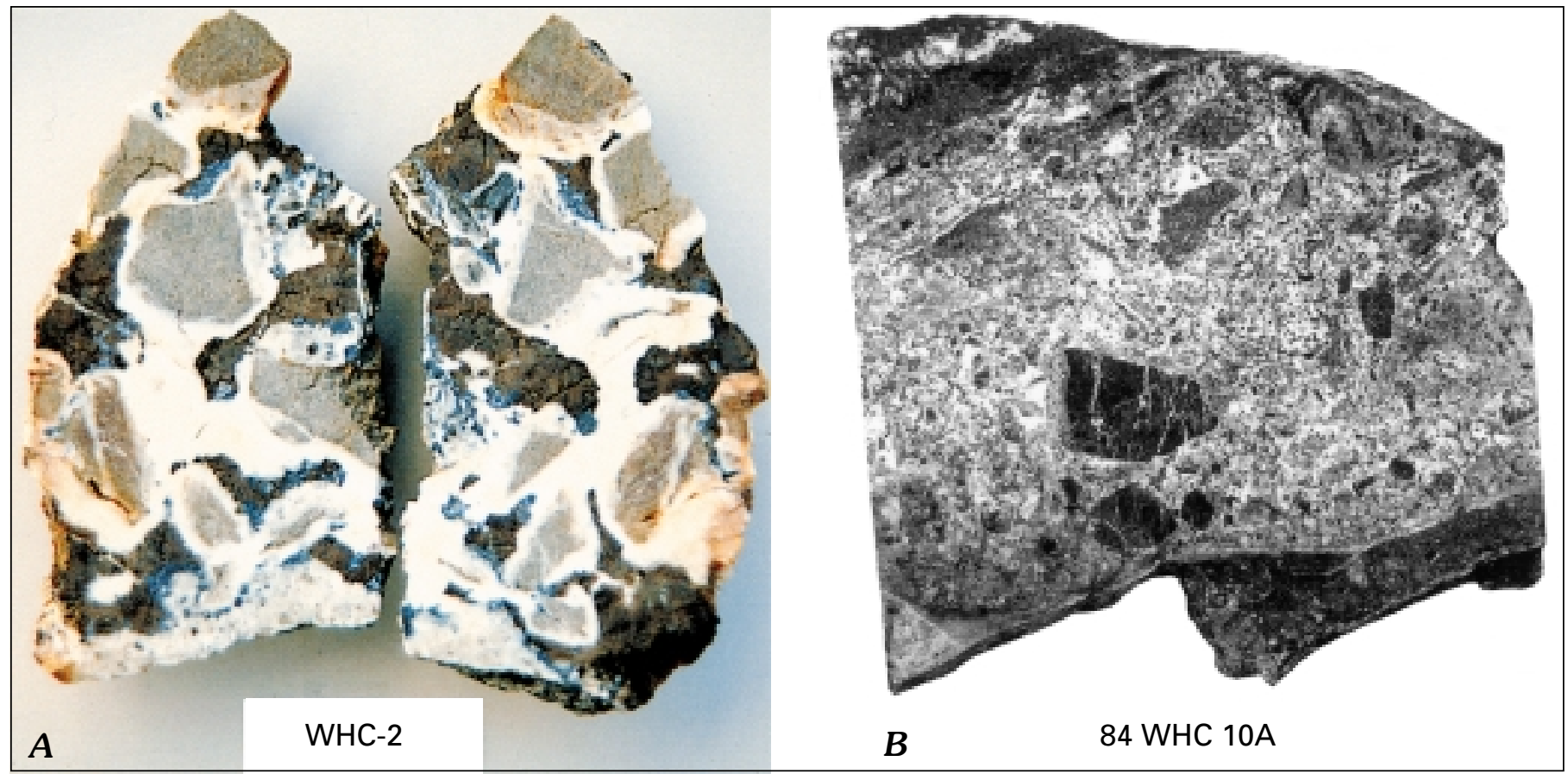

Figure 5. Photographs of mineralized rock samples from Whoopee Creek area. A, Mineralized, matrix-supported breccia from station 84 WHC2 (fig. 3), with fine-grained, quartz-rich sandstone fragments (light gray-brown) surrounded by hydrothermal quartz (white) and infilled by sphalerite (dark brown) and galena (bluish gray). Sample is $15 \mathrm{~cm}$ long. $B$, Mineralized breccia vein from station $84 W H C 10$ (fig. 3). Angular fragments of shale (black) and siltstone (dark gray) in a quartz-rich (white) matrix containing abundant galena and moderate sphalerite. Sample is $10 \mathrm{~cm}$ wide. 
Table 1. Geochemical data for mineralized and unmineralized rock samples from the Whoopee Creek Zn-Pb-Ag occurrence.

\begin{tabular}{|c|c|c|c|c|c|c|c|c|c|c|c|c|c|c|c|c|c|c|c|c|c|}
\hline Sample & $\mathrm{Pb}$ & $\mathrm{Zn}$ & $\mathrm{Ag}$ & \%Tot C & $\% \operatorname{Org} C$ & \%Tot S & As & $\mathrm{Au}$ & $B$ & $\mathrm{Ba}$ & $\mathrm{Bi}$ & $\mathrm{Cd}$ & Co & $\mathrm{Cr}$ & $\mathrm{Cu}$ & $\mathrm{Fe}-\%$ & $\mathrm{Mn}$ & $\mathrm{Ni}$ & $\mathrm{Sb}$ & Sn & $\mathrm{Ti} \%$ \\
\hline $84 \mathrm{WHC} 1$ & 70 & 300 & $\mathrm{~L}$ & & & & 40 & & 20 & 200 & & 0.1 & $\mathrm{~N}$ & 50 & $\mathrm{~L}$ & 1.5 & 10 & 15 & 4 & $\mathrm{~N}$ & 0.20 \\
\hline $84 \mathrm{WHC} 2$ & $10.5 \%^{\wedge}$ & $9.2 \%^{\wedge}$ & $69^{*}$ & 0.08 & $<0.01$ & 5.06 & $64 *$ & 0.4 & 20 & 130 & $<10$ & $130^{*}$ & $60^{\wedge}$ & 20 & $150^{\wedge}$ & $1.4^{\wedge}$ & 100 & 30 & 280 & $\mathrm{~N}$ & 0.10 \\
\hline 84WHC3 & $2500^{\wedge}$ & $62.1 \%^{\wedge}$ & $56^{*}$ & 13.00 & 11.40 & 31.0 & $20 *$ & 0.4 & $\mathrm{~N}$ & 32 & 15 & $1600^{*}$ & $250^{\wedge}$ & $\mathrm{N}$ & $700^{\wedge}$ & $4.40^{\wedge}$ & 50 & 15 & 420 & 50 & \\
\hline 84WHC5 & 50 & 290 & 0.5 & & & & 20 & & 20 & 70 & & 0.6 & $\mathrm{~N}$ & 20 & $\mathrm{~L}$ & 0.5 & 30 & 5 & 13 & $\mathrm{~N}$ & 0.07 \\
\hline 84WHC6A & $500^{\wedge}$ & $1.16 \%^{\wedge}$ & 0.5 & 0.71 & 0.14 & 0.30 & $37 *$ & $<0.2$ & 20 & 120 & $<10$ & $19^{*}$ & 7 & 20 & $50^{\wedge}$ & $4.60^{\wedge}$ & 1000 & 10 & 11 & $\mathrm{~N}$ & 0.10 \\
\hline 84WHC6B & $\mathrm{L}$ & 20 & $\mathrm{~N}$ & & & & 10 & & 10 & 100 & & $\mathrm{~N}$ & 20 & 50 & 15 & 5.0 & 1500 & 50 & $\mathrm{~N}$ & $\mathrm{~N}$ & 0.15 \\
\hline 84WHC7A & $1.50 \%$ & $>2000$ & 50 & & & & 110 & 0.5 & 20 & 150 & & $>100$ & 50 & 20 & 150 & 0.7 & 150 & 20 & 120 & 15 & 0.10 \\
\hline 84WHC7B & $1.50 \%$ & $>2000$ & 50 & & & & 50 & 0.35 & 15 & 70 & & 52 & 15 & $\mathrm{~L}$ & 200 & 0.3 & 100 & 15 & 160 & $\mathrm{~L}$ & 0.03 \\
\hline 84WHC8 & $\mathrm{L}$ & 180 & $\mathrm{~N}$ & & & & 10 & & 30 & 200 & & 0.3 & 15 & 70 & 7 & 5.0 & 1000 & 50 & $\mathrm{~N}$ & $\mathrm{~N}$ & 0.30 \\
\hline 84WHC9 & 50 & 300 & $\mathrm{~L}$ & & & & 10 & & 50 & 300 & & 0.5 & 20 & 100 & 50 & 5.0 & 300 & 70 & $\mathrm{~N}$ & $\mathrm{~N}$ & 0.50 \\
\hline $84 \mathrm{WHC} 10 \mathrm{~A}$ & $19.9 \%^{\wedge}$ & $2.80 \%^{\wedge}$ & $170^{*}$ & 2.10 & 2.02 & 4.61 & $54 *$ & 0.05 & 10 & 38 & $<10$ & $86^{*}$ & $40^{\wedge}$ & 10 & $450^{\wedge}$ & $0.34^{\wedge}$ & 100 & 500 & 1000 & 30 & 0.05 \\
\hline 84WHC10A2 & $33.0 \% \wedge$ & $5.35 \%^{\wedge}$ & $320^{*}$ & 2.60 & 2.50 & 6.98 & $45^{*}$ & 1 & & 45 & $<10$ & $130^{*}$ & $40^{\wedge}$ & & $470^{\wedge}$ & $0.70^{\wedge}$ & & & 1300 & & \\
\hline 84WHC10B & $>2.0 \%$ & $>2000$ & 70 & & & & 140 & 0.05 & 20 & 30 & & 50 & 20 & 10 & 70 & 0.3 & 10 & 70 & 500 & $\mathrm{~N}$ & 0.05 \\
\hline 84WHC11 & $55.0 \%^{\wedge}$ & $2.05 \%^{\wedge}$ & $380^{*}$ & 2.88 & 2.55 & 7.28 & $60^{*}$ & 1 & & 45 & $<10$ & $68^{*}$ & $<25^{\wedge}$ & & $610^{\wedge}$ & $0.75^{\wedge}$ & & & 1300 & & \\
\hline
\end{tabular}

[L: present at less than detection limit; N: not detected; All values are in ppm, unless otherwise noted. See text for explanation of analytical methods.] DESCRIPTION OF SAMPLES (see fig. 3 for locations)

$84 \mathrm{WHC1} \quad$ Iron-oxide-stained quartz float with pyrite.

84WHC2 Breccia with quartz rimming sandstone fragments and dark red-brown sphalerite $>$ galena infill.

84WHC3 Massive, dark-brown sphalerite, fragment of vein.

84WHC5 Quartz-cemented breccia with sandstone and shale chips; no visible sulfides.

84WHC6A Breccia with 1-8 mm quartz rimming f.g. sandstone fragments; minor infill is dark-brown sphalerite.

84WHC6B Quartzose sandstone with $1 \%$ black chert grains and $<5 \%$ Fe-oxides; minor disseminated pyrite.

84WHC7A Quartz veins with interstitial galena crosscut silicified sandstone, shale; rock fragments are $<3 \mathrm{~cm}$.

84WHC7B Breccia with $<5 \%$ fragments of shale, sandstone, quartz matrix, and clots of galena $>$ sphalerite infill.

84WHC8 Red-brown-weathering sandstone.

84WHC9 Gray siltstone/ shale, strongly cleaved, minor Fe-oxide stain.

84WHC10A Breccia of siltstone/ shale fragments, with quartz matrix; galena, sphalerite infill; crosscuts massive galena.

84WHC10A2 Breccia of siltstone/ shale fragments, with quartz matrix; galena, sphalerite infill; crosscuts massive galena.

84WHC10B Quartz-galena (sphalerite) veins cutting shale, with wallrock fragments displaced.

$84 \mathrm{WHC} 11$

Quartz-galena breccia crosscuts siltstone/shale. 


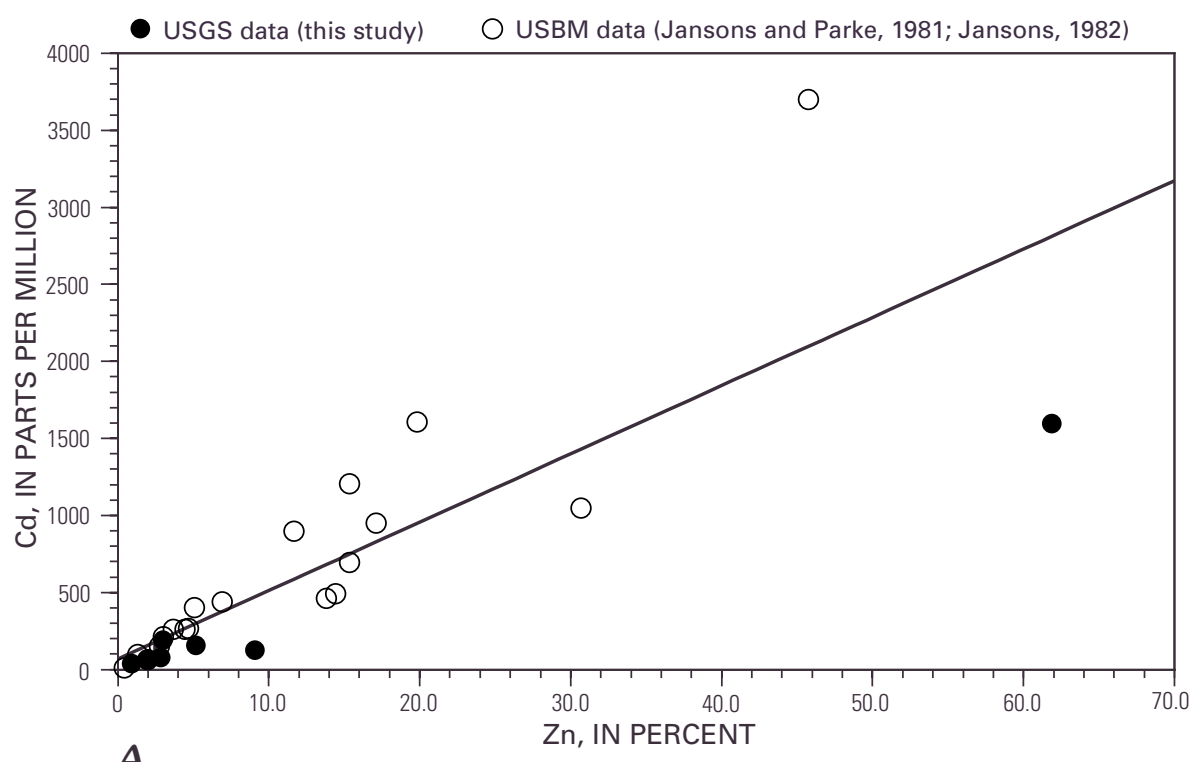

A
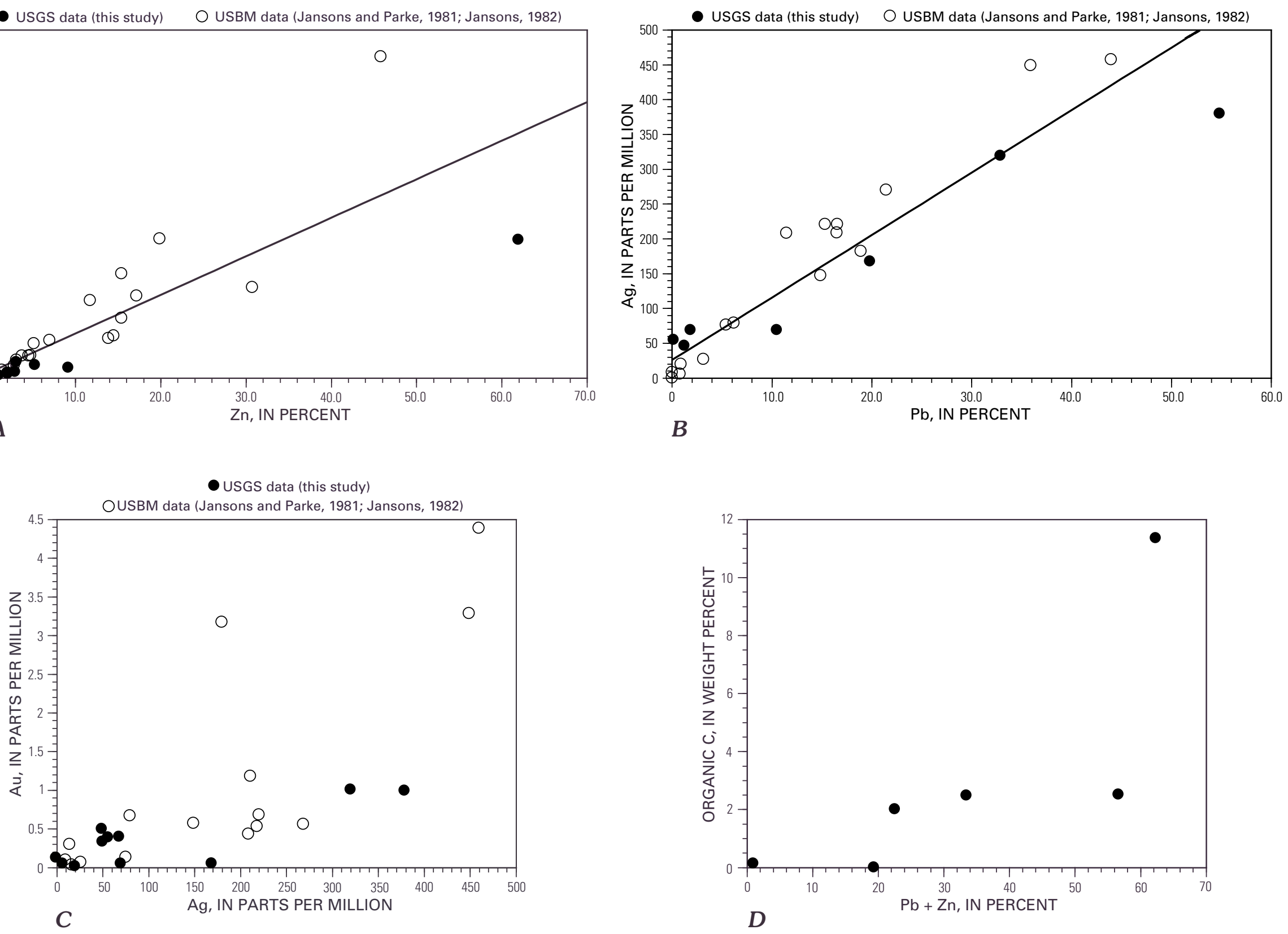

Figure 6. Plots of element concentrations in rock samples from the Whoopee Creek mineral occurrence. $A, C d$ vs. Zn content; $B, A g$ vs. Pb content; $C$, Au vs. Ag content; and $D$, organic carbon vs. combined $\mathrm{Pb}+\mathrm{Zn}$. All concentrations indicated are in weight percent. Data in $A, B$, and $C$ include mineralized and unmineralized samples from this study (closed circles) (table 1), and U.S. Bureau of Mines data (open circles) (Jansons and Parke, 1981; Jansons, 1982). Data in $D$ show six mineralized samples from this study (table 1). 
These rock analyses give values of 2 to 38 percent combined $\mathrm{Pb}+\mathrm{Zn}$ in most vein-breccia samples, as much as 55 percent $\mathrm{Pb}$ in a galena-rich breccia, and as much as 62.1 percent $\mathrm{Zn}$ in massive vein sphalerite. A linear correlation between $\mathrm{Cd}$ and $\mathrm{Zn}$ values (fig. 6A) indicates that $\mathrm{Cd}$ is substituting for $\mathrm{Zn}$ in the sphalerite crystal lattice. Ag values range to as much as $380 \mathrm{ppm}$ in galena-rich samples, and correlate directly with $\mathrm{Pb}$ contents in mineralized samples (fig. 6B). This is consistent with the fact that no Ag-bearing sulfide or sulfosalt phases have been identified and suggests that $\mathrm{Ag}$ occurs as a substitute for $\mathrm{Pb}$ in the galena crystal lattice, or possibly as microscopic inclusions within galena.

Gold concentrations in mineralized rocks at Whoopee Creek range from $<0.2$ to $1 \mathrm{ppm}$ (table 1) and appear to correlate with Ag content (fig. 6C). Values of As (20-140 ppm), Bi ( $\leq 15$ ppm), $\mathrm{Cu}(50-700 \mathrm{ppm})$, and $\mathrm{Sb}(11-1,300 \mathrm{ppm})$ are low but enriched relative to crustal abundance $(1.8,0.17,55,0.2 \mathrm{ppm}$, respectively) or average shale values $(6.6,0.01,57,1.5 \mathrm{ppm}$, respectively) (Krauskopf, 1967). Ba (30-300 ppm) in the mineralized samples is depleted relative to both crustal abundance (425 ppm) and to the average shale value (580 ppm). Three samples with detectable $\operatorname{Sn}(15,30$, and $50 \mathrm{ppm})$ contain $>2,000$ ppm, 2.8 percent, and 62.1 percent $\mathrm{Zn}$, respectively, but other samples with 1 to 9 percent $\mathrm{Zn}$ contain no detectable $\mathrm{Sn}$.

Total carbon content of five mineralized samples ranges from 0.08 to 2.88 weight percent $\mathrm{C}$, and a single massive sphalerite sample contains 13.0 percent $\mathrm{C}$ (table 1 ). The majority of the carbon occurs as organic carbon (vs. inorganic or carbonate forms) and roughly correlates with the overall $\mathrm{Pb}+\mathrm{Zn}$ content (fig. 6D). A straw-colored phase, which dissolved upon crushing in kerosene, was found in several fluid inclusions from the Whoopee Creek occurrence and was tentatively identified as methane. This phase, and the relatively high carbon content of some samples, suggests that organic matter may have played a significant role in the deposition of sulfides, possibly by acting as a reductant for oxidizing fluids.

\section{Soil and Sediment Geochemistry}

In order to define the extent of mineralization in the Whoopee Creek area, stream-sediment and soil samples were taken at sites surveyed with a chain and Brunton compass. A base station was established at a relatively prominent creek intersection (surveyed elevation 2,240 ft; fig. 3). From that point, an east-west base-line, an $800-\mathrm{ft} \times 1000$-ft grid, and a chain line along the west bank of Whoopee Creek were surveyed. Fifteen bulk stream-sediment samples were collected from the intermittently flowing channel of Whoopee Creek and from the beds of dry, side creeks. Eighteen samples were taken of thin (few centimeters to tens of centimeters), frozen soils that directly overlie float and boulders of clastic rocks. Not all $200-\mathrm{ft}$ intersections on the grid were sampled due to time constraints. Soil and stream-sediment samples were sieved to minus-800 mesh and analyzed for $\mathrm{As}, \mathrm{Bi}, \mathrm{Sb}, \mathrm{Zn}$, and $\mathrm{Cd}$ by atomic absorption spectrometry (O'Leary and Viets, 1986). These samples were also analyzed for 30 elements by semiquantitative 6-step D.C. arc optical emission spectrography (Grimes and Marranzino, 1968) in USGS laboratories.
Most soils and sediments sampled at Whoopee Creek (table 2) contain $>100 \mathrm{ppm} \mathrm{Zn} \mathrm{(fig.} \mathrm{7)} \mathrm{and}>100 \mathrm{ppm} \mathrm{Pb}$ (fig. 8). A large part of the central and western grid area, however, contains 500 to $>2,000$ ppm $\mathrm{Zn}, 500$ to $10,000 \mathrm{ppm} \mathrm{Pb}, 1$ to $5.1 \mathrm{ppm} \mathrm{Cd}$, and 1 to $7 \mathrm{ppm} \mathrm{Ag}$. Ag content of the soils and sediments is proportional to $\mathrm{Pb}$ (figs. 8, 9, and 10A) and $\mathrm{Cd}$ content is proportional to $\mathrm{Zn}$ (figs. 7, 10B, and 11 ), similar to the relationship seen in rock samples.

Other pathfinder elements are less enriched ( $\leq 40 \mathrm{ppm}$ As, $\leq 1,500 \mathrm{ppm} \mathrm{Ba}, \leq 200 \mathrm{ppm} \mathrm{Cu}, \leq 2,000 \mathrm{ppm} \mathrm{Mn}$; table 2) and show no clear correlation to $\mathrm{Zn}$ or $\mathrm{Pb}$ values (e.g., $\mathrm{Cu}$, fig. $10 C) . \mathrm{Pb}, \mathrm{Zn}, \mathrm{Ag}$, and $\mathrm{Cd}$ anomalies extend off the sampled grid both to east and west, and the area prospective for mineralization is open in both directions. Sphalerite- and galenabearing boulders occur outside the area of highly anomalous soils as well (e.g., along gridline $100 \mathrm{~N}$ ), and it is difficult to suggest large-scale $(100 \mathrm{~m})$ downslope transport or soil creep in this area of very low relief. Vein-breccia $\mathrm{Zn}-\mathrm{Pb}-\mathrm{Ag}$ occurrences in the Brooks Range generally have a very subtle physical expression because mineralized rocks often weather without significant color anomalies. They contain little pyrite and no magnetic sulfides or oxides, and, where tested, have poor conductivity (Anaconda Minerals Co., unpub. report, [available from Cook Inlet Region Inc., Anchorage]; Kennecott Exploration [Ebish, James, 1993], Spokane, unpub. company report). Therefore, soil sampling combined with detailed examination of float is required to accurately outline the extent of mineralization.

\section{Genesis of Brooks Range $\mathrm{Zn}-\mathrm{Pb}-\mathrm{Ag}$ Vein-Breccias}

At least sixteen $\mathrm{Zn}-\mathrm{Pb}-\mathrm{Ag}$ vein-breccia occurrences similar to Whoopee Creek are known from a $250-\mathrm{km}$ east-west elongate area of the central and western Brooks Range. These include Story Creek (Ellersieck and others, 1982; Kurtak and others, 1995), West Koiyaktat and West Kivliktort (Kurtak and others, 1995); Kady (Werdon, 1999); Husky (Kurtak and others, 1995); Ginny Creek (Mayfield and others, 1979a, 1979b), and other occurrences in the Killik River and Howard Pass quadrangles (Duttweiler, 1987; Kurtak and others, 1995; Kelley and others, 1997). At each of these locations, vein and (or) breccia material containing as much as 60 percent sulfides extends over areas of tens by hundreds of meters. The occurrences share a simple, sphalerite-galena-dominant mineralogy; they contain little pyrite or chalcopyrite; they have high Ag and low Ba and Bi contents; and they are not associated with any igneous rocks. Wallrock alteration is limited to silicification or destruction of minor carbonate cement extending a few centimeters into host sandstones or siltstones. The $\mathrm{Pb}$ isotopic compositions of all veins fall within a very narrow range and closely match those of both disseminated and massive-sulfide $\mathrm{Zn}-\mathrm{Pb}$ deposits in the western Brooks Range (Gaccetta and Church, 1989; Werdon and others, 1999). This signature suggests derivation of the $\mathrm{Pb}$ from a regional, isotopically homogeneous source, which would occur if ore fluids were derived from a single, large sedimentary basin or from a series of hydraulically interconnected basins. 
Table 2. Geochemical data for minus- 80 mesh soil and stream sediment samples from the Whoopee Creek $\mathrm{Zn}-\mathrm{Pb}-\mathrm{Ag}$ occurrence.

\begin{tabular}{|c|c|c|c|c|c|c|c|c|c|c|c|c|c|c|c|c|c|c|c|}
\hline Sample & $\mathbf{P b}$ & $\mathrm{Zn}$ & $\mathbf{A g}$ & As & B & $\mathrm{Ba}$ & $\mathrm{Ca}-\%$ & Cd & Co & $\mathrm{Cr}$ & $\mathrm{Cu}$ & $\mathrm{Fe}-\%$ & $\mathbf{M n}$ & $\mathbf{N i}$ & Sb & Ti\% $\%$ & v & $Y$ & $\mathrm{Zr}$ \\
\hline $84 \mathrm{WHCA}$ & 100 & 90 & $\mathrm{~N}$ & 10 & 200 & 1000 & 0.10 & 0.1 & 30 & 200 & 100 & 7.0 & 1000 & 100 & $\mathrm{~N}$ & $>1$ & 200 & 100 & $\overline{500}$ \\
\hline 84WHCB & 70 & 75 & $\mathrm{~N}$ & $\mathrm{~L}$ & 200 & 700 & 0.05 & 0.2 & 20 & 200 & 70 & 5.0 & 500 & 50 & $\mathrm{~N}$ & 1.00 & 200 & 70 & 200 \\
\hline 84WHCC & 70 & 80 & $\mathrm{~N}$ & 10 & 200 & 700 & 0.05 & 0.2 & 30 & 200 & 70 & 5.0 & 1000 & 100 & $\mathrm{~N}$ & 1.00 & 200 & 70 & 200 \\
\hline 84WHCD & 70 & 75 & $\mathrm{~N}$ & 10 & 200 & 700 & 0.05 & 0.1 & 30 & 200 & 70 & 5.0 & 1000 & 70 & $\mathrm{~N}$ & 1.00 & 200 & 70 & 200 \\
\hline 84WHCE & 200 & 200 & $\mathrm{~L}$ & 10 & 200 & 700 & 0.05 & 0.6 & 20 & 200 & 70 & 5.0 & 1000 & 70 & $\mathrm{~N}$ & 1.00 & 200 & 70 & 200 \\
\hline 84WHCF & 5,000 & 1000 & 7 & 20 & 200 & 700 & 0.05 & 4.1 & 50 & 200 & 100 & 5.0 & 1000 & 70 & 20 & 1.00 & 200 & 70 & 200 \\
\hline 84WHCG & 300 & 660 & 0.5 & 20 & 200 & 1000 & $\mathrm{~L}$ & 2 & 30 & 200 & 70 & 5.0 & 1000 & 50 & 4 & 1.00 & 200 & 70 & 200 \\
\hline $84 \mathrm{WHCH}$ & 1,000 & 680 & 1 & 20 & 200 & 1000 & 0.05 & 2 & 30 & 200 & 70 & 5.0 & 1000 & 50 & 4 & 1.00 & 200 & 70 & 200 \\
\hline $84 \mathrm{WHCI}$ & 1,000 & 220 & 1 & $\mathrm{~L}$ & 200 & 1000 & 0.05 & 0.7 & 30 & 200 & 70 & 5.0 & 700 & 70 & 2 & 1.00 & 200 & 50 & 200 \\
\hline $84 \mathrm{WHCJ}$ & 100 & 200 & $\mathrm{~L}$ & 10 & 200 & 1000 & 0.10 & 0.4 & 30 & 200 & 70 & 5.0 & 700 & 70 & $\mathrm{~L}$ & 1.00 & 200 & 50 & 300 \\
\hline 84WHCK & 200 & 200 & $\mathrm{~L}$ & 10 & 200 & 1000 & 0.10 & 0.4 & 30 & 200 & 70 & 5.0 & 1000 & 50 & $\mathrm{~L}$ & 0.70 & 200 & 50 & 300 \\
\hline 84WHC78W & 70 & 90 & $\mathrm{~N}$ & 10 & 200 & 1500 & 0.15 & 0.2 & 30 & 200 & 100 & 5.0 & 1000 & 70 & $\mathrm{~N}$ & 1.00 & 200 & 70 & 300 \\
\hline 84EK127 & 500 & 95 & 1 & 20 & 300 & 1000 & 0.10 & 0.2 & 30 & 200 & 100 & 5.0 & 1000 & 70 & $\mathrm{~N}$ & 1.00 & 200 & 50 & 200 \\
\hline 84EK128 & 100 & 250 & $\mathrm{~N}$ & 20 & 200 & 1000 & 0.10 & 0.2 & 50 & 150 & 100 & 5.0 & 1500 & 70 & $\mathrm{~N}$ & 1.00 & 200 & 50 & 300 \\
\hline 84EK130 & 100 & 260 & $\mathrm{~N}$ & 20 & 200 & 1500 & 0.20 & 0.6 & 50 & 200 & 100 & 5.0 & 1000 & 70 & $\mathrm{~L}$ & 1.00 & 200 & 70 & 300 \\
\hline 84WHC11 & 200 & 780 & 1 & 10 & 200 & 1500 & $\mathrm{~L}$ & 2.3 & 50 & 200 & 100 & 5.0 & 1000 & 70 & 4 & 1.00 & 200 & 70 & 300 \\
\hline 84WHC12 & 500 & 1400 & 1 & 10 & 200 & 1500 & $\mathrm{~L}$ & 5.1 & 50 & 200 & 100 & 5.0 & 1000 & 70 & 8 & 1.00 & 200 & 70 & 300 \\
\hline 84WHC13 & 70 & 70 & $\mathrm{~N}$ & $\mathrm{~L}$ & 200 & 1000 & $\mathrm{~L}$ & 0.2 & 30 & 200 & 70 & 5.0 & 1000 & 50 & $\mathrm{~N}$ & 1.00 & 200 & 70 & 300 \\
\hline 84WHC14 & 70 & 70 & $\mathrm{~N}$ & $\mathrm{~L}$ & 200 & 1500 & 0.05 & $\mathrm{~L}$ & 30 & 200 & 70 & 5.0 & 1000 & 50 & $\mathrm{~N}$ & 1.00 & 200 & 70 & 300 \\
\hline $84 \mathrm{WHC} 15$ & 50 & 50 & $\mathrm{~N}$ & $\mathrm{~L}$ & 200 & 1500 & 0.05 & $\mathrm{~L}$ & 30 & 200 & 70 & 5.0 & 500 & 70 & $\mathrm{~N}$ & 1.00 & 200 & 100 & 300 \\
\hline $84 \mathrm{WHC} 16$ & 70 & 75 & $\mathrm{~N}$ & 10 & 200 & 1000 & $\mathrm{~L}$ & $\mathrm{~L}$ & 30 & 100 & 50 & 5.0 & 1000 & 70 & $\mathrm{~N}$ & 1.00 & 200 & 100 & 200 \\
\hline $84 \mathrm{WHC} 17$ & 50 & 110 & $\mathrm{~N}$ & $\mathrm{~L}$ & 200 & 1000 & $\mathrm{~L}$ & 0.2 & 20 & 200 & 200 & 10.0 & 1500 & 70 & $\mathrm{~N}$ & $>1$ & 200 & 70 & 300 \\
\hline $84 \mathrm{WHC} 18$ & 100 & 150 & $\mathrm{~N}$ & 10 & 200 & 1000 & $\mathrm{~L}$ & 0.2 & 30 & 200 & 50 & 5.0 & 1000 & 70 & $\mathrm{~N}$ & 1.00 & 200 & 70 & 200 \\
\hline 84WHC19 & 150 & 350 & $\mathrm{~L}$ & $\mathrm{~L}$ & 200 & 1000 & $\mathrm{~L}$ & 0.3 & 30 & 200 & 50 & 5.0 & 1000 & 70 & $\mathrm{~N}$ & 1.00 & 200 & 70 & 200 \\
\hline $84 \mathrm{WHC} 20$ & 100 & 210 & $\mathrm{~N}$ & $\mathrm{~L}$ & 200 & 1000 & $\mathrm{~L}$ & 0.5 & 30 & 200 & 20 & 5.0 & 1000 & 70 & $\mathrm{~N}$ & 1.00 & 200 & 70 & 200 \\
\hline $84 \mathrm{WHC} 21$ & 5,000 & 340 & 2 & 30 & 300 & 1000 & 0.07 & 0.6 & 30 & 200 & 100 & 0.7 & 1500 & 100 & 18 & 1.00 & 200 & 100 & 300 \\
\hline $84 \mathrm{WHC} 22$ & 200 & 560 & 0.5 & 20 & 200 & 1000 & $\mathrm{~L}$ & 1.3 & 20 & 200 & 70 & 0.7 & 700 & 70 & 2 & 1.00 & 200 & 70 & 200 \\
\hline $84 \mathrm{WHC} 23$ & 500 & 1300 & $\mathrm{~L}$ & 40 & 200 & 1500 & $\mathrm{~L}$ & 2.7 & 70 & 200 & 100 & 0.7 & 1500 & 70 & 6 & $>1$ & 200 & 100 & 300 \\
\hline $84 \mathrm{WHC} 24$ & 10,000 & $>2000$ & 10 & 40 & 300 & 1500 & 0.05 & 3.4 & 50 & 200 & 100 & 0.7 & 1500 & 100 & 26 & $>1$ & 200 & 100 & 300 \\
\hline $84 \mathrm{WHC} 25$ & 700 & 320 & 1 & 20 & 300 & 1500 & 0.05 & 0.8 & 30 & 200 & 100 & 0.7 & 2000 & 70 & 4 & $>1$ & 200 & 100 & 200 \\
\hline $84 \mathrm{WHC} 26$ & 50 & 85 & $\mathrm{~N}$ & $\mathrm{~L}$ & 100 & 700 & 0.50 & 0.4 & 5 & $\mathrm{~L}$ & 20 & 1.0 & 700 & 20 & $\mathrm{~N}$ & 0.20 & 150 & 30 & 100 \\
\hline $84 \mathrm{WHC} 27$ & 100 & 180 & $\mathrm{~N}$ & 20 & 200 & 1500 & 0.07 & 0.3 & 50 & 200 & 100 & 7.0 & 1000 & 100 & 2 & 1.00 & 200 & 100 & 300 \\
\hline $84 \mathrm{WHC} 28$ & 1,000 & 510 & $\mathrm{~L}$ & 20 & 200 & 1500 & 0.05 & 1.4 & 30 & 200 & 100 & 7.0 & 1000 & 100 & 4 & 1.00 & 200 & 100 & 300 \\
\hline
\end{tabular}

All samples analyzed by 6-step optical emission spectrography, except $\mathrm{As}, \mathrm{Cd}, \mathrm{Sb}$ and $\mathrm{Zn}$ by atomic absorption spectrometry.

$\mathrm{L}$ : present at less than detection limit; N: not detected; All values are in ppm unless otherwise noted. 


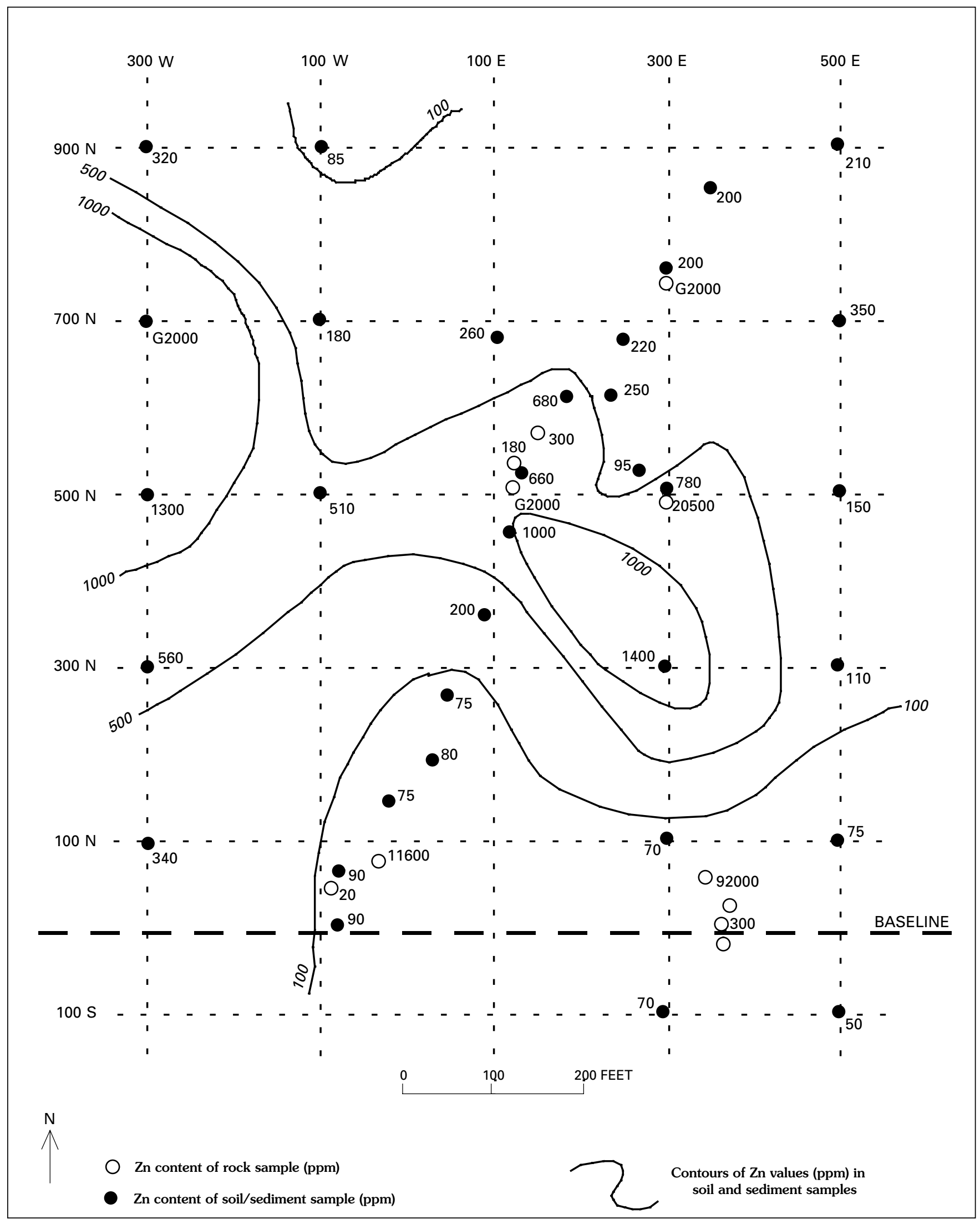

Figure 7. Map of WHC grid area showing Zn content of rock, soil and sediment samples, and contours of Zn content in soils and sediments. 


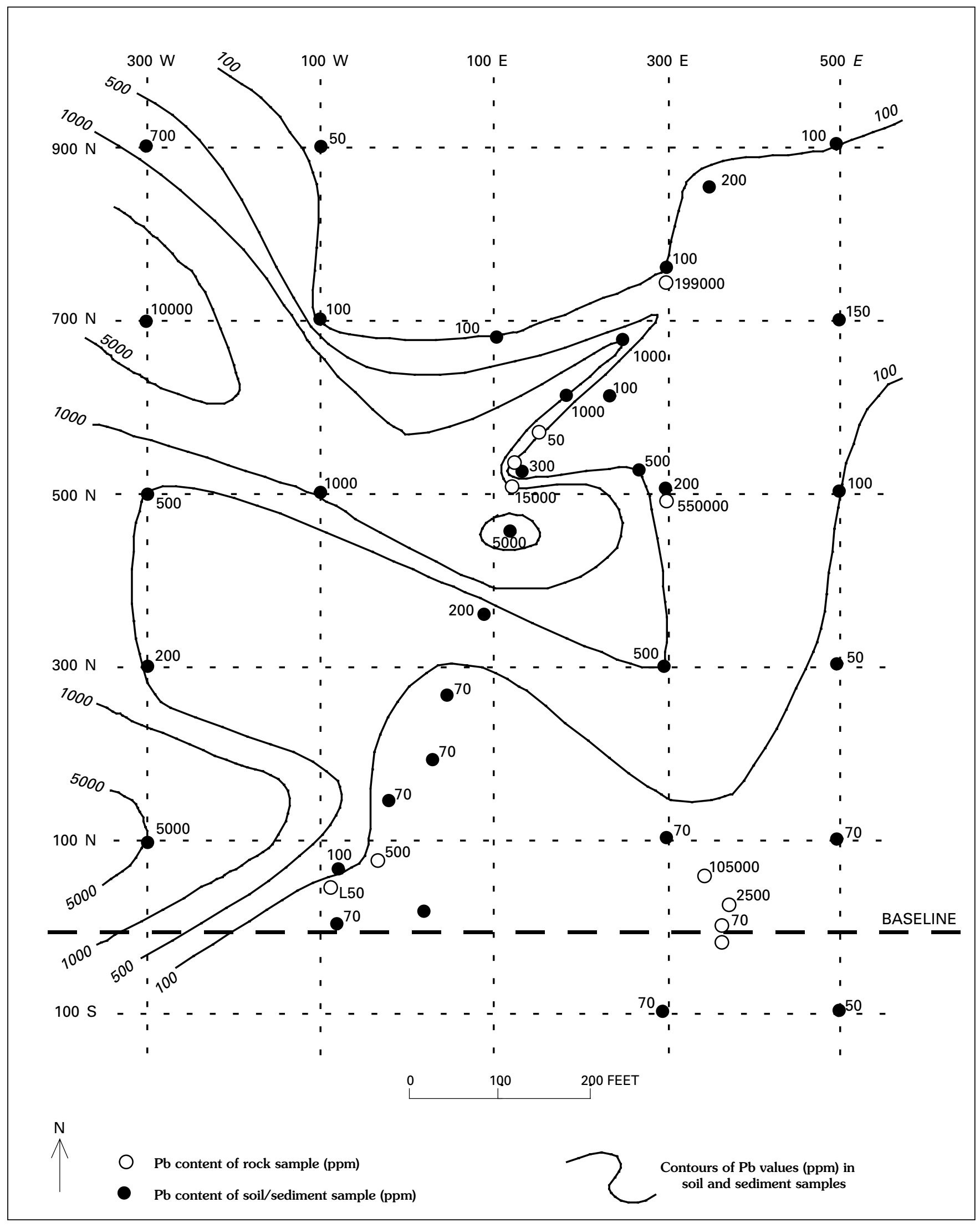

Figure 8. Map of WHC grid area showing Pb content of rock, soil and sediment samples, and contours of Pb content in soils and sediments. 


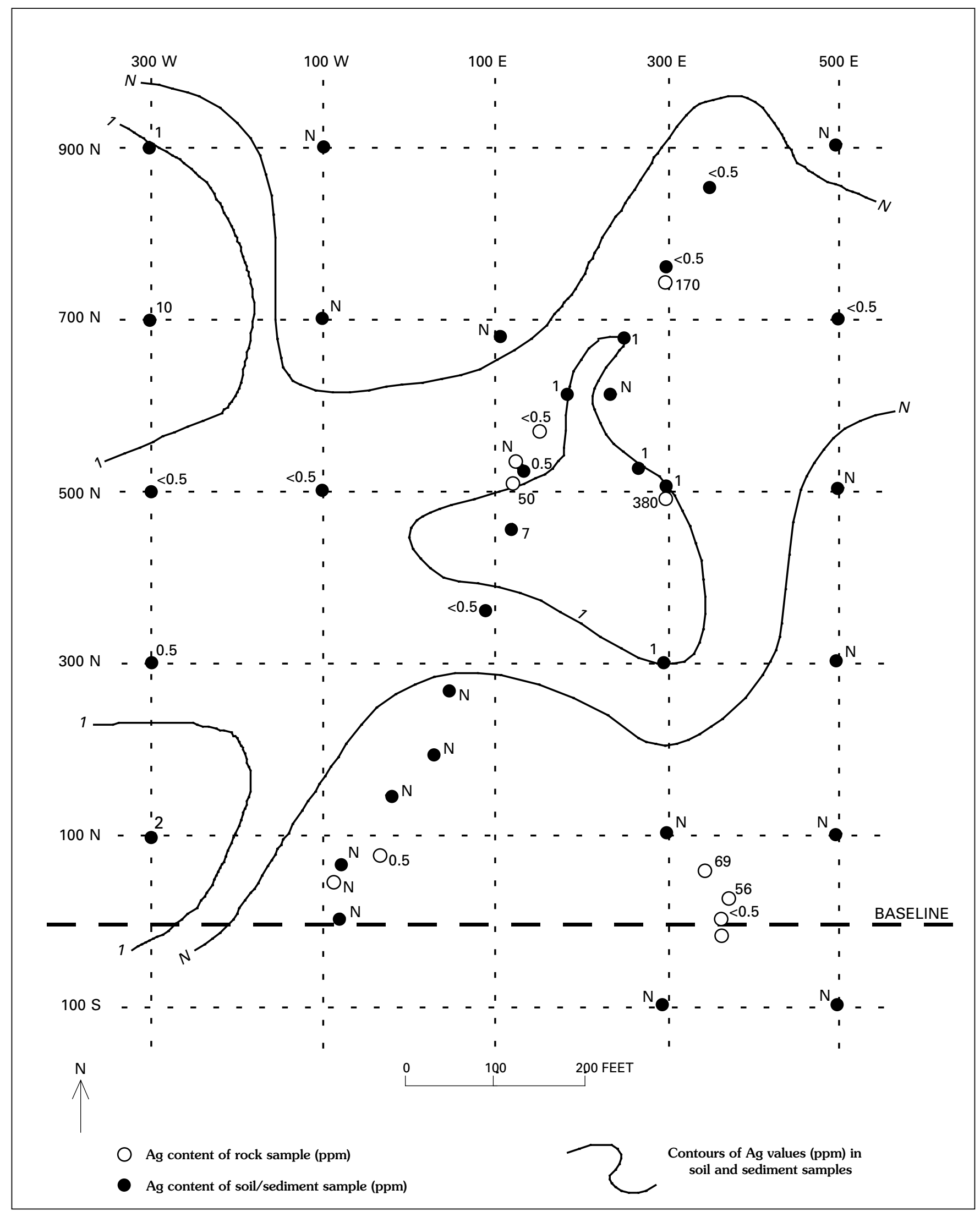

Figure 9. Map of WHC grid area showing Ag content of rock, soil and sediment samples, an contours of Ag content in soils and sediments. Samples labeled "N" contained no detectable Ag. 


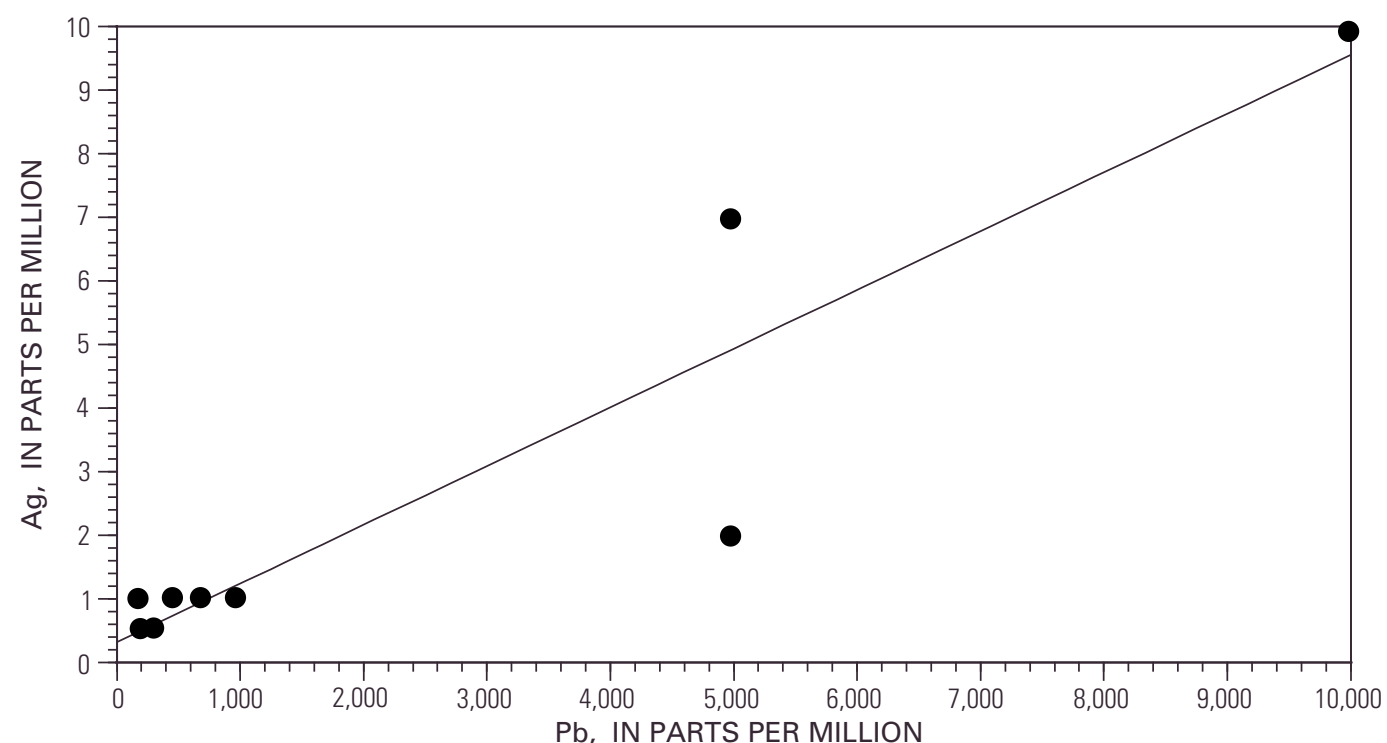

A

$\mathrm{Pb}$, IN PARTS PER MILLION

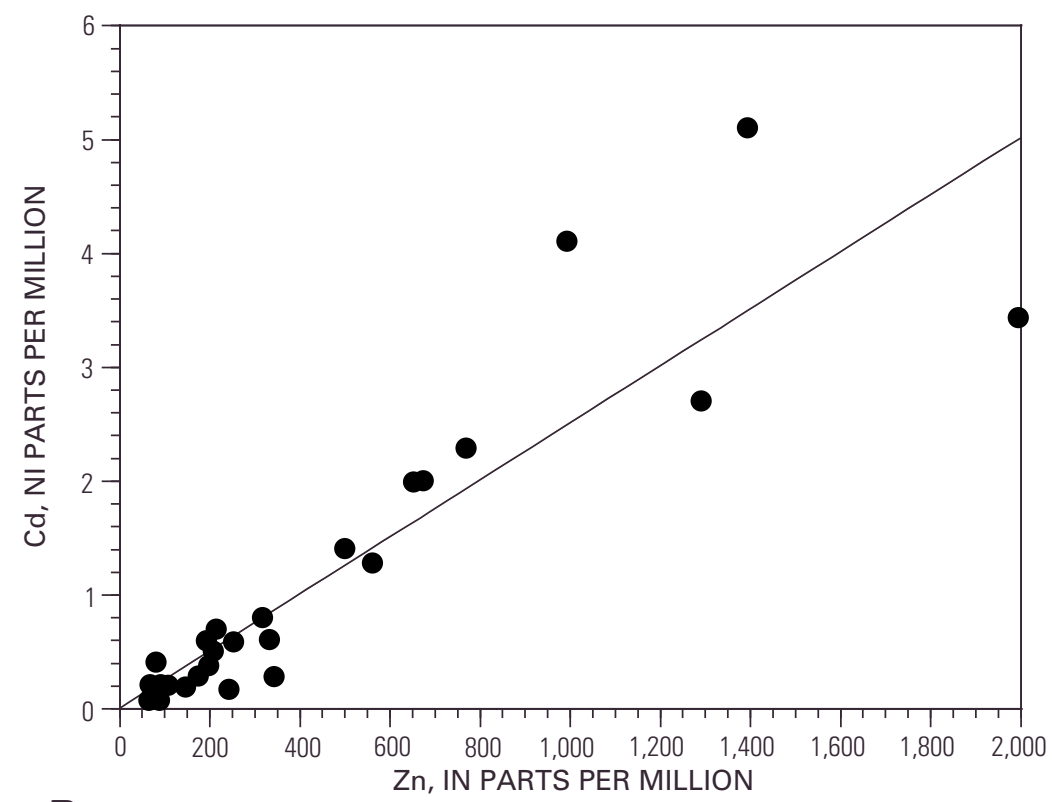

B

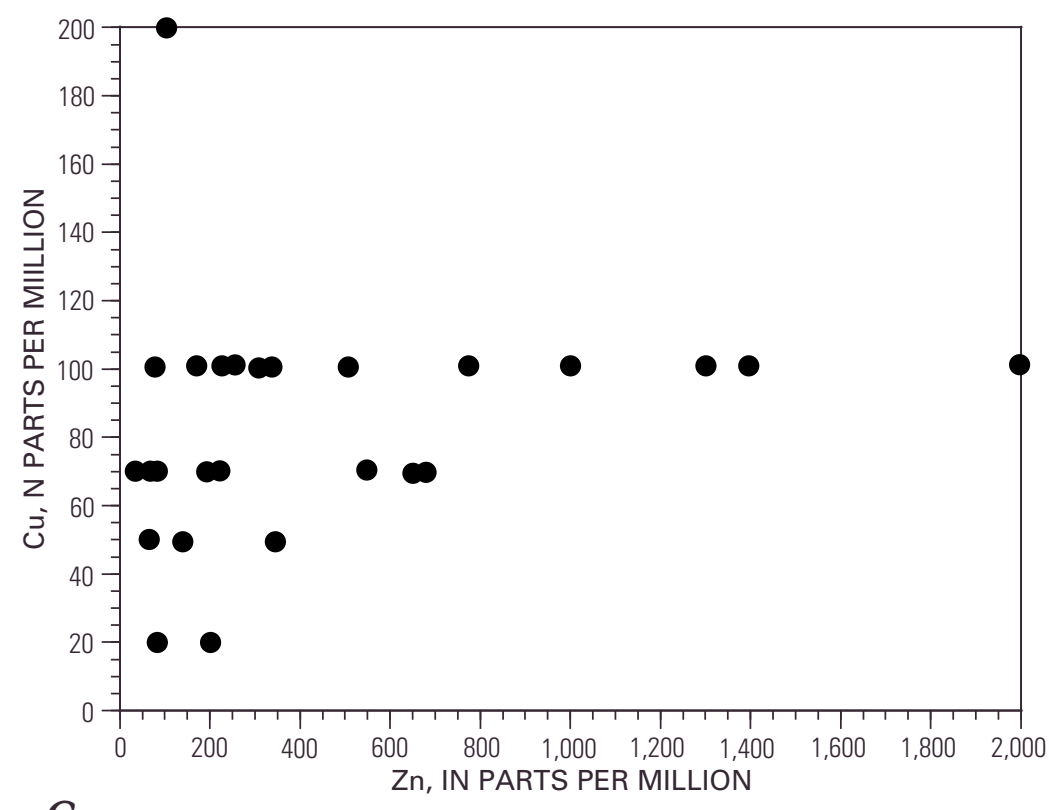

Figure 10. Plots of element concentrations in soil samples from the Whoopee Creek mineral occurrence. $A, \mathrm{Ag}$ vs. Pb content; $B, \mathrm{Cd}$ vs. Zn content; $C$, Cu vs. Zn content. All data from this study (table 2). 


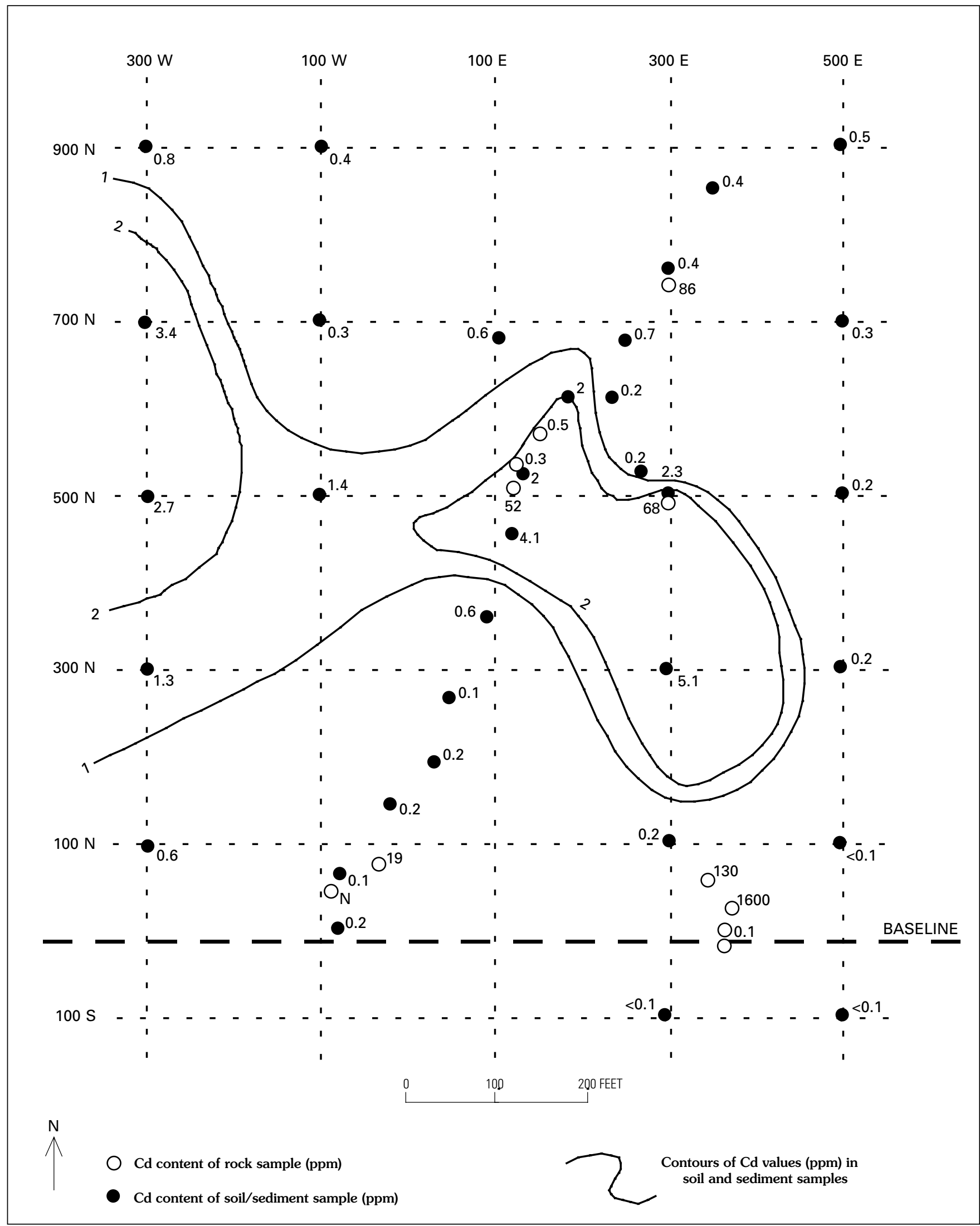

Figure 11. Map of WHC grid area showing Cd content of rock, soil and sediment samples, an contours of Cd content in soils and sediments. Samples labeled "N" contained no detectable $\mathrm{Cd}$. 


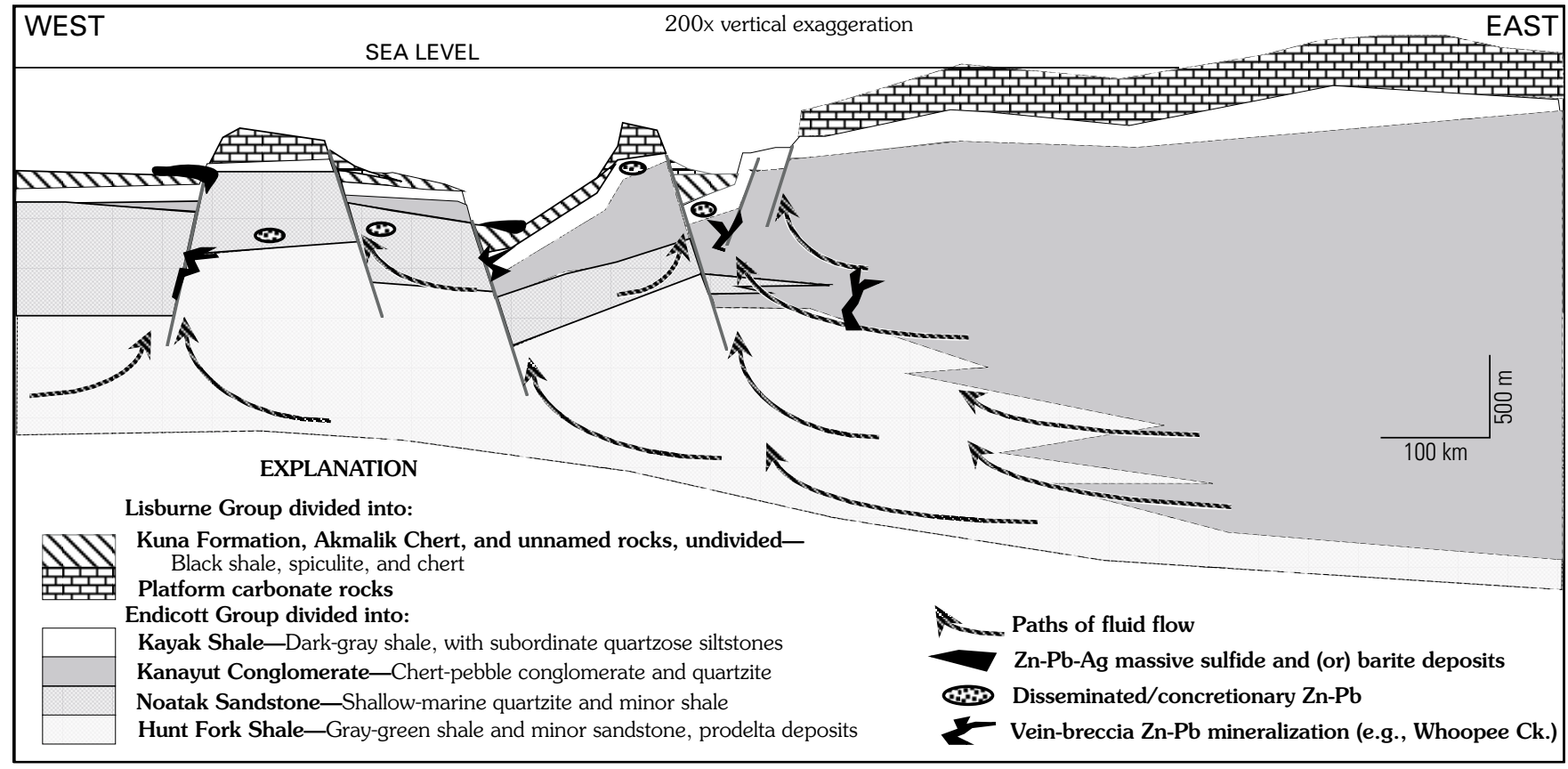

Figure 12. Proposed model of stratigraphic and structural setting during formation of Zn-Pb-Ag vein-breccia deposits, such as Whoopee Creek in Upper Devonian and Mississippian sedimentary rocks of the Brooks Range (modified from Schmidt, 1997).

Rocks hosting the vein-breccia occurrences include: (1) quartzitic sandstones of the Kanayut Conglomerate; (2) finegrained sandstones of the Endicott Group, possibly belonging to the Noatak Sandstone; (3) siltstones with lesser shale, fine sandstone, and coal, which probably belong to the Isikut Member of the Kayak Shale; or (4) Hunt Fork Shale. These units are latest Devonian to earliest Mississippian in age, and all are older than black siliceous mudstones and cherts of the Lisburne Group (Kuna Formation, Akmalik Chert), which host massive $\mathrm{Zn}-\mathrm{Pb}-$ $\mathrm{Ag}$ sulfide, and barite deposits, respectively. ${ }^{40} \mathrm{Ar} /{ }^{39} \mathrm{Ar}$ dating of recrystallized detrital white mica in narrow vein selvages (Werdon and others, 1999) indicates a Late Mississippian to Early Pennsylvanian age for the formation of vein-breccia mineralization. This age is consistent with the presence of the veinbreccias in the Endicott Group and their absence in Permian and younger rocks.

Young (1989) suggested that large-scale fluid movement linked disseminated galena and pyrite occurrences in EndicottGroup sandstones to the development of nearby syngenetic massive sulfide deposits (i.e., Lik, Red Dog). The formation of veinbreccia occurrences such as Whoopee Creek can be linked to both the disseminated and massive sulfide occurrences through an integrated model such as that shown in figure 12 (Schmidt and Werdon, 1993; Schmidt, 1997; Werdon, 1999). In this model, disseminated and concretionary sulfides are fluid-flow indicators that mark the path of $\mathrm{Zn}-\mathrm{Pb}$-Ag-rich basinal fluids through a dominantly clastic aquifer (e.g., the Endicott Group), whereas massive sulfide deposits mark the location where those fluids vented into relatively deep water, restricted seafloor basins. The vein-breccias indicate the locations of focused flow, such as along extensional fractures cutting the sedimentary section below deep-water, shallow-water, and possibly emergent areas in Mississippian time. Color-banded sphalerite-rich veins and simple wallrock inclusion breccias at Whoopee Creek and other vein-breccia occurrences are remarkably similar in texture and mineralogy to "feeder vein" mineralization below the Red Dog deposit. In this model, "feeder veins" and vein-breccias would have formed under similar conditions (extensional tectonic regime; similar fluid, pressure, and temperature conditions) but a massive sulfide deposit would not necessarily have formed over any given vein-breccia.

Whoopee Creek is analogous to $\mathrm{Pb}-\mathrm{Zn}$ veins and breccias in other districts (e.g., Bad Grund and Westphalian coal seams, Germany; Benue Trough, Nigeria) that crosscut sandstones and shales and are interpreted to form by expulsion of sedimentary brines (basin dewatering) related to wrench faulting (Klau, 1986) or intracontinental rifting (Mitchell and Garson, 1981). Although long-distance fluid transport through a sedimentary basin is suggested for the Brooks Range, there are several differences between this model and those usually invoked for Mississippi Valley-type (MVT) Pb-Zn systems. These include differences in (1) relative timing of mineralization (syndiagenetic for Brooks Range vs. epigenetic for MVT's); (2) depth of burial of sediments within the basin $(0.5-3 \mathrm{~km}$ vs. $5-10 \mathrm{~km})$; (3) in host rocks (clastic vs. carbonate); and (4) possible tectonic setting (extensional vs. compressional foreland).

Acknowledgments-I would like to thank Inyo Ellersieck for his able assistance in the field during a mosquito-infested and windy campout at Buhach Lake on this project. Jim Riehle and Tom Light provided very prompt and helpful reviews of the manuscript.

\section{References Cited}

Brosge, W.P., Nilsen, T.H., Moore, T.E., and Dutro, J.T., Jr., 1988, Generalized geologic map showing distribution of the members of the Kanayut Conglomerate and the Noatak Sandstone in the central and eastern Brooks Range, AK, in Gryc, George, ed., Geology and Exploration of the National Petroleum Reserve in Alaska, 1974 to 1982: 
U.S. Geological Survey Professional Paper 1399, plate 14.1, scale 1:500,000.

Duttweiler, K.A., 1987, Use of factor analysis in locating base metal mineralization in the Killik River quadrangle, Alaska, in Hamilton, T.D., and Galloway, J.P., eds.., Geologic Studies in Alaska by the U.S. Geological Survey During 1986: U.S. Geological Survey Circular 998, p. 27-30.

Ellersieck, Inyo, Jansons, Uldis, Mayfield, C.F., and Tailleur, I.L., 1982, The Story Creek and Whoopee Creek lead-zinc-silver occurrences, western Brooks Range, Alaska, in Coonrad, W.L., ed., U.S. Geological Survey in Alaska: Accomplishments During 1980: U.S. Geological Survey Circular 844, p. 35-38.

Gaccetta, J.D., and Church, S.E., 1989, Lead isotope data base for sulfide occurrences from Alaska, December, 1989: U.S. Geological Survey Open-File Report 89-688, $60 \mathrm{p}$.

Grimes, D.J., and Marranzino, A.P., 1968, Direct-current arc and alternating-current spark emission spectrographic field methods for the semiquantitative analysis of geologic materials: U.S. Geological Survey Circular 591, 6 p.

Jackson, L.L., Brown, F.W., and Neil, S.T., 1987, Major and minor elements requiring individual determination, classical whole rock analysis, and rapid rock analysis, in Baedecker, P.A., .ed., Methods for Geochemical Analysis: U.S. Geological Survey Bulletin 1770, p. G1G23.

Jansons, Uldis, 1982, Zinc-lead occurrences in and near the National Petroleum Reserve in Alaska: U.S. Bureau of Mines Mineral Lands Assessment Report MLA 121-82, 55 p.

Jansons, Uldis, and Parke, M.A., 1981, 1978 Mineral investigations in the Misheguk Mountain and Howard Pass quadrangles, Alaska: U.S. Bureau of Mines Open-File Report 26-81, 195 p.

Johnson, R.G., and King, B.-S. L., 1987, Energy-dispersive X-ray fluorescence spectrometry, in Baedecker, P.A., .ed., Methods for Geochemical Analysis: U.S. Geological Survey Bulletin 1770, p. F1-F5.

Kelley, K.D., Taylor, C.D., and Cieutat, B.A., 1997, Silver-lead-zinc mineral occurrences in the Howard Pass quadrangle, Brooks Range, Alaska, in Dumoulin, J..A., and Gray, J., eds., Geologic Studies in Alaska by the U.S. Geological Survey, 1995: U.S. Geological Survey Professional Paper 1574, p. 101-110.

Klau, Wolfgang, 1986, Forgotten $\mathrm{Pb}-\mathrm{Zn}$ veins in Westphalian strata of the Ruhr, West Germany, in Andrew, C.J., Crowe, R.W.A., Finlay, S., Pennell, W.M., and Pyne, J.F., eds., Geology and Genesis of Mineral Deposits in Ireland: Dublin, Irish Association for Economic Geology, p. 693-699.

Krauskopf, K.B., 1967, Introduction to Geochemistry: New York, McGraw Hill, $721 \mathrm{p}$.

Kurtak, J.M., Hicks, R.W., Werdon, M.B., Meyer, M.P., and Mull, C.G., 1995, Mineral investigations in the Colville mining district and southern National Petroleum Reserve in Alaska: U.S.Bureau of Mines Open-File Report 8-95, $217 \mathrm{p}$.

Mayfield, C.F., Curtis, S.M., Ellersieck, Inyo, and Tailleur, I.L., 1979a, Reconnaissance geology of the Ginny Creek zinc-lead-silver and Nimiuktuk barite deposits, northwestern Brooks Range, Alaska: U.S. Geological Survey Open-File Report 79-1092, scale 1:63,360, 2 sheets, $20 \mathrm{p}$.

Mayfield, C.F., Curtis, S.M., Ellersieck, I.F., and Tailleur, I.L., 1979b, The Ginny Creek zinc-lead-silver and Nimiuktuk barite deposits, northwestern Brooks Range, Alaska, in Johnson, K.M., and Williams, J.R., eds., The United States Geological Survey in Alaska: Accomplishments During 1978: U.S. Geological Survey Circular 804-B, p. B11-B13.

Mayfield, C.F., Tailleur, I.L., and Ellersieck, Inyo, 1988, Stratigraphy, structure, and palinspastic synthesis of the western Brooks Range, northwestern Alaska, in Gryc, George, ed., Geology and Exploration of the National Petroleum Reserve in Alaska, 1974-1982: U.S. Geological Survey Professional Paper 1399, p. 143-186.

Mitchell, A.H.G., and Garson, M.S., 1981, Mineral deposits and global tectonic settings: New York, Academic Press, $405 \mathrm{p}$.

Moore, T.E., Wallace, W.K., Bird, K.J., Karl, S.M., Mull, C.G., and Dillon, J.T., 1994, Geology of northern Alaska, chap. 3 of Plafker, G., and Berg, H.C., eds., The Geology of Alaska: Boulder, Colorado, Geological Society of America, The Geology of North America, v. G1, p. 49140.

Mull, C.G., Harris, A.G., and Carter, J.L., 1997, Lower Mississippian (Kinderhookian) biostratigraphy and lithostratigraphy of the western Endicott Mountains, Brooks Range, Alaska, in Dumoulin, J.A., and Gray, J.E., eds., Geologic Studies in Alaska by the U.S. Geological Survey, 1995: U.S. Geological Survey Professional Paper 1574, p. 221-242.

Mull, C.G., and Werdon, M.B., 1994, Generalized geologic map of the western Endicott Mountains, central Brooks Range, Alaska: Alaska Division of Geological and Geophysical Surveys Public Data File PDF-94-55, 1 sheet, 1:250,000 scale.

O'Leary, R.M., and Viets, J.G., 1986, Determination of antimony, bismuth, cadmium, copper, lead, molybdenum, silver, and zinc in geologic material by atomic absorption spectrometry using a hydrochloric acid-hydrogen peroxide digestion: Atomic Spectroscopy, v. 7, no. 1, p. 4-8.

Schmidt, J.M., 1997, Shale-hosted $\mathrm{Zn}-\mathrm{Pb}-\mathrm{Ag}$ and barite deposits of Alaska, in Goldfarb, R.J., and Miller, L., eds., Mineral Deposits of Alaska: Economic Geology Monograph 9, p. 35-65.

Schmidt, J.M., and Werdon, M.B., 1993, Clastic-hosted stratiform, vein/ breccia and disseminated $\mathrm{Zn}-\mathrm{Pb}-\mathrm{Ag}$ deposits of the northwestern Brooks Range, AK.: Are they different expressions of dewatering of the same source basin? [abs.]: Geological Society of America, Abstracts with Program, v. 24, no. 5, p. 143.

Theobold, P.K., and Barton, H.N., 1978, Geochemical evaluation of National Petroleum Reserve, Alaska: U.S. Geological Survey OpenFile Report 78-70D, scale 1:250,000, 2 sheets, $102 \mathrm{p}$.

Thompson, C.E., Nakagawa, H.M., and VanSickle, G.H., 1968, Rapid analysis for gold in geologic materials: U.S. Geological Survey Professional Paper 600-B, p. B130-B132.

Werdon, M.B., 1999, Geologic setting of Mississippian vein-breccias at the Kady $\mathrm{Zn}-\mathrm{Pb}-\mathrm{Cu}-\mathrm{Ag}$ prospect: Plumbing system for a failed Sedex deposit?, in Kelley, K.A., ed., Geologic Studies in Alaska by the U.S. Geological Survey, 1997, U.S. Geological Survey Professional Paper 1614 , p. 5-34.

Werdon, M.B., Layer, P.L., and Newberry, R.J., 1999, Dating the undateable using ${ }^{40} \mathrm{Ar} /{ }^{39} \mathrm{Ar}$ laser step-heating: an application in the northern Brooks Range Zn-Pb-Ag district, Alaska: Economic Geology, v. 94, no. $x$, p. $x x-x x$.

Young, L.E., 1989, Geology and genesis of the Red Dog deposit, western Brooks Range, Alaska: Canadian Institute of Bulletin, v. 82, no. 929, p. 57-67. 


\title{
U.S. Geological Survey Reports on Alaska Released in 1998
}

\author{
Compiled by John P. Galloway and Susan Toussaint
}

Berg, H.C., 1998, Alaska resource data file: Bradfield Canal quadrangle: U.S. Geological Survey Open-File Report 98-327, 181 p.

Bickerstaff, Damon, 1998, Alaska resource data file: Lake Clark quadrangle: U.S. Geological Survey Open-File Report 98-359, $108 \mathrm{p}$.

Carlson, P.R., Bruns, T.R., Evans, K.R., Gann, J.T., Hogg, D.J., Taggart, S.J., and Hooge, P.N., 1998, Cruise report of $M / V$ Quillback in Glacier Bay, Alaska: Physical characteristics of Dungeness crab and halibut habitats: U.S. Geological Survey Open-File Report 98-134, 50 p.

Dmowska, Renata, and Rice, J.R., 1998, Seismicity and deformation at convergent margins due to heterogeneous coupling (with focus on region affected by the 1964 Alaska earthquake): U.S. Geological Survey FY 98 grant 1434-H0-96-GR-02735, Annual project summary, December 1998, 6 p.

Fierstein, Judy, Hildreth, Wes, Hendley, J.W., II, and Stauffer, P.H., 1998, Can another great volcanic eruption happen in Alaska?: U.S. Geological Survey Fact Sheet 075-98, 2 p.

Hansen, R.A., and Christensen, D.H., 1999, Seismic network operations in Alaska 1998: U.S. Geological Survey Final Technical Report \#1434-95-A-01310, 9 p.

Hudson, Travis, 1998, Alaska resource data file: Teller quadrangle: U.S. Geological Survey Open-File Report 98-328, 235 p.

Kropschot, S.J., 1998, USGS mineral resources program: A national perspective: U.S. Geological Survey Fact Sheet FS-008-98, 4 p.

March, R.S., 1998, Mass balance, meteorological, ice motion, surface altitude, and runoff data at Gulkana Glacier, Alaska, 1994 balance year: U.S. Geological Survey Water Resources Investigations Report 97-4251, $31 \mathrm{p}$.

McCarthy, K.A., Lilly, M.R., Braddock, J.F., and Hinzman, L.D., 1998, Natural attenuation of chlorinated-hydrocarbon contamination at Fort Wainwright, Alaska: A hydrogeochemical and microbiological investigation workplan: U.S. Geological Survey Open-File Report 98-198, $49 \mathrm{p}$.

Molnia, B.F, and Post, Austin, 1998, An integrated approach for monitoring changes at Bering Glacier, Alaska, in Williams, R.S., Jr., and Ferrigno, J.G., compilers, Final Report of the Workshop on Long-Term Monitoring of Glaciers of North America and Northwestern Europe: U.S. Geological Survey Open-File Report 98-31, p. 92-97.
Nakanishi, A.S., and Lilly, M.R., 1998, Estimate of aquifer properties by numerically simulating ground-water/surface-water interactions, Fort Wainwright, Alaska: U.S. Geological Survey Water-Resources Investigations Report 98-4088, 35 p.

Neal, E.G., 1998, Hydrologic investigation of the Ophir Creek watershed near Yakutat, Alaska: U.S. Geological Survey Open-File Report 98-199, $33 \mathrm{p}$.

Nokleberg, W.J., Parfenov, L.M., Monger, J.W.H., Norton, I.O., Khanchuk, A.I., Stone, D.B., Scholl, D.W., and Fujita, K., 1998, Phanerozoic tectonic evolution of the circum-north Pacific: U.S. Geological Survey Open-File Report 98-754, 125 p.

Nokleberg, W.J., West, T.D., Dawson, K.M., Shpikerman, V.I., Bundtzen, T.K., Parfenov, L.M., Monger, J.W.H., Ratkin, V.V., Baranov, B.V., Byalobshesky, S.G., Diggles, M.F., Eremin, R.A., Fujita, Kazuya, Gordey, S.P., Gorodinskiy, M.E., Goryachev, N.A., Feeney, T.D., Frolov, Y.F., Grantz, Arthur, Khanchuk, A.I., Koch, R.D., Natallin, B.A., Natapov, L.M., Norton, I.O., Patton, W.W., Jr., Plafker, George, Pozdeev, A.I., Rozenblum, I.S., Scholl, D.W., Sokolov, S.D., Sosunov, G.M., Stone, D.B., Tabor, R.W., Tsukanov, N.V., and Vallier, T.L., 1998, Summary terrane, mineral deposit, and metallogenic belt maps of the Russian Far East, Alaska, and the Canadian Cordillera: U.S. Geological Survey Open-File Report 98-136, 1 CD-ROM.

Perry, C.A., and Combs, L.J., eds., 1998, Summary of floods in the United States, January 1992 through September 1993: U.S. Geological Survey Water Supply Paper 2499, 286 p.

Philpotts, J.A., Taylor, C.D., Tatsumoto, Mitsunobu, and Belkin H.E., 1998, Petrogenesis of late-stage granites and Y-REE-Zr-Nbenriched vein dikes of the Bokan Mountain stock, Prince of Wales Island, southeastern Alaska: U.S. Geological Survey OpenFile Report 98-459, $71 \mathrm{p}$.

Reimnitz, Erk, and Wolf, S.C, 1998, Are North Slope surface alluvial fans pre-Holocene relicts?: U.S. Geological Survey Professional Paper 1605, $9 \mathrm{p}$.

Richter, Donald, 1998, Alaska resource date file: McCarthy quadrangle: U.S. Geological Survey Open-File Report 98-227, 120 p.

Richter, D.H., Symonds, R.B., Rosenkrans, D.S., McGimsey, R.G., Evans, W.C., and Poreda, R.J., 1998, Report on the 1997 activity of Shrub Mud Volcano, Wrangell-St. Elias National Park and Preserve, southcentral Alaska: U.S. Geological Survey Open-File Report 98-128, $13 \mathrm{p}$. 
Rickman, R.L., 1998, Effects of ice formation on hydrology and water quality in the lower Bradley River, Alaska-Implications for salmon incubation habitat: U.S. Geological Survey Water Resource Investigations Report 98-4191, $50 \mathrm{p}$.

Rickman, R.L., 1998, Hydrologic and water-quality data for the lower Bradley River, Alaska, November through April 1995-98: U.S. Geological Survey Open-File Report 98-385, 38 p.

U.S. Geological Survey, 1998, The 1995 national assessment of United States oil and gas resources-The economic component: U.S. Geological Survey Fact Sheet FS-024-98, 4 p.

U.S. Geological Survey, 1998, Arctic National Wildlife Refuge, 1002 area, petroleum assessment, 1998: U.S. Geological Survey Fact Sheet FS040-98, $6 \mathrm{p}$.

Waythomas, C.F., Power, J.A., Richter, D.H., and McGimsey, R.G., 1998, Preliminary volcano-hazard assessment for Akutan Volcano east-central Aleutian Islands, Alaska: U.S. Geological Survey OpenFile Report 98-360, 36 p., 1 plate.

Weathers, J.G., and Plafker, George, 1998, References on Alaska and adjacent regions, cited in Plafker, George, and Berg, H.C., eds., The Geology of Alaska: U.S. Geological Survey Open-File Report 98-126, 181 p. [digital file on the World Wide Web at URL http:// caldera.wr.usgs.gov/akbiblio/0F98-126.PDF].

Wilson, F.H., Dover, J.H., Bradley, D.C., Weber, F.R., Bundtzen, T.K., and Haeussler, P.J., 1998, Geologic map of Central (Interior) Alaska: U.S. Geological Survey Open-File Report 98-133, 3 sheets, scale 1:500,000, 76 p. [color].

Yeend, Warren, Stauffer, P.H., and Hendley, J.W., II, 1998, Rivers of gold-Placer mining in Alaska: U.S. Geological Survey Fact Sheet 058-98, $2 \mathrm{p}$. 


\title{
Reports on Alaska in Non-USGS Publications Released in 1998 that Include USGS Authors
}

\author{
Compiled by John P. Galloway and Susan Toussaint
}

[USGS authors are marked with asterisks $\left.\left.{ }^{*}\right)\right]$

*Barnhardt, W.A., *Kayen, R.E., and *Atwater, B.F., 1998, Radar-based stratigraphic records of the 1964 Alaskan Earthquake [abs.]: Geological Society of America Abstracts with Programs, v. 30, no. 7, p. 398.

${ }^{*}$ Casadevall, T.J., Fox, Tom, and *Miller, T.P., 1998, Volcanic Ash Advisory Centers and the mitigation of volcanic hazards to aviation [abs.]: Eos (American Geophysical Union Transactions), v. 79, no. 45, supplement, p. 992.

Cashman, Katharine, * Gardner, Cynthia, *Power, John, and Houghton, Bruce, 1998, Recent Cook Inlet eruptions: I. Lava effusion and eruption terminations [abs.]: Eos (American Geophysical Union Transactions), v. 79, no. 45, supplement, p. 1000.

${ }^{*}$ Clow, G.D., *Saltus, R.W., * Lachenbruch, A.H. and Brewer, M.C., 1998, Arctic Alaska climate change estimated from borehole temperatures: Past, present, future [abs.]: Eos (American Geophysical Union Transactions), v. 79, no. 45, supplement, p. 833.

Cohn, J.B., *Krimmel, R.M., Pfeffer, W.T., and Meier, M.F., 1998, The surface strain rate field at the Columbia Glacier calving margin [abs.]: Eos (American Geophysical Union Transactions), v. 79, no. 45, supplement, p. 274.

Cooper, J.M., Powell, R.D., and *Carlson, P.R., 1998, Late Pleistocene seismic sequence architectue of the Yakataga Formation within the Bering Trough and adjacent continental shelf, northern Gulf of Alaska [abs.]: Geological Society of America Abstracts with Programs, v. 30, no. 7, p. 135.

Davis, J.S., Roeske, S.M., and *Karl, S.M., 1998, Late Cretaceous to early Tertiary transtension and strain partitioning in the Chugach accretionary complex, SE Alaska: Journal of Structural Geology, v. 20, p. 639-654.

Davis, J.S., Roeske, S.M., and *Karl, S.M., 1998, Late Cretaceous to early Tertiary transtension and strain partitioning in the Chugach accretionary complex, SE Alaska: Journal of Structural Geology, v. 20, p. 639-654.

*Day, W.C., *Wanty, R.B., * Gamble, B.M., Henning, M.W., *Crock, J., ${ }^{*}$ Gough, L., and *Wang, B., 1998, Geology and regional surfacewater quality of the Fortymile Mining District, Yukon-Tanana uplands, Alaska [abs.]: Geological Society of America, Abstracts with Programs, v. 30, no. 7, p. 183.

*Dorava, J.M., and Milner, A.M., 1998, Aquatic habitat features of glacier-fed rivers [abs.]: Eos (American Geophysical Union Transactions), v. 79, no. 45, supplement, p. 373.
*Fuis, G.S., 1998, West margin of North America-A synthesis of recent seismic transects: Tectonophysics, v. 288, p. 265-292.

${ }^{*}$ Gardner, C.A., Cashman, K.V., and *Neal, C.A., 1998, Tephra-fall deposits from the 1992 eruption of Crater Peak, Alaska: Implications of clast textures for eruptive processes: Bulletin of Volvanology, $v$. 59 , no. 8, p. 537-555.

*Gardner, C.A., Cashman, K.V., and *Power, J.A., 1998, Recent Cook Inlet eruptions: II. Degassing-induced crystalization and eruption inception [abs.]: Eos (American Geophysical Union Transactions), v. 79, no. 45, supplement, p. 1000.

${ }^{*}$ Goldfarb, Richard, *duBray, Edward, *Gray, John, ${ }^{*}$ Kelley, Karen, and *Plumlee, Geoffrey, 1998, Geoenvironmental mineral deposit models for the northern Cordillera, in Metallogeny of Volcanic Arcs: British Columbia Geological Survey Short Course Notes, Open File 19988, p. C1-C49.

Gottschalk, R.R., and *Snee, L.W., 1998, Tectonothermal evolution of metamorphic rocks in the south-central Brooks Range, Alaska: Constraints from ${ }^{40} \mathrm{Ar} /{ }^{39} \mathrm{Ar}$ geochronology, in Oldow, J.S., and Avé Lallemant, H.G., eds., Architecture of the Central Brooks Range Fold and Thrust Belt, Arctic Alaska: Boulder, Colo., Geological Society of America Special Paper 324, p. 225-251.

Hansen, V.L., and *Dusel-Bacon, C., 1998, Structural and kinematic evolution of the Yukon-Tanana upland tectonites, east-central Alaska: A record of late Paleozoic to Mesozoic crustal assembly: Geological Society of America Bulletin, v. 110, p. 211-230.

${ }^{*}$ Hodge, S.M., ${ }^{*}$ Trabant, D.C., ${ }^{*}$ Krimmel, R.M., ${ }^{*}$ Heinrichs, T.A., *March, R.S., and * Josberger, E.G., 1998, Climate variations and changes in mass of three glaciers in western North America: Journal of Climate, v. 11, no. 9, p. 2161-2179.

Jolly, A.D., * Moran, S.C., and McNutt, S.R., 1998, P-wave tomography at Katmai National Park, Alaska Peninsula, Alaska [abs.]: Eos (American Geophysical Union Transactions), v. 79, no. 45, supplement, p. 621.

*Keller, M.A., and *Bird, K.J., 1998, Challenges of petroleum sourcerock evaluation using sonic and resistivity logs and the $A E \log R$ method, northeastern Alaska [abs.]: AAPG Bulletin, v. 82, no. 5A, p. 850.

*Kvenvolden, K.A., *Carlson, P.R., *Warden, Augusta, and *Threlkeld, C.N., 1998, Carbon isotopic comparisons of oil products used in the developmental history of Alaska: Chemical Geology, v. 152, no. 1-2, p. 73-84. 
Mann, D.M., Crowell, A.L., ${ }^{*}$ Hamilton, T.D., and Finney, B.P., 1998, Holocene geologic and climatic history around the Gulf of Alaska: Arctic Anthropology, v. 35, no. 1., p. 112-131.

Mann, Doerte, Freymueller, J.T., and *Lu, Zhong, 1998, SAR interferometry as a versatile tool to investigate $0 \mathrm{kmok}$ Volcano, Alaska [abs.]: Eos (American Geophysical Union Transactions), v. 79, no. 45, supplement, p. 35.

*Marlow, M.S., *Stevenson, A.J., *Chezar, Hank, and McConnaughey, R.A., 1998, Unusual seafloor lineations imaged with sidescan sonar in Bristol Bay, Alaska [abs.]: Eos (American Geophysical Union Transactions), v. 79, no. 45, supplement, p. 450.

*Miller, T.P., *Schneider, D.J., and Kirianov, V. Yu., 1998, Advances in monitoring and communicating of volcanic ash hazards to aviation across the north Pacific: A possible model for wider use [abs.]: Eos (American Geophysical Union Transactions), v. 79, no. 45, supplement, p. 992.

*Moore, T.E., *Aleinikoff, J.N., and Wirth, K.R., 1998, Middle Jurassic U$\mathrm{Pb}$ ages for Brooks Range ophiolites, Alaska [abs.]: Eos (American Geophysical Union Transactions), v. 79, no. 45, supplement, p. 807.

*Moran, S.C., and Jolly, A.D., 1998, The shallow stress field at Katmai National Park, Alaska, as inferred from focal mechanisms and B-values [abs.]: Eos (American Geophysical Union Transactions), v. 79, no. 45 , supplement, p. 622.

O'Sullivan, P.B., ${ }^{*}$ Moore, T.E., and Murphy, J.M., 1998, Tertiary uplift of the Mt. Doonerak antiform, central Brooks Range, Alaska: Apatite fission-track evidence from the Trans-Alaska crustal transect, in Oldow, J.S., and Avé Lallemant, H.G., eds., Architecture of the Central Brooks Range Fold and Thrust Belt, Arctic Alaska: Boulder, Colo., Geological Society of America Special Paper 324, p. 179-193.

*Pierson, T.C., 1998, An empirical method for estimating travel times for wet volcanic mass flows: Bulletin of Volcanology, v. 60, no. 2, p. 98109.

*Power, J.A., *Villaseñor, A., and *Benz, H.M., 1998, Seismic image of the Mount Spurr magmatic system: Bulletin of Volcanology, v. 60, no. 1, p. 27-37.

Ridgway, K.D., Trop, J.M., *Nokleberg, W.J., and Davidson, C.M., 1998, Mesozoic and Cenozoic tectonics of the eastern and central Alaska Range: Progressive basin development and deformation within a suture zone [abs.]: Geological Society of America Abstracts with Programs, v. 30, no. 7, p. 242.

*Rowan, E.L., *Bird, K.J., Hayba, D.O., Choueiri, Walid, Wendebourg, Johannes, and Rudkiewicz, Jean-Luc, 1998, Hydrogeologic factors affecting oil migration in the Canning River region, eastern North Slope, Alaska [abs.]: Eos (American Geophysical Union Transactions), v. 79, no. 45, supplement, p. 845.

*Saltus, R.W., Hudson, T.L., and Connard, G.G., 1998, Alaskan crustal framework inferred from aeromagnetic data [abs.]: Geological Society of America Abstracts with Programs, v. 30, no. 7, p. 107.

*Saltus, R.W., and *Phillips, J.D., 1998, Gravity and magnetic interpretation supports basin structure studies in the northern part of the Arctic National Wildlife Refuge, Alaska [abs.]: Eos (American Geophysical Union Transactions), v. 79, no. 45, supplement, p. 876.
${ }^{*}$ Savage, J.C., ${ }^{*}$ Svarc, J.L., *Prescott, W.H., and *Gross, W.K., 1998, Deformation across the rupture zone of the 1964 Alaska earthquake, 1993-1997: Journal of Geophysical Research, v. 103, no. B9, p. 21275-21283.

*Scholl, D.W., and *Hart, P.E., 1998, Geophysical evidence for dense masses of methane hydrate in the Bering Sea basin: Thoughts about their origin, occurrence, and resource potential [abs.]: AAPG Bulletin, v. 82 , no. 5 A, p. 857.

Scholl, D.W., *Stevenson, A.J., *Noble, M.A., and Rea, D.K., 1998, Turnon and turn-off oceanographic, climatic, and tectonic conditions for the formation of thermohaline bottom waters in the Bering Sea and their southward discharge via an Aleutian gateway into the North Pacific basin [abs.]: Eos (American Geophysical Union Transactions), v. 79, no. 45, supplement, p. 32.

*Scholl, D.W., and von Huene, Roland, 1998, New geophysical and geological studies support higher, but comparable, rates of both arc growth and crustal recycling at subduction zones [abs.]: Geological Society of America Abstracts with Programs, v. 30, no. 7, p. 209.

*Stricker, G.D., Houle, J.A., *Flores, R.M., Myers, M.D., and *Bader, L.R., 1998, The Tertiary Tyonek Formation in the upper Cook Inlet, Alaska: Depositional environments and reservoir characteristics [abs.]: AAPG Bulletin, v. 82, p. 1278.

*Trabant, D.C., *March, R.S., and *Kennedy, B.W., 1998, Glacier massbalance trends in Alaska and climate-region shifts [abs.]: Eos (American Geophysical Union Transactions), v. 79, no. 45, supplement, p. 277.

Walker, M.D., Walker, D.A., Welker, J.M., Arft, A.M., Bardsley, T., *Brooks, P.D., Fahnestock, J.T., Jones, M.H., Losleben, M., Parson, A.N., Seastedt, T.R., and Turner, P.L., 1998, Long-term experimental manipulation of winter snow regime and summer temperature in arctic and alpine tundra: An integrated ecosystem approach, in Hardy, Janet, Albert, Mary, and March, Phillip, eds., 1998, Abstracts from the International Conference on Snow Hydrology: The Integration of Physical, Chemical, and Biological Systems: U.S. Army Cold Regions Research and Engineering Laboratory Special Report 9810, p. 28.

*Waythomas, C.F., 1998, Late Holocene caldera formation and stratigraphic framework of Holocene volcaniclastic deposits, Akutan Volcano, east-central Aleutian Islands, Alaska [abs.]: Eos (American Geophysical Union Transactions), v. 79, no. 45, supplement, p. 937.

*Waythomas, C.F., and *Neal, C.A., 1998, Tsunami generation by pryroclastic flow during the 3500-year B.P. caldera-forming eruption of Aniakchak Volcano, Alaska: Bulletin of Volcanology, v. 60, no. 2, p. 110-124.

*Wilson, F.H., and *Weber, F.R., 1998, The Tintina fault system and speculations on the Denali fault system of Alaska [abs]: Geological Society of America Abstracts with Programs, v. 30, no. 7, p. 176-177.

Wissinger, E.S., Levander, A.R., Oldow, J.S., ${ }^{*} F u i s$, G.S., and *Lutter, W.J., 1998, Seismic profiling constraints on the evoluton of the central Brooks Range, Arctic Alaska, in Oldow, J.S., and Avé Lallemant, H.G., eds., Architecture of the Central Brooks Range Fold and Thrust Belt, Arctic Alaska: Boulder, Colo., Geological Society of America Special Paper 324, p. 269-291. 